\title{
METODOLOGIA PARA A AVALIAÇÃO DE MEDIDAS VOLTADAS À DISTRIBUIÇÃO URBANA DE CARGAS ATRAVÉS DO USO DA MICROSSIMULAÇÃO DE TRÁFEGO
}

Tese apresentada à Escola Politécnica da Universidade de São Paulo para obtenção do título de Doutor em Engenharia de Transportes.

SÃO PAULO 


\title{
METODOLOGIA PARA A AVALIAÇÃO DE MEDIDAS VOLTADAS À DISTRIBUIÇÃO URBANA DE CARGAS ATRAVÉS DO USO DA MICROSSIMULAÇÃO DE TRÁFEGO
}

\author{
Tese apresentada à Escola Politécnica \\ da Universidade de São Paulo para \\ obtenção do título de Doutor em \\ Engenharia de Transportes.
}

Área de concentração:

Engenharia de Transportes

Orientador:

Professor Associado Claudio Barbieri da Cunha

SÃO PAULO

2015 
Este exemplar foi revisado e corrigido em relação à versão original, sob responsabilidade única do autor e com a anuência de seu orientador.

São Paulo, de de

Assinatura do autor:

Assinatura do orientador:

Catalogação-na-publicação

Zambuzi, Nathalia de Castro

METODOLOGIA PARA A AVALIAÇÃO DE MEDIDAS VOLTADAS À DISTRIBUIÇÃO URBANA DE CARGAS ATRAVÉS DO USO DA MICROSSIMULAÇÃO DE TRÁFEGO / N. C. Zambuzi -- versão corr. -- São Paulo, 2015.

$333 \mathrm{p}$.

Tese (Doutorado) - Escola Politécnica da Universidade de São Paulo. Departamento de Engenharia de Transportes.

1.Distribuição urbana de cargas 2.Microssimulação de tráfego 3.Avaliação de medidas 4.Logística urbana I.Universidade de São Paulo. Escola Politécnica. Departamento de Engenharia de Transportes II.t. 
"Dou valor as coisas, não por aquilo que valem, mas por aquilo que significam" Gabriel Garcia Marques 


\section{RESUMO}

O presente trabalho trata da avaliação de medidas voltadas à distribuição urbana de cargas considerando ser essa uma etapa fundamental do processo de tomada de decisão, pois permite a análise dos possíveis resultados acerca dos objetivos pretendidos, os quais geralmente estão relacionados à diminuição dos congestionamentos de veículos e das emissões de gases poluentes. Considerando que grande parte dos problemas decorrentes da distribuição urbana ocorrem localmente, no nível desagregado, propõe-se um procedimento que dê subsídios ao desenvolvimento de uma metodologia para a avaliação de medidas através da microssimulação de tráfego. Isso porque a microssimulação permite um alto nível de detalhe na modelagem e na observação do comportamento dos veículos, o que é essencial para a quantificação dos possíveis impactos locais gerados pelos veículos de carga. A integração entre as coletas de dados e os modelos que compõem o procedimento forneceu os dados necessários à representação dos movimentos dos veículos de carga no VISSIM, onde foram simulados três diferentes cenários, cada um representando alterações impostas por diferentes medidas em avaliação. A aplicação do procedimento proposto, a modelagem no VISSIM e os resultados da microssimulação permitiram a ponderação sobre o uso dessa técnica para a avaliação de medidas voltadas à distribuição urbana de cargas, considerando suas vantagens e limitações. 


\begin{abstract}
The present research deals with the evaluation of urban freight policies, considering this is fundamental for the decision making process of a policy implementation. Evaluation allows an analysis of the possible policy effects compared to its intended objectives, which are generally related to reductions in traffic congestion and pollutant emissions. Whereas most of the problems caused by urban distribution occur locally, in the disaggregated level, we propose a procedure that supports the development of a methodology for evaluating freight policies through traffic microsimulation. That's because this technique allows a high level of detail in modeling and observation of vehicles' behavior, which is essential for quantifying the likely local impacts generated by freight vehicles. The procedure is based on a set of integrated data collections and models, which provided the data for representing freight vehicles movement in VISSIM, were three different scenarios, each one representing changes imposed by different freight policies, were simulated. The application of the proposed procedure, the VISSIM's modeling process and the microsimulation results allowed the weighing for the use of this technique in evaluating urban freight policies, considering its advantages and limitations.
\end{abstract}




\section{SUMÁRIO}

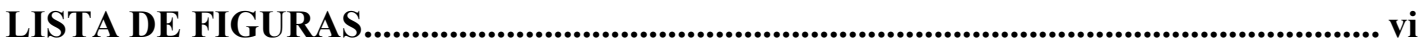

LISTA DE QUADROS................................................................................................................ xiii

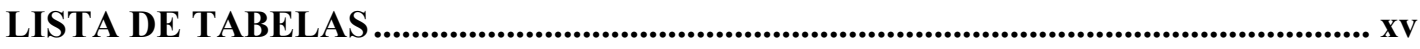

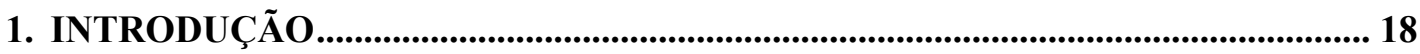

1.1. Caracterização e Relevância do Problema.................................................................. 18

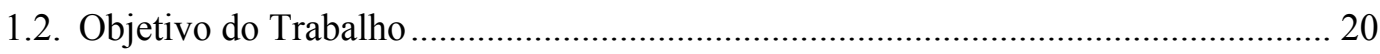

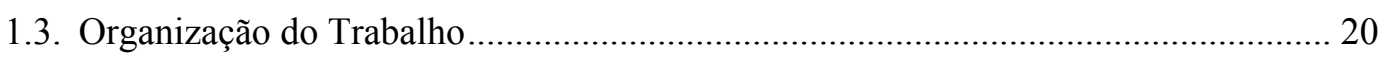

2. DISTRIBUIÇÃO URBANA DE CARGAS ....................................................... 23

2.1. Definições da Distribuição Urbana de Cargas ........................................................... 23

2.2. Sistemas da Distribuição Urbana de Cargas ............................................................. 24

2.3. Elementos e Agentes da Distribuição Urbana de Cargas .......................................... 28

2.4. Impactos Negativos no Ambiente Urbano Decorrentes da Distribuição Urbana de

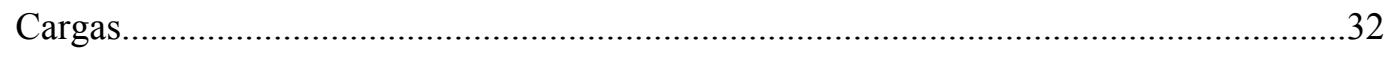

3. A DISTRIBUIÇÃO URBANA DE CARGAS NAS GRANDES CIDADES............... 34

3.1. Uso do Solo e Disponibilidade Restrita de Espaço ....................................................... 34

3.2. Oferta Restrita de Vagas de Estacionamento......................................................... 37

3.3. Estabelecimentos de Pequeno Porte ……................................................................. 39

3.4. Características Heterogêneas do Município e Questões de Segurança....................... 43

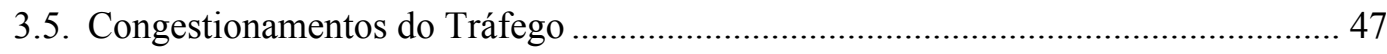

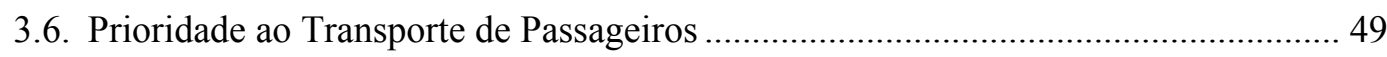

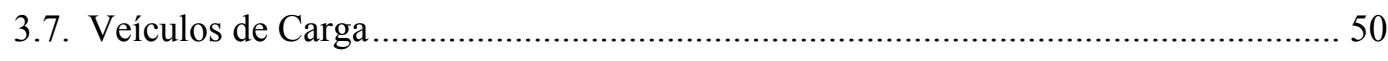

4. RESTRIÇÕES AO TRANSPORTE DE CARGAS ........................................................ 54

4.1. Restrições ao Transporte de Cargas Adotadas nos Municípios Brasileiro ................. 54

4.2. Evolução das Restrições no Município de São Paulo................................................. 58

4.3. Restrições em Vigência no Município de São Paulo................................................. 65

4.3.1. Exceç̧̃es das Restrições ................................................................................... 67

4.3.2. Fatos e Considerações Sobre as Restrições ..................................................... 73 


\section{AVALIAÇÃO DE MEDIdAS VOLTADAS À DISTRIBUIÇÃO URBANA DE}

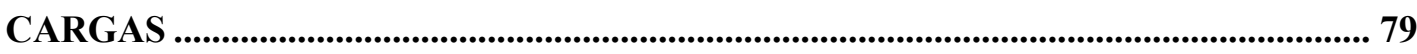

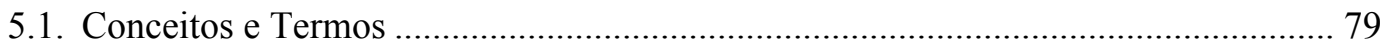

5.2. Importância da Avaliação de Medidas Voltadas à Distribuição Urbana de Cargas .. 81

5.3. Modelos para a Avaliação de Medidas Voltadas à Distribuição Urbana de Cargas.. 82

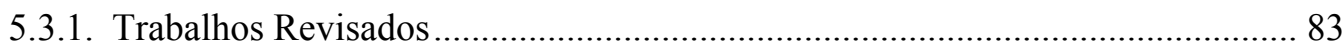

5.3.2. Considerações Sobre os Trabalhos Revisados................................................... 114

6. PROCEDIMENTO PARA AVALIAÇÃO DE MEDIDAS VOLTADAS À DISTRIBUIÇÃO URBANA DE CARGAS USANDO MICROSSIMULAÇÃO DE

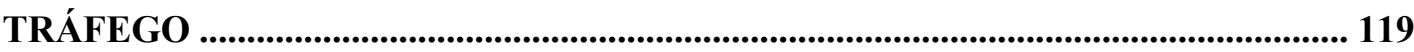

6.1. Contexto Geral da Simulação de Tráfego ................................................................. 119

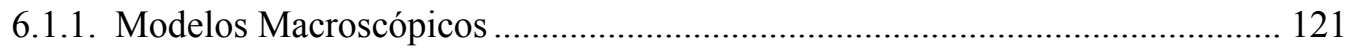

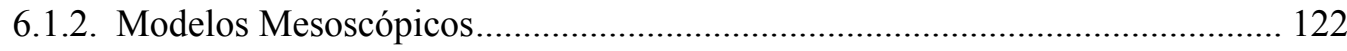

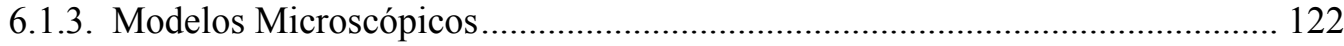

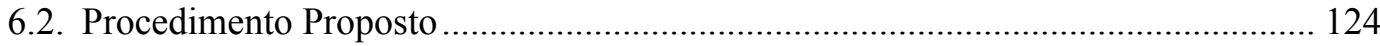

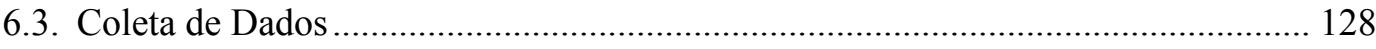

6.3.1. Levantamento e Classificação dos Estabelecimentos........................................ 128

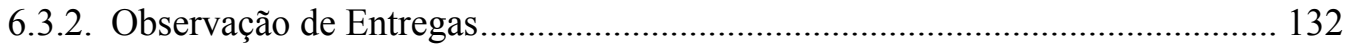

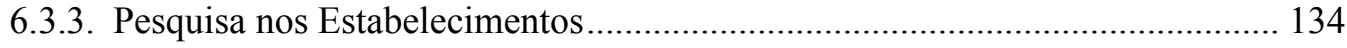

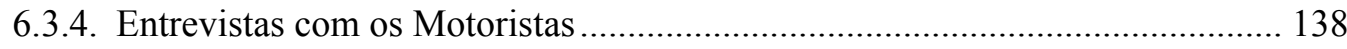

6.4. Modelos para a Microssimulação …………........................................................... 148

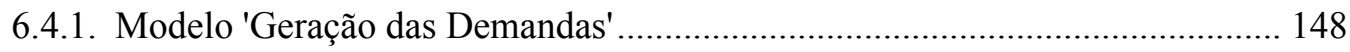

6.4.2. Modelo 'Geração dos Veículos de Entrega' ......................................................... 151

6.4.3. Modelo 'Preferências de Estacionamento' ....................................................... 155

7. MODELAGEM DO AMBIENTE DE MICROSSIMULAÇÃO ................................. 160

7.1. Escolha do Software de Microssimulação de Tráfego............................................... 160

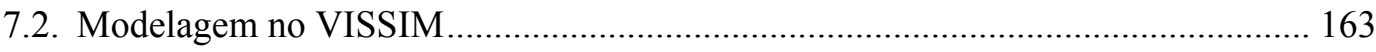

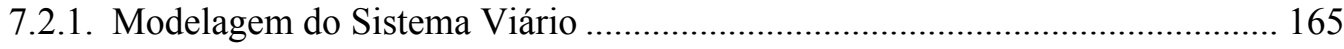


7.2.2. Modelagem do Fluxo de Veículos em Geral ................................................. 169

7.2.3. Calibração e Validação do Modelo.................................................................. 178

7.2.4. Modelagem dos Movimentos dos Veículos de Carga ..................................... 183

7.2.4.1. Modelagem dos Estabelecimentos...................................................... 184

7.2.4.2. Modelagem das Rotas de Entrega ....................................................... 186

7.2.4.3. Modelagem das Decisões de Estacionamento ......................................... 191

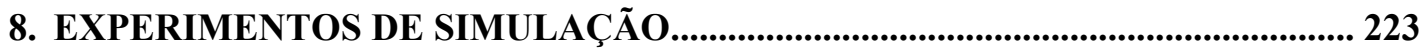

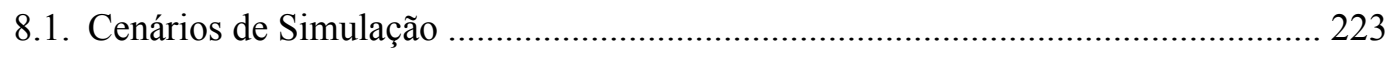

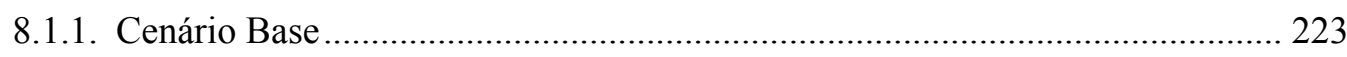

8.1.2. Cenário Alternativo 1 - Consolidação de Cargas em Veículos Maiores .......... 227

8.1.3. Cenário Alternativo 2 - Vagas Exclusivas para Carga e Descarga.................... 230

8.2. Resultados da Simulação ..................................................................................... 232

8.2.1. Impactos no Tráfego Veicular .................................................................... 233

8.2.2. Impactos na Operação dos Veículos de Carga ............................................... 242

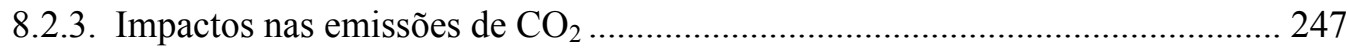

9. CONCLUSÕES FINAIS E RECOMENDAÇÕES ............................................... 250

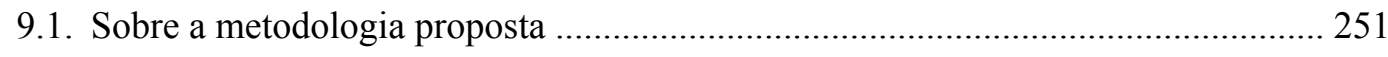

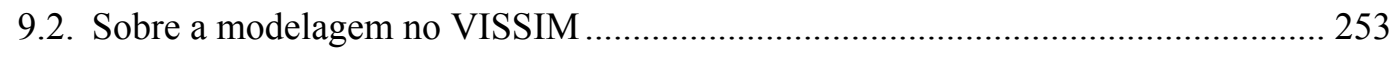

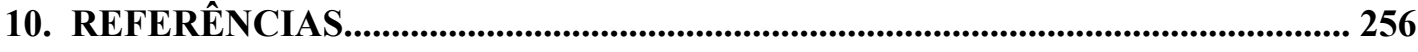

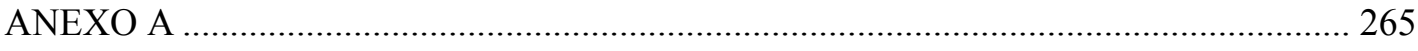

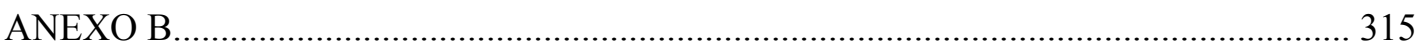

B.1 Discussão sobre os resultados obtidos nas entrevistas com os motoristas................ 321

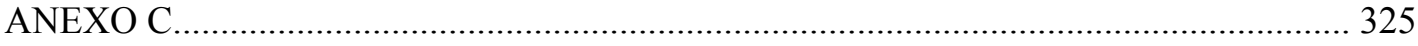

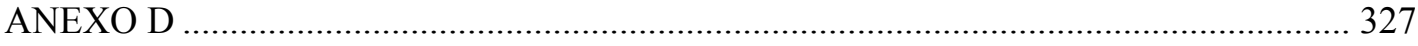

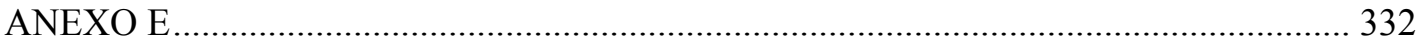




\section{LISTA DE FIGURAS}

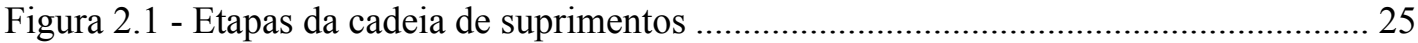

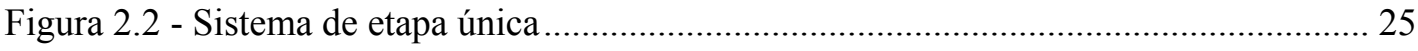

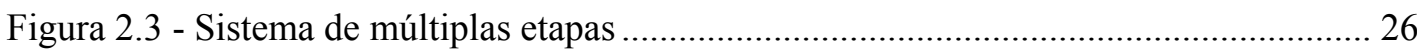

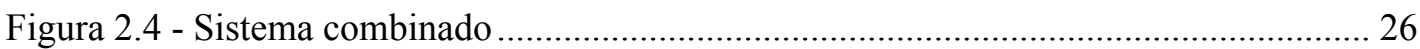

Figura 2.5 - Representação da viagem de parada única ....................................................... 27

Figura 2.6 - Representação da viagem de paradas múltiplas................................................. 27

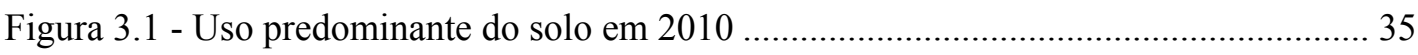

Figura 3.2 - Veículo de carga estacionado em local não autorizado .................................... 37

Figura 3.3 - Veículos de carga estacionados em locais não autorizados, ocupando uma das

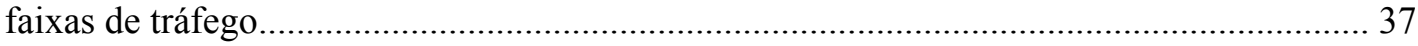

Figura 3.4 - Veículo de entrega estacionado em fila dupla, ocupando uma das faixas de

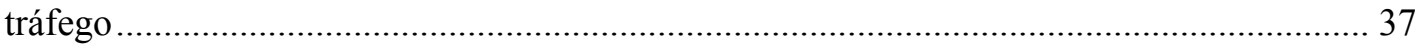

Figura 3.5 - Veículo de carga estacionado sobre a calçada ................................................... 38

Figura 3.6 - Estacionamento de veículo de carga sem perturbação do tráfego de passagem 38

Figura 3.6 - Estacionamento de veículo de carga sem perturbação do tráfego de passagem 39

Figura 3.8 - Exemplos de estabelecimentos de pequeno porte .......................................... 40

Figura 3.9 - Levantamento da localização de supermercados em uma área da cidade de São

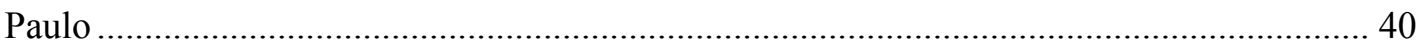

Figura 3.10 - Concentração de estabelecimentos comerciais nas áreas periféricas da

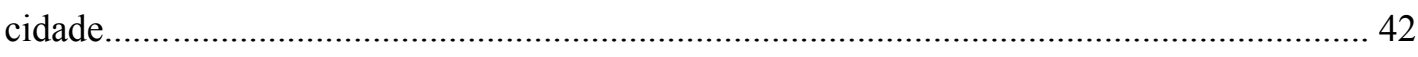

Figura 3.11 - Exemplos de locais de difícil acesso localizados nas áreas periféricas da cidade. 42

Figura 3.12 - Delimitação de zonas de entrega de uma região.............................................. 43

Figura 3.13 - Distribuição do acordo com a faixa de renda em 2010................................... 44

Figura 3.14 - Zonas adjacentes com diferentes características........................................... 44

Figura 3.15 - Risco de registro de ocorrência em 2005 ..................................................... 45

Figura 3.16 - Escolta acompanhando o veículo de carga ….................................................. 46

Figura 3.17 - Veículo de carga compartimentado ........................................................... 46 
Figura 3.18 - Tráfego intenso na Avenida 23 de maio, em São Paulo ................................... 47

Figura 3.19 - Distribuição da população e dos empregos formais - IPVS 9......................... 48

Figura 3.20 - Veículo urbano de Carga (VUC) …................................................................ 50

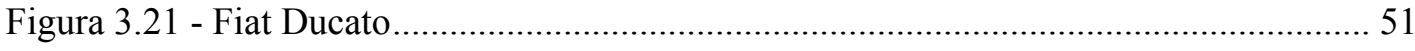

Figura 3.22 - (a) Volkswagen Kombi e (b) Volkswagem Kombi Pick-up ........................... 51

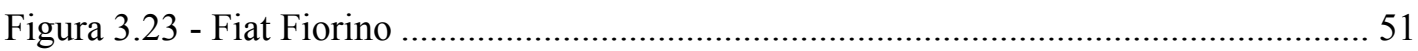

Figura 3.24 - Caminhão médio semipesado (Toco) …….................................................. 52

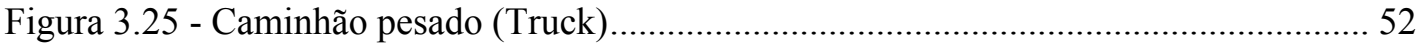

Figura 3.26 - Conjunto caminhão trator mais semirreboque (eixo traseiro de rodagem

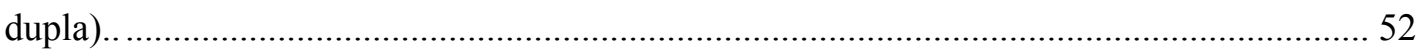

Figura 3.27 - Conjunto caminhão trator mais semirreboque (eixo traseiro duplo) .............. 53

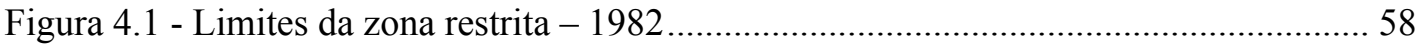

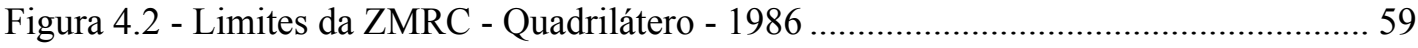

Figura 4.3 - Limites da ZMRC - Quadrilátero - 1986 a 1998 .............................................. 59

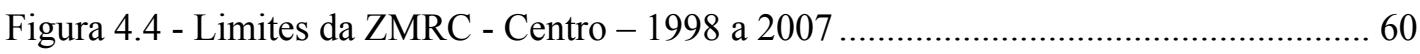

Figura 4.5 - Mini anel viário do Município de São Paulo ........................................................ 61

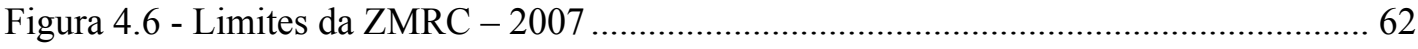

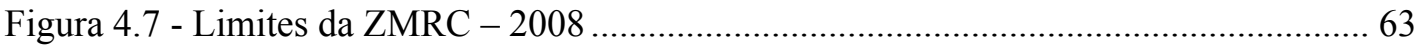

Figura 4.8 - Resumo da evolução das restrições à circulação do município de São Paulo ... 64

Figura 4.9 - Zona de Máxima Restrição à Circulação - ZMRC e Vias Estruturais Restritas -

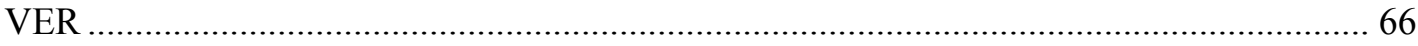

Figura 5.1 - Estrutura do modelo híbrido de simulação ......................................................... 85

Figura 5.2 - Representação de uma viagem de atendimento ............................................... 90

Figura 5.3 - Planejamento do transporte em quatro etapas................................................. 93

Figura 5.4 - Estrutura de processamento dos dados ............................................................... 96

Figura 5.5 - Deslocamento do baricentro e distância em torno do baricentro........................ 97

Figura 5.6 - Área central da cidade de Nijmegen, Holanda ............................................ 100

Figura 6.1 - Nível de detalhe dos modelos de simulação .................................................. 121 
Figura 6.2 - Modelo conceitual da distribuição urbana de cargas 125

Figura 6.3 - Modelos para a microssimulação 127

Figura 6.4 - Associação entre as coletas de dados e os modelos para a microssimulação .. 127

Figura 6.5 - Limites da área de estudo 128

Figura 6.6 - Mapeamento dos estabelecimentos da área de estudo 131

Figura 6.7 - Locais de observação das entregas 132

Figura 6.8 - Diagramas apresentados aos motoristas: cenário A e cenário B 144

Figura 6.9 - Diagramas apresentados aos motoristas: cenário C e cenário D 145

Figura 6.10 - Diagramas apresentados aos motoristas: cenário E, cenário F e cenário G... 145

Figura 6.11 - Esquema da versão inicial do modelo 'Geração das Demandas' 149

Figura 6.12 - Esquema da versão final do modelo de 'Geração das Demandas' 151

Figura 6.13 - Esquema do modelo 'Geração dos Veículos de Entrega' 152

Figura 6.14 - Lógica da geração de veículos no modelo 'Geração dos Veículos de Entrega' 154

Figura 6.15 - Fluxo de decisões do modelo 'Preferências de Estacionamento' 156

Figura 7.1 - Área escolhida para a simulação 164

Figura 7.2 - Parte do mapa digital cartográfico utilizado como base para a representação das vias 166

Figura 7.3 - Exemplo da inserção de links e nós sobre o mapa base 167

Figura 7.4 - Rede viária completa da área de simulação 167

Figura 7.5 - Representação gráfica da modelagem de (a) semáforos, (b) sinais de 'pare' e (c) áreas de estacionamento 167

Figura 7.6 - Exemplo da modelagem de uma regra de conflito 168

Figura 7.7 - Diferenciação entre uma área de estacionamento e uma vaga de estacionamento.. 169

Figura 7.8 - Exemplo de fluxo de veículos bloqueado devido à manobra de estacionamento 169

Figura 7.9 - Locais de registro da ocupação das vagas de estacionamento 171 
Figura 7.10 - Exemplo dos dados de entrada para a geração de veículos através do objeto 'vehicle inputs' 171

Figura 7.11 - Entrada (geração) de veículos na rede durante a simulação 172

Figura 7.12 - Representação gráfica da modelagem dos movimentos de giro em uma interseção 173

Figura 7.13 - Exemplo dos dados de entrada para a definição dos movimentos de giro em uma interseção através do objeto 'static vehicle route decision' 174

Figura 7.14 - Representação gráfica e exemplo dos dados de entrada de objetos do tipo 'desired speed decision' 174

Figura 7.15 - Representação gráfica e exemplo dos dados de entrada de objetos do tipo 'reduced speed areas' 175

Figura 7.16 - Representação gráfica da modelagem das rotas dos veículos da classe 'parking cars' através de objetos do tipo 'parking routing decision'. 176

Figura 7.17 - Parâmetros para a modelagem do comportamento dos motoristas - distâncias longitudinais entre os veículos 177

Figura 7.18 - Parâmetros para a modelagem do comportamento dos motoristas - mudança de faixa 177

Figura 7.19 - Parâmetros para a modelagem do comportamento dos motoristas - distâncias laterais entre os veículos 178

Figura 7.20 - Parâmetros para a modelagem do comportamento dos motoristas - reações aos semáforos 178

Figura 7.21 - Exemplo da localização dos pontos de coleta de dados ('data collection points'). 179

Figura 7.22 - Representação dos estabelecimentos existentes na área de simulação 185 Figura 7.23 - Exemplo da atribuição de áreas de estacionamento aos estabelecimentos.... 185 Figura 7.24 - Exemplo da modelagem de áreas de carga e descarga internas ao estabelecimento 186

Figura 7.25 - Exemplo de um arquivo do tipo 'trip chain' para a modelagem das rotas dos veículos de entrega 188

Figura 7.26 - Exemplo da atribuição de objetos do VISSIM à uma classes de veículos .... 190 
Figura 7.27 - Exemplo da modelagem de uma decisão de rota dinâmica ('vehicle routing dynamic') 192

Figura 7.28 - Fluxo de decisões 'A' 194

Figura 7.29 - Arquivo da 'trip chain' para rota com destino à área de carga e descarga..... 195 Figura 7.30 - Exemplo da modelagem de uma vaga de estacionamento em posto de gasolina 196

Figura 7.31 - Fluxo de decisões 'B'. 197

Figura 7.32 - Exemplo de vaga fictícia para estacionamento irregular sobre a faixa de tráfego. 198

Figura 7.33 - Exemplo de vaga fictícia inserida no mesmo link que a vaga adjacente 198

Figura 7.34 - Exemplo de vaga fictícia inserida em um conector auxiliar 199

Figura 7.35 - Exemplo de veículo estacionado em fila dupla não sendo percebido pelos veículos que circulam na via 199

Figura 7.36 - Exemplo de vaga fictícia inserida no link principal e vagas regulares adjacentes inseridas em um conector auxiliar 199

Figura 7.37 - Exemplo de veículo estacionado em fila dupla sendo percebido pelos veículos que circulam na via 200

Figura 7.38 - Exemplo do fluxo bloqueado devido ao veículo estacionado em fila dupla e impossibilidade de ultrapassagem pela via de sentido oposto 200

Figura 7.39 - Fluxo de decisões 'C' 201

Figura 7.40 - Exemplo da modelagem de rota dinâmica para a busca por uma vaga de estacionamento 202

Figura 7.41 - Detalhe da modelagem de rota dinâmica para a busca por uma vaga de estacionamento 203

Figura 7.42- Exemplo da limitação do uso da decisão de rota dinâmica 205

Figura 7.43 - Exemplo da inserção de áreas de velocidade reduzida (em amarelo) ao longo do percurso de busca por uma vaga de estacionamento 206

Figura 7.44 - Fluxo de decisões 'D' 207 
Figura 7.45 - Exemplo da modelagem de decisões de rota dinâmica para a segunda tentativa

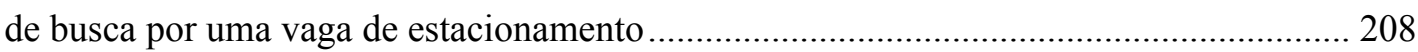

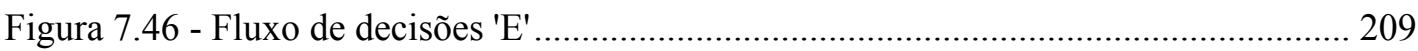

Figura 7.47 - Exemplo da modelagem das seções de decisão adicionais............................. 211

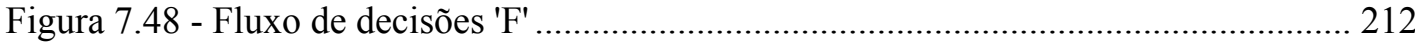

Figura 7.49 - Exemplo de rota a ser alterada pela decisão do motorista de adiar a entrega

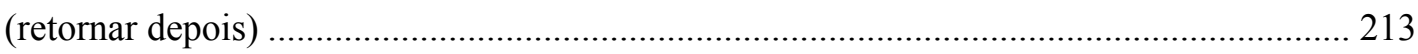

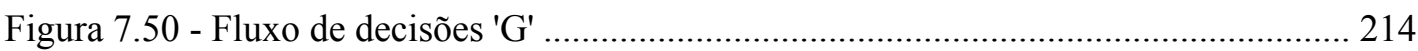

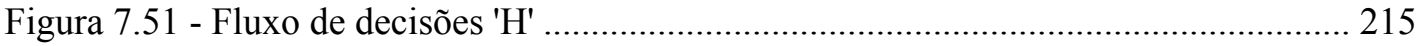

Figura 7.52 - Exemplo de vaga fictícia para espera por liberação de uma vaga interna ao

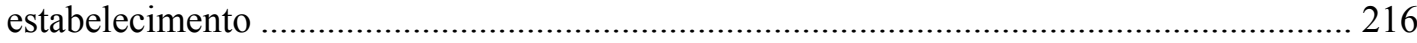

Figura 7.53 - Exemplo de inclusão da vaga fictícia de espera na rota original do veículo, no

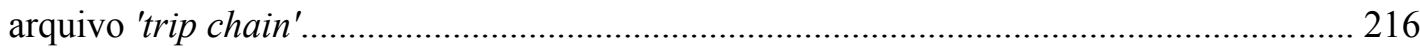

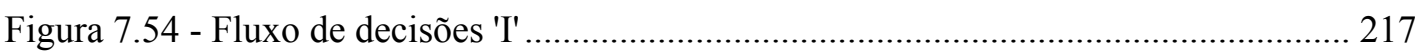

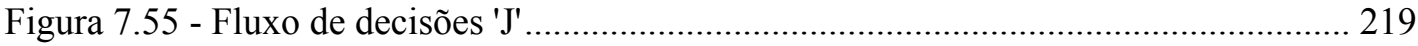

Figura 7.56 - Exemplo da modelagem de decisões de rota dinâmica para rotas que incluem

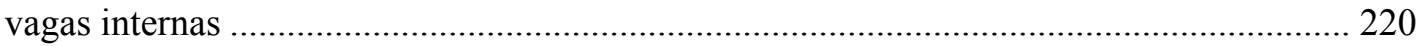

Figura 7.57 - Exemplo da modelagem das regras de prioridade para vagas internas.......... 221

Figura 7.58 - Exemplo de veículo respeitando a regra de prioridade: (a) aguardando liberação da vaga interna e (b) entrando no estabelecimento após a saída do outro

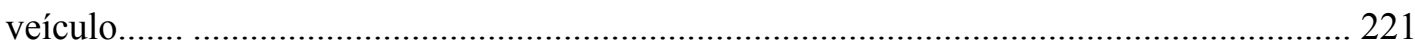

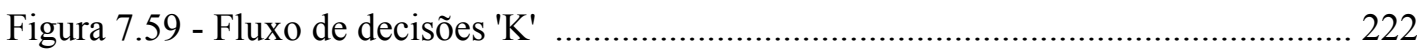

Figura 8.1- Histograma da frequência do número total de entregas na área de simulação . 224

Figura 8.2 - Histograma da frequência do número total de entregas na área de simulação

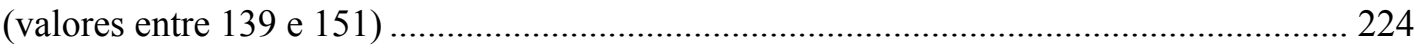

Figura 8.3 - Redução do número de vagas de carga e descarga na Rua Albuquerque Lins 230 Figura 8.4 - Reposicionamento da área de carga e descarga da Avenida Angélica para a Rua

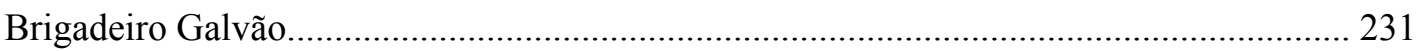

Figura 8.5 - Área de carga e descarga criada na Alameda Barão de Limeira ...................... 232 
Figura 8.6 - Dados de saída fornecidos pelo VISSIM para as velocidades dos veículos .... 234

Figura 8.7 - Dados de saída fornecidos pelo VISSIM para as formações de filas 239

Figura 8.8 - Exemplo de formação de fila devido à manobra de estacionamento de um veículo de carga ..... 243

Figura 8.9 - Exemplo dos dados de saída fornecidos pelo VISSIM para os tempos de viagem e distâncias percorridas pelos veículos durante a simulação 245

Figura B.1 - Diagramas utilizados nas entrevistas com os motoristas e porcentagens de

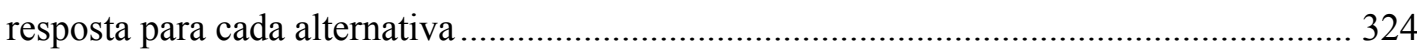

Figura C.1 - Mapeamento dos semáforos e das áreas de estacionamento da área de simulação 325

Figura C.2 - Tempos de verde, vermelho e amarelo para os semáforos identificados na área de simulação 326

Figura D.1 - Seções de entrada e interseções da área de simulação 327 


\section{LISTA DE QUADROS}

Quadro 4.1 - Resumo das restrições ao transporte de carga .................................................. 54

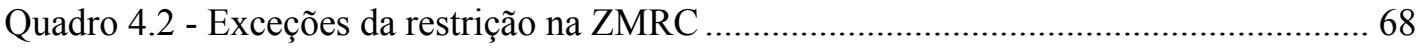

Quadro 4.3 - Exceções da restrição nas VER previstas na Portaria SMT. GAB. 125/12 ..... 69

Quadro 4.4 - Exceções da restrição nas VER previstas na Portaria SMT. GAB. 124/12 ..... 70

Quadro 4.5 - Exceções da restrição nas VER previstas na Portaria SMT. GAB. 123/12 ..... 71

Quadro 4.6 - Exceções da restrição nas ZERC...................................................................... 72

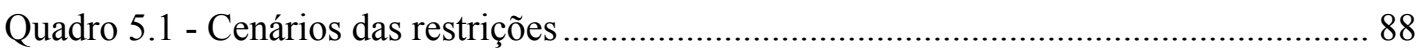

Quadro 5.2 - Emissões Unitárias de $\mathrm{CO}_{2}$ para diferentes veículos de carga ......................... 98

Quadro 5.3 - Exemplo de alternativas apresentadas na pesquisa ...................................... 109

Quadro 5.4 - Exemplo de cenário (mix de medidas) apresentado na pesquisa ................... 110

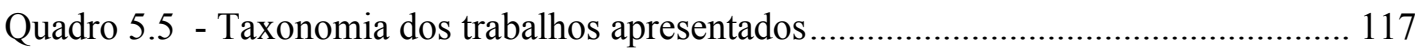

Quadro 6.1 - Respostas obtidas para as entrevistas com os motoristas (Pergunta 1) .......... 139

Quadro 6.2 - Respostas obtidas para as entrevistas com os motoristas (Pergunta 2) .......... 140

Quadro 6.3 - Respostas obtidas para as entrevistas com os motoristas (Pergunta 3) .......... 140

Quadro 6.4 - Respostas obtidas para as entrevistas com os motoristas (Pergunta 4).......... 141

Quadro 6.5 - Respostas obtidas para as entrevistas com os motoristas (Pergunta 5) .......... 141

Quadro 6.6 - Respostas obtidas para as entrevistas com os motoristas (Pergunta 6) .......... 142

Quadro 6.7 - Respostas obtidas para as entrevistas com os motoristas (Pergunta 7) .......... 142

Quadro 6.8 - Respostas obtidas para as entrevistas com os motoristas (Pergunta 8) .......... 143

Quadro 6.9 - Respostas obtidas para as entrevistas com os motoristas (Pergunta 9) .......... 143

Quadro 6.10 - Respostas obtidas dos motoristas diante dos diagramas apresentados......... 147

Quadro 6.11 - Probabilidades adotadas para a escolha das alternativas no fluxo de

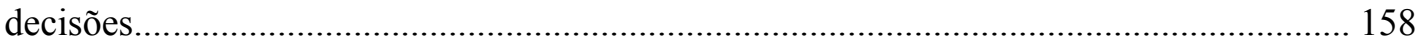

Quadro 7.1 - Critérios para escolha do simulador ........................................................... 160

Quadro 7.2 - Métodos de coleta adotado para a determinação dos dados necessários à modelagem do sistema viário 161 
Quadro 7.3 - Métodos de coleta adotados para a determinação dos dados necessários à

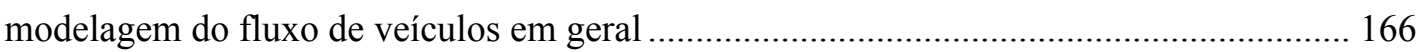

Quadro 7.4 - Dimensões dos tipos de veículos de passeio adotados na modelagem ........... 170

Quadro 7.5 - Características dos tipos de veículos de carga adotados na modelagem........ 172

Quadro 7.6 - Estratégias das decisões de rota dinâmica para a busca por uma vaga de

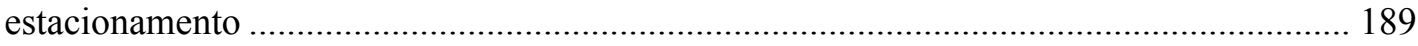

Quadro 7.7- Estratégias para as decisões de rota dinâmica para a segunda tentativa de busca

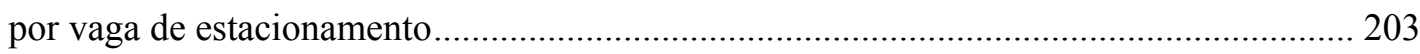

Quadro 7.8 - Estratégias da modelagem de decisões de rota dinâmica para rotas que incluem

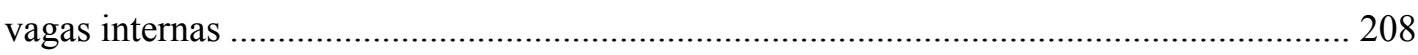

Quadro 8.1 - Decisões de estacionamento dos veículos do cenário base (situação

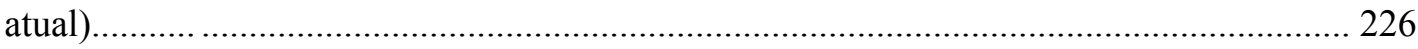

Quadro 8.2 - Decisões de estacionamento dos veículos do cenário alternativo 1

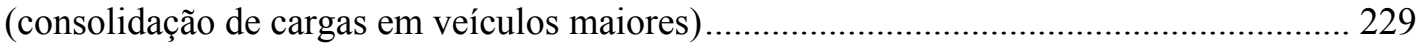




\section{LISTA DE TABELAS}

Tabela 5.1 - Impactos nos quilômetros percorridos e nos tempos de viagem dos veículos de carga. 91

Tabela 6.1 - Dados de entrega semanal e número de funcionários, obtidos nas entrevistas nos estabelecimentos 135

Tabela 6.2 - Valores dos coeficientes de Pearson por classe de estabelecimento 150

Tabela 7.1 - Comparação entre os valores reais e simulados das variáveis de calibração (volume de veículos e velocidades) - primeira iteração 180

Tabela 7.2 - Comparação entre os valores reais e simulados das variáveis de calibração (volume de veículos e velocidades) - segunda iteração 182

Tabela 7.3 - Velocidades desejadas adotadas para os veículos de carga...... 191

Tabela 8.1 - Número de veículos resultantes, necessários para realizar 148 entregas ........ 224

Tabela 8.2 - Rotas de entrega dos veículos do cenário base (situação atual) 225

Tabela 8.3 - Rotas de entrega dos veículos do cenário alternativo 1 (consolidação de cargas em veículos maiores)

Tabela 8.4 - Velocidades médias dos veículos para o cenário base (situação atual) e situações onde ocorre a interferência de uma veículo de carga (em destaque) 235

Tabela 8.5 - Velocidades médias dos veículos para o cenário alternativo (consolidação de cargas em veículos maiores) e situações onde ocorre a interferência de um veículo de carga (em destaque) 236

Tabela 8.6 - Velocidades médias dos veículos para o cenário alternativo 2 (vagas exclusivas para carga e descarga) e situações onde ocorre a interferência de uma veículo de carga (em destaque)

Tabela 8.7 - Comprimentos máximos de fila para o cenário base (situação atual) e situações onde ocorre a interferência de uma veículo de carga (em destaque) 240

Tabela 8.8 - Comprimentos máximos de fila para o cenário alternativo 1 (consolidação de cargas em veículos maiores) e situações onde ocorre a interferência de uma veículo de carga (em destaque) 
Tabela 8.9 - Comprimentos máximos de fila para o cenário alternativo 2 (vagas exclusivas para carga e descarga) e situações onde ocorre a interferência de uma veículo de carga (em destaque) 242

Tabela 8.10 - Resultados para o desempenho dos veículos de carga durante as rotas de entrega 246

Tabela 8.11 - Parâmetros adotados para o cálculo das emissões de $\mathrm{CO}_{2}$ 248

Tabela 8.12 - Resultados para as emissões de $\mathrm{CO}_{2}$ 249

Tabela A.1 - Dados coletados durante as observações das entregas 266

Tabela A.2 - Dados coletados durante as observações das entregas do shopping center.... 297 Tabela A.3 - Probabilidades de entrega na semana (por classe de estabelecimento e grupo de produtos) 311

Tabela A.4 - Probabilidades de entrega no período da simulação 312

Tabela A.5 - Probabilidades de transporte (tipo de veículo - grupo de produtos). 312

Tabela A.6 - Tamanho médio da entrega (por classe de estabelecimento e grupo de produtos) 313

Tabela A.7 Tempo médio de duração da entrega (por classe de estabelecimento e grupo de produtos) 314

Tabela B.1 - Parâmetros da regressão logística 315

Tabela B.2 - Resultado da regressão logística para a pergunta 1 315

Tabela B.3 - Resultado da regressão logística para a pergunta 2 316

Tabela B.4 - Resultado da regressão logística para a pergunta 3 316

Tabela B.5 - Resultado da regressão logística para a pergunta 4 317

Tabela B.6 - Resultado da regressão logística para a pergunta 5 317

Tabela B.7 - Resultado da regressão logística para a pergunta 6 318

Tabela B.8 - Resultado da regressão logística para a pergunta 7 318

Tabela B.9 - Resultado da regressão logística para a pergunta 8

Tabela B.10 - Resultado da regressão logística para a pergunta 9 319

Tabela B.11 - Resultado da regressão logística para o cenário A do diagrama 320

Tabela B.12 - Resultado da regressão logística para o cenário B do diagrama 320 
Tabela B.13 - Resultado da regressão logística para o cenário C do diagrama.................... 320

Tabela B.14 - Resultado da regressão logística para o cenário D do diagrama ................... 320

Tabela B.15 - Resultado da regressão logística para o cenário E do diagrama .................... 321

Tabela B.16 - Resultado da regressão logística para o cenário F do diagrama .................... 321

Tabela D.1 - Contagem de veículos nas seções de entrada da área de simulação (input de

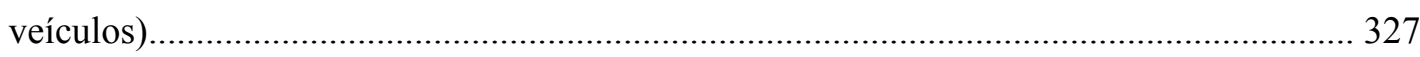

Tabela D.2 - Porcentagem dos movimentos de giro nas interseções da área de simulação 328

Tabela D.3 - Registro das velocidades praticadas e velocidades (desejadas) adotadas para as

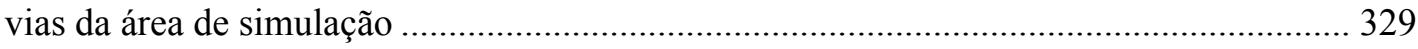

Tabela D.4 - Registro da ocupação das vagas de estacionamento da área de simulação .... 330 Tabela D.5 - Valores adotados para a ocupação das vagas de estacionamento da área de simulação 331

Tabela D.6 - Registro da ocupação das vagas de estacionamento da área de simulação (vagas de carga e descarga) 331

Tabela D.7 - Nova contagem de veículos nas seções de entrada da área de simulação durante a calibração do modelo (input de veículos) 331

Tabela E.1 - Velocidades declaradas pelos motoristas dos veículos de carga 332 


\title{
1. INTRODUÇÃO
}

\subsection{CARACTERIZAÇÃO E RELEVÂNCIA DO PROBLEMA}

A distribuição urbana de cargas, ou seja, o transporte e a entrega de produtos dentro dos limites da cidade, constitui uma operação de grande importância, fundamental para a realização da maioria das atividades econômicas e sociais que se estabelecem na área urbana.

\begin{abstract}
Para os habitantes da cidade, abastece os estabelecimentos comerciais e os espaços de trabalho e de lazer, realiza a entrega de correspondências e de produtos a domicílio, fornece os meios para o descarte de lixo, e assim por diante. Para as empresas localizadas dentro dos limites da cidade, forma uma ligação vital entre seus fornecedores e seus clientes (BENJELLOUN; CRAINIC, 2009, p. 45, tradução livre).
\end{abstract}

No entanto, ao mesmo tempo em que exerce papel fundamental no funcionamento da cidade, a distribuição de cargas é também causadora de distúrbios à população urbana. Os veículos de carga competem pela capacidade das vias com os veículos coletivos e particulares de transporte de passageiros e, assim, contribuem para a formação dos congestionamentos e para a degradação da qualidade do ar, além da poluição sonora e visual (FIGLIOZZI, 2007; PATIER; BROWNE, 2010). Os efeitos negativos causados pelos veículos de carga acabam sendo potencializados devido a algumas de suas características e condições operacionais: as maiores dimensões, as velocidades reduzidas e o menor poder de aceleração e frenagem dos caminhões fazem com que a sua presença no tráfego cause maiores transtornos quando comparados aos automóveis e outros veículos menores (IOANNOU; CHASSIAKOS, 2001).

Até quando estacionados os veículos de carga podem causar transtornos. Devido à falta de espaços reservados para as operações de carga e descarga desses veículos, sejam eles espaços pertencentes aos próprios estabelecimentos comerciais ou vagas públicas regulamentadas, é comum ver esses veículos estacionados em locais proibidos, em filas duplas, ou até mesmo em cima de calçadas. $\mathrm{O}$ estacionamento irregular é uma prática que prejudica a circulação de outros veículos e de pedestres, além de aumentar as chances de acidentes (HAN et al., 2005). 
A distribuição urbana de cargas torna-se então uma questão crucial no planejamento da cidade. Especialistas em transporte e urbanistas têm estudado os desafios relacionados à organização eficiente dos movimentos de cargas dentro do ambiente urbano, uma vez que os problemas decorrentes dessa atividade não devem desaparecer tão cedo (STATHOPOULOS et al., 2012). Isso porque o número de veículos de carga que se movimentam nas áreas urbanas é crescente, devido, principalmente, às atuais práticas de produção e distribuição, baseadas em baixos níveis de estoque e na pontualidade das entregas, e no crescimento expressivo do comércio eletrônico, o qual gera volumes significativos de entregas individuais e dispersas (BENJELLOUN; CRAINIC, 2009).

É fácil concluir, portanto, que os problemas originados da distribuição urbana de cargas tendem a aumentar à medida que crescem as áreas urbanas e suas populações. Em grandes cidades como São Paulo e Rio de Janeiro, além da alta demanda pelo transporte de cargas, os elevados níveis de congestionamento e a crescente quantidade de estabelecimentos comerciais de pequeno porte, podem aumentar o número de viagens realizadas e os quilômetros percorridos diariamente pelos veículos de carga, potencializando os impactos negativos causados pelos mesmos.

$\mathrm{Na}$ busca por amenizar esses impactos, diversos municípios no Brasil vêm intensificando a implementação de medidas que restringem a circulação de veículos de carga em algumas áreas da cidade. A Prefeitura de São Paulo, por exemplo, desde 2008, restringe a circulação de caminhões em uma área de aproximadamente $100 \mathrm{~km}^{2}$, incluindo a Marginal Tietê e a Marginal Pinheiros. Já no Rio de Janeiro e em Salvador, além da proibição à circulação de veículos de carga em determinadas áreas da cidade, são também restritas as operações de carga e descarga.

Tais medidas, embora necessárias, acabam afetando a produtividade dos agentes logísticos e a dinâmica do comércio na cidade e devem, portanto, contar com um planejamento adequado, o qual inclua a realização de estudos onde se avaliem os impactos de diferentes alternativas acerca do objetivo pretendido, diminuindo, assim, as chances de benefícios pouco duradouros e efeitos secundários não esperados (VASCONCELOS, 2004). Nesse contexto, os modelos de simulação de tráfego assumem um papel importante no processo de decisão, já que procuram reproduzir o sistema de transportes e permitem modelar, observar e quantificar os impactos decorrentes das alterações impostas pela medida em avaliação. 
É importante, porém, que esses impactos sejam considerados em todos os níveis da cidade, desde o nível macro, mais agregado, como as alterações nos índices de lentidão das vias expressas, resultado da proibição de circulação de caminhões, até o nível micro, mais desagregado, como a interferência causada no fluxo de veículos em uma determinada via devido à manobra de estacionamento de um veículo de carga. Isso porque as operações da distribuição urbana de cargas vão além da circulação de caminhões nas principais vias. Elas acontecem localmente, ao nível micro da cidade, onde quer que haja um estabelecimento comercial ou uma residência que demande por um produto, e englobam atividades que vão desde a procura por uma vaga de estacionamento até a disposição de produtos sobre a calçada, em frente ao cliente.

A avaliação de medidas deve então considerar um modelo de simulação que seja capaz de representar a distribuição urbana de cargas nesse nível de detalhe, englobando as diversas atividades que compõem essa operação e estimando impactos locais. Nesse sentido, a microssimulação de tráfego torna-se promissora, uma vez que permite um alto nível de detalhe na modelagem e na observação do comportamento dos veículos, tratando-os de forma inteiramente individualizada. Além disso, sua capacidade de representar os fluxos de tráfego em ambientes virtuais bi ou tridimensionais garante a visualização do sistema e dos movimentos dos veículos, tornando seus resultados facilmente compreensíveis, inclusive, a não especialistas.

\subsection{OBJETIVO DO TRABALHO}

O presente trabalho tem como objetivo propor um procedimento que dê subsídios ao desenvolvimento de uma metodologia para a utilização da microssimulação de tráfego na avaliação de medidas voltadas à distribuição urbana de cargas, considerando os possíveis impactos locais decorrentes das atividades que compõem essa operação.

\subsection{ORGANIZAÇÃO DO TRABALHO}

Esta seção apresenta uma descrição da organização e da estrutura do presente trabalho. 
O capítulo 2 caracteriza a distribuição urbana de cargas a partir das definições e dos conceitos de diferentes autores, contextualizando-a no sistema de distribuição de cargas. São apresentados os elementos que compõem essa operação, assim como os agentes envolvidos, e uma relação de seus possíveis impactos negativos na área urbana.

No capítulo 3 são discutidas algumas das características das grandes cidades e como as mesmas podem afetar as operações da distribuição de cargas. A discussão mostra que os impactos decorrentes das atividades da distribuição urbana dependem de uma série de fatores relacionados ao ambiente onde ela se dá, e reforça a necessidade de um processo de avaliação de medidas que considere a quantificação de impactos locais.

As regulamentações em vigência nos principais municípios do Brasil são relacionadas no capítulo 4, com destaque para aquela do munícipio de São Paulo e sua evolução desde a primeira restrição ao transporte de cargas, em 1982.

O capítulo 5 aborda a importância da avaliação de medidas voltadas à distribuição urbana de cargas, em especial durante a fase de planejamento, e traz uma revisão dos principais trabalhos da literatura que apresentam modelos desenvolvidos para essa avaliação.

O objetivo do capítulo 6 é apresentar o procedimento proposto pelo presente trabalho. Nele são explicadas as coletas de dados e os modelos que compõem esse procedimento, os quais fornecem os parâmetros necessários à modelagem dos movimentos dos veículos de carga no software de microssimulação.

A modelagem dos movimentos dos veículos de carga, assim como as outras etapas que completam a modelagem do ambiente de simulação são exibidas no capítulo 7. Nele são relacionadas e discutidas as limitações do software de microssimulação escolhido no que diz respeito à representação dos movimentos dos veículos de carga.

O capítulo 8 apresenta os três cenários de simulação e os resultados dos experimentos computacionais. O objetivo é avaliar se os resultados fornecidos pela microssimulação permitem a identificação e a quantificação dos impactos locais gerados pelos veículos de carga. 
As conclusões e recomendações deste trabalho são apresentadas no Capítulo 9, seguidas das referências bibliográficas utilizadas.

Finalmente, os Anexos A, B, C, D e E contêm as infomações complementares a respeito das coletas de dados realizadas. 


\section{DISTRIBUIÇÃO URBANA DE CARGAS}

Este capítulo tem por finalidade caracterizar a distribuição urbana de cargas, apresentando algumas das definições da literatura, assim como os movimentos de carga, os elementos, e os agentes que a compõem.

\subsection{DEFINIÇÕES DA DISTRIBUIÇÃO URBANA DE CARGAS}

Constantemente, diferentes fluxos de cargas entram, cruzam e deixam as áreas urbanas, incluindo bens de consumo, materiais de construção, resíduos, correspondências, dentre outros (DABLANC, 2007).

Não existe uma definição exata para o transporte urbano de cargas. Ogden (1992, p. 14, tradução livre) é conciso ao defini-lo como "a movimentação de coisas (distintamente de pessoas) para, a partir de, dentro de e através de áreas urbanas”.

Alvarenga e Novaes (2000) distinguem dois tipos predominantes do transporte urbano de carga: (i) a transferência, a qual consiste no deslocamento entre dois pontos interiores à cidade e (ii) a distribuição ou entrega, caracterizada pelo atendimento de vários destinos em uma única viagem de um mesmo veículo, ou a coleta de produtos a partir de fontes diversas, para um depósito central. Ainda segundo os autores, enquanto a transferência caracteriza um fluxo direto entre dois pontos, no qual geralmente a capacidade do veículo é completamente utilizada, os fluxos da distribuição estão sujeitos a um roteiro, de acordo com os destinos a serem atendidos; logo, estão mais vulneráveis aos meios de circulação, às estratégias de estoque, às operações de carga e descarga e às frequências e prazos de entrega.

Allen et al. (2000a), por sua vez, trazem uma definição mais ampla, a qual inclui:

- Todos os tipos e tamanhos de veículos de entrega (desde vans até caminhões pesados) e outros veículos motorizados (incluindo carros, motocicletas, etc.) utilizados para a coleta e entrega de produtos em estabelecimentos na área urbana; 
- Todos os tipos de movimentação de veículos de entrega, de e para estabelecimentos comerciais urbanos, incluindo transferências de produtos entre estabelecimentos, entregas de materiais auxiliares para uso do próprio estabelecimento (como artigos de papelaria, sacos plásticos, material de escritório, lâmpadas, etc.), coletas e entregas de dinheiro, coletas de resíduos e entregas a domicílio, feitas a partir dos estabelecimentos urbanos para seus clientes;

- Viagens de veículos prestadores de serviços e outros veículos essenciais para o funcionamento dos estabelecimentos comerciais urbanos.

No ambiente urbano, pode-se dizer que predominam as viagens de múltiplas paradas (atendimento a vários destinos em uma única viagem de um mesmo veículo), ou seja, as atividades de distribuição. Neste trabalho, então, será adotado o termo "distribuição urbana de cargas" para se referir à operação de entrega de produtos em estabelecimentos comerciais localizados na área urbana da cidade. Tal operação compreende as atividades que vão desde o transporte desses produtos, no veículo de carga, passando pelo descarregamento das unidades a serem entregues em cada parada do veículo, até os procedimentos administrativos que concretizam a entrega ao cliente (como a emissão de nota fiscal, por exemplo).

\subsection{SISTEMAS DA DISTRIBUIÇÃO URBANA DE CARGAS}

A cadeia de suprimentos é um conjunto de atividades funcionais (transporte, controle de estoques, etc.) [...]. Uma vez que as fontes de matérias primas, fábricas e pontos de venda em geral não têm a mesma localização e o canal representa uma sequência de etapas de produção, as atividades logísticas podem ser repetidas várias vezes até um produto chegar ao mercado (BALLOU, 2006, p. 29).

Em uma visão simplificada da cadeia de suprimentos (Figura 2.1), o fluxo de produtos tem início nos fornecedores de matérias primas, passando pela manufatura, distribuidores, varejistas e consumidores. 


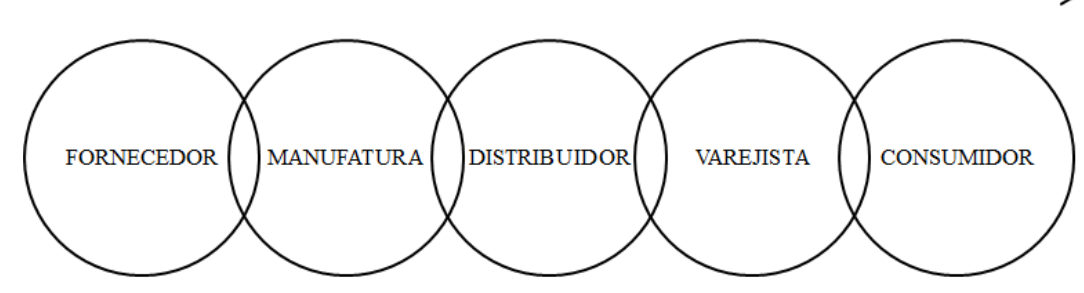

Figura 2.1 - Etapas da cadeia de suprimentos

Fonte: Adaptado de CHRISTOPHER ${ }^{1}$ (2002 apud FACHINNI, 2006, p. 23)

As etapas da cadeia de suprimentos que ocorrem no ambiente urbano, caracterizando a distribuição urbana de cargas, geralmente envolvem o transporte de produtos a partir do distribuidor, com destino aos estabelecimentos varejistas que atendem ao mercado consumidor da área urbana. O distribuidor, nesse caso, é caracterizado como o ponto de abastecimento dos veículos que realizam as entregas urbanas, e pode assumir diferentes papéis na cadeia de suprimentos, representando o centro de distribuição do próprio estabelecimento varejista, um distribuidor atacadista, ou até mesmo uma instalação da própria manufatura, de onde partem seus produtos diretamente aos seus clientes, o que, na prática, excluiria da cadeia a etapa do distribuidor (FACHINNI, 2006).

As etapas da distribuição urbana de cargas podem, ainda, englobar diferentes processos entre o distribuidor e os estabelecimentos recebedores. De acordo com o Portal (2003), o fluxo de produtos dentro do transporte de cargas está dividido em dois tipos de processos logísticos: (i) sistemas de etapa única e (ii) sistemas de múltiplas etapas.

Nos sistemas de etapa única (Figura 2.2) o fluxo de produtos entre a origem (ponto de abastecimento) e o destino (ponto de recebimento) é direto. Esse sistema apresenta a vantagem de não haver ruptura entre a origem e o destino, não sendo necessário nenhum tipo de estoque ou processo de movimentação adicionais.

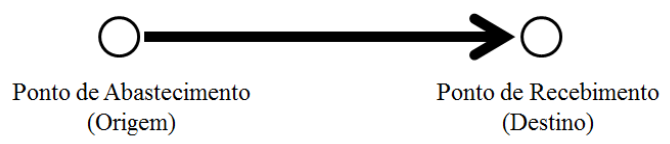

Figura 2.2 - Sistema de etapa única Fonte: Adaptado de PORTAL (2003), p. 12 
Nos sistemas de múltiplas etapas (Figura 2.3) o fluxo de produtos entre a origem e o destino é indireto. O fluxo é interrompido em pelo menos um momento, quando ocorre o processo de consolidação (várias cargas diferentes são consolidadas em uma única carga) ou desconsolidação, também conhecido como fracionamento (divisão da carga em cargas menores).

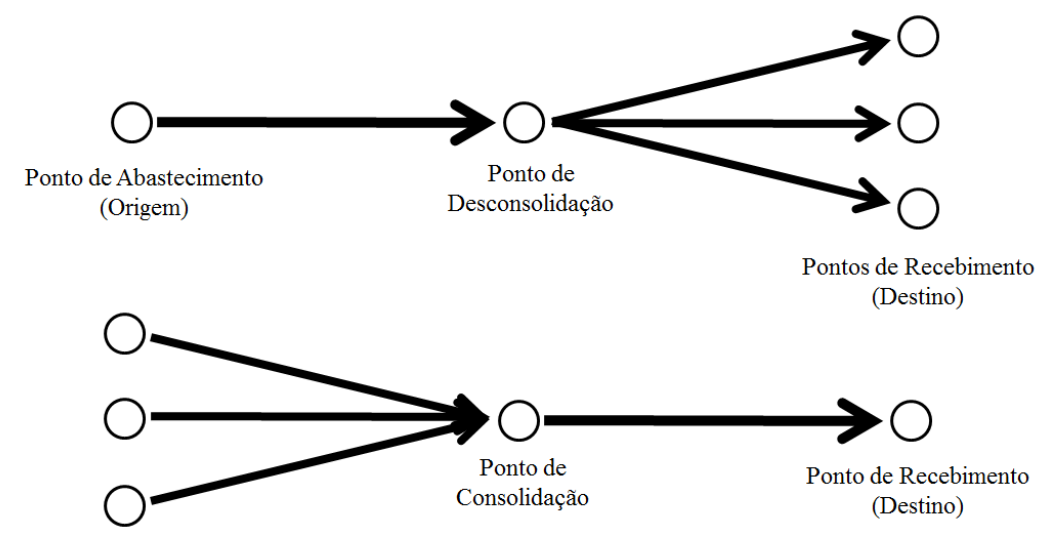

Pontos de Abastecimento

(Origem)

Figura 2.3 - Sistema de múltiplas etapas

Fonte: Adaptado de PORTAL (2003), p. 13

Existe ainda o sistema combinado (Figura 2.4), no qual, simultaneamente, fluxos diretos e indiretos são possíveis. Isso ocorre, por exemplo, em uma situação na qual a distância entre a origem e o destino seja muito grande, impossibilitando o atendimento de determinados pontos de recebimento num prazo aceitável, a contar do momento da realização do pedido pelo cliente.

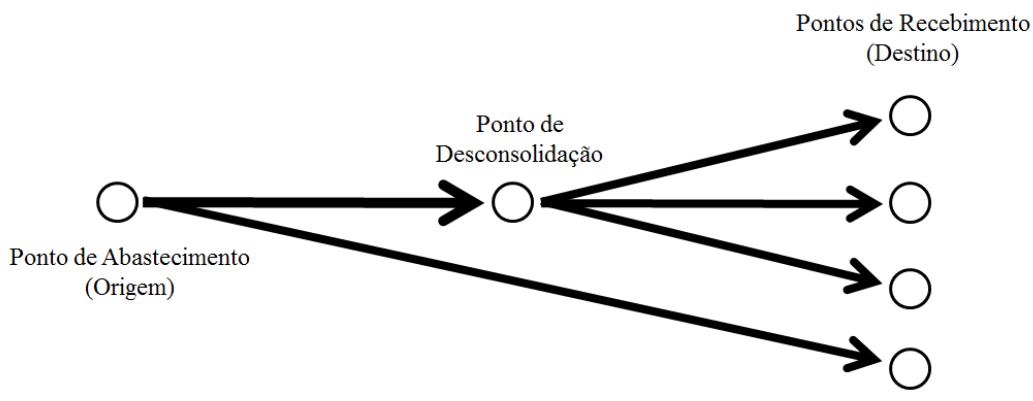

Figura 2.4 - Sistema combinado Fonte: Adaptado de PORTAL (2003), p. 13

Allen et al. (2000b) definem, ainda, os padrões de viagens que os veículos de carga realizam no ambiente urbano, de acordo com sua origem e destino: 
- Origem fora da área urbana e destinos de entrega dentro da área urbana;

- Origem e destinos de entrega dentro da área urbana;

- Origem e destinos de entrega fora da área urbana, sendo necessário atravessar a cidade;

- Coleta na área urbana com destinos de entrega também dentro da área urbana;

- Coleta na área urbana com destinos de entrega fora da área urbana;

- Destino fora da área urbana, após entrega dentro da área urbana;

- Origem na área urbana, para coletas fora da área urbana.

Dentre os padrões de viagens definidos por Allen et al. (2000b), pode-se ainda considerar o números de paradas que as caracterizam, conforme já apontado por Alvarenga e Novaes (2000), porém independentemente da localização das origens e destinos (dentro ou fora da área urbana). Definem-se então: (i) as viagens de parada única (Figura 2.5), na qual o veículo é carregado em um depósito ou centro de distribuição, de onde parte a um único destino de entrega, retornando à origem para um novo carregamento, e (ii) as viagens de paradas múltiplas (Figura 2.6), mais comumente chamadas de viagens multiparadas, na qual o mesmo veículo atende a vários destinos em uma única viagem, sendo que cada estabelecimento de destino recebe uma parte da carga do veículo, o qual retorna à origem ao términos das entregas.

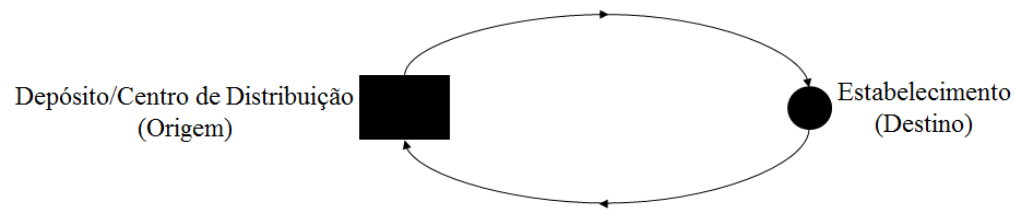

Figura 2.5 - Representação da viagem de parada única

Fonte: Adaptado de ALLEN et al. (2000b), p. 26

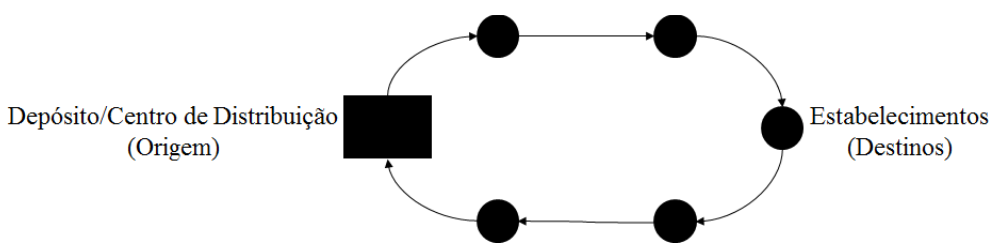

Figura 2.6 - Representação da viagem de paradas múltiplas

Fonte: Adaptado de ALLEN et al. (2000b), p. 26

Embora respondam pela maior parte das entregas realizadas na área urbana, os estabelecimentos varejistas não são os únicos geradores de viagens de veículos de carga. Além das entregas a domicílio feitas a partir dos estabelecimentos comerciais para seus 
clientes, conforme consta na definição apresentada por Allen et al. (2000a), as entregas feitas a partir de centros de distribuição diretamente aos consumidores também fazem parte da distribuição urbana de cargas. Tais entregas provém de compras realizadas pela internet, ou seja, através do comércio eletrônico ou em estabelecimentos que não possuem entrega imediata de todos seus produtos, como por exemplo as lojas de móveis, caso em que o produto é enviado diretamente ao consumidor sem passar pela loja física onde a compra foi realizada.

\subsection{ELEMENTOS E AGENTES DA DISTRIBUIÇÃO URBANA DE CARGAS}

Muitos são os elementos que compõem a distribuição de cargas. Ma (2001) apresenta as características dos elementos da cadeia de carga/descarga e os divide em dez diferentes categorias:

- Receptores (comerciantes, lojistas, etc.) - diferem de acordo com suas funções, tamanhos e localização;

- Veículos de entrega - variam com o tamanho (geralmente, pequenos e médios caminhões se encarregam das entregas nos centros urbanos) e tipo de propulsão (pode-se fazer pequenas entregas a pé, em bicicletas ou em carros de passeio);

- Vias - a classificação varia com a função (vias expressas, arteriais, coletoras e locais), capacidade e tipo de pavimento; ciclovias e calçadões (para pedestres) também são considerados;

- Estacionamento - pode ser aberto (em ruas) ou fechado (área delimitada), público ou privado, e pode funcionar com janelas de tempo específicas (durante o dia, por exemplo, pode abrigar mais de um tipo de veículo);

- Percurso - tem forte influência nos tempos e velocidades, bem como na conveniência de acessibilidade; 
- Carga - diferentes tipos de cargas exigem distintos padrões de acondicionamentos; suas formas determinam a facilidade de carregamento;

- Motoristas - devem procurar respeitar os prazos de entrega; no caso de algum imprevisto, a boa comunicação entre o motorista e a base se faz imprescindível; o bom treinamento é também fundamental;

- Carregadores - dependendo da quantidade e do tipo de mercadoria são necessários para levar a carga do ponto de descarga até o destino (quando o próprio motorista não é capaz);

- Equipamentos usados na entrega - incluem as ferramentas que são usadas para descarregar e levar a carga até o destino (carrinhos de mão, contêineres, reboques, etc.); a escolha do conjunto de equipamentos adequados dependerá do tipo de carga e do percurso entre o veículo e o ponto de entrega.

Alguns dos elementos apresentados estão diretamente ligados entre si. Características da carga, como peso, volume, dimensões, estado físico, compatibilidade com outras cargas e sua fragilidade e perecibilidade definem os tipos de veículos e equipamentos necessários ao seu transporte, por exemplo, os veículos refrigerados que realizam o transporte de produtos perecíveis (ZIONI, 2009).

Observações realizadas em campo têm mostrado ainda que, no ambiente urbano, as características dos destinos das cargas e a regulamentação vigente nas áreas onde os mesmos estão localizados também influenciam na escolha do tipo de veículo. Em geral, veículos maiores são utilizados para as entregas realizadas a estabelecimentos de grande porte, enquanto os pequenos e médios estabelecimentos necessitam de veículos menores, como vans e utilitários. Isso ocorre porque os estabelecimentos de grande porte normalmente estão aptos a receber suas entregas em horários fora da restrição à circulação de veículos maiores, ou estão localizados em áreas não afetadas por ela; além disso, observa-se que muitos deles fazem parte de grandes redes, as quais possuem centros de distribuição próprios, onde produtos de diferentes fornecedores são consolidados em um único veículo. Já os estabelecimentos de pequeno e médio porte, normalmente, estão localizados nas áreas mais centrais da cidade, onde os veículos maiores muitas vezes são proibidos de circular durante 
o horário comercial, e dificilmente estão aptos a receber suas entregas em horários alternativos, uma vez que isso geraria um custo adicional, por exemplo, com a contratação de funcionários. Pode-se dizer então que os caminhões pequenos, vans e utilitários exercem um papel importante na entrega urbana (OCDE, 2003).

O tempo necessário para realizar a atividade de distribuição de cargas também pode ser subdividido em vários componentes: tempo de carregamento do veículo, tempo de viagem desde a origem (centro de distribuição ou estabelecimento) até o cliente (estabelecimento ou consumidor), tempo procurando o local para estacionamento, tempo estacionando o veículo próximo ao cliente, tempo de descarregamento, tempo de contato com o cliente e tempo da viagem de retorno (SINAY et al., 2004). Allen et al. (2000b) identificam, ainda, dois fatores chaves que determinam o tempo da distribuição de cargas em uma área urbana: (i) as janelas de entrega na área onde o estabelecimento recebedor da carga está localizado (devido a restrições à circulação e/ou às operações de carga e descarga) e (ii) os horários em que o estabelecimento está preparado para receber a carga a ser entregue.

Além do tempo da distribuição de cargas e dos padrões de viagem, apresentados anteriormente na seção 2.2, Allen et al. (2000b) identificam outras características das atividades da distribuição urbana de cargas, ligadas aos estabelecimentos recebedores. São elas:

- Sistema de abastecimento adotado (a partir de um único ou de vários distribuidores);

- Quantidade de produtos entregues;

- Frequência das entregas;

- Tamanho dos veículos;

- Distância percorrida pelos veículos;

- Fator de carregamento dos veículos;

- Tempo de permanência dos veículos durante o carregamento e descarregamento.

A distribuição urbana de cargas se torna ainda mais complexa devido ao grande número de agentes que nela estão envolvidos, os quais diferem em seus interesses, muitas vezes conflitantes, recursos e possibilidades, bem como em seu poder de decisão (KANT et al., 2012; STATHOPOULOS et al., 2012). O termo "agentes" empregado neste trabalho, refere-se a todos aqueles envolvidos/interessados na distribuição urbana de cargas. 
Baseado nos trabalhos de Sinay et al. (2004) e Ruesch e Glücker (2001), esses agentes englobam:

- Fabricantes/produtores da carga - interesse principal é a sua colocação e permanência no mercado, o que pode ser obtido através da redução do preço final do produto, mas mantendo a margem de lucro para a empresa;

- Varejistas - são um dos pontos de contato das transportadoras e dos operadores logísticos, cuja preocupação é a de obter os produtos na hora marcada, com boa qualidade e a um preço acessível, pois o não atendimento dessas condições pode causar aumento nos estoques, perda de vendas potenciais e até mesmo a perda definitiva do cliente para um concorrente;

- Empresas transportadoras - ligam os fabricantes aos varejistas, e buscam fretes compensadores e qualidade de atendimento a seus clientes, de forma que possam ter competitividade no mercado;

- Autoridades locais - têm por obrigação regulamentar a circulação dos veículos de carga, visando proteger e atender às expectativas da população (redução de ruídos, da poluição atmosférica, de acidentes, etc.), mantendo a cidade atrativa para seus residentes e visitantes sem prejudicar a economia local, a qual depende da logística de distribuição pra crescer e competir;

- População (residentes e visitantes) - demanda bens e serviços, busca disponibilidade e variedade de produtos nas prateleiras dos estabelecimentos e maior facilidade de circulação nos grandes centros urbanos, assim como a minimização dos distúrbios causados pelo transporte urbano de cargas.

À exceção das autoridades locais, que têm um papel gerenciador no transporte urbano de cargas, todos os agentes fazem uso dos mesmos recursos disponíveis nas áreas urbanas, o que torna difícil o desenvolvimento de soluções sustentáveis, já que existe uma grande variedade de percepções do problema, assim como de soluções para o mesmo (KANT et al., 2012). 


\subsection{IMPACTOS NEGATIVOS NO AMBIENTE URBANO DECORRENTES DA DISTRIBUIÇÃO URBANA DE CARGAS}

Das operações da distribuição urbana de cargas decorrem alguns impactos negativos para o ambiente urbano e para as pessoas que nele vivem, provenientes tanto da circulação dos veículos de carga nas vias, como de suas atividades de carga e descarga (ALLEN et al., 2000b).

De acordo com a UK Round Table on Sustainable Development ${ }^{1}$ (1996, apud ALLEN et al., $2000 \mathrm{~b}$ ) e Allen et al. (2000b), esses impactos negativos podem ser agrupados em quatro categorias, a saber:

- Ambientais:

- uso de energia não renovável;

- poluição do ar, proveniente de emissões de gases como monóxido de carbono, dióxido de enxofre, compostos orgânicos e partículas voláteis;

- emissões de gases do efeito estufa;

- Sociais:

- mortes, doenças e problemas de saúde pública, decorrentes da poluição do ar;

- acidentes com outros veículos e pedestres, causando prejuízos e mortes;

- poluição sonora causada pelos veículos de carga e pelas instalações logísticas;

- vibrações causadas pelos veículos de carga, as quais podem resultar em distúrbios e danos às vias e construções adjacentes;

- intrusão visual causada pelos veículos e infraestruturas do transporte de cargas;

- outras questões relacionadas à perda de qualidade de vida, como a redução de áreas verdes no espaço urbano devido à implantação de novas infraestruturas de transporte;

- Econômicos:

- contribuição dos veículos de carga aos congestionamentos das vias urbanas;

- prejuízos dos estabelecimentos e impactos na economia local, decorrentes de ineficiências na entrega de produtos;

- custos dos impactos negativos ambientais e sociais;

\footnotetext{
${ }^{1}$ UK ROUND TABLE ON SUSTAINABLE DEVELOPMENT. Defining a sustainable transport sector. Department of the Environment, 1996, 38 p.
} 
- Operacionais:

- congestionamentos, interrupções no tráfego e obstruções aos pedestres e ciclistas, causados pelos veículos de carga enquanto os mesmos estão sendo carregados ou descarregados, estacionados ou manobrados nas vias;

- congestionamentos e interrupções no tráfego, causados pelos veículos de carga enquanto os mesmos estão entrando ou saindo do espaço de circulação das vias;

- impactos operacionais causados aos estabelecimentos comerciais devido a entregas com atraso ou não concretizadas.

Por fim, Benjelloun e Crainic (2009) afirmam que coletas e análises de dados em diferentes pesquisas confirmam que o transporte de carga em áreas urbanas são responsáveis pela geração de um grande número de viagens com uma baixa média de utilização das capacidades dos veículos, sendo que, muitas vezes, esses estão circulando vazios. 


\section{A DISTRIBUIÇÃO URBANA DE CARGAS NAS GRANDES CIDADES}

No capítulo anterior foram relacionados os possíveis impactos negativos no ambiente urbano decorrentes das atividades que compõem a distribuição de cargas. Não é possível, no entanto, atribuir esses impactos apenas a essas atividades, mas sim a uma associação dessas com um conjunto de fatores do ambiente urbano onde elas ocorrem, os quais podem definir as estratégias e práticas adotadas pela distribuição urbana de cargas.

Este capítulo, portanto, discorre sobre alguns desses fatores, considerando o ambiente de cidades brasileiras que se caracterizam como grandes aglomerações urbanas, como São Paulo e Rio de Janeiro, e como eles podem afetar as operações da distribuição urbana de cargas.

Por ser esse um assunto ainda inédito na literatura, a relação entre alguns fatores e as operações da distribuição urbana são baseadas em observações feitas em campo ${ }^{2}$, assim como na troca de informações com profissionais do ramo e pesquisadores do assunto durante uma série de workshops ${ }^{3}$ realizados até o momento.

\subsection{USO DO SOLO E DISPONIBILIDADE RESTRITA DE ESPAÇO}

A heterogeneidade do uso do solo é outra característica que pode ser observada nas áreas urbanas das metrópoles. Usando como exemplo um mapa da predominância do uso do solo na cidade de São Paulo (Figura 3.1), fica evidente a incidência do comércio em meio às outras diversas atividades que tomam lugar por toda a superfície do município. Essa heterogeneidade indica uma demanda pelo transporte de cargas e um fluxo intenso de veículos de carga espalhados por toda a cidade, podendo trazer algumas implicações às operações da distribuição urbana.

\footnotetext{
2 (i) Acompanhamento das rotas de entrega das empresas Staples (na cidade de Boston - EUA, em setembro de 2012 e na cidade de São Paulo, em outubro de 2012), Natura, Ambev (ambas na cidade de São Paulo, em outubro de 2012) e Coca-Cola (na cidade de Boston - EUA, em setembro de 2013); (ii) observação de mais de 1.000 entregas durante a etapa de coleta de dados realizada para o desenvolvimento do procedimento proposto por este trabalho.

3 (i) Megacity Logistic Workshops (realizados pelo Massachusetts Institute of Technology e pela Universidade de São Paulo na cidade de Boston - EUA em setembro de 2012 e na cidade de São Paulo em outubro de 2012); (ii) Small Store Logistics in Megacities (realizado pela Universidade de São Paulo na cidade de São Paulo em dezembro de 2012); (iii) Logística em Megacidades (realizado pela Universidade de São Paulo na cidade de São Paulo em dezembro de 2012); Megacity Logistics Workshop (realizado pela Universidade Federal do Rio de Janeiro na cidade do Rio de Janeiro em agosto de 2012).
} 


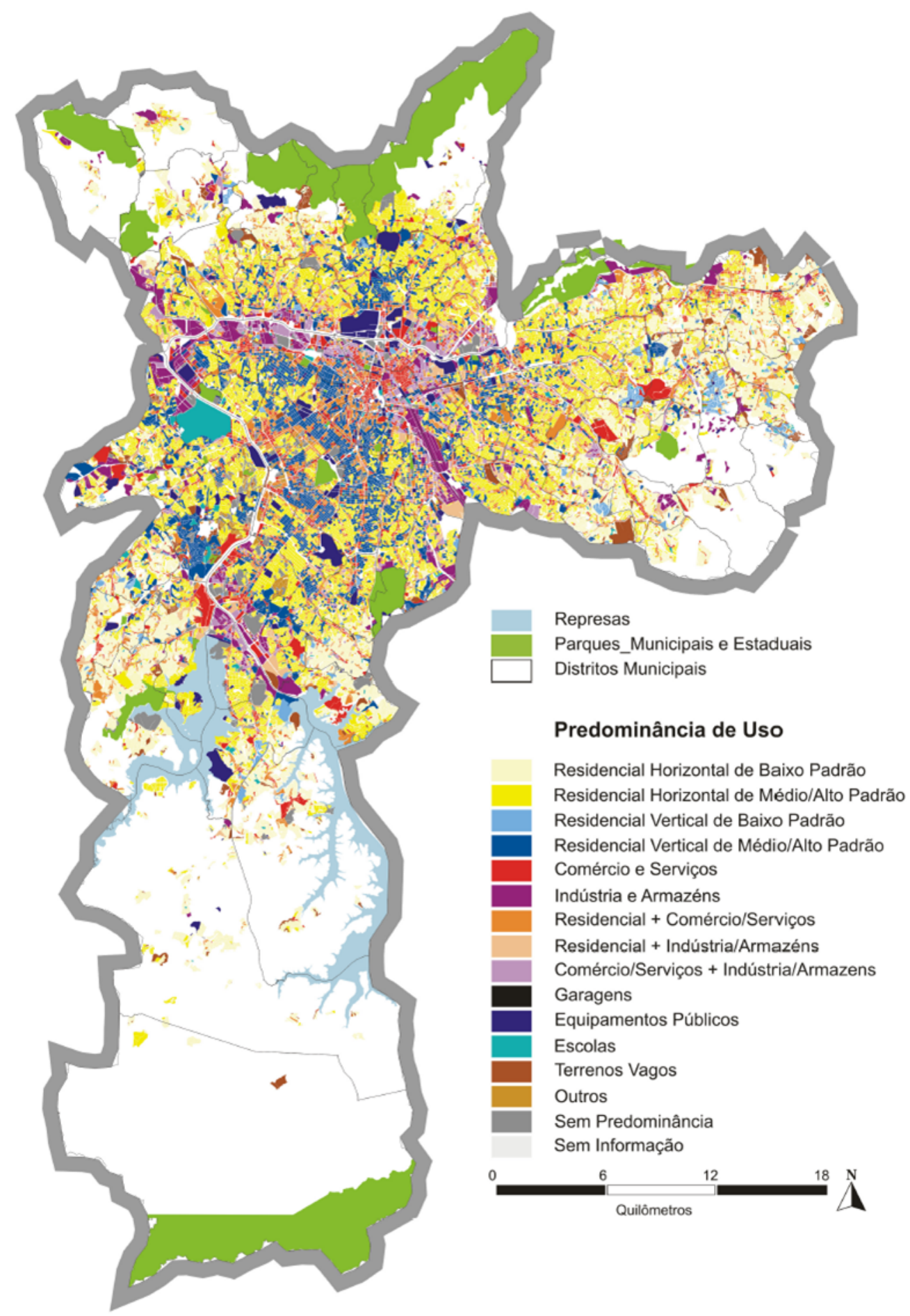

Figura 3.1 - Uso predominante do solo em 2010

Fonte: SMDU; DIPRO (2010a) 
Ainda no mesmo mapa, é possível observar uma grande concentração de indústrias e armazéns em áreas próximas às marginais e rodovias, o que é de total relevância para o transporte de cargas. Isso porque, uma vez que essas instalações geralmente são grandes geradoras e atratoras de veículos de carga transportando grandes volumes, ou seja, demandam viagens de grandes caminhões, sua localização próxima às rodovias e aos eixos viários estruturais da cidade é fundamental ao planejamento e à operação das empresas transportadoras de cargas que as atendem (ZIONI, 2009).

Algumas áreas predominantemente residenciais, por exemplo, descartam a possibilidade de serem utilizadas como opção de rota pelos veículos de carga, pois têm suas vias restritas aos caminhões em tempo integral. Ainda, no caso dessas áreas conterem um ponto de abastecimento, o acesso é permitido somente a veículos menores e, mesmo assim, portando autorização especial. Em áreas mistas, onde os estabelecimentos comerciais estão menos concentrados, o número de entregas a pé a partir do veículo estacionados tende a ser menor, ou seja, ocorrem mais deslocamentos dos veículos de carga dentro dessa área em comparação com as áreas predominantemente comerciais, onde os estabelecimentos estão mais próximos. Ainda, em áreas onde o uso do solo é compartilhado por comércio e residências pode haver um fluxo misto intenso de veículos, composto pelos veículos de carga circulando e descarregando, pelos veículos de outras áreas atraídos pelo comércio e pelos veículos pertencentes aos residentes daquela área.

O espaço restrito e oneroso pode contribuir, ainda, para a escassez de estacionamentos e vagas apropriadas para carga e descarga. O que se pode observar é que os estabelecimentos comerciais, principalmente os de pequeno porte, dificilmente possuem espaços dedicados às operações de carga e descarga dos veículos de entrega. Isso provavelmente porque a prioridade, nesse caso, deva ser em relação ao máximo aproveitamento do espaço para a área construída do próprio estabelecimento e, ainda assim, quando houver a disponibilidade de um espaço para o estacionamento de veículos, imagina-se que o mesmo deverá ser dedicado aos veículos particulares dos clientes. As implicações da escassez de vagas dedicadas à carga e descarga e espaços disponíveis para o estacionamento do veículos de carga são discutidas na próxima seção. 


\subsection{OFERTA RESTRITA DE VAGAS DE ESTACIONAMENTO}

A falta de locais apropriados e suficientes para o estacionamento dos veículos de carga, associada ao elevado número de entregas a serem realizadas em um mesmo dia, muitas vezes levam os motoristas desses veículos a estacionarem em locais proibidos (Figuras $3.2 \mathrm{e}$ 3.3), nas faixas de tráfego, muitas vezes em fila dupla (Figura 3.4), ou até mesmo sobre as calçadas (Figura 3.5). Estudos a respeito dos impactos decorrentes dessas práticas mostram que o estacionamento irregular dos veículos de carga é responsável por perdas significativas de capacidade das vias (HAN et al., 2005; HOLGUÍN-VERAS et al., 2001).

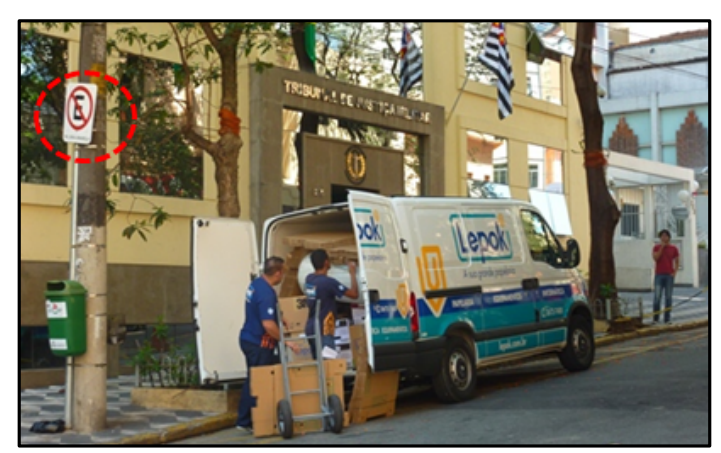

Figura 3.2 - Veículo de carga estacionado em local não autorizado Fonte: Pesquisa de campo realizada pela autora

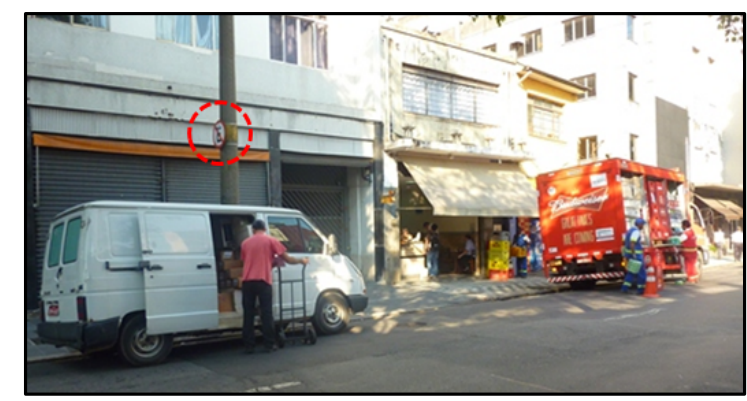

Figura 3.3 - Veículos de carga estacionados em locais não autorizados, ocupando uma das faixas de tráfego Fonte: Pesquisa de campo realizada pela autora

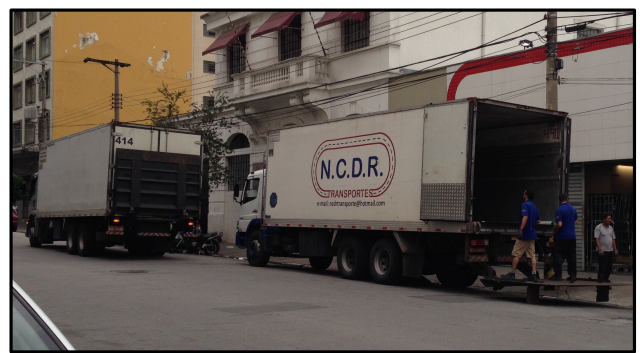

Figura 3.4 - Veículo de entrega estacionado em fila dupla, ocupando uma das faixas de tráfego Fonte: Pesquisa de campo realizada pela autora 


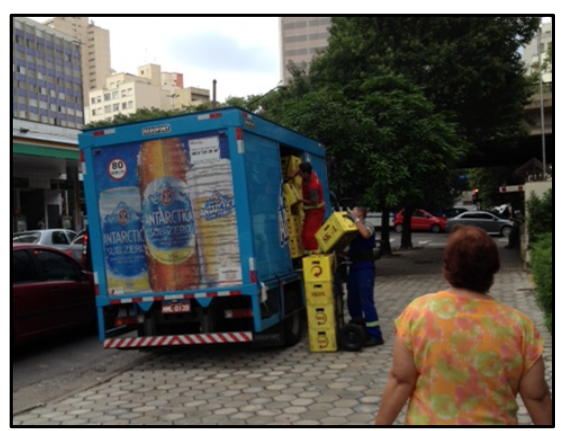

Figura 3.5 - Veículo de carga estacionado sobre a calçada Fonte: Pesquisa de campo realizada pela autora

Ma (2001) define três situações geradas pelo estacionamento dos veículos de carga:

- Sem perturbação do tráfego de passagem (Figura 3.6), na qual seis configurações podem ser encontradas: estacionamento em espaço livre [(a), (b), (c) e (d)], estacionamento em espaço livre, ocupando algum espaço do pedestre (e) e estacionamento usando parte de uma baia recuada para ônibus (f);

- Com perturbação do tráfego de passagem (Figura 3.7), com duas configurações possíveis: os veículos de carga ocupando uma faixa de tráfego completa $(\mathrm{g})$ ou parcialmente $(\mathrm{h})$;

- Com perturbação do movimento de pedestres, na qual o veículo ocupa parcialmente a calçada [Figura 3.6 (e) e Figura 3.7 (h)].

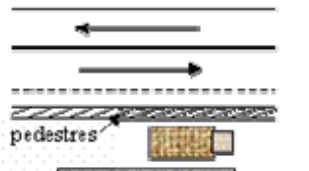

(a)

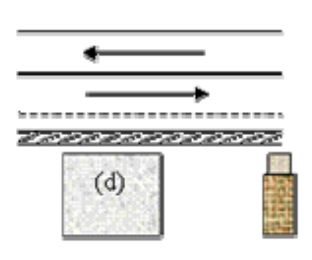

Figura 3.6 - Estacionamento de veículo de carga sem perturbação do tráfego de passagem
Fonte: MA (2011)
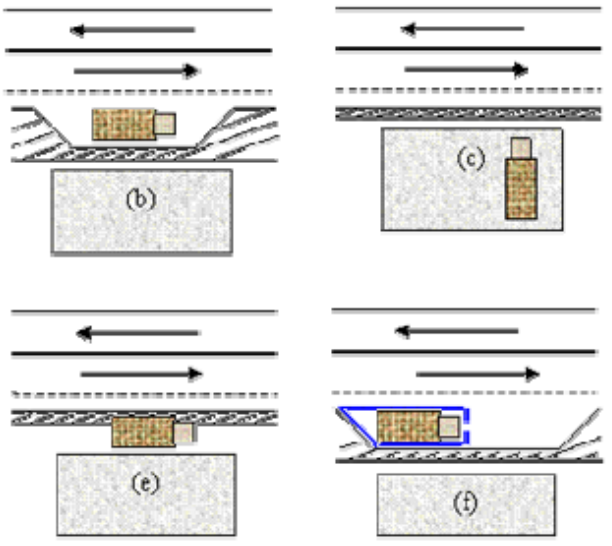


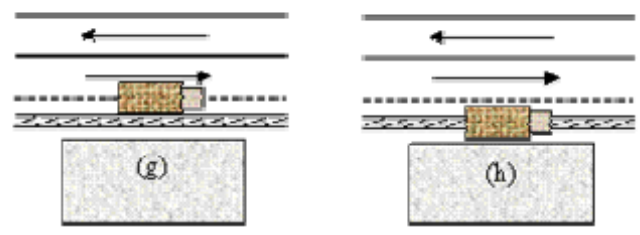

Figura 3.7 - Estacionamento de veículo de carga com perturbação do tráfego de passagem Fonte: MA (2011)

A existência de restrições à circulação impostas em determinadas áreas, em determinados períodos do dia, aliadas à exigência dos clientes em relação à pontualidade, reduzem as janelas de entrega e também contribuem para o estacionamento em locais não autorizados, já que os motoristas não dispõem de tempo para procurar por vagas disponíveis, as quais podem, inclusive, estar muito distantes do local da entrega.

Observações em campo apontam ainda para situações nas quais os veículos de carga utilizam espaços destinados a outras finalidades, como postos de gasolina e vagas de táxi, como áreas de estacionamento. De outras ocasiões pode-se observar também que nem sempre o veículo permanece no local de entrega após o descarregamento da carga. Isso porque, devido à falta de local apropriado para estacionamento próximo ao local de entrega, o veículo para apenas para o descarregamento da carga. A entrega então é realizada por um ou mais ajudantes enquanto o motorista segue para um local mais distante onde haja uma vaga disponível ou permanece em circulação com o veículo, retornando ao local de entrega após sua conclusão para buscar os ajudantes.

\subsection{ESTABELECIMENTOS DE PEQUENO PORTE}

Fransoo (2012) destaca que os elevados níveis de congestionamento, constantemente observados nas grandes cidades, fazem com que a população esteja cada vez menos disposta a enfrentar quilômetros de tráfego pesado para chegar aos grandes centros de compra, o que pode contribuir para um fenômeno presente nesses ambientes: o crescimento do número de estabelecimentos comerciais de pequeno porte, o pequeno varejo (informação verbal) ${ }^{4}$. Tal crescimento está ligado também às mudanças de perfil e de comportamento dos consumidores nos últimos anos, o qual valoriza a conveniência, a proximidade e o atendimento personalizado, principais diferenciais oferecidos pelo pequeno varejo (PIGATTO, 2006). Deve-se considerar o aumento do poder de compra das classes mais

\footnotetext{
${ }^{4}$ Informação fornecida por Fransoo no II Seminário Novas Fronteiras e Desafios da Logística, em 2012.
} 
baixas, aliado à localização mais central dos estabelecimentos de pequeno porte e ao estilo de vida nas grandes metrópoles, onde o tempo fora do espaço de trabalho é escasso e as famílias são cada vez menores, existindo, inclusive, um grande número de pessoas que vivem sozinhas. Esses fatores são fundamentais para que as grandes compras mensais em hiper e supermercados percam cada vez mais espaço para visitas mais frequentes ao pequeno varejo, o qual atende às necessidades do consumidor atual, que busca pequenas quantidades de produtos específicos para o abastecimento mais imediato (GFK, 2012; PIGATTO, 2006).

Pequenos mercados, mercearias, hortifrutis, padarias, etc., como os dos exemplos mostrados na Figura 3.8, buscam estar cada vez mais próximos de seus consumidores (LOPES et al., 2004).
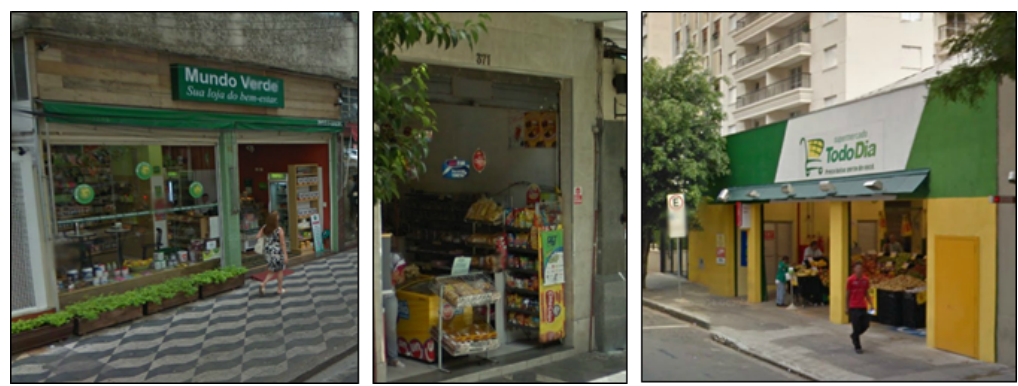

Figura 3.8 - Exemplos de estabelecimentos de pequeno porte Fonte: material da pesquisa

Observações em campo mostram que estabelecimentos desse tipo estão presentes em diversas áreas da cidade e em número bastante significativo. Isso pode ser observado a partir de um rápido levantamento do número de supermercado pequenos (de até 4 checkouts) existentes em uma pequena área da cidade de São Paulo (Figura 3.9). São sete estabelecimentos desse tipo em apenas $0,3 \mathrm{~km}^{2}$.

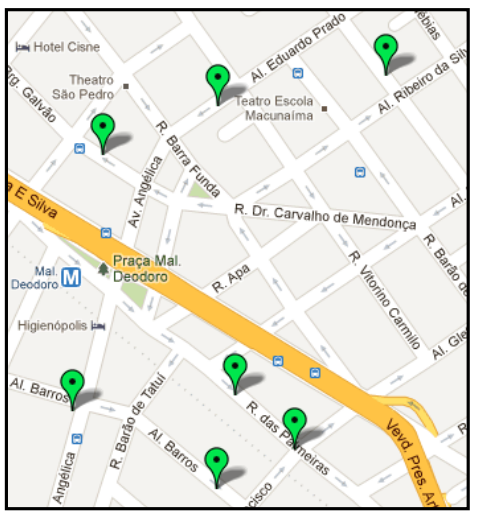

Figura 3.9 - Levantamento da localização de supermercados em uma área da cidade de São Paulo 
A grande quantidade de estabelecimentos pertencentes ao pequeno varejo, por si só, já afetaria a distribuição urbana, uma vez que aumenta a demanda pelo transporte de cargas. No entanto, o abastecimento de estabelecimentos desse tipo apresenta outras peculiaridades que acabam por ser um complicador para a distribuição de cargas na cidade e um desafio para os responsáveis por essa operação.

A limitação de espaço disponível nessas lojas, por exemplo, resulta em estoques reduzidos, o que, por sua vez, leva à necessidade de reabastecimento frequente de pequenas quantidades de produtos, prática comum aos pequenos varejistas, e que pode elevar, ainda mais, o número de viagens dos veículos dedicados ao abastecimento desse setor. De acordo com dados do ranking ABAD 2011, 51,7\% dos pequenos supermercados fazem compras de produtos de mercearia semanalmente.

Sendo assim, esses estabelecimentos são bastante atendidos por viagens do tipo multiparadas, recebendo entregas não só de diferentes fornecedores, como também em diferentes dias e horários, tornando frequentes a circulação e as operações de carga e descarga dos veículos de carga nas áreas que abrigam esses estabelecimentos e, portanto, frequentes também as perturbações ao tráfego e aos residentes em seus arredores.

Outras características observadas em alguns estabelecimentos do pequeno varejo, e que também podem influenciar as operações da distribuição de cargas, são a falta de planejamento e controle adequado dos estoques e a necessidade de negociação direta com o proprietário. O gerenciamento do estoque, quando mal executado, pode resultar em constantes alterações nos pedidos feitos aos fornecedores, causando, muitas vezes, atrasos e custos adicionais de transporte. Já a necessidade de muitas vezes ter que negociar diretamente com o proprietário do estabelecimento pode caracterizar um obstáculo ao fornecedor ou à empresa de transporte. Isso porque muitos dos estabelecimentos do pequeno varejo são empresas familiares (aquelas fundadas e administradas pela mesma família há pelo menos duas gerações) ou têm proprietários que atuam no setor há muitos anos (quinze anos, em média, de acordo com GFK (2012)), sendo comum a adoção de modelos tradicionais de gerenciamento, muitas vezes defasados e pouco receptivos à adoção de novas práticas. 
Dentre os estabelecimentos de pequeno porte, pode-se dizer que, do ponto de vista da distribuição urbana, existiria ainda uma subcategoria: os estabelecimentos de pequeno porte localizados em áreas periféricas, menos desenvolvidas. Tais estabelecimentos surgem como resultado da expansão da urbanização que, aliada à desigualdade social e aos altos custos da terra nas áreas mais centrais, leva as cidades a estenderem seus limites além de suas fronteiras administrativas, "empurrando" a população menos favorecida financeiramente para áreas cada vez mais afastadas e menos providas de recursos e infraestrutura (BRITO; SOUZA, 2005; BRENNAN, 1999). Essa população, no entanto, também faz parte do mercado de consumo, e suas necessidades diárias precisam ser atendidas. O resultado são estabelecimentos comerciais bastante pequenos localizados dentro dessas comunidades, geralmente áreas de difícil acesso, como, por exemplo, os morros que abrigam as favelas (Figuras 3.10 e 3.11).

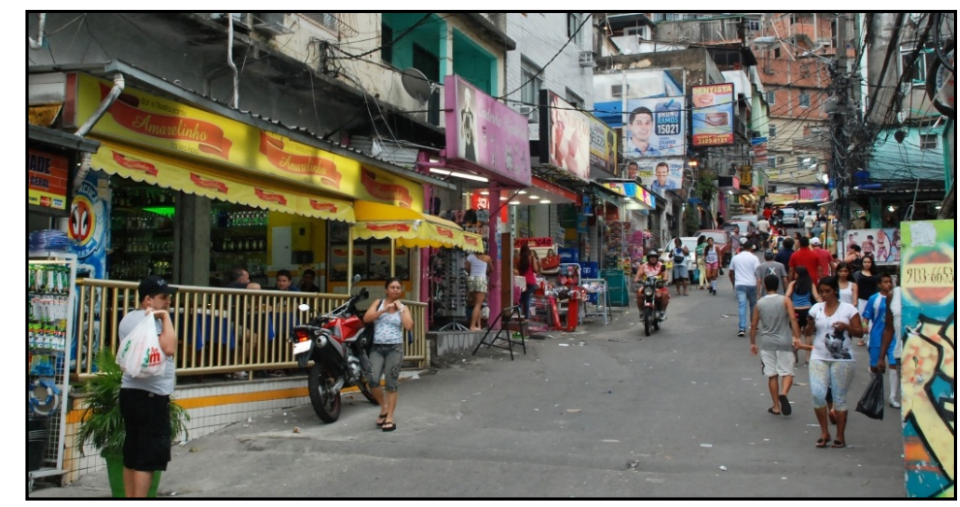

Figura 3.10 - Concentração de estabelecimentos comerciais nas áreas periféricas da cidade Fonte: REIS (2012)
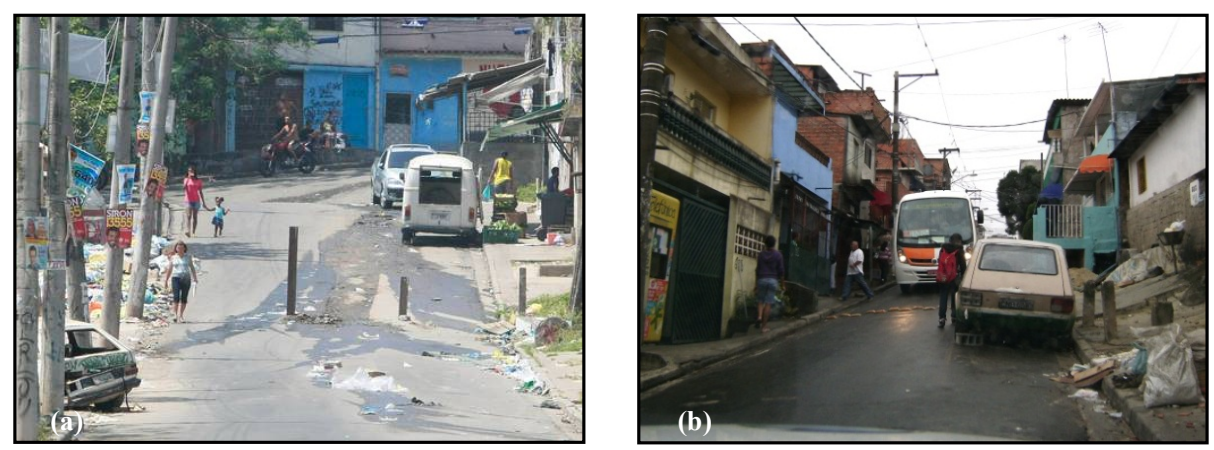

Figura 3.11 - Exemplos de locais de difícil acesso localizados nas áreas periféricas da cidade Fonte: (a) ROCHA (2012); (b) FARIAS (2009)

Abastecer esses estabelecimentos pode ser um desafio às empresas. Além das barreiras físicas impostas pelas ruas estreitas, sem pavimentação e/ou muito íngremes, que dificultam 
o acesso de veículos convencionais, essas áreas, muitas vezes, são consideradas áreas com altos níveis de violência e criminalidade, o que destaca um outro problema existente nas grandes metrópoles: a questão da segurança, tratada na seção 3.4, a seguir.

\subsection{CARACTERÍSTICAS HETEROGÊNEAS DO MUNICÍPIO E QUESTÕES DE SEGURANÇA}

A heterogeneidade da cidade, destacada anteriormente, não está limitada ao uso do solo. Diferentes áreas do município podem possuir características distintas entre si, como densidade demográfica, renda da população, índice de criminalidade, infraestrutura disponível, perfil de consumo, tipos de estabelecimentos existentes, etc. Observações realizadas em campo e informações obtidas com algumas empresas mostram que essas diferenças podem trazer, para a distribuição urbana de cargas, a necessidade de estratégias e ações específicas perante determinadas áreas da cidade. É comum, por exemplo, a divisão da cidade em zonas de atuação de acordo com o perfil da operação de entrega em cada uma delas, conforme ilustra a Figura 3.12.

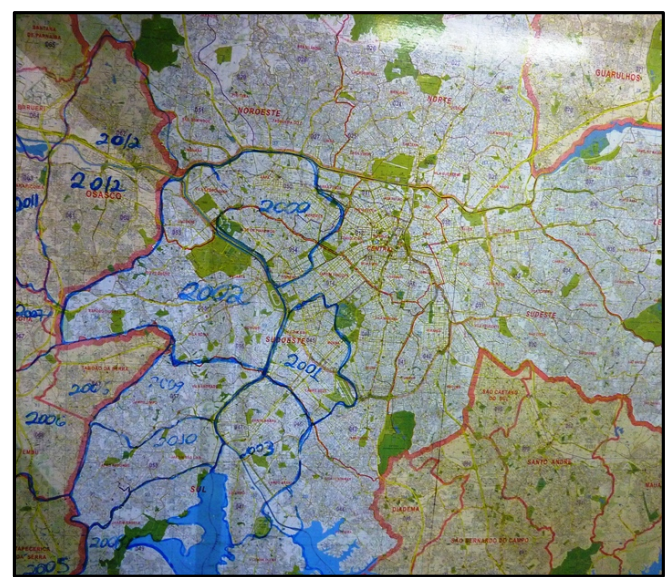

Figura 3.12 - Delimitação de zonas de entrega de uma região Fonte: material da pesquisa

A distribuição de renda domiciliar também é uma fator que pode afetar a distribuição urbana de cargas, já que a faixa de renda da população determina seu perfil de consumo, e esse perfil tem influência direta nos tamanhos dos pedidos, na variedade de produtos, na frequência de entrega e até na forma de pagamento praticadas pelos estabelecimentos. $\mathrm{O}$ mapa da Figura 3.13 traz como exemplo a distribuição de renda para a região metropolitana de Salvador. As cores em tons de azul representam área com alta renda, a cor magenta 
representa uma faixa intermediária entre alta e baixa renda e as cores em tons de amarelo e vermelho representam áreas com baixa renda.

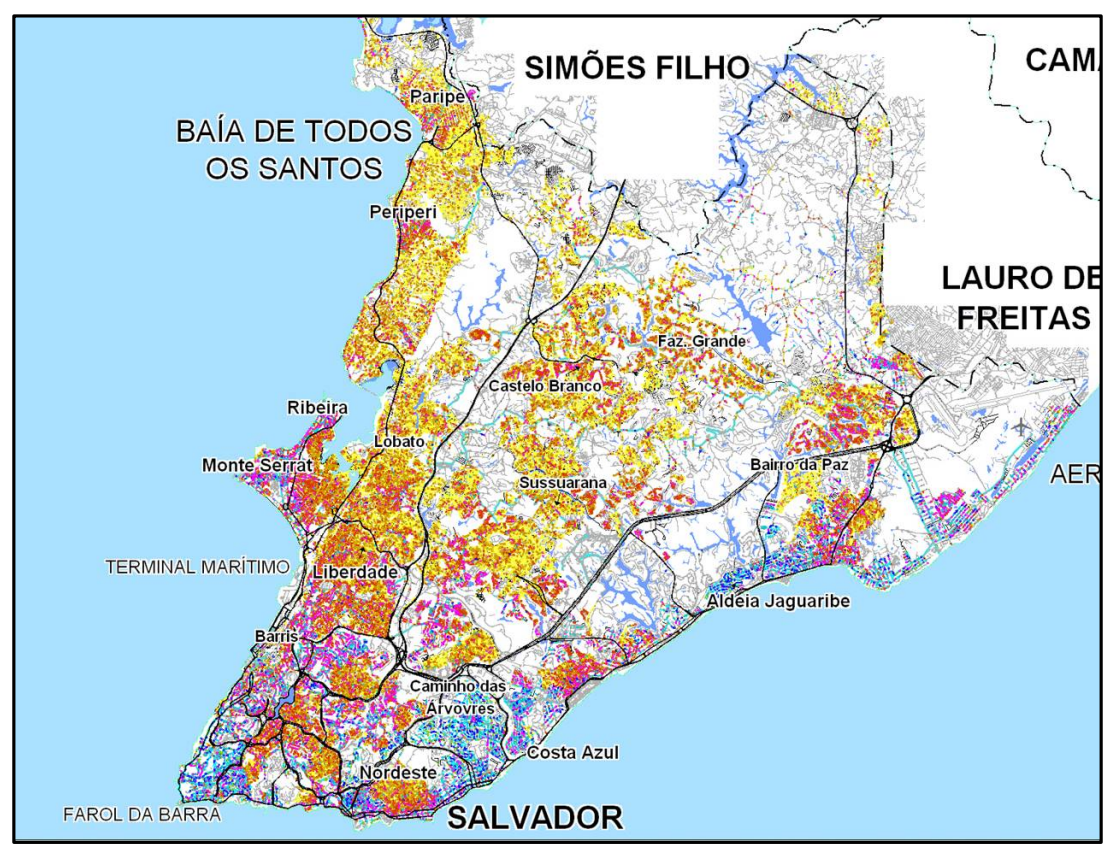

Figura 3.13 - Distribuição do acordo com a faixa de renda em 2010 Fonte: ATLA UFBA (2010)

Além disso, geralmente, as áreas cuja população possui menor renda também possuem características diferentes em termos da infraestrutura de acesso disponível. Na Figura 3.14 fica evidente o contraste entre duas áreas adjacentes, em termos da renda domiciliar e a infraestrutura disponível em cada uma delas, o que evidencia a realidade enfrentada pela distribuição urbana de cargas, da possível necessidade de diferentes estratégias de entrega em diferentes áreas da cidade.

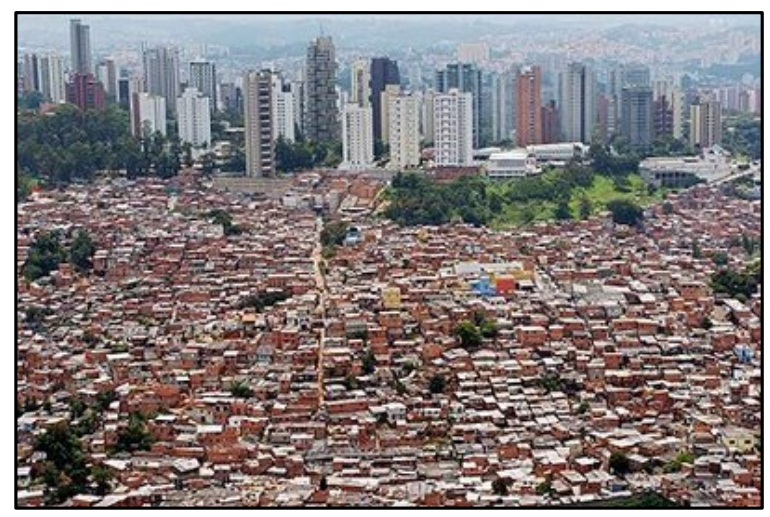

Figura 3.14 - Zonas adjacentes com diferentes características Fonte: MENEGHINI (2004) 
A Figura 3.15, por sua vez, traz o mapa de registro de ocorrências de furtos e roubos na cidade de São Paulo, como exemplo para a questão dos problemas de segurança que podem afetar a distribuição urbana de cargas.

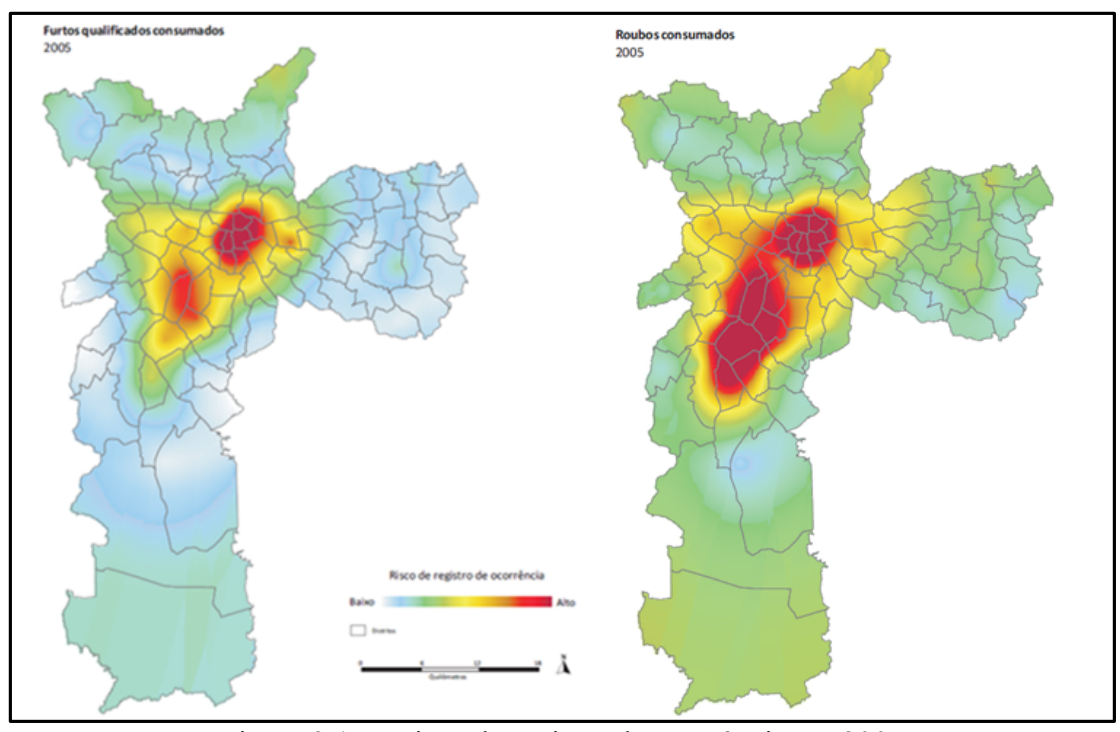

Figura 3.15 - Risco de registro de ocorrência em 2005 Fonte: SSP-SP; CAP (2005)

Nele, diferentes áreas da cidade são classificadas de acordo com o risco de ocorrência de incidentes (em termos dos furtos qualificados, no mapa da esquerda, e dos roubos, no mapa da direita), podendo ser observadas aquelas cujo risco é maior, em vermelho. Esse tipo de informação é relevante também para o transporte de carga, principalmente no caso de produtos de alto valor agregado como eletrônicos, cigarros e bebidas alcoólicas, para os quais a ocorrência de assaltos é maior (TRC, 2012). Essa realidade traz para as empresas a necessidade de novas estratégias no gerenciamento de suas operações logísticas de forma a minimizar a ocorrência de incidentes desse tipo.

Algumas empresas, quando da necessidade de realizar entregas em áreas de risco, são levadas a contratar serviços de escolta para acompanhar seus veículos ou a utilizar veículos de carga específicos, os quais geralmente não estão identificados e possuem sistemas de travamento à distância e/ou espaços compartimentados e trancados para acondicionamento

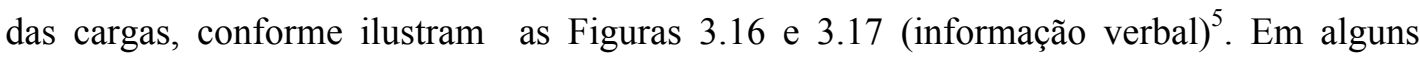
casos, ainda, a empresa opta por enviar dois funcionários no veículos, de forma que um

\footnotetext{
${ }^{5}$ Informações obtidas em observações realizadas em campo e fornecidas por empresas durante o Workshop Logística em Megacidades, 2012
} 
deles permaneça no veículo estacionado enquanto o outro realiza a entrega no estabelecimento (informação verbal) ${ }^{6}$.

Os horários de entrega e os locais de estacionamento também podem ser uma restrição para as entregas nessas áreas; alguns horários e determinados locais isolados, com pouco movimento de pessoas e iluminação precária, apresentam maior risco de ocorrência de assaltos e acabam sendo excluídos da rota de entrega (informação verbal) ${ }^{6}$.

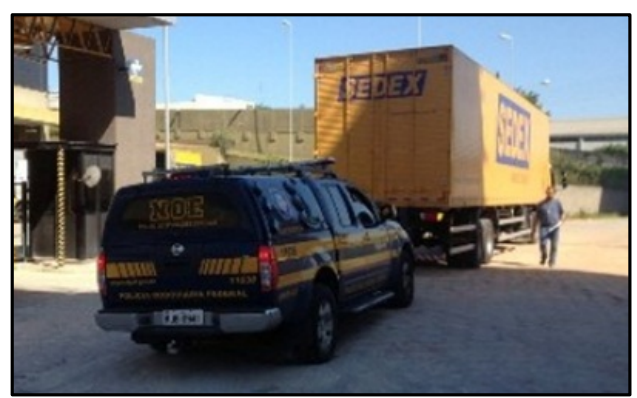

Figura 3.16 - Escolta acompanhando o veículo de carga Fonte: RAMOS (2012)

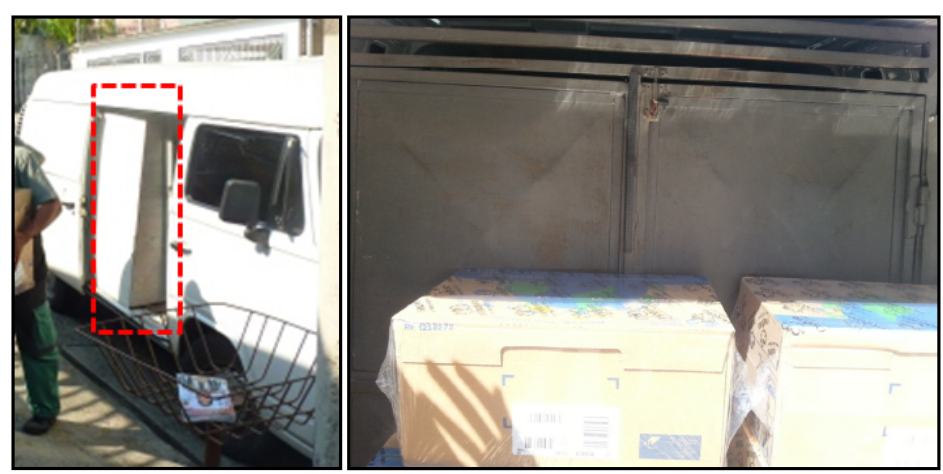

Figura 3.17 - Veículo de carga compartimentado Fonte: material da pesquisa

Não é difícil concluir que as medidas tomadas pelas empresas, na tentativa de reduzir os incidentes com seus veículos, cargas e funcionários, podem ter impactos negativos nas operações de entrega em áreas de risco. O investimento em veículos adaptados e a contratação de escolta e funcionários extras, assim como a necessidade de adaptação às restrições impostas pelos horários e locais de maior risco de incidentes, podem aumentar os custos e diminuir o desempenho da distribuição de produtos.

\footnotetext{
${ }^{6}$ Informações obtidas em observações realizadas em campo e fornecidas por empresas durante o Workshop Logística em Megacidades, 2012
} 


\subsection{CONGESTIONAMENTOS DO TRÁFEGO}

Os congestionamentos provocam o aumento do chamado custo generalizado para o usuário e causam um leque de externalidades negativas, com destaque para: poluição do ar, grande consumo de combustíveis fósseis, aumento do número de acidentes e perda de produtividade causada pelo estresse e pelo tempo perdido nos deslocamentos (SMDU/SP2040, 2012, p. 178).

Os congestionamentos decorrentes do tráfego intenso (Figura 3.18), que reduzem drasticamente a velocidade média do fluxo de veículos e aumentam os tempos de viagem de passageiros e cargas, são provavelmente um dos problema mais marcantes enfrentados diariamente pelas grandes metrópoles.

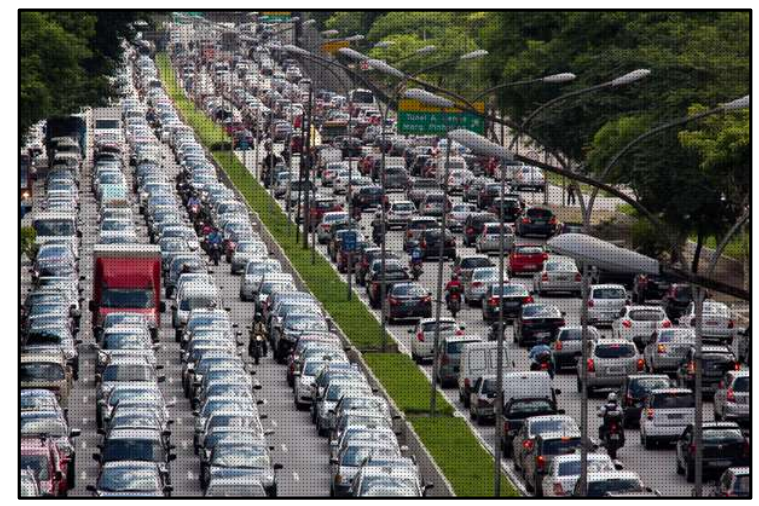

Figura 3.18 - Tráfego intenso na Avenida 23 de maio, em São Paulo Fonte: MOREIRA (2013)

Em 2015, segundo dados da CET-SP (2015), a cidade de São Paulo enfrentou uma média de 109 quilômetros de congestionamentos no pico da tarde e 97,5 quilômetros no pico da manhã. Na região metropolitana do Rio de Janeiro, um estudo do Sistema Firjan (Federação das Indústrias do Rio de Janeiro, 2014) constatou que a média diária de congestionamentos no ano de 2013 foi de 130 quilômetros.

Schweitzer e Taylor (2008) sugerem que dois fatores básicos afetam o trânsito e causam congestionamento: excesso de veículos em horários específicos (horários de pico) e acidentes ou ocorrências que podem bloquear a pista (veículos quebrados, pistas bloqueadas para reparos, condições do tempo, etc.).

Grande parte do excesso de veículos em circulação na cidade, nos horários de pico, surge da necessidade crescente de seus habitantes pelo uso de alternativas motorizadas em seus 
deslocamentos diários, seja por motivo de trabalho ou de estudo. Em algumas delas, como no caso de São Paulo, essa necessidade é fruto, principalmente, do desequilíbrio existente entre as concentrações de oferta de empregos e a distribuição da população na superfície da cidade (STM/PITU2025, 2006; SMDU/SP2040, 2012), o que pode ser observado no mapa da Figura 3.19. As manchas mais escuras, em vermelho e laranja, correspondem às zonas de maior concentração de empregos, enquanto os tons mais carregados de verde indicam as áreas mais populosas da cidade.

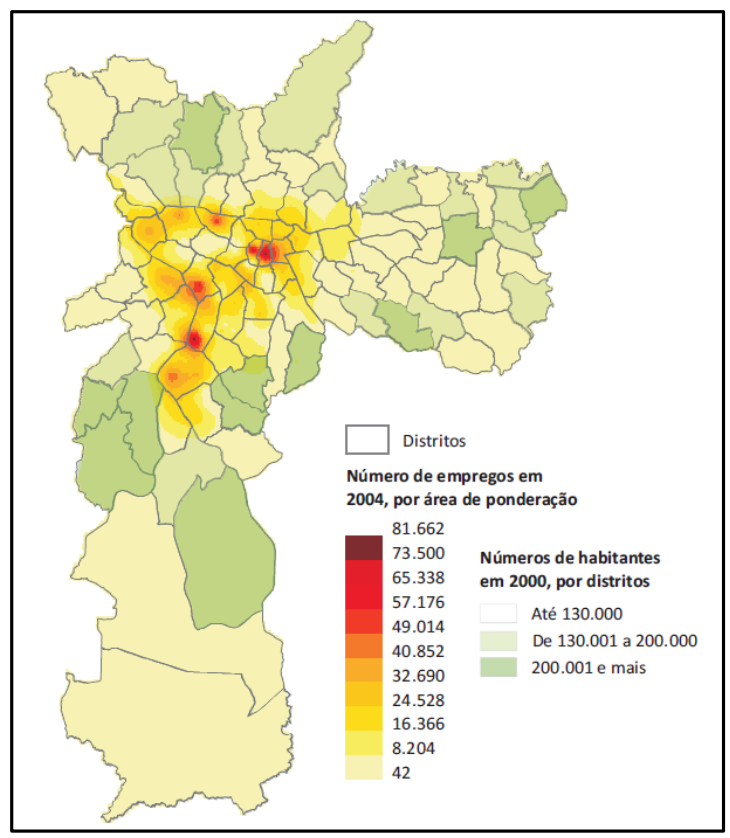

Figura 3.19 - Distribuição da população e dos empregos formais - IPVS 9 Fonte: SEMPLA; DIPRO (2004)

A participação dos veículos de carga no tráfego das cidades também tem contribuição aos elevados níveis de congestionamento, muitas vezes agravando esse problema. Ainda usando como exemplo a cidade de São Paulo, de acordo com a Pesquisa de Desenvolvimento do Sistema Viário Principal, realizada pela CET-SP (2013), no ano de 2012, 190 mil veículos de carga circularam pelas vias da cidade. $44 \%$ desses veículos chegando pelas rodovias, $10 \%$ representando o tráfego de passagem e $40 \%$ circulando pelo centro expandido. Embora esse número represente $20 \%$ do total de veículos, a ocupação dessas vias por esses caminhões chegou a 42\% (CET-SP, 2013). 


\subsection{PRIORIDADE AO TRANSPORTE DE PASSAGEIROS}

A pouca atenção dada à distribuição urbana de cargas por parte das autoridades locais caracteriza outro aspecto que compromete diretamente o seu desempenho. Segundo Blanco (2012), há um grande desequilíbrio entre os esforços direcionados ao transporte urbano de cargas e aqueles que são direcionados ao transporte de passageiros, sendo esse último a prioridade das autoridades (informação verbal) ${ }^{7}$. As grandes cidades, por exemplo, têm gerenciado o transporte de pessoas através do desenvolvimento de redes de transporte integradas, enquanto que para os sistemas voltados à distribuição urbana de cargas a situação é bastante diferente: o transporte urbano de cargas é quase completamente gerenciado por empresas logísticas privadas que planejam e implementam seus próprios sistemas de transporte, na maioria das vezes sem qualquer coordenação (DABLANC, 2007; KANT et al., 2012).

Entretanto, para as mesmas pessoas que se deslocam pela cidade é preciso garantir o abastecimento de suas residências e dos inúmeros estabelecimentos comerciais com os produtos que atendam suas necessidades de consumo, e nesse, sentido, o transporte de cargas se torna tão importante quanto o transporte de passageiros.

Para Dablanc (2007), essa importância, no entanto, muitas vezes parece ser negligenciada e os veículos de carga são vistos, simplesmente, como um mal necessário; causam distúrbios ao tráfego e à população e deveriam ser banidos ou, pelo menos, ter sua circulação limitada. O resultado, geralmente, é a implementação de medidas cada vez mais restritivas, que limitam ao máximo as áreas e os horários para circulação e operação dos veículos de cargas, obrigando as empresas a buscarem alternativas emergenciais e onerosas para não prejudicarem o atendimento a seus clientes. Para a população, que percebe apenas a melhoria momentânea no tráfego e, em geral, tem garantida a entrega dos produtos de sua preferência, os impactos dessas medidas parecem positivos e levam a um sentimento de aprovação, o que é bom para as autoridades. Mas para a distribuição urbana de cargas, ou seja, para os agentes responsáveis pela sua realização, o cenário pode ser cada vez mais desfavorável: enquanto o aumento da demanda e as necessidades de clientes (cada vez mais exigentes) solicitam um transporte de cargas mais frequente e personalizado, as medidas restritas voltadas à distribuição (e suas constantes alterações) limitam suas operações, aumentam seus custos e, até, impedem o desenvolvimento do setor.

\footnotetext{
${ }^{7}$ Informação fornecida por Blanco no II Seminário Novas Fronteiras e Desafios da Logística, em 2012.
} 


\subsection{VEÍCULOS DE CARGA}

Por fim, faz-se necessária uma apresentação dos principais veículos mais comumente observados realizando o transporte de cargas em áreas urbanas de todo o país. É importante ressaltar que em algumas cidades alguns deles, e até outros tipos não listados aqui (como motocicletas), podem ser observados com mais ou menos frequência, dependendo, inclusive, das restrições ao transporte de cargas adotadas nesses locais.

Os VUCs (Figura 3.20) são pequenos caminhões criados para a realização de entregas em áreas urbanas diante das restrições à circulação de grandes caminhões adotadas em diversas cidades no país. Não existe uma lei federal que especifique suas dimensões, essas variam de acordo com a legislação vigente em cada município. Em São Paulo, por exemplo, os VUCs possuem largura máxima de 2,20 metros e comprimento máximo de 6,30 metros. No Rio de Janeiro esses limites são maiores: 2,60 metros de largura máxima e 6,50 metros de comprimento máximo. Os VUCs no Recife são os menores, com seis metros de comprimento, enquanto que os de Curitiba chegam a sete metros. As capacidades de carga também variam e vão de 2,6 a 3,5 toneladas. Os VUCs devem ainda obedecer ao limite de emissão de poluentes especificado pelo PROCONVE L-5 ou P-6.

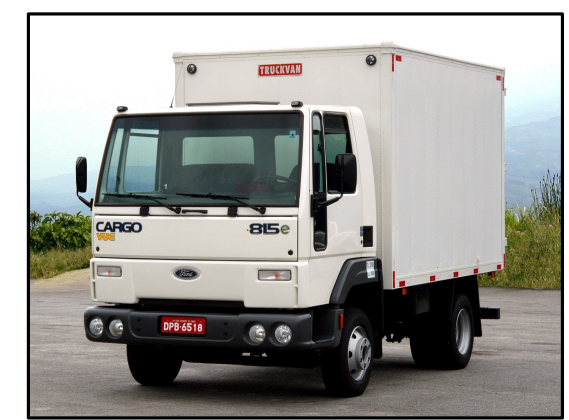

Figura 3.20 - Veículo urbano de Carga (VUC) Fonte: FOTOSFORD (2012)

Assim como o VUCs, vans e utilitários são também bastante utilizados no transporte de cargas na área urbana. Dentre as vans destacam-se a Fiat Ducato (Figura 3.21) e a Volkswagen Kombi [Figura 3.22 (a) e (b)]. A primeira possui comprimentos que variam de 4,70 a 5,40 metros, 2,00 metros de largura e capacidade de carga de 1,50 toneladas, enquanto a última apresenta dimensões de 4,50 metros de comprimento e 1,72 metros de largura, e capacidade de uma tonelada. 


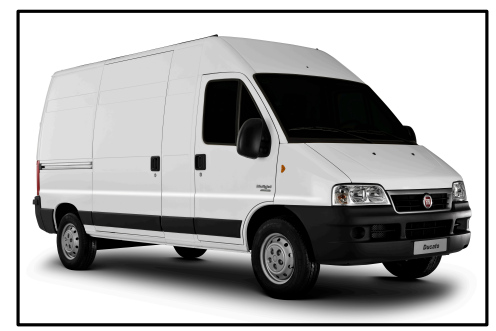

Figura 3.21 - Fiat Ducato Fonte: FiatPress (2015)

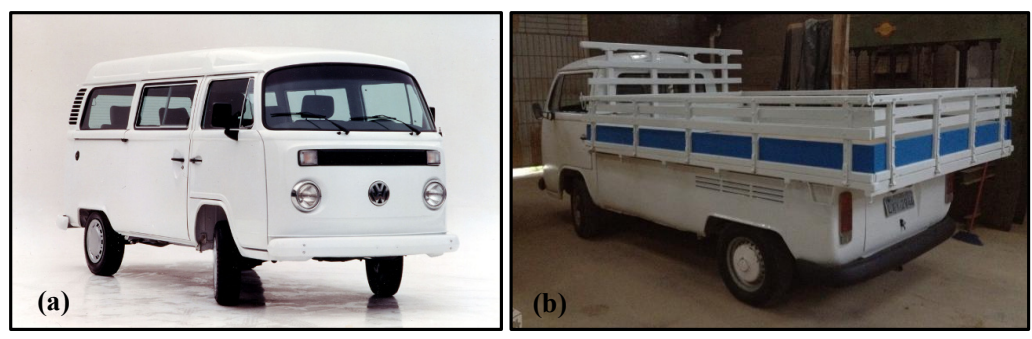

Figura 3.22 - (a) Volkswagen Kombi e (b) Volkswagen Kombi Pick-up Fonte: (a) FOTOSFACE (2012); (b) BOMNEGOCIO (2012)

Dentre os utilitários destaca-se a Fiat Fiorino, medindo 4,20 metros de comprimento e 1,60 metro de largura, e com capacidade de carga de 620 quilos (Figura 3.23).

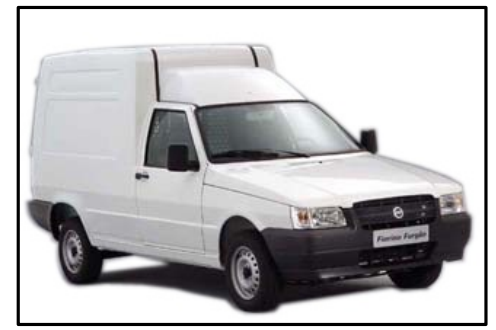

Figura 3.23 - Fiat Fiorino Fonte: COMPARECAR (2012)

Embora de circulação limitada nas área urbanas da maioria das grandes cidades, devido às restrições, caminhões maiores também podem ser observados realizando a distribuição urbana de carga em algumas circunstâncias (no período noturno, por exemplo), dentre eles destacam-se:

- Caminhão médio semipesado (Toco) (Figura 3.24) - possui um eixo traseiro de rodagem dupla; comprimento máximo de 14 metros e capacidade da carga de até 6 toneladas; 


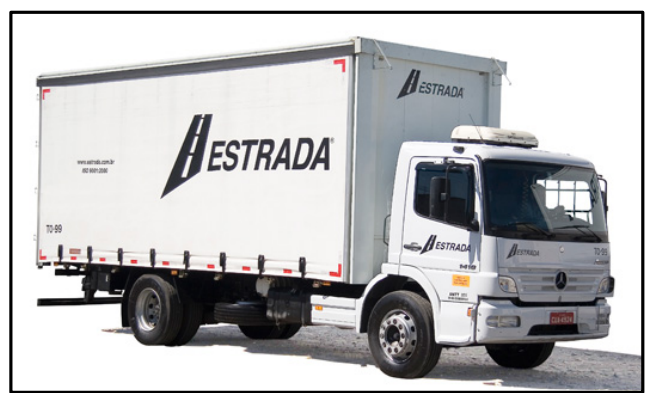

Figura 3.24 - Caminhão médio semipesado (Toco) Fonte: ESTRADA (2012)

- Caminhão pesado (Truck) (Figura 3.25) - possui um eixo traseiro duplo; comprimento máximo também de 14 metros, porém com capacidade carga de 10 a 14 toneladas;

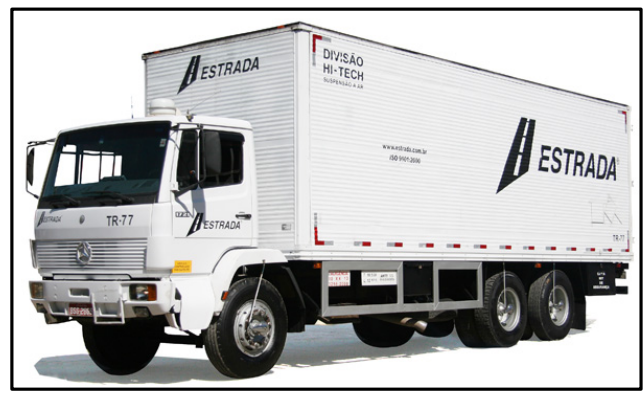

Figura 3.25 - Caminhão pesado (Truck) Fonte: ESTRADA (2012)

- Conjunto caminhão trator mais semirreboque - possui conjunto formado por dois veículos: um caminhão trator e um semirreboque, o primeiro com um eixo traseiro de rodagem dupla (Figura 3.26) ou com eixo traseiro duplo (Figura 3.27), o que aumenta sua capacidade de transporte;

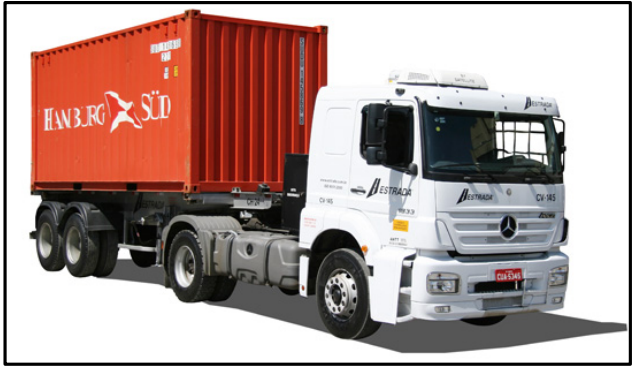

Figura 3.26 - Conjunto caminhão trator mais semirreboque (eixo traseiro de rodagem dupla) Fonte: ESTRADA (2012) 


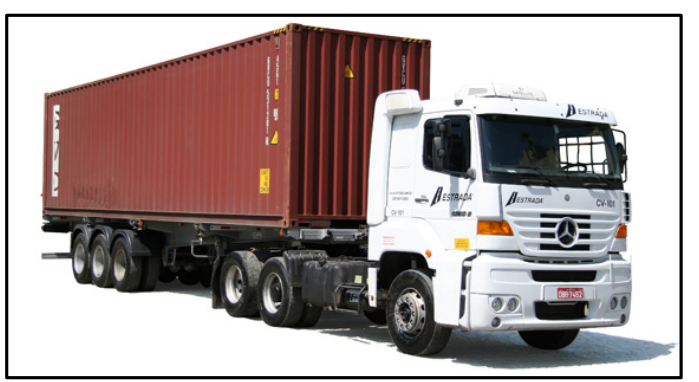

Figura 3.27 - Conjunto caminhão trator mais semirreboque (eixo traseiro duplo) Fonte: ESTRADA (2012)

Dentro dos horários e áreas permitidos é possível observar que os caminhões do tipo Toco e Truck realizam entregas de todos os tipos, desde o abastecimento de supermercados, shoppings e grandes redes, até a entrega a domicílio de grandes volumes, como móveis e eletrodomésticos. Os veículos do tipo caminhão trator mais semirreboque, por sua vez, não são tão frequentes na área urbana, uma vez que transportam volumes de carga muito grandes, geralmente para o abastecimento da indústria, compondo, assim, grande parte do tráfego de passagem da cidade. Dentro da área urbana, são comuns no transporte de combustível para o abastecimento de postos. 


\section{RESTRIÇÕES AO TRANSPORTE DE CARGAS}

Desde 1982, quando foi criada a primeira legislação que limitava a circulação e o estacionamento de veículos de carga na cidade de São Paulo, mais de cem municípios brasileiros já adotaram alguma medida voltada à distribuição urbana de cargas. Essas medidas, invariavelmente, incluem a restrição ao trânsito de caminhões em determinadas áreas da cidades, considerando como fator limitante o peso bruto total dos mesmos e/ou suas dimensões.

Neste capítulo estão relacionadas as regulamentações atualmente em vigência nos principais município do Brasil. Dentre elas, destacam-se aquelas referentes ao município de São Paulo, resultado de diversas modificações na legislação, desde a primeira medida adotada, em 1982. A situação de São Paulo serve, ainda, como exemplo ilustrativo da possível falta de um planejamento adequado no processo de implementação dessas medidas, ao serem apresentadas informações que sugerem divergências em relação aos benefícios das mesmas.

\subsection{RESTRIÇÕES AO TRANSPORTE DE CARGAS ADOTADAS NOS MUNICÍPIOS BRASILEIROS}

O Quadro 4.1, a seguir, apresenta o resumo das restrições ao transporte de cargas em vigência nos principais municípios brasileiros. Os textos apresentados respeitam aqueles publicados nos respectivos decretos, portarias e leis.

\begin{tabular}{|c|c|c|c|c|}
\hline Município & Regulamentação & $\begin{array}{l}\text { Período de } \\
\text { Restrição }\end{array}$ & Área Restrita & Condição \\
\hline \multirow{3}{*}{$\begin{array}{l}\text { Belém } \\
\text { (PA) }\end{array}$} & \multirow{3}{*}{$\begin{array}{l}\text { Decreto Municipal } \mathrm{n}^{\circ} \\
66.368 \text { de } 31 \text { de março } \\
\text { de } 2011\end{array}$} & $\begin{array}{l}\text { Seg. à sex. das } 6 h \\
\text { às } 9 h\end{array}$ & $\begin{array}{l}13 \text { vias no centro } \\
\text { da cidade. }\end{array}$ & $\begin{array}{l}\text { Caminhões com PBT } \\
\text { acima de } 5,5 \text { toneladas }\end{array}$ \\
\hline & & $\begin{array}{l}\text { Seg. à sex. das } 6 h \\
\text { às } 9 h\end{array}$ & $\begin{array}{c}\text { Controle na } \\
\text { entrada de Belém }\end{array}$ & \multirow{2}{*}{$\begin{array}{l}\text { Veículos com mais de } 14 \\
\text { metros de comprimento }\end{array}$} \\
\hline & & $\begin{array}{c}\text { Seg. à sex. das } 17 \mathrm{~h} \\
\text { às } 20 \mathrm{~h}\end{array}$ & $\begin{array}{l}\text { Controle na saída } \\
\text { de Belém }\end{array}$ & \\
\hline
\end{tabular}


continuação

\begin{tabular}{|c|c|c|c|c|}
\hline Município & Regulamentação & $\begin{array}{l}\text { Período de } \\
\text { Restrição }\end{array}$ & Área Restrita & Condição \\
\hline $\begin{array}{l}\text { Belo } \\
\text { Horizonte } \\
\text { (MG) }\end{array}$ & $\begin{array}{c}\text { Portaria } \\
\text { BHTRANS/DPR } \\
138, \text { de } 2009\end{array}$ & $\begin{array}{l}\text { Seg. à sex. das } 7 \mathrm{~h} \\
\text { às } 20 \mathrm{~h} ; \\
\text { Sáb. das } 7 \mathrm{~h} \text { às } 15 \mathrm{~h}\end{array}$ & $\begin{array}{c}\text { Hipercentro, Savassi, } \\
\text { Lourdes, } \\
\text { Assembleia/Barro } \\
\text { Preto e Área Hospitalar }\end{array}$ & $\begin{array}{c}\text { Veículos acima de } 5 \\
\text { toneladas e } 6,5 \text { metros e } \\
\text { carretas }\end{array}$ \\
\hline \multirow{2}{*}{$\begin{array}{c}\text { Campo } \\
\text { Grande (MS) }\end{array}$} & \multirow{2}{*}{$\begin{array}{l}\text { Decreto no } \\
11.178 \text {, de } 20 \text { de } \\
\text { abril de } 2010\end{array}$} & $\begin{array}{l}\text { Seg. à sex. das } \\
10 \mathrm{~h} \text { às } 20 \mathrm{~h}\end{array}$ & \multirow[b]{2}{*}{ Região central } & $\begin{array}{l}\text { Caminhões com PBT } \\
\text { entre } 1 \text { e } 5 \text { toneladas }\end{array}$ \\
\hline & & $\begin{array}{l}\text { Seg. à sex. das } \\
6: 30 \mathrm{~h} \text { às } 20 \mathrm{~h}\end{array}$ & & $\begin{array}{c}\text { Caminhões com mais de } \\
12 \text { toneladas }\end{array}$ \\
\hline \multirow{2}{*}{ Cuiabá (MT) } & \multirow{2}{*}{$\begin{array}{l}\text { Lei } n^{\circ} 5.463, \text { de } \\
\text { setembro de } 2011\end{array}$} & $\begin{array}{l}\text { Seg. à sex. das } 6 \mathrm{~h} \\
\text { às } 20 \mathrm{~h}\end{array}$ & Zona de Área Central & $\begin{array}{l}\text { Caminhões com carga } \\
\text { acima de } 24 \text { toneladas }\end{array}$ \\
\hline & & $\begin{array}{l}\text { Todos os dias, } \\
\text { qualquer horário }\end{array}$ & $\begin{array}{l}\text { Zona de Restrição } \\
\text { Máxima }\end{array}$ & $\begin{array}{l}\text { Caminhões com PBT } \\
\text { superior a } 10 \text { toneladas }\end{array}$ \\
\hline \multirow{3}{*}{ Curitiba (PR) } & \multirow{3}{*}{$\begin{array}{l}\text { Portaria } 073, \text { de } \\
2011\end{array}$} & $\begin{array}{l}\text { Seg. à sex. das } 7 \mathrm{~h} \\
\text { às } 20 \mathrm{~h} ; \text { sáb. das } \\
9 \mathrm{~h} \text { às } 14 \mathrm{~h}\end{array}$ & Centro expandido & $\begin{array}{c}\text { Caminhões com mais de } \\
5 \text { metros e } 7 \text { toneladas }\end{array}$ \\
\hline & & $\begin{array}{l}\text { Seg. à sex., das } 7 \mathrm{~h} \\
\text { às } 22 \mathrm{~h} \text {; sáb. das } \\
9 \mathrm{~h} \text { às } 14 \mathrm{~h}\end{array}$ & Algumas ruas & Carretas \\
\hline & & $\begin{array}{l}\text { Todos os dias, } \\
\text { qualquer horário }\end{array}$ & $\begin{array}{l}\text { Linha Verde (trecho } \\
\text { urbano da BR-116) }\end{array}$ & $\begin{array}{l}\text { Caminhões com mais de } \\
6 \text { toneladas e } 6 \text { metros }\end{array}$ \\
\hline \multirow{3}{*}{$\begin{array}{l}\text { Florianópolis } \\
\text { (SC) }\end{array}$} & \multirow{3}{*}{$\begin{array}{l}\text { Decreto } \mathrm{n}^{\mathrm{o}} \\
11.942, \text { de } 1^{\circ} \mathrm{de} \\
\text { agosto de } 2013\end{array}$} & \multirow{3}{*}{$\begin{array}{c}\text { Seg. à sex. das } 6 \mathrm{~h} \\
\text { às } 9 \mathrm{~h} \text { e das } 17 \mathrm{~h} \text { às } \\
20 \mathrm{~h} \text {; sáb. das } 10 \mathrm{~h} \\
\text { às } 14 \mathrm{~h}\end{array}$} & $\begin{array}{l}\text { Algumas avenidas e } \\
\text { ruas do Centro e da } \\
\text { área continental, além } \\
\text { das pontes }\end{array}$ & \multirow{3}{*}{$\begin{array}{c}\text { Caminhões acima de } 7 \\
\text { toneladas ou } 7 \text { metros de } \\
\text { comprimento }\end{array}$} \\
\hline & & & $\begin{array}{l}\text { No centro, toda a } \\
\text { região entre a Avenida } \\
\text { Beira-Mar Norte e a } \\
\text { Avenida Mauro Ramos }\end{array}$ & \\
\hline & & & $\begin{array}{l}12 \text { vias na Ilha } \\
10 \text { vias no continente }\end{array}$ & \\
\hline \multirow{3}{*}{$\begin{array}{l}\text { Fortaleza } \\
\quad(\mathrm{CE})\end{array}$} & \multirow{3}{*}{$\begin{array}{c}\text { Portaria AMC No } \\
218, \text { de } 5 \mathrm{de} \\
\text { novembro de } \\
2012\end{array}$} & $\begin{array}{l}\text { Seg. à sex. das } 7 \mathrm{~h} \\
\text { às } 20 \mathrm{~h} \text {; sáb. das } \\
6 \mathrm{~h} \text { às } 13 \mathrm{~h}\end{array}$ & Centro & $\begin{array}{c}\text { Caminhões com mais de } \\
2 \text { toneladas }\end{array}$ \\
\hline & & $\begin{array}{l}\text { Seg. à sex., das } 6 \mathrm{~h} \\
\text { às } 20 \mathrm{~h} ; \text { sáb. das } \\
6 \mathrm{~h} \text { à } 13 \mathrm{~h}\end{array}$ & Bairro Aldeota & $\begin{array}{l}\text { Veículos acima de } 2,5 \\
\text { toneladas }\end{array}$ \\
\hline & & $\begin{array}{l}\text { Seg. às sex. das } \\
\text { 0h às 9h; sáb. das } \\
6 \mathrm{~h} \text { às } 24 \mathrm{~h}\end{array}$ & Avenida Beira Mar & $\begin{array}{l}\text { Veículos acima de } 2,5 \\
\text { toneladas }\end{array}$ \\
\hline
\end{tabular}


continuação

\begin{tabular}{|c|c|c|c|c|}
\hline Município & Regulamentação & $\begin{array}{l}\text { Período de } \\
\text { Restrição }\end{array}$ & Área Restrita & Condição \\
\hline \multirow[b]{2}{*}{$\begin{array}{l}\text { Goiânia } \\
\text { (GO) }\end{array}$} & \multirow[b]{2}{*}{$\begin{array}{l}\text { Lei Municipal } \\
9.028 \text {, de } 20 \text { de } \\
\text { abril de } 2011\end{array}$} & $\begin{array}{l}\text { Seg. à sex. das } \\
7 \mathrm{~h} \text { às } 19 \mathrm{~h} \text {; sáb. } \\
\text { das } 7 \mathrm{~h} \text { às } 14 \mathrm{~h}\end{array}$ & $\begin{array}{l}\text { Setor central } \\
\text { e várias ruas e } \\
\text { avenidas }\end{array}$ & Veículos pesados e caminhões \\
\hline & & $\begin{array}{l}\text { Seg. à sex. das } \\
7 \mathrm{~h} \text { às } 19 \mathrm{~h}\end{array}$ & $\begin{array}{l}\text { Toda área urbana, } \\
\text { exceto nos eixos } \\
\text { viários e rodoviários }\end{array}$ & $\begin{array}{c}\text { Circulação dos veículos pesados } \\
\text { do tipo CTV (Combinações para } \\
\text { Transporte de Veículos, } \\
\text { Caminhões e Cegonha) acima } \\
\text { de } 14 \text { metros }\end{array}$ \\
\hline $\begin{array}{l}\text { Maceió } \\
(\mathrm{AL})\end{array}$ & $\begin{array}{l}\text { Lei } 5593 \text {, } \\
\text { de } 2007\end{array}$ & $\begin{array}{l}\text { Seg. à sex. das } \\
\quad 6 \mathrm{~h} \text { às } 20 \mathrm{~h}, \\
\text { exceto feriados }\end{array}$ & Área central & $\begin{array}{l}\text { Caminhões acima de } 4,5 \\
\text { toneladas }\end{array}$ \\
\hline \multirow{2}{*}{$\begin{array}{l}\text { Manaus } \\
\text { (AM) }\end{array}$} & \multirow{2}{*}{$\begin{array}{c}\text { Decreto } \\
\text { Municipal } \mathrm{n}^{\mathrm{o}} \\
2.100, \text { de } 10 \mathrm{de} \\
\text { janeiro de } 2013\end{array}$} & $\begin{array}{l}\text { Seg. à sex. das } \\
6 \mathrm{~h} \text { às } 9 \mathrm{~h} \text { e das } \\
17 \mathrm{~h} \text { às } 20 \mathrm{~h}\end{array}$ & $\begin{array}{l}\text { Avenida Constantino } \\
\text { Néri e centro } \\
\text { histórico }\end{array}$ & $\begin{array}{l}\text { Veículos com PBT acima de } 8 \\
\text { toneladas; dimensões máximas } \\
\text { permitidas: comprimento de } \\
\text { 18,60m; altura de } 4,40 \mathrm{~m} \mathrm{e} \\
\text { largura de } 2,60 \mathrm{~m}\end{array}$ \\
\hline & & $\begin{array}{l}\text { Seg. à sex. das } \\
\text { das } 6 \mathrm{~h} \text { às } 20 \mathrm{~h}\end{array}$ & $\begin{array}{l}\text { Avenida Constantino } \\
\text { Néri e centro } \\
\text { histórico }\end{array}$ & $\begin{array}{c}\text { Veículos com PBT acima de } 16 \\
\text { toneladas; dimensões máximas } \\
\text { permitidas são o comprimento } \\
\text { de } 18,60 \mathrm{~m} \text {; altura de } 4,40 \mathrm{~m} \mathrm{e} \\
\text { largura de } 2,60 \mathrm{~m}\end{array}$ \\
\hline $\begin{array}{l}\text { Natal } \\
(\mathrm{RN})\end{array}$ & $\begin{array}{l}\text { Lei Municipal } \\
256 \text {, de } 10 \text { de } \\
\text { junho de } 2008\end{array}$ & $\begin{array}{l}\text { Seg. à sex. das } \\
5 \text { h às } 20 \mathrm{~h}\end{array}$ & $\begin{array}{l}\text { Ruas de tráfego } \\
\text { intenso do município }\end{array}$ & $\begin{array}{c}\text { Veículos com PBT acima de } 5 \\
\text { toneladas }\end{array}$ \\
\hline \multirow{2}{*}{$\begin{array}{l}\text { Porto } \\
\text { Alegre } \\
\text { (RS) }\end{array}$} & \multirow{2}{*}{-} & $\begin{array}{l}\text { Seg. à sex. das } \\
7 \mathrm{~h} \text { às } 19 \mathrm{~h} ; \text { sáb. } \\
\text { das } 7 \mathrm{~h} \text { às } 14 \mathrm{~h}\end{array}$ & $\begin{array}{c}\text { Centro da capital, } \\
\text { bairros Moinhos de } \\
\text { Vento e Cidade Baixa }\end{array}$ & $\begin{array}{c}\text { Veículos com PBT acima de } 10 \\
\text { toneladas ou com comprimento } \\
\text { superior a } 7 \text { metros }\end{array}$ \\
\hline & & $\begin{array}{l}\text { Seg. à sex. das } \\
7 \mathrm{~h} \text { às } 19 \mathrm{~h} \text {; sáb. } \\
\text { das } 7 \mathrm{~h} \text { às } 13 \mathrm{~h}\end{array}$ & Área central & $\begin{array}{c}\text { Caminhões com PBT acima de } \\
3 \text { toneladas }\end{array}$ \\
\hline $\begin{array}{l}\text { Recife } \\
(\mathrm{PE})\end{array}$ & - & $\begin{array}{l}\text { Seg. à sex. das } \\
\text { das } 6 \mathrm{~h} \text { às } 20 \mathrm{~h}\end{array}$ & $\begin{array}{l}\text { Bairros do Recife, } \\
\text { São José e Santo } \\
\text { Antônio, na região } \\
\text { central da capital }\end{array}$ & $\begin{array}{l}\text { Veículos de carga com mais de } \\
6 \text { metros de comprimento }\end{array}$ \\
\hline
\end{tabular}


continuação

\begin{tabular}{|c|c|c|c|c|}
\hline Município & Regulamentação & $\begin{array}{l}\text { Período de } \\
\text { Restrição }\end{array}$ & Área Restrita & Condição \\
\hline \multirow{3}{*}{$\begin{array}{l}\text { Rio de } \\
\text { Janeiro } \\
(\mathrm{RJ})\end{array}$} & \multirow{3}{*}{$\begin{array}{c}\text { Decreto } \\
\text { Municipal 29.231, } \\
\text { de } 24 \text { de abril de } \\
2008\end{array}$} & $\begin{array}{l}\text { Seg. à sex. das } 6 \mathrm{~h} \text { às } \\
10 \mathrm{~h} \text { e das } 17 \mathrm{~h} \text { às } 20 \mathrm{~h}\end{array}$ & $\begin{array}{l}\text { Orla marítima, } \\
\text { de Copacabana até a Barra, } \\
\text { e em } 26 \text { vias na Zona Sul, } \\
\text { Centro, Tijuca, Vila Isabel, } \\
\text { Méier e Jacarepaguá, entre } \\
\text { outros bairros }\end{array}$ & \multirow{3}{*}{ Caminhões } \\
\hline & & $\begin{array}{l}\text { Todos os dias, em } \\
\text { qualquer horário }\end{array}$ & $\begin{array}{c}\text { Túnel Rebouças, que liga a } \\
\text { Zona Norte à Zona Sul, e } \\
\text { na Linha Vermelha }\end{array}$ & \\
\hline & & $\begin{array}{l}\text { Seg. à sex. das } 6 \mathrm{~h} \text { às } \\
10 \mathrm{~h} \text { e das } 17 \mathrm{~h} \text { às } 20 \mathrm{~h}\end{array}$ & $\begin{array}{c}\text { Linha Amarela, que liga a } \\
\text { Barra da Tijuca à Zona } \\
\text { Norte }\end{array}$ & \\
\hline \multirow{2}{*}{$\begin{array}{l}\text { Salvador } \\
\text { (BA) }\end{array}$} & \multirow{2}{*}{$\begin{array}{c}\text { Decreto } \\
\text { Municipal 23.975, } \\
\text { de } 4 \text { de junho de } \\
2013\end{array}$} & $\begin{array}{l}\text { Seg. à sex. das } 6 \mathrm{~h} \text { às } \\
21 \mathrm{~h} \text {; sáb. até às } 14 \mathrm{~h}\end{array}$ & $\begin{array}{l}\text { Zonas de Restrição de } \\
\text { Operação de Carga e } \\
\text { Descarga (ZRCD) }\end{array}$ & Caminhões \\
\hline & & $\begin{array}{l}\text { Seg. à sáb. das } 6 \text { às } \\
\text { 10h; seg. à sex. das } \\
17 \mathrm{~h} \text { às } 20 \mathrm{~h} ; \text { sáb. das } \\
9 \mathrm{~h} \text { às } 20 \mathrm{~h}\end{array}$ & $\begin{array}{l}\text { Áreas de Restrição à } \\
\text { Circulação (ARC) }\end{array}$ & Caminhões e tratores \\
\hline \multirow{2}{*}{$\begin{array}{l}\text { São Luiz } \\
\text { (MA) }\end{array}$} & \multirow{2}{*}{$\begin{array}{l}\text { Portaria } n^{\circ} 122, \\
\text { de } 2009\end{array}$} & $\begin{array}{c}\text { Seg. à sex. das } 6 \mathrm{~h} \text { às } \\
21 \mathrm{~h}\end{array}$ & Centro & \multirow{2}{*}{ Caminhões } \\
\hline & & $\begin{array}{l}\text { Todos os dias, em } \\
\text { qualquer horário }\end{array}$ & Centro histórico & \\
\hline \multirow{2}{*}{$\begin{array}{l}\text { Teresina } \\
\quad(\mathrm{PI})\end{array}$} & \multirow{2}{*}{$\begin{array}{l}\text { Lei Municipal no } \\
3.887 \text {, de } 8 \text { de } \\
\text { julho de } 2009\end{array}$} & $\begin{array}{l}\text { Todos os dias, em } \\
\text { qualquer horário }\end{array}$ & Vias do centro da cidade & $\begin{array}{c}\text { Caminhões com PBT } \\
\text { superior a } 16 \\
\text { toneladas }\end{array}$ \\
\hline & & Horários específicos & $\begin{array}{l}\text { Perímetro formado pelas } \\
\text { Avenidas Maranhão, } \\
\text { Joaquim Ribeiro, Miguel } \\
\text { Rosa e Frei Serafim }\end{array}$ & $\begin{array}{l}\text { Veículos com PBT } \\
\text { entre } 7 \text { e } 16 \text { toneladas }\end{array}$ \\
\hline \multirow{4}{*}{$\begin{array}{l}\text { Vitória } \\
\text { (ES) }\end{array}$} & \multirow{4}{*}{$\begin{array}{c}\text { Decreto } \\
\text { Municipal } \mathrm{n}^{\mathrm{o}} \\
\text { 10.364, de } 28 \text { de } \\
\text { maio de } 1999\end{array}$} & $\begin{array}{l}\text { Seg. à sex. das } 7 \mathrm{~h} \text { às } \\
\text { 19h; sáb. das } 8 \mathrm{~h} \text { às } \\
14 \mathrm{~h}\end{array}$ & $\begin{array}{l}\text { Rua Henrique Novaes, } \\
\text { Avenida Jerônimo } \\
\text { Monteiro, Rua General } \\
\text { Osório, Rua Thiers Velozo } \\
\text { e Rua José de Anchieta }\end{array}$ & $\begin{array}{l}\text { Veículos com PBT } \\
\text { acima de } 10 \\
\text { toneladas }\end{array}$ \\
\hline & & $\begin{array}{l}\text { Todos os dias em } \\
\text { qualquer horário }\end{array}$ & $\begin{array}{c}\text { Avenida Marechal } \\
\text { Mascarenhas de Moraes } \\
\text { (Beira Mar), entre a Rua } \\
\text { Josué Prado e Avenida } \\
\text { Paulino Muller }\end{array}$ & \multirow{2}{*}{$\begin{array}{l}\text { Veículos com PBT } \\
\text { acima de } 16 \\
\text { toneladas }\end{array}$} \\
\hline & & $\begin{array}{l}\text { Seg. à sex. das } 6 \mathrm{~h} \text { às } \\
20 \mathrm{~h} \text {; sáb. das } 6 \mathrm{~h} \text { às } \\
14 \mathrm{~h}\end{array}$ & Centro & \\
\hline & & $\begin{array}{l}\text { Seg. à sex. das } 6 \mathrm{~h} \text { às } \\
10 \mathrm{~h} \text { e das } 16 \mathrm{~h} \text { às } 20 \mathrm{~h} ; \\
\text { sáb. das } 6 \mathrm{~h} \text { às } 10 \mathrm{~h}\end{array}$ & Demais vias do município & $\begin{array}{l}\text { Veículos com PBT } \\
\text { maior que } 23 \\
\text { toneladas }\end{array}$ \\
\hline
\end{tabular}




\subsection{EVOLUÇÃO DAS RESTRIÇÕES NO MUNICÍPIO DE SÃO PAULO}

A seguir estão apresentadas as restrições à circulação e estacionamento de veículos de carga que vêm sendo adotadas e modificadas desde 1982 no município de São Paulo. As informações foram extraídas de Silva (2011).

Em 1982 foi estabelecida a primeira regulamentação para restringir a circulação de caminhões dentro da área urbana do município. Das $6 \mathrm{~h}$ às $9 \mathrm{~h}$ e das $16 \mathrm{~h}$ às $21 \mathrm{~h}$, foram proibidos de circular os caminhões com peso bruto total (PBT) acima de 15 toneladas em uma extensa área da cidade, um pouco menor do que área atual de abrangência da Zona Máxima de Restrição à Circulação (Figura 4.1). Por dificuldade de fiscalização, a medida se tornou ineficaz e foi rapidamente revogada.

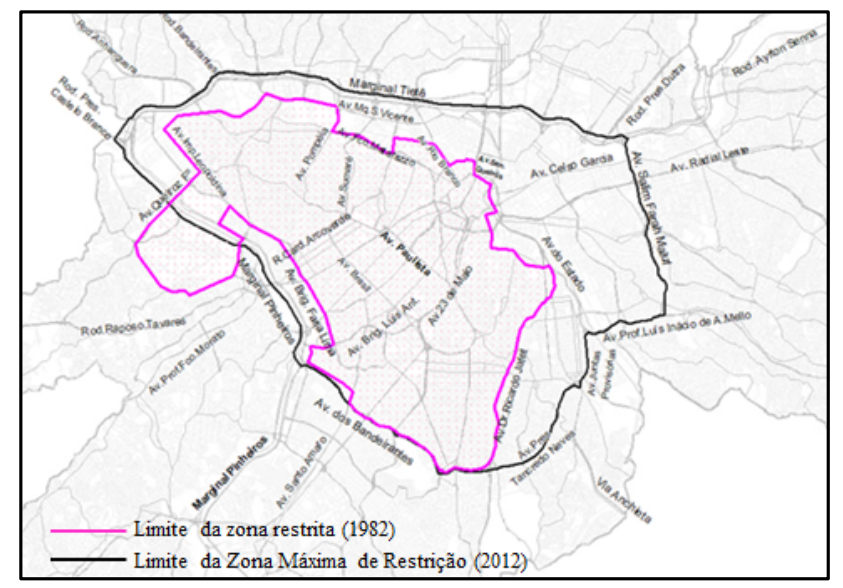

Figura 4.1 - Limites da zona restrita - 1982

Fonte: SILVA (2011)

Dois anos após, em 1986, uma nova restrição à circulação foi implementada em uma área consideravelmente menor, de apenas $11,5 \mathrm{~km}^{2}$, na qual os caminhões eram proibidos de circular durante o período diurno. A medida fez parte do Plano Emergencial para Melhoria do Trânsito de São Paulo, e teve como área piloto as proximidades do bairro dos Jardins, onde havia grande concentração de atividades. A área, conhecida como "Quadrilátero", delimitada pelas Avenidas Paulista, Brigadeiro Luís Antônio, Brasil e Rebouças (Figura 4.2), foi denominada oficialmente como Zona de Máxima Restrição à Circulação - ZMRC. 

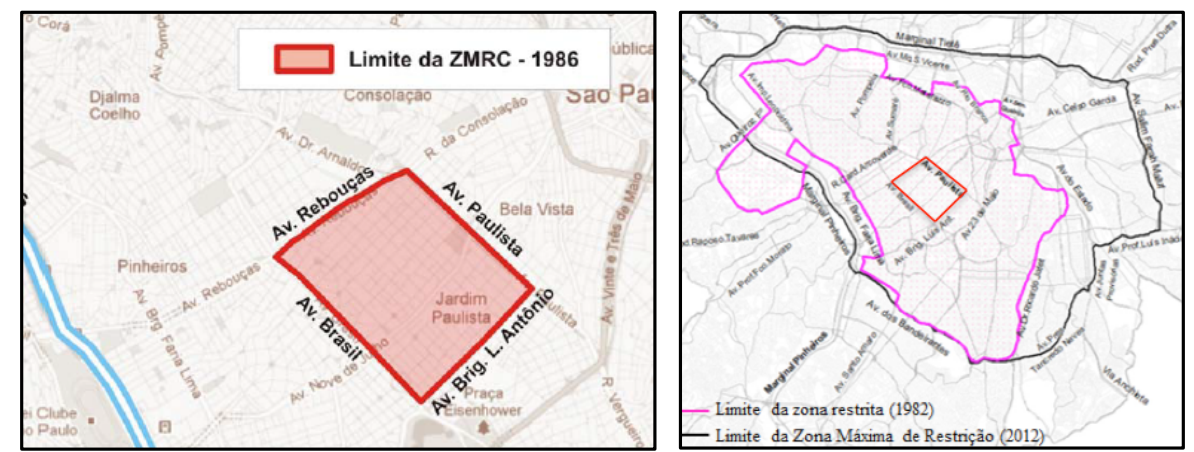

Figura 4.2 - Limites da ZMRC - Quadrilátero - 1986 Fonte: SILVA (2011)

Em pouco tempo a restrição passou a vigorar em horário determinado, de segunda à sextafeira das $6 \mathrm{~h}$ às $21 \mathrm{~h}$ e aos sábados das $8 \mathrm{~h}$ às $14 \mathrm{~h}$. Para alguns casos, nos quais os caminhões não tinham condições de realizar entregas ou prestar serviços fora dos horários de restrição, foi prevista a emissão de autorizações especiais, assim como a liberação para abastecimento e prestação de serviços essenciais. No mesmo ano, foram alterados também os limites da área restrita, que se estendeu até a Rua Cardeal Arcoverde e Avenida Brigadeiro Faria Lima (Figura 4.3), configuração que permaneceu até o ano de 1998.

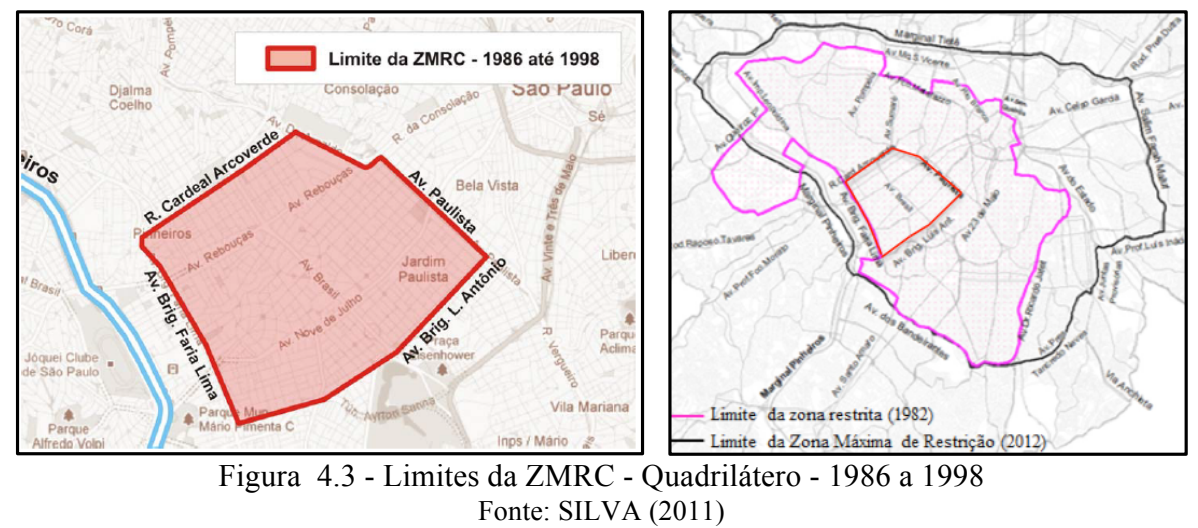

Em 1993, houve uma alteração nos horários de vigência da ZMRC, que deixaram de incluir o período de pico da manhã e passaram a ser de segunda à sexta-feira das $10 \mathrm{~h}$ às $20 \mathrm{~h}$ e aos sábados das $10 \mathrm{~h}$ às $14 \mathrm{~h}$. Nesse mesmo ano, na área da ZMRC, foi aplicado um plano de reorganização das ações vinculadas às operações de carga e descarga, o qual previa intervenções relacionadas à implantação de vagas dedicadas a essas operações, para caminhões e caminhonetes. Uma das propostas foi o aumento do número dessas vagas em locais com estacionamento rotativo pago (Zona Azul), dando origem às vagas da Zona Marrom. 
A área central da cidade teve seu primeiro projeto de restrição implementado em 1996, nas Ruas 25 de Março, Florêncio de Abreu e José Paulino. A regulamentação previa, para as Ruas 25 de Março e Florêncio de Abreu, a restrição à circulação e estacionamento de caminhões de segunda à sexta-feira das $9 \mathrm{~h}$ às $19 \mathrm{~h}$. Em contrapartida, com o objetivo de garantir a disponibilidade de vagas para carga e descarga das $6 \mathrm{~h}$ às $9 \mathrm{~h}$, o estacionamento de automóveis foi proibido nesse período. Na região da Rua José Paulino foi adotada a mesma política quanto ao estacionamento, porém sem a restrição ao trânsito de caminhões.

Desse projeto, surgiu, em 1998, a ZMRC - Centro, que ampliou as restrições das ruas para os seus entornos (Figura 4.4). Nessa alteração, a área que englobava a Rua José Paulino tornou-se restrita também ao trânsito de caminhões, que passaram a não poder circular de segunda à sexta-feira das $9 \mathrm{~h}$ às $19 \mathrm{~h}$ e aos sábados das $9 \mathrm{~h}$ às $13 \mathrm{~h}$.

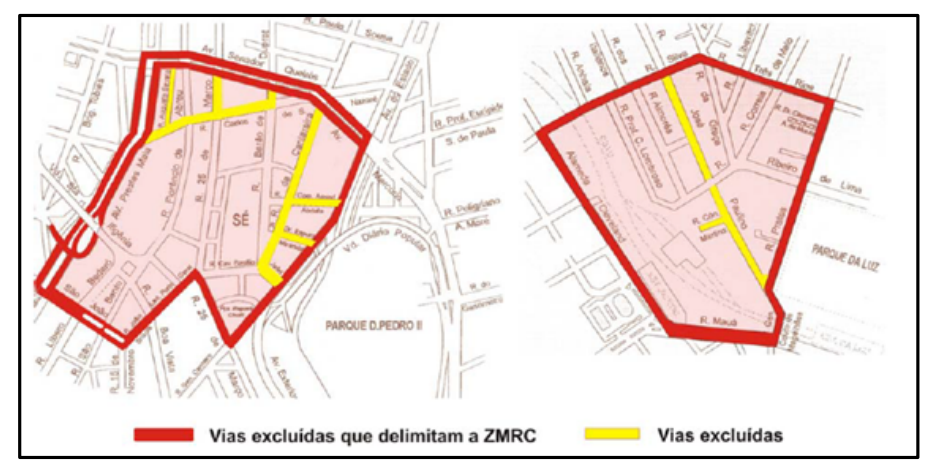

Figura 4.4 - Limites da ZMRC-Centro - 1998 a 2007

Fonte: SILVA (2011)

Na ZMRC-Centro foram implantadas as chamadas vagas de Zona Azul Mista, as quais consistiam na adaptação das vagas de estacionamento rotativo pago (Zona Azul) para o uso de veículos de carga. Ou seja, de posse do chamado Cartão Marrom, caminhões e caminhonetes estavam autorizados a estacionar nas vagas da Zona Azul Mista, de segundafeira a sábado das $7 \mathrm{~h}$ às $9 \mathrm{~h}$.

Entre a implementação da primeira restrição na área central, em 1986, e a criação da ZMRC - Centro, em 1998, foi implementado, em 1997, o rodízio de placas no centro expandido da cidade. O rodízio limitou a circulação dos automóveis na área da cidade delimitada pelo Minianel Viário (Figura 4.5). 


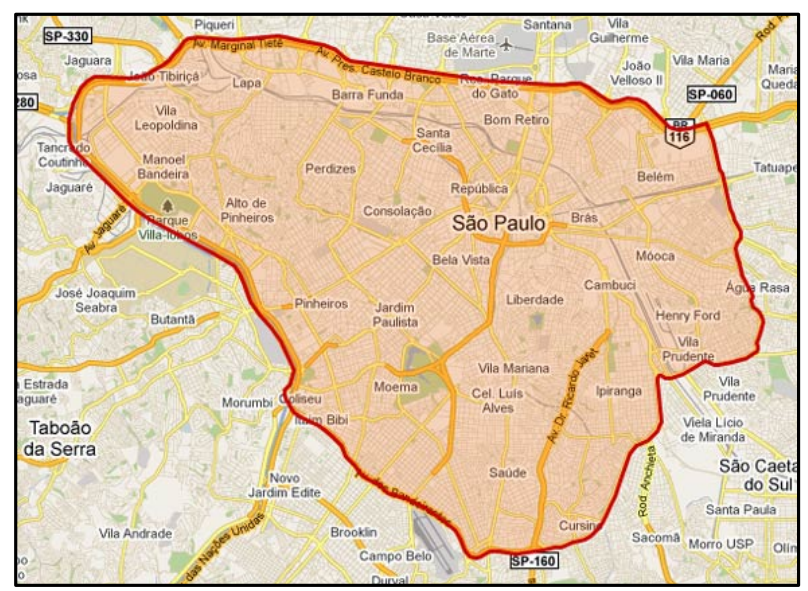

Figura 4.5 - Mini anel viário do Município de São Paulo Fonte: SILVA (2011)

Nesse mesmo ano, 1997, entraram em circulação dois novos tipos de veículos alternativos ao transportes de carga, resultados de um estudo que teve início dois anos antes, em meio às dificuldades de alguns transportadores em realizar suas entregas fora dos horários da restrição e à crescente expedição de autorizações especiais. Tais estudos visavam a criação de um veículo alternativo apropriado ao transporte de carga nas áreas de restrição, mas que apresentasse desempenho operacional compatível com as necessidades de uma área com vias muito solicitadas pelo tráfego. Surgem então o Veículo Urbano de Carga - VUC e o Veículo Leve de Carga - VLC. O primeiro com largura máxima de 2,20 metros e comprimento de até 5,50 metros, e o segundo com comprimento que podia chegar até 6,30 metros e largura máxima também de 2,20 metros.

Com as áreas da ZMRC - Quadrilátero e ZMRC - Centro em operação, restringindo o trânsito de caminhões durante o dia, foi determinado, em 2005, que os estabelecimentos comerciais e de serviços de grande porte localizados no município deveriam realizar todas as suas operações de carga e descarga no período noturno. Essa determinação foi revogada dois anos depois, em 2007, quando foram liberadas as operações diurnas de carga e descarga utilizando os VUCs, que nesse mesmo ano tiveram seu comprimento ampliado para 6,30 metros, extinguiram os VLCs.

No final de 2007 houve a criação de uma nova ZMRC (Figura 4.6), a qual englobou as duas zonas existentes, ZMRC - Quadrilátero e ZMRC - Centro, em uma área total de $25 \mathrm{~km}^{2}$, na qual os caminhões eram proibidos de circular das $10 \mathrm{~h}$ às $20 \mathrm{~h}$ de segunda à sexta-feira e das $10 \mathrm{~h}$ às $14 \mathrm{~h}$ aos sábados. 


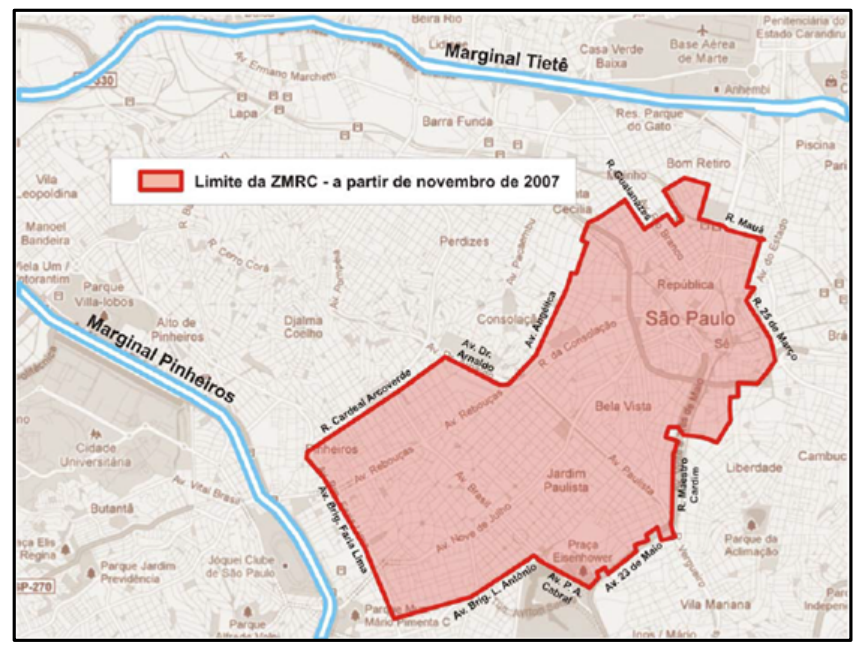

Figura 4.6 - Limites da ZMRC - 2007

Fonte: SILVA (2011)

O mesmo decreto que instituiu a nova ZMRC estabeleceu também novas áreas com restrições ao trânsito de caminhões: as Vias Estruturais Restritas - VER e as Zonas Especiais de Restrição de Circulação - ZERC

A VER são vias integrantes do sistema viário principal (arteriais ou de trânsito rápido) que apresentam alto volume veicular e são importantes eixos de ligação da cidade, como a Avenida Paulista, Rebouças, Vinte e Três de Maio, etc.; a restrição aos caminhões nessas vias são determinadas por meio de regulamentação local. As ZERC são áreas ou vias localizadas nas zonas definidas pelo plano diretor do município como Zonas Exclusivamente Residenciais (ZERs).

Em 2008, a área de restrição aos caminhões passou por uma nova ampliação, chegando aos $100 \mathrm{~km}^{2}$ (Figura 4.7). O horário da restrição também foi ampliado, valendo agora de segunda à sexta-feira das $5 \mathrm{~h}$ às $21 \mathrm{~h}$ e aos sábados das $10 \mathrm{~h}$ às $14 \mathrm{~h}$.

No mesmo ano, os VUCs, até então de circulação livre, passaram a ter o trânsito proibido na ZMRC. A decisão, porém, foi revogada pouco mais de um mês depois, quando os VUCs tiveram circulação liberada na ZMRC das $10 \mathrm{~h}$ às $16 \mathrm{~h}$, respeitando um rodízio de placas pares e ímpares. Em 2010 esse rodízio foi suspenso e os VUCs tiveram trânsito liberado no período das $10 \mathrm{~h}$ às $16 \mathrm{~h}$ na $\mathrm{ZMRC}$. 


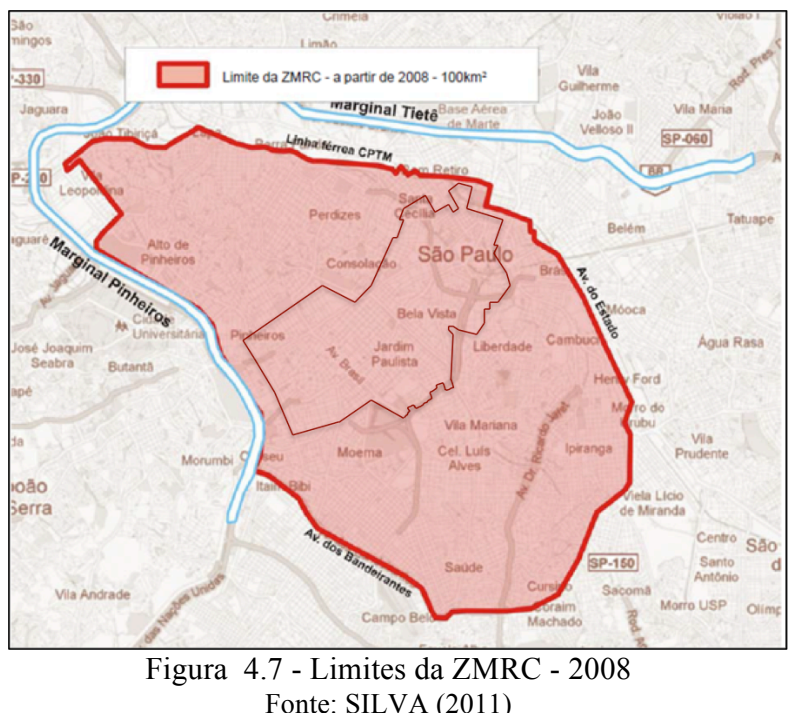

No ano de 2009 os caminhões foram incluídos no rodízio de placas que vigora para os automóveis e, assim como esses, deveriam respeitar a regra que vincula o dia da semana ao final da placa do veículo no centro expandido da Capital, delimitado pelo mini anel viário. Desde 2012, a mesma regra deve ser respeitada também pelos VUCs, quando esses foram liberados para circular por toda a ZMRC em período integral, mediante cadastro do veículo.

A inclusão das Marginais Tietê e Pinheiros na área de restrição à circulação de caminhões também foi um marco importante nas alterações que ocorreram ao longo do tempo. Em setembro de 2010, o trecho da Marginal Pinheiros entre as pontes do Jaguaré e Morumbi passou a fazer parte da ZMRC e teve o trânsito de caminhões proibido de segunda à sextafeira das $5 \mathrm{~h}$ às $21 \mathrm{~h}$ e aos sábados das $10 \mathrm{~h}$ às $14 \mathrm{~h}$. Na Marginal Tietê, em praticamente toda sua extensão, a restrição passou a valer em março de 2012, de segunda à sexta-feira das $5 \mathrm{~h}$ às $9 \mathrm{~h}$ e das $17 \mathrm{~h}$ às $21 \mathrm{~h}$ e aos sábados das $10 \mathrm{~h}$ às $14 \mathrm{~h}$.

A linha do tempo, apresentada na Figura 4.8, traz um panorama das diversas alterações que ocorreram desde a primeira restrição, implementada em 1982, até as restrições em vigor atualmente, as quais serão apresentadas em detalhe na seção 4.3. 


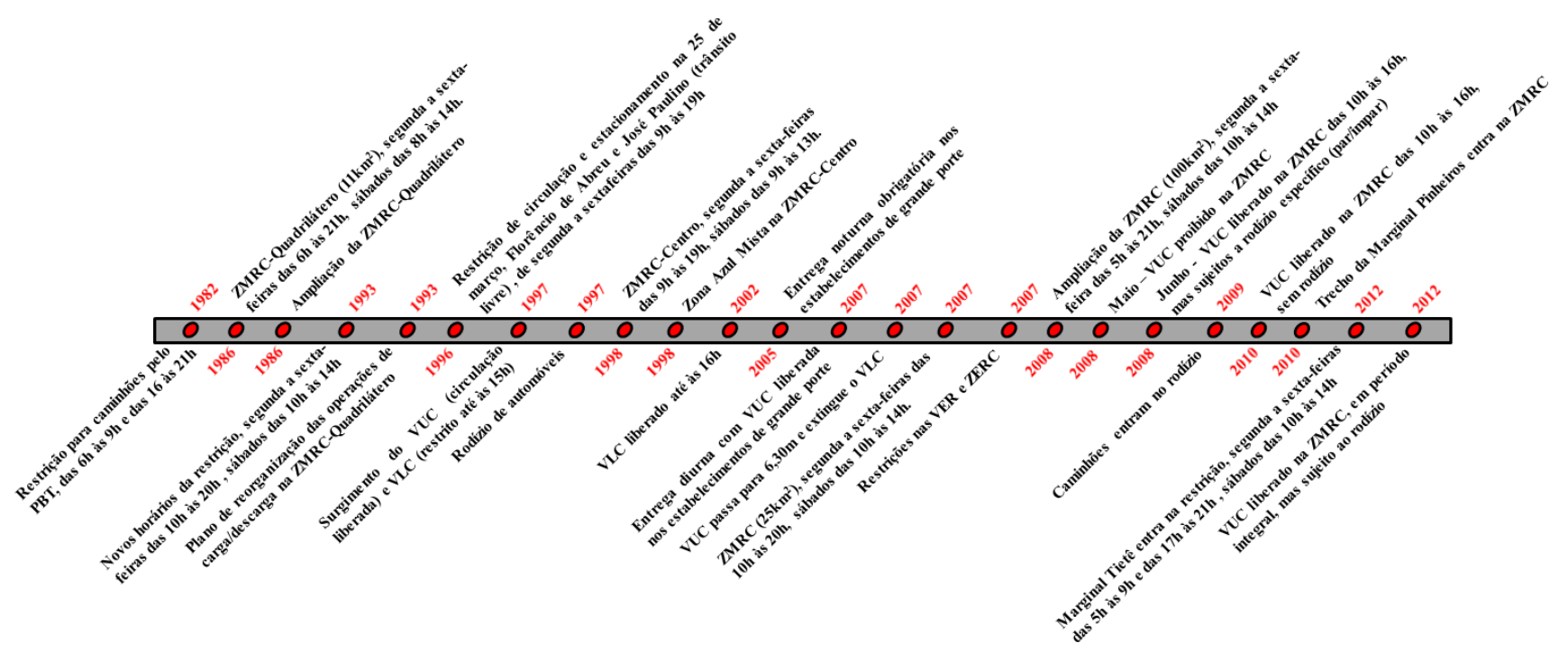

Figura 4.8 - Resumo da evolução das restrições à circulação do município de São Paulo 


\subsection{RESTRIÇÕES EM VIGÊNCIA NO MUNICÍPIO DE SÃO PAULO}

Desde 2008, à exceção da inclusão do trecho da Marginal Pinheiros, não houve alterações nos limites e nos horários da ZMRC. A regulamentação vigente atua nas áreas e vias destacadas no mapa da Figura 4.9 e é composta das seguintes restrições:

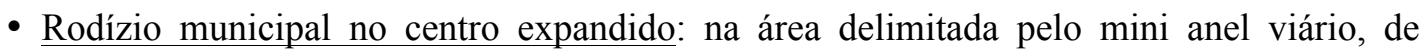
segunda à sexta-feira (exceto feriados) das $7 \mathrm{~h}$ às $10 \mathrm{~h}$ e das $17 \mathrm{~h}$ às $20 \mathrm{~h}$. Todos os veículos, incluindo automóveis, VUCs e caminhões, devem obedecer ao rodízio de placas, o qual proíbe a circulação do veículo de acordo com o último número de sua placa e o dia da semana:

- segunda-feira: não circulam veículos com placas de final 1 e 2 ;

- terça-feira: não circulam veículos com placas de final 3 e 4;

- quarta-feira: não circulam veículos com placas de final 5 e 6;

- quinta-feira: não circulam veículos com placas de final 7 e 8;

- sexta-feira: não circulam veículos com placas de final 9 e 0.

- ZMRC - Zona de Máxima Restrição à Circulação: restrição ao trânsito de caminhões de segunda à sexta-feira, das $5 \mathrm{~h}$ às $21 \mathrm{~h}$, e aos sábados, das $10 \mathrm{~h}$ às $14 \mathrm{~h}$; circulação de VUCs liberada;

- VER - Vias Estruturais Restritas: vias e seus acessos, com restrição ao trânsito de caminhões em horário determinado por meio de regulamentação local, conforme a seguinte distinção:

- vias representadas em verde: restritas ao trânsito de caminhões de segunda à sextafeira, das $5 \mathrm{~h}$ às $21 \mathrm{~h}$, e aos sábados, das $10 \mathrm{~h}$ às $14 \mathrm{~h}$ (exceto feriados); circulação de VUCs proibida, exceto na Radial Leste, onde a circulação é liberada das $10 \mathrm{~h}$ às $16 \mathrm{~h}$;

- vias representadas em vermelho (inclui parte da Marginal Pinheiros): restritas ao trânsito de caminhões de segunda à sexta-feira, das $4 \mathrm{~h}$ às $22 \mathrm{~h}$, e aos sábados, das $10 \mathrm{~h}$ às $14 \mathrm{~h}$ (exceto feriados); circulação de VUCs liberada; 


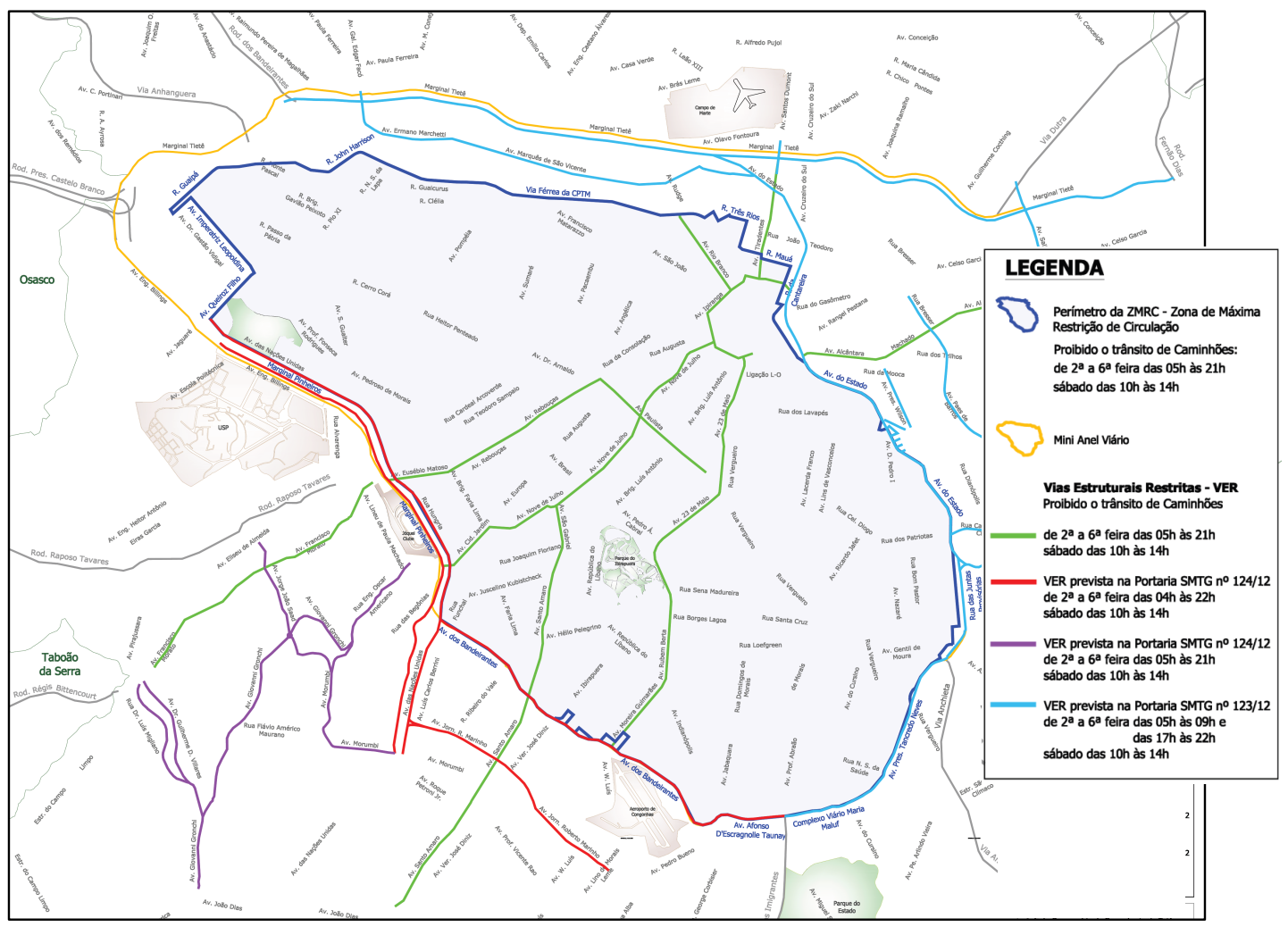

Figura 4.9- Zona de Máxima Restrição à Circulação - ZMRC e Vias Estruturais Restritas - VER

Fonte: CET-SP (2015) 
- vias representadas em roxo: restritas ao trânsito de caminhões de segunda à sextafeira, das $5 \mathrm{~h}$ às $21 \mathrm{~h}$, e aos sábados, das $10 \mathrm{~h}$ às $14 \mathrm{~h}$ (exceto feriados); circulação de VUCs liberada;

- vias representadas em azul claro (inclui a Marginal Tietê): restritas ao trânsito de caminhões de segunda à sexta-feira, das $5 \mathrm{~h}$ às $9 \mathrm{~h}$ e das $17 \mathrm{~h}$ às $22 \mathrm{~h}$, e aos sábados, das $10 \mathrm{~h}$ às $14 \mathrm{~h}$ (exceto feriados); circulação de VUCs liberada;

- ZERC - Zona Especial de Restrição à Circulação: área ou via em Zonas Exclusivamente Residenciais (ZERs), de acordo com o Plano Diretor Estratégico do Município de São Paulo, com restrição total à circulação de caminhões e VUCs;

- Vias com Trânsito Restrito de Caminhões: vias sem classificação específica mas que são restritas ao trânsito de caminhões de segunda à sexta-feira, das $5 \mathrm{~h}$ às $9 \mathrm{~h}$ e das $17 \mathrm{~h}$ às $22 \mathrm{~h}$ e aos sábados, das $10 \mathrm{~h}$ às $14 \mathrm{~h}$; são sinalizadas com placa de regulamentação R-9, complementada com a legenda "Exceto Veículos Autorizados".

\subsubsection{Exceções das Restrições}

Dentre os setores de transporte e serviços que utilizam caminhões, alguns consistem em exceções às regras gerais e possuem tratamento diferenciado, sendo liberados em determinados horários ou recebendo autorizações especiais, de acordo com a área ou a via de circulação. Os Quadros 4.2, 4.3, 4.4, 4.5 e 4.6, apresentados a seguir, contêm as informações fornecidas pela CET-SP para as exceções da regulamentação em vigência, para cada conjunto de vias da cidade. 
Quadro 4.2 - Exceções da restrição na ZMRC

\section{EXCEÇÕES NA ZONA MÁXIMA DE RESTRIÇÃO Ȧ CIRCULAÇÃO (ZMRC)}

\begin{tabular}{|c|c|}
\hline \multicolumn{2}{|r|}{ AUTORIZADOS } \\
\hline $\begin{array}{c}\text { Em período } \\
\text { integral }\end{array}$ & $\begin{array}{l}\text { - VUC } \\
\text { - Cobertura jornalística (links e/ou geradores) } \\
\text { - Correios } \\
\text { - Serviços de urgência (bombeiro, polícia, fiscalização/operação de trânsito e } \\
\text { ambulâncias) } \\
\text { - Serviço emergencial de sinalização de trânsito } \\
\text { - Obras e serviços de emergência até } 48 \text { horas da comunicação ao órgão de trânsito } \\
\text { - Socorro mecânico de emergência (guincho) }\end{array}$ \\
\hline Das $5 \mathrm{~h}$ às $16 \mathrm{~h}$ & $\begin{array}{l}\text { - Coleta de lixo } \\
\text { - Concretagem } \\
\text { - Remoção de terra em obras civis }\end{array}$ \\
\hline Das $10 \mathrm{~h}$ às $16 \mathrm{~h}$ & $\begin{array}{l}\text { - Prestação de serviços públicos essenciais } \\
\text { - Remoção de entulho e transporte de caçamba } \\
\text { - Transporte de produtos perigosos de consumo local (com até } 2 \text { eixos traseiros) }\end{array}$ \\
\hline Das $10 \mathrm{~h}$ às $20 \mathrm{~h}$ & - Transporte de valores \\
\hline \multicolumn{2}{|r|}{ COM AUTORIZAÇÃO ESPECIAL } \\
\hline $\begin{array}{c}\text { Em período } \\
\text { integral }\end{array}$ & $\begin{array}{l}\text { - Acesso a estacionamento próprio } \\
\text { - Obras e serviços de emergência entre } 48 \text { horas e } 15 \text { dias da comunicação ao órgão } \\
\text { de trânsito }\end{array}$ \\
\hline Das $5 \mathrm{~h}$ às $12 \mathrm{~h}$ & - Transporte de produtos alimentícios perecíveis \\
\hline Das $5 \mathrm{~h}$ às $16 \mathrm{~h}$ & $\begin{array}{l}\text { - Concretagem bomba } \\
\text { - Feiras livres } \\
\text { - Mudanças } \\
\text { - Obras e serviços de infraestrutura urbana }\end{array}$ \\
\hline
\end{tabular}

Fonte: CET-SP (2015) 
Quadro 4.3 - Exceções da restrição nas VER previstas na Portaria SMT. GAB. 125/12

\begin{tabular}{|c|c|}
\hline \multicolumn{2}{|c|}{ EXCEÇÕES NAS VIAS ESTRUTURAIS RESTRITAS (representadas em verde) } \\
\hline \multicolumn{2}{|r|}{ AUTORIZADOS } \\
\hline $\begin{array}{l}\text { Em período } \\
\text { integral }\end{array}$ & $\begin{array}{l}\text { - obras e serviços de emergência até } 48 \text { horas da comunicação ao órgão de trânsito } \\
\text { - serviço emergencial de sinalização de trânsito } \\
\text { - serviços de urgência (bombeiro, polícia, fiscalização/operação de trânsito e } \\
\text { ambulâncias) } \\
\text { - socorro mecânico de emergência (guincho) } \\
\text { - cobertura jornalística (links e/ou geradores) }\end{array}$ \\
\hline $\begin{array}{l}\text { Das } 10 \mathrm{~h} \text { às } \\
20 \mathrm{~h}\end{array}$ & - transporte de valores \\
\hline \multicolumn{2}{|r|}{ COM AUTORIZAÇÃO ESPECIAL } \\
\hline $\begin{array}{l}\text { Em período } \\
\text { integral }\end{array}$ & $\begin{array}{l}\text { - acesso a estacionamento próprio } \\
\text { - Correios } \\
\text { - obras e serviços de emergência entre } 48 \text { horas e } 15 \text { dias da comunicação ao órgão de } \\
\text { trânsito }\end{array}$ \\
\hline Das $5 \mathrm{~h}$ às $12 \mathrm{~h}$ & - transporte de produtos alimentícios perecíveis \\
\hline Das $5 \mathrm{~h}$ às $16 \mathrm{~h}$ & $\begin{array}{l}\text { - remoção de terra em obras civis } \\
\text { - concretagem } \\
\text { - concretagem bomba }\end{array}$ \\
\hline $\begin{array}{l}\text { Das } 10 \mathrm{~h} \text { às } \\
16 \mathrm{~h}\end{array}$ & $\begin{array}{l}\text { - obras e serviços de infraestrutura urbana } \\
\text { - remoção de entulho e transporte de caçamba }\end{array}$ \\
\hline
\end{tabular}


Quadro 4.4 - Exceções da restrição nas VER previstas na Portaria SMT. GAB. 124/12

\begin{tabular}{|c|c|}
\hline \multicolumn{2}{|c|}{ EXCEÇÕES NAS VIAS ESTRUTURAIS RESTRITAS (representadas em vermelho e roxo) } \\
\hline \multicolumn{2}{|c|}{ AUTORIZADOS } \\
\hline $\begin{array}{l}\text { Em período } \\
\text { integral }\end{array}$ & $\begin{array}{l}\text { - VUC } \\
\text { - serviços de urgência (bombeiro, polícia, fiscalização/operação de trânsito e } \\
\text { ambulâncias) } \\
\text { - socorro mecânico de emergência (guincho) } \\
\text { - cobertura jornalística (links e/ou geradores) } \\
\text { - obras e serviços de emergência até } 48 \text { horas da comunicação ao órgão de trânsito } \\
\text { - Correios } \\
\text { - serviço emergencial de sinalização de trânsito } \\
\text { - obras e serviços de emergência entre } 48 \text { horas e } 15 \text { dias da comunicação ao órgão de } \\
\text { trânsito }\end{array}$ \\
\hline Das $4 \mathrm{~h}$ às $16 \mathrm{~h}$ & $\begin{array}{l}\text { - } \text { concretagem } \\
\text { - concretagem bomba } \\
\text { - remoção de terra em obras civis } \\
\text { - coleta de lixo } \\
\text { - feiras livres } \\
\text { - mudanças }\end{array}$ \\
\hline Das $4 \mathrm{~h}$ às $12 \mathrm{~h}$ & - transporte de produtos alimentícios perecíveis \\
\hline $\begin{array}{l}\text { Das } 10 \mathrm{~h} \text { às } \\
16 \mathrm{~h}\end{array}$ & $\begin{array}{l}\text { - obras e serviços de infraestrutura urbana } \\
\text { - remoção entulho e transporte de caçambas } \\
\text { - prestação de serviços públicos essenciais } \\
\text { - transporte de máquinas, equipamentos e materiais básicos para construção civil }\end{array}$ \\
\hline $\begin{array}{l}\text { Das } 10 \mathrm{~h} \text { às } \\
20 \mathrm{~h}\end{array}$ & - transporte de valores \\
\hline \multicolumn{2}{|r|}{ COM AUTORIZAÇÃO ESPECIAL } \\
\hline $\begin{array}{l}\text { Em período } \\
\text { integral }\end{array}$ & - acesso a estacionamento próprio \\
\hline
\end{tabular}


Quadro 4.5 - Exceções da restrição nas VER previstas na Portaria SMT. GAB. 123/12

EXCEÇÕES NAS VIAS ESTRUTURAIS RESTRITAS (representadas em azul claro)

\begin{tabular}{|c|c|}
\hline \multicolumn{2}{|r|}{ AUTORIZADOS } \\
\hline Em período integral & $\begin{array}{l}\text { - } \text { VUC } \\
\text { - serviços de urgência (bombeiro, polícia, } \\
\text { fiscalização/operação de trânsito e ambulâncias) } \\
\text { - } \text { socorro mecânico de emergência (guincho) } \\
\text { - cobertura jornalística (links e/ou geradores) } \\
\text { - obras e serviços de emergência até } 48 \text { horas da } \\
\text { comunicação ao órgão de trânsito } \\
\text { - Correios } \\
\text { - } \text { serviço emergencial de sinalização de trânsito }\end{array}$ \\
\hline $\begin{array}{l}\text { De seg. à sex. das } 5 \mathrm{~h} \text { às } 9 \mathrm{~h} \text { e } \\
\text { aos sábados das } 10 \mathrm{~h} \text { às } 14 \mathrm{~h}\end{array}$ & $\begin{array}{l}\text { - } \text { concretagem } \\
\text { - concretagem-bomba } \\
\text { - feiras livres } \\
\text { - mudança } \\
\text { - coleta de lixo/coleta seletiva } \\
\text { - transporte de produtos alimentícios perecíveis } \\
\text { - obras e serviços de infraestrutura urbana } \\
\text { - transporte de máquinas, equipamentos e materiais básicos } \\
\text { para a construção civil }\end{array}$ \\
\hline $\begin{array}{l}\text { De seg. à sex. das } 5 \mathrm{~h} \text { às } 9 \mathrm{~h} \text { e das } 17 \mathrm{~h} \text { às } \\
18 \mathrm{~h} \text { e aos sábados das } 10 \mathrm{~h} \text { às } 14 \mathrm{~h}\end{array}$ & - remoção de terra em obras civis \\
\hline $\begin{array}{l}\text { De seg. à sex. das } 17 \mathrm{~h} \text { às } 20 \mathrm{~h} \text { e aos } \\
\text { sábados das } 10 \mathrm{~h} \text { às } 14 \mathrm{~h}\end{array}$ & - transporte de valores \\
\hline Aos sábados das $10 \mathrm{~h}$ às $14 \mathrm{~h}$ & $\begin{array}{l}\text { - remoção de entulho e transporte de caçambas } \\
\text { - prestação de serviços públicos essenciais }\end{array}$ \\
\hline \multicolumn{2}{|c|}{ com autorização especial } \\
\hline Em período integral & - acesso a estacionamento próprio \\
\hline
\end{tabular}

Fonte: CET-SP (2015) 
Quadro 4.6 - Exceções da restrição nas ZERC

\begin{tabular}{|c|c|}
\hline \multicolumn{2}{|c|}{ EXCEÇÕES NA ZONA ESPECIAL DE RESTRIÇÃO À CIRCULAÇÃO (ZERC) } \\
\hline \multicolumn{2}{|c|}{$\begin{array}{l}\text { AUTORIZADOS } \\
\end{array}$} \\
\hline $\begin{array}{l}\text { Em período } \\
\text { integral }\end{array}$ & $\begin{array}{l}\text { - Correios } \\
\text { - obras e serviços de emergência até } 48 \text { horas da comunicação ao órgão de trânsito } \\
\text { - serviços emergencial de sinalização de trânsito } \\
\text { serviços de urgência (bombeiro, polícia, fiscalização/operação de trânsito e } \\
\text { ambulâncias) } \\
\text { - socorro mecânico de emergência (guincho) } \\
\text { - cobertura jornalística (links e/ou geradores) }\end{array}$ \\
\hline Das $5 \mathrm{~h}$ às $16 \mathrm{~h}$ & $\begin{array}{l}\text { - coleta de lixo } \\
\text { - concretagem } \\
\text { - remoção de terra em obras civis }\end{array}$ \\
\hline Das $10 \mathrm{~h}$ às $16 \mathrm{~h}$ & $\begin{array}{l}\text { - prestação de serviços públicos essenciais } \\
\text { - remoção de entulho e transporte de caçamba }\end{array}$ \\
\hline Das $21 \mathrm{~h}$ às $16 \mathrm{~h}$ & - coleta de lixo \\
\hline Das $21 \mathrm{~h}$ às $5 \mathrm{~h}$ & - entrega e retirada de mercadorias \\
\hline \multicolumn{2}{|r|}{ COM AUTORIZAÇÃO ESPECIAL } \\
\hline $\begin{array}{l}\text { Em período } \\
\text { integral }\end{array}$ & $\begin{array}{l}\text { - acesso a estacionamento próprio } \\
\text { - obras e serviços de emergência entre } 48 \text { horas e } 15 \text { dias da comunicação ao órgão de } \\
\text { trânsito }\end{array}$ \\
\hline Das $5 \mathrm{~h}$ às $16 \mathrm{~h}$ & $\begin{array}{l}\text { - concretagem bomba, obrigatório permanecer estacionado das } 12 \mathrm{~h} \text { às } 14 \mathrm{~h} \\
\text { - feiras livres } \\
\text { - mudanças } \\
\text { - obras e serviços de infraestrutura urbana }\end{array}$ \\
\hline Das $21 \mathrm{~h}$ às $5 \mathrm{~h}$ & - transporte de máquinas, equipamentos e materiais básicos para construção civil \\
\hline Das $10 \mathrm{~h}$ às $16 \mathrm{~h}$ & $\begin{array}{l}\text { - remoção de entulho e transporte de caçamba } \\
\text { - transporte de produtos perigosos de consumo local, com até } 2 \text { eixos }\end{array}$ \\
\hline
\end{tabular}




\subsubsection{Fatos e Considerações Sobre as Restrições}

A distribuição urbana de cargas, como já mencionado neste trabalho, envolve diversos agentes e engloba muitos aspectos. Para que uma medida atinja seus objetivos e tenha resultados duradouros, todos os fatores precisam ser considerados, de forma que os efeitos esperados sejam otimizados e os efeitos negativos secundários possam ser evitados ou controlados. As informações apresentadas nesta seção mostram algumas das divergências que surgem em relação às medidas que restringem a circulação de caminhões no município de São Paulo.

Após a ampliação da Zona Máxima de Restrição à Circulação, dados de monitoramentos realizados e divulgados pela CET-SP mostraram que as medidas implementadas têm trazido resultados positivos para a cidade.

Com a ampliação da ZMRC em 2008, os principais resultados observados em termos numéricos na cidade toda foram redução do volume total de caminhões em $8 \%$, aumento da velocidade média em $34 \%$, diminuição da extensão da lentidão em 7\% (a imediata foi de 19\%) e redução média de 6\% das ocorrências de trânsito envolvendo caminhões (LAIZA et al., 2009, p. 4).

Recentemente, outra análise foi divulgada, dessa vez para os efeitos da implementação da restrição na Marginal Tietê e em outras importantes vias, no ano de 2012. Os resultados mostraram que "na Marginal Tietê houve uma queda de 77\% no volume de caminhões nos horários de pico, passando de 11.874 (no ano de 2010) para 2.725 em março de 2012" (CET-SP, 2012).

A opinião sobre os benefícios da restrição à circulação, no entanto, não é unânime, e os resultados positivos são contestados por dados que indicam novos registros de lentidão nas vias da cidade e o surgimentos de alguns efeitos secundários, como o aumento expressivo na frota de veículos utilitários e no número de assaltos a caminhões.

\section{Reações dos Setores de Transporte}

As reações negativas de alguns setores de transporte mostram um ponto de vista diferente em relação aos efeitos esperados e indicam que as empresas transportadoras não 
participaram dos processos decisórios, tendo que tomar medidas emergenciais para se adaptar às novas regras.

Em março de 2008, através de nota divulgada no Portal NTC\&Logística, Flávio Benatti, Presidente da Associação Nacional do Transporte de Cargas e Logística, afirmou que a restrição aos caminhões na cidade afetaria o transporte rodoviário de carga de todo o Brasil, já que o segmento é responsável por movimentar aproximadamente $90 \%$ de tudo o que se produz e se consome no estado de São Paulo e por cerca de $60 \%$ de todas as cargas do país. Benatti disse ainda que outros transtornos também poderiam ser formados ao longo das rodovias que dão acesso à Capital, como congestionamentos de veículos em outros horários, e destacou a necessidade de atenção ao pequeno comerciante, alegando que esse seria diretamente afetado pela proibição de entregas de mercadorias durante o dia. (PORTAL NTC\&LOGÍSTICA, 2008).

Em matéria publicada na Gazeta Mercantil, o presidente do Sindicato das Empresas de Transportes de Carga de São Paulo e Região (SETCESP), Francisco Pelucio, afirmou que a restrição iria impactar principalmente as transportadoras que trabalham na cidade de São Paulo, já que essas reduziriam o número de entregas e coletas realizadas diariamente no município.

Acredito que há medidas mais eficientes para solucionar o problema do trânsito e não penalizar o transportador. Irão fazer isso e verão que o vilão dessa história não é o transportador, pois o congestionamento continuará. Se a Prefeitura retirasse de circulação os veículos clandestinos, que chegam a 1,8 milhão de carros, já amenizaria a situação [...] (GAZETA MERCANTIL, 2008).

Na mesma matéria, Edilson Binotto, diretor de uma das principais transportadoras do país, relata a necessidade de aquisição de 60 vans, como alternativa para driblar a proibição de circulação aos caminhões durante o dia, imposta pela restrição.

Fazemos um total de 20 mil entregas diárias, $60 \%$ delas na cidade de São Paulo. Além das 60 vans, vamos comprar mais 20 para compensar as restrições aos VUCs que temos. Os cálculos indicam que, em nosso caso, com as vans, vamos ter que rodar quatro vezes mais. Isso representa uma piora no trânsito. (GAZETA MERCANTIL, 2008) 
O Sindicato das Empresas de Transportes de Carga de São Paulo e Região (SETCESP) divulgou uma nota em sua página na internet, com o objetivo de esclarecer a posição dos empresários de transporte sobre as restrições à circulação. Na publicação, a SETCESP afirma que

as restrições [...] são fundamentadas em falsos argumentos, confundindo o tráfego de passagem de caminhões, que tem a opção de uso do rodoanel, com o tráfego urbano de caminhões [...] que precisam circular dentro da cidade para atender com eficiência a demanda de abastecimento[...]. A restrição é uma medida paliativa e de resultados pífios e de pouca duração [...] (SETCESP, 2012).

A entidade critica, ainda, a suposta possibilidade de realização das entregas em horários noturnos.

\begin{abstract}
Como efeito das restrições temos o agravamento das condições operacionais das empresas com evidente repercussão e aumento significativo nos custos do abastecimento A medida ignora o limite da jornada do trabalhador e supõe a possibilidade de abastecimento na madrugada mas que na realidade é inaplicável: os caminhões carregados circulando pela cidade deserta são alvos fáceis do crime organizado. Não há segurança e nem mesmo transporte público nesses horários para conduzir o trabalhador aos seus lares e nem mesmo os estabelecimentos comerciais [...] estão dispostos a funcionar e receber mercadorias do transportador (SETCESP, 2012).
\end{abstract}

\title{
Curta Duração dos Benefícios
}

Os resultados positivos trazidos pela restrição à circulação dos veículos de carga são confrontados também pela opinião de especialistas e por novos dados de congestionamentos, divulgados pela própria CET-SP, os quais levam a crer em uma curta duração desses benefícios e acabam por reduzir a credibilidade das medidas diante das empresas transportadoras. As notícias divulgadas pelo O Estado de São Paulo e pelo Portal Transporta Brasil, reproduzidas a seguir, indicam uma curta duração dos efeitos positivos trazidos pela ampliação da ZMRC, no ano de 2008, e mostram que o mesmo aconteceu com a inclusão da Marginal Tietê, em 2012. 
Segundo especialistas em transporte, a proibição da circulação de caminhões nos horários de pico tem seu efeito reduzido por causa da grande quantidade de veículos de passeio na região. Para eles, a conclusão do Rodoanel, a construção do Ferroanel e a ampliação da malha do metrô e dos corredores exclusivos de ônibus é o que efetivamente aliviará o trânsito na região. Os fatos comprovam essa avaliação pouco otimista dos especialistas. Em São Paulo, a primeira etapa da restrição à circulação dos caminhões melhorou o trânsito apenas durante um curto período. Para aliviar os congestionamentos na capital, os governos estadual e municipal conjugaram iniciativas como a instituição da zona de máxima restrição ao tráfego pesado, o rodízio da circulação de caminhões e obras de melhorias viárias, como a ampliação da Marginal do Tietê e a construção do Trecho Sul do Rodoanel. Com tudo isso, os congestionamentos diminuíram 32\%, de acordo com dados da Companhia de Engenharia de Tráfego (CET) de abril de 2010. Mas esse alívio durou pouco. Conforme dados de setembro, o índice de engarrafamentos às $19 \mathrm{~h}$ foi $10 \%$ superior ao mesmo mês do ano passado, atingindo 129,7 quilômetros de filas no horário - 11,8 quilômetros a mais do que um ano antes (O ESTADO DE SÃO PAULO, 2011).

Após um mês de proibições aos caminhões na Marginal Tietê e outras 25 vias de São Paulo, os números das restrições mostram que a cidade já sente os efeitos da medida em seu cotidiano. De acordo com o levantamento divulgado na última quinta-feira pela Companhia de Engenharia de Tráfego (CET-SP), houve melhora de 12\% nos congestionamentos da Marginal durante o horário de pico da manhã, efeito esperado pela Prefeitura. Mas, em contrapartida, os números do trânsito da cidade mostram que, entre as $9 \mathrm{~h}$ e as $17 \mathrm{~h}$, período liberado para o tráfego dos caminhões, houve piora no trânsito, de quase 4\%. O motivo: o grande número de veículos disputando as vias em um horário concentrado, causando um efeito indesejável. [...] Entidades que representam as transportadoras, como SETCESP, [...] se colocam contrários às medidas. 'Não se pode restringir o caminhão na Marginal Tietê sem que haja alternativas, como o Rodoanel. Hoje, só temos os trechos sul e oeste operado e o tráfego de passagem não tem para onde ir. Estas restrições, além de terem vida curta, como vimos na Marginal Pinheiros, aumenta o custo do transporte na cidade e não melhoram o trânsito' (PORTAL TRANSPORTA BRASIL, 2012).

\section{Efeitos Secundários}

As restrições geraram também alguns efeitos secundários. $\mathrm{O}$ aumento do número de veículos menores na frota de veículos de carga talvez tenha sido um efeito secundário esperado. Especialistas afirmam, no entanto, que houve uma "explosão" no número de utilitários em menos de quatro anos, devido à rápida necessidade dos transportadores de se adaptarem às restrições, sem perder competitividade no mercado.

Dados do Detran-SP, entre 2008 e 2012, mostram que o número de caminhões pesados diminuiu, enquanto o número de veículos utilitários de carga, categoria que inclui os VUCs, 
aumentou acima da média. Houve um aumento de cerca de $43 \%$ no número de VUCs, entre maio de 2008 (antes da implementação da restrição) e dezembro de 2012, sendo que o número de caminhões pesados, no mesmo período, sofreu uma redução de aproximadamente 8\% (DETRAN-SP, 2013). O consultor de engenharia urbana Luiz Bottura, em entrevista ao Terra, afirma que o aumento no número de VUCs é uma tendência natural, já que eles possibilitam a chegada das cargas aos estabelecimentos de maneira mais rápida e com menos incômodo ao trânsito, mas ressalta que faltaram pesquisa e embasamento para que as restrições à circulação fossem impostas.

Faltou conhecer origem, destino, qualidade e peso do que carregavam os caminhões, para aí tomar uma atitude mais coerente. Faltam locais - como os warehouses americanos - que permitam os caminhões pesados desovarem sua carga para depois utilizar caminhões menores e outros veículos para distâncias curtas (TERRA, 2012).

Outros efeitos secundários, provavelmente não previstos, incluem as filas formadas nos acostamentos das vias, pelos caminhões aguardando poderem circular nas Marginais, e os assaltos e roubos decorrentes dessa prática, os quais são destaque em notícias divulgadas pelo Jornal da Tarde e pelo Portal G1.

Sem poder entrar em São Paulo nos horários de restrição de caminhões nas Marginais do Tietê e do Pinheiros, caminhoneiros transformaram os acostamentos das rodovias que chegam à capital em pontos perigosos de parada. As filas, que em alguns casos têm mais de 20 caminhões, prejudicam os motoristas que precisam usar esses pontos em caso de emergência, atrapalham a entrada em acessos para outras vias e aumentam o perigo de colisões. Caminhoneiros ainda correm risco de serem assaltados (BOMFIM, 2012).

O registro de roubos de carga na cidade de São Paulo aumentou 39\% em março de 2012 em relação a março de 2011, segundo as estatísticas criminais divulgadas pela Secretaria de Segurança Pública do Estado. [...] $\mathrm{O}$ aumento no número de casos nos distritos da Sé e do Pari, na região central de São Paulo, são creditados pelo Sindicam-SP (Sindicato dos Transportadores Rodoviários Autônomos de Bens do Estado de São Paulo) pelo grande movimento de carga e descarga na região. Com a restrição de horários, muitos veículos ficam parados na região esperando para poder seguir viagem, ou passaram a fazer entregas depois das $22 \mathrm{~h}$ e antes das $5 \mathrm{~h}$ (CARDILLI, 2012).

A evolução das restrições, aliada aos números e relatos apresentados nesta seção sugerem que, ao longo dos anos, não foram elaboradas propostas que buscassem uma racionalização do transporte urbano de carga, mas sim foram implementadas medidas restritivas em caráter 
emergencial, sem um planejamento adequado que permitisse a previsão de seus efeitos. Em setembro de 2007, mesmo ano em que a ZMRC possuía apenas $25 \mathrm{~km}^{2}$, a Gazeta Mercantil trazia a notícia intitulada "São Paulo quer ordenar a distribuição metropolitana", dizendo que para desafogar o trânsito de caminhões na cidade de São Paulo, o governo do estado planejava a construção de cinco plataformas logísticas na região metropolitana (MACHADO, 2007). Em junho de 2008, sem nenhuma das cinco plataformas construída, entrava em vigor a restrição à circulação de caminhões na área ampliada da ZMRC, então com $100 \mathrm{~km}^{2}$. 


\section{AVALIAÇÃO DE MEDIDAS VOLTADAS À DISTRIBUIÇÃO URBANA DE CARGAS}

Este capítulo aborda a importância da avaliação de medidas voltadas à distribuição urbana de cargas, em especial durante a fase de planejamento, e traz uma revisão dos principais trabalhos da literatura internacional, além de duas teses de doutorado nacionais, publicados entre os anos 2000 e 2012, e que apresentam metodologias e modelos desenvolvidos para essa avaliação.

\subsection{CONCEITOS E TERMOS}

Antes de tratar da questão da avaliação de medidas para a distribuição urbana de cargas é necessária a definição precisa de alguns dos termos que serão utilizados ao longo deste capítulo e no restante do trabalho:

- Medidas: iniciativas ou ações voltadas à melhoria de um sistema, através da alteração e do controle das operações que dele fazem parte. No caso deste trabalho, as medidas são voltadas ao transporte urbano de cargas, podendo ser agrupadas em três categorias (Kant et al., 2012):

- medidas de natureza política: iniciadas pelo governo local através de incentivos às empresas, coordenação entre as operações de diferentes agentes logísticos ou aplicação de novas regulamentações; alguns exemplos são a restrição à circulação de veículos, o pedágio urbano e a entrega noturna;

- medidas de natureza logística ou operacional: geralmente iniciativas dos agentes envolvidos no processo logístico da distribuição urbana, ou seja, os embarcadores, os transportadores e os recebedores das cargas; a consolidação de cargas e o transporte intermodal são exemplos;

- medidas de natureza tecnológica: ligadas ao uso da tecnologia para a otimização das operações do transporte de cargas e trazidas ou estimuladas tanto pelos fabricantes de 
veículos e autoridades locais, como pelos embarcadores e transportadores; podem ser associadas aos veículos, como por exemplo na utilização de propulsão híbrida ou eletricidade, ou à informação e comunicação, como no caso dos sistemas avançados de informação ao condutor (ATIS - Advanced Traveler Information System), de gerenciamento de tráfego (ATMS - Advanced Traffic Management System) e de controle de veículo (AVCS - Advanced Vehicle Control System).

- Objetivo: é a situação que se deseja obter ao final da implementação da medida (COHEN; FRANCO, $2004^{8}$ apud CUNHA, 2006);

- Efeito: é o que decorre da influência da medida implementada. Enquanto o objetivo está localizado temporalmente antes do início da vigência da medida, os efeitos são seus resultados. Podem ser intermediários, durante os estágios de implementação, ou finais, que são os que perduram após a completa implementação da medida. Os efeitos podem ter sido estabelecidos como objetivos ou não, sendo que nesse último caso, podem ainda ser ou não previstos (CUNHA, 2006);

- Impacto: é o resultado que pode ser atribuído exclusivamente à medida, após a eliminação dos efeitos externos (CUNHA, 2006);

- Impacto local: impacto observado ao nível micro da cidade, decorrente das atividades que compõem as operações de entrega de um conjunto de veículos em uma pequena área da cidade, ou até mesmo de um único veículo em uma única via;

- Eficácia: conceito ligado ao alcance dos objetivos pretendidos;

- Efetividade: diz respeito à capacidade de se alcançar os objetivos pretendidos; é a relação entre os resultados obtidos e os esperados, ou seja, o grau de alcance dos objetivos (COHEN; FRANCO, $2004^{8}$, apud CUNHA, 2006).

${ }^{8}$ COHEN, E.; FRANCO, R. Avaliação de Projetos Sociais. Petrópolis: Vozes, 2004. 


\subsection{IMPORTÂNCIA DA AVALIAÇÃO DE MEDIDAS VOLTADAS À DISTRIBUIÇÃO URBANA DE CARGAS}

A avaliação é considerada uma etapa fundamental no processo de implementação de uma medida, pois permite a análise de seus resultados acerca dos objetivos por ela pretendidos e contribui para a verificação de sua eficácia e efetividade (RAMOS; SCHABBACH, 2012). Segundo Cohen e Franco ${ }^{9}$ (2004, apud CUNHA, 2006), a avaliação pode ser realizada em dois momentos:

i. antes da implementação da medida (avaliação ex-ante): com a finalidade de dar suporte à decisão de implementação da medida, tal avaliação deve ser capaz de prever seus efeitos, assim como verificar se os objetivos pretendidos seriam alcançados e em qual grau de alcance. Sendo assim, permite prever a eficácia e a efetividade da medida em sua configuração original e/ou em configurações alternativas, ou até mesmo determinar que a medida não é viável;

ii. após a implementação da medida (avaliação ex-post): neste tipo de avaliação os resultados alcançados pela implementação da medida podem ser comparados aos seus objetivos. Neste caso, deve ser possível verificar a eficácia e a eficiência reais da medida em execução e determinar se a mesma deve ser mantida, em sua configuração original ou não, ou até mesmo se deve ser suspensa.

Taniguchi et al. (2001) consideram a avaliação como uma das principais etapas no processo de desenvolvimento de uma medida. Os autores afirmam que:

- Os problemas a serem minimizados pela medida devem ser identificados e definidos, podendo estar relacionados, dentre outros fatores:

- ao planejamento e gerenciamento da frota;

- aos impactos ambientais;

- aos congestionamentos no tráfego.

- Os critérios de avaliação da medida devem ser definidos de acordo com os objetivos do sistema, os quais podem ser:

${ }^{9}$ COHEN, E.; FRANCO, R. Avaliação de Projetos Sociais. Petrópolis: Vozes, 2004. 
- sociais: redução dos congestionamentos no tráfego, através de um sistema mais eficiente de coleta e entrega, capaz de reduzir o número de veículos e maximizar o fator de carregamento dos mesmos;

- ambientais: como consequência da redução de emissões e ruídos;

- econômicos: devido à redução nos custos fixos e operacionais;

- voltados à redução no consumo de energia: resultado de reduções no consumo de combustível ou da utilização de energias alternativas.

A avaliação da eficácia e/ou da efetividade de uma medida voltada ao transporte de cargas, seja ela de natureza política, logística ou tecnológica, deve considerar diversos aspectos, dentre eles: as características da medida avaliada, a força de sua ligação com os problemas que busca solucionar, os efeitos externos e secundários que ela pode trazer, seus impactos operacionais para os diferentes agentes, o nível de análise desejado e os dados necessários para a avaliação (MARCUCCI et al., 2011). Hensher e Puckett (2004, p. 3, tradução livre) afirmam que "políticas que não levam em conta as complexas interações dentro da cadeia podem levar a resultados subótimos, baseados em projeções imprecisas dos efeitos esperados".

Avaliar os resultados de medidas voltadas ao transporte urbano de cargas requer a elaboração de modelos que descrevam o comportamento dos principais agentes envolvidos, incorporem suas atividades e descrevam os fluxos dos veículos de carga nas vias urbanas, bem como o fluxo de carros de passageiros. Modelos também são necessários para quantificar mudanças nos custos das atividades logísticas, nos congestionamentos do tráfego, nas emissões de gases poluentes e nos níveis de ruído após a implementação das medidas escolhidas (TANIGUCHI; THOMPSON, 2002).

\subsection{MODELOS PARA A AVALIAÇÃO DE MEDIDAS VOLTADAS À DISTRIBUIÇÃO URBANA DE CARGAS}

Muitos são os trabalhos que abordam o problema da distribuição urbana de cargas e apresentam ou propõem soluções voltadas à racionalização de suas operações e redução dos impactos por elas gerados (BENJELLOUN et al., 2010; CRAINIC et al., 2003; GOLDMAN e GORHAM, 2006; KANT et al., 2012 e QUAK, 2008). Existe, no entanto, uma lacuna na 
literatura quando se pensa na distribuição urbana de cargas no ambiente de uma grande cidade e principalmente na modelagem voltada à avaliação de medidas nesse contexto. Tal lacuna é ainda mais expressiva quando se pensa nessa avaliação considerando o nível microscópico da cidade, de forma que impactos locais decorrentes das operações da distribuição urbana possam ser estimados.

Esta seção tem como um de seus objetivos confirmar essa lacuna na literatura, através da revisão dos principais trabalhos que tratam da modelagem do transporte urbano de cargas, com especial foco para aqueles que apresentam metodologias e modelos aplicados na avaliação de medidas, através da quantificação de seus impactos. A revisão engloba trabalhos publicados entre os anos 2000 e 2012, incluindo artigos de revistas internacionais, apresentados em ordem cronológica de publicação, e duas teses de doutorado nacionais.

Os trabalhos selecionados apresentam diferentes abordagens. Dentre eles, destacam-se aqueles cujos modelos baseiam-se no uso de técnicas de simulação do tráfego, para os quais será possível constatar o uso predominante da macrossimulação, a qual despreza a individualidade dos veículos ao considerar apenas o comportamento agregado da corrente veicular ao se deslocar pelas vias da rede, ou seja, são modeladas apenas suas características médias (MAIA, 2007).

Dessa forma, esta seção pretende, também, destacar a escassez de trabalhos que utilizam a técnica da microssimulação na modelagem do transporte urbano de cargas, uma vez que tal abordagem parece adequada nesse contexto. Isso porque, na microssimulação, os veículos podem ser tratados de forma inteiramente individualizada e o ambiente modelado com alto nível de detalhamento, o que pode ser importante para a avaliação de impactos locais e a análise do comportamento dos veículos de carga no ambiente urbano, quando esses estão sujeitos a determinadas medidas que alteram suas operações.

\subsubsection{Trabalhos Revisados}

Taniguchi e van der Heijden (2000) propõem a aplicação de um modelo para representar o comportamento dos veículos urbanos de carga e de passageiros em uma rede de transportes, com o objetivo de quantificar as consequências da implementação de iniciativas de city logistics, em termos da redução dos custos totais e das emissões de $\mathrm{CO}_{2}$. De acordo com os 
autores city logistics é um processo de planejamento integrado, envolvendo o estabelecimento de parcerias entre os setores público e privado, o qual promove projetos inovadores para redução do custo total (econômicos, sociais e ambientais) da movimentação de cargas dentro das cidades.

O modelo é composto de dois submodelos que sofrem sucessivas iterações até que a solução ótima seja encontrada: (i) um modelo para o problema da roteirização dos veículos de entrega, com janelas de entrega (Vehicle Routing Problem with Time Window - VRPTW) e (ii) um modelo híbrido (micro/macroscópico) de simulação dinâmica do tráfego para a frota de veículos de carga e de passageiros na rede de transporte que compõe a área urbana da cidade.

Considerando, para cada operador de transporte, um depósito e um determinado número de clientes, frota homogênea de veículos e a janela de entrega de cada cliente, o modelo para o $V R P T W$ determina, para cada operador, a alocação ótima de veículos para o atendimento dos clientes, assim como seus horários de partida e a sequência de atendimento a ser realizada. Para tal, o modelo busca a minimização dos custos totais de transporte (custos fixos, operacionais e penalidades por atraso), obedecendo às limitações de capacidade dos caminhões e às janelas de entrega. Em seguida, o modelo de simulação dinâmica estima o tempo de viagem em cada arco da rede. O VRPTW é então novamente resolvido, considerando os tempos médios de viagem em cada arco da rede, obtidos da simulação. Sucessivas iterações do $V R P T W$ e da simulação são feitas até que o critério de convergência para a solução ótima seja satisfeito.

O modelo híbrido de simulação consiste em dois componentes: (i) uma simulação dos fluxos e (ii) uma simulação para a escolha das rotas; conforme mostra a Figura 5.1.

Embora considerado híbrido, o modelo de simulação apresenta características essencialmente macroscópicas. Sua característica microscópica está apenas na determinação as origens e os destinos de cada veículo de carga, necessários para o modelo de simulação de fluxos. 


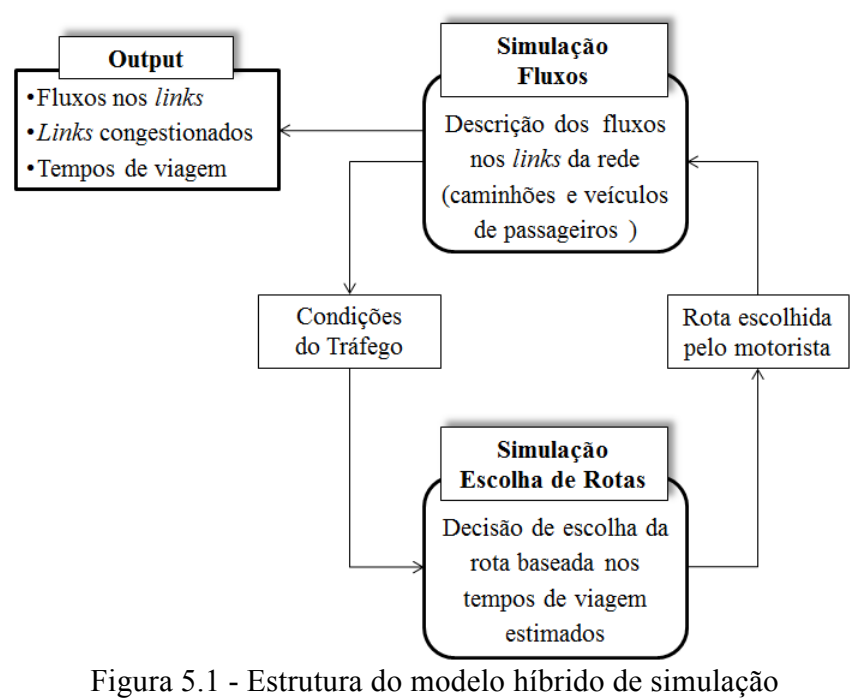

Fonte: TANIGUCHI; VAN DER HEIJDEN (2000), p. 74

O modelo proposto, composto pelos submodelos de roteirização e simulação, foi então testado em uma rede hipotética para avaliar, em relação ao crescimento da demanda por transporte de carga, os efeitos de três iniciativas distintas:

i. Sistemas avançados de roteirização, baseados em sistemas de informação: tal sistema utiliza as informações resultantes do modelo de roteirização previamente descrito; neste caso, consideram-se três situações distintas de adesão ao sistema: $0 \%, 50 \%$ e $100 \%$ dos operadores;

ii. Sistemas cooperativos de transporte de carga: o trabalho considera tal sistema como o compartilhamento de um mesmo veículo por operadores distintos; neste caso o sistema avançado de roteirização é utilizado por todos os operadores;

iii. Controle de fatores de carregamento dos veículos: ou seja, controle da porcentagem de peso transportada pelo veículo em relação à sua capacidade; neste caso o sistema avançado de roteirização também é utilizado por todos os operadores.

Para um aumento de $100 \%$ na demanda e adesão total ao sistema de roteirização, os resultados mostraram uma redução de $8,3 \%$ nas emissões de $\mathrm{CO}_{2}$, quando comparadas ao cenário com mesmo aumento de demanda, mas sem a implementação do novo sistema. A utilização de um sistema cooperativo reduziu as distâncias percorridas pelos caminhões e foi efetiva tanto para a redução dos custos totais quanto das emissões: as emissões de $\mathrm{CO}_{2}$ 
permaneceram praticamente ao mesmo nível, mesmo com um aumento de $100 \%$ da demanda, e reduziram cerca de $52 \%$ considerando a mesma demanda, quando comparadas ao cenário sem a iniciativa. Por fim, considerando um fator de carregamento mínimo de 35\% e nenhum variação na demanda, os resultados mostraram reduções de até $18,2 \%$ na emissões de $\mathrm{CO}_{2}$.

Dentro dos mesmos conceitos explorados no trabalho de Taniguchi e van der Heijden (2000) e com um objetivo agora mais direcionado ao aumento da eficiência das operações de distribuição de cargas na área urbana, Taniguchi e Thompson (2002) propõem a mesma estrutura de modelo, porém, considerando um procedimento estocástico para a roteirização de veículos, o qual utiliza dados históricos dos tempos de viagem, representados por distribuições de probabilidade. Sendo assim, em conjunto com a simulação o submodelo de roteirização que compõe o modelo proposto resolve agora um problema probabilístico da roteirização de veículos com janelas de entrega (Probabilistic Vehicle Routing Problem with Time Window - VRPTW-P). Ao contrário do modelo anterior, o qual utiliza apenas um valor para representar os tempos de viagem previstos para o período de operação considerado, o modelo híbrido de simulação dinâmica estima a distribuição dos tempos de viagem em cada arco da rede, para determinados intervalos de tempo, as quais servirão como dados de entrada para o $V R P T W-P$ a cada iteração do modelo.

A rede hipotética utilizada para o teste do modelo é bastante similar à utilizada no trabalho de Taniguchi e van der Heijden (2000), com alterações apenas nas velocidades das vias, no intervalo para geração randômica do número de clientes por empresa transportadora, no intervalo para cálculo dos tempos de viagem e nas localizações dos depósitos (prédeterminadas no modelo anterior e geradas aleatoriamente no novo modelo). A abordagem para avaliação dos resultados também é diferente, sendo que agora são testadas três condições diferentes de tráfego (em termos do número de veículos de passageiros gerados por dia) para comparar o modelo probabilístico proposto $(V R P T W-P)$ ao modelo padrão $(V R P T W)$. Os resultados indicam que o modelo probabilístico pode reduzir os custos em comparação ao modelo padrão, sendo que essa redução é mais expressiva para os casos com maiores volumes de tráfego. Os tempos totais de viagem são levemente maiores para o modelo probabilístico, principalmente os tempos de espera dos caminhões, devido à tendência desse modelo de buscar soluções nas quais os caminhões cheguem mais cedo a seus clientes, evitando as penalidades por atraso. Finalmente, utilizando o modelo 
probabilístico, as emissões de $\mathrm{CO}_{2}$ dos veículos de entrega foram reduzidas em cerca de $6 \%$ em relação ao modelo padrão.

A rede urbana hipotética a qual os modelos apresentados por Taniguchi e van der Heijden (2000) e por Taniguchi e Thompson (2002) foram aplicados apresenta uma escala muito reduzida quando comparada à realidade de uma cidade. Tal rede possui apenas 25 nós e 40 arcos, para os quais são considerados dez operadores de transporte, cada um associado a um depósito e com uma frota máxima de 12 veículos por operador. Além disso, como mencionado anteriormente, no primeiro trabalho são consideradas conhecidas as demandas nos clientes hipotéticos e não fica claro se as mesmas variam de um para outro, o que levaria a variações também nos tempos de atendimento. Ainda, ao comparar a as iniciativas em relação aos aumentos na demanda, o modelo considera que todos os clientes aumentam sua demanda de forma homogênea.

O trabalho de Quak e de Koster (2006) utiliza informações referentes aos prováveis comportamentos de três empresas fornecedoras de alimentos atuantes nos Países Baixos para avaliar medidas de restrição, em termos de seus impactos nos custos do transporte, nas emissões de $\mathrm{CO}_{2}$ e nas operações de entrega dessas empresas. Duas medidas são avaliadas: (i) restrição ao acesso de veículos à cidade em determinado período do dia e (ii) restrição à circulação de veículos de acordo com o peso dos mesmos.

O método proposto divide-se em quatro partes. A primeira envolve o levantamento de informações das empresas analisadas em relação: (i) ao centro de distribuição (localização e produtos distribuídos), sendo considerado apenas um centro de distribuição para cada empresa; (ii) aos estabelecimentos atendidos (localização e qualquer tipo de restrição envolvendo o recebimento de produtos); (iii) aos veículos (número, capacidade, especificações ambientais, etc.). A segunda parte diz respeito à elaboração dos cenários a serem analisados: cada cenário (A, B, C, D e E) corresponde às variações nas restrições em avaliação e, para cada um deles, diferentes números de municípios afetados são considerados (Quadro 5.1). 
Quadro 5.1 - Cenários das restrições

\begin{tabular}{|c|c|c|c|c|c|}
\hline \multirow[b]{2}{*}{ RESTRIÇÃO } & \multicolumn{5}{|c|}{ MUNICÍPIOS AFETADOS } \\
\hline & $\begin{array}{c}5 \text { maiores } \\
\text { cidades } \\
\text { nos Países } \\
\text { Baixos } \\
\end{array}$ & $\begin{array}{c}25 \text { maiores } \\
\text { cidades } \\
\text { nos Países } \\
\text { Baixos } \\
\end{array}$ & $\begin{array}{l}50 \text { maiores } \\
\text { cidades } \\
\text { nos Países } \\
\text { Baixos } \\
\end{array}$ & $\begin{array}{l}100 \text { maiores } \\
\text { cidades } \\
\text { nos Países } \\
\text { Baixos } \\
\end{array}$ & $\begin{array}{c}250 \text { maiores } \\
\text { cidades } \\
\text { nos Países } \\
\text { Baixos }\end{array}$ \\
\hline $\begin{array}{l}\text { acesso restrito das } \\
7 \mathrm{~h} \text { às } 11 \mathrm{~h}\end{array}$ & A1 & $\mathrm{A} 2$ & A3 & A4 & A5 \\
\hline $\begin{array}{l}\text { acesso restrito das } \\
7 \mathrm{~h} \text { às } 10 \mathrm{~h}\end{array}$ & B1 & $\mathrm{B} 2$ & B3 & B4 & B5 \\
\hline $\begin{array}{l}\text { acesso restrito das } \\
7 \mathrm{~h} \text { às } 9 \mathrm{~h}\end{array}$ & $\mathrm{C} 1$ & $\mathrm{C} 2$ & $\mathrm{C} 3$ & C4 & $\mathrm{C} 5$ \\
\hline $\begin{array}{l}\text { peso do veículo } \\
<18 \text { toneladas }\end{array}$ & D1 & D2 & D3 & D4 & D5 \\
\hline $\begin{array}{l}\text { peso do veículo } \\
<12 \text { toneladas }\end{array}$ & E2 & \multicolumn{4}{|c|}{ E4 (somente para a empresa 1) } \\
\hline $\begin{array}{l}\text { peso do veículo } \\
<7,5 \text { toneladas }\end{array}$ & E1 & \multicolumn{3}{|c|}{ E3 (somente para a empresa 1) } & \\
\hline
\end{tabular}

Os cenários foram apresentados aos gerentes das empresas participantes, de forma a obter suas prováveis reações à implementação de cada um deles. No caso da restrição de acesso, os resultados obtidos foram os mesmos: as empresas continuariam realizando suas entregas, já que, em geral, os veículos que transportam alimentos conseguem obter permissões especiais de circulação; no caso dessa permissão não ser possível, as empresas alegaram que passariam a realizar as entregas nos horários permitidos, adquirindo veículos extras, se necessário. Para a restrição baseada no peso dos veículos, as reações entre as empresas participantes seriam diferentes, já que as mesmas não utilizam os mesmos tipos de veículos em suas entregas.

A partir das respostas fornecidas, foram determinados os veículos a serem utilizados em cada cenário avaliado, por cada empresa, e novas rotas de entrega foram calculadas. A terceira parte do método pretende então avaliar os impactos das restrições nas operações dos veículos de entrega e utilizou um software de roteirização de veículos para calcular as novas rotas, considerando todas as demandas a serem atendidas e a minimização do número de veículos utilizados. Os dados de entrada necessários compreendem as demandas nos estabelecimentos, os horários da restrição, o horário de abertura do centro de distribuição, o máximo de horas trabalhadas pelos motoristas e a capacidade dos veículos.

A última parte do método consiste em determinar os custos ambientais e de transporte para os cenários em avaliação. Os custos de transporte correspondem aos custos fixos diários e aos custos variáveis, por quilômetro e por hora, e os custos ambientais consideram as taxas 
de emissão, em gramas por quilômetro, para diferentes pesos de veículos, diferentes poluentes e diferentes velocidades.

Em resumo, os resultados mostram que ambas as restrições têm impactos negativos nos custos de transporte e nas atividades dos veículos. Nos dois casos os custos de transporte crescem à medida que mais estabelecimentos são afetados e há a necessidade de utilização de veículos extras. Para as restrições de acesso, a utilização de veículos extras ocorre somente nos períodos específicos da restrição, enquanto que no caso das restrições por peso, a necessidade de veículos extras ocorre ao longo de todo o dia. No que diz respeito às emissões de $\mathrm{CO}_{2}$, estas não são reduzidas pelas restrições em avaliação; ao contrário: para a maioria dos cenários avaliados as restrições resultam em aumento nas emissões de $\mathrm{CO}_{2}$, sendo que os aumentos provocados pelas restrições de peso são mais significativos.

O trabalho de Quak e de Koster (2006) traz uma contribuição interessante ao ressaltar a consideração dos prováveis comportamentos das empresas distribuidoras diante de determinada medida. O trabalho, porém, baseia-se apenas nas informações de três empresas, o que torna os resultados pouco expressivos em relação ao sistema como um todo. Além disso, não considera os efeitos das restrições nos outros agentes envolvidos no transporte de produtos e não utiliza informações adicionais do tráfego e das vias por onde os veículos de cargas circulam. Considerar os efeitos das restrições no tráfego como um todo certamente alteraria os resultados, ao passo que as operações dos veículos em análise seriam diretamente afetadas.

Figliozzi (2007) analisa as viagens de veículos comerciais e discute a influência que algumas mudanças nas operações logísticas (como no número de paradas por viagem), assim como novas medidas (como restrições de janelas de entrega) podem ter no total de quilômetros percorridos pelos veículos de carga. Considerando um depósito (ou centro de distribuição) que atende a vários estabelecimentos clientes, a modelagem baseia-se em uma expressão matemática capaz de relacionar a extensão da viagem com: (i) o número de clientes a serem atendidos (paradas por viagem), (ii) a proximidade entre esses clientes e (iii) a proximidade entre eles e o centro de distribuição. Tal expressão matemática (1) é derivada da aproximação contínua do comprimento de viagem $l$ para instâncias do Problema de Roteirização de Veículos (Vehicle Routing Problem - VRP) e do Problema do Caixeiro Viajante (Travel Salesman Problem - TSP): 


$$
l(n)=2 z \bar{r}+k_{l} \sqrt{a n}+k_{b} \sqrt{a / n}
$$

Onde, $z$ é o número de rotas, $\bar{r}$ é a distância média entre o depósito e os clientes, $k_{l}$ e $k_{b}$ são constantes que dependem da localização do depósito e $a$ é a extensão da área de atendimento onde estão localizados os $n$ clientes.

O primeiro termo da expressão representa a distância de conexão entre o depósito e a área de atendimento, incluindo a viagem de retorno [Figura 5.2 (a)], o segundo representa a viagem local que conecta os clientes na área de atendimento [Figura 5.2 (b)], e o terceiro termo pode ser interpretado como a distância de ligação entre a viagem local e a conexão entre o depósito e a área de atendimento [Figura 5.2 (c)].

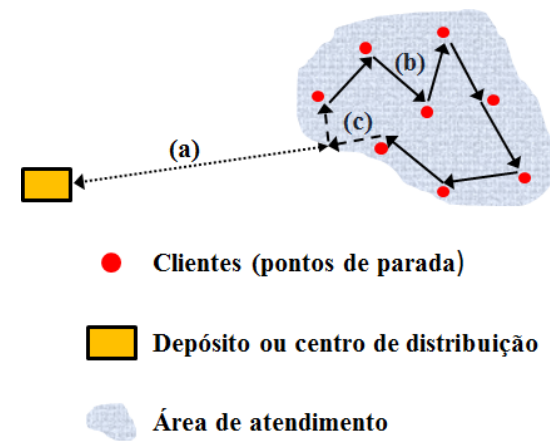

Figura 5.2 - Representação de uma viagem de atendimento Fonte: Adaptado de FIGLIOZZI (2007), p. 1017

Quatro restrições foram escolhidas para caracterizar as viagens consideradas no modelo:

i. Capacidade do veículo - viagens tipo 0: atendem apenas um cliente, uma vez que o tamanho do pedido é igual à capacidade do caminhão;

ii. Frequência do serviço - viagens tipo 1: atendem dois ou mais clientes, e o tamanho do pedido depende da frequência de atendimento requerida;

iii. Duração da viagem - viagens tipo 2: atendem dois ou mais clientes, no entanto o número de clientes atendidos é restringido por um limite imposto à duração da viagem; 
iv. Duração da janela de entrega - viagens tipo 3: o tempo disponível na área de atendimento e o número de clientes atendidos são limitado pelas janelas de entrega impostas pelo cliente.

Sendo assim, a partir da expressão (1), o autor deriva novas expressões matemáticas que calculam os comprimentos de viagem para cada um dos tipos considerados, de forma a avaliar como algumas mudanças nas operações logísticas, assim como a introdução de novas medidas, afetariam os quilômetros percorridos pelos veículos $(K P V)$ e os tempos totais das viagens (TTV) dos veículos de carga. Cinco diferente situações são analisadas para cada um dos tipos de viagens, cujos resultados resumidos estão indicados na Tabela 5.1:

i. Limitações nas dimensões dos veículos;

ii. Limitações na circulação dos veículos de carga;

iii. Restrições ao estacionamento de veículos de carga;

iv. Aumento nos congestionamentos;

v. Menores volumes transportados.

Tabela 5.1 - Impactos nos quilômetros percorridos e nos tempos de viagem dos veículos de carga

\begin{tabular}{ccccccccc}
\hline & \multicolumn{2}{c}{ VIAGEM } & \multicolumn{2}{c}{ VIAGEM } & \multicolumn{2}{c}{ VIAGEM } & \multicolumn{2}{c}{ VIAGEM } \\
\multirow{2}{*}{ SITUAÇÃO } & \multicolumn{2}{c}{ TIPO 0 } & \multicolumn{2}{c}{ TIPO 1} & \multicolumn{2}{c}{ TIPO 2 } & \multicolumn{2}{c}{ TIPO 3 } \\
\cline { 2 - 9 } & $($ KPV $)$ & $(\mathrm{TTV})$ & $($ KPV $)$ & $(\mathrm{TTV})$ & $($ KPV $)$ & $(\mathrm{TTV})$ & $($ KPV $)$ & $(\mathrm{TTV})$ \\
\hline i & ++ & ++ & $=/+$ & $=/+$ & $=$ & $=$ & $=$ & $=$ \\
ii & + & + & + & + & ++ & ++ & +++ & +++ \\
iii & $=$ & $=$ & $=/+$ & $=/+$ & ++ & ++ & +++ & +++ \\
iv & $=$ & + & $=$ & + & ++ & ++ & +++ & +++ \\
v & ++ & ++ & ++ & ++ & + & + & $=/+$ & $=/+$ \\
\hline
\end{tabular}

O sinal “+” indica um provável aumento nos quilômetros percorridos $(K P V)$ e nos tempos totais das viagens (TTV), o sinal "++" indica um aumento significativamente maior, e assim por diante. O sinal "=” indica que nenhum alteração ocorreu. A presença conjunta dos sinais “+”e "=" indica que houve alteração somente em uma circunstância específica dentro da situação analisada, o que pode ser melhor compreendido, a seguir, na interpretação de alguns dos resultados. 
A redução na capacidade dos veículos (situação i) aumentaria consideravelmente o $K P V$ para as viagens do tipo 0 , já que essas, por definição, são sempre restritas pela capacidade dos veículos. Para as viagens do tipo 1 , o $K P V$ aumentaria somente para as viagens nas quais a capacidade já é restrita, ou se torna restrita após a redução da capacidade do veículo. Limitações na circulação dos veículos (situação ii) aumentariam o $K P V$ para todos os tipos de viagem, sendo aquelas do tipo 3 as mais afetadas, uma vez que são as mais restritas. As restrições ao estacionamento dos veículos de carga (situação iii) aumentariam o tempo médio de atendimento e o comprimento médio de viagem, pois quanto maior o número de paradas por viagem, maior o tempo adicional necessário para atender a um mesmo número de clientes. As viagens do tipo 2 e 3, portanto, seriam mais afetadas quando a duração limite da viagem fosse atingida.

Um aumento no congestionamento (situação iv) reduziria a velocidade das viagens e, portanto, aumentaria seu tempo total. Neste caso, somente o impacto no $K P V$ é insuficiente para descrever os efeitos dessa alteração e deve-se considerar também o impacto no TTV. O $K P V$ das viagens do tipo 0 e 1 não se alteraria, mas a mesma distância agora levaria mais tempo para ser percorrida, e por isso haveria um aumento no $T T V$. As viagens do tipo 2 e 3 apresentariam diferentes resultados, com aumento significativo tanto no $K P V$ quanto no $T T V$, pois o congestionamento dificultaria ainda mais o atendimento dentro dos períodos restritos impostos a essas viagens (menores durações da viagem, para o tipo 2, e janelas de entrega, para o tipo 3).

Finalmente, a redução no tamanho dos carregamentos (situação v) afetaria a capacidade de utilização dos veículos e aumentaria a frequência de entrega. Dessa forma, as viagens do tipo 0 acabariam por se tornar viagens do tipo 1, as quais seriam diretamente afetadas pelo aumento na frequência de atendimento. As viagens do tipo 2 e 3 também seriam afetadas, mas somente aquelas que não estivessem limitadas por suas respectivas restrições.

A modelagem apresentada por Figliozzi (2007) apresenta a vantagem de ser independente do levantamento de dados. No entanto, está limitada apenas às viagens dos veículos de carga e não considera os efeitos que as alterações e medidas avaliadas teriam no tráfego em geral. $\mathrm{O}$ próprio autor ressalta que a análise não leva em conta os efeitos secundários que possam ocorrer nas situações consideradas e que os mesmos podem ser importantes no caso de cidades onde a porcentagem de veículos de carga seja significante. No entanto, ainda que os 
resultados não representem por completo as mudanças que podem ocorrer na área urbana, eles mostram como as alterações nas operações dos veículos de carga poderiam afetar os diferentes tipos de viagem e podem ser úteis em uma primeira análise de diferentes alternativas em avaliação.

O trabalho de Benjelloun e Crainic (2009) propõe um método para a avaliação de medidas voltadas ao transporte urbano de cargas, assim como para o planejamento de suas atividades. Os autores afirmam que "similarmente a qualquer sistema complexo, os sistemas de transporte requerem planejamento nos níveis estratégico, tático e operacional” (Benjelloun e Crainic, 2009, p. 47, tradução livre), sendo o primeiro relacionado à concepção do sistema e à avaliação das medidas propostas, essa última através do estudo dos prováveis comportamento e desempenho do sistema para uma série de cenários da medida proposta. Logo, propõem para o nível estratégico o chamado "método de planejamento de quatro etapas" (Figura 5.3), baseado no modelo aplicado a passageiros e que é composto dos seguintes submodelos: (i) modelo de oferta, (ii) modelo de demanda e (iii) modelo de alocação de fluxos multiprodutos.

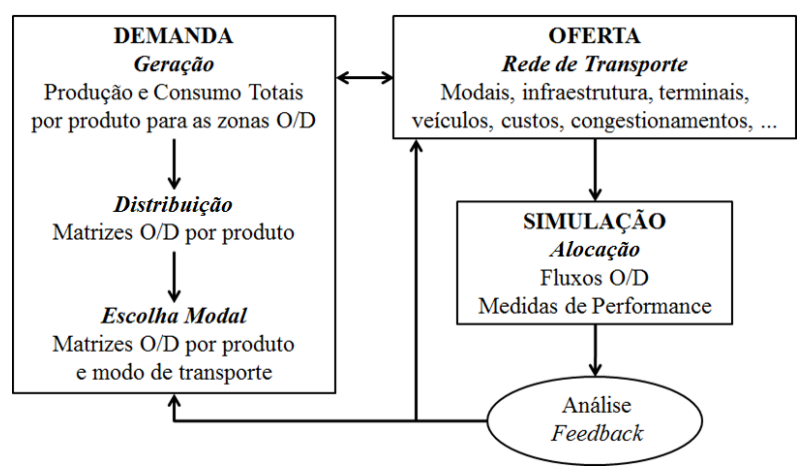

Figura 5.3 - Planejamento do transporte em quatro etapas Fonte: BENJELLOUN; CRAINIC (2009), p. 48

O modelo de oferta representa a infraestrutura de transporte: os modais, transportadores e serviços, os veículos e comboios, os terminais (inclusive os intermodais), as capacidades e congestionamentos das vias, as métricas e critérios de desempenho adotados, etc. O modelo de demanda tem a finalidade de capturar as definições dos produtos transportados, identificar os produtores, embarcadores e intermediários, representar a produção, o consumo e a distribuição dos produtos ponto a ponto. A determinação do modo de transporte, para cada par origem-destino dos fluxos de produtos, também é determinada nesse modelo. Por fim, o modelo de alocação, como o próprio nome já diz, tem o objetivo de alocar os fluxos 
multiprodutos (do modelo de demanda) à rede multimodal (representada no modelo de oferta). Esse procedimento simula o comportamento do sistema de transporte e suas variáveis de saída são a base da análise do planejamento estratégico.

Previamente à aplicação do método, é necessária uma abordagem da região a ser estudada. Tal abordagem inclui o levantamento dos dados econômicos, demográficos, sociais e políticos dessa região, assim como a identificação da estrutura organizacional e gerencial do sistema em análise, e dos papéis de todos os agentes envolvidos. Essa abordagem inicial também determina a divisão geográfica da região estudada em zonas (representadas em matrizes de origem e destino, como no modelo para passageiros) e identifica os grupos de produtos a serem considerados para transporte.

Assim, a demanda por cada tipo de produto é gerada em duas etapas: (i) volumes totais de produção e consumo dentro de cada zona (etapa 1: geração de demanda), e (ii) distribuição dessas quantidades entre os pares de zonas da região, o que resulta na matriz de origem e destino dos fluxos de produtos (etapa 2: de distribuição da demanda). A etapa 3, de escolha modal, especifica o conjunto de modos (tipos de infraestrutura e serviços) que transporta cada demanda de produtos entre os pares de zonas. Finalmente, a etapa 4, chamada alocação, determina as rotas de transporte desses produtos, entre os pares de zonas e nos modais determinados, permitindo assim, a simulação do comportamento global do sistema para determinado cenário de análise.

Os dois últimos passos do método (escolha modal e alocação) requerem a definição da estrutura de transporte oferecida na região, em particular a estrutura multimodal e os serviços disponíveis para o transporte de produtos, assim como seus atributos em termos de custos, tempos de viagem e operacionais, consumo de energia, níveis de emissões, etc., todos fornecidos pelo modelo de oferta. A etapa de alocação também requer a especificação dos critérios para escolha das rotas e para as medidas de performance.

Embora não tenha sido aplicado, o método proposto por Benjelloun e Crainic (2009) traz uma importante contribuição para os procedimentos de avaliação de medidas para o transporte de cargas. O método apresenta uma estrutura genérica, o que é bastante pertinente, pois permite a adequação e aplicação do mesmo a diversas situações que podem 
ser analisadas no contexto da distribuição urbana de cargas (diferentes medidas em avaliação, cenários de simulação, impactos a serem quantificados, operações, etc.).

Em uma abordagem semelhante a do método proposto por Benjelloun e Crainic (2009), Muñuzuri et al. (2010) desenvolveram um modelo para estimar o transporte de produtos em Sevilha, na Espanha, e a sua contribuição para a pegada ecológica da cidade, proposta como um indicador de eficiência para essa operação. A partir da estimativa e validação das matrizes origem-destino e do uso de simulação, os autores foram capazes de determinar os fluxos de veículos de carga nas ruas da cidade e, consequentemente, o consumo de combustível dos mesmos.

Quatro áreas da cidade foram analisadas, a fim de determinar, para cada uma delas, a demanda e o fluxo de produtos. Para isso, foram realizadas entrevistas com os entregadores e comerciantes, e a contagem dos veículos de carga nos principais pontos de cada área, além da classificação das diferentes atividades comerciais a serem consideradas (farmácias, floriculturas, restaurantes, bancos, etc.). A partir dos dados obtidos nas entrevistas, foram determinados os números de entregas diárias por veículo, em cada uma das quatro áreas analisadas e para cada tipo de atividade. Ainda, a cidade foi dividida em 181 zonas e, para cada um delas, foram obtidas as quantidades de estabelecimentos comerciais, de acordo com a classificação preestabelecida. Os resultados dos números de entregas diárias, de acordo com o tipo de atividade comercial foram então extrapolados para toda a cidade, permitindo o cálculo do número de veículos de entrega que entram e saem de cada zona. A Figura 5.4 mostra a estrutura empregada para o processamento dos dados que levaram à obtenção desse resultado.

Para a estimativa do número de veículos com origem e destino em cada zona, os autores consideraram a premissa de que o número de veículos que entram em uma zona é igual ao número de veículos que saem dela, o qual equivale à soma dos fluxos de passagem e dos fluxos originados nessa mesma zona. O número de veículos que apenas atravessam cada zona (fluxo de passagem) foram calculados para cada setor de atividade, levando em conta o número de estabelecimentos existentes e o número de entregas diárias que ele recebe. Já o número de veículos que têm origem em cada zona foram estimados a partir de dados resultantes de um trabalho anterior (MUÑUZURI et al., 2009) o qual obteve os números de veículos gerados no período de pico da manhã, para cada setor de atividade considerado. 


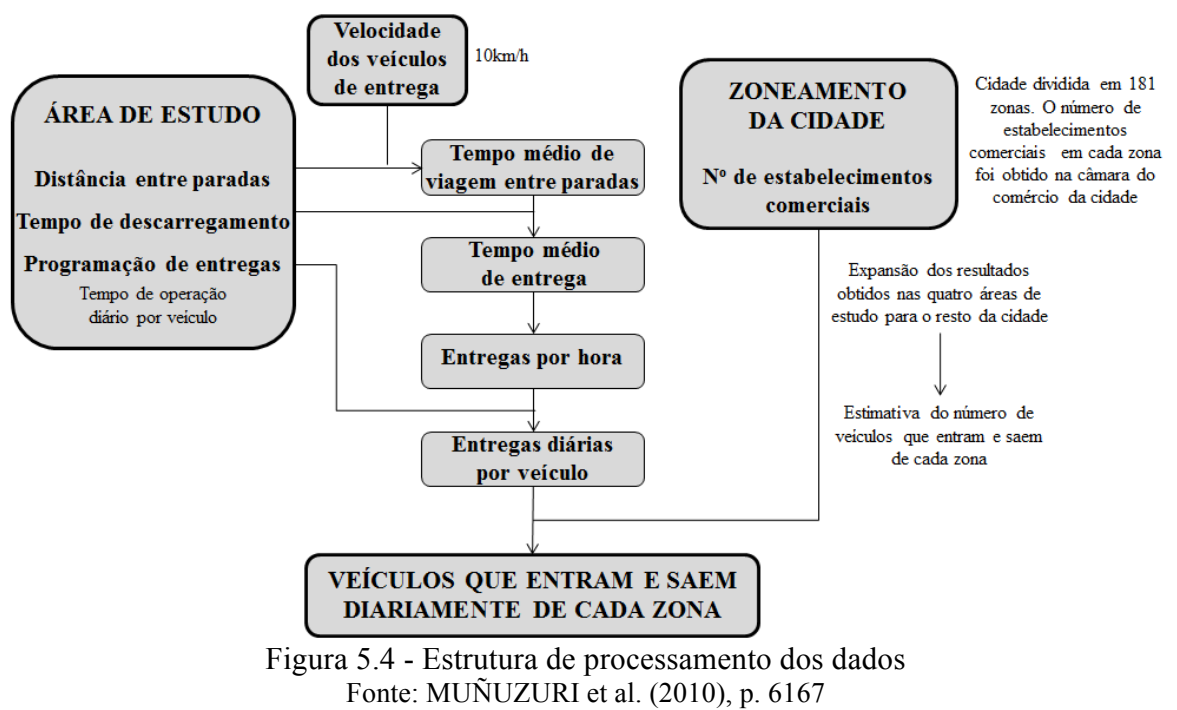

Os autores então calcularam a matriz de origem e destinos dos fluxos de produtos, cujos resultados serviram de dados de entrada para um software de macrossimulação que atribuiu os fluxos a cada uma das vias da cidade. O primeiro processo, que calcula os elementos da matriz, é baseado na maximização da entropia dos fluxos de origem e destino, ou seja, na maximização da desordem, encontrando pares de origem e destino que estejam o mais distribuídos possível na matriz, na tentativa de representar algumas das características da entrega de produtos, como a dispersão da localização dos clientes e/ou as janelas de entrega.

Finalmente, de posse dos resultados obtidos, e de outros provenientes da simulação dos fluxos de veículos, como distância total e velocidade média, foi possível calcular o consumo total de combustível correspondente aos deslocamentos e às paradas dos veículos de entrega. Tal consumo é necessário para o cálculo da pegada ecológica, a qual está relacionada à energia liberada na queima de combustível e representa (em hectares) a quantidade de terra e água que seria necessária para equilibrar determinado processo. No caso apresentado, a distribuição de produtos na cidade Sevilha resultou em uma pegada ecológica de 16.427 Ha.

O trabalho de Muñuzuri et al. (2010) traz uma contribuição importante ao estimar os fluxos de veículos que entram e saem em cada zona da cidade, através do levantamento dos tipos de estabelecimentos em cada uma delas e da quantidade média de entregas diárias feitas a cada um deles. Os autores consideram, no entanto, um valor médio de entregas diárias para os estabelecimento classificados dentro de uma mesma categoria, o que sugere uma uniformidade entre as diferentes zonas da cidade. Por exemplo, supõe-se que as farmácias de 
uma zona central recebem, em média, a mesma quantidade de entregas diárias que as farmácias localizadas na periferia. Admitem, ainda, que cada veículo observado realiza entregas exclusivamente a um único tipo de estabelecimento. $O$ trabalho utiliza a macrossimulação para determinar os parâmetros necessários ao cálculo da pegada ecológica. Neste caso, a técnica parece adequada, já que não se pretende analisar os efeitos no tráfego da cidade, sendo o nível de detalhamento fornecido pela macrossimulação é suficiente para a análise pretendida.

Dablanc e Rakotonarivo (2010) avaliam o efeito das mudanças na localização de terminais de cross-docking na região metropolitana de Paris, em termos das emissões de $\mathrm{CO}_{2}$. Terminais de cross-docking são aqueles nos quais a mercadoria recebida é redirecionada sem uma armazenagem prévia, muito utilizados por empresas de transporte fracionado ou expresso.

A partir de registros dos endereços dos terminais pertencentes às 17 maiores empresas transportadoras da cidade e da utilização de um software capaz de representá-los espacialmente em mapas, os autores identificaram uma descentralização gradual desses terminais entre os anos de 1974 e 2008, desde os núcleos urbanos até as periferias. Ainda, através da aplicação da técnica de análise centográfica, a qual identifica o centro geométrico de um conjunto de pontos e a dispersão ao redor dele, foi possível quantificar essa descentralização e estimar o aumento nas distâncias percorridas pelos veículos de entrega, devido à maior distância entre os terminais e os destinos finais das cargas. Os autores calcularam uma distância de 6 quilômetros entre os terminais e seu baricentro, em 1974, e de 16 quilômetros, em 2008 (Figura 5.5), e adotaram essa diferença de 10 quilômetros como sendo a distância média adicional percorrida pelos veículos.

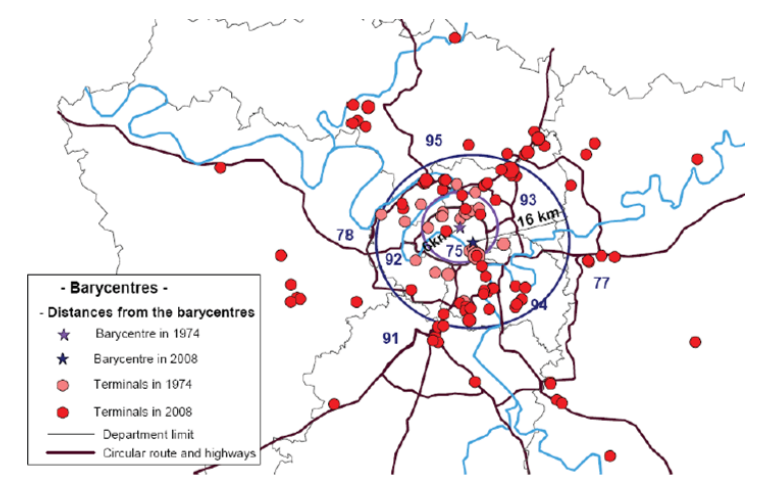

Figura 5.5 - Deslocamento do baricentro e distância em torno do baricentro Fonte: DABLANC; RAKOTONARIVO (2010), p. 6092 
A avaliação dos impactos da descentralização dos terminais nas emissões de $\mathrm{CO}_{2}$, durante o período estudado, utilizou dados baseados nas emissões unitárias (em gramas por tonelada) de caminhões e vans, fornecidas pela Agência Francesa de Meio Ambiente e Energia, conforme indica o Quadro 5.2.

\begin{tabular}{lc} 
Quadro 5.2 - Emissões Unitárias de $\mathrm{CO}_{2}$ para diferentes veículos de carga \\
\hline TIPO DE VEÍCULO & $\begin{array}{c}\text { EMISSÃO UNITÁRIA } \\
\text { (em g/t.km) }\end{array}$ \\
\hline Veículos de carga leves & 1.103 \\
Caminhões (6,1 a 10,9 t) & 435 \\
Caminhões (11 a 21 t) & 221 \\
Caminhões (21 a 32,6 t) & 196 \\
\hline \multicolumn{2}{c}{ Fonte: DABLANC; RAKOTONARIVO (2010), p. 6092}
\end{tabular}

A avaliação considerou apenas as entregas com destino à região central da cidade de Paris, e para isso, os autores adotaram os seguintes valores: (i) média de 193 toneladas de carga gerada por dia, por cada terminal, para os dois períodos de análise (1974 e 2008), obtida através da média de diferentes fontes estatísticas; (ii) $30 \%$ dos fluxos da região metropolitana destinados ao munícipio de Paris, de acordo com entrevistas realizadas nas empresas consideradas; (iii) $82 \%$ das entregas fracionadas feitas por veículos leves, enquanto o restante (18\%) utiliza caminhões.

Os autores obtiveram que os 10 quilômetros adicionais percorridos, a partir de cada terminal até os destinos finais no centro de Paris, geraram, anualmente, cerca de 15 mil toneladas extras de $\mathrm{CO}_{2}$.

Embora façam referência a uma grande cidade, Dablanc e Rakotonarivo (2010) utilizam dados bastante simplificados em sua análise, sem qualquer tipo de levantamento das localizações e demandas dos clientes, assim como das rotas executadas pelos veículos de carga, uma vez que adota apenas um valor médio para a distância adicional percorrida pelos veículos, devido à relocação dos terminais. Os autores ainda consideram que a descentralização dos terminais foi suficientemente maior e mais rápida do que a descentralização dos pontos de demanda, a ponto dessa informação poder ser ignorada. Por fim, a análise é realizada a partir de dados de uma pequena amostra das empresas transportadoras e não busca extrapolar seus resultados para o universo geral das empresas. 
Tal extrapolação, no entanto, não faria sentido, pois acumularia os erros decorrentes do resultado aproximado obtido, gerando resultados ainda mais distantes da realidade.

Rooijen e Quak (2010) examinam alguns dos impactos locais causados pela implantação de um centro de consolidação urbano na cidade de Nijmegen, Holanda. Os autores analisam os impactos relativos à qualidade do ar, emissão de ruídos e incômodo aos residentes, após um ano de operação do centro de consolidação e, ainda, os impactos esperados para três cenários futuros, considerando um provável crescimento no número de clientes nos anos seguintes ao estudo: após dois e três anos de operação, e para o caso no qual o centro estaria trabalhando em sua capacidade máxima. Os autores analisam também, para efeitos de comparação, um cenário base, representando a situação prévia à implementação do centro de consolidação.

Várias fontes de dados foram utilizadas para o desenvolvimento da metodologia de avaliação apresentada. Pesquisas realizadas pelo governo, antes da instalação do centro de consolidação, forneceram o número de entregas, por tipo de estabelecimento, e os transportadores que as realizaram, e dados relativos aos movimentos de caminhões de e para o centro da cidade, baseados na contagem de placas desses veículos. Esse conjunto de dados foi utilizado pelos autores para estimar alguns parâmetros referentes ao cenário base: o número de entregas semanais na cidade, os tipos de caminhões, as rotas dos mesmos no centro da cidade e as entregas combinadas na viagem de um mesmo caminhão.

Em seguida, foi realizada, no próprio centro de consolidação, uma coleta de dados sobre as entregas realizadas aos estabelecimentos clientes do centro, além de uma pesquisa entre os motoristas, para levantar informações sobre sua origem, destino, entregas, dentre outras. Sendo assim, foi possível definir o cenário corrente, alterando as informações relativas aos estabelecimentos que, no período da pesquisa, recebiam seus produtos a partir do centro de consolidação. Por último, os três cenários futuros, já apresentados, foram definidos. Outros dados referentes ao tráfego (incluindo o transporte de passageiros) e a aspectos geográficos (como o número de residentes por domicílio) também foram levantados.

De forma a obter os impactos locais das atividades do centro de consolidação urbano, todos os cenários (cenário base, cenário atual e futuros) foram simulados, para um dia representativo. A simulação permitiu a obtenção das rotas dos caminhões no centro da cidade e de dados como o tamanho da frota necessária e os tempos e distâncias das viagens. 
Os dados dos veículos pertencentes ao centro de consolidação, em conjunto com os dados dos outros veículos que circulam no centro da cidade, incluindo os de passageiros, foram utilizados como entrada para o cálculo da emissão de poluentes e ruídos, através da aplicação de softwares especializados. Da mesma forma, o incômodo aos residentes também foi calculado, sendo representado pela quantidade de pessoas que experimentam um certo número de operações de carga e descarga dentro de um raio de 100 metros de suas residências.

Em resumo, os resultados da implantação do centro de consolidação na cidade de Nijmegen mostraram-se bastante positivos e promissores. Todos os valores dos parâmetros avaliados para os caminhões em circulação no centro da cidade, obtidos através da simulação, foram reduzidos: quantidade, quilômetros percorridos, número de paradas e tempo total viajado. A redução do incômodo sofrido pelos moradores também foi expressivas, mesmo no primeiro ano de funcionamento. Já os efeitos na qualidade do ar e na emissão de ruídos foram limitados, devido ao tráfego remanescente de automóveis e ônibus.

O trabalho de Rooijen e Quak (2010) chama a atenção pelo extenso levantamento de dados reais para caracterizar a distribuição urbana de produtos na cidade, o que acaba sendo uma das maiores limitações nas modelagens com esse propósito. Tal levantamento, no entanto, é viável devido a duas importantes características do estudo:

i. A dimensão do ambiente em análise: a cidade de Nijmegen, na Holanda, possui apenas 165 mil habitantes e uma única área central, em destaque na Figura 5.6, onde estão concentrados praticamente todos os estabelecimentos comerciais;

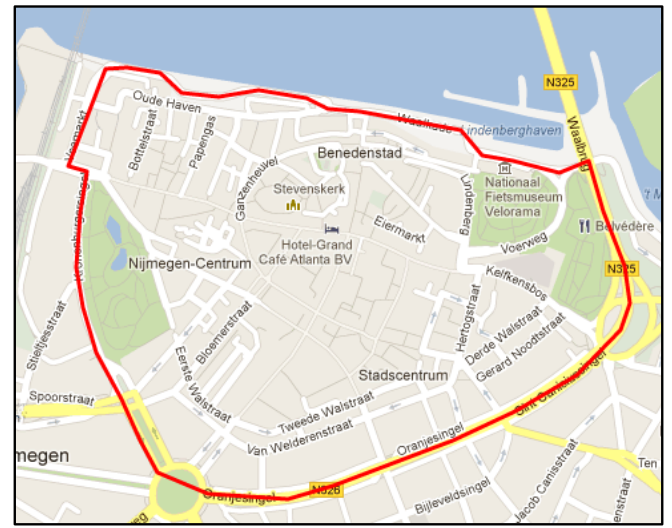

Figura 5.6 - Área central da cidade de Nijmegen, Holanda Fonte: GOOGLE MAPS 
ii. A avaliação específica de uma medida logística já implementada: as análises dos efeitos da implementação do centro de consolidação baseiam-se em dados da situação atual da cidade, não sendo necessária a previsão do comportamento dos transportadores e dos estabelecimentos. Como a avaliação de cenários futuros considerou variação apenas na quantidade de estabelecimentos atendidos pelo centro, bastou realocar o atendimento das demandas (conhecidas) aos veículos do centro de consolidação e determinar os novos resultados através da simulação.

Tamagawa et al. (2010) desenvolveram um modelo multiagente para avaliar a efetividade de medidas baseadas em city logistics, considerando os diferentes objetivos e comportamentos dos agentes que atuam na distribuição urbana de cargas: embarcadores, transportadores, residentes, administradores e operadores das vias. Os embarcadores selecionam as transportadoras de carga e requisitam que as mesmas efetuem o transporte de seus produtos; os transportadores oferecem seu serviço de transporte aos embarcadores, mediante pagamento de uma taxa; os residentes decidem sobre realizar ou não reclamações aos administradores em relação aos níveis de emissão de gases poluentes em sua vizinhança, quando esses excederem os limites aceitáveis; os administradores determinam se alguma iniciativa de melhoria deve ou não ser implementada na área onde houve reclamação por parte dos residentes; e, finalmente, os operadores das vias têm como única função alterar os valores das taxas de pedágio nas vias que dão acesso à cidade.

O modelo iterativo está baseado no seguinte raciocínio: i) as medidas implementadas geram uma mudança no ambiente; ii) surge um novo comportamento dos agentes (de acordo com seus objetivos); iii) o ambiente sofre uma atualização, o que gera uma nova reação nos agentes. Ainda, o modelo apresentado está dividido em dois submodelos que são executados alternadamente: i) modelo de aprendizado (Learning Model), o qual avalia, "aprende" e seleciona o comportamento dos agentes; e ii) modelo VRPTW (Vehicle Routing Problem with Time Window), o qual planeja e executa roteiros de entrega dos caminhões de cada transportadora, dentro de uma solução ótima que minimiza os custos de transporte. A iteração entre os dois submodelos (Figura 5.7) permite que os agentes aprendam seus comportamentos mais favoráveis, a partir da interação entre eles, uma vez que existem vários indivíduos representando cada agente no sistema e cada um deles se comporta e aprende de forma independente. 


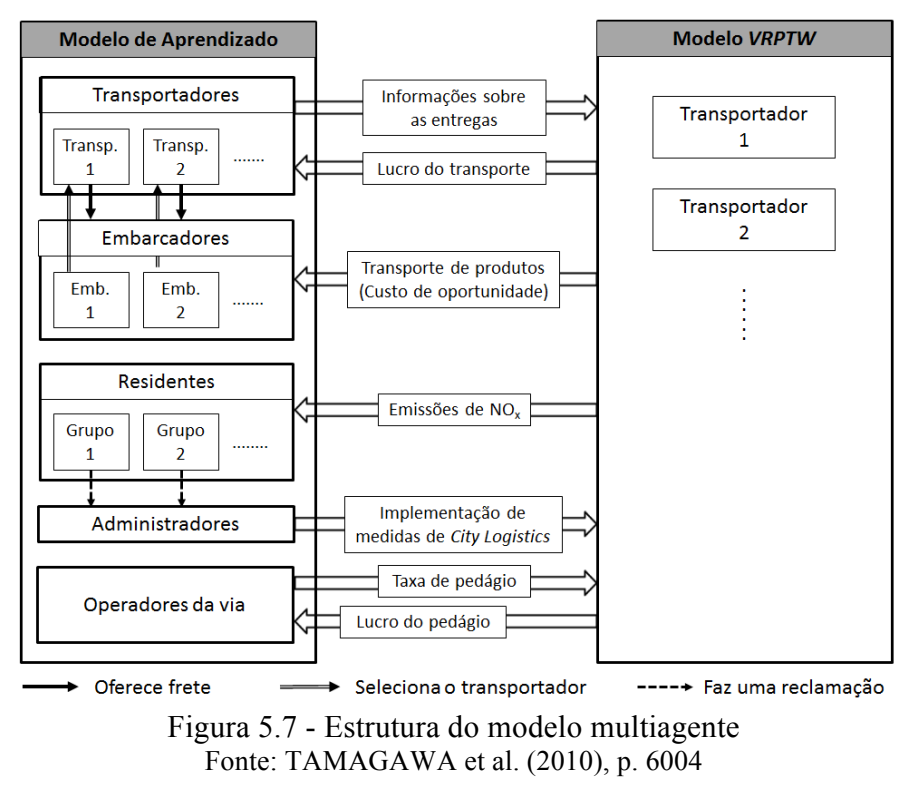

O fluxo dos cálculos executados a cada iteração obedece aos seguintes passos:

- Passo 1: modelo de aprendizado determina e implementa o comportamento dos agentes; nesse momento os transportadores disponibilizam seus serviços aos embarcadores, que selecionam aqueles que farão as entregas de seus pedidos, de acordo com os melhores fretes oferecidos;

- Passo 2: modelo $V R P T W$ planeja e executa a roteirização dos veículos para cada transportadora, de acordo com os pedidos dos embarcadores;

- Passo 3: após a realização das entregas, as emissões de $\mathrm{NO}_{\mathrm{x}}$, em cada área, e as taxas de pedágio, impostas pelos operadores das vias, são calculadas e o ambiente da rede é atualizado;

- Passo 4: os parâmetros do novo ambiente são atualizados no modelo de aprendizado;

- Passo 5: o modelo de aprendizado avalia o comportamento dos agentes frente ao novo ambiente, atualizando suas experiências; depois disso, volta ao passo 1.

O modelo de aprendizado apresentado pelos autores utiliza a técnica conhecida como $Q$ learning (WATKINS; DAYAN, 1992), na qual a escolha de uma ação (comportamento) é 
baseada em uma função de utilidade que associa estados e ações a um valor numérico. $\mathrm{O}$ principal objetivo do algoritmo Q-learning é estimar, para cada estado em que o aprendiz se encontra, o valor para cada possível ação e, a partir daí, determinar a melhor ação (ou seja, a ação com maior valor de utilidade). Essa função de utilidade pode ser, por exemplo, o lucro esperado pelos transportadores.

Os autores aplicaram o modelo para uma rede urbana de teste em quatro cenários: dois deles para quando medidas fossem implementadas apenas pelos administradores: (i) pedágio urbano para todos os caminhões e (ii) restrição à circulação de caminhões acima de 10 toneladas, nas áreas que excedem os limites de emissões; e os outros dois para quando medidas fossem implementadas pelos administradores e pelos operadores das vias: (iii) pedágio urbano para todos os caminhões e mudanças nas taxas de pedágios e (iv) restrição à circulação de caminhões acima de 10 toneladas nas áreas que excedem os limites de emissões e mudanças nas taxas de pedágios. A efetividade das medidas implementadas são medidas em relação à situação onde elas não existem, considerando cada um dos agentes, em termos dos parâmetros que os afetam, por exemplo o total de emissões de $\mathrm{NO}_{\mathrm{x}}$ é o parâmetro que afeta a população. Em resumo, os resultados indicaram que os efeitos das medidas de city logistics implementadas em áreas que excediam os limites de emissões e os efeitos da isenção das taxas dos pedágio em todas as vias não competem entre si, além disso os efeitos ambientais foram menores, quando comparados ao caso em que apenas foram implementadas medidas por parte dos administradores.

O modelo multiagente apresentado por Tamagawa et al. (2010) não considera como um dos agentes os recebedores das cargas, ou seja, os destinos das entregas. Sendo assim, analisa apenas as viagens de coleta das cargas, nos embarcadores. O modelo considera também que a adoção de determinada medida depende, primariamente, de reclamações dos residentes a respeito dos níveis de gases poluentes, o que poderia não ser adequado no caso da aplicação do modelo em uma situação real. Isso porque os congestionamentos de veículos podem representar, também, um importante impacto negativo decorrente do transporte urbano de cargas e, nesse caso, deveriam ser considerados.

Para avaliar os impactos da implementação de uma programa de entrega noturna na cidade de Nova Iorque, Holguín-Veras et al. (2011) utilizam um conjunto de dados/modelos obtidos/desenvolvidos em alguns de seus trabalhos anteriores, os quais estão detalhadamente 
apresentados nas referências a eles associadas. Em resumo, a quantificação dos impactos do programa de entrega noturna compreendeu: (i) a quantificação do total de viagens de veículos de carga que, potencialmente, participariam do programa de entrega noturna, mediante um incentivo financeiro, e (ii) o uso de modelos de simulação para quantificar os impactos da implementação do programa.

A determinação da potencial participação no programa de entrega noturna foi realizada em duas etapas que envolveram: (i) a estimativa da resposta do mercado aos incentivos financeiros e (ii) a quantificação do número de entregas geradas pelos diferentes segmentos do comércio. A primeira etapa envolveu a estimativa da resposta do mercado, a qual foi obtida utilizando uma modelo de simulação comportamental (SILAS; HOLGUÍN-VERAS, 2009) e um modelo analítico especialmente desenvolvido (HOLGUÍN-VERAS, 2010). Baseado em uma pesquisa realizada com os recebedores e transportadores de cargas, esses modelos:

$1^{\circ}$. Estimaram quantos dos estabelecimentos considerados nas rotas de entregas simuladas adotariam a entrega noturna;

$2^{\circ}$. Simularam o comportamento dos transportadores correspondentes a esses estabelecimentos;

$3^{\circ}$. Agregaram os resultados para os vários segmentos do comércio considerados.

As estimativas dos estabelecimentos foram obtidas através do uso de modelos de escolha discreta, calibrados a partir dos dados de preferência declarada coletados na pesquisa, os quais quantificaram o comportamento dos recebedores das cargas a partir do fornecimento de incentivos para participação no programa de entrega noturna. Métodos de escolha discreta permitem o estudo e a modelagem de aspectos do comportamento dos usuários relativos à avaliação e escolha dentre alternativas hipotéticas. Através de expressões matemáticas é possível determinar a função utilidade, a qual exprime matematicamente as preferências manifestadas e representa a atratividade de uma alternativa em comparação a outras. Os modelos de escolha discreta baseiam-se na atratividade para determinar a probabilidade de um indivíduo fazer uma certa escolha. 
Os dados coletados na pesquisa forneceram também detalhes em relação às viagens de entrega, número de paradas e outros parâmetros operacionais. A partir desses dados foi possível simular o comportamento dos transportadores, ligados aos estabelecimentos recebedores pesquisados, que participariam do programa e estimar o impacto financeiro sobre eles. Tal cálculo considerou o prejuízo/economia associado à entrega naquele estabelecimento, no horário de sua escolha.

Após a simulação dos resultados, para viagens aleatoriamente geradas a partir dos dados coletados, foi possível estimar, para os vários segmentos do comércio, o percentual de estabelecimentos (recebedores) e transportadores que, potencialmente, participariam do programa de entrega noturna.

A segunda etapa consistiu na quantificação do número total de entrega realizadas para cada setor do comércio, possibilitando a determinação dos impactos que o programa de entrega noturna causaria na rede de transporte. Nesse processo ocorreram:

$1^{\circ}$. O processamento dos dados obtidos na pesquisa, para estimar os modelos de geração de viagem;

$2^{\circ}$. A utilização dos modelos para estimar o número total de entregas, por segmento do comércio e por código postal, na área de Manhattan;

$3^{\circ}$. O cálculo do número e da porcentagem de entregas que participariam do programa de entrega noturna, para cada código postal;

$4^{\circ}$. A utilização dessas estimativas como dados de entrada dos modelos de simulação de tráfego utilizados.

O modelo macroscópico Best Practice Model, já utilizado pelo Conselho do Transporte Metropolitano de Nova Iorque, foi adotado para a estimativa das viagens de entregas, assim como para analisar os efeitos do programa na região metropolitana de Nova Iorque (HOLGUÍN-VERAS et al., 2010). Um outro modelo mesoscópico, desenvolvido na pesquisa, foi utilizado para analisar, com maiores detalhes, os efeitos do programa em uma rede representativa de Manhattan (HOLGUÍN-VERAS et al., 2010). 
O uso extensivo da simulação produziu estimativas sólidas dos impactos em Mahanttan e no resto da região metropolitana. O impacto resultante mostrou-se positivo, pois os efeitos negativos no tráfego durante o período noturno foram compensados pelos benefícios nos horários regulares, devido à redução do número de veículos comerciais. Como um número significante das viagens têm origem fora da área de Manhattan, a participação dos estabelecimentos de Manhattan acaba por reduzir também o número de veículos em circulação em toda a região metropolitana.

Os impactos econômicos foram quantificados em termos da economia do tempo de viagem e da redução nas emissões de gases poluentes. Os autores adotaram uma composição do valor do tempo, considerando os diferentes tipos de veículos no tráfego, e apresentaram os impactos econômicos para três diferentes grupos: os usuários das vias, os transportadores e os recebedores. Para cada um deles, os resultados foram expressos em termos dos benefícios anuais, estimados a partir das alterações nos congestionamentos, custos operacionais, ruídos e poluição do ar. Na análise consolidada, o benefício anual médio chegou a US\$ 193 milhões, considerando um incentivo anual de 15 mil dólares aos estabelecimentos participantes.

O trabalho de Holguín-Veras et al. (2011) apresenta uma modelagem completa para caracterizar a distribuição urbana de cargas e estimar os impactos da implementação do programa de entrega noturna na cidade. A modelagem abrange desde a estimativa das viagens de entrega até a simulação das condições de tráfego, considerando todos os veículos que o compõem. Mais ainda, para realizar tal avaliação, os autores consideram as interações entre recebedores e transportadores na determinação de decisões a respeito da participação no programa, e, dessa forma, conseguem estimar a provável adesão ao mesmo. Ainda, a determinação dos impactos, através da simulação, não ficou restrita a uma área pequena, uma vez que toda a região metropolitana foi incluída no modelo de macrossimulação, embora a análise mais detalhada, através da mesossimulação, tenha sido realizada para a ilha de Manhattan. O próprio autor afirma, no entanto, que os dados levantados para a pesquisa consideraram uma amostra muito reduzida e que uma amostra maior levaria a um melhor conhecimento dos impactos do programa e, portanto, a uma avaliação mais consistente.

Gebresenbet et al. (2011) apresentam um mapeamento do segmento de distribuição de alimentos na cidade de Uppsala, na Suécia, e medem os impactos, em termos dos tempos e 
distâncias de viagem e das emissões de gases poluentes, resultantes da implementação de um sistema coordenado de entregas. Catorze empresas colaboraram com o estudo, que utilizou dados de GPS para medir rotas, localizações geográficas de produtores e pontos de entrega, velocidades dos veículos e altitude das vias. Os tempos de várias atividades foram medidos manualmente (início e término das rotas, horário da entrega em cada cliente, circulação, carregamento e descarregamento do veículo, intervalo do motorista e parada do veículo com e sem os motores ligados). Ainda, para cada rota, foram armazenados o fator de carregamento e o peso da carga.

Um software permitiu a otimização das rotas de distribuição, tanto para rotas únicas quanto para rotas múltiplas, neste caso considerando todas as rotas do sistema ou determinadas combinação de rotas. Os resultados da otimização puderam ser comparados aos valores reais levantados e indicaram as alterações nos tempos de viagem e nas distâncias percorridas. É interessante observar que a otimização das rotas não considerou primariamente as menores distâncias de viagem, mas uma ordem de prioridade de atendimento aos estabelecimentos, obtida através de entrevistas com os motoristas das empresas participantes: $1^{\circ}$ estabelecimentos do varejo, $2^{\circ}$ restaurantes e $3^{\circ}$ escolas ou creches.

No caso das múltiplas rotas, foram consideradas as possibilidades de coordenação da distribuição de alimentos da mesma categoria (combinação entre as rotas de diferentes empresas transportando a mesma categoria de produto) e a codistribuição de alimentos de diferentes categorias (combinação entre as rotas de diferentes empresas atuantes na mesma área geográfica). Essas rotas foram combinadas e otimizadas a partir de duas instâncias: (i) considerando todas as rotas e todos os veículos (otimização total do sistema), resultando em uma redução de $42 \%$ no número de veículos, $58 \%$ no número de rotas e $35 \%$ no total de quilômetros percorridos; (ii) considerando algumas combinações de rotas testadas através de experimentos de simulação, sendo que a otimização de seis dessas combinações, utilizadas como exemplo, mostrou uma redução de até $46 \%$ para as distâncias percorridas e de até $42 \%$ para os tempos de viagem. A redução média para o caso das rotas únicas foi de $9,8 \%$ para os tempos e $10,2 \%$ para as distâncias.

Os autores estimaram também os benefícios ao meio ambiente através da redução nas emissões de gases poluentes, resultante da otimização das rotas. Dados de posição, carregamento (incluindo o peso do veículo), velocidade, distância, motor ligado com o 
veículo parado, área de distribuição, condições da via e idade do veículo, juntamente com as medidas de altitude, foram usados como dados de entrada para um modelo de simulação dinâmica, que considera o veículo como um corpo em movimento e de massa variável (que diminui, por exemplo, se o veículo está executando entregas). O modelo calculou as emissões geradas pelos veículos, em função do consumo de combustível, as quais foram $48 \%$ menores comparadas à situação antes da otimização.

Assim como no caso de Rooijen e Quak (2010), o levantamento de dados reais no trabalho de Gebresenbet et al. (2011) e a representação da rede viária da cidade na simulação, são viáveis principalmente devido à dimensão reduzida de sua área de estudo e a avaliação em torno de uma medida específica, nesse caso, a coordenação da distribuição de produtos da mesma categoria e a codistribuição de produtos diferentes, o que traz um alto grau de controle às variáveis do problema. A simulação foi utilizada em dois momentos do estudo: na macrossimulação do tráfego, para o teste das combinações de rotas a serem otimizadas e na simulação das rotas já otimizadas, de forma a determinar as emissões de gases poluentes. Aqui, chama a atenção o segundo modelo de simulação, que considera a taxa de emissão de poluentes variável com o carregamento (peso) do veículo, que muda a cada carregamento/descarregamento ao longo da rota, um diferencial que não foi observado em nenhum dos outros trabalhos estudados.

Outra abordagem do comportamento dos diferentes agentes para a avaliação de medidas é apresentada no trabalho de Stathopoulos et al. (2012), o qual explora as diferentes percepções dos agentes em relação a políticas para o transporte urbano de cargas, com os seguintes objetivos: (i) identificar os principais problemas relativos ao transporte urbano de cargas, (ii) descobrir quais medidas são as preferidas para os diferentes agentes, e (iii) estudar os efeitos dessas medidas, em termos da aceitabilidade e das reações dos operadores de frete. A pesquisa foi realizada na zona de tráfego limitado da cidade de Roma, na Itália.

A primeira parte da pesquisa, apresentada em detalhes no trabalho de Marcucci et al. (2011), compreendeu uma consulta aos agentes, na qual esses descreveram os principais problemas percebidos em relação à distribuição urbana de cargas e ranquearam um conjunto de medidas divididas em cinco categorias: (i) medidas para os veículos, (ii) medidas para as entregas, (iii) medidas de acessibilidade urbana, (iv) medidas de informação e (v) medidas para os sistemas de distribuição. A segunda parte buscou avaliar as reações comportamentais 
plausíveis dos operadores de frete (transportadores, empresas com frota própria e varejistas) em relação às medidas mais bem avaliadas na consulta aos agentes. Essa avaliação baseouse na utilização de um método de escolha discreta, o método da preferência declarada, e foi dividida em duas etapas:

A primeira etapa utilizou os resultados da primeira parte da pesquisa e definiu um conjunto de atributos para serem utilizados nos experimentos de escolha discreta: número de baias para carga e descarga, probabilidade de encontrar uma baia de carga e descarga livre, taxa anual a ser paga para acessar a zona de tráfego limitado e janela de entrega, este último somente para operadores de frota própria. A cada um dos 195 operadores da amostra foi solicitada a sua ordem de preferência entre três cenários: o atual e outros dois alternativos, caracterizados por alterações nos valores dos atributos previamente definidos, conforme exemplo do Quadro 5.3. Ao todo foram elaborados dez cenários alternativos.

Quadro 5.3 - Exemplo de alternativas apresentadas na pesquisa

\begin{tabular}{lccc}
\hline & POLÍTICA 1 & POLÍTICA 2 & POLÍTICA ATUAL \\
\hline Baias de carga/descarga & 400 & 800 & 400 \\
Probabilidade de encontrar uma baia livre & $20 \%$ & $10 \%$ & $10 \%$ \\
Taxa de acesso & $1000 €$ & $200 €$ & $600 €$ \\
Ordem de preferência das políticas & a ser preenchido & a ser preenchido & a ser preenchido \\
\hline \multicolumn{2}{c}{ Fonte: MARCUCCI et al. (2011), p. 8 }
\end{tabular}

As respostas obtidas foram utilizadas como dados de entrada para a análise comportamental dos agentes, através da aplicação do método da preferência declarada. Stathopoulos et al. (2012) utilizaram o modelo logit multinomial para calcular as probabilidades de escolha de cada alternativa, a partir dos dados dos experimentos de preferência declarada. Os autores consideraram uma função de utilidade unificada, que permitiu a comparação entre os resultados para os diferentes grupos de operadores e a avaliação de suas diferentes sensibilidades para cada atributo.

Os resultados indicaram que os operadores diferem em relação à maioria dos atributos. Nesse sentido, destacam-se a importância dada pelos transportadores às taxas de acesso, o peso dado às variações nas janelas de entrega por parte das empresas com frota própria e a relevância do tamanho dos estabelecimentos para os varejistas. A etapa seguinte apresentou, para cada operador, um cenário específico, caracterizado por um mix de medidas propostas e 
uma lista com possíveis reações, caso o cenário fosse implementado (Quadro 5.4). Cada operador deveria escolher, no máximo, três das possíveis reações listadas e avaliar a aceitabilidade do cenário em uma escala de 1 (inaceitável) a 5 (totalmente aceitável). Foram elaborados diferentes cenários para cada grupo de operador de frete.

Quadro 5.4 - Exemplo de cenário (mix de medidas) apresentado na pesquisa

\section{CENÁRIO PROPOSTO PARA OS TRANSPORTADORES}

Janelas de entrega

Centros de distribuição urbanos (CDUs) ( $5 €$ por entrega, divididos entre transportador e cliente)

Faixas de tráfego exclusivas para veículos de carga

\begin{tabular}{lc}
\hline REAÇÕES POSSÍVEIS & $\begin{array}{c}\text { Assinalar no } \\
\text { máximo três }\end{array}$ \\
\hline Uso dos CDUs para uma parte das entregas & a ser preenchido \\
Para qual \% das entregas? & a ser preenchido \\
Uso do CDU somente se o cliente cobrir 100\% dos custos & a ser preenchido \\
Uso das faixas exclusivas & a ser preenchido \\
Programar as entregas fora dos horários restritos & a ser preenchido \\
Entregar dentro dos horários restritos sob risco próprio & a ser preenchido \\
Não mudar a programação, pois não realizo entregas nos horários restritos & a ser preenchido \\
Praticar entrega noturna (até as 22h) & a ser preenchido \\
Praticar entregas noturnas sem limite de horário & a ser preenchido \\
Otimizar as rotas de entrega e coleta & a ser preenchido \\
Outros & a ser preenchido \\
Aceitação do cenário proposto (de 1 a 5) & a ser preenchido \\
\hline
\end{tabular}

Fonte: STATHOPOULOS et al. (2012), p. 40

Para cada grupo de operador, as respostas foram consolidadas e analisadas em termos da porcentagem de escolha para cada reação possível. Foram identificados resultados positivos, como a migração para veículos mais eficientes, por parte dos operadores de frota própria, e o uso parcial dos CDUs, pelas transportadoras. No entanto, algumas barreiras em relação à cooperação entre os operadores também foram reveladas. Os varejistas, por exemplo, não estão dispostos a utilizar pontos de retiradas de produtos, a não ser que todos os custos sejam cobertos pelas transportadoras. No que diz respeito às janelas de entrega, os varejistas têm preferência clara em receber suas entregas durante o dia, enquanto os transportadores concentram suas preferências no horário noturno.

Diferentemente dos trabalhos até então, a avaliação de medidas para a distribuição urbana de cargas apresentada por Stathopoulos et al. (2012) está completamente baseada em uma 
análise comportamental dos agentes envolvidos. Tal avaliação não deve bastar como base para o processo de tomada de decisão sobre a adoção ou não de uma medida, mas traz resultados importantes ao mostrar a importância da identificação das diferentes percepções às medidas de transporte, sugerindo que a previsão dos comportamentos dos agentes, por parte das autoridades, pode prevenir reações negativas e evitar efeitos indesejados quando novas medidas forem adotadas.

Em âmbito nacional dois trabalhos, ambos teses de doutorado, analisam os efeitos da implementação de iniciativas voltadas à otimização da distribuição urbana de cargas:

Dutra (2004) analisou os benefícios da aplicação dos conceitos de city logistics na melhoria do ambiente urbano, tomando como exemplo o setor de entregas de encomendas através do estudo do comportamento da área central da cidade de Florianópolis. A autora analisou os efeitos da implementação de um centro de serviços, onde os próprios clientes devem retirar suas encomendas, através de um modelo dividido em duas etapas (i) determinação da localização do centro de serviços e (ii) análise dos impactos econômicos da implementação do mesmo, comparando o cenário tradicional atual com um cenário futuro, no qual o centro de serviços estaria em atividade.

Inicialmente, foram levantados os dados de custos (instalações, veículos e mão de obra) e calculadas as distâncias entre o centro de encomendas existente e as zonas da região. Na primeira etapa, através da resolução de um problema da p-mediana, determinou-se o ponto ótimo dentro da área de estudo, minimizando a distância total percorrida pelos usuários do sistema a partir das diversas zonas em que a região foi dividida. Os usuários de cada zona, na verdade, são representados pelo número de encomendas pertencentes àquela zona, determinados através de dados obtidos na central de distribuição dos Correios.

Para a segunda etapa, com base na evolução do número de pacotes, foi determinada a projeção da demanda por encomendas para o cenário futuro. Para determinar a probabilidade de adesão ao novo serviço, ainda na segunda etapa, Dutra (2004) lança mão da teoria da difusão, definida como o processo pelo qual uma inovação é comunicada ao longo do tempo, através de certos canais, entre os membros de um sistema social (ROGERS, 1995). A autora considera o comportamento da demanda em relação ao modo de coleta do produto (nesse caso o deslocamento a pé) para calcular as proporções de demanda atraídas para o 
novo sistema. Então, baseada nos resultados obtidos, em conjunto com os dados de custo e distância levantados, a rotina proposta pela autora calcula (ano a ano) os custos envolvidos na distribuição das encomendas, permitindo a comparação dos mesmos para os cenários escolhidos.

Os resultados mostraram-se benéficos, uma vez que houve redução significativa nos custos de operação de veículos, o que, na prática, significa menos veículos em operação, menos quilômetros rodados e, portanto, menos emissões de gases poluentes. Os custos com mão de obra também diminuíram.

Em uma continuação da análise proposta por Dutra (2004), Oliveira (2007) desenvolveu uma metodologia baseada na teoria da difusão da inovação e na dinâmica de sistemas para analisar a viabilidade da implantação de pontos de entrega inteligentes na cidade de Florianópolis, analisando também a adesão ao serviço e seus impactos. Diferentemente do trabalho em que se baseou, além de considerar uma área de análise mais abrangente, a autora propõe a instalação de múltiplos pontos de entrega e uma avaliação não só econômica, mas também ambiental, no que diz respeito aos impactos causados pelo novo sistema. O processo de adesão ao novo serviço também analisa aspectos diferentes, uma vez que considera o comportamento da demanda frente a um novo sistema de distribuição automatizado e não em relação ao modo de deslocamento para a coleta do produto.

A modelagem proposta é composta por quatro fases e engloba o planejamento para a implementação do novo sistema, permitindo avaliar a adesão dos clientes e fornecendo informações preliminares da quantidade necessária de equipamentos, instalações e veículos, e os possíveis impactos econômicos e ambientais resultantes dessa implementação.

A fase I analisa a adesão ao novo sistema por parte dos clientes, através da teoria da difusão. São considerados os percentuais de eficácia da publicidade, de influência por parte de outros usuários e do custo percebido, para o cálculo do número de adotantes do sistema em função do tempo decorrido desde a implementação do mesmo. A fase II pretende identificar a demanda adicional de futuros clientes do sistema e utiliza dados de projeção de demanda, assim como os resultados da fase I. A fase III, por sua vez, foi desenvolvida para analisar o comportamento das variáveis relativas à distribuição urbana e, a partir da demanda determinada pelas fases antecedentes e de dados operacionais, calcula os número de veículos 
e equipamentos (pontos de entrega) necessários. As relações entre as variáveis consideradas nos modelos são representadas por equações matemáticas, que expressam quantitativamente as relações de causa e efeito do sistema modelado.

Finalmente, a fase IV avalia, econômica e ambientalmente, os impactos da implementação dos pontos de entrega inteligentes. A avaliação econômica baseia-se no estudo da viabilidade econômica do sistema a ser implementado, considerando o número de equipamentos necessários (investimento) e o custo de distribuição das encomendas (custo operacional), este último composto pelo custo de transferência desde a origem das mesmas até a cidade de Florianópolis e pelo custo de distribuição para os pontos de entrega. A avaliação ambiental, por sua vez, consiste na análise da quantidade de poluentes emitidos por cada um dos sistemas analisados. Essa análise se concentra na emissão dos três principais poluentes nocivos à saúde: monóxido de carbono, hidrocarbonetos e óxido de nitrogênio. Para isso, a autora utilizou equações que relacionam as emissões desses poluentes com a velocidade dos veículos, utilizando estimativas da Companhia de Tecnologia de Saneamento Ambiental (CETESB) para o veículo médio da cidade de São Paulo.

A modelagem proposta pelo trabalho foi validada com uma aplicação para a região metropolitana de Florianópolis. Foram simulados três cenários diferentes para a implementação de pontos de entrega inteligentes, com diferentes níveis para a difusão do sistema entre a população: divulgação intensa, divulgação moderada e nenhuma política de difusão. Para o cenário II, cuja política de difusão foi menos onerosa e com adesão significativa, foi realizada a avaliação econômica e ambiental, cujos resultados apontaram uma tarifa de $\mathrm{R} \$ 1,89$ a ser cobrada pela utilização do equipamento e uma redução significativa na emissão de poluentes.

Pode-se dizer que os trabalhos de Oliveira (2006) e Dutra (2004) são complementares, à medida que o primeiro expande a abordagem do último: Dutra (2004) avalia economicamente a viabilidade da implantação de um centro de serviço na área central de Florianópolis, enquanto Oliveira (2006) avalia, econômica e ambientalmente, a viabilidade da implementação de múltiplos centros de serviços na região metropolitana de Florianópolis. Um dos aspectos interessantes levantados nos trabalhos foi a consideração dos processos de adesão (processo de difusão de Bass) no comportamento da demanda, não utilizado em 
nenhum dos outros trabalhos pesquisados. Os coeficientes utilizados no processo, no entanto, foram adotados de outros trabalhos e as próprias autoras recomendam que os mesmos sejam calculados de forma mais adequada, por exemplo, através do método da preferência declarada.

\subsubsection{Considerações Sobre os Trabalhos Revisados}

Dos trabalhos revisados, nota-se que existe um grande esforço no estudo e na modelagem da distribuição urbana de cargas, principalmente nas cidades europeias, onde esse problema e suas soluções têm recebido atenção há mais tempo. É comum à maioria das modelagens a coleta de uma grande quantidade de dados relativos ao transporte de produtos, dentre eles dados de demanda, viagens de entrega, infraestrutura, condições do tráfego, distribuição espacial de clientes, depósitos e residências, custos fixos e operacionais, velocidades e capacidades dos veículos, fluxos de veículos de passageiros, horários das entregas, etc. A acurácia desses dados é essencial para que resultados confiáveis sejam alcançados. No entanto, obter dados de qualidade e na quantidade necessária é a maior dificuldade para aqueles que desejam avaliar quantitativamente a distribuição urbana de cargas.

Alguns dos trabalhos apresentados não chegaram a aplicar seus modelos [Benjelloun e Crainic, (2008) Crainic et al. (2009) e Figliozzi (2007)], enquanto outros o fizeram a situações hipotéticas, nas quais os dados são assumidos e de fácil controle [Tamagawa et al. (2010) Taniguchi e Thompson (2002) e Taniguchi e Van der Heijden (2000)].

Aqueles que aplicaram seus modelos a situações reais, no entanto, ou tinham como ambiente de estudo cidades ou áreas bastante pequenas [Dutra (2004), Gebresenbet et al. (2011) e Rooijen e Quak (2010)] ou então, no caso de cidades maiores, apresentaram limitações em seus dados [Muñuzuri et al. (2010) e Quak e de Koster (2006)]. Muñuzuri et al. (2010), por exemplo, cujo modelo foi aplicado à cidade Sevilha, na Espanha, com cerca de 700 mil habitantes, utilizou dados de apenas quatro zonas da cidade, extrapolando-os posteriormente para as outras 181 zonas. Já o trabalho de Quak e de Koster (2006), o qual considera diversas cidades dos Países Baixos, chegando a analisar um cenário no qual as restrições afetam 250 delas, avalia um número máximo de apenas 134 estabelecimentos, ou seja, aborda o problema em uma escala muito reduzida. 
Dentre os trabalhos revisados, apenas dois fazem referência a grandes cidades [Dablanc e Rakotonarivo (2010) e Holguín-Veras et al. (2011)]. Holguín-Veras et al. (2011) consideram desde a estimativa das viagens de entrega até a simulação das condições de tráfego para toda a região metropolitana de Nova Iorque, mas os dados levantados para a pesquisa consideraram uma amostra reduzida, o que impediu a realização de uma avaliação mais consistente. Dablanc e Rakotonarivo (2010), por sua vez, estudam a relocalização de terminais na região metropolitana de Paris, mas baseia-se em dados bastante simplificados para calcular as emissões de $\mathrm{CO}_{2}$ devido à essa relocalização: considera uma amostra muito pequena de empresas transportadoras e adota um único valor médio como sendo a distância adicional percorrida devido à relocalização dos terminais.

No que diz respeito aos diferentes agentes envolvidos no transporte urbano de cargas, além do trabalho de Holguín-Veras et al. (2011), o qual simula a interação entre os recebedores e transportadores para determinar suas decisões a respeito da participação no programa de entrega noturna, conforme explicado anteriormente, mais três trabalhos apresentam essa abordagem: Quak e de Koster (2006), que determina os prováveis comportamentos das empresas distribuidoras analisadas, diante dos cenários de restrições avaliados, Stathopoulos et al. (2012), que trabalha a percepção dos agentes a determinadas medidas (aceitabilidade e possíveis reações), mas não determina os efeitos dessas reações nas operações de distribuição, e Tamagawa et al. (2010), que considera os diferentes objetivos dos agentes como determinantes de seus comportamentos diante de uma nova medida. O trabalho de Tamagawa et al. (2010), no entanto, não menciona a realização de nenhuma pesquisa ou consulta aos agentes para a definição desses objetivos e portanto, trabalha com informações hipotéticas.

Muitos trabalhos apresentados avaliam os impactos apenas nas viagens dos veículos de entrega [Figliozzi (2007), Gebresenbet et al. (2011) Muñuzuri et al. (2010) e Quak e de Koster (2006)]. Ignorar o sistema viário como um todo, excluindo os veículos de passageiros pode ser apropriado quando o transporte de cargas acontece em uma rede exclusiva, o que não é a realidade da distribuição de produtos que ocorre na área urbana.

Por fim, da análise dos trabalhos revisados, fica clara a importância do uso da simulação do tráfego veicular no processo de análise do comportamento e desempenho do sistema diante de uma mudança que o afeta [Gebresenbet et al. (2011) Holguín-Veras et al. (2011), 
Muñuzuri et al. (2010), Taniguchi e Thompson (2002) e Taniguchi e Van Der Heijden (2000)], o que vai ao encontro do princípio básico da avaliação das medidas voltadas ao transporte urbano de cargas, apresentado neste capítulo. O uso da microssimulação de tráfego e a avaliação de impactos locais, no entanto, não são observados em nenhum dos trabalhos apresentados e em nenhum dos outros que puderam ser encontrados durante essa pesquisa. Tal constatação aponta para a necessidade de um estudo voltado à modelagem do transporte de cargas, visando a utilização da microssimulação de tráfego para a avaliação dos impactos locais decorrentes dessa atividade, em sistemas viários urbanos.

O Quadro 5.5, a seguir, apresenta uma proposta de taxonomia dos trabalhos apresentados nesta seção. 
Quadro 5.5 - Taxonomia dos trabalhos apresentados

\begin{tabular}{|c|c|c|c|c|c|c|c|c|c|c|c|c|}
\hline Trabalho & $\mathrm{O}$ que avalia & Foco da avaliąăo & 0 que analisa & $\begin{array}{c}\text { Demanda por } \\
\text { produtos }\end{array}$ & Como é obtida & Viagens de entrega & Como é obtida & Agentes envolvidos & \multicolumn{3}{|c|}{ Modelagem } & Aplicąã̃o \\
\hline \multirow{2}{*}{$\begin{array}{l}\text { Taniguchi e van der } \\
\text { Heijden (2000) }\end{array}$} & \multirow{2}{*}{$\begin{array}{l}\text { consequências da } \\
\text { implementaçăo de } \\
\text { iniciativas de City } \\
\text { Logistics }\end{array}$} & \multirow{2}{*}{ sistema viário } & \multirow{2}{*}{$\begin{array}{c}\text {.custos totais } \\
\text { emissōes de } \mathrm{CO} 2\end{array}$} & \multirow{2}{*}{$\begin{array}{l}\text { em cada ponto de } \\
\text { atendimento }\end{array}$} & \multirow{2}{*}{ hipotética } & \multirow{2}{*}{ rotas conhecidas } & \multirow{2}{*}{ hipotética } & \multirow{2}{*}{ - } & \multirow{2}{*}{$\begin{array}{l}\text { modelo } \\
\text { integrado } \\
\text { iterativo }\end{array}$} & VRPTW & \begin{tabular}{|c|} 
alocacăão \\
.hoŕrios de partida \\
sequência de atendimento
\end{tabular} & \multirow{2}{*}{ rede hipotettica } \\
\hline & & & & & & & & & & $\begin{array}{l}\text { macrosimulacão } \\
\text { simulaçăo do toráftego }\end{array}$ & $\begin{array}{l}\text { tempos de viagem em } \\
\text { cada link da rede }\end{array}$ & \\
\hline \multirow{2}{*}{$\begin{array}{c}\text { Taniguchi e } \\
\text { Thompson (2002) }\end{array}$} & \multirow{2}{*}{$\begin{array}{c}\text { aplicação do } \\
\text { VRPTW- P em } \\
\text { comparação ao } \\
\text { VRPTW para a } \\
\text { roteirizaçăo dos } \\
\text { veiculos de entrega }\end{array}$} & \multirow{2}{*}{ sistema viário } & \multirow{2}{*}{$\begin{array}{c}\text { custos totais } \\
\text { emissoses de } \mathrm{CO} 2 \\
\text { tempos totais de viagem }\end{array}$} & \multirow{2}{*}{$\begin{array}{l}\text { em cada ponto de } \\
\text { atendimento }\end{array}$} & \multirow{2}{*}{ hipotética } & \multirow{2}{*}{ rotas conhecidas } & \multirow{2}{*}{ hipotética } & \multirow{2}{*}{ - } & \multirow{2}{*}{$\begin{array}{l}\text { modelo } \\
\text { integrado } \\
\text { iterativo }\end{array}$} & VRPTWP & $\begin{array}{c}\text {.alocacẵo } \\
\text {.hoŕarios de partida } \\
\text { sequênecia de atendimento }\end{array}$ & \multirow{2}{*}{ rede hipotética } \\
\hline & & & & & & & & & & $\begin{array}{c}\text { macrosimulacão } \\
\text { simulacâao do tráfego }\end{array}$ & $\begin{array}{l}\text { tempos de viagem em } \\
\text { cada link da rede }\end{array}$ & \\
\hline $\begin{array}{l}\text { Quak e de Koster } \\
\text { (2006) }\end{array}$ & \begin{tabular}{|l|} 
impactos de \\
medidas: \\
-restriăo de acesso \\
restrição por pseso \\
do veiculo
\end{tabular} & $\begin{array}{l}\text { viagens dos } \\
\text { veiculos de } \\
\text { entrega de } \\
\text { alimentos }\end{array}$ & $\begin{array}{l}\text {.custos do transporte } \\
\text { emissōes de } \mathrm{CO} 2\end{array}$ & $\begin{array}{l}\text { em cada ponto de } \\
\text { atendimento }\end{array}$ & entrevista & rotas conhecidas & $\begin{array}{l}\text { nas empresas } \\
\text { distribuidoras }\end{array}$ & $\begin{array}{l}\text { prováveis comportamentos } \\
\text { das empresas distrubidoras } \\
\text { diante das medidas avaliadas }\end{array}$ & & ttimização & rotas de atendimento & $\begin{array}{c}3 \text { empresas analisadas o } \\
\text { estabelecimentos } \\
\text { atendidos por elas (em } \\
\text { diversos municipios } \\
\text { localizados nos paises } \\
\text { baixos) }\end{array}$ \\
\hline Figliozzi (2007) & \begin{tabular}{|c|} 
mudancas nas \\
operaçōes logisticas \\
implementacáa de \\
novas medidas
\end{tabular} & $\begin{array}{l}\text { viagens dos } \\
\text { veiculos de } \\
\text { entrega }\end{array}$ & $\begin{array}{c}\text { total de quilommetros } \\
\text { percorridos pelos veiculos } \\
\text { de carga }\end{array}$ & não ut & & não uti & & - & $\begin{array}{l}\text { expressão mal } \\
\text { instância } \\
\text { roteirizaçắa } 0\end{array}$ & $\begin{array}{l}\text { atemática baseada em } \\
\text { as do problema de } \\
\text { e do caixeiro viajante }\end{array}$ & \begin{tabular}{|c|} 
comprimento da viagem \\
em relação ao numeroro de \\
clientes, a proximidade \\
entre clientes e a \\
proximidade entre eles e o \\
centro de distribuiçăo
\end{tabular} & - \\
\hline \multirow{3}{*}{$\begin{array}{c}\text { Benjelloun e } \\
\text { Crainic (2009) }\end{array}$} & \multirow{3}{*}{$\begin{array}{c}\text { medidas que afetam } \\
\text { o transporte de } \\
\text { cargas }\end{array}$} & \multirow{3}{*}{$\mid \begin{array}{c}\text { comportamento do } \\
\text { sistema de } \\
\text { transporte }\end{array}$} & & & & & $\begin{array}{l}\begin{array}{l}\text { offerta de transporte } \\
\text { (rede multimodal e }\end{array} \\
\end{array}$ & & \begin{tabular}{|c|}
$\begin{array}{c}\text { método de } \\
\text { planejamento }\end{array}$ \\
\end{tabular} & modelo de oferta & & \\
\hline & & & $\begin{array}{l}\text { medidas de performance } \\
\text { obtidas através de }\end{array}$ & & econômicos, & entre pares de zonas & $\begin{array}{c}\text { servicos) } \\
\text {.custos das viagem }\end{array}$ & - & \begin{tabular}{|c} 
quatro etapas \\
baseado no
\end{tabular} & modelo de demanda & $\begin{array}{l}\text { matriz origem-destino } \\
\text { dos fluxos de produtos }\end{array}$ & - \\
\hline & & & & . em cada zona & $\begin{array}{l}\text { demograficicos e } \\
\text { sociais }\end{array}$ & (origem e destino) & $\begin{array}{c}\text { (tempo, consumo de } \\
\text { energia, niveis de } \\
\text { emissăo, etc.) }\end{array}$ & 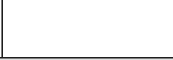 & $\begin{array}{c}\text { modelo } \\
\text { aplicado a } \\
\text { passageiros }\end{array}$ & \begin{tabular}{|c|c|}
$\begin{array}{c}\text { modelo de alocação } \\
\text { de fluxos } \\
\text { multiprodutos }\end{array}$ \\
\end{tabular} & rotas de transporte & 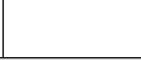 \\
\hline & contribuição do & & & & & & .entrevistas com os & & $\overline{\text { maximiza }}$ & zação da entropia & $\begin{array}{l}\begin{array}{c}\text { origem e destino dos } \\
\text { fluxos }\end{array} \\
\end{array}$ & \\
\hline $\begin{array}{l}\text { Muñuzuriet al. } \\
(2010)\end{array}$ & $\begin{array}{c}\text { transporte de } \\
\text { produtos para a } \\
\text { pegada ecologica da } \\
\text { cidade }\end{array}$ & $\begin{array}{l}\text { viagns ods } \\
\text { veiculos de } \\
\text { entrega }\end{array}$ & $\begin{array}{l}\text {. consumo de combustivel } \\
\text { dos veiculos de carga }\end{array}$ & não ut & & $\mid \begin{array}{c}\text { entre zonas da cidade } \\
\text { (origem e destino) }\end{array}$ & \begin{tabular}{|c|} 
entregadorese \\
comerciantes \\
.contagem de \\
veículos
\end{tabular} & - & macrosimt & nulą̧ão do tráfego & $\begin{array}{l}\text {.atribução dos fluxos às } \\
\text { vias } \\
\text { vistância total } \\
\text {.velocidade média, etc }\end{array}$ & Sevilla, Espanha \\
\hline $\begin{array}{c}\text { Dablance } \\
\text { Rakotonarivo } \\
\text { (2010) }\end{array}$ & \begin{tabular}{|c|} 
efeitos das \\
mudancas na \\
localizaząo de \\
terminais de cross- \\
docking entrer 1978 \\
e 2008
\end{tabular} & $\begin{array}{l}\text { viagens dos } \\
\text { veiculos de } \\
\text { entrega }\end{array}$ & emissões de $\mathrm{CO} 2$ & total da cidade & $\begin{array}{l}\text { média de } \\
\text { diferentes fontes } \\
\text { estatisticas }\end{array}$ & $\begin{array}{c}\text { considera iguais } \\
\text { todas as viagens com } \\
\text { destino à cidade }\end{array}$ & $\begin{array}{c}\text { entrevistas } \\
\text { realizadas nas } \\
\text { empresas }\end{array}$ & - & análisc & se centográfica & \begin{tabular}{|c|} 
centro geométrico da \\
localização dos terminais \\
que pemite calcular a \\
distância extra percorrida \\
pelos veículos de carga
\end{tabular} & $\begin{array}{l}17 \text { empresas da região } \\
\text { metropolitana de Paris }\end{array}$ \\
\hline
\end{tabular}


continuação

\begin{tabular}{|c|c|c|c|c|c|c|c|c|c|c|c|c|}
\hline \multicolumn{13}{|c|}{ continuação } \\
\hline Trabalho & $O$ que avalia & Foco da avaliação & $O$ que analisa & $\begin{array}{l}\text { Demanda por } \\
\text { produtos }\end{array}$ & Comoé obtida & Viagens de entrega & Como é obtida & Agentes envolvidos & & Modelagem & O que determina & Aplicą̧ão \\
\hline \multirow{2}{*}{$\begin{array}{l}\text { Rooijen e Quak } \\
\text { (2010) }\end{array}$} & \multirow{2}{*}{$\begin{array}{c}\text { impactos locais } \\
\text { causados pela } \\
\text { implementação de } \\
\text { um centro de } \\
\text { consolidação } \\
\end{array}$} & \multirow{2}{*}{$\begin{array}{l}\text { viagens dos } \\
\text { veiculos de } \\
\text { entrega }\end{array}$} & \multirow{2}{*}{$\begin{array}{c}\text {.qualidade do ar } \\
\text { emisšo de ruidos } \\
\text { incômodo aos residentes }\end{array}$} & $\begin{array}{c}\begin{array}{c}\text { por tipo de } \\
\text { estabelecimento }\end{array} \\
\end{array}$ & $\begin{array}{c}\text { pesquisas } \\
\text { realizadas pelo } \\
\text { governo }\end{array}$ & rotas conhecidas & $\begin{array}{c}\text { pesquisas realizadas } \\
\text { pelo governo }\end{array}$ & \multirow[b]{2}{*}{-} & \multirow{2}{*}{\multicolumn{2}{|c|}{ macrosimulação do tráfego }} & \multirow{2}{*}{$\begin{array}{l}\text { rotas dos caminhöes no } \\
\text { centro da cidade } \\
\text { tamanho da frota } \\
\text { necessária }\end{array}$} & \multirow{2}{*}{ Nijmegen, Holanda } \\
\hline & & & & \begin{tabular}{|c|}
$\begin{array}{c}\text { por estabelecimento } \\
\text { atendido pelo centro } \\
\text { de consolidaçăo }\end{array}$ \\
\end{tabular} & \begin{tabular}{|l|}
$\begin{array}{l}\text { obtidas no centro } \\
\text { de consolidą̧ăo }\end{array}$ \\
\end{tabular} & rotas conhecidas & $\begin{array}{l}\text { no centro de } \\
\text { consolidação }\end{array}$ & & & & & \\
\hline \multirow{2}{*}{$\begin{array}{l}\text { Tamagawa et al. } \\
\text { (2010) }\end{array}$} & \multirow{2}{*}{$\begin{array}{l}\text { efetividade de } \\
\text { medidas baseadas } \\
\text { em City Logistics }\end{array}$} & \multirow{2}{*}{$\begin{array}{c}\text { sistema } \\
\text { viário }\end{array}$} & \multirow{2}{*}{$\begin{array}{c}\text { emissões de NOx } \\
. \text { lucros dos operadores das } \\
\text { vias } \\
\text { lucro dos transportadores. } \\
\text {.ustos para os } \\
\text { embarcadores }\end{array}$} & \multirow{2}{*}{$\begin{array}{l}\text { em cada ponto de } \\
\text { atendimento }\end{array}$} & \multirow{2}{*}{ hipotética } & \multirow{2}{*}{ rotas conhecidas } & \multirow{2}{*}{ hipotética } & \multirow{2}{*}{$\begin{array}{l}\text { objetivos dos embarcadores, } \\
\text { transportadores, residentes, } \\
\text { administradores e operadores } \\
\text { das vias definem seus } \\
\text { comportamentos diante das } \\
\text { medidas }\end{array}$} & \multirow{2}{*}{$\begin{array}{l}\text { modelo } \\
\text { integrado } \\
\text { itterativo }\end{array}$} & $\begin{array}{l}\text { modelo de } \\
\text { aprendizado }\end{array}$ & $\begin{array}{c}\text { avalia, "aprende"e } \\
\text { seleciona o } \\
\text { comportanento dos } \\
\text { agentes }\end{array}$ & \multirow{2}{*}{ rede hipotettica } \\
\hline & & & & & & & & & & modelo VRPTW & $\begin{array}{c}\text { alocacāão } \\
\text { horários de partida } \\
\text { sequência de atendimento }\end{array}$ & \\
\hline \multirow{3}{*}{$\begin{array}{l}\text { Holguin-Veras et } \\
\text { al., (2011) }\end{array}$} & \multirow{3}{*}{$\begin{array}{l}\text { impactos resultantes } \\
\text { da implementaçąo } \\
\text { de um programa de } \\
\text { entregas noturnas }\end{array}$} & \multirow{3}{*}{$\begin{array}{c}\text { sistema } \\
\text { viário }\end{array}$} & \multirow{3}{*}{$\begin{array}{l}\text { custo generalizado } \\
\text { considerando: } \\
\text { congestionamentos } \\
\text {.custos operacionais } \\
\text { ruuidos } \\
\text {.poluiçáo do ar }\end{array}$} & \multirow{3}{*}{\multicolumn{2}{|c|}{ não utiliza }} & \multirow{3}{*}{$\begin{array}{l}\text { por tipo de } \\
\text { estabelecimento }\end{array}$} & \multirow{3}{*}{$\begin{array}{c}\text { pesquisa com } \\
\text { amostra de } \\
\text { recebedores } \mathrm{e} \\
\text { transportadores }\end{array}$} & \multirow{3}{*}{$\begin{array}{l}\text { considera o comportamento } \\
\text { dos recebedores e } \\
\text { transportadores na decisião } \\
\text { sobre participar ou não do } \\
\text { programa }\end{array}$} & \multicolumn{2}{|c|}{\begin{tabular}{|c} 
modelo de escolha discreta + modelo \\
analitico especifico
\end{tabular}} & $\begin{array}{c}\text { porcentagem de } \\
\text { recebedorese } \mathrm{e} \\
\text { transportadores que } \\
\text { potencialmente } \\
\text { participariand do } \\
\text { programa }\end{array}$ & \multirow{3}{*}{\begin{tabular}{|c} 
Manhatan e região \\
metropolitana de Nova \\
Iorque (somente a \\
macrossimulação)
\end{tabular}} \\
\hline & & & & & & & & & \multicolumn{2}{|c|}{ modelo de geraạẫo de viagem } & $\begin{array}{c}\text { número total de entregas } \\
\text { por tipo de } \\
\text { estabelecimento }\end{array}$ & \\
\hline & & & & & & & & & \multicolumn{2}{|c|}{$\begin{array}{l}\text { simulaç̃o macro e mesoscópica do } \\
\text { tráfego }\end{array}$} & \begin{tabular}{|l|} 
tempos de viagem \\
distâncias totais \\
\end{tabular} & \\
\hline \multirow{2}{*}{$\begin{array}{l}\text { Gebresenbet et al. } \\
\text { (2011) }\end{array}$} & \multirow{2}{*}{$\begin{array}{c}\text { impactos resultantes } \\
\text { da implementaçâo } \\
\text { de um sistema } \\
\text { coordenado de } \\
\text { entregas } \\
\end{array}$} & viagens dos & $\begin{array}{l}\text { tempos totais de viagem } \\
\text { distâncias percorridas }\end{array}$ & & & & & & & timizaçăo & rotas de atendimento & 14 empresas de \\
\hline & & $\begin{array}{l}\text { veiculos de } \\
\text { entrega }\end{array}$ & $\begin{array}{l}\text { pelos veiculos de carga } \\
\text { emissous de gases } \\
\text { poluentes }\end{array}$ & não util & & rotas conhecidas & empresas & - & $\begin{array}{r}\text { macrossimula } \\
\text { rota }\end{array}$ & $\begin{array}{l}\text { Ação do tráfego para as } \\
\text { as otimizadas }\end{array}$ & $\begin{array}{c}\text {.tempos de viagem } \\
\text { distâncias totais }\end{array}$ & Uppsala, Suécia \\
\hline & & & medidas preferidas pelos & & & & & percep̧̧̋ess, aceitabilidade e & $\begin{aligned} \text { modelo de esc } \\
\text { logit }\end{aligned}$ & $\begin{array}{l}\text { colha discreta/modelo } \\
\text { tmultinomial }\end{array}$ & $\begin{array}{c}\begin{array}{c}\text { sensiblidades dos agentes } \\
\text { para cada atributo das } \\
\text { medidas }\end{array} \\
\end{array}$ & \\
\hline $\begin{array}{l}\text { Stathopoulos et al. } \\
\text { (2012), }\end{array}$ & $\begin{array}{c}\text { percentes as } \\
\text { determinadas } \\
\text { medidas }\end{array}$ & agentes & $\begin{array}{c}\text { agentes } \\
\text { acectiabilidade } \\
\text { reaçôes dos operadores de } \\
\text { frete }\end{array}$ & não se ap & & não se & caplica & $\begin{array}{c}\text { comportamentos dos } \\
\text { transportadores, empresas } \\
\text { com frota propiria varésistas } \\
\text { diante das medidas }\end{array}$ & pesquisa & comportamental & $\begin{array}{c}\text { reaçőes dos agentes } \\
\text { diante das medidas } \\
\text { avaliadas } \\
\text { aceitabilidade das } \\
\text { medidas por parte dos } \\
\text { agentes }\end{array}$ & $\begin{array}{c}\text { 195 operadores que } \\
\text { atuam na zona de } \\
\text { tráfego restrito no centro } \\
\text { histórico de Roma }\end{array}$ \\
\hline & efeitos da & viagens dos & & & & & & & macrosim & ulação do tráfego & \begin{tabular}{ll|l} 
distâncias totais \\
\end{tabular} & \\
\hline Dutra (2004) & $\begin{array}{l}\text { implementação de } \\
\text { um centro de }\end{array}$ & $\begin{array}{l}\text { veiculos de } \\
\text { entrega }\end{array}$ & .custos operacionais & \begin{tabular}{|} 
número de pacotes de \\
encomendas em cada
\end{tabular} \mid & $\begin{array}{l}\text { levantados nos } \\
\text { correios }\end{array}$ & $\begin{array}{l}\text { em cada rua de } \\
\text { atendimento }\end{array}$ & $\begin{array}{l}\text { levantados nos } \\
\text { correios }\end{array}$ & - & problem & na da p-mediana & $\begin{array}{l}\text { localização do centro de } \\
\text { serviços }\end{array}$ & $\begin{array}{l}\text { região central de } \\
\text { Floriańnolis }\end{array}$ \\
\hline & serviços & $\begin{array}{l}\text { instalacōes } \\
\text { operacionais }\end{array}$ & & & & & & & & ia da difusãoo & $\begin{array}{c}\text { probabilidade de adesão } \\
\text { ao novo serviço }\end{array}$ & \\
\hline & \begin{tabular}{|c|} 
efeitos da \\
implementaçăo de
\end{tabular} & $\begin{array}{l}. \text { viagens dos } \\
\text { veiculos de }\end{array}$ & & número de pacotes de & & & & & & ia da difusãa & $\begin{array}{c}\text { probabilidade de adesão } \\
\text { ao novo sistema }\end{array}$ & \\
\hline Oliveira (2007) & $\begin{array}{c}\text { coleta para } \\
\text { encomendas } \\
\text { e-commerce }\end{array}$ & $\begin{array}{c}\text { entrega } \\
\text { instalaçós } \\
\text { operacionais }\end{array}$ & emissão de poluentes & $\left|\begin{array}{c}\text { encomendas em cada } \\
\text { zona da cidade }\end{array}\right|$ & correios & por zona da cidade & correios & - & $\begin{array}{l}\text { dinâmica de } \\
\text { sistemas }\end{array}$ & \begin{tabular}{|c|} 
simulação de \\
modelos de estoque e \\
fluxo
\end{tabular} & $\begin{array}{l}\text { número de veiculos } \\
\text {.número de equipamentos }\end{array}$ & Florianópolis \\
\hline
\end{tabular}




\section{PROCEDIMENTO PARA A AVALIAÇÃO DE MEDIDAS VOLTADAS À DISTRIBUIÇÃO URBANA DE CARGAS USANDO MICROSSIMULAÇÃO DE TRÁFEGO}

Conforme exposto nos capítulos anteriores, para a avaliação de medidas voltadas à distribuição urbana de cargas é desejável e importante entender e quantificar os impactos decorrentes das atividades que compõem essa operação. Deve-se considerar, ainda que a maioria dos problemas gerados pela distribuição urbana ocorre ao nível desagregado, caracterizando impactos locais, como, por exemplo, as interferências no tráfego decorrentes das práticas ilegais de estacionamento dos veículos de carga. Em ambientes heterogêneos como a cidade de São Paulo a quantificação desses impactos é ainda mais relevante, pois a implementação de uma mesma medida em áreas de características distintas da cidade pode acarretar em impactos completamente diferentes, seja para o tráfego local, seja para a própria operação da distribuição urbana. Nesse contexto, a microssimulação de tráfego se torna uma alternativa promissora para a avaliação de medidas considerando a quantificação dos impactos locais, pois permite a modelagem detalhada do sistema viário e dos movimentos dos veículos, assim como a obtenção de resultados individualizados.

Este trabalho propõe então um procedimento que dê subsídios ao desenvolvimento de uma metodologia para a avaliação de medidas voltadas à distribuição urbana de cargas através do uso da microssimulação de tráfego. O procedimento se baseia em um conjunto de coleta de dados e no desenvolvimento de modelos que permitem a representação dos movimentos dos veículos de carga em um ambiente da microssimulação.

Este capítulo objetiva apresentar esse procedimento e está organizado da seguinte forma: inicialmente é feita uma caracterização dos modelos de microssimulação, considerando o contexto geral da simulação de tráfego, seguida do detalhamento do procedimento proposto, o qual está dividido entre as coletas de dados e o desenvolvimento dos modelos.

\subsection{CONTEXTO GERAL DA SIMULAÇÃO DE TRÁFEGO}

$\mathrm{Na}$ tentativa de representar o fluxo de veículos pela malha viária, começou a ser desenvolvida, por volta de 1930, a teoria dos fluxos de tráfego, a qual tenta descrever as 
interações entre os condutores, os veículos e a infraestrutura, composta do sistema viário e dos dispositivos de controle de fluxo na rede (MAIA, 2007). Tal teoria consiste na aplicação de formulações matemáticas, da teoria das probabilidades e da física, para descrever o comportamento do tráfego de veículos no sistema viário e baseia-se nas variáveis de fluxo, velocidade e densidade dos veículos (JAYAKRISHNAN et al., 2002).

Acompanhando a teoria dos fluxos e a necessidade de um maior detalhamento da representação do tráfego, a partir dos anos 60 começaram a ser desenvolvidos modelos capazes de simular o deslocamento de veículos, considerando algumas das realidades observadas no sistema viário, como por exemplo, a mudança de faixa (MAIA, 2007).

Segundo May (1990), a simulação do tráfego veicular é uma técnica numérica para a representação de sistemas viários em um computador, cujo principal objetivo é replicar a sequência de eventos hipotéticos do sistema estudado, ao longo do tempo, tratando as entidades (veículos) que percorrem o modelo de forma agregada ou individualizada.

A complexidade das redes viária e os avanços nas técnicas de modelagem contribuem para que a simulação de tráfego torne-se uma ferramenta importante no auxílio da tomada de decisão, a partir da análise do comportamento do sistema viário. May (1990) lista as principais vantagens do uso da simulação de tráfego em termos das possibilidades de uso dessa técnica:

- Melhor entendimento da realidade do sistema estudado;

- Realização de experimentos sem qualquer impacto aos usuários do sistema representado;

- Simulação de cenários alternativos, diferentes da realidade;

- Melhor conhecimento das variáveis envolvidas no problema e das suas relações;

- Referenciação dos dados de saída no tempo e no espaço (informações desagregadas);

- Estudo dos sistemas em tempo real, tempo estendido ou tempo reduzido;

- Simulação de experimentos inseguros, sem riscos para os usuários do sistema real;

- Replicação das condições originais como base de comparação entre alternativas;

- Estudo dos efeitos de mudanças operacionais nos sistemas estudados;

- Variação da demanda ao longo do tempo e do espaço. 
O grande diferencial dos modelos de simulação de tráfego reside, entretanto, no fato dos mesmos incorporarem a variabilidade espaço-temporal dos elementos que compõem o sistema simulado, o que lhes confere um maior poder de representatividade (MAIA, 2007).

Os modelos de simulação de tráfego podem ser classificados de acordo com o nível de detalhe com que representam o fluxo de tráfego (Figura 6.1), ou ainda, de acordo com a natureza do sistema que esses tentam representar. Na literatura em geral, a classificação dos modelos de simulação é feita em duas categorias, dividindo-se entre modelos macroscópicos e microscópicos. Existe, no entanto, uma classificação mais recente que inclui uma nova categoria e divide os modelos em macroscópicos, mesoscópicos e microscópicos.

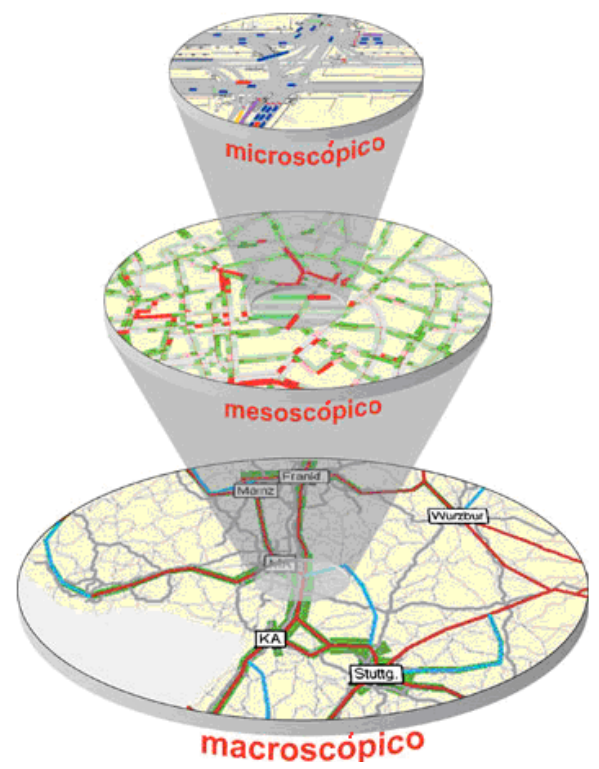

Figura 6.1 - Nível de detalhe dos modelos de simulação Fonte: MAIA (2007)

\subsubsection{Modelos Macroscópicos}

Caracterizam-se pela análise integrada das correntes de tráfego. Na simulação macroscópica, o comportamento individual de cada um dos veículos que compõem a corrente de tráfego é desprezado, sendo modeladas apenas suas características médias, através do comportamento agregado da corrente veicular ao se deslocar pelas vias da rede. Os modelos macroscópicos são determinísticos e têm abordagem estática, ou seja, não incorporam o conceito de variabilidade na representação dos fluxos de veículos na rede de simulação e avaliam um 
único estado da rede, supostamente representativo das condições médias ou agregadas ao longo de um determinado período (ARIOTTI et al., 2004).

\subsubsection{Modelos Mesoscópicos}

Apresentam um nível de detalhamento um pouco maior do que os modelos de macrossimulação, pois embora se baseiem nas relações macroscópicas de tráfego, realizam o acompanhamento individual dos veículos, caracterizando uma classe intermediária quanto ao realismo e detalhamento (PORTUGAL, 2005; VASCONCELOS, 2004). Os modelos mesoscópicos também estão restritos ao caráter estático e agregado da representação da rede viária, porém com uma representação mais detalhada do que os modelos macroscópicos, exigindo, entretanto, menor esforço e menos recursos computacionais do que os modelos microscópicos, o que os torna mais apropriados para a representação relativamente mais detalhada de redes extensas (ARIOTTI et al., 2004).

\subsubsection{Modelos Microscópicos}

Nos modelos microscópios os veículos são tratados de forma inteiramente individualizada, sendo o modelo tão detalhado quanto for o propósito da análise (MAIA, 2007). Todas as variáveis para o cálculo das medidas de desempenho da rede simulada são gravadas de forma desagregada para cada veículo, sendo que os mesmos são acompanhados individualmente desde sua entrada na rede até atingirem o seu destino, caracterizando o aspecto estocástico da modelagem do tráfego (RAKHA, 2002). Os detalhes observados nos modelos microscópicos de simulação permitem grande flexibilidade para adicionar vários contextos (ambientes) de simulação e opções de cenários. Além disso, os resultados de saída, desagregados para cada veículo, permitem análises mais detalhadas do comportamento e do desempenho dos mesmos e da rede viária (RAKHA, 2010; VASCONCELOS, 2004).

Os modelos microscópicos apresentam, ainda, a capacidade de representar o comportamento dos fluxos do tráfego em ambientes virtuais bi ou tridimensionais, o que garante a visualização do sistema e dos movimentos dos veículos. Esse tipo de representação permite que não especialistas observem e compreendam os impactos decorrentes das diferentes alternativas analisadas. 
A desagregação na modelagem e na observação dos movimentos dos veículos, possibilitada pela microssimulação, resulta, no entanto, em algumas desvantagens: modelos microscópicos requerem a coleta de todos (ou quase todos) os detalhes da rede simulada, e de inúmeros dados que reflitam os comportamentos individuais dos veículos, o que pode tornar a obtenção e implementação desses dados mais demorada e complicada; o esforço de calibração nesses tipos de modelo também mostra-se maior, podendo dificultar o início do processo de simulação (MAIA, 2007).

Segundo Rakha (2004), a representação do sistema viário necessária aos modelos de microssimulação consiste de informações sobre:

- Topologia do sistema (na forma de arcos e nós);

- Geometria dos componentes viários (número e largura de faixas, rampas, etc.);

- Tipo dos arcos (vias urbanas ou expressas);

- Solicitação das vias do sistema viário (fluxo de veículos);

- Porcentagem de movimentos de giro;

- Regulamentação do tráfego e dos dispositivos de controle (sinal "pare", "dê a preferência", etc.);

- Tempos semafóricos;

- Canalização de faixas para giros ou faixas exclusivas para ônibus;

- Comportamento dos motoristas, que determinam o desempenho operacional dos veículos no sistema (aceleração, desaceleração, respeito ao sinal amarelo, etc.);

- Tipos de veículos (carros, caminhões, ônibus, etc.);

- Especificação do sistema de ônibus (rota, pontos de parada, frequência, etc.).

A determinação dos fluxos de veículos que solicitam as vias do sistema viário simulado pode ser feita de duas maneiras distintas (VILARINHO, 2008):

i. Matriz origem-destino: define quantitativamente as viagens realizadas num período de tempo, onde cada célula $(i, j)$ da matriz contém o número de veículos que se deslocam de $i$ para j;

ii. Estados de tráfego: contém o número de veículos, por período, em cada seção de entrada na rede, e as proporções de movimentos de giro em uma interseção, no caso de existir 
mais do que um movimento permitido. Cada estado de tráfego é definido para um tipo de veículo em particular e um período de tempo definido.

A estimativa do número de tráfego em cada seção de interesse pode ser feita a partir da contagem de veículos, manual ou através de sensores. Existem ainda outras tecnologias, baseadas na identificação automática de veículos (do inglês Automatic Vehicle Identification - $A V I)$ que podem ser utilizadas para determinar os fluxos de tráfego, e que se utilizam da leitura de dispositivos instalados nos veículos, identificação de placas ou rastreamento de telefones celulares (DIXON; RILLET, 2002), mas que são pouco utilizadas no Brasil.

\subsection{PROCEDIMENTO PROPOSTO}

Conforme explicado ao início deste capítulo, o procedimento proposto por este trabalho se baseia em um conjunto de coleta de dados e no desenvolvimento de modelos que permitam a representação dos movimentos dos veículos de carga em um ambiente da microssimulação. Para que isso seja possível faz-se necessário o levantamento de algumas informações específicas, além das apresentadas na seção anterior. Essas informações são relacionadas às atividades que compõem a operação da distribuição urbana de cargas e podem ser identificadas no modelo conceitual apresentado na Figura 6.2. O modelo conceitual baseiase na observação e no acompanhamento de entregas ${ }^{10}$, realizados ao longo do desenvolvimento deste trabalho e relaciona todas as atividades que podem ser atribuídas a cada um dos veículos de carga que realizam entregas na área urbana. Algumas dessas atividades são imprescindíveis, pois são observadas em todas as operações de entrega, são elas: procura, estacionamento do veículo, descarregamento, entrega, fechamento e partida. As demais atividades, como a coleta e a notificação da entrega podem ser consideradas complementares.

\footnotetext{
${ }^{10}$ (i) Acompanhamento das rotas de entrega das empresas Staples (na cidade de Boston - EUA, em setembro de 2012 e na cidade de São Paulo, em outubro de 2012), Natura, Ambev (ambas na cidade de São Paulo, em outubro de 2012) e Coca-Cola (na cidade de Boston - EUA, em setembro de 2013); (ii) observação de mais de 1.000 entregas durante a etapa de coleta de dados realizada para o desenvolvimento do procedimento proposto por este trabalho.
} 


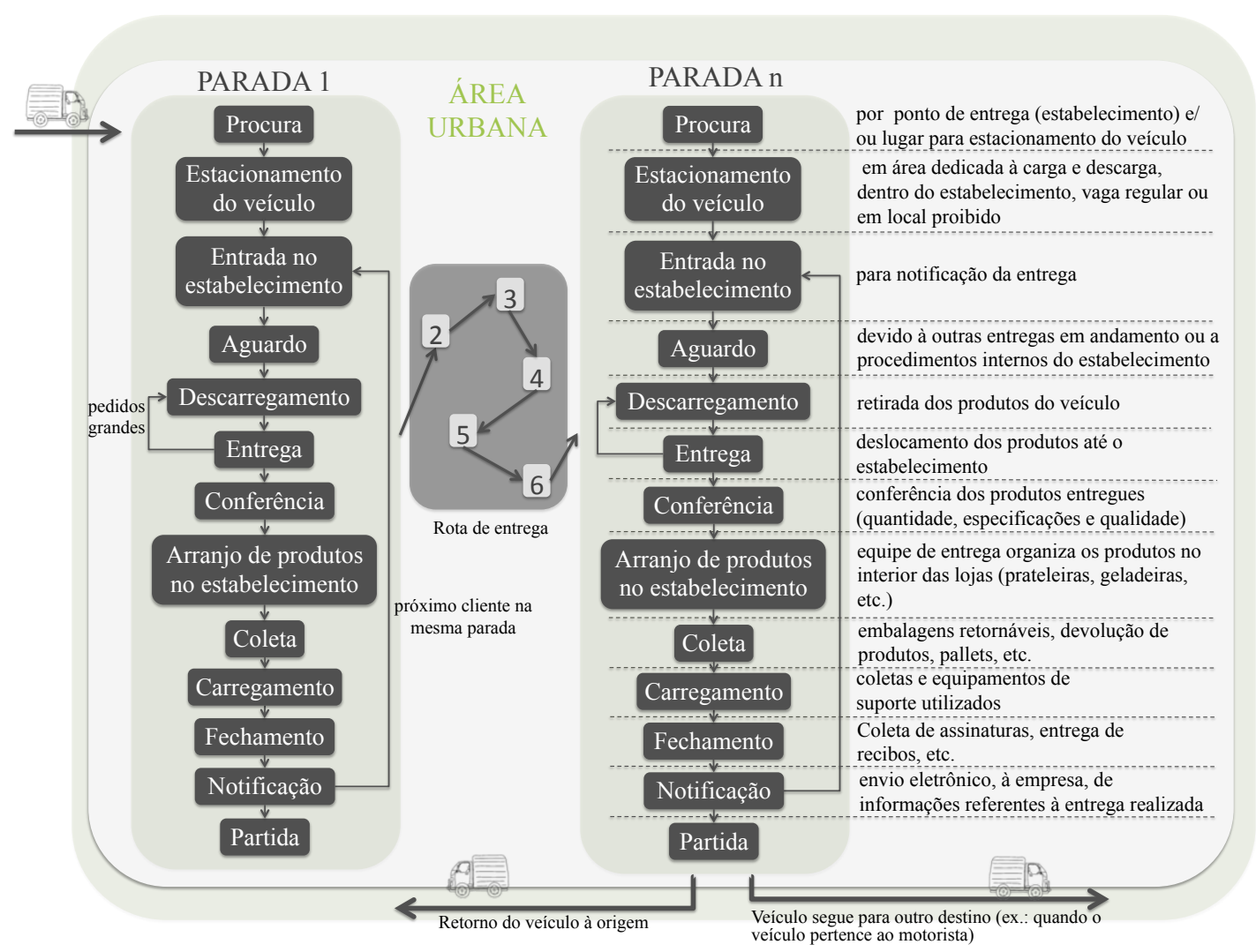

Figura 6.2 - Modelo conceitual da distribuição urbana de cargas

De acordo com o modelo conceitual, ao adentrar a área urbana onde as entregas serão realizadas, o veículo de carga segue para o primeiro estabelecimento a ser atendido (parada 1). A primeira atividade que caracteriza a entrega nesse estabelecimento é a procura pelo próprio estabelecimento (no caso de motoristas pouco familiarizados com a rota de entrega) e por um local para estacionar o veículo. Em seguida, o motorista, ou o ajudante, notifica aquele estabelecimento sobre a entrega a ser realizada e (se necessário) aguarda pela autorização para o início da mesma. Autorizada a entrega, os produtos são então descarregados do veículo e levados até o interior do estabelecimento (ou até seu depósito). Para entregas de grandes volumes pode ser necessária a repetição dessas duas atividades, ou seja, o descarregamento e o deslocamento dos produtos até o estabelecimento são feitos para uma parte da carga e repetidos até que todo o pedido tenha sido entregue. Após o descarregamento e entrega de todos os produtos, um responsável pelo estabelecimento realiza a conferência do pedido, checando se todos itens solicitados foram entregues na quantidade e especificações corretas. A atividade seguinte, a qual consiste na organização dos produtos no interior do estabelecimento (em prateleiras geladeiras, etc.) é, na maioria das vezes, de responsabilidade do próprio estabelecimento. Existem empresas, no entanto, 
que incluem essa atividade em seu contrato com o cliente e assumem essa responsabilidade, seja por exigência do próprio cliente ou por uma questão estratégica da própria empresa, como por exemplo, garantir a visibilidade de seu produto na loja. Quando existem itens a serem coletados, sejam eles embalagens retornáveis, pallets utilizados em uma entrega anterior ou até mesmo produtos devolvidos, ocorrem as atividades de coleta e carregamento (no veículo) desses itens. Por fim, procede-se para o fechamento da entrega, o que engloba todos os processos administrativos necessários entre o cliente e a empresa entregadora (pagamento, emissão de nota fiscal, coleta de assinaturas, etc.), após o qual o motorista notifica sua empresa sobre o status da entrega realizada e parte para o próximo estabelecimento que consta em sua rota. A sequência de atividades se repete em cada um dos estabelecimentos visitados até que, após a realização da entrega no último estabelecimento da rota (parada $n$ ), o veículo retorna à sua origem (centro de distribuição, por exemplo) ou segue para outro destino (quando, por exemplo, o motorista é o dono do veículo).

Conforme mencionado anteriormente, o modelo conceitual relaciona a sequência de atividades de cada um dos veículos que realizam entregas em uma determinada área. Em um cenário real, portanto, no qual diversas entregas, em diferentes estabelecimentos, ocorrem ao mesmo tempo, as atividades apresentadas no modelo conceitual são cumpridas concomitantemente pelos diferentes veículos que realizam essas entregas. Considerando, então, uma área de interesse delimitada (área de simulação) e um período de tempo prédefinido (um dia, uma semana, etc.), faz-se necessário determinar quantas e quais entregas são realizadas por quais desses veículos. Por uma outra perspectiva, pode-se pensar em determinar quantos veículos de entrega essa área atrai, em determinado período, e quais estabelecimentos serão atendidos por cada um deles (pontos de parada nas rotas de entrega).

Sendo assim, para cada um dos veículos que realizam entregas na área de interesse, as informações necessárias à microssimulação são:

- Características do veículo: capacidade de carga, dimensões, velocidade, consumo de combustível, etc.;

- Rota de entrega: local de entrada na área de interesse, pontos de parada (estabelecimentos atendidos), local de saída da área de interesse e caminhos percorridos;

- Horário de entrada na área de interesse; 
- Local de estacionamento desejado (em cada ponto de parada);

- Tempo para a manobra de estacionamento (em cada ponto de parada); tempo total para realização da entrega (em cada ponto de parada): engloba o tempo de duração de todas as atividades desde a entrada no estabelecimento até a partida do veículo.

Determinar os veículos de entrega que atendem a área de interesse (área de simulação), assim como as informações relacionadas acima é o objetivo final da integração dos três modelos que compõem o procedimento proposto, apresentados na Figura 6.3.

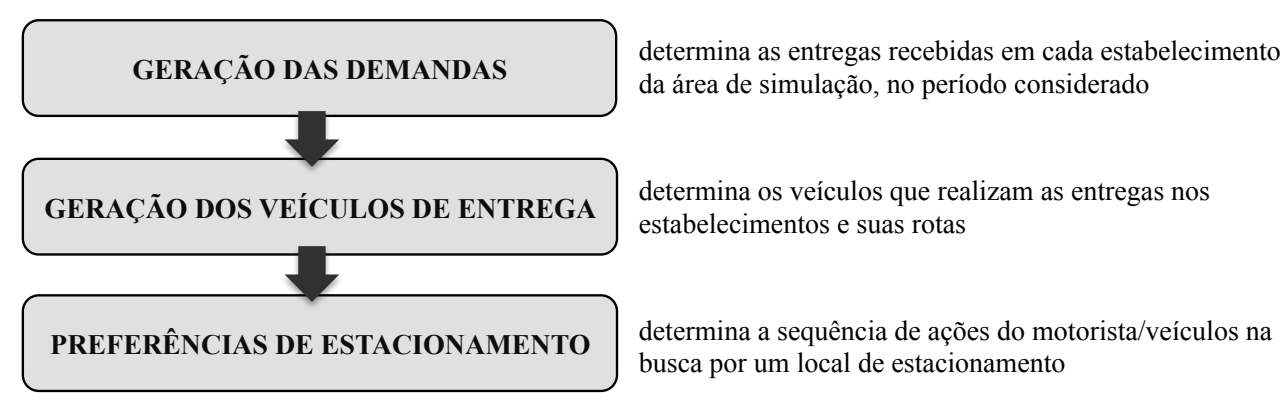

Figura 6.3 - Modelos para a microssimulação

Os modelos apresentados, e a coleta de dados, a qual também compõe o procedimento, podem ser considerados mutuamente dependentes, uma vez que os modelos determinaram quais dados deveriam ser coletados, ao mesmo tempo que esses dados serviram para a validação de algumas hipóteses acerca dos mesmos, conforme será detalhado ao longo deste capítulo. A Figura 6.4 mostra as diferentes coletas de dados realizadas e o(s) modelo(s) com o qual cada uma está relacionada.

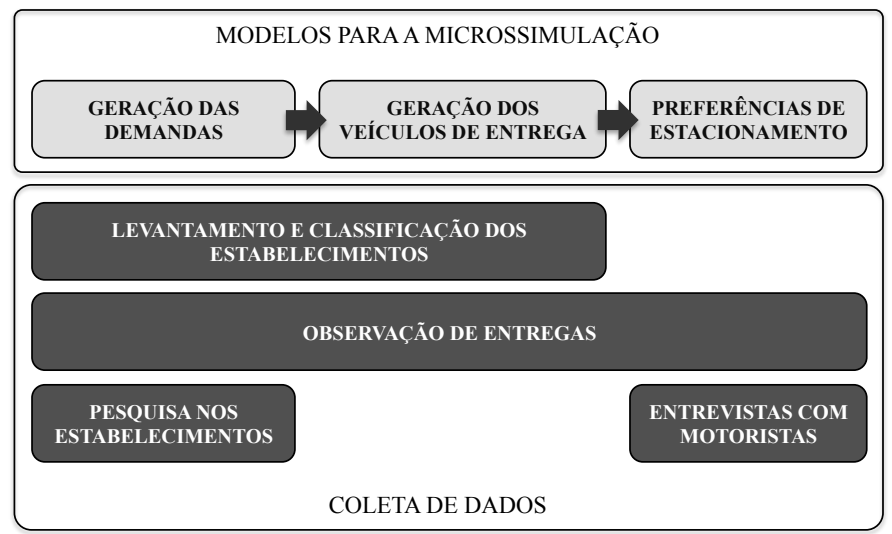

Figura 6.4 - Associação entre as coletas de dados e os modelos para a microssimulação 


\subsection{COLETA DE DADOS}

A área de estudo onde foi realizada a coleta de dados possui $1 \mathrm{~km}^{2}$ e trata-se da região localizada entre os bairros de Higienópolis, Santa Cecília e Vila Buarque, conforme ilustra a Figura 6.5. A escolha da área de estudo buscou por uma região que estivesse inserida na Zona Máxima de Restrição à Circulação (ZMRC) e cuja predominância de uso do solo fosse do tipo 'residencial + comércio e serviços', de forma que fosse possível observar os fluxos tanto de veículos de carga como de veículos particulares. A definição dos limites dessa área buscou, ainda, incluir um shopping center [shopping Higienópolis, Figura 6.5 (a)], uma via principal [Avenida Angélica, Figura 6.5 (b)]), onde a concentração de estabelecimentos comerciais e o fluxo de veículos fosse maior, e vias locais, mais estreitas. Além disso, foram incluídos dois quarteirões onde uma alta concentração de restaurantes pode ser observada [Praça VilaBoim, Figura 6.5 (c)].

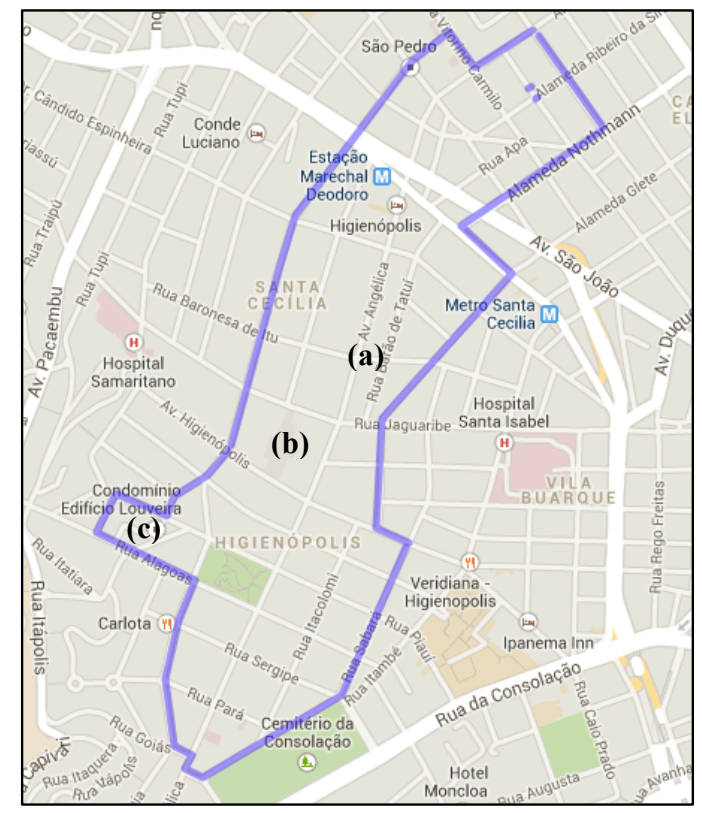

Figura 6.5 - Limites da área de estudo

\subsubsection{Levantamento e Classificação dos Estabelecimentos}

Neste trabalho serão consideradas apenas as viagens de entrega para o abastecimento de estabelecimentos comerciais ligados ao setor alimentício e de bebidas. A escolha desses setores em específico está baseada na hipótese de que sejam eles os responsáveis pela 
maioria das viagens de entrega de produtos em áreas urbanas como a de estudo, por dois motivos principais:

- Grande quantidade de estabelecimentos: na cidade de São Paulo, por exemplo, os estabelecimentos do ramo de alimentação (bares, restaurantes, padarias, etc.) somados aos que se enquadram dentre os diversos tipos de mercados (açougues, hiper/supermercados, hortifrutis, mercearias, etc.) chegam a quase 59 mil unidades (SECRETARIA DA FAZENDA DO ESTADO DE SÃO PAULO, 2015), representando o setor com o maior número de estabelecimentos na cidade, quase $30 \%$ do total;

- Alta frequência de entregas: estabelecimentos que comercializam alimentos e bebidas, sejam eles industrializados (no caso de supermercados) ou preparados (no caso de restaurantes) trabalham com uma alta frequência de recebimento de entregas, devido às características de perecibilidade de boa parte dos produtos e/ou à grande quantidade $\mathrm{e}$ variedade de fornecedores.

Os estabelecimentos pertencentes ao setor alimentício foram identificados dentro dos limites da área de estudo e classificados de acordo com as seguintes classes:

- Açougue;

- Adega / distribuidora de bebidas;

- Bar tradicional: local pouco estruturado que comercializa, basicamente, bebidas alcoólicas para serem consumidas in-loco, no balcão;

- Bar premium: local que possui mesas e horário de funcionamento geralmente no período noturno; o produto predominante são as bebidas alcoólicas, mas também serve porções e refeições rápidas;

- Bombonière: pequenos estabelecimentos especializados em guloseimas, como balas, chocolates e biscoitos;

- Buffet / casa de festas;

- Café / doceria / casa de salgados / casa de sucos;

- Loja de conveniência: localizadas em postos de gasolina;

- Empório;

- Hortifruti; 
- Lanchonete: venda de lanches e pratos rápidos para consumo em balcão;

- Lanchonete fast-food;

- Lanchonete / restaurante: venda de lanches e pratos rápidos para consumo em balcão ou mesa; o atendimento conta com garçons;

- Padaria;

- Restaurante;

- Shopping center;

- Supermercado pequeno: possui até 4 checkouts;

- Supermercado pequeno / médio: possui de 5 a 9 checkouts;

- Supermercado médio: possui de 10 a 19 checkouts;

A classificação dos estabelecimentos do tipo 'bar' nas classes 'bar tradicional' e 'bar premium', baseou-se na classificação utilizada pela empresa Ambev para seus pontos de venda. A classificação dos estabelecimentos do tipo 'supermercado' nas classes 'supermercado pequeno', 'supermercado pequeno / médio' e 'supermercado médio' utilizou como referência a classificação adotada pela Associação Brasileira de Supermercados (Abras). As classes 'supermercado grande' e 'hipermercado' não foram consideradas devido à inexistência de estabelecimentos desse tipo na área de estudo. As demais classes estabelecidas foram definidas de acordo com os tipos de estabelecimentos observados em campo. Descartou-se o uso da classificação CNAE (Classificação Nacional da Atividades Econômicas), elaborada pela Comissão Nacional de Classificação (CONCLA), por se entender que a mesma não refletia os estabelecimentos do ponto de vista logístico, ou seja, de acordo com o seu perfil de recebimento de entregas. Por exemplo, a classificação CNAE agrupa sorveteria e lanchonete em uma mesma classe, sendo que, do ponto de vista logístico esses dois tipos de estabelecimentos apresentam frequências de recebimento de entregas diferentes, conforme observado em campo. Na literatura também não foi possível encontrar nenhuma classificação voltada aos estabelecimentos do setor alimentício no contexto da distribuição urbana; trabalhos que apresentam alguma classificação nesse contexto (Gebresenbet et al., 2011; Muñuzuri et al., 2010; Quak e de Koster, 2006) adotam classificações abrangente, considerando esse setor com uma única classe ('alimentação', por exemplo).

Tanto a identificação quanto a localização de cada um dos estabelecimentos existentes na área de estudo foram determinadas através de um levantamento em campo realizado entre os 
meses de setembro e outubro de 2013. Foram identificados, localizados e classificados 232 estabelecimentos, conforme mostra o mapa da Figura 6.6. O mapeamento dos estabelecimentos utilizou como base um mapa digital contendo as informações cartográficas da área em estudo, obtido através do site da Secretaria Municipal de Desenvolvimento Urbano da Prefeitura de São Paulo.

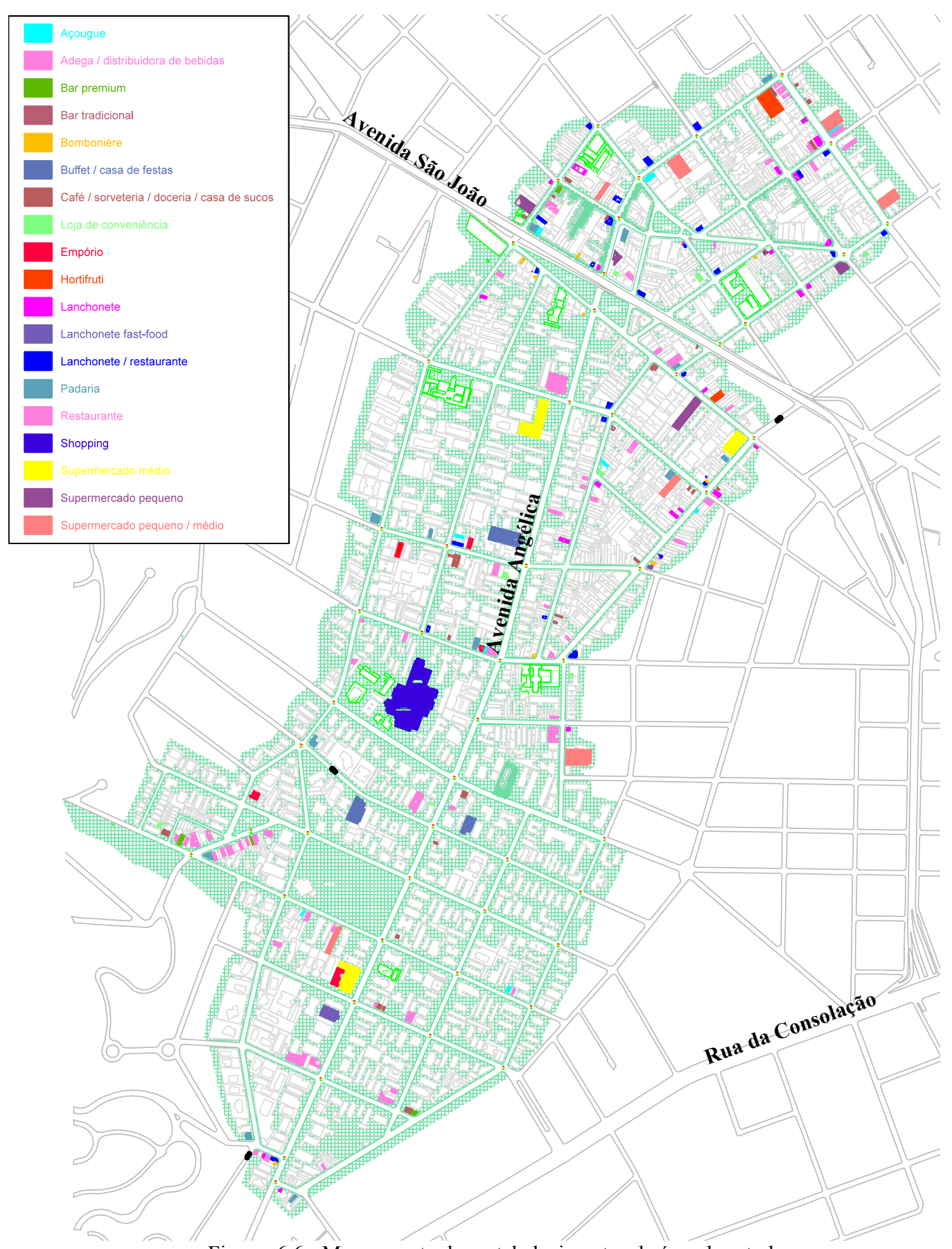

Figura 6.6 - Mapeamento dos estabelecimentos da área de estudo 


\subsubsection{Observação de Entregas}

A coleta de dados que envolve a observação das entregas teve como objetivo fornecer os dados de entrada necessários aos três modelos desenvolvidos para a microssimulação.

Entre os meses de dezembro de 2013 e janeiro de 2014, foram observadas, in loco, 1.552 entregas em 20 estabelecimentos, incluindo pelo menos um de cada classe, localizados dentro dos limites da área de estudo ou próximo a eles. A fim de reduzir o número de dias necessários para essa coleta de dados, os estabelecimentos foram agrupados, de acordo com a proximidade entre si, em 10 locais de observação, conforme mostra o mapa da Figura 6.7. Dessa forma, a partir de um único ponto de observação, foi possível realizar a coleta de dados para mais de um estabelecimento. As observações foram realizadas por uma equipe formada por três alunos de iniciação científica.

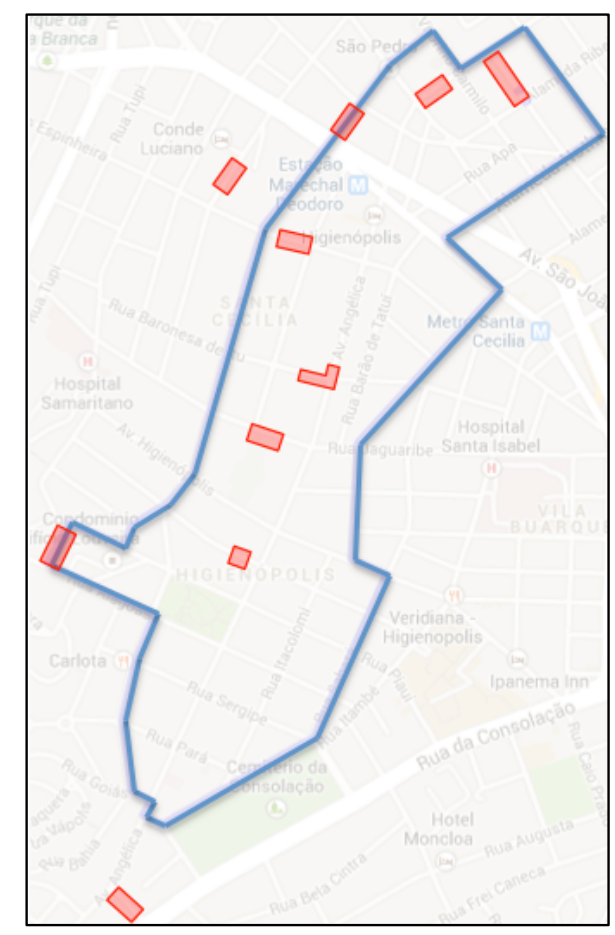

Figura 6.7 - Locais de observação das entregas

Durante o período de uma semana (de segunda-feira a sábado), das $6 \mathrm{~h}$ às $17 \mathrm{~h}$, foram coletados dados referentes, principalmente, ao estabelecimento observado, ao produto entregue, aos veículos de entrega, ao local de estacionamento dos mesmos e aos tempos decorridos durante a entrega, conforme a listagem a seguir. 
- Nome do estabelecimento atendido (ponto de entrega);

- Classe do estabelecimento (de acordo com a classificação previamente definida);

- Empresa entregadora;

- Tipo de produto;

- Veículo (modelo);

- Veículo (marca);

- Tamanho da entrega (número de pallets, de caixas, de engradados, etc.);

- Distância entre o local de estacionamento do veículo e o ponto de entrega;

- Número de viagens a pé (entre o local de estacionamento do veículo e o ponto de entrega);

- Ocorrência de outras entregas a partir do mesmo local de estacionamento do veículo;

- Equipamento de auxílio (carrinho de mão, empilhadeira, gaiola, etc.);

- Número de pessoas no veículo;

- Posição da porta de descarregamento (traseira, lateral ou ambas);

- Local de estacionamento do veículo (em frente ao ponto de entrega, dentro do ponto de entrega ou em outro endereço a ser especificado);

- Características do local de estacionamento do veículo (vaga normal, vaga exclusiva para carga e descarga, zona azul, fila dupla, sobre a calçada ou faixa de tráfego);

- Local de disposição da carga descarregada (calçada, faixa de tráfego ou atrás do veículo);

- Tempos relacionados à entrega:

- horário de chegada do veículo ao local de entrega;

- início do descarregamento (abertura das portas de descarregamento);

- término do descarregamento (fechamento das portas de descarregamento);

- início do carregamento (se houver coleta);

- término do carregamento (se houver coleta);

- saída do veículo.

Os resultados obtidos para essa etapa da coleta de dados estão apresentados nas Tabelas A.1 e A.2, do Anexo A. Nelas é possível observar que nem todos os dados puderam ser coletados para todas as entregas, o que ocorreu por dois motivos principais: (i) algumas entregas aconteceram simultaneamente, dificultando o registro de todas as informações e (ii) em outros momentos não foi possível obter a informação visualmente, por exemplo nas 
situações em que o veículo não trazia nenhuma identificação da empresa ou estacionava em um local fora da vista do observador.

A partir dos dados coletados foram extraídas informações necessárias à determinação de alguns dos dados de entrada dos modelos 'Geração das Entregas' e 'Geração dos Veículos de Entrega'. Foi possível, por exemplo, identificar quais tipos de veículos entregavam, com mais frequência, determinado grupo de produto, ou então qual o dia da semana e o período com maior número de entregas. Além disso, dados como o tempo médio de duração das entregas e o tamanho (drop size) das mesmas, por grupo de produto e por classe de estabelecimento, também puderam ser estimados.

\subsubsection{Pesquisa nos Estabelecimentos}

Essa coleta de dados consistiu em uma pesquisa realizada em todos os estabelecimentos do ramo alimentício existentes na área em estudo (identificados na etapa de levantamento e classificação dos estabelecimentos). O objetivo foi obter dados referentes ao número médio de entregas semanais em cada estabelecimento, de forma que pudessem ser determinados alguns dos dados de entrada necessários ao modelo 'Geração das Demandas'.

A pesquisa foi realizada pessoalmente, pela própria autora e por um aluno de mestrado, entre os meses de outubro e novembro de 2014, quando foram obtidas informações a respeito do número de funcionários e da quantidade de entregas recebidas semanalmente pelo estabelecimento visitado. O levantamento de tais informações baseou-se na hipótese de que o número de entregas semanais em um determinado estabelecimento poderia estar correlacionado à sua classe e a algum outro atributo relacionado ao tamanho desse estabelecimento, como por exemplo sua área ou número de funcionários. Durante a pesquisa, no entanto, o levantamento de dados referentes à área dos estabelecimentos mostrou-se inviável, uma vez que a maioria dos respondentes não tinha o conhecimento de tal informação.

As perguntas foram feitas, preferencialmente, ao responsável pelo recebimento de produtos ou, caso o mesmo não estivesse disponível, a um funcionário do estabelecimento. 
Dos estabelecimentos visitados, $62 \%$ responderam à pesquisa de forma completa, sendo que os outros $38 \%$ não souberam responder a respeito do número de entregas ou não quiseram colaborar com a pesquisa. As respostas obtidas estão apresentadas na Tabela 6.1.

Tabela 6.1 - Dados de entrega semanal e número de funcionários, obtidos nas entrevistas nos estabelecimentos

\begin{tabular}{|c|c|c|c|c|c|}
\hline \multirow{2}{*}{ ID } & \multirow{2}{*}{ Classe do Estabelecimento } & \multicolumn{2}{|l|}{ Endereço } & \multirow{2}{*}{$\begin{array}{c}\text { Núm. de } \\
\text { Funcionários }\end{array}$} & \multirow{2}{*}{$\begin{array}{c}\text { Entregas } \\
\text { por semana }\end{array}$} \\
\hline & & Rua/Avenida & Núm. & & \\
\hline 1 & Supermercado médio & Palmeiras & 187 & 54 & 40 \\
\hline 2 & Padaria & Martim Francisco & 64 & 25 & 30 \\
\hline 3 & Bombonière & Martim Francisco & 0 & 2 & 1 \\
\hline 15 & Restaurante & Martinico Prado & 341 & 69 & 90 \\
\hline 16 & Empório & Martim Francisco & 742 & 742 & 30 \\
\hline 18 & Restaurante & Itacolomi & 636 & 31 & 65 \\
\hline 19 & $\begin{array}{l}\text { Café / sorveteria / doceria / } \\
\text { casa de sucos }\end{array}$ & Itacolomi & 639 & 14 & 0 \\
\hline 23 & Restaurante & Praça Vilaboim & 113 & 26 & 9 \\
\hline 24 & Restaurante & Praça Vilaboim & 93 & 20 & 10 \\
\hline 25 & Restaurante & Praça Vilaboim & 77 & 39 & 15 \\
\hline 26 & Bar premium & Praça Vilaboim & 65 & 21 & 18 \\
\hline 27 & Restaurante & Praça Vilaboim & 63 & 60 & 25 \\
\hline 28 & Restaurante & Praça Vilaboim & 55 & 18 & 12 \\
\hline 31 & Padaria & Armando Penteado & 33 & 45 & 60 \\
\hline 33 & Restaurante & Armando Penteado & 48 & 11 & 5 \\
\hline 34 & Restaurante & Armando Penteado & 56 & 16 & 4 \\
\hline 35 & Restaurante & Alagoas & 828 & 18 & 4 \\
\hline 36 & Bar premium & Alagoas & 836 & 9 & 8 \\
\hline 41 & Restaurante / Empório & Aracaju & 239 & 27 & 10 \\
\hline 47 & Supermercado pequeno & Palmeiras & 303 & 26 & 30 \\
\hline 49 & Bar tradicional & São João & 2049 & 1 & 3 \\
\hline 50 & Restaurante & Palmeiras & 430 & 8 & 20 \\
\hline 51 & $\begin{array}{l}\text { Café / sorveteria / doceria / } \\
\text { casa de sucos }\end{array}$ & Palmeiras & 403 & 4 & 2 \\
\hline 52 & Restaurante & Palmeiras & 388 & 8 & 15 \\
\hline 53 & Lanchonete / Restaurante & Nothmann & 882 & 5 & 20 \\
\hline 54 & Lanchonete & $\begin{array}{l}\text { Dr. Carvalho de } \\
\text { Mendonça }\end{array}$ & 20 & 2 & 4 \\
\hline 55 & Lanchonete / Restaurante & Barão de Limeira & 1069 & 8 & 8 \\
\hline 56 & Lanchonete / Restaurante & Barão de Limeira & 1087 & 8 & 20 \\
\hline 57 & Lanchonete & Ribeiro da Silva & 729 & 2 & 4 \\
\hline 58 & Restaurante & Barão de Tatuí & 0 & 12 & 4 \\
\hline 61 & Bar tradicional & Barão de Tatuí & 167 & 2 & 15 \\
\hline 62 & Açougue & Barão de Tatuí & 229 & 5 & 36 \\
\hline 63 & Loja de Conveniência & Im. Conceição & 118 & 2 & 4 \\
\hline 64 & Lanchonete & Barão de Tatuí & 275 & 2 & 6 \\
\hline 68 & Lanchonete & Barão de Tatuí & 402 & 3 & 3 \\
\hline 69 & Restaurante & Barão de Tatuí & 536 & 5 & 18 \\
\hline 70 & $\begin{array}{l}\text { Café / sorveteria / doceria / } \\
\text { casa de sucos }\end{array}$ & Barão de Tatuí & 547 & 2 & 3 \\
\hline
\end{tabular}


continuação

\begin{tabular}{|c|c|c|c|c|c|}
\hline \multirow{2}{*}{ ID } & \multirow{2}{*}{ Classe do Estabelecimento } & \multicolumn{2}{|l|}{ Endereço } & \multirow{2}{*}{$\begin{array}{c}\text { Núm. de } \\
\text { funcionários }\end{array}$} & \multirow{2}{*}{$\begin{array}{c}\text { Entregas } \\
\text { por semana }\end{array}$} \\
\hline & & Rua/Avenida & Núm. & & \\
\hline 71 & Lanchonete / Restaurante & Barão de Tatuí & 558 & 3 & 12 \\
\hline 72 & $\begin{array}{l}\text { Café / sorveteria / doceria / } \\
\text { casa de sucos }\end{array}$ & Barão de Tatuí & 563 & 2 & 12 \\
\hline 73 & Bombonière & Jaguaribe & 742 & 2 & 8 \\
\hline 75 & Bombonière & Angélica & 288 & 3 & 5 \\
\hline 76 & Restaurante & Angélica & 310 & 10 & 15 \\
\hline 78 & Supermercado médio & Angélica & 546 & 118 & 60 \\
\hline 80 & Loja de Conveniência & Angélica & 0 & 6 & 12 \\
\hline 82 & Restaurante & Albuquerque Lins & 491 & 7 & 10 \\
\hline 83 & Lanchonete & Albuquerque Lins & 555 & 4 & 3 \\
\hline 85 & Supermercado pequeno & Veiga Filho & 134 & 2 & 60 \\
\hline 86 & $\begin{array}{c}\text { Café / sorveteria / doceria / } \\
\text { casa de sucos }\end{array}$ & Veiga Filho & 102 & 3 & 3 \\
\hline 88 & Empório & Veiga Filho & 30 & 5 & 6 \\
\hline 89 & Açougue & Veiga Filho & 22 & 5 & 10 \\
\hline 92 & Açougue & São Vicente de Paula & 551 & 6 & 25 \\
\hline 93 & Bombonière & São Vicente de Paula & 18 & 1 & 1 \\
\hline 94 & Lanchonete / Restaurante & Palmeiras & 213 & 6 & 12 \\
\hline 95 & Bombonière & Palmeiras & 249 & 4 & 5 \\
\hline 96 & Bar premium & Itacolomi & 2 & 5 & 18 \\
\hline 97 & Restaurante & Mato Grosso & 402 & 15 & 30 \\
\hline 99 & Restaurante & Alagoas & 549 & 30 & 24 \\
\hline 100 & $\begin{array}{c}\text { Café / sorveteria / doceria / } \\
\text { casa de sucos }\end{array}$ & Alagoas & 493 & 4 & 5 \\
\hline 101 & Restaurante & Alagoas & 493 & 6 & 1 \\
\hline 102 & Açougue & Alagoas & 126 & 6 & 12 \\
\hline 103 & Restaurante & Alagoas & 124 & 6 & 12 \\
\hline 104 & Restaurante & Sergipe & 412 & 26 & 20 \\
\hline 108 & Empório & Sergipe & 568 & 22 & 40 \\
\hline 110 & Restaurante & Pará & 210 & 25 & 10 \\
\hline 112 & Padaria & São João & 268 & 50 & 12 \\
\hline 113 & Bombonière & Albuquerque Lins & 371 & 1 & 15 \\
\hline 114 & Lanchonete / Restaurante & Albuquerque Lins & 343 & 5 & 10 \\
\hline 115 & Restaurante & Albuquerque Lins & 323 & 12 & 5 \\
\hline 117 & Bar premium & Brigadeiro Galvão & 181 & 12 & 20 \\
\hline 118 & $\begin{array}{l}\text { Café / sorveteria / doceria / } \\
\text { casa de sucos }\end{array}$ & Brigadeiro Galvão & 184 & 3 & 2 \\
\hline 119 & Lanchonete & Albuquerque Lins & 211 & 3 & 3 \\
\hline 120 & Açougue & Barra Funda & 44 & 6 & 15 \\
\hline 121 & Supermercado pequeno & Eduardo Prado & 793 & 20 & 35 \\
\hline 122 & Hortifruti & Eduardo Prado & 589 & 60 & 40 \\
\hline 123 & Restaurante & Eduardo Prado & 579 & 6 & 5 \\
\hline 124 & Restaurante & Barão de Limeira & 1233 & 10 & 30 \\
\hline 125 & Restaurante & Barão de Limeira & 1223 & 12 & 5 \\
\hline 126 & Restaurante & Barão de Limeira & 1199 & 8 & 25 \\
\hline 127 & Supermercado pequeno & Barão de Limeira & 1153 & 5 & 20 \\
\hline 128 & $\begin{array}{c}\text { Café / sorveteria / doceria / } \\
\text { casa de sucos }\end{array}$ & Barão de Limeira & 1147 & 5 & 20 \\
\hline
\end{tabular}


continuação

\begin{tabular}{|c|c|c|c|c|c|}
\hline \multirow{2}{*}{ ID } & \multirow{2}{*}{ Classe do Estabelecimento } & \multicolumn{2}{|l|}{ Endereço } & \multirow{2}{*}{$\begin{array}{c}\text { Núm. de } \\
\text { funcionários }\end{array}$} & \multirow{2}{*}{$\begin{array}{c}\text { Entregas } \\
\text { por semana }\end{array}$} \\
\hline & & Rua/Avenida & Núm. & & \\
\hline 129 & $\begin{array}{l}\text { Café / sorveteria / doceria / } \\
\text { casa de sucos }\end{array}$ & Ribeiro da Silva & 666 & 5 & 1 \\
\hline 130 & Restaurante & Ribeiro da Silva & 674 & 8 & 8 \\
\hline 131 & Restaurante & Ribeiro da Silva & 693 & 7 & 6 \\
\hline 133 & Adega & Adolfo Gordo & 227 & 3 & 17 \\
\hline 134 & Lanchonete & Ribeiro da Silva & 756 & 1 & 4 \\
\hline 136 & Lanchonete / Restaurante & Ribeiro da Silva & 944 & 3 & 6 \\
\hline 137 & Lanchonete / Restaurante & Angélica & 56 & 5 & 11 \\
\hline 138 & Lanchonete / Restaurante & Brigadeiro Galvão & 83 & 13 & 17 \\
\hline 139 & Lanchonete / Restaurante & Brigadeiro Galvão & 97 & 3 & 6 \\
\hline 140 & Supermercado pequeno & Brigadeiro Galvão & 118 & 11 & 30 \\
\hline 141 & Padaria & Angélica & 101 & 72 & 75 \\
\hline 142 & Supermercado pequeno & Angélica & 161 & 16 & 50 \\
\hline 143 & Adega & Pirineus & 39 & 3 & 4 \\
\hline 144 & Lanchonete & Pirineus & 0 & 1 & 4 \\
\hline 145 & Loja de Conveniência & Angélica & 197 & 1 & 3 \\
\hline 146 & Lanchonete / Restaurante & São João & 134 & 6 & 10 \\
\hline 147 & Bombonière & São João & 170 & 3 & 8 \\
\hline 149 & Bar tradicional & São João & 248 & 2 & 3 \\
\hline 150 & Açougue & São João & 285 & 8 & 6 \\
\hline 151 & Lanchonete / Restaurante & Julio M. Carvalho & 274 & 5 & 4 \\
\hline 152 & Lanchonete & Julio M. Carvalho & 355 & 2 & 2 \\
\hline 153 & Lanchonete / Restaurante & Julio M. Carvalho & 343 & 7 & 12 \\
\hline 154 & Loja de Conveniência & Apa & 140 & 1 & 1 \\
\hline 156 & Restaurante & $\begin{array}{l}\text { Carvalho de } \\
\text { Mendonça }\end{array}$ & 249 & 4 & 5 \\
\hline 157 & Lanchonete & Vitorino Carmilo & 285 & 1 & 4 \\
\hline 158 & Bar tradicional & Apa & 5 & 1 & 5 \\
\hline 159 & Bombonière & Apa & 38 & 1 & 1 \\
\hline 165 & $\begin{array}{l}\text { Café / sorveteria / doceria / } \\
\text { casa de sucos }\end{array}$ & Baronesa de Itu & 363 & 10 & 15 \\
\hline 166 & $\begin{array}{c}\text { Café / sorveteria / doceria / } \\
\text { casa de sucos }\end{array}$ & Baronesa de Itu & 301 & 3 & 18 \\
\hline 167 & Restaurante & Baronesa de Itu & 281 & 23 & 30 \\
\hline 169 & Buffet / casa de festas & Maranhão & 621 & 4 & 10 \\
\hline 170 & Buffet / casa de festas & Piauí & 540 & 20 & 8 \\
\hline 171 & Restaurante & Maranhão & 512 & 42 & 20 \\
\hline 172 & Loja de Conveniência & Angélica & 1332 & 5 & 30 \\
\hline 174 & Hortifruti & Bahia & 91 & 3 & 6 \\
\hline 176 & Padaria & Maranhão & 220 & 110 & 60 \\
\hline 177 & Buffet / casa de festas & Maranhão & 404 & 18 & 10 \\
\hline 183 & Lanchonete & Nothmann & 0 & 5 & 5 \\
\hline 184 & Lanchonete & Nothmann & 0 & 7 & 10 \\
\hline 185 & Supermercado pequeno & Nothmann & 885 & 6 & 12 \\
\hline 186 & Loja de Conveniência & Nothmann & 0 & 2 & 5 \\
\hline 187 & Lanchonete / Restaurante & Nothmann & 0 & 3 & 10 \\
\hline 188 & Supermercado pequeno & Barão de Limeira & - & 20 & 33 \\
\hline
\end{tabular}


continuação

\begin{tabular}{|c|c|c|c|c|c|}
\hline \multirow{2}{*}{ ID } & \multirow{2}{*}{ Classe do Estabelecimento } & \multicolumn{2}{|l|}{ Endereço } & \multirow{2}{*}{$\begin{array}{c}\text { Núm. de } \\
\text { funcionários }\end{array}$} & \multirow{2}{*}{$\begin{array}{c}\text { Entregas } \\
\text { por semana }\end{array}$} \\
\hline & & Rua/Avenida & Núm. & & \\
\hline 191 & Açougue & Barão de Limeira & 1096 & 12 & 13 \\
\hline 192 & Supermercado pequeno & Barão de Limeira & - & 16 & 7 \\
\hline 193 & $\begin{array}{c}\text { Café / sorveteria / doceria / } \\
\text { casa de sucos }\end{array}$ & Barão de Limeira & 1170 & 4 & 5 \\
\hline 194 & $\begin{array}{l}\text { Café / sorveteria / doceria / } \\
\text { casa de sucos }\end{array}$ & Barão de Limeira & 1210 & 5 & 2 \\
\hline 195 & Padaria & Barão de Limeira & 1253 & 11 & 25 \\
\hline 196 & Lanchonete / Restaurante & Vitorino Carmilo & 562 & 12 & 5 \\
\hline 197 & Lanchonete / Restaurante & Eduardo Prado & 860 & 9 & 10 \\
\hline 202 & Bar tradicional & Albuquerque Lins & - & 4 & 6 \\
\hline 203 & Bombonière & Albuquerque Lins & 362 & 5 & 10 \\
\hline 204 & Supermercado pequeno & Alburquerque Lins & 358 & 3 & 10 \\
\hline 205 & Lanchonete & Albuquerque Lins & 217 & 5 & 10 \\
\hline 206 & Lanchonete / Restaurante & Albuquerque Lins & - & 8 & 15 \\
\hline 211 & Restaurante & Goiás & 27 & 8 & 30 \\
\hline 214 & Supermercado pequeno-médio & Martim Francisco & 777 & 150 & 50 \\
\hline 217 & Lanchonete / Restaurante & Martim Francisco & 553 & 10 & 12 \\
\hline 226 & Lanchonete & Martim Francisco & 0 & 5 & 20 \\
\hline 228 & Lanchonete & Martim Francisco & 0 & 4 & 15 \\
\hline 229 & Restaurante & Palmeiras & 0 & 8 & 6 \\
\hline 230 & Hortifruti & Palmeiras & 0 & 70 & 200 \\
\hline 231 & Lanchonete & Palmeiras & 0 & 5 & 10 \\
\hline 233 & Adega & Barão de Tatuí & 179 & 2 & 25 \\
\hline 234 & Supermercado médio & Martim Francisco & 349 & 120 & 100 \\
\hline
\end{tabular}

\subsubsection{Entrevistas com os Motoristas}

As informações necessárias ao desenvolvimento do modelo 'Preferências de Estacionamento' provém da coleta de dados baseada em entrevistas realizadas pessoalmente com motoristas dos veículos de entrega. O objetivo foi determinar as preferências dos motoristas para diferentes alternativas de estacionamento e seus comportamentos diante da indisponibilidade de vagas, e verificar uma possível relação entre as respostas obtidas e alguns atributos relativos às entregas, registrados durante as entrevistas.

Os motoristas foram escolhidos aleatoriamente, dentro dos limites da área de estudo, enquanto realizavam operações de entrega. As entrevistas foram conduzidas pessoalmente, pela própria autora, durante três semanas entre os meses de fevereiro e março de 2014, majoritariamente no período entre $8 \mathrm{~h}$ e $14 \mathrm{~h}$. 
Ao todo 150 motoristas foram abordados, sendo que 137 concordaram em participar da entrevista. Nove perguntas com respostas de múltipla escolha compuseram o roteiro de entrevista com a finalidade de cobrir as seguintes características relativas ao comportamento dos motoristas:

- Local de estacionamento desejado para o veículo;

- Distância máxima aceitável entre o local de estacionamento e o ponto de entrega;

- Locais alternativos considerados para o estacionamento do veículo, diante da indisponibilidade do local desejado;

- Predisposição do motorista ao estacionamento irregular.

Os Quadros 6.1 a 6.9 apresentam o conjunto de perguntas realizadas, assim como os resultados, em porcentagem, para as preferências declaradas em vista das alternativas apresentadas a cada pergunta. As respostas estão divididas de acordo com os seguintes atributos (registrados para cada uma das entrevistas):

- Tipo de produto entregue (perecíveis, não perecíveis, bebidas ou outros);

- Tipo de veículo (utilitário, Kombi/van, VUC pequeno ou VUC grande);

- Posição da porta de descarregamento (lateral, traseira ou ambas);

- Presença ou não de ajudante.

Quadro 6.1 - Respostas obtidas para as entrevistas com os motoristas (Pergunta 1)

\begin{tabular}{|c|c|c|c|c|}
\hline \multicolumn{5}{|c|}{ 1. Qual é a distância máxima do ponto de entrega que você está disposto a estacionar seu veiculo? } \\
\hline & & a) $100 \mathrm{~m}$ & b) $200 \mathrm{~m}$ & c) $300 \mathrm{~m}$ \\
\hline \multicolumn{2}{|c|}{ Total da Amostra } & $29,9 \%$ & $65 \%$ & $5,1 \%$ \\
\hline \multirow{4}{*}{ Tipo de produto } & perecíveis & $27,3 \%$ & $68,8 \%$ & $3,9 \%$ \\
\hline & não perecíveis & $19 \%$ & $76,2 \%$ & $4,8 \%$ \\
\hline & bebidas & $58,3 \%$ & $33,3 \%$ & $8,3 \%$ \\
\hline & outros & $13,3 \%$ & $80 \%$ & $6,7 \%$ \\
\hline \multirow{4}{*}{ Tipo de veículo } & utilitário & $31,6 \%$ & $57,9 \%$ & $10,5 \%$ \\
\hline & Kombi/van & $15,4 \%$ & $76,9 \%$ & $7,7 \%$ \\
\hline & VUC pequeno & $36,7 \%$ & $59,2 \%$ & $4,1 \%$ \\
\hline & VUC grande & $36,7 \%$ & $63,3 \%$ & $0 \%$ \\
\hline \multirow{2}{*}{$\begin{array}{c}\text { Presença de } \\
\text { ajudante }\end{array}$} & não & $27 \%$ & $67,6 \%$ & $5,4 \%$ \\
\hline & $\operatorname{sim}$ & $31 \%$ & $64 \%$ & $5 \%$ \\
\hline \multirow{3}{*}{$\begin{array}{l}\text { Posição da porta de } \\
\text { descarregamento }\end{array}$} & traseira & $17,5 \%$ & $77,5 \%$ & $5 \%$ \\
\hline & lateral & $100 \%$ & $0 \%$ & $0 \%$ \\
\hline & ambas & $0 \%$ & $0 \%$ & $100 \%$ \\
\hline
\end{tabular}


Quadro 6.2 - Respostas obtidas para as entrevistas com os motoristas (Pergunta 2)

\section{Qual tipo de vaga você procura para estacionar o seu veículo?}

a) carga e descarga

\begin{tabular}{cccc}
\hline \multicolumn{2}{c}{ Total da Amostra } & \multicolumn{2}{c}{ ponto de entrega } \\
\hline \multirow{3}{*}{ Tipo de produto } & perecíveis & $71,5 \%$ & $28,5 \%$ \\
& não perecíveis & $74 \%$ & $26 \%$ \\
& bebidas & $66,7 \%$ & $33,3 \%$ \\
& outros & $58,3 \%$ & $41,7 \%$ \\
& utilitário & $86,7 \%$ & $13,3 \%$ \\
\hline \multirow{2}{*}{ Tipo de veículo } & Kombi/van & $73,7 \%$ & $26,3 \%$ \\
& VUC pequeno & $76,9 \%$ & $23,1 \%$ \\
& VUC grande & $67,3 \%$ & $32,7 \%$ \\
Presença de & não & $70 \%$ & $30 \%$ \\
ajudante & sim & $75,7 \%$ & $24,3 \%$ \\
Posição da porta de & traseira & $70 \%$ & $30 \%$ \\
descarregamento & lateral & $68 \%$ & $32 \%$ \\
& ambas & $71 \%$ & $29 \%$ \\
\hline
\end{tabular}
ponto de entrega

b) o mais próximo possível do 
Quadro 6.4 - Respostas obtidas para as entrevistas com os motoristas (Pergunta 4)

4. Onde você estacionaria se, mesmo depois de procurar, você ainda não achasse uma vaga livre? (Perguntado apenas para aqueles que escolheram a alternativa a) na pergunta 3)

\begin{tabular}{|c|c|c|c|c|c|c|}
\hline & & $\begin{array}{l}\text { a) continua a } \\
\text { procura por } \\
\text { uma vaga livre }\end{array}$ & $\begin{array}{l}\text { b) retorna } \\
\text { mais tarde } \\
\text { (segue para o } \\
\text { próximo } \\
\text { cliente) }\end{array}$ & $\begin{array}{l}\text { c) vaga de } \\
\text { táxi } \\
\text { próxima }\end{array}$ & $\begin{array}{l}\text { d) posto de } \\
\text { gasolina } \\
\text { próximo }\end{array}$ & $\begin{array}{l}\text { e) estaciona } \\
\text { irregularmente }\end{array}$ \\
\hline \multicolumn{2}{|c|}{ Total da Amostra } & $54,3 \%$ & $25,7 \%$ & $7,6 \%$ & $3,8 \%$ & $8,6 \%$ \\
\hline \multirow{4}{*}{ Tipo de produto } & perecíveis & $49,2 \%$ & $32,2 \%$ & $10,2 \%$ & $1,7 \%$ & $6,8 \%$ \\
\hline & não perecíveis & $55,6 \%$ & $22,2 \%$ & $5,6 \%$ & $5,6 \%$ & $11,1 \%$ \\
\hline & bebidas & $42,9 \%$ & $28,6 \%$ & $0 \%$ & $14,3 \%$ & $14,3 \%$ \\
\hline & outros & $85,7 \%$ & $0 \%$ & $7,1 \%$ & $0 \%$ & $7,1 \%$ \\
\hline \multirow{4}{*}{ Tipo de veículo } & utilitário & $64,7 \%$ & $17,6 \%$ & $11,8 \%$ & $0 \%$ & $5,9 \%$ \\
\hline & Kombi/van & $60,7 \%$ & $28,6 \%$ & $3,6 \%$ & $0 \%$ & $7,1 \%$ \\
\hline & VUC pequeno & $53,8 \%$ & $23,1 \%$ & $10,3 \%$ & $5,1 \%$ & $7,7 \%$ \\
\hline & VUC grande & $38,1 \%$ & $33,3 \%$ & $4,8 \%$ & $9,5 \%$ & $14,3 \%$ \\
\hline \multirow{2}{*}{$\begin{array}{c}\text { Presença de } \\
\text { ajudante }\end{array}$} & não & $51,6 \%$ & $25,8 \%$ & $9,7 \%$ & $3,2 \%$ & $9,7 \%$ \\
\hline & $\operatorname{sim}$ & $55,4 \%$ & $25,7 \%$ & $6,8 \%$ & $4,1 \%$ & $8,1 \%$ \\
\hline \multirow{3}{*}{$\begin{array}{l}\text { Posição da porta de } \\
\text { descarregamento }\end{array}$} & traseira & $56,3 \%$ & $21,9 \%$ & $12,5 \%$ & $0 \%$ & $9,4 \%$ \\
\hline & lateral & $0 \%$ & $33,3 \%$ & $0 \%$ & $0 \%$ & $66,7 \%$ \\
\hline & ambas & $55,7 \%$ & $27,1 \%$ & $5,7 \%$ & $5,7 \%$ & $5,7 \%$ \\
\hline
\end{tabular}

Quadro 6.5 - Respostas obtidas para as entrevistas com os motoristas (Pergunta 5)

5. No caso em que o estacionamento irregular é a única opção, onde você estacionaria?

$\begin{array}{ll}\text { a) na faixa de tráfego } & \text { b) em frente a alguma garagem }\end{array}$

\begin{tabular}{cccc}
\hline \multicolumn{2}{c}{ Total da Amostra } & $75,3 \%$ & $24,7 \%$ \\
\hline \multirow{2}{*}{ Tipo de produto } & perecíveis & $74,3 \%$ & $25,7 \%$ \\
& não perecíveis & $69,1 \%$ & $30,9 \%$ \\
& bebidas & $82,2 \%$ & $17,8 \%$ \\
& outros & $72,6 \%$ & $27,4 \%$ \\
\hline \multirow{2}{*}{ Tipo de veículo } & utilitário & $72,4 \%$ & $27,6 \%$ \\
& Kombi/van & $72,5 \%$ & $27,5 \%$ \\
& VUC pequeno & $69,2 \%$ & $30,8 \%$ \\
Presença de & VUC grande & $84,7 \%$ & $15,3 \%$ \\
ajudante & não & $64,9 \%$ & $35,1 \%$ \\
Posição da porta de & sim & $76 \%$ & $24 \%$ \\
descarregamento & traseira & $75 \%$ & $25,0 \%$ \\
& lateral & $100 \%$ & $0 \%$ \\
\hline
\end{tabular}


Quadro 6.6 - Respostas obtidas para as entrevistas com os motoristas (Pergunta 6)

6. Como você escolheu a faixa de tráfego, você estacionaria bem em frente ao ponto de entrega? (Perguntado apenas para aqueles que escolheram a alternativa a) na pergunta 5)

\begin{tabular}{cccc}
\hline & & a) sim & b) depende \\
\hline \multirow{2}{*}{ Total da Amostra } & perecíveis & $58,4 \%$ & $41,6 \%$ \\
\hline \multirow{2}{*}{ Tipo de produto } & não perecíveis & $54,2 \%$ & $45,8 \%$ \\
& bebidas & $66,7 \%$ & $33,3 \%$ \\
& outros & $63,2 \%$ & $36,8 \%$ \\
\hline \multirow{2}{*}{ Tipo de veículo } & utilitário & $60 \%$ & $40 \%$ \\
\hline \multirow{2}{*}{ Presença de } & Vombi/van & $53,8 \%$ & $46,2 \%$ \\
ajudante & VUC grande & $62,5 \%$ & $37,5 \%$ \\
Posição da porta de & não & $58,6 \%$ & $41,4 \%$ \\
descarregamento & sim & $56,5 \%$ & $43,5 \%$ \\
\hline \multirow{2}{*}{ traseira } & lateral & $54,2 \%$ & $45,8 \%$ \\
\hline
\end{tabular}

Quadro 6.7 - Respostas obtidas para as entrevistas com os motoristas (Pergunta 7)

7. Depende de quê? (Perguntado apenas para aqueles que escolheram a alternativa b) na pergunta 6 )
a) não bloquear o tráfego
b) não ser esquina
c) ambos

\begin{tabular}{ccccc}
\hline \multicolumn{2}{c}{ Total da Amostra } & $40,5 \%$ & $29,8 \%$ & $29,7 \%$ \\
\hline \multirow{2}{*}{ Tipo de produto } & perecíveis & $36,4 \%$ & $27,3 \%$ & $36,4 \%$ \\
& não perecíveis & $50 \%$ & $25 \%$ & $25 \%$ \\
& bebidas & $57,1 \%$ & $28,6 \%$ & $14,3 \%$ \\
& outros & $25 \%$ & $50 \%$ & $25 \%$ \\
\hline \multirow{2}{*}{ Tipo de veículo } & utilitário & $50 \%$ & $50 \%$ & $0 \%$ \\
& Kombi/van & $44,4 \%$ & $44,4 \%$ & $11,1 \%$ \\
VUC pequeno & $33,3 \%$ & $16,7 \%$ & $50 \%$ \\
Presença de & Vujudante & $40 \%$ & $20 \%$ & $40 \%$ \\
\hline \multirow{2}{*}{ Posição da porta de } & não & $61,5 \%$ & $23,1 \%$ & $15,4 \%$ \\
descarregamente & sim & $50 \%$ & $50 \%$ & $0 \%$ \\
\hline
\end{tabular}


Quadro 6.8 - Respostas obtidas para as entrevistas com os motoristas (Pergunta 8)

8. Considere que você está fazendo uma entrega em um estabelecimento que possui uma vaga de carga e descarga interna. $O$ que você faria se essa vaga não estivesse disponível?

\begin{tabular}{|c|c|c|c|c|}
\hline & & a) espera pela vaga & $\begin{array}{l}\text { b) estaciona na rua, } \\
\text { se possível }\end{array}$ & $\begin{array}{l}\text { c) retorna mais } \\
\text { tarde (segue para o } \\
\text { próximo cliente) }\end{array}$ \\
\hline \multicolumn{2}{|c|}{ Total da Amostra } & $71,2 \%$ & $16,8 \%$ & $12 \%$ \\
\hline \multirow{4}{*}{ Tipo de produto } & perecíveis & $71,6 \%$ & $16,8 \%$ & $11,6 \%$ \\
\hline & não perecíveis & $61,7 \%$ & $22 \%$ & $16,3 \%$ \\
\hline & bebidas & $74,2 \%$ & $7,8 \%$ & $18 \%$ \\
\hline & outros & $70,3 \%$ & $20,8 \%$ & $8,9 \%$ \\
\hline \multirow{4}{*}{ Tipo de veículo } & utilitário & $58,2 \%$ & $31,4 \%$ & $10,4 \%$ \\
\hline & Kombi/van & $71,9 \%$ & $14,5 \%$ & $13,6 \%$ \\
\hline & VUC pequeno & $70,5 \%$ & $18,5 \%$ & $11 \%$ \\
\hline & VUC grande & $75 \%$ & $18,9 \%$ & $6,1 \%$ \\
\hline \multirow{2}{*}{$\begin{array}{l}\text { Presença de } \\
\text { ajudante }\end{array}$} & não & $65,3 \%$ & $25,7 \%$ & $9 \%$ \\
\hline & $\operatorname{sim}$ & $72 \%$ & $17,5 \%$ & $10,5 \%$ \\
\hline \multirow{3}{*}{$\begin{array}{l}\text { Posição da porta de } \\
\text { descarregamento }\end{array}$} & traseira & $72,5 \%$ & $16,3 \%$ & $11,2 \%$ \\
\hline & lateral & $93 \%$ & $1,7 \%$ & $5,3 \%$ \\
\hline & ambas & $66,9 \%$ & $27,6 \%$ & $5,5 \%$ \\
\hline
\end{tabular}

Quadro 6.9 - Respostas obtidas para as entrevistas com os motoristas (Pergunta 9)

9. Caso não haja vaga disponível para estacionar e esperar, o que você faz? (Perguntado apenas para aqueles que escolheram a alternativa a) na pergunta 8)

\begin{tabular}{cccc}
\hline & perecíveis & $\begin{array}{c}\text { a) estaciona } \\
\text { irregularmente }\end{array}$ & $\begin{array}{c}\text { b) retorna mais tarde (segue } \\
\text { para o próximo cliente) }\end{array}$ \\
\hline \multirow{2}{*}{ Total da Amostra } & $14,4 \%$ & $85,6 \%$ \\
\hline \multirow{2}{*}{ Tipo de produto } & não perecíveis & $5,1 \%$ & $94,9 \%$ \\
& bebidas & $11,3 \%$ & $88,7 \%$ \\
& outros & $25,4 \%$ & $74,6 \%$ \\
Tipo de veículo & utilitário & $14,2 \%$ & $85,8 \%$ \\
\hline \multirow{2}{*}{ Pombi/van } & VUC pequeno & $11,4 \%$ & $88,6 \%$ \\
ajudante & VUC grande & $9,6 \%$ & $90,4 \%$ \\
Posição da porta de & não & $11,7 \%$ & $88,3 \%$ \\
descarregamento & sim & $22,9 \%$ & $77,1 \%$ \\
\hline \multirow{2}{*}{ traseira } & lateral & $18,1 \%$ & $81,9 \%$ \\
& ambas & $16,5 \%$ & $83,5 \%$ \\
\hline
\end{tabular}


Além das nove perguntas do roteiro de entrevista, os motoristas foram solicitados a indicar onde estacionariam seus veículos diante das opções apresentadas em sete diferentes cenários, representados por um conjunto diagramas a eles apresentados. Os diagramas foram adicionados ao roteiro de entrevista após a realização de uma pesquisa piloto com 27 motoristas, durante a qual foram constatadas as seguintes dificuldades:

i. Para a maioria dos motoristas entrevistados foi necessário fornecer maiores detalhes para que os mesmos compreendessem as alternativas fornecidas em cada pergunta de entrevista;

ii. Foi observada uma forte tendência dos entrevistados a relacionarem suas respostas à situação (entrega) que estava ocorrendo no momento da entrevista e não a uma situação genérica.

As Figuras 6.8, 6.9 e 6.10 mostram os diagramas na mesma ordem em que foram mostrados aos motoristas. O retângulo vermelho representa a localização do ponto de entrega e os círculos numerados representam as opções de estacionamento.
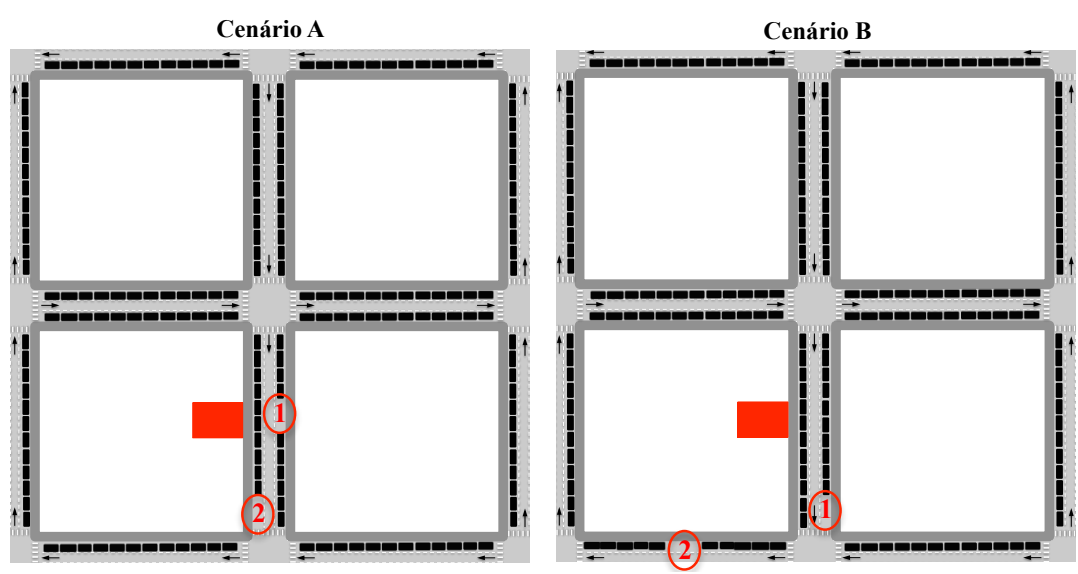

Figura 6.8 - Diagramas apresentados aos motoristas: cenário A e cenário B 

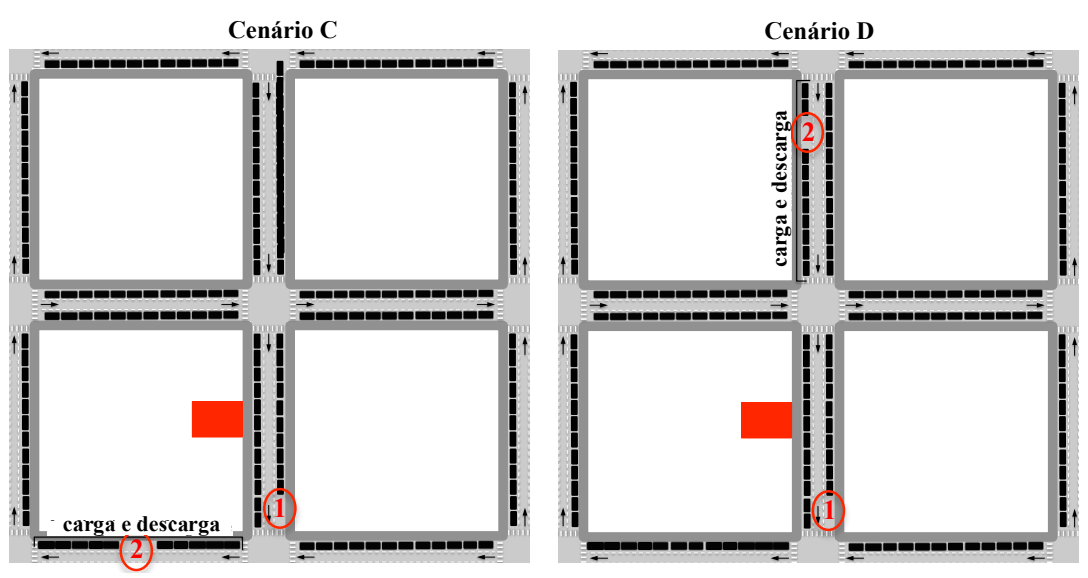

Figura 6.9 - Diagramas apresentados aos motoristas: cenário C e cenário D

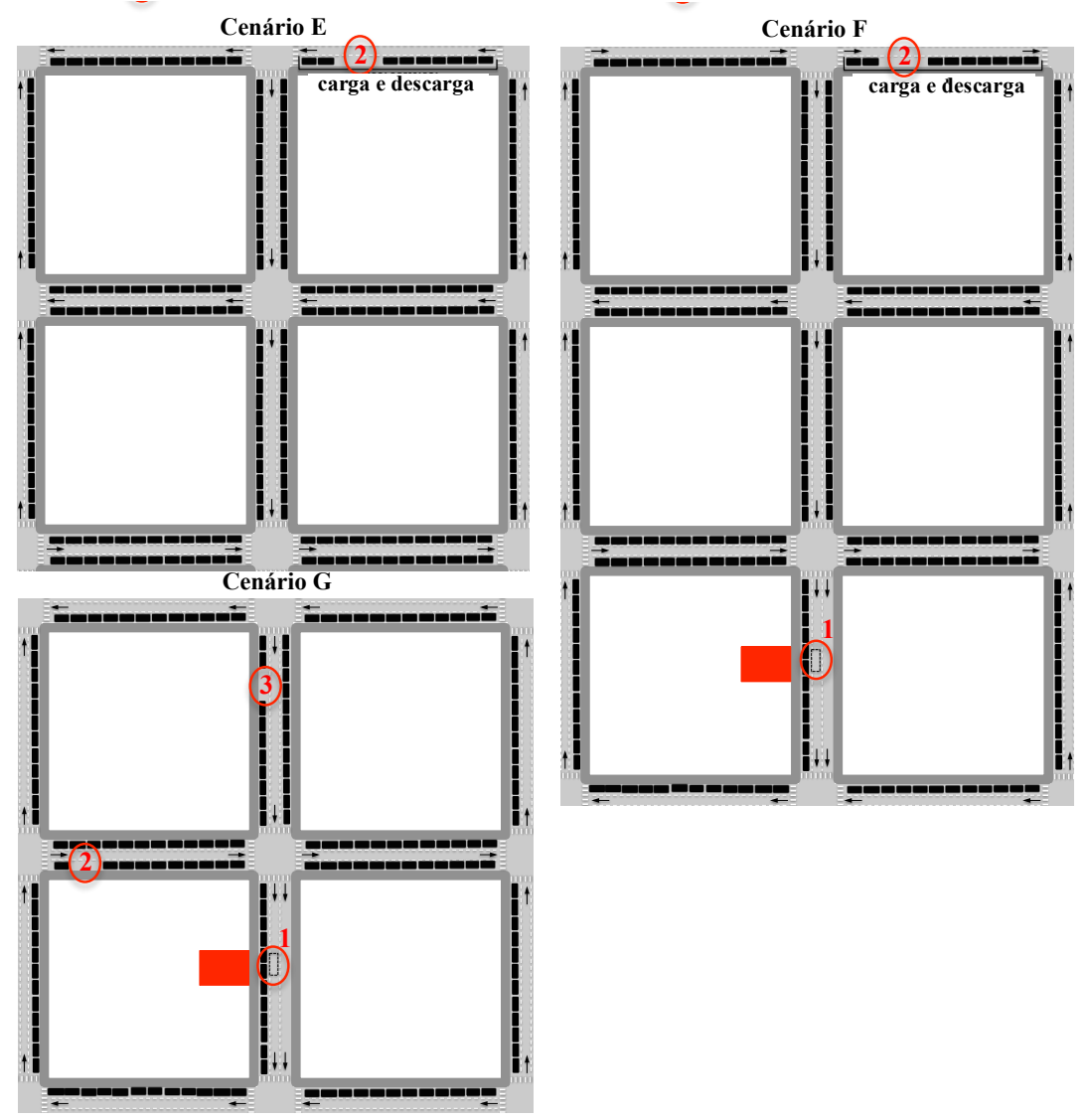

Figura 6.10 - Diagramas apresentados aos motoristas: cenário E, cenário F e cenário G

Os sete cenários foram elaborados para explorar como determinadas situações poderiam impactar no comportamento dos motoristas, sendo elas: 
- Distância ao ponto de entrega;

- Existência de área para carga e descarga;

- Necessidade de atravessar a rua para realizar a entrega;

- Veículo estacionado fora do campo de visão do motorista;

- Indisponibilidade de vagas de estacionamento (opção pelo estacionamento irregular).

No cenário A, a opção de estacionamento 1 está localizada bem em frente ao ponto de entrega, mas do outro lado da rua, enquanto a opção 2 está no mesmo lado da rua, mas mais distante do ponto de entrega. Os cenários B e C apresentam as mesmas opções de locais disponíveis para estacionamento: a opção 1 é mais próxima ao ponto de entrega, do outro lado da rua; a opção 2 é do mesmo lado da rua, mas mais distante, e ainda virando a esquina (conversão), ou seja, o veículo estacionado fica fora do campo de visão do motorista enquanto ele está realizando a entrega no estabelecimento. A diferença entre os cenários $\mathrm{B}$ e C está no tipo de vaga disponível: no cenário B a opção de estacionamento 2 é uma vaga regular, enquanto no cenário $\mathrm{C}$ é uma vaga exclusiva para carga e descarga. $\mathrm{O}$ cenário $\mathrm{D}$ mantém a mesma configuração do cenário $\mathrm{C}$, apenas tornando mais distante a vaga exclusiva para carga e descarga (opção 2). No cenário E a vaga exclusiva para carga e descarga (opção 2) está localizada ainda mais distante (mais de dois quarteirões) e disputa a preferência do entrevistado com uma vaga regular (opção 1) localizada a meio quarteirão do ponto de entrega. O cenário F compara a opção de um estacionamento bem em frente ao ponto de entrega, porém irregular, à opção de uma vaga regular localizada a mais de dois quarteirões de distância. Finalmente, o cenário $G$ apresenta três opções de estacionamento: a opção 1 é a mais próxima do ponto de entrega, localizada bem em frente ao mesmo, porém trata-se de um estacionamento irregular em fila dupla; a opção 2 é uma vaga regular, virando a esquina, distante um quarteirão do ponto de entrega; a opção 3 é tão distante quanto a opção 2, mas está localizada no próximo quarteirão, ou seja, é necessário atravessar a rua para realizar a entrega.

As respostas obtidas, também foram divididas de acordo com mesmos os atributos registrados na entrevista, e são apresentadas no Quadro 6.10.

A discussão a respeito dos resultados obtidos nessa coleta de dados faz parte do desenvolvimento do modelo 'Preferências de Estacionamento', sendo, portanto, apresentada na seção 6.4.3, adiante. 
Quadro 6.10 - Respostas obtidas dos motoristas diante dos diagramas apresentados

\begin{tabular}{|c|c|c|c|c|c|c|c|c|c|c|c|c|c|c|c|c|}
\hline & & \multicolumn{2}{|c|}{ Cenário A } & \multicolumn{2}{|c|}{ Cenário B } & \multicolumn{2}{|c|}{ Cenário $\mathrm{C}$} & \multicolumn{2}{|c|}{ Cenário D } & \multicolumn{2}{|c|}{ Cenário $\mathbf{E}$} & \multicolumn{2}{|c|}{ Cenário $F$} & \multicolumn{3}{|c|}{ Cenário G } \\
\hline & & $\begin{array}{c}\text { opção } \\
1\end{array}$ & $\begin{array}{c}\text { opção } \\
2\end{array}$ & $\begin{array}{c}\text { opção } \\
1\end{array}$ & $\begin{array}{c}\text { opção } \\
2\end{array}$ & $\begin{array}{c}\text { opção } \\
1\end{array}$ & $\begin{array}{c}\text { opção } \\
2\end{array}$ & $\begin{array}{c}\text { opção } \\
1\end{array}$ & $\begin{array}{c}\text { opção } \\
2\end{array}$ & $\begin{array}{c}\text { opção } \\
1\end{array}$ & $\begin{array}{l}\text { opção } \\
2\end{array}$ & opção & $\begin{array}{c}\text { opção } \\
2\end{array}$ & $\begin{array}{c}\text { opção } \\
1\end{array}$ & $\begin{array}{c}\text { opção } \\
2\end{array}$ & $\begin{array}{c}\text { opção } \\
\mathbf{3}\end{array}$ \\
\hline Total da $A$ & Amostra & $57,7 \%$ & $42,3 \%$ & $81 \%$ & $19 \%$ & $28,5 \%$ & $71,5 \%$ & $65,7 \%$ & $34,3 \%$ & $100 \%$ & $0 \%$ & $81,8 \%$ & $18,2 \%$ & $31,4 \%$ & $46,7 \%$ & $21,9 \%$ \\
\hline \multirow{3}{*}{ Tipo de Produto } & perecíveis & $58,4 \%$ & $41,6 \%$ & $80,5 \%$ & $19,5 \%$ & $28,6 \%$ & $71,4 \%$ & $70,1 \%$ & $29,9 \%$ & $100 \%$ & $0 \%$ & $81,8 \%$ & $18,2 \%$ & $31,2 \%$ & $44,2 \%$ & $24,7 \%$ \\
\hline & não perecíveis & $42,9 \%$ & $57,1 \%$ & $85,7 \%$ & $14,3 \%$ & $28,6 \%$ & $71,4 \%$ & $61,9 \%$ & $38,1 \%$ & $100 \%$ & $0 \%$ & $61,9 \%$ & $38,1 \%$ & $23,8 \%$ & $52,4 \%$ & $23,8 \%$ \\
\hline & bebidas & $75 \%$ & $25 \%$ & $79,2 \%$ & $20,8 \%$ & $33,3 \%$ & $66,7 \%$ & $62,5 \%$ & $37,5 \%$ & $100 \%$ & $0 \%$ & $95,8 \%$ & $4,2 \%$ & $41,7 \%$ & $54,2 \%$ & $4,2 \%$ \\
\hline \multirow{4}{*}{ Tipo de Veículo } & utilitário & $73,7 \%$ & $26,3 \%$ & $89,5 \%$ & $10,5 \%$ & $36,8 \%$ & $63,2 \%$ & $68,4 \%$ & $31,6 \%$ & $100 \%$ & $0 \%$ & $57,9 \%$ & $42,1 \%$ & $15,8 \%$ & $47,4 \%$ & $36,8 \%$ \\
\hline & Kombi/van & $64,1 \%$ & $35,9 \%$ & $89,7 \%$ & $10,3 \%$ & $17,9 \%$ & $82,1 \%$ & $53,8 \%$ & $46,2 \%$ & $100 \%$ & $0 \%$ & $76,9 \%$ & $23,1 \%$ & $28,2 \%$ & $53,8 \%$ & $17,9 \%$ \\
\hline & VUC pequeno & $49 \%$ & $51 \%$ & $83,3 \%$ & $16,7 \%$ & $26,5 \%$ & $73,5 \%$ & $71,4 \%$ & $28,6 \%$ & $100 \%$ & $0 \%$ & $87,8 \%$ & $12,2 \%$ & $34,7 \%$ & $38,8 \%$ & $26,5 \%$ \\
\hline & VUC grande & $53,3 \%$ & $46,7 \%$ & $69,4 \%$ & $30,6 \%$ & $40 \%$ & $60 \%$ & $70 \%$ & $30 \%$ & $100 \%$ & $0 \%$ & $93,3 \%$ & $6,7 \%$ & $40 \%$ & $50 \%$ & $10 \%$ \\
\hline \multirow{2}{*}{$\begin{array}{c}\text { Presença de } \\
\text { ajudante }\end{array}$} & não & $64,9 \%$ & $35,1 \%$ & $94,6 \%$ & $5,4 \%$ & $27 \%$ & $73 \%$ & $67,6 \%$ & $32,4 \%$ & $100 \%$ & $0 \%$ & $56,8 \%$ & $43,2 \%$ & $0 \%$ & $70,3 \%$ & $29,7 \%$ \\
\hline & $\operatorname{sim}$ & $55 \%$ & $45 \%$ & $76 \%$ & $24 \%$ & $29 \%$ & $71 \%$ & $65 \%$ & $35 \%$ & $100 \%$ & $0 \%$ & $91 \%$ & $9 \%$ & $43 \%$ & $38 \%$ & $19 \%$ \\
\hline \multirow{2}{*}{$\begin{array}{c}\text { Posição da } \\
\text { porta de } \\
\text { descarregamento }\end{array}$} & traseira & $60 \%$ & $40 \%$ & $82,5 \%$ & $17,5 \%$ & $32,5 \%$ & $67,5 \%$ & $65 \%$ & $35 \%$ & $100 \%$ & $0 \%$ & $72,5 \%$ & $27,5 \%$ & $27,5 \%$ & $45 \%$ & $27,5 \%$ \\
\hline & ambas & $53,9 \%$ & $46,1 \%$ & $80,9 \%$ & $19,1 \%$ & $25,8 \%$ & $74,2 \%$ & $66,3 \%$ & $33,7 \%$ & $100 \%$ & $0 \%$ & $84,3 \%$ & $15,7 \%$ & $31,5 \%$ & $47,2 \%$ & $21,3 \%$ \\
\hline
\end{tabular}




\subsection{MODELOS PARA A MICROSSIMULAÇÃO}

Os modelos apresentados a seguir servem como base para a representação dos movimentos dos veículos de carga na microssimulação. Considerando uma área e um período escolhidos para a simulação, é a partir desses modelos que serão determinadas as entregas a serem realizadas em cada estabelecimento e os veículos que irão realizá-las, sendo que, para cada um desses veículos, são definidas suas rotas de entrega e as preferências relativas às escolhas dos seus locais de estacionamento.

Embora também estime os fluxos de veículos de carga a partir do número de entregas em estabelecimentos, o modelo proposto por Muñuzuri et al. (2010), apresentado no Capítulo 5, não se adequa aos propósitos deste trabalho. Os autores apresentam um modelo cuja perspectiva é o veículo, estimando o número médio de entregas diárias realizadas por um veículo de determinado tipo, a cada categoria de estabelecimento, a partir do tempo médio de atendimento e das horas diárias de operação do veículo. Além disso consideram que os veículos observados em cada categoria de estabelecimento atendem exclusivamente àquela categoria, o que é plausível para os estabelecimentos considerados. No entanto, os veículos que transportam e entregam produtos dos setores alimentício e de bebidas, na maioria das vezes, atendem a diversos tipos de estabelecimentos em uma mesma viagem multiparadas, já que tais estabelecimentos recebem muitos produtos em comum. Um veículo transportando cervejas, águas e refrigerantes, por exemplo, em uma mesma viagem, pode atender a padarias, bares, supermercados e restaurantes. Logo, sendo o setor alimentício e de bebidas o foco da análise deste trabalho, a simplificação adotada por Muñuzuri et al. (2010) não parece adequada, podendo resultar em estimativas discrepantes da realidade. Por fim, ao utilizarem a macrossimulação para determinar os parâmetros necessários ao cálculo da pegada ecológica, os autores não se preocupam com as rotas praticadas pelos veículos e determinam apenas volumes que entram ou saem de uma determinada zona, o que é insuficiente para a quantificação de impactos locais dentro do contexto do procedimento proposto por este trabalho.

\subsubsection{Modelo 'Geração das Demandas'}

O modelo 'Geração das Demandas' tem por objetivo determinar a demanda por entregas, por grupo de produtos, em cada estabelecimento da área de simulação, considerando um período 
pré-estabelecido. Saber as entregas em cada estabelecimento é essencial para que possam ser determinadas as rotas de entrega dos veículos que as realizam. Essas rotas são geradas pelo modelo 'Geração dos Veículos de Entrega', explicado logo adiante.

A Figura 6.11 apresenta o esquema que representa o esquema da versão inicial do modelo 'Geração das Demandas'.

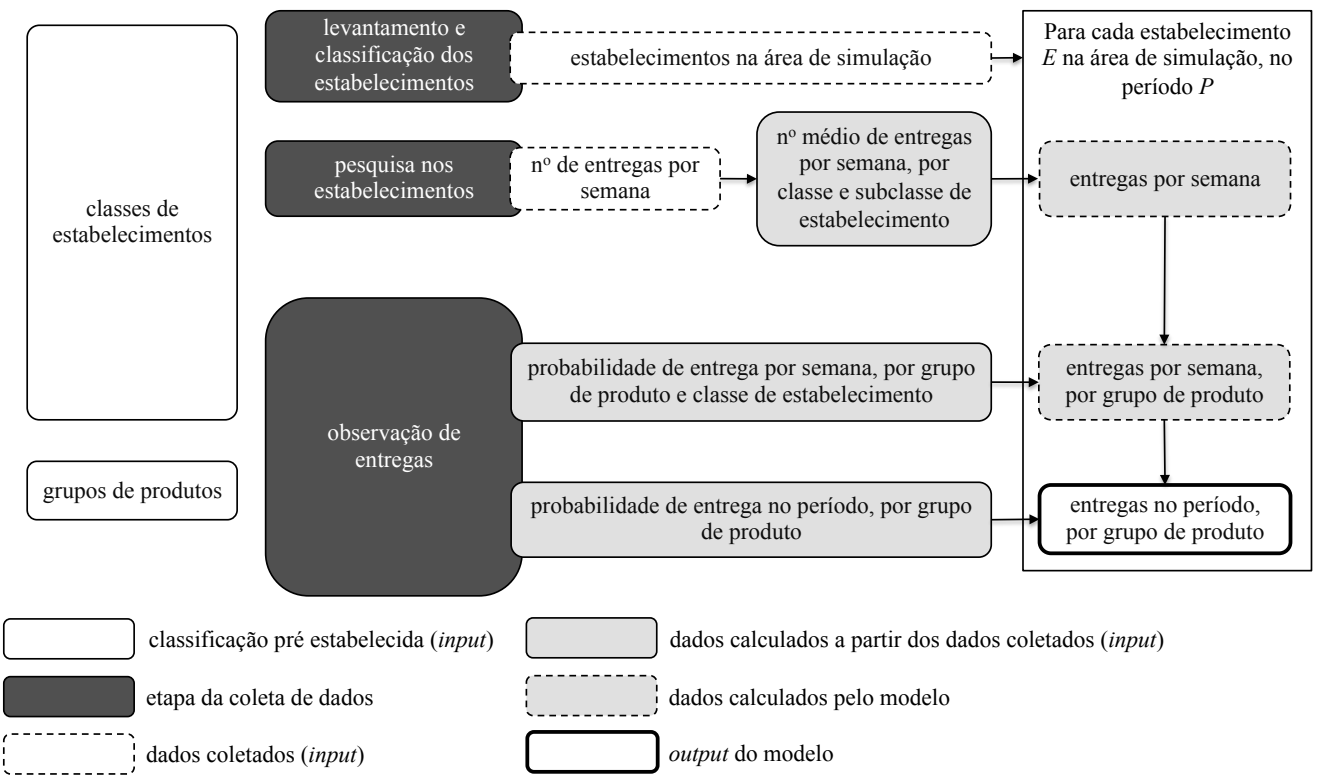

Figura 6.11 - Esquema da versão inicial do modelo 'Geração das Demandas'

O modelo 'Geração das Demandas', e sua versão inicial, baseou-se na hipótese de que o número de entregas semanais em um determinado estabelecimento poderia estar correlacionado ao seu número de funcionários. Sendo verdadeira a hipótese considerada, a partir dos dados coletados para os estabelecimentos existentes na área em estudo (apresentados na seção 6.3.3 - Tabela 6.1) seria possível estimar o número de entregas semanais nos estabelecimentos da área de simulação, uma vez conhecidos sua classe seu número de funcionários.

Todavia, a análise dos dados obtidos mostrou que, para a maioria das classes de estabelecimentos, não há correlação significativa entre o número de funcionários e o número semanal de entregas informado pelo entrevistado. Tal análise se deu através do cálculo do coeficiente de correlação de Pearson, o qual mede a direção e o grau de relação linear entre duas variáveis quantitativas (Moore, 2007). Nesse caso então, o coeficiente de Pearson foi 
calculado para cada classe de estabelecimento, conforme exibe a Tabela 6.2, considerando as variáveis 'número de funcionários' e 'número de entregas por semana', obtidas para cada estabelecimento visitado durante a coleta de dados.

\begin{tabular}{cc} 
Tabela 6.2 - Valores dos coeficientes de Pearson por classe de estabelecimento \\
\hline Classe de estabelecimento & Coeficiente de Pearson (r) \\
\hline Açougue & $-0,3666$ \\
Adega & $-0,3712$ \\
Bar premium & 0,2534 \\
Bar tradicional & 0,1640 \\
Bombonière & 0,2209 \\
Buffet / casa de festas & $-0,5960$ \\
Eafé / sorveteria / doceria / casa de sucos & 0,2798 \\
Hortifruti & 0,7619 \\
Lanchonete & 0,7361 \\
Lanchonete / Restaurante & 0,5943 \\
Loja de conveniência & 0,2333 \\
Padaria & 0,7591 \\
Restaurante & 0,6094 \\
Supermercado médio & 0,6132 \\
Supermercado pequeno & 0,7731 \\
Supermercado pequeno-médio & 0,0905 \\
\hline
\end{tabular}

O coeficiente de correlação Pearson (r) varia de -1 a 1 . O sinal indica a direção positiva ou negativa do relacionamento e o valor sugere a força da relação entre as variáveis. Uma correlação perfeita ( -1 ou 1) indica que o valor da variável dependente pode ser determinado exatamente ao se saber o valor da variável independente; no outro oposto, uma correlação de valor zero indica que não há relação linear entre as variáveis. Em geral valores entre 0,1 e 0,3 indicam relação fraca entre as variáveis; entre 0,4 e 0,6 indicam relação moderada; entre 0,7 e 1, forte relação entre as variáveis (Dancey e Reidy, 2005).

Note-se que para apenas quatro classes de estabelecimentos é possível considerar que existe alguma relação entre o número de funcionários e o número semanal de entregas. Mesmo assim, os valores obtidos para o coeficiente de Pearson estão no limite inferior do intervalo, ou seja, todos menores que 0,8 .

Sendo assim, na versão final do modelo 'Geração das Demandas', apresentada na Figura 6.12, o número médio de entregas da versão inicial do modelo foi substituído pelo número real de entregas, por semana, em cada um dos estabelecimentos, considerando como real o 
valor declarado pelos respondentes da pesquisa. Foi então necessário coletar os dados de entrega para todos os estabelecimentos da área de simulação.

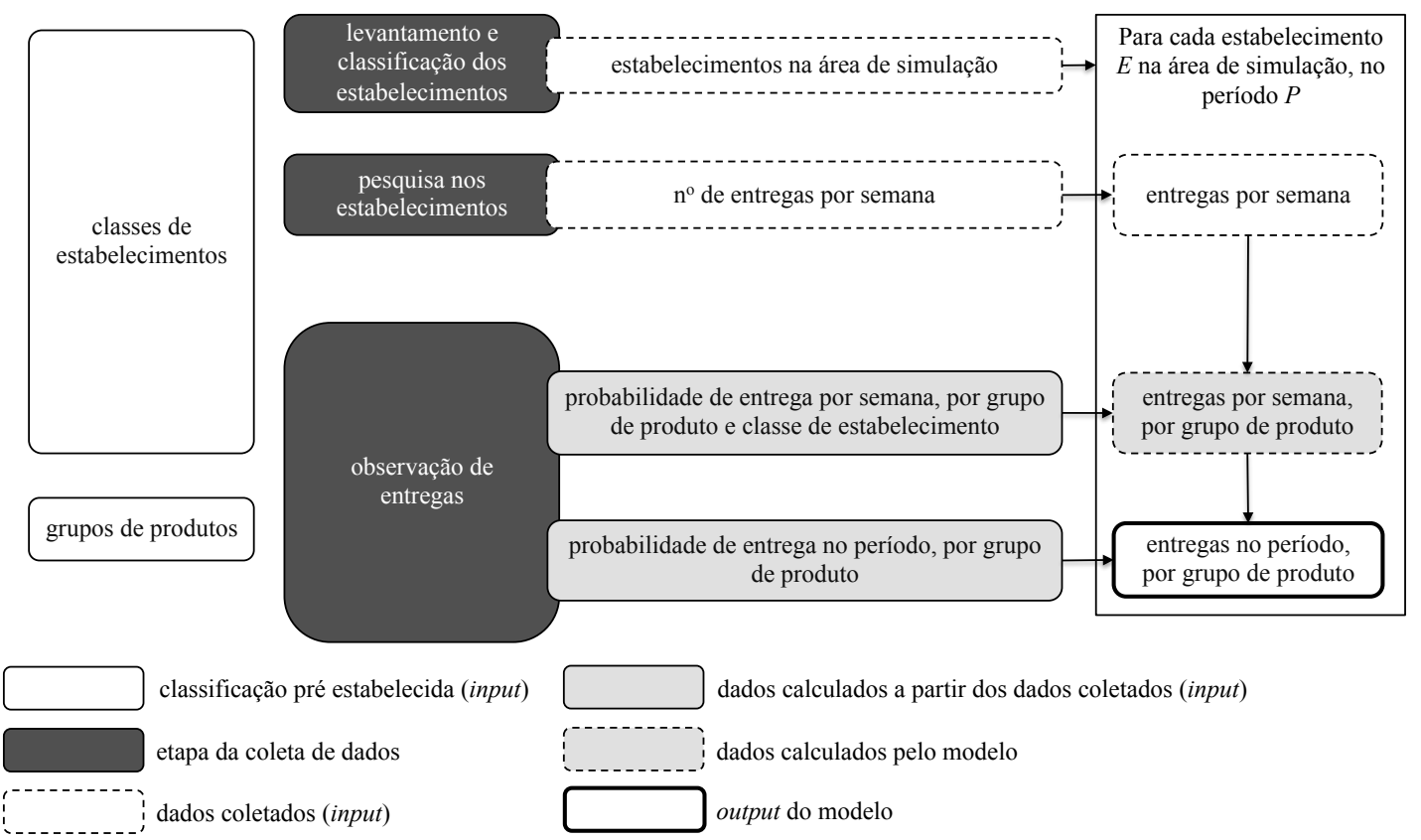

Figura 6.12 - Esquema da versão final do modelo 'Geração das Demandas'

A determinação do número semanal de entregas, por grupo de produtos, baseia-se na probabilidade de entrega de cada um desses grupos em cada um dos tipos de estabelecimentos considerados. $\mathrm{O}$ valor de probabilidade foi calculado a partir da proporção de entregas semanais observadas para cada grupo de produto, durante a coleta de dados que envolveu a observação de entregas. Da mesma forma, o número de entregas no período, por grupo de produto, também considera um valor de probabilidade, dessa vez a probabilidade de entrega de cada um dos grupos de produtos no período escolhido, a qual também foi calculada a partir das proporções observadas durante a coleta dados (número de entregas de cada grupo observadas no período escolhido, em relação ao número total de entregas observadas no mesmo período). Os valores de probabilidade calculados e adotados no modelo estão exibidos na Tabelas A.3 e A.4, do Anexo A.

\subsubsection{Modelo 'Geração dos Veículos de Entrega'}

A partir do número de entregas demandadas no período escolhido, o modelo 'Geração dos Veículos de Entrega' determina o número de veículos (por tipo) atraídos para a área de simulação, de forma que toda a demanda seja atendida. Ao mesmo tempo, considerando a 
capacidade de carga dos veículos e o intervalo de tempo para que todas as entregas sejam realizadas (janela de entrega), atribui a cada um deles um conjunto de estabelecimentos a serem visitados, formando, assim, suas respectivas rotas de entregas. Os dados de entrada necessários ao modelo, assim como as etapas da coleta de dados necessárias para obtê-los são apresentados na Figura 6.13.

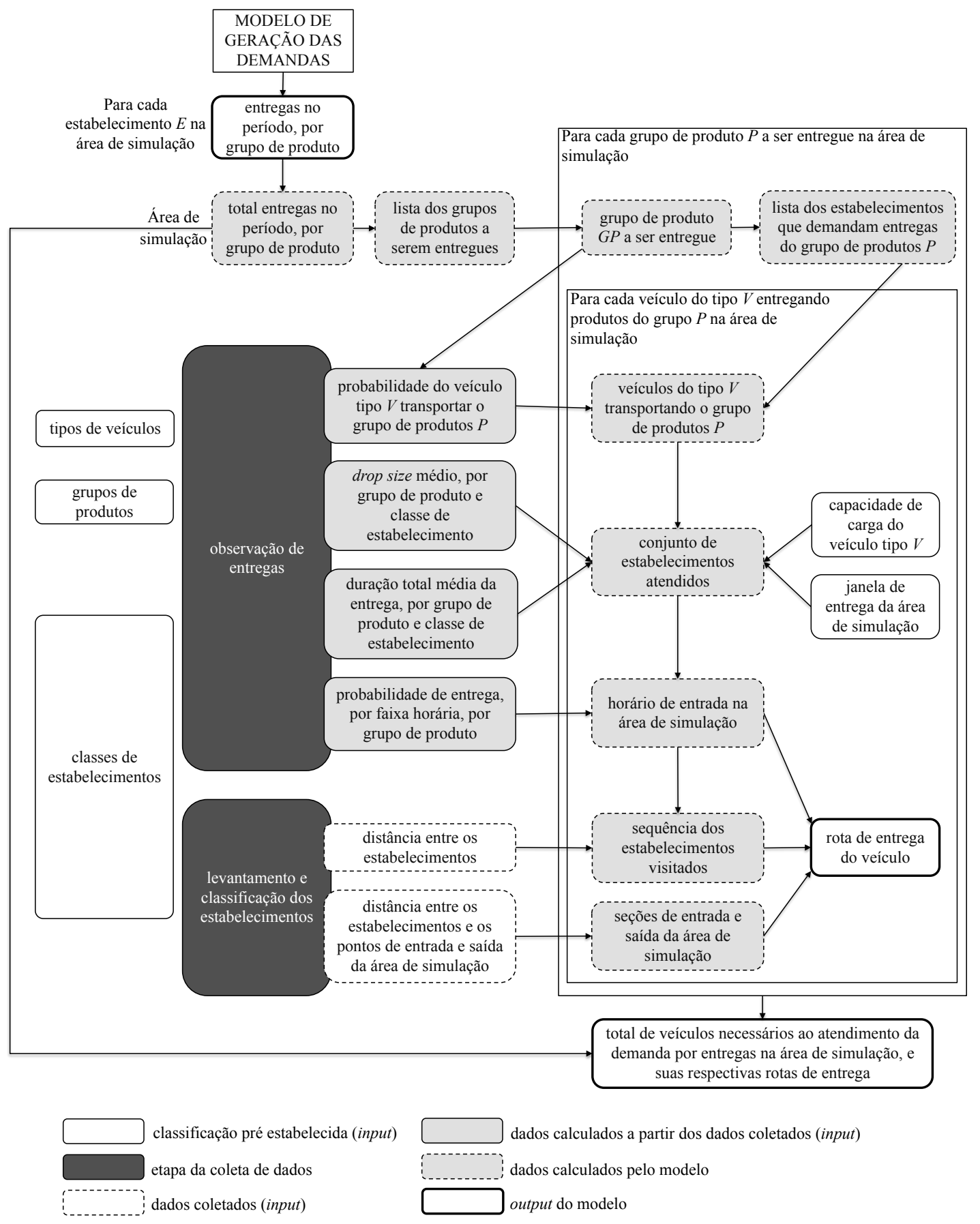

Figura 6.13 - Esquema do modelo 'Geração dos Veículos de Entrega' 
A geração do número e dos tipos de veículos necessários ao atendimento de todos os estabelecimentos da área de interesse (área de simulação) dependem da demanda por entregas, por grupo de produtos. Para um grupo de produtos $P$ a ser entregue é definido o tipo de veículo $V$ que o transportará. Isso é feito considerando a probabilidade de que um veículo do tipo $V$ transporte o grupo de produtos $P$. Essa probabilidade foi calculada a partir dos dados coletados durante as observações das entregas, os quais forneceram um valor de proporção, sendo ele a proporção de entregas de um determinado grupo de produtos realizada por um dado tipo de veículo, em relação ao total de entregas observadas para o mesmo grupo de produto. Os valores de probabilidades adotados para a atribuição dos tipos de veículos aos grupos de produtos estão exibidos na Tabela A.4 do Anexo A.

Para o veículo do tipo $V$ que transporta produtos do grupo $P$ é definido um conjunto de entregas a serem realizadas (estabelecimentos a serem atendidos). A inclusão de um estabelecimento na rota de entrega de um veículo deve atender a duas restrições: a restrição de capacidade do veículo e a restrição de janela de entrega. A restrição de capacidade considera o tamanho (drop size) de cada entrega a ser realizada, e impõe que a somatória dos tamanhos de todas as entregas atribuídas a um veículo não ultrapasse a capacidade de carregamento do mesmo, conforme a expressão 1:

$\sum_{s=1}^{N} d_{s} \leq W$

Onde $N$ é o número total de estabelecimentos visitados pelo veículo, $d_{s}$ é o tamanho da entrega no estabelecimento $s$ e $W$ é a capacidade do veículo. O tamanho de uma entrega depende do grupo de produtos e da classe de estabelecimento. Os valores adotados estão apresentados na Tabela A.6 (Anexo A) e foram definidos a partir de valores médios, calculados com base nos dados coletados em campo durante as observações das entregas.

A restrição da janela de entrega impõe que todas as entregas sejam realizadas dentro do período escolhido, ou seja, a somatória da duração de cada entrega realizada pelo veículo deve ser menor ou igual à duração da janela de entrega considerada para a área de simulação, conforme a expressão 2 :

$\sum_{s=1}^{N} t_{s} \leq T$ 
Onde $N$ é o número total de estabelecimentos visitados pelo veículo, $t_{s}$ é a duração da entrega no estabelecimento $s$ e $T$ é a janela de entrega disponível.

A duração de cada entrega, assim como seu drop size, também depende do grupo de produtos e da classe de estabelecimento. Os valores adotados estão apresentados na Tabela A.7 (Anexo A) e foram definidos a partir das durações médias, calculadas com base nos dados coletados em campo.

O modelo 'Geração dos Veículos de Entrega' foi implementado utilizando programação em linguagem VBA (Visual Basic Applications), através do programa Microsoft ${ }^{\circledR}$ Excel. A lógica que rege a determinação dos veículos que realizam entregas na área de interesse (área de simulação) e o conjunto de estabelecimentos atendidos por cada um deles é apresentada na Figura 6.14, a seguir.

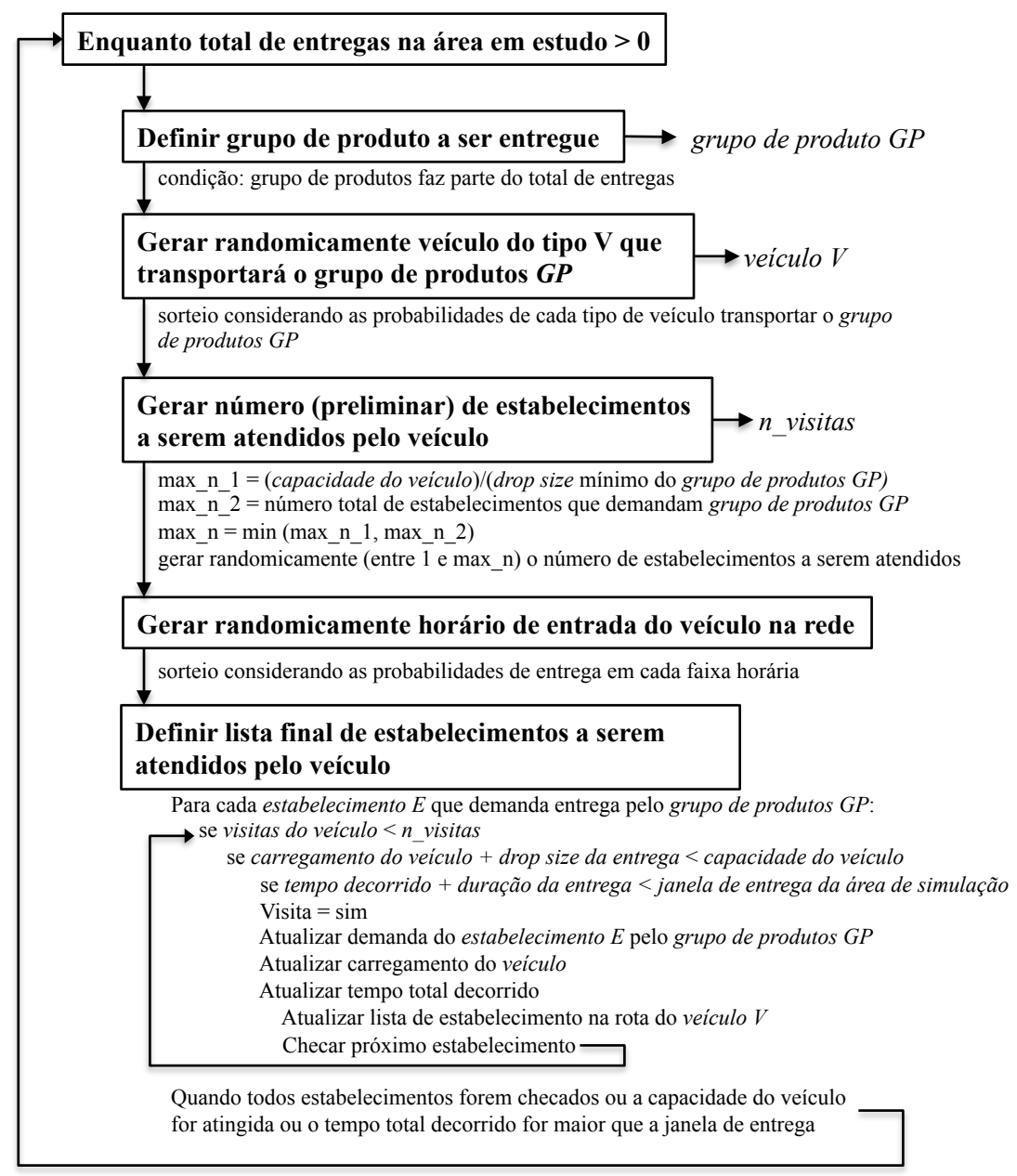

Figura 6.14 - Lógica da geração de veículos no modelo 'Geração dos Veículos de Entrega' 
Após definir a lista de estabelecimentos a serem visitados por cada um dos veículos, o modelo determina a sequência das entregas e os locais de entrada e saída dos veículos na área de simulação, compondo, assim, a rota de entrega do veículo. A definição da sequência de atendimento dos estabelecimentos é feita através de uma lista ordenada dos estabelecimentos, a qual obedece ao critério de menor distância, a partir de um primeiro estabelecimento definido aleatoriamente. Da mesma forma, a definição dos locais de entrada e de saída da área de simulação consideram, respectivamente, aqueles mais próximos ao primeiro e ao último estabelecimento da lista ordenada de atendimento.

\subsubsection{Modelo 'Preferências de Estacionamento'}

O modelo 'Preferências de Estacionamento' tem a finalidade de determinar, para cada veículo de carga que realiza entregas na área de simulação, seu comportamento diante de diferentes situações relacionadas a não disponibilidade de vagas de estacionamento. Além disso, o modelo associa a cada parada, a existência ou não de interferência no tráfego durante o estacionamento do veículo e a realização da entrega.

O modelo baseia-se em um fluxograma (Figura 6.15), denominado fluxo de decisões, onde são representadas as decisões a serem tomadas pelos motoristas no momento da escolha do local de estacionamento e as ações que são geradas por essas decisões.

A decisão D1 determina a distância máxima aceitável $D c$ entre o estabelecimento e o local de estacionamento do veículo. Se o estabelecimento de destino possuir vaga interna de carga e descarga o veículo então segue para o estabelecimento e, estando essa vaga disponível, realiza a entrega. Caso a vaga esteja ocupada, o motorista deve decidir (D2) entre adiar a entrega, ou seja, seguir para outro estabelecimento e voltar mais tarde, ou seguir com a entrega. Ao optar por seguir com a entrega o motorista está, na verdade, escolhendo (D10) entre aguardar a liberação da vaga interna ao estabelecimento ou buscar por uma vaga regular, na rua. A espera pela vaga do estabelecimento se dá em alguma vaga regular localizada na rua, próxima ao estabelecimento. Caso não haja uma vaga disponível o motorista pode novamente optar (D11) por adiar a entrega, caso não queira estacionar irregularmente na faixa de tráfego. 


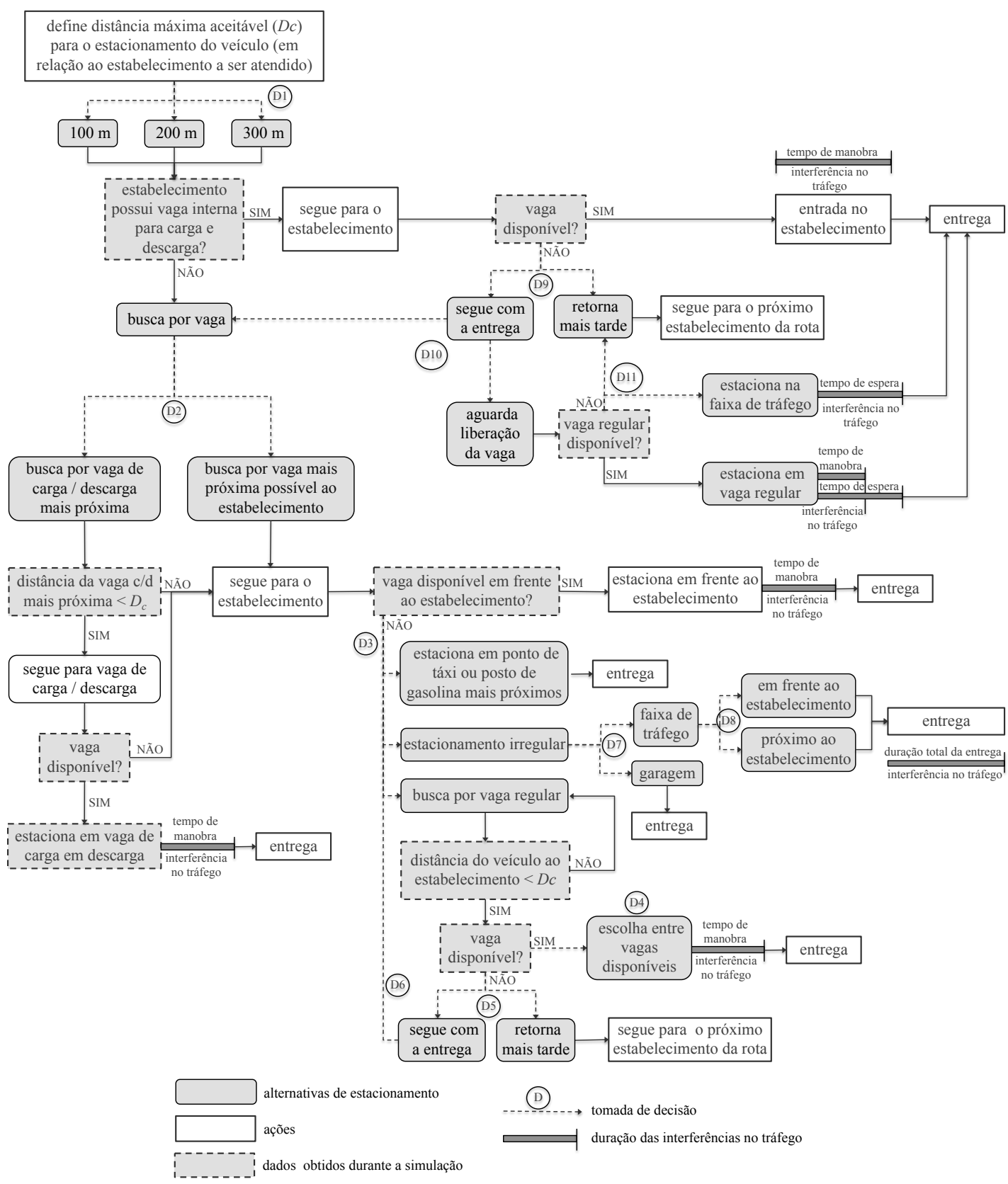

Figura 6.15 - Fluxo de decisões do modelo 'Preferências de Estacionamento'

Para as entregas realizadas a partir de uma vaga localizada fora do estabelecimento, seja porque o mesmo não possui uma vaga interna de carga e descarga ou porque a sua está ocupada, o veículo deve então iniciar a busca por uma vaga disponível, a qual pode ser uma vaga regular ou uma exclusiva para carga e descarga (D2), caso exista uma dentro dos limites da distância $D c$ previamente definida. Não havendo uma vaga de carga e descarga ou estando essa indisponível, o veículo segue para o estabelecimento, pois o modelo assume 
que, ao descartar a vaga de carga e descarga, o motorista sempre optará por uma que seja o mais próximo possível ao estabelecimento.

Ao se aproximar do estabelecimento e encontrar uma vaga disponível, o veículo estaciona e a entrega é realizada. Diante indisponibilidade de uma vaga de estacionamento o motorista deve decidir pelas seguintes alternativas (D3): (i) estacionar em um posto de gasolina ou ponto de táxi próximos, (ii) estacionar irregularmente [em frente a uma garagem ou na faixa de tráfego (D7)], ou (iii) buscar por uma vaga regular. No caso do estacionamento irregular, este pode ser em frente ou próximo ao estabelecimento (D8). Se optar pela busca por uma vaga regular, o motorista considera apenas aquelas dentro dos limites da distância $D_{c}$, escolhendo entre aquelas que estão disponíveis (D4), caso haja mais do que uma. Ao contrário, deve escolher entre adiar a entrega ou seguir com a entrega (D5). Nesse caso, seguir com a entrega significa que o motorista pode decidir (D6) ou por insistir na busca por uma vaga, ou pelo estacionamento irregular ou, ainda, por estacionar em um posto de gasolina ou ponto de táxi.

As tomadas de decisão D baseiam-se nas probabilidades de escolha de cada uma das alternativas a ela relacionadas. A determinação dessas probabilidades partiu da análise estatística dos resultados das entrevistas com os motoristas, exibidos na seção 6.3.4. Em princípio, através de modelos de regressão logística binomial e multinomial, buscou-se obter alguma relação entre as preferências dos motoristas, declaradas durante a entrevista, e os atributos registrados ('tipo de produto', 'tipo de veículo', 'posição da porta de descarregamento' e 'presença de ajudante').

A regressão logística é indicada para a análise de variáveis qualitativas nominais, sendo a regressão logística multinomial aplicada quando o número de categorias excede dois. Ambos os modelos (bi e multinomial) procuram determinar a relação entre a variável resposta (ou variável dependente) e um conjunto de variáveis explanatórias (ou variáveis independentes), permitindo observar a significância entre essas relações (Hosmer and Lemeshow, 2004). Nesse caso, as respostas dos motoristas são a variáveis dependentes e os atributos são as variáveis independentes. Em suma, deseja-se determinar o impacto que esses quatro atributos poderiam ter nas preferências dos motoristas em relação ao local de estacionamento dos veículos de entrega. 
A análise através da regressão logística foi feita utilizando o programa Minitab 17, e o modelo foi aplicado tanto às respostas das nove perguntas do roteiro de entrevista quanto àquelas relacionadas aos diagramas de opções de estacionamento. Os resultados, no entanto, não constataram haver relação significativa entre as respostas fornecidas pelos motoristas e os atributos considerados, uma vez que os valores obtidos para o parâmetro $p$-value foram maiores do que 0,05 , conforme mostram as Tabelas B.1 a B.16 do Anexo B.

O parâmetro $p$-value para cada variável explanatória (independente) testa a hipótese nula de que o coeficiente a ela associado é igual a zero, ou seja, sem efeito na variável resposta (dependente). Valores baixos de p-value $(<0,05)$ indicam que a hipótese nula pode ser rejeitada. Em outras palavras, variáveis explanatórias com p-value $<0,05$ provavelmente contribuem de forma significativa ao modelo, uma vez que alterações em seus valores resultam em alterações na variável resposta. O contrário se aplica a variáveis independentes com $p$-value $>0,05$, i.e., alterações em seus valores não estão associadas a alterações na variável resposta.

Uma vez que não foram encontradas relações significativas, os valores adotados para as probabilidades de escolha em cada uma das decisões $\mathrm{D}$ independem dos atributos considerados e baseiam-se apenas nas porcentagens relativas ao total da amostra. O Quadro 6.11, a seguir, relaciona cada decisão com a pergunta e/ou diagrama utilizado na obtenção das respectivas probabilidades de escolha.

Quadro 6.11 - Probabilidades adotadas para a escolha das alternativas no fluxo de decisões

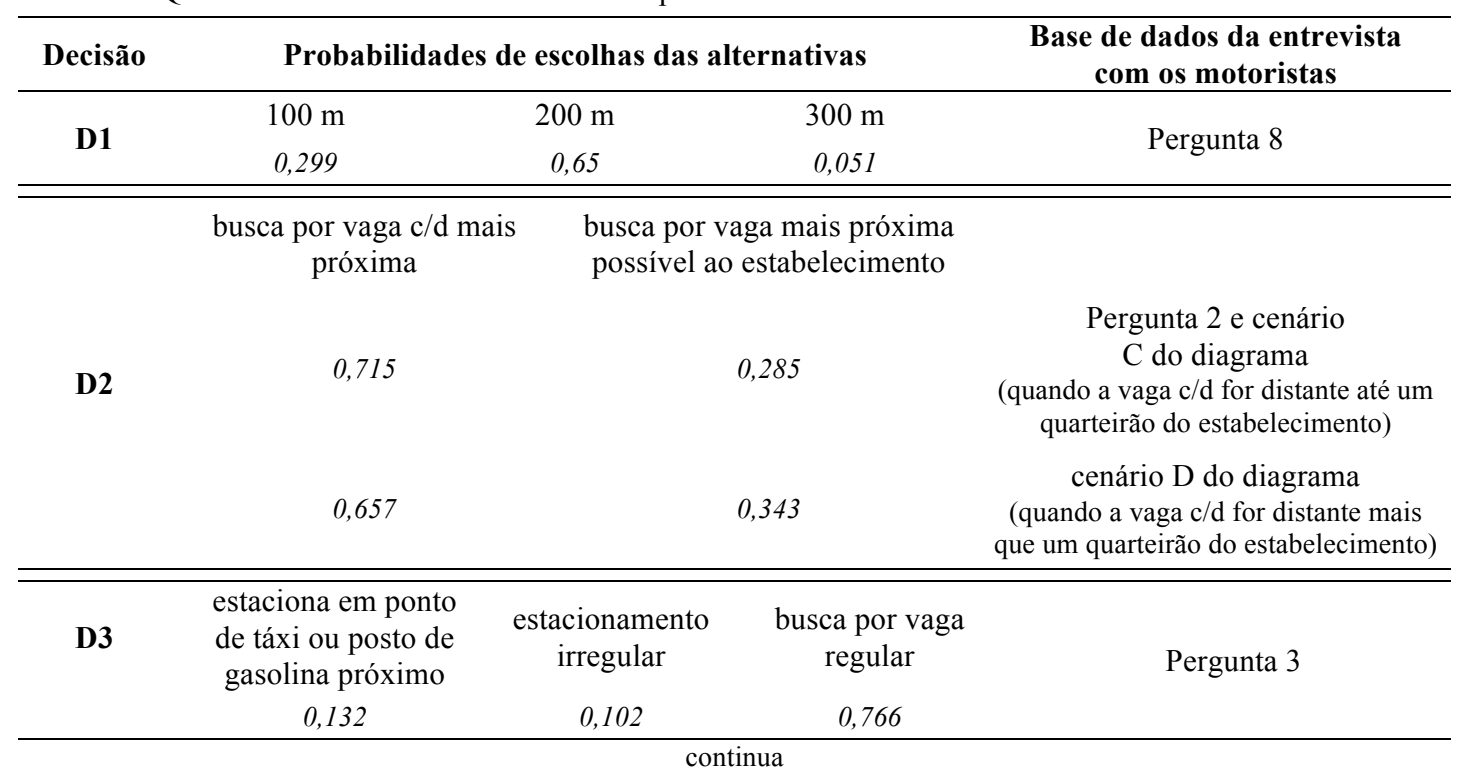


continuação

\begin{tabular}{|c|c|c|c|}
\hline Decisão & Probabilidades c & de escolhas das alternativas & $\begin{array}{c}\text { Base de dados da entrevista } \\
\text { com os motoristas }\end{array}$ \\
\hline \multirow{4}{*}{ D4 } & $\begin{array}{l}\text { vaga mais próxima, do } \\
\text { outro lado da rua }\end{array}$ & $\begin{array}{l}\text { vaga mais distante, do } \\
\text { mesmo lado da rua }\end{array}$ & \multirow[t]{2}{*}{ Cenário A } \\
\hline & 0,577 & 0,423 & \\
\hline & $\begin{array}{l}\text { vaga mais próxima, do } \\
\text { outro lado da rua }\end{array}$ & $\begin{array}{l}\text { vaga mais distante, do mesmo } \\
\text { lado da rua (virando a esquina) }\end{array}$ & \multirow{2}{*}{ Cenário B } \\
\hline & 0,81 & 0,19 & \\
\hline \multirow{2}{*}{ D5 } & segue com a entrega & retorna mais tarde & \multirow{2}{*}{ Pergunta 4} \\
\hline & 0,743 & 0,257 & \\
\hline \multirow[t]{2}{*}{ D6 } & $\begin{array}{l}\text { estaciona em ponto } \\
\text { de táxi ou posto de } \\
\text { gasolina próximo }\end{array}$ & $\begin{array}{cc}\text { estacionamento } & \text { busca por vaga } \\
\text { irregular } & \text { regular }\end{array}$ & \multirow[t]{2}{*}{ Pergunta 4} \\
\hline & 0,154 & 0,116 & \\
\hline \multirow{2}{*}{ D7 } & faixa de tráfego & garagem & \multirow{2}{*}{ Pergunta 5} \\
\hline & 0,753 & 0,247 & \\
\hline \multirow{4}{*}{ D8 } & $\begin{array}{l}\text { em frente ao } \\
\text { estabelecimento }\end{array}$ & $\begin{array}{c}\text { próximo ao } \\
\text { estabelecimento }\end{array}$ & Perguntas 6 e 7 \\
\hline & 0,752 & 0,248 & $\begin{array}{l}\text { quando o estabelecimento } \\
\text { está localizado em esquina }\end{array}$ \\
\hline & 0,708 & 0,292 & $\begin{array}{c}\text { quando o estabelecimento está } \\
\text { localizado em via com faixa de } \\
\text { tráfego estreita }\end{array}$ \\
\hline & 1 & 0 & $\begin{array}{l}\text { quando o estabelecimento não está } \\
\text { localizado em esquina nem em via } \\
\text { com faixa de tráfego estreita }\end{array}$ \\
\hline \multirow{2}{*}{ D9 } & segue com a entrega & retorna mais tarde & \multirow{2}{*}{ Pergunta 8} \\
\hline & 0,88 & 0,12 & \\
\hline \multirow{2}{*}{ D10 } & busca por vaga & aguarda liberação da vaga & \multirow{2}{*}{ Pergunta 8} \\
\hline & 0,19 & 0,81 & \\
\hline \multirow[t]{2}{*}{ D11 } & retorna mais tarde & $\begin{array}{l}\text { estaciona na faixa } \\
\text { de tráfego }\end{array}$ & \multirow[t]{2}{*}{ Pergunta 9} \\
\hline & 0,856 & 0,144 & \\
\hline
\end{tabular}

Embora a análise estatística das preferências declaradas nas entrevistas não tenha mostrado haver relação significativa entre as mesmas e os atributos relativos às entregas, é possível observar, a partir das porcentagens obtidas para cada resposta, que existem algumas tendências no comportamento dos motoristas, como por exemplo a maior predisposição ao estacionamento irregular por parte dos motoristas que entregam bebidas. Como essas informações não foram consideradas na determinação das probabilidades que regem o modelo 'Preferências de Estacionamento', optou-se por apresentá-las no Anexo B deste trabalho. 


\section{MODELAGEM DO AMBIENTE DE MICROSSIMULAÇÃO}

Neste capítulo são apresentadas as etapas necessárias à modelagem do ambiente de microssimulação capaz de representar, em uma área urbana, os movimentos dos veículos de carga em suas respectivas rotas de entrega e a interação desses veículos com o tráfego local. Dentre as etapas apresentadas destaca-se aquela que consiste na operacionalização dos modelos desenvolvidos neste trabalho, apresentados no Capítulo 6, pois diferencia o ambiente de microssimulação daqueles que consideram apenas os fluxos de veículos em geral, ao criar um ambiente capaz de representar os movimentos dos veículos de entrega, o que é fundamental para a avaliação das medidas voltadas à distribuição urbana de cargas.

\subsection{ESCOLHA DO SOFTWARE DE MICROSSIMULAÇÃO DE TRÁFEGO}

O Quadro 7.1, a seguir, apresenta os critérios a serem considerados na escolha do simulador, sugeridos pelo Highway Capacity Manual 2000 (TRB, 2000). Embora tenha seu foco voltado a modelos para a simulação da capacidade de rodovias, o próprio manual destaca que os critérios sugeridos servem para a escolha de simuladores de tráfego para diversas aplicações, inclusive em área urbanas. Em parênteses, foram adicionados alguns requisitos específicos considerados na escolha do software de microssimulação de tráfego utilizado nesta pesquisa.

Quadro 7.1 - Critérios para escolha do simulador

\begin{tabular}{ll}
\hline Critério & O que deve ser verificado \\
\hline Tamanho da rede & Limitações do modelo quanto ao número de nós e arcos. \\
Representação da rede & $\begin{array}{l}\text { Capacidade de representação do modelo, de forma que todas as características } \\
\text { de interesse possam ser representadas (vagas de carga e descarga). }\end{array}$ \\
Representação do tráfego & $\begin{array}{l}\text { Se a representação de movimentos mais complexos dos veículos atendem aos } \\
\text { propósitos da simulação (ultrapassagem; manobras de estacionamento; busca } \\
\text { por vaga de estacionamento; velocidade reduzida em trechos da via). }\end{array}$ \\
Composição do tráfego & $\begin{array}{l}\text { Se todos os diferentes tipos de veículos que compõem o tráfego (carros de } \\
\text { passeio, diversos tipos de veículos de carga) e suas características de } \\
\text { performance podem ser representados. }\end{array}$ \\
Operações de tráfego & $\begin{array}{l}\text { Se todas as operações verificadas na rede real (restrições de utilização de faixas } \\
\text { de tráfego; estacionamento em filla dupla) podem ser representadas pelo modelo. }\end{array}$ \\
\hline
\end{tabular}

continua 
continuação

\begin{tabular}{|c|c|c|c|c|}
\hline Critério & \multicolumn{4}{|l|}{ O que deve ser verificado } \\
\hline Controle de tráfego & \multicolumn{4}{|c|}{$\begin{array}{l}\text { Representação dos tipos de controle de interesse existentes em campo, como } \\
\text { sinais de "pare", sinalização semafórica e controle de velocidade (horário de } \\
\text { utilização das vagas de estacionamento - carga e descarga). }\end{array}$} \\
\hline Resultados do modelo & \multicolumn{4}{|c|}{$\begin{array}{l}\text { Se os resultados de saída do modelo atendem aos objetivos da análise através da } \\
\text { simulação. Por exemplo, se o modelo é capaz de fornecer as emissões de } \mathrm{CO} \\
\text { dos veículos, ou se possui integração com algum outro modelo que calcule } \\
\text { emissões. }\end{array}$} \\
\hline Dados de entrada & \multicolumn{4}{|c|}{$\begin{array}{l}\text { Quais são os dados de entrada necessários para se realizar a calibração e as } \\
\text { simulações no modelo escolhido e se os mesmos estão disponíveis ou são } \\
\text { possíveis de serem coletados. }\end{array}$} \\
\hline Usabilidade & \multicolumn{4}{|c|}{$\begin{array}{l}\text { Se o modelo possui ferramentas de fácil compreensão, que otimizem sua } \\
\text { utilização, a interpretação dos resultados e a identificação de erros, como } \\
\text { interfaces gráfica dos dados de saída e depuradores. }\end{array}$} \\
\hline Recursos necessários & \multicolumn{4}{|c|}{$\begin{array}{l}\text { Os custos relativos à aquisição e utilização do modelo e à obtenção e preparação } \\
\text { dos dados, assim como a disponibilidade de apoio técnico, caso necessário. }\end{array}$} \\
\hline \multicolumn{5}{|c|}{$\begin{array}{c}\text { conclusão } \\
\text { Fonte: Adaptado de TRB (2000) p. } 19-22\end{array}$} \\
\hline \multirow{8}{*}{\multicolumn{5}{|c|}{$\begin{array}{l}\text { Dentre os softwares de microssimulação considerados para este trabalho estã } \\
\text { TransModeler, o TSS Aimsun e o PTV VISSIM. É importante ressaltar que não existe } \\
\text { software de microssimulação voltado à modelagem do transporte de carga e que nenhum } \\
\text { programas disponíveis foi capaz de atender a todos os requisitos para a modelagem } \\
\text { movimentos dos veículos de carga, conforme mostra o Quadro 7.2. Nenhum deles, } \\
\text { exemplo, possui um recurso para a modelagem de estacionamento de veículos em fila du } \\
\text { Sendo assim, a capacidade de adaptação das funções e recursos dos softwares candid } \\
\text { também foi considerada no processo de escolha. }\end{array}$}} \\
\hline & & & & \\
\hline & & & & \\
\hline & & & & \\
\hline & & & & \\
\hline & & & & \\
\hline & & & & \\
\hline & & & & \\
\hline \multicolumn{2}{|c|}{ Característica / Requisito } & TransModeler & Aimsun & VISSIM \\
\hline \multicolumn{2}{|c|}{ Representação do sistema viário urbano } & $\checkmark$ & $\checkmark$ & $\checkmark$ \\
\hline \multicolumn{2}{|c|}{ Estacionamento de veículos } & $\checkmark$ & $\checkmark$ & $\checkmark$ \\
\hline \multicolumn{2}{|c|}{ Busca por vaga de estacionamento } & $\checkmark$ & $\checkmark$ & $\checkmark$ \\
\hline \multicolumn{2}{|c|}{ Controle do tráfego (semáforos, sinais de 'pare', etc.) } & $\checkmark$ & $\checkmark$ & $\checkmark$ \\
\hline \multicolumn{2}{|c|}{ Características de desempenho dos veículos de carga } & $\checkmark$ & $\checkmark$ & $\checkmark$ \\
\hline \multicolumn{2}{|c|}{$\begin{array}{l}\text { Customização das características dos veículos (dimensões e } \\
\text { desempenho operacional) }\end{array}$} & $\checkmark$ & $\checkmark$ & $\checkmark$ \\
\hline
\end{tabular}

continua 
continuação

\begin{tabular}{|c|c|c|c|}
\hline Característica / Requisito & TransModeler & Aimsun & VISSIM \\
\hline Ultrapassagem de veículos em movimentos & $\checkmark$ & $\checkmark$ & $\checkmark$ \\
\hline Ultrapassagem de veículos parados/estacionados na via & $\checkmark$ & $\checkmark$ & $\checkmark$ \\
\hline $\begin{array}{l}\text { Ultrapassagem de veículos parados / estacionados na via por uma } \\
\text { via de sentido oposto }\end{array}$ & $x$ & $x$ & $x$ \\
\hline Atribuição de várias paradas às rotas dos veículos & $\checkmark$ & $\checkmark$ & $\checkmark$ \\
\hline Alteração da sequência de paradas na rota & $x$ & $x$ & $x$ \\
\hline Associação de tempos às paradas (duração do estacionamento) & $\checkmark$ & $\checkmark$ & $\checkmark$ \\
\hline Manobras de estacionamento & $\checkmark$ & $\checkmark$ & $\checkmark$ \\
\hline Representação do movimento da manobra de estacionamento & $x$ & $x$ & $x$ \\
\hline Associação de tempos às manobras(duração da manobra) & $\checkmark$ & $\checkmark$ & $\checkmark$ \\
\hline Estacionamento em fila dupla & $x$ & $x$ & $x$ \\
\hline Estacionamento na faixa de tráfego & $\checkmark$ & $\checkmark$ & $\checkmark$ \\
\hline Visualização em 2D & $\checkmark$ & $\checkmark$ & $\checkmark$ \\
\hline Visualização em 3D & $\checkmark$ & $\checkmark$ & $\checkmark$ \\
\hline Registro das velocidades médias nos links, por faixa de tráfego & $\checkmark$ & $\checkmark$ & $\checkmark$ \\
\hline Registro da formação de filas & $\checkmark$ & $\checkmark$ & $\checkmark$ \\
\hline Cálculo da emissão de gases poluentes de cada veículo & $\checkmark$ & $\checkmark$ & $\checkmark$ \\
\hline Disponibilidade de versão acadêmica gratuita & $x$ & $x$ & $\checkmark$ \\
\hline
\end{tabular}

conclusão

Dentre os três softwares candidatos, todos atendem aos mesmos requisitos considerados necessários para a simulação dos movimentos dos veículos de carga e estimação dos impactos locais. O VISSIM, porém, foi o que apresentou interface mais amigável e menor complexidade em relação às adaptações necessárias, principalmente no que diz respeito à modelagem das rotas de entrega, feita de forma bastante simples através de arquivos de entrada de dados do tipo texto, conforme explicado em detalhes na seção 7.2.4. Além disso, foi o único software com disponibilidade de versão acadêmica gratuita, embora este não tenha sido um requisito decisivo na escolha. $\mathrm{O}$ software pertence à empresa alemã PTV (Planung Transport Verkehr) e a versão utilizada neste trabalho foi a 6.00. 
O VISSIM é uma ferramenta de simulação microscópica, orientada por incrementos de tempo e baseada em comportamento, para a modelagem do tráfego de veículos e do fluxo de pedestres. O VISSIM simula o fluxo de tráfego movendo unidades motorista-veículo através de uma rede, sob a regência de um modelo de fluxo de tráfego baseado em um modelo psicofísico de percepção, desenvolvido por Wiedemann (1974). Cada motorista possui características específicas de comportamento, que é atribuído a um veículo específico, ou seja, o comportamento do motorista corresponde às capacidades técnicas de seu veículo.

Os atributos que caracterizam cada motorista-veículo podem ser subdivididos em três categorias:

- Especificações técnicas do veículo: comprimento do veículo, velocidade máxima, poder de aceleração, etc.;

- Limites de percepção psicofísica do motorista: percepção de segurança, propensão ao risco, memória, etc.;

- Interdependência das unidades motorista-veículo: referência em relação aos outros veículos na mesma faixa ou na faixa adjacente, referência em relação à próxima sinalização, etc.;

A rede de simulação é construída a partir de objetos, de diversos tipos, constituídos por um conjunto de atributos que o definem. São exemplos de objetos no VISSIM: os links da rede, as áreas de velocidade reduzidas, os semáforos, os inputs de veículos, as áreas de estacionamento, as decisões de rotas dos veículos e os pontos de coleta de dados. Por exemplo, ao objeto 'vehicle input', o qual gera os veículos na rede de simulação, são associados atributos como: número, nome, link, posição no link, volume de veículos (gerados na rede) e sua composição, em cada intervalo de tempo.

\subsection{MODELAGEM NO VISSIM}

A modelagem do ambiente de microssimulação no VISSIM pode ser dividida em quatro etapas principais:

i. Modelagem do sistema viário; 
ii. Modelagem do fluxo de veículos em geral;

iii. Calibração e validação do modelo;

iv. Modelagem dos movimentos dos veículos de carga.

A área de simulação escolhida tem aproximadamente $0,28 \mathrm{~km}^{2} \mathrm{e}$ faz parte da área de estudo, como mostra a Figura 7.1

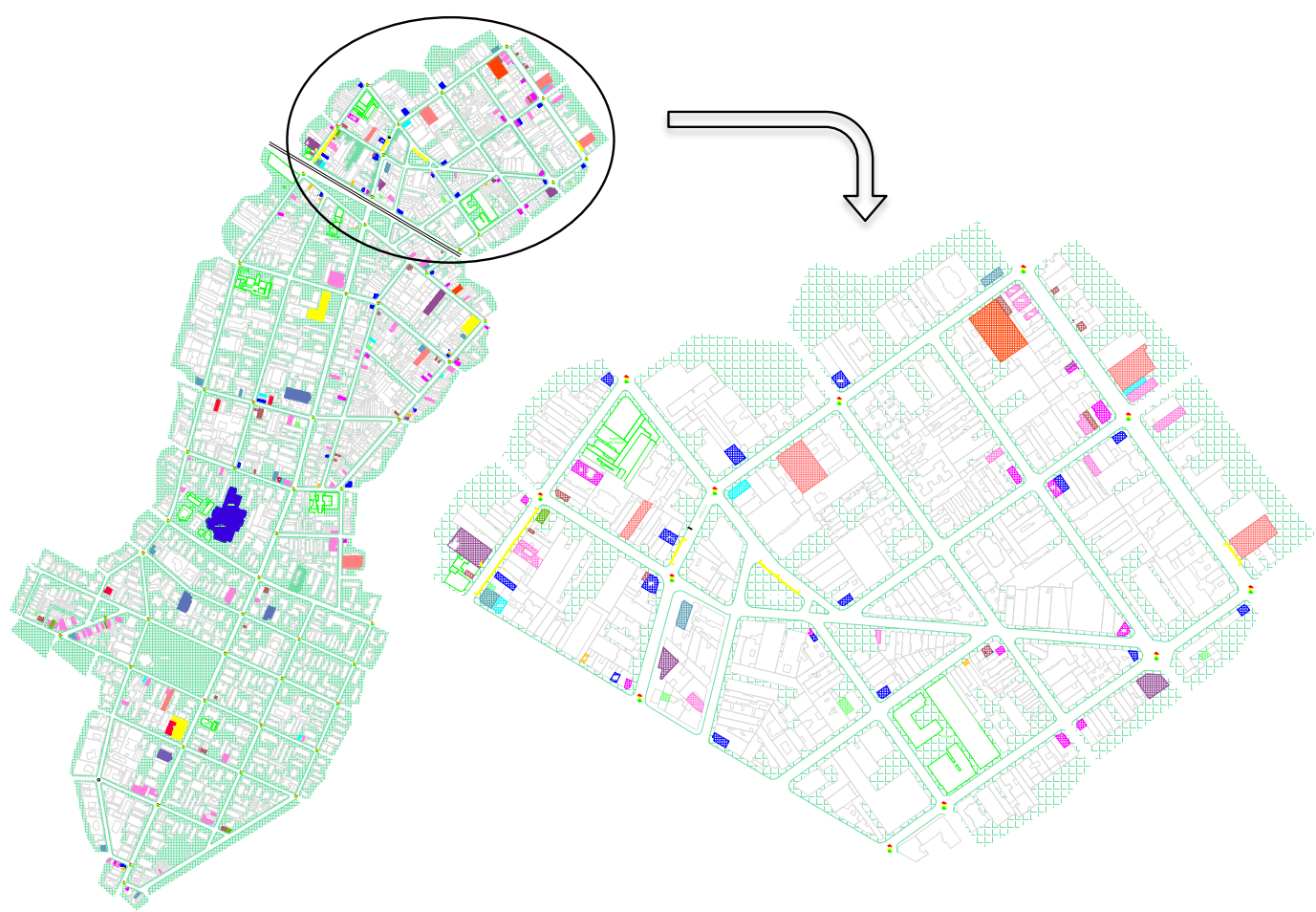

Figura 7.1 - Área escolhida para a simulação

A área está inserida no bairro de Santa Cecília e é delimitada pelas seguintes vias: Rua Albuquerque Lins, Alameda Eduardo Prado, Alameda Barão de Limeira, Alameda Nothman e Avenida São João. Ao todo, 66 estabelecimentos do ramo de alimentos e bebidas estão localizados nessa área, dentre eles:

- 3 açougues;

- 2 adegas / distribuidoras de bebidas;

- 1 bar premium;

- 3 bares tradicionais;

- 4 bombonières; 
- 4 cafés / docerias / casas de salgados / casas de sucos;

- 1 hortifruti;

- 10 lanchonetes;

- 15 lanchonetes / restaurantes;

- 3 lojas de conveniência;

- 3 padarias;

- 9 restaurantes;

- 8 supermercados pequenos;

O período escolhido para a simulação compreende o horário das $6 \mathrm{~h}$ às $12 \mathrm{~h}$ de uma quartafeira. A escolha justifica-se no fato de que, a partir dos dados das observações das entregas, realizadas durante a coleta de dados, esse foi o período que apresentou maior número de ocorrências de entregas (cerca de $20 \%$ do total das entregas observadas em estabelecimentos da mesma classe que os existentes na área de simulação).

\subsubsection{Modelagem do Sistema Viário}

A modelagem do sistema viário compreende:

- A representação das vias e suas interseções na forma de arcos (links), nós e conectores (ligação entre dois links), considerando a geometria das mesmas (número e largura das faixas, raios de curvatura, etc.) e os sentidos permitidos para os fluxos de veículos;

- A representação dos dispositivos de controle de tráfego (sinais de 'pare', 'dê a preferência', semáforos e regulamentações de estacionamento).

O levantamento de dados que caracterizam o sistema viário são importantes para que se represente adequadamente a região de interesse. O Quadro 7.3, a seguir, apresenta o conjunto de dados necessários à modelagem do sistema viário, assim como o método utilizado para a coleta dos mesmos. 
Quadro 7.3 - Métodos de coleta adotados para a determinação dos dados necessários à modelagem do sistema viário

\begin{tabular}{|c|c|}
\hline Conjunto de Dados & Método de Coleta \\
\hline Número e largura das faixas & Site do google street view e medição em campo \\
\hline Localização dos sinais de "pare" & Levantamento em campo \\
\hline Localização do semáforos & Levantamento em campo \\
\hline $\begin{array}{l}\text { Localização e tamanho das áreas e vagas de } \\
\text { estacionamento, (incluindo vagas de táxi e } \\
\text { exclusivas para carga e descarga) }\end{array}$ & Levantamento e medição em campo \\
\hline Tempos semafóricos & $\begin{array}{l}\text { Medição em campo durante o período entre } 6 \text { h e } 12 \mathrm{~h} \text { às } \\
\text { quartas-feiras; realizada com intervalos de uma hora por } \\
\text { dez ciclos em cada um dos semáforos identificados }\end{array}$ \\
\hline
\end{tabular}

O mapeamento dos semáforos e das áreas de estacionamento, assim como os valores obtidos para os tempos semafóricos estão apresentados, respectivamente, nas Figuras C.1 e C.2 do Anexo C.

A representação das vias e suas interseções, no VISSIM, se deu através da inserção de links, nós e conectores, utilizando como base o mesmo mapa digital usado no mapeamento dos estabelecimentos identificados na área em estudo, conforme mostram as Figuras 7.2, $7.3 \mathrm{e}$

\section{4 .}

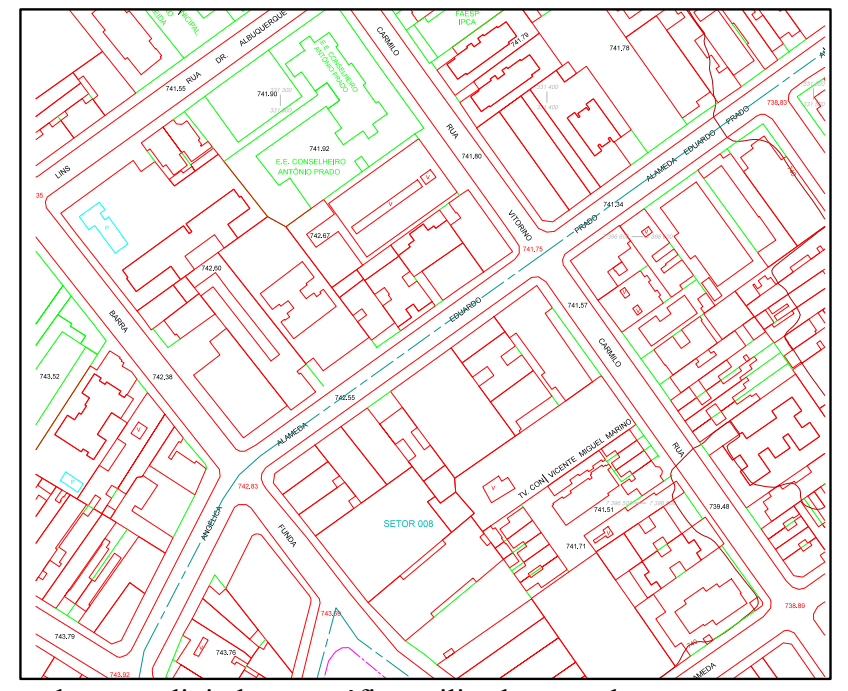

Figura 7.2 - Parte do mapa digital cartográfico utilizado como base para a representação das vias 


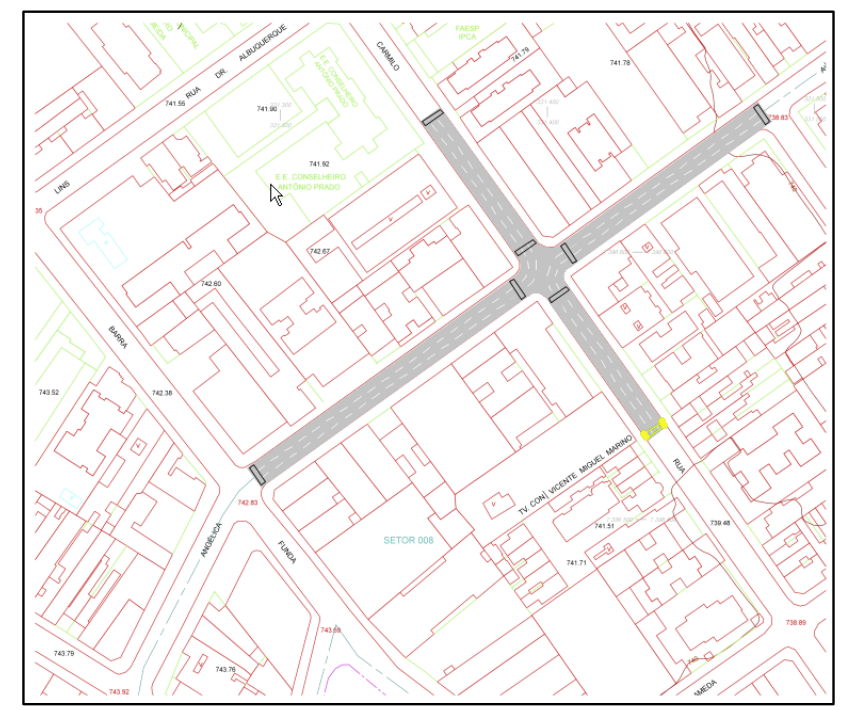

Figura 7.3 - Exemplo da inserção de links e nós sobre o mapa base

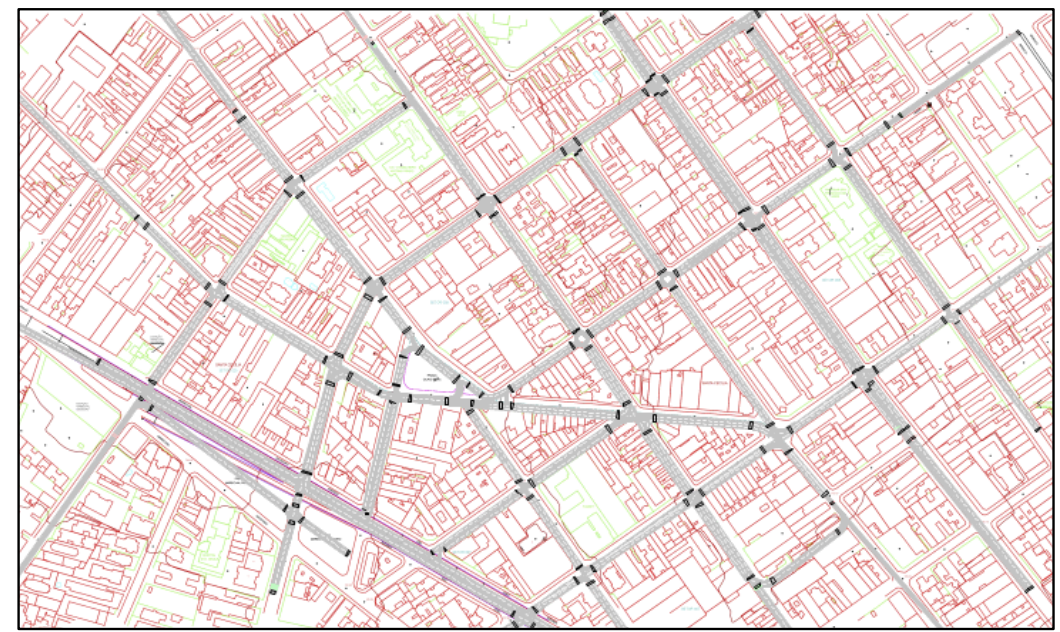

Figura 7.4 - Rede viária completa da área de simulação

A Figura 7.5, a seguir, ilustra a representação gráfica da modelagem, no VISSIM, dos semáforos, sinais de 'pare' e áreas de estacionamento.
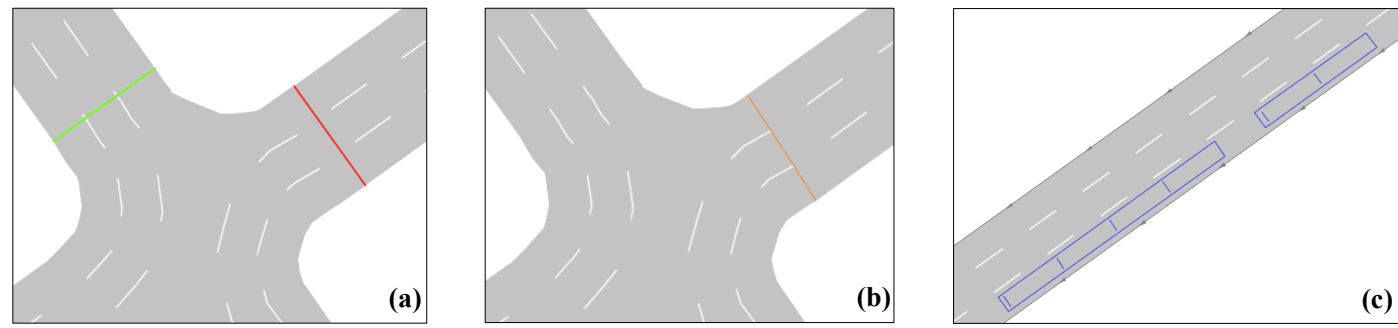

Figura 7.5 - Representação gráfica da modelagem de (a) semáforos, (b) sinais de 'pare' e (c) áreas de estacionamento 
Em cada interseção foram também modeladas as regras de conflito de tráfego de veículos. Essa regras devem ser definidas para todas as áreas de conflito da rede, as quais ocorrem nas seguintes situações:

- Cruzamento (interseção): dois links que se cruzam

- Junção: dois conectores que chegam ao mesmo link ou um conector que chega a um link com fluxo de veículos à montante.

- Ramificação: dois conectores que saem de um mesmo link ou um conector que sai de um link com fluxo de veículos à jusante.

Para essas áreas, define-se qual o fluxo que tem o direito de passagem (em verde) e qual o fluxo que dá o direito de passagem (em vermelho), como exemplificado na Figura 7.6.

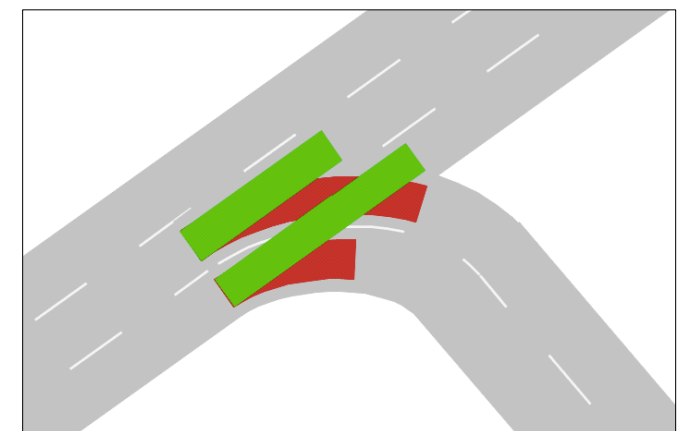

Figura 7.6 - Exemplo da modelagem de uma regra de conflito

Para a modelagem das áreas de estacionamento identificadas em campo, essas foram consideradas, no VISSIM, como do tipo 'real parking space', quais representam vagas de estacionamento reais, onde os veículos ficam parados durante certo tempo para depois seguirem em sua rota. Essa tipologia foi adotada para todas as áreas de estacionamento consideradas na modelagem: áreas com vagas regulares, áreas com vagas exclusivas para carga e descarga e áreas com vagas de táxi. No VISSIM, uma área de estacionamento corresponde a uma conjunto de vagas, sendo vaga o espaço destinado ao estacionamento de um veículo, conforme ilustra a Figura 7.7, a seguir. 


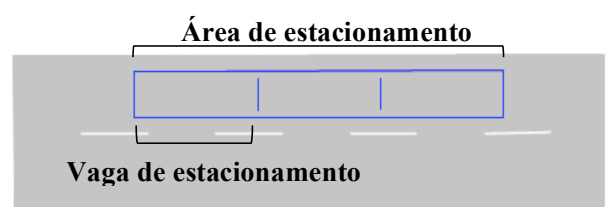

Figura 7.7 - Diferenciação entre uma área de estacionamento e uma vaga de estacionamento

Para cada área de estacionamento do tipo 'real parking space' devem ser definidos: (i) sua extensão total, (ii) o tamanho de cada vaga, (iii) a capacidade (i.e., quantas vagas cabem na área) e (iv) sua ocupação inicial (em número e composição de veículos). Podem ainda ser definidos: (i) o tempo de manobra [i.e., tempo no qual o veículo em manobra de estacionamento bloqueia o fluxo na faixa adjacente (Figura 7.8)], (ii) o período no qual é permitido utilizar a área de estacionamento, (iii) a duração máxima permitida para o estacionamento, (iv) a atração de cada vaga (i.e., qual vaga tem prioridade de escolha dentro da área de estacionamento) e (v) uma zona (necessária para a que área de estacionamento possa ser modelada como um destino na viagem de um veículo, conforme será detalhado adiante).

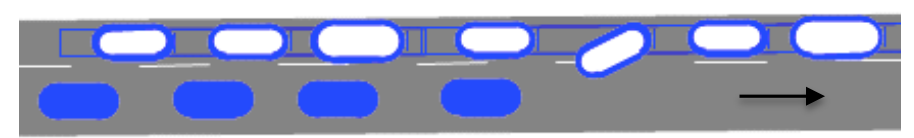

Figura 7.8 - Exemplo de fluxo de veículos bloqueado devido à manobra de estacionamento

Além das áreas do tipo 'real parking space', dois outros tipos de áreas de estacionamento podem ser utilizados. Áreas do tipo 'zone connector' são utilizadas como origens e destinos de veículos e, em geral, são inseridas nos extremos da rede; através delas os veículos são inseridos e removidos da rede instantaneamente, uma vez concluído o seu trajeto previsto. Áreas do tipo 'abstract parking lot' são utilizadas para a modelagem de pátios de estacionamento de alta capacidade, nos quais os veículos permanecem durante um período mais longo do que o de simulação; os veículos são excluídos da rede assim que estacionam em vagas desse tipo. Esse tipo de área de estacionamento não será utilizado na modelagem aqui apresentada.

\subsubsection{Modelagem do Fluxo de Veículos em Geral}

Os fluxos de veículos que circulam pela rede no período de simulação foram obtidos através da determinação dos estados de tráfego (VILARINHO, 2008), os quais contêm o número de 
veículos, por período, em cada seção de entrada da rede, e as proporções de movimentos de giro nas interseções, quando existir mais de um movimento permitido. As seções de entrada (ou saída) na rede correspondem ao início (ou final) dos links localizados nos extremos da mesma. Os movimentos de giro, por sua vez, caracterizam os movimentos de curva dos veículos nas interseções.

Além dos fluxos de veículos, as velocidades desejadas para os mesmos em cada link e a ocupação das áreas de estacionamento também foram definidas, conforme detalha o Quadro 7.4. Os valores obtidos para os dados coletados são exibidos nas Tabelas D.1 a D.6 do Anexo D.

Quadro 7.4 - Métodos de coleta adotados para a determinação dos dados necessários à modelagem do fluxo de veículos em geral

Conjunto de Dados Método de Coleta

Fluxos de veículos

Velocidade desejada para os veículos ${ }^{11}$

Porcentagem de ocupação das áreas de estacionamento regular

Porcentagem de ocupação das áreas de carga e descarga
Contagem, em campo, do número de veículos que passam pelas seções de entrada da área de simulação e dos movimentos de giro em cada uma das interseções; contagem realizada a cada 45 minutos, durante quinze minutos, no período entre $6 \mathrm{~h}$ e $12 \mathrm{~h}$, às quartas-feiras. Dois tipos de veículos foram considerados: veículos de passeio (automóveis) e veículos de carga (caminhões de todos os tipos e tamanhos)

Registro das velocidades praticadas em cada segmento da rede; realização de um percurso de automóvel, passando por todos os segmentos da rede, realizado em cada intervalo de hora, entre $6 \mathrm{~h}$ e $12 \mathrm{~h}$, por três quartas-feiras consecutivas.

Registro do número de vagas ocupadas em dez segmentos de via, localizados conforme a Figura 7.9; registro feito em cada intervalo de hora, no período entre $6 \mathrm{~h}$ e $12 \mathrm{~h}$, e em dias aleatórios, entre segunda e sexta-feira. Os valores obtidos foram adotados para os outros segmentos da mesma via.

Registro do número de vagas ocupadas em todas as áreas de carga e descarga da área de simulação; registro feito em cada intervalo de hora, no período entre $6 \mathrm{~h}$ e $12 \mathrm{~h}$, e em dias aleatórios, entre segunda e sexta-feira;

${ }^{11}$ Conforme explicado no Quadro 7.4, as velocidades desejadas para os veículos foram definidas através de registros da velocidade real praticada em cada segmento de via. Em rodadas preliminares da simulação, no entanto, utilizou-se o limite de velocidade estipulado para cada via como valor adotado para a velocidade desejada. Pode-se observar, porém, que as velocidades praticadas pelos veículos, durante a simulação, eram maiores do que aquelas observadas na situação real, razão pela qual optou-se por adotar a velocidade praticada registrada de acordo com a coleta de dados. 


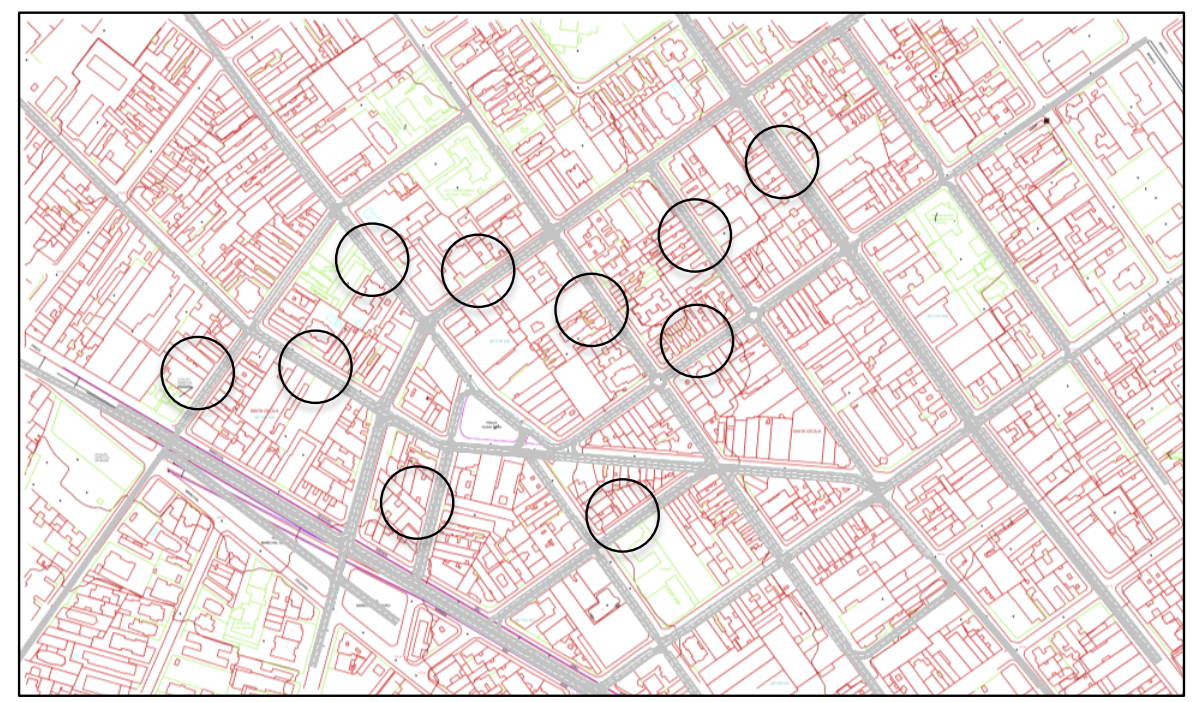

Figura 7.9 - Locais de registro da ocupação das vagas de estacionamento

No VISSIM, os volumes de veículos gerados na rede foram definidos por seção de entrada e por período, sendo que a entrada de veículos em cada seção é distribuída uniformemente ao longo do período para o qual o volume de veículos foi atribuído. Por exemplo, se das $6 \mathrm{~h}$ às7h o número de veículos gerados na seção E1 é 600, então a taxa de entrada de veículos nessa seção é de um veículo a cada seis segundos. As Figuras 7.10 mostra a janela do VISSIM onde são inseridos os dados referentes aos volumes de veículos gerados (objeto do tipo 'vehicle inputs'). Já a Figura 7.11 exibe como se dá entrada de um veículo na rede durante a simulação.

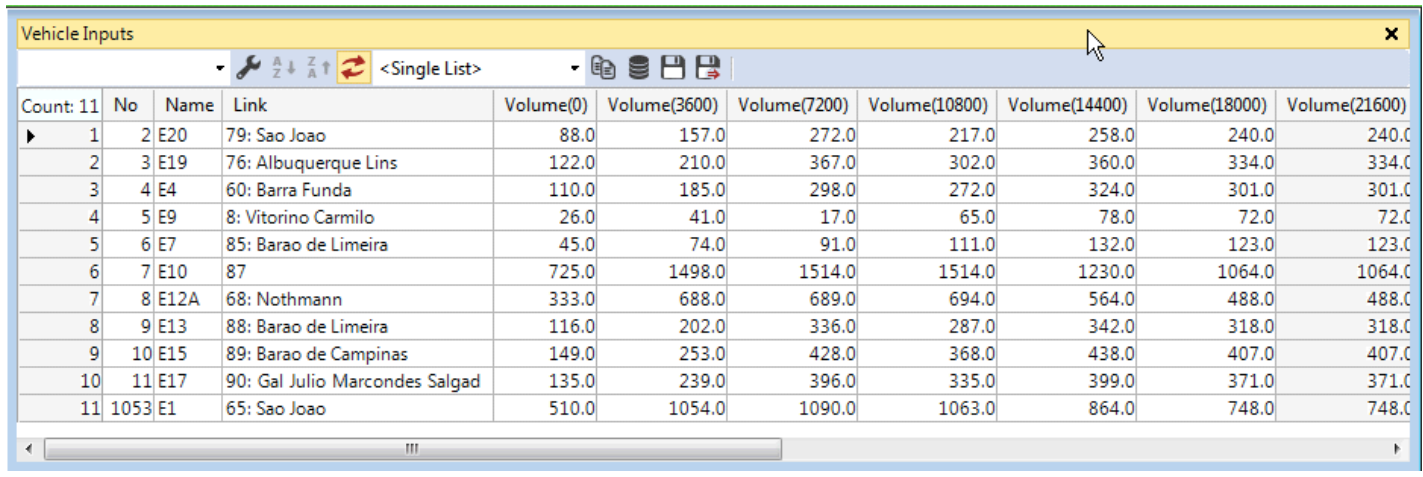

Figura 7.10 - Exemplo dos dados de entrada para a geração de veículos através do objeto 'vehicle inputs' 


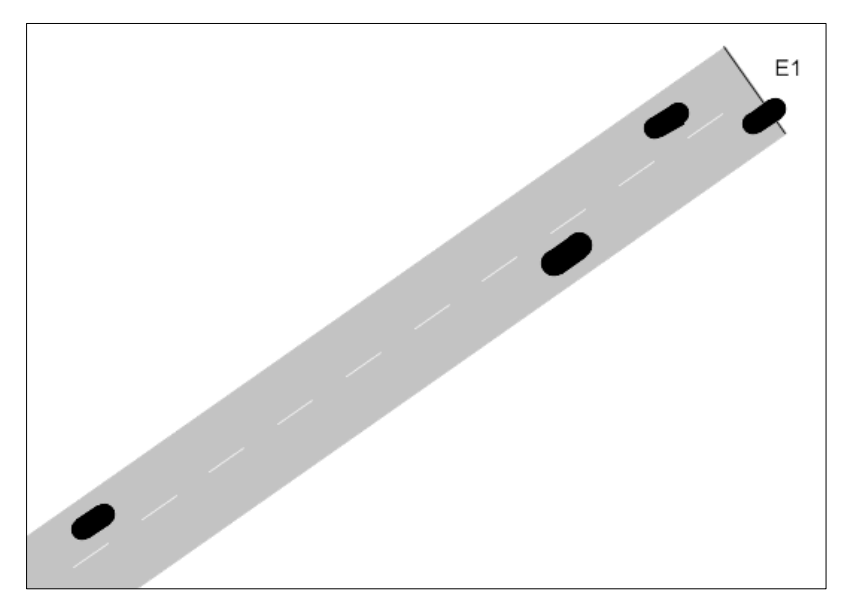

Figura 7.11 - Entrada (geração) de veículos na rede durante a simulação

A modelagem dos veículos que compõem o tráfego geral considerou três modelos de veículo de passeio ('passenger car'): (i) compacto, (ii) sedan e (iii) SUV, os quais foram distribuídos uniformemente dentre os volumes coletados. O Quadro 7.5, a seguir, apresenta as dimensões adotadas para cada um dos modelos considerados, assim como o veículo utilizado como referência para determinação das mesmas:

Quadro 7.5 - Dimensões dos modelos de veículos de passeio adotados na modelagem

$\begin{array}{ccc}\text { Modelo } & \begin{array}{c}\text { Dimensões } \\ \text { (comprimento x largura) }\end{array} \\ \text { Compacto } & 3.605 \mathrm{~m} \times 1.645 \mathrm{~m} \\ \text { Sedan } & 4.169 \mathrm{~m} \times 1.939 \mathrm{~m} & \text { Veículo de Referência } \\ \text { SUV } & 4.795 \mathrm{~m} \times 2.208 \mathrm{~m}\end{array}$

No VISSIM, esses veículos foram modelados sob o mesmo tipo, classe e categoria de veículo, diferindo apenas em suas dimensões. O VISSIM utiliza essas três classificações para agrupar veículos de acordo com suas características. A classificação por tipo permite agrupar veículos com as mesmas características técnicas de condução, incluindo 
comportamentos de aceleração e desaceleração; além disso o tipo de veículo é a classificação considerada para o cálculo das emissões de poluentes. Diferentes tipos de veículos podem ser agrupados em classes, uma vez que elas servem como base para a atribuição de diversas funções do VISSIM. Por fim, as categorias contêm veículos que possuem comportamentos similares de interação no tráfego. A criação de tipos e classes de veículos é ilimitada. Novas categorias, no entanto, não podem ser criadas pelo usuário, devendo ser utilizadas aquelas que são padrão do VISSIM.

Os movimentos de giro nas interseções, em cada intervalo horário, foram modelados através do objeto do tipo 'static vehicle route decision'. Para cada veículo, em cada ponto da rede onde há mais de um movimento possível, a decisão por qual deles realizar é determinada a partir de um valor de porcentagem associado a cada movimento. O ponto da rede onde existe mais de um movimento possível é representado pela seção de início da rota, [em rosa na Figuras 7.12 (a) e (b)]. O movimento em si, é definido pela seção de fim da rota [em ciano na Figuras 7.12 (a) e (b)], a qual define a trajetória do veículo [em amarelo na Figuras 7.12 (a) e (b)]. Por fim, as porcentagens que determinam o número de veículos que fará cada um dos movimentos possíveis corresponde aos valores 'RelFlow' associados a cada um deles, conforme exibe a Figura 7.13.
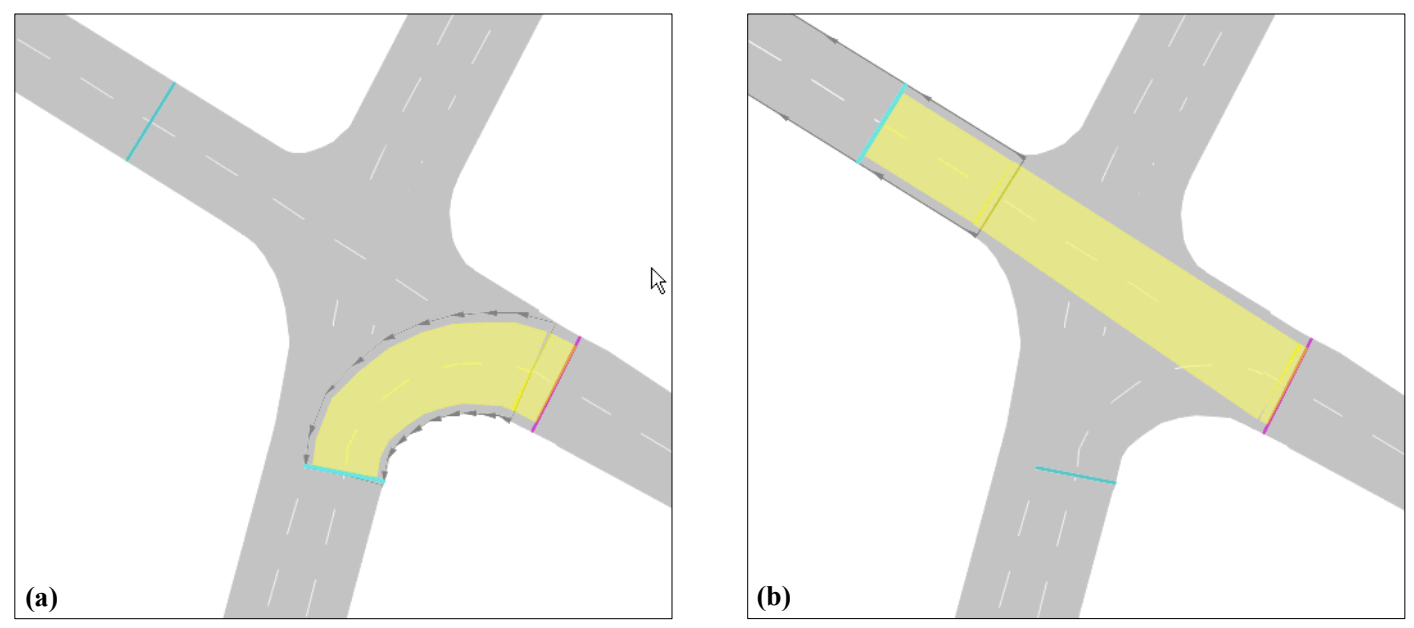

Figura 7.12 - Representação gráfica da modelagem dos movimentos de giro em uma interseção 


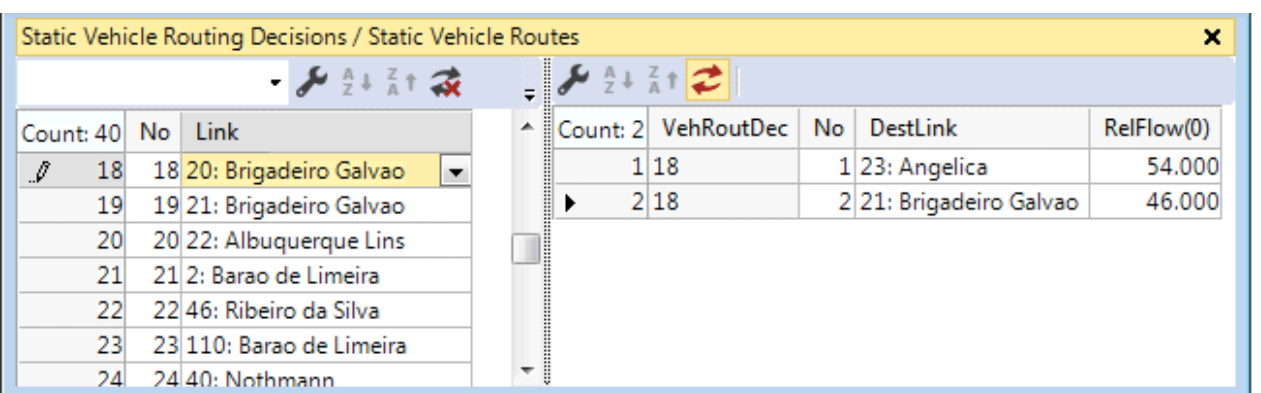

Figura 7.13 - Exemplo dos dados de entrada para a definição dos movimentos de giro em uma interseção através do objeto 'static vehicle route decision'

As velocidades adotadas em cada segmento de link, apresentadas na tabela D.3 do Anexo D, consideram a média das velocidades registradas no período de medição (das $6 \mathrm{~h}$ às $12 \mathrm{~h}$ ). Considerando, porém, o desvio padrão para as velocidades registradas nos seis períodos de medição, este não ultrapassa 3,5 , razão pela qual o valor médio foi adotado para todo o período de simulação.

No VISSIM, a velocidade desejada para os veículos são atribuídas aos mesmos no momento em que esses cruzam as chamadas 'desired speed decision' e, a partir daí, não são alteradas a menos que o veículo passe por outra 'desired speed decision'. Sendo assim, diversos objetos do tipo 'desired speed decision' (em amarelo na Figura 7.14) foram inseridos na rede, um ao início de cada segmento de link. A velocidade atribuída a cada um desses objetos corresponde àquela adotada como velocidade desejada paro o segmento de link no qual os mesmos estão localizados. Tais velocidades foram definidas a partir dos registros das velocidades praticadas nesses segmento, conforme explicado no Quadro 7.4.

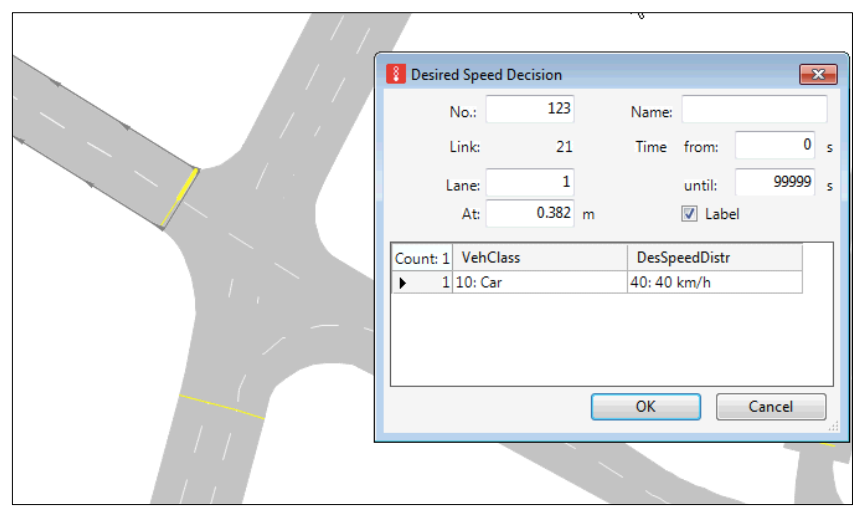

Figura 7.14 - Representação gráfica e exemplo dos dados de entrada de objetos do tipo 'desired speed decision' 
Já nos conectores em curva as velocidades foram modeladas através de objetos do tipo 'reduced speed areas' (Figura 7.15). Nesse caso, o veículo tem sua velocidade alterada

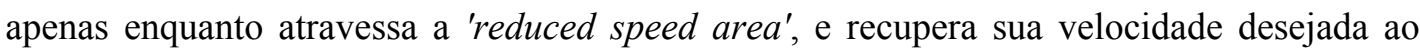
final do percurso.

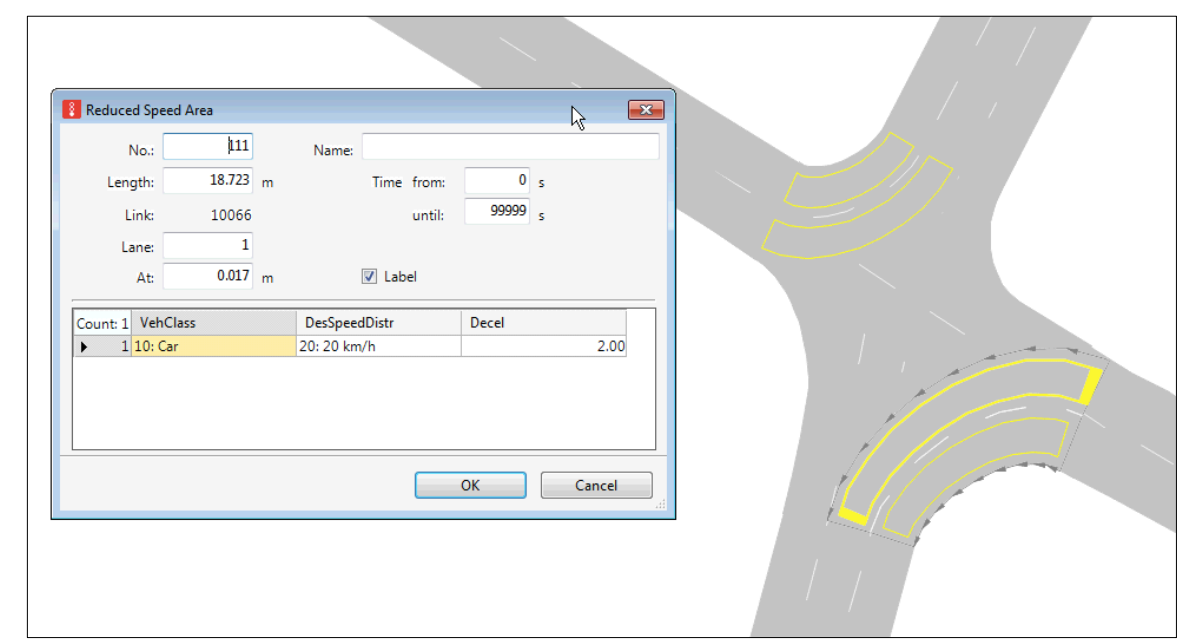

Figura 7.15 - Representação gráfica e exemplo dos dados de entrada de objetos do tipo 'reduced speed areas'

Para ocupação das vagas de estacionamento foram considerados os valores adotados para as porcentagens de ocupação, em cada intervalo horário, obtidos a partir da coleta de dados, conforme explicado no Quadro 7.4. A ocupação no primeiro intervalo horário, das $6 \mathrm{~h}$ às $7 \mathrm{~h}$ foi modelada como sendo a ocupação inicial das áreas de estacionamento. Para a ocupação nos horários posteriores, uma nova classe de veículos ('parking cars') foi criada. Os veículos pertencentes a essa classe fazem parte do tráfego geral e têm a função de, ao entrarem na rede, se dirigirem até as vagas de estacionamento, de forma que as porcentagens de ocupação calculadas, para cada intervalo horário, sejam satisfeitas. As rotas dos veículos foram modeladas através de objetos do tipo 'parking routing decision', nos quais os destinos dos veículos são as vagas das áreas de estacionamento (seção de destino da rota localizada no início da área de estacionamento, conforme mostra a Figura 7.16). Para cada 'parking routing decision', em cada intervalo horário, são atribuídas: (i) as classes de veículos, (ii) a porcentagem dos veículos dessa classe que seguem para o estacionamento de destino ao passarem pela seção de início da rota (em rosa na Figura 7.16) e (iii) o tempo de permanência no estacionamento. 


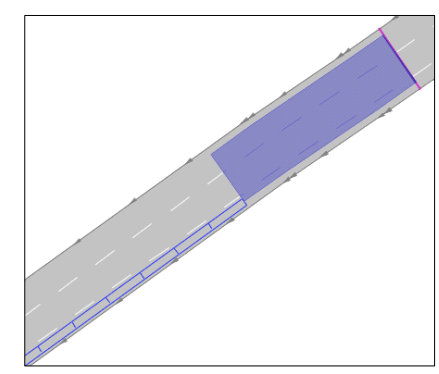

Figura 7.16 - Representação gráfica da modelagem das rotas dos veículos da classe 'parking cars' através de objetos do tipo 'parking routing decision'

Por fim, os parâmetros que regem o fluxo dos veículos e o comportamento dos condutores também foram definidos (Figuras 7.17, 7.18, 7.19 e 7.20). À exceção da distância lateral a ser mantida entre os veículos ['keep lateral distance to vehicles on next lane(s)'], em destaque na Figura 7.19, e da possibilidade de ultrapassagem na mesma faixa ('overtake on same lane'), também em destaque na Figura 7.19, todos os parâmetros foram mantidos com os valores padrão do VISSIM.

Manter uma distância lateral mínima faz com que veículos que trafegam na faixa adjacente a uma faixa onde ocorre uma manobra de estacionamento percebam essa interferência e alterem seu comportamento. Além disso, permitir a ultrapassagem na mesma faixa faz com que esses mesmos veículos ultrapassem o veículo em manobra, se a distância lateral mínima for atendida. A alteração dos parâmetros mencionados é valida uma vez que as interferências causadas pelo estacionamento dos veículos de carga deverão ser observadas durante a simulação.

Esses parâmetros alimentam o modelo de tráfego do VISSIM, o qual engloba um modelo psicofísico do veículo seguidor ('psycho-fisical car following model') para os movimentos longitudinais dos veículos e um algoritmo baseado em regras ('rule-based algorithm') para os movimentos laterais dos veículos, ambos baseados nos trabalhos desenvolvidos por Wiedemann (1974 e 1991). Mais especificamente, o modelo Wiedemann 74 é o adotado nesse caso, por ser o mais compatível com os movimentos de veículos que trafegam em áreas urbanas.

O conceito básico do modelo Wiedemann 74 se baseia no fato de que o motorista de um veículo que se move mais rapidamente (veículo A) começa a desacelerar assim que ele atinge seu limite individual de percepção em relação a um veículo que se move mais 
lentamente (veículo B). Como esse motorista (A) não pode determinar a velocidade exata do veículo mais lento (B), sua velocidade é reduzida até menos do que a velocidade daquele veículo (B) até que ele (A), ao atingir uma nova percepção, começa a acelerar novamente. Os diferentes comportamentos dos motoristas são modelados através de funções de distribuição de velocidade e das distâncias aceitáveis entre o seu e os outros veículos.

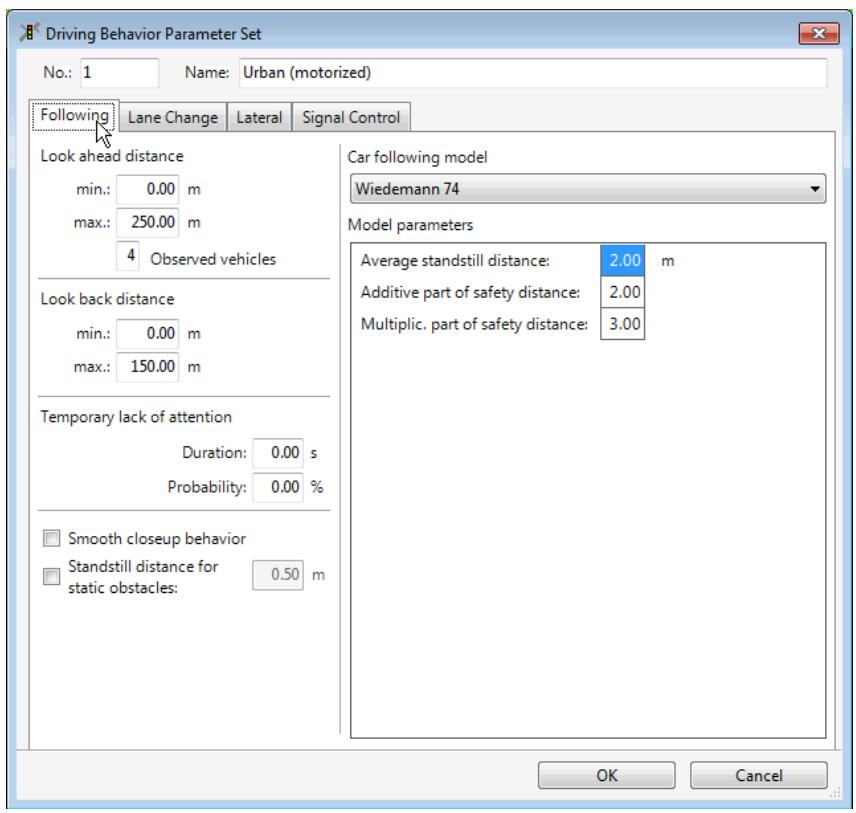

Figura 7.17 - Parâmetros para a modelagem do comportamento dos motoristas - distâncias longitudinais entre os veículos

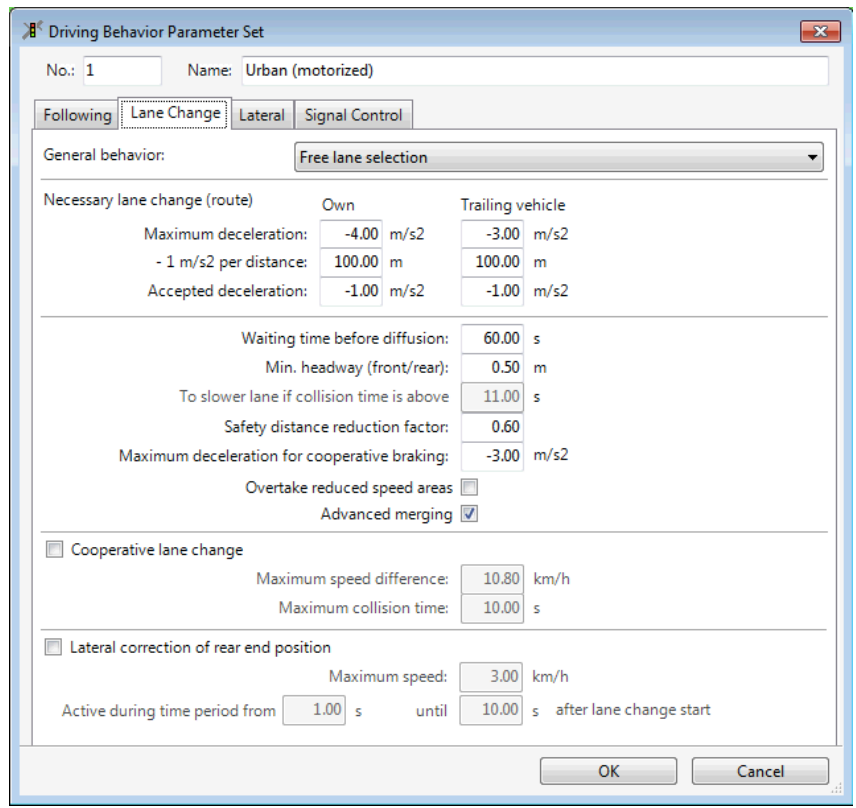

Figura 7.18 - Parâmetros para a modelagem do comportamento dos motoristas - mudança de faixa 


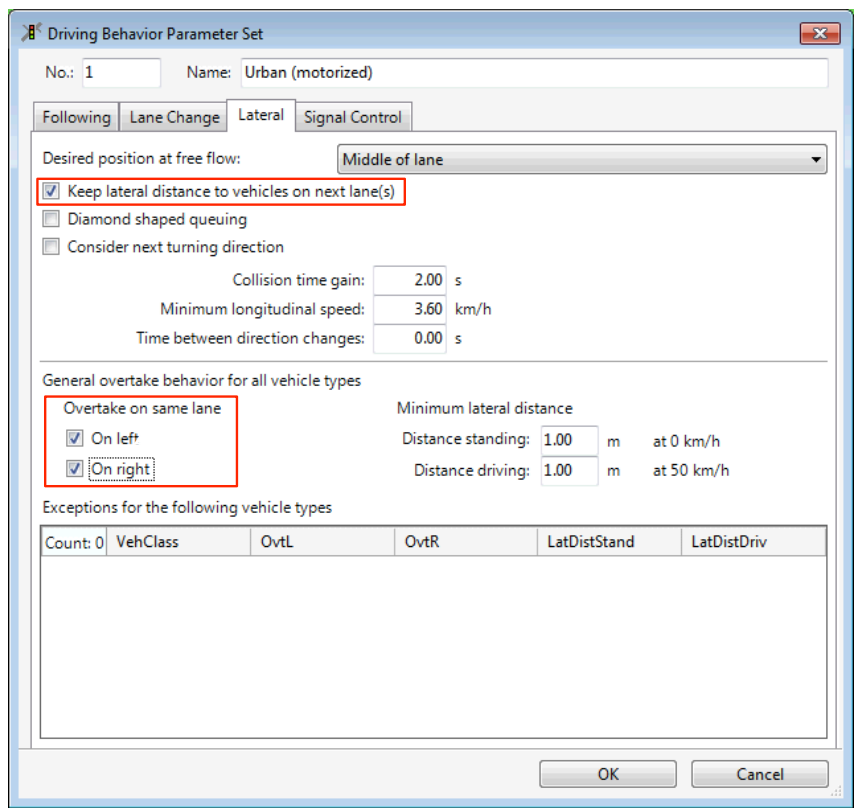

Figura 7.19 - Parâmetros para a modelagem do comportamento dos motoristas - distâncias laterais entre os veículos

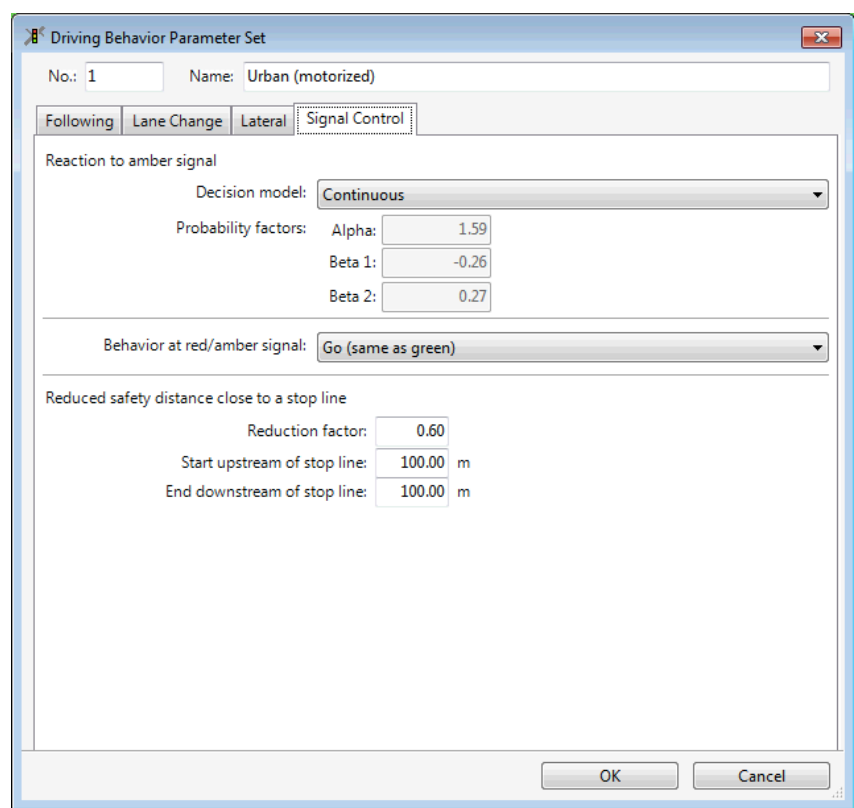

Figura 7.20 - Parâmetros para a modelagem do comportamento dos motoristas - reações aos semáforos

\subsubsection{Calibração e Validação do Modelo}

O próximo passo após a modelagem dos fluxos de veículos é a validação do modelo de microssimulação, i.e., determinar se o mesmo representa adequadamente o sistema real. Esse processo consiste num método iterativo envolvendo a calibração dos parâmetros do modelo e a comparação do comportamento do mesmo com o sistema real. 
$\mathrm{Na}$ calibração, as variáveis do modelo são ajustadas de modo a buscar melhorar sua capacidade de reprodução da situação real. É necessário então definir as variáveis que vão ser o alvo da calibração e comparar seus valores reais (observados em campo) aos resultantes da aplicação do modelo (valores simulados). Essa comparação é realizada quantas vezes forem necessárias até que se atinja um limite de similaridade entre os valores comparados, limite este definido como aceitável para a análise em questão.

Neste trabalho, a calibração do modelo baseou-se na comparação entre os valores reais e os valores simulados de duas variáveis: (i) volume de veículos e (ii) velocidade dos veículos. Foram inseridos, na rede de simulação, 14 pontos de coleta de dados (objetos do tipo 'data collection points'), capazes de registrar o número de veículos que passam por eles e a velocidade dos mesmos. Cada segmento de via escolhido para receber um ponto de registro, teve o mesmo localizado no ponto médio da sua extensão, como mostra a Figura 7.21.

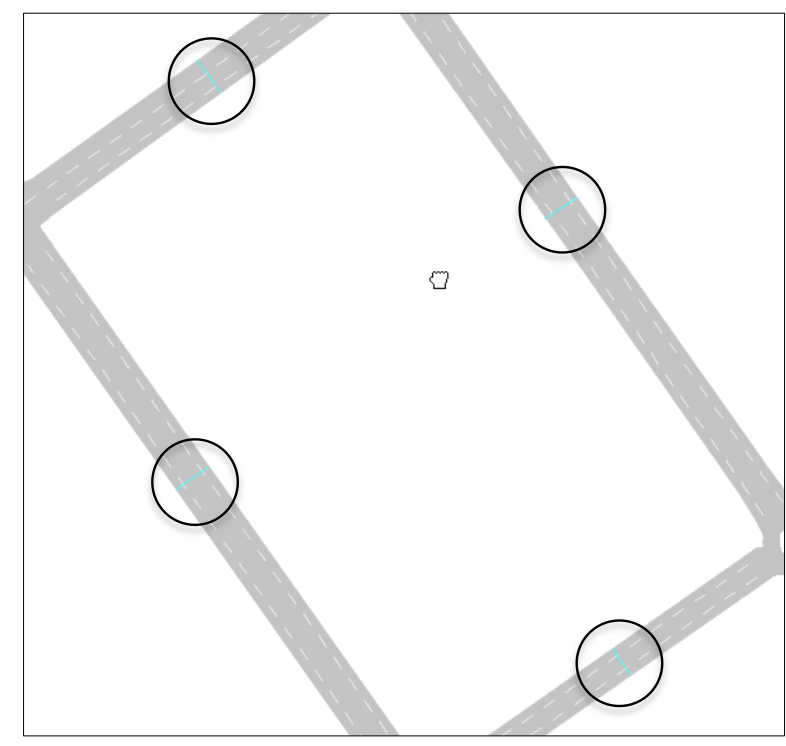

Figura 7.21 - Exemplo da localização dos pontos de coleta de dados ('data collection points')

Para esses segmentos de via foram registrados, em campo, os volumes de veículos. O registro foi feito para o mesmo período da simulação (quarta-feira das $6 \mathrm{~h}$ às $12 \mathrm{~h}$ ), dividido em intervalos de uma hora. Sendo assim foi possível comparar os valores registrados em campo (valores reais) com aquele obtidos a partir da simulação. Os resultados obtidos para a primeira rodada, exibidos na Tabela 7.1, mostram um erro percentual médio de 33,7\% para a variável 'volume de veículos'. Já a variável 'velocidade' apresentou um erro percentual médio de $6,1 \%$. 
Tabela 7.1 - Comparação entre os valores reais e simulados das variáveis de calibração (volume de veículos e velocidades) - primeira iteração

\begin{tabular}{|c|c|c|c|c|c|c|c|}
\hline \multirow[b]{2}{*}{ Período } & \multirow[b]{2}{*}{ Segmento de Via (ponto de registro } & \multicolumn{3}{|c|}{ Contagem de veículos } & \multicolumn{3}{|c|}{ Velocidade } \\
\hline & & $\begin{array}{c}\text { Registro } \\
\text { (simulação) }\end{array}$ & $\begin{array}{l}\text { Registro } \\
\text { (campo) }\end{array}$ & $\begin{array}{c}\text { erro } \\
\text { percentual }\end{array}$ & $\begin{array}{c}\text { Registro } \\
\text { (simulação) }\end{array}$ & $\begin{array}{l}\text { Registro } \\
\text { (campo) }\end{array}$ & $\begin{array}{c}\text { erro } \\
\text { percentual }\end{array}$ \\
\hline \multirow{15}{*}{ 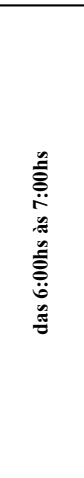 } & Albuquerque Lins - 2 & 169 & 225 & $25,0 \%$ & 41,7 & 40,5 & $3,0 \%$ \\
\hline & Brigadeiro Galvão - 2 & 143 & 356 & $59,9 \%$ & 42,4 & 42,7 & $0,7 \%$ \\
\hline & Albuquerque Lins - 4 & 123 & 131 & $5,8 \%$ & 42,8 & 41,2 & $3,9 \%$ \\
\hline & Vitorino Carmilo (sentido SO) - 3 & 145 & 163 & $11,2 \%$ & 33,7 & 41,3 & $18,4 \%$ \\
\hline & São João (sentido L) - 4 & 504 & 501 & $0,5 \%$ & 51,3 & 51,8 & $1,0 \%$ \\
\hline & Angélica - 2 & 429 & 855 & $49,8 \%$ & 41,3 & 39,8 & $3,6 \%$ \\
\hline & Angélica - 1 & 405 & 717 & $43,5 \%$ & 41,0 & 42,0 & $2,3 \%$ \\
\hline & Dr Carvalho de Mendonca - 3 & 220 & 507 & $56,6 \%$ & 36,7 & 41,7 & $12,0 \%$ \\
\hline & Gal Julio Marcondes Salgado - 2 & 202 & 274 & $26,2 \%$ & 42,9 & 42,2 & $1,7 \%$ \\
\hline & Nothmann - 5 & 353 & 387 & $8,8 \%$ & 30,3 & 28,8 & $4,9 \%$ \\
\hline & Nothmann - 2 & 401 & 474 & $15,4 \%$ & 41,9 & 40,7 & $2,9 \%$ \\
\hline & Barão de Limeira (sentido SE) - 3 & 275 & 167 & $64,3 \%$ & 41,5 & 40,8 & $1,5 \%$ \\
\hline & Ribeiro da Silva -3 & 286 & 314 & $9,0 \%$ & 31,5 & 29,5 & $6,9 \%$ \\
\hline & Vitorino Carmilo (sentido SE) - 5 & 145 & 78 & $85,9 \%$ & 36,6 & 43,3 & $15,5 \%$ \\
\hline & & \multicolumn{2}{|c|}{ Erro Percentual médio } & $33,0 \%$ & \multicolumn{2}{|c|}{ Erro Percentual médio } & $5,6 \%$ \\
\hline \multirow{15}{*}{ 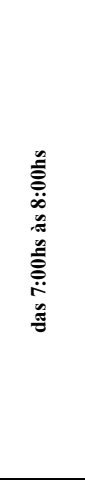 } & Albuquerque Lins - 2 & 294 & 415 & $29,2 \%$ & 39,5 & 40,5 & $2 \%$ \\
\hline & Brigadeiro Galvão - 2 & 190 & 718 & $73,5 \%$ & 41,0 & 42,7 & $4 \%$ \\
\hline & Albuquerque Lins - 4 & 144 & 259 & $44,4 \%$ & 41,4 & 41,2 & $1 \%$ \\
\hline & Vitorino Carmilo (sentido SO) - 3 & 166 & 319 & $48,0 \%$ & 33,5 & 41,3 & $19 \%$ \\
\hline & São João (sentido L) - 4 & 926 & 1028 & $9,9 \%$ & 48,1 & 51,8 & $7 \%$ \\
\hline & Angélica - 2 & 700 & 1879 & $62,7 \%$ & 37,3 & 39,8 & $6 \%$ \\
\hline & Angélica - 1 & 632 & 1576 & $59,9 \%$ & 40,3 & 42,0 & $4 \%$ \\
\hline & Dr Carvalho de Mendonca - 3 & 342 & 1061 & $67,8 \%$ & 37,5 & 41,7 & $10 \%$ \\
\hline & Gal Julio Marcondes Salgado - 2 & 307 & 584 & $47,4 \%$ & 41,7 & 42,2 & $1 \%$ \\
\hline & Nothmann -5 & 610 & 824 & $25,9 \%$ & 26,9 & 28,8 & $7 \%$ \\
\hline & Nothmann -2 & 784 & 995 & $21,2 \%$ & 41,1 & 40,7 & $1 \%$ \\
\hline & Barão de Limeira (sentido SE) - 3 & 331 & 354 & $6,4 \%$ & 41,2 & 40,8 & $1 \%$ \\
\hline & Ribeiro da Silva - 3 & 337 & 665 & $49,4 \%$ & 29,5 & 29,5 & $0 \%$ \\
\hline & Vitorino Carmilo (sentido SE) - 5 & 230 & 173 & $33,0 \%$ & 35,4 & 43,3 & $18 \%$ \\
\hline & & \multicolumn{2}{|c|}{ Erro Percentual médi } & $41,3 \%$ & \multicolumn{2}{|c|}{ Erro Percentual médio } & $5,8 \%$ \\
\hline \multirow{15}{*}{ 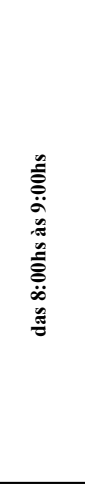 } & Albuquerque Lins - 2 & 332 & 465 & $28,5 \%$ & 39,6 & 40,5 & $2 \%$ \\
\hline & Brigadeiro Galvão - 2 & 227 & 670 & $66,1 \%$ & 41,5 & 42,7 & $3 \%$ \\
\hline & Albuquerque Lins - 4 & 160 & 261 & $38,7 \%$ & 41,9 & 41,2 & $2 \%$ \\
\hline & Vitorino Carmilo (sentido SO) - 3 & 176 & 312 & $43,6 \%$ & 33,4 & 41,3 & $19 \%$ \\
\hline & São João (sentido L) - 4 & 1026 & 1085 & $5,4 \%$ & 48,7 & 51,8 & $6 \%$ \\
\hline & Angélica - 2 & 832 & 1879 & $55,7 \%$ & 40,0 & 39,8 & $0 \%$ \\
\hline & Angélica - 1 & 774 & 1552 & $50,1 \%$ & 39,7 & 42,0 & $5 \%$ \\
\hline & Dr Carvalho de Mendonca - 3 & 478 & 1077 & $55,6 \%$ & 40,1 & 41,7 & $4 \%$ \\
\hline & Gal Julio Marcondes Salgado - 2 & 427 & 602 & $29,1 \%$ & 39,3 & 42,2 & $7 \%$ \\
\hline & Nothmann - 5 & 719 & 824 & $12,7 \%$ & 25,1 & 28,8 & $13 \%$ \\
\hline & Nothmann - 2 & 858 & 1011 & $15,2 \%$ & 41,4 & 40,7 & $2 \%$ \\
\hline & Barão de Limeira (sentido SE) - 3 & 345 & 340 & $1,4 \%$ & 41,4 & 40,8 & $2 \%$ \\
\hline & Ribeiro da Silva - 3 & 535 & 702 & $23,8 \%$ & 28,7 & 29,5 & $3 \%$ \\
\hline & Vitorino Carmilo (sentido SE) - 5 & 269 & 165 & $62,9 \%$ & 35,5 & 43,3 & $18 \%$ \\
\hline & & \multicolumn{2}{|c|}{ Erro Percentual médio } & $34,9 \%$ & \multicolumn{2}{|c|}{ Erro Percentual médio } & $6,1 \%$ \\
\hline \multirow{15}{*}{ 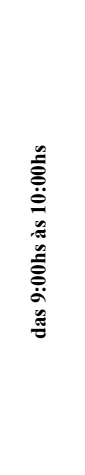 } & Albuquerque Lins - 2 & 341 & 419 & $18,6 \%$ & 39,3 & 40,5 & $3 \%$ \\
\hline & Brigadeiro Galvão - 2 & 202 & 637 & $68,3 \%$ & 41,2 & 42,7 & $4 \%$ \\
\hline & Albuquerque Lins - 4 & 152 & 259 & $41,3 \%$ & 42,6 & 41,2 & $4 \%$ \\
\hline & Vitorino Carmilo (sentido SO) - 3 & 159 & 283 & $43,9 \%$ & 33,4 & 41,3 & $19 \%$ \\
\hline & São João (sentido L) - 4 & 991 & 1036 & $4,3 \%$ & 48,3 & 51,8 & $7 \%$ \\
\hline & Angélica - 2 & 853 & 1668 & $48,9 \%$ & 38,2 & 39,8 & $4 \%$ \\
\hline & Angélica - 1 & 709 & 1411 & $49,8 \%$ & 40,0 & 42,0 & $5 \%$ \\
\hline & Dr Carvalho de Mendonca - 3 & 429 & 989 & $56,6 \%$ & 40,8 & 41,7 & $2 \%$ \\
\hline & Gal Julio Marcondes Salgado - 2 & 390 & 561 & $30,5 \%$ & 41,7 & 42,2 & $1 \%$ \\
\hline & Nothmann -5 & 697 & 755 & $7,7 \%$ & 25,2 & 28,8 & $13 \%$ \\
\hline & Nothmann - 2 & 822 & 995 & $17,4 \%$ & 41,4 & 40,7 & $2 \%$ \\
\hline & Barão de Limeira (sentido SE) - 3 & 395 & 332 & $18,9 \%$ & 41,3 & 40,8 & $1 \%$ \\
\hline & Ribeiro da Silva - 3 & 524 & 618 & $15,3 \%$ & 28,7 & 29,5 & $3 \%$ \\
\hline & Vitorino Carmilo (sentido SE) - 5 & 270 & 161 & $67,5 \%$ & 35,3 & 43,3 & $19 \%$ \\
\hline & & Erro & centual méd & $34,9 \%$ & Erro & centual médio & $6,1 \%$ \\
\hline
\end{tabular}




\begin{tabular}{|c|c|c|c|c|c|c|c|}
\hline \multirow[b]{2}{*}{ Período } & \multirow[b]{2}{*}{ Segmento de Via (ponto de registro } & \multicolumn{3}{|c|}{ Contagem de veículos } & \multicolumn{3}{|c|}{ Velocidade } \\
\hline & & $\begin{array}{c}\text { Registro } \\
\text { (simulação) }\end{array}$ & $\begin{array}{l}\text { Registro } \\
\text { (campo) }\end{array}$ & $\begin{array}{c}\text { erro } \\
\text { percentual }\end{array}$ & $\begin{array}{c}\text { Registro } \\
\text { (simulação) }\end{array}$ & $\begin{array}{l}\text { Registro } \\
\text { (campo) }\end{array}$ & $\begin{array}{c}\text { erro } \\
\text { percentual }\end{array}$ \\
\hline \multirow{15}{*}{ 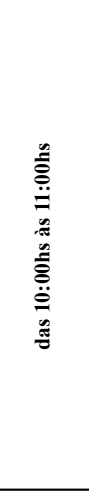 } & Albuquerque Lins - 2 & 226 & 352 & $35,8 \%$ & 40,2 & 40,5 & $1 \%$ \\
\hline & Brigadeiro Galvão - 2 & 412 & 540 & $23,7 \%$ & 41,7 & 42,7 & $2 \%$ \\
\hline & Albuquerque Lins - 4 & 235 & 204 & $15,2 \%$ & 42,8 & 41,2 & $4 \%$ \\
\hline & Vitorino Carmilo (sentido SO) - 3 & 179 & 240 & $25,4 \%$ & 33,5 & 41,3 & $19 \%$ \\
\hline & São João (sentido L) - 4 & 853 & 822 & $3,8 \%$ & 50,1 & 51,8 & $3 \%$ \\
\hline & Angélica - 2 & 792 & 1402 & $43,5 \%$ & 40,2 & 39,8 & $1 \%$ \\
\hline & Angélica - 1 & 690 & 1176 & $41,3 \%$ & 39,1 & 42,0 & $7 \%$ \\
\hline & Dr Carvalho de Mendonca - 3 & 684 & 804 & $14,9 \%$ & 38,8 & 41,7 & $7 \%$ \\
\hline & Gal Julio Marcondes Salgado - 2 & 397 & 456 & $12,9 \%$ & 39,9 & 42,2 & $5 \%$ \\
\hline & Nothmann -5 & 592 & 624 & $5,1 \%$ & 23,9 & 28,8 & $17 \%$ \\
\hline & Nothmann - 2 & 634 & 790 & $19,7 \%$ & 41,3 & 40,7 & $2 \%$ \\
\hline & Barão de Limeira (sentido SE) - 3 & 301 & 270 & $11,5 \%$ & 41,3 & 40,8 & $1 \%$ \\
\hline & Ribeiro da Silva - 3 & 467 & 524 & $10,9 \%$ & 28,1 & 29,5 & $5 \%$ \\
\hline & Vitorino Carmilo (sentido SE) - 5 & 278 & 130 & $113,8 \%$ & 35,5 & 43,3 & $18 \%$ \\
\hline & & \multicolumn{2}{|c|}{ Erro Percentual médi } & $27,0 \%$ & \multicolumn{2}{|c|}{ Erro Percentual médio } & $6,6 \%$ \\
\hline \multirow{15}{*}{ 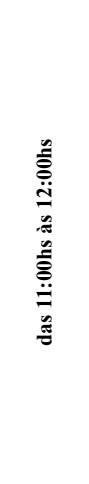 } & Albuquerque Lins - 2 & 203 & 292 & $30,5 \%$ & 39,6 & 40,5 & $2 \%$ \\
\hline & Brigadeiro Galvão - 2 & 138 & 470 & $70,6 \%$ & 41,6 & 42,7 & $3 \%$ \\
\hline & Albuquerque Lins - 4 & 162 & 180 & $9,8 \%$ & 43,0 & 41,2 & $4 \%$ \\
\hline & Vitorino Carmilo (sentido SO) - 3 & 172 & 216 & $20,4 \%$ & 33,6 & 41,3 & $19 \%$ \\
\hline & São João (sentido L) - 4 & 736 & 690 & $6,6 \%$ & 50,2 & 51,8 & $3 \%$ \\
\hline & Angélica - 2 & 830 & 1206 & $31,2 \%$ & 40,7 & 39,8 & $2 \%$ \\
\hline & Angélica - 1 & 773 & 1058 & $27,0 \%$ & 33,6 & 42,0 & $20 \%$ \\
\hline & Dr Carvalho de Mendonca - 3 & 433 & 675 & $35,9 \%$ & 38,8 & 41,7 & $7 \%$ \\
\hline & Gal Julio Marcondes Salgado - 2 & 395 & 401 & $1,6 \%$ & 40,8 & 42,2 & $3 \%$ \\
\hline & Nothmann - 5 & 506 & 562 & $9,9 \%$ & 27,0 & 28,8 & $6 \%$ \\
\hline & Nothmann - 2 & 646 & 719 & $10,1 \%$ & 41,4 & 40,7 & $2 \%$ \\
\hline & Barão de Limeira (sentido SE) - 3 & 376 & 243 & $54,7 \%$ & 41,2 & 40,8 & $1 \%$ \\
\hline & Ribeiro da Silva - 3 & 414 & 430 & $3,6 \%$ & 28,8 & 29,5 & $2 \%$ \\
\hline & Vitorino Carmilo (sentido SE) - 5 & 269 & 120 & $124,9 \%$ & 35,7 & 43,3 & $18 \%$ \\
\hline & & \multicolumn{2}{|c|}{ Erro Percentual médi } & $31,2 \%$ & \multicolumn{2}{|c|}{ Erro Percentual médio } & $6,6 \%$ \\
\hline
\end{tabular}

conclusão

O valores elevados para o erro percentual médio da variável 'volume de veículos' indicou a necessidade de ajustes nos dados de entrada da simulação, uma vez que os volumes simulados não representavam de maneira adequada a distribuição espacial daqueles observados em campo. A estratégia adotada consistiu em uma nova coleta dos dados referentes aos fluxos de veículos, em especial, ao número de veículos que entram na área de simulação. Na primeira coleta de dados os registros foram feitos durante os primeiros quinze minutos de cada hora do período de simulação (das $6 \mathrm{~h}$ as $12 \mathrm{~h}$ ) e os valores obtidos extrapolados para os sessenta minutos que compõem os intervalos do período de observação. Na nova coleta de dados, porém, optou-se pela não extrapolação dos resultados e os registros foram feitos, ininterruptamente, para as seis horas que compõem todo o período de simulação, mantendo-se o mesmo período escolhido das $6 \mathrm{~h}$ às $12 \mathrm{~h}$, às quartas-feiras. A tabela contendo os novos valores para os volumes de veículos que entram na rede de simulação são apresentadas na Tabela D.7 do Anexo D. 
Utilizando os novos valores obtidos em campo como o dado de entrada de veículos da rede de simulação, o erro percentual médio da variável 'volume de veículos' caiu para 7,9\%. Para a variável 'velocidade' o valor obtido $(6,3 \%)$ manteve-se praticamente o mesmo . Os resultados obtidos são mostrados na Tabela 7.2.

Tabela 7.2 - Comparação entre os valores reais e simulados das variáveis de calibração (volume de veículos e velocidades) - segunda iteração

\begin{tabular}{|c|c|c|c|c|c|c|c|}
\hline \multirow[b]{2}{*}{ Período } & \multirow[b]{2}{*}{ Segmento de Via (ponto de registro } & \multicolumn{3}{|c|}{ Contagem de veículos } & \multicolumn{3}{|c|}{ Velocidade } \\
\hline & & $\begin{array}{c}\text { Registro } \\
\text { (simulação) }\end{array}$ & $\begin{array}{l}\text { Registro } \\
\text { (campo) }\end{array}$ & $\begin{array}{c}\text { erro } \\
\text { percentual }\end{array}$ & $\begin{array}{c}\text { Registro } \\
\text { (simulação) }\end{array}$ & $\begin{array}{l}\text { Registro } \\
\text { (campo) }\end{array}$ & $\begin{array}{c}\text { erro } \\
\text { percentual }\end{array}$ \\
\hline \multirow{15}{*}{ 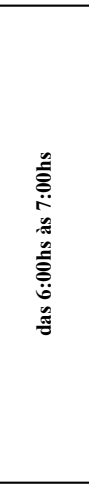 } & Albuquerque Lins - 2 & 200 & 225 & $11,2 \%$ & 41,7 & 40,5 & $3,0 \%$ \\
\hline & Brigadeiro Galvão - 2 & 321 & 356 & $9,9 \%$ & 42,8 & 42,7 & $0,3 \%$ \\
\hline & Albuquerque Lins - 4 & 128 & 131 & $2,0 \%$ & 42,3 & 41,2 & $2,9 \%$ \\
\hline & Vitorino Carmilo (sentido SO) - 3 & 155 & 163 & $5,0 \%$ & 33,7 & 41,3 & $18,4 \%$ \\
\hline & São João (sentido L) - 4 & 493 & 501 & $1,7 \%$ & 51,3 & 51,8 & $1,0 \%$ \\
\hline & Angélica - 2 & 787 & 855 & $8,0 \%$ & 41,7 & 39,8 & $4,7 \%$ \\
\hline & Angélica - 1 & 665 & 717 & $7,3 \%$ & 41,4 & 42,0 & $1,3 \%$ \\
\hline & Dr Carvalho de Mendonca - 3 & 497 & 507 & $1,9 \%$ & 35,9 & 41,7 & $13,8 \%$ \\
\hline & Gal Julio Marcondes Salgado - 2 & 244 & 274 & $10,8 \%$ & 42,9 & 42,2 & $1,7 \%$ \\
\hline & Nothmann - 5 & 386 & 387 & $0,2 \%$ & 29,7 & 28,8 & $2,8 \%$ \\
\hline & Nothmann - 2 & 453 & 474 & $4,4 \%$ & 41,4 & 40,7 & $1,9 \%$ \\
\hline & Barão de Limeira (sentido SE) - 3 & 192 & 167 & $14,7 \%$ & 41,0 & 40,8 & $0,5 \%$ \\
\hline & Ribeiro da Silva - 3 & 308 & 314 & $2,0 \%$ & 30,9 & 29,5 & $4,8 \%$ \\
\hline & Vitorino Carmilo (sentido SE) - 5 & 103 & 78 & $32,1 \%$ & 36,2 & 43,3 & $16,4 \%$ \\
\hline & & \multicolumn{2}{|c|}{ Erro Percentual médi } & $7,9 \%$ & \multicolumn{2}{|c|}{ Erro Percentual médio } & $5,2 \%$ \\
\hline \multirow{15}{*}{ 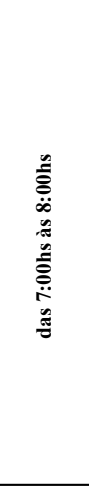 } & Albuquerque Lins - 2 & 382 & 415 & $8 \%$ & 39,9 & 40,5 & $1 \%$ \\
\hline & Brigadeiro Galvão - 2 & 650 & 718 & $9 \%$ & 40,2 & 42,7 & $6 \%$ \\
\hline & Albuquerque Lins - 4 & 224 & 259 & $14 \%$ & 41,9 & 41,2 & $2 \%$ \\
\hline & Vitorino Carmilo (sentido SO) - 3 & 271 & 319 & $15 \%$ & 32,8 & 41,3 & $21 \%$ \\
\hline & São João (sentido L) - 4 & 1016 & 1028 & $1 \%$ & 48,1 & 51,8 & $7 \%$ \\
\hline & Angélica - 2 & 1704 & 1879 & $9 \%$ & 36,6 & 39,8 & $8 \%$ \\
\hline & Angélica - 1 & 1472 & 1576 & $7 \%$ & 39,4 & 42,0 & $6 \%$ \\
\hline & Dr Carvalho de Mendonca - 3 & 1108 & 1061 & $4 \%$ & 36,8 & 41,7 & $12 \%$ \\
\hline & Gal Julio Marcondes Salgado - 2 & 498 & 584 & $15 \%$ & 41,7 & 42,2 & $1 \%$ \\
\hline & Nothmann -5 & 749 & 824 & $9 \%$ & 26,3 & 28,8 & $9 \%$ \\
\hline & Nothmann -2 & 879 & 995 & $12 \%$ & 41,5 & 40,7 & $2 \%$ \\
\hline & Barão de Limeira (sentido SE) - 3 & 348 & 354 & $2 \%$ & 40,7 & 40,8 & $0 \%$ \\
\hline & Ribeiro da Silva - 3 & 560 & 665 & $16 \%$ & 29,2 & 29,5 & $1 \%$ \\
\hline & Vitorino Carmilo (sentido SE) - 5 & 176 & 173 & $2 \%$ & 35,0 & 43,3 & $19 \%$ \\
\hline & & \multicolumn{2}{|c|}{ Erro Percentual médi } & $8,7 \%$ & \multicolumn{2}{|c|}{ Erro Percentual médio } & $6,8 \%$ \\
\hline \multirow{15}{*}{ 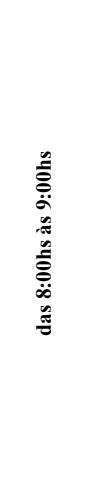 } & Albuquerque Lins - 2 & 399 & 465 & $14 \%$ & 39,6 & 40,5 & $2 \%$ \\
\hline & Brigadeiro Galvão - 2 & 576 & 670 & $14 \%$ & 41,9 & 42,7 & $2 \%$ \\
\hline & Albuquerque Lins - 4 & 242 & 261 & $7 \%$ & 41,1 & 41,2 & $0 \%$ \\
\hline & Vitorino Carmilo (sentido SO) - 3 & 279 & 312 & $11 \%$ & 33,8 & 41,3 & $18 \%$ \\
\hline & São João (sentido L) - 4 & 1045 & 1085 & $4 \%$ & 49,2 & 51,8 & $5 \%$ \\
\hline & Angélica - 2 & 1818 & 1879 & $3 \%$ & 40,0 & 39,8 & $0 \%$ \\
\hline & Angélica - 1 & 1513 & 1552 & $3 \%$ & 39,7 & 42,0 & $5 \%$ \\
\hline & Dr Carvalho de Mendonca - 3 & 965 & 1077 & $10 \%$ & 39,7 & 41,7 & $5 \%$ \\
\hline & Gal Julio Marcondes Salgado - 2 & 541 & 602 & $10 \%$ & 38,5 & 42,2 & $9 \%$ \\
\hline & Nothmann -5 & 732 & 824 & $11 \%$ & 24,6 & 28,8 & $15 \%$ \\
\hline & Nothmann -2 & 943 & 1011 & $7 \%$ & 41,0 & 40,7 & $1 \%$ \\
\hline & Barão de Limeira (sentido SE) - 3 & 302 & 340 & $11 \%$ & 40,6 & 40,8 & $1 \%$ \\
\hline & Ribeiro da Silva - 3 & 670 & 702 & $5 \%$ & 28,1 & 29,5 & $5 \%$ \\
\hline & Vitorino Carmilo (sentido SE) - 5 & 181 & 165 & $10 \%$ & 35,2 & 43,3 & $19 \%$ \\
\hline & & \multicolumn{2}{|c|}{ Erro Percentual médi } & $8,5 \%$ & \multicolumn{2}{|c|}{ Erro Percentual médio } & $6,2 \%$ \\
\hline
\end{tabular}




\begin{tabular}{|c|c|c|c|c|c|c|c|}
\hline \multirow[b]{2}{*}{ Período } & \multirow[b]{2}{*}{ Segmento de Via (ponto de registro } & \multicolumn{3}{|c|}{ Contagem de veículos } & \multicolumn{3}{|c|}{ Velocidade } \\
\hline & & $\begin{array}{c}\text { Registro } \\
\text { (simulação) }\end{array}$ & $\begin{array}{l}\text { Registro } \\
\text { (campo) }\end{array}$ & $\begin{array}{c}\text { erro } \\
\text { percentual }\end{array}$ & $\begin{array}{c}\text { Registro } \\
\text { (simulação) }\end{array}$ & $\begin{array}{l}\text { Registro } \\
\text { (campo) }\end{array}$ & $\begin{array}{c}\text { erro } \\
\text { percentual }\end{array}$ \\
\hline \multirow{15}{*}{ 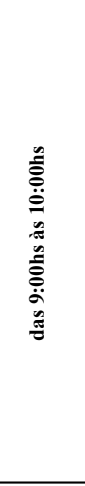 } & Albuquerque Lins - 2 & 385 & 419 & $8 \%$ & 39,7 & 40,5 & $2 \%$ \\
\hline & Brigadeiro Galvão - 2 & 595 & 637 & $7 \%$ & 41,6 & 42,7 & $3 \%$ \\
\hline & Albuquerque Lins - 4 & 222 & 259 & $14 \%$ & 41,8 & 41,2 & $2 \%$ \\
\hline & Vitorino Carmilo (sentido SO) - 3 & 229 & 283 & $19 \%$ & 33,7 & 41,3 & $18 \%$ \\
\hline & São João (sentido L) - 4 & 1003 & 1036 & $3 \%$ & 47,4 & 51,8 & $9 \%$ \\
\hline & Angélica - 2 & 1516 & 1668 & $9 \%$ & 38,6 & 39,8 & $3 \%$ \\
\hline & Angélica - 1 & 1289 & 1411 & $9 \%$ & 40,4 & 42,0 & $4 \%$ \\
\hline & Dr Carvalho de Mendonca - 3 & 861 & 989 & $13 \%$ & 40,4 & 41,7 & $3 \%$ \\
\hline & Gal Julio Marcondes Salgado - 2 & 492 & 561 & $12 \%$ & 42,1 & 42,2 & $0 \%$ \\
\hline & Nothmann - 5 & 750 & 755 & $1 \%$ & 25,4 & 28,8 & $12 \%$ \\
\hline & Nothmann - 2 & 980 & 995 & $2 \%$ & 41,8 & 40,7 & $3 \%$ \\
\hline & Barão de Limeira (sentido SE) - 3 & 315 & 332 & $5 \%$ & 40,9 & 40,8 & $0 \%$ \\
\hline & Ribeiro da Silva - 3 & 584 & 618 & $6 \%$ & 29,0 & 29,5 & $2 \%$ \\
\hline & Vitorino Carmilo (sentido SE) - 5 & 192 & 161 & $19 \%$ & 34,9 & 43,3 & $19 \%$ \\
\hline & & \multicolumn{2}{|c|}{ Erro Percentual médi } & $9,0 \%$ & \multicolumn{2}{|c|}{ Erro Percentual médio } & $5,6 \%$ \\
\hline \multirow{15}{*}{ 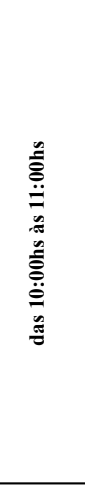 } & Albuquerque Lins - 2 & 327 & 352 & $7 \%$ & 39,8 & 40,5 & $2 \%$ \\
\hline & Brigadeiro Galvão - 2 & 473 & 540 & $12 \%$ & 42,1 & 42,7 & $1 \%$ \\
\hline & Albuquerque Lins - 4 & 210 & 204 & $3 \%$ & 43,2 & 41,2 & $5 \%$ \\
\hline & Vitorino Carmilo (sentido SO) - 3 & 224 & 240 & $7 \%$ & 32,8 & 41,3 & $21 \%$ \\
\hline & São João (sentido L) - 4 & 853 & 822 & $4 \%$ & 49,6 & 51,8 & $4 \%$ \\
\hline & Angélica - 2 & 1252 & 1402 & $11 \%$ & 40,2 & 39,8 & $1 \%$ \\
\hline & Angélica - 1 & 1121 & 1176 & $5 \%$ & 38,7 & 42,0 & $8 \%$ \\
\hline & Dr Carvalho de Mendonca - 3 & 744 & 804 & $7 \%$ & 38,4 & 41,7 & $8 \%$ \\
\hline & Gal Julio Marcondes Salgado - 2 & 414 & 456 & $9 \%$ & 39,9 & 42,2 & $5 \%$ \\
\hline & Nothmann -5 & 594 & 624 & $5 \%$ & 24,2 & 28,8 & $16 \%$ \\
\hline & Nothmann - 2 & 726 & 790 & $8 \%$ & 40,5 & 40,7 & $0 \%$ \\
\hline & Barão de Limeira (sentido SE) - 3 & 259 & 270 & $4 \%$ & 41,3 & 40,8 & $1 \%$ \\
\hline & Ribeiro da Silva - 3 & 506 & 524 & $3 \%$ & 28,4 & 29,5 & $4 \%$ \\
\hline & Vitorino Carmilo (sentido SE) - 5 & 167 & 130 & $28 \%$ & 35,2 & 43,3 & $19 \%$ \\
\hline & & \multicolumn{2}{|c|}{ Erro Percentual médi } & $8,1 \%$ & \multicolumn{2}{|c|}{ Erro Percentual médio } & $6,8 \%$ \\
\hline \multirow{15}{*}{ 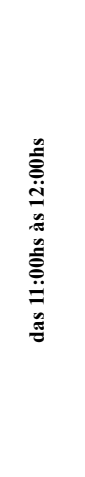 } & Albuquerque Lins - 2 & 266 & 292 & $9 \%$ & 38,8 & 40,5 & $4 \%$ \\
\hline & Brigadeiro Galvão - 2 & 412 & 470 & $12 \%$ & 42,0 & 42,7 & $2 \%$ \\
\hline & Albuquerque Lins - 4 & 178 & 180 & $1 \%$ & 43,4 & 41,2 & $5 \%$ \\
\hline & Vitorino Carmilo (sentido SO) - 3 & 206 & 216 & $5 \%$ & 33,6 & 41,3 & $19 \%$ \\
\hline & São João (sentido L) - 4 & 702 & 690 & $2 \%$ & 50,2 & 51,8 & $3 \%$ \\
\hline & Angélica - 2 & 1169 & 1206 & $3 \%$ & 39,9 & 39,8 & $0 \%$ \\
\hline & Angélica - 1 & 987 & 1058 & $7 \%$ & 33,6 & 42,0 & $20 \%$ \\
\hline & Dr Carvalho de Mendonca - 3 & 598 & 675 & $11 \%$ & 38,0 & 41,7 & $9 \%$ \\
\hline & Gal Julio Marcondes Salgado - 2 & 401 & 401 & $0 \%$ & 40,0 & 42,2 & $5 \%$ \\
\hline & Nothmann -5 & 534 & 562 & $5 \%$ & 26,4 & 28,8 & $8 \%$ \\
\hline & Nothmann -2 & 660 & 719 & $8 \%$ & 41,0 & 40,7 & $1 \%$ \\
\hline & Barão de Limeira (sentido SE) - 3 & 268 & 243 & $10 \%$ & 41,6 & 40,8 & $2 \%$ \\
\hline & Ribeiro da Silva - 3 & 421 & 430 & $2 \%$ & 28,5 & 29,5 & $3 \%$ \\
\hline & Vitorino Carmilo (sentido SE) - 5 & 125 & 120 & $5 \%$ & 35,3 & 43,3 & $18 \%$ \\
\hline & & \multicolumn{2}{|c|}{ Erro Percentual médi } & $5,7 \%$ & \multicolumn{2}{|c|}{ Erro Percentual médio } & $7,1 \%$ \\
\hline
\end{tabular}

conclusão

\subsubsection{Modelagem dos Movimentos dos Veículos de Carga}

A modelagem dos movimentos dos veículos de carga baseia-se nos modelos para a microssimulação apresentados no Capítulo 6 e traduz, para o VISSIM, os dados de saída (outputs) desses modelos, ou seja, as rotas dos veículos de entrega, incluindo as decisões de cada motorista na busca por um local de estacionamento e a entrega em si. Dessa forma, a modelagem apresentada nesta seção tem a finalidade de permitir que sejam simulados, em 
conjunto com os fluxos de veículos em geral, os fluxos dos veículos de carga que realizam entregas nos estabelecimentos localizados na área de simulação. A apresentação de como foram modelados, no VISSIM, os objetos e as regras que regem esses movimentos está dividida em três etapas: (i) modelagem dos estabelecimentos; (ii) modelagem das rotas de entrega e (iii) modelagem das decisões de estacionamento.

\subsubsection{Modelagem dos Estabelecimentos}

O primeiro conjunto de dados a ser modelado provém do modelo 'Geração de Demandas' e define, para o período escolhido, as entregas a serem realizadas dentro da área de simulação. Os estabelecimentos nos quais acontecem essas entregas foram então representados na rede de simulação uma vez que esses são os possíveis destinos dos veículos de carga. As áreas representando os estabelecimentos foram desenhadas no próprio VISSIM, tendo como base o mapa contendo os estabelecimentos da área em estudo, apresentado na Figura 7.22. Cada uma delas foi identificada com o mesmo número ID utilizado na coleta de dados e no modelo 'Geração de Demandas'. Cada cor representa uma classe de estabelecimento (padaria, restaurante, lanchonete, etc.), conforme a classificação adotada, apresentada no Capítulo 6.

Foi atribuída, para cada um dos estabelecimentos, uma área de estacionamento, cuja zona possui o mesmo número ID do estabelecimento. No caso de existir uma área de estacionamento em frente ao estabelecimento essa é a área atribuída a ele, caso contrário escolheu-se aquela mais próxima, como mostra a Figura 7.23. No caso de duas áreas equidistantes atribui-se ao estabelecimento aquela localizada antes dele. 


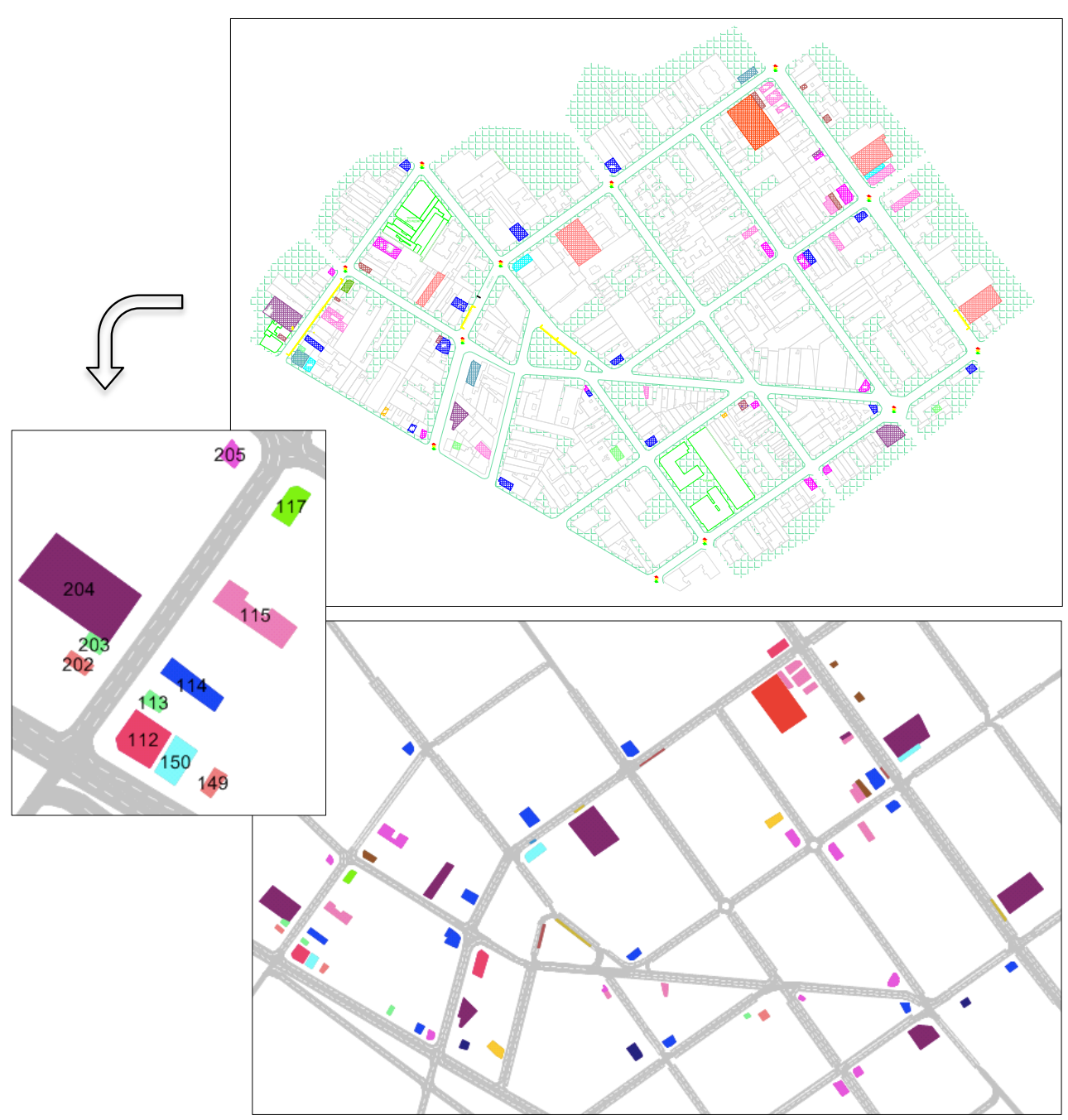

Figura 7.22 - Representação dos estabelecimentos existentes na área de simulação

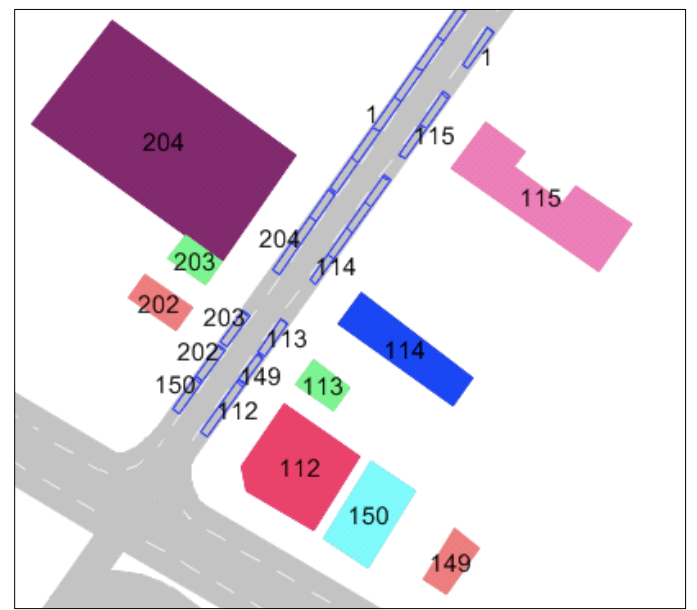

Figura 7.23 - Exemplo da atribuição de áreas de estacionamento aos estabelecimentos 
Sendo assim, e considerando como exemplo os estabelecimentos apresentados na Figura 7.23, um veículo que vai realizar uma entrega no estabelecimento 204 tem como destino, no VISSIM, a área de estacionamento da zona 204.

No caso de estabelecimentos que possuem área interna para a carga e descarga, essa foi inserida em um link criado 'dentro' do estabelecimento, conforme ilustra a Figura 7.24. A entrada e saída dos veículos nessas áreas de carga e descarga ocorre com velocidade reduzida e se dá através dos conectores que ligam o link que contém a área de estacionamento (1) ao link principal que representa a via onde o estabelecimento está localizado (2). A redução da velocidade nos conectores é obtida através de objetos do tipo 'reduced speed areas'.

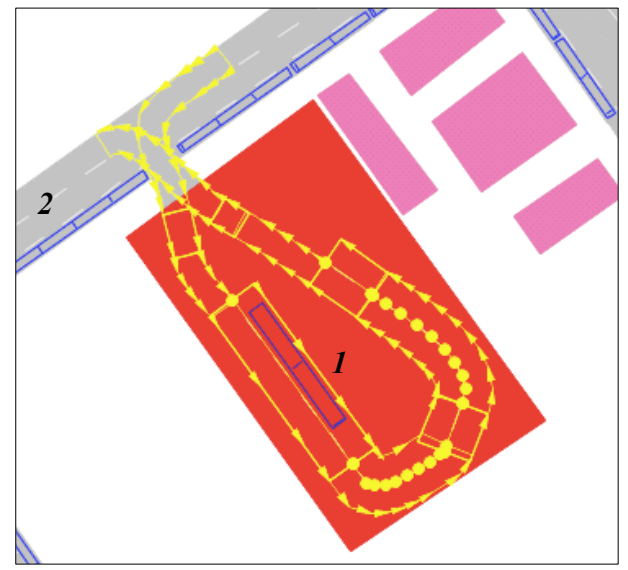

Figura 7.24 - Exemplo da modelagem de áreas de carga e descarga internas ao estabelecimento

\subsubsection{Modelagem das Rotas de Entrega}

O modelo 'Geração dos Veículos de Entrega' determina o número e o tipo dos veículos de carga necessários ao atendimento das demandas por entregas dos estabelecimentos da área de simulação e define, para cada um deles, quais estabelecimentos visitar. Os dados de saída do modelo são as rotas de entrega desses veículos, compostas por:

- Seção de entrada do veículo na rede de simulação;

- Horário de entrada do veículo na rede de simulação (início da rota);

- Lista ordenada dos estabelecimentos atendidos pelo veículo;

- Duração da entrega em cada estabelecimento; 
- Seção de saída do veículo da rede de simulação (após realização de todas as entregas).

No VISSIM, as rotas de entrega dos veículos de carga foram modeladas utilizando um arquivo de texto tipo 'trip chain', o qual alimenta o módulo de atribuição dinâmica de veículos do VISSIM. Um arquivo do tipo 'trip chain' (cadeia de viagens) gera veículos na rede e atribui, a cada um deles, uma série de viagens, caracterizadas por uma origem e múltiplos destinos. As origens e destinos dos veículos são atribuídos às áreas de estacionamento, de acordo com a zona da qual essas áreas fazem parte. Ou seja, se um veículo tem como destino a área de estacionamento $\mathrm{X}$ e essa área faz parte da zona $\mathrm{Y}, \mathrm{o}$ destino desse veículo, no arquivo 'trip chain' será a zona Y. As zonas que se caracterizam como origem e destino final do veículo (saída da rede) devem estar associadas às áreas de estacionamentos do tipo 'zone connector', localizadas nas seções de entrada e saída da rede. As zonas de destino intermediárias são aquelas dos estacionamentos associados aos estabelecimentos atendidos (pontos de parada na rota), os quais são do tipo 'real parking space'.

Um arquivo do tipo 'trip chain' contém múltiplas cadeias de viagem, uma para cada veículo, para as quais devem ser definidos: (i) número de identificação do veículo, (ii) tipo do veículo, (iii) zona de origem, (iv) horário de partida para a zona de destino (em segundos), (v) zona de destino, (vi) atividade, e (vii) tempo mínimo de permanência em cada zona de destino (duração do estacionamento), sendo que os quatro últimos atributos se repetem para cada parada existente na viagem do veículo.

$\mathrm{Na}$ modelagem da rota de um veículo de entrega através de um arquivo 'trip chain' cada zona de destino em uma viagem representa um estabelecimento atendido. Supondo um veículo cuja rota de entrega seja a seguinte:

- Seção de entrada na rede de simulação: zona 4;

- Horário de entrada na área de simulação: 07:45;

- Lista ordenada dos estabelecimentos atendidos (representados pelo ID) e respectiva duração da entrega (entre parênteses): 115 (25min), 234 (45min), 98 (1h20min);

- Seção de saída da rede de simulação: zona 11. 
Considerando o início da simulação às $6 \mathrm{~h}$, o arquivo 'trip chain' que gera o veículo em questão e sua rota de entrega corresponde ao exibido na Figura 7.25.

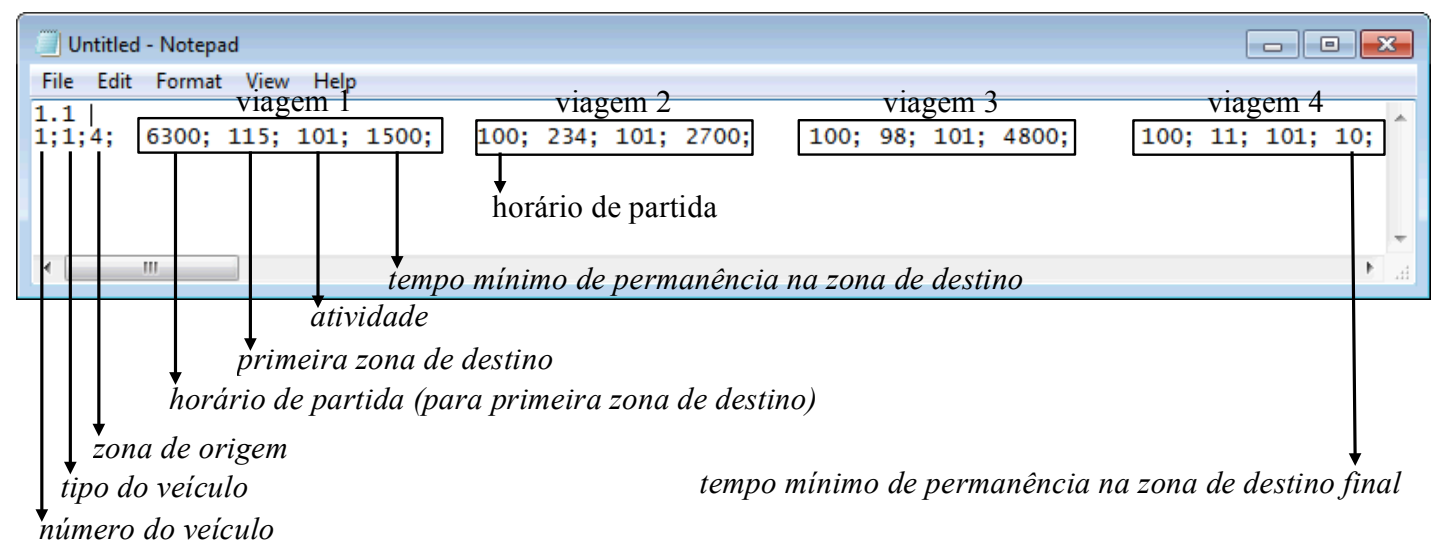

Figura 7.25 - Exemplo de um arquivo do tipo 'trip chain' para a modelagem das rotas dos veículos de entrega

O horário de partida para a primeira zona de destino (primeiro estabelecimento da rota) corresponde ao início da rota do veículo. O tempo mínimo de permanência na zona de destino corresponde ao tempo que o veículo fica estacionado, ou seja, a duração total da entrega. Para que o veículo não deixe a área de estacionamento antes de completar o tempo de entrega, o horário de partida para as demais zonas deve ser anterior ao término da duração da entrega. Por fim, o valor atribuído ao tempo mínimo de permanência na zona de destino final é irrelevante, uma vez que, por se tratar de uma área de estacionamento do tipo 'zone connector', o veículo é excluído da rede imediatamente após cruzá-la.

Os caminhos percorridos pelos veículos de carga entre os diversos pontos de parada da rota de entrega são calculados automaticamente pelo VISSIM considerando os custos generalizados dos diversos caminhos possíveis. Esse custo generalizado é composto pela ponderação do tempo de viagem esperado e da distância de viagem. É assumido ainda que nem todos os veículos seguem pelo melhor caminho, mas que esses são distribuídos por todos os caminhos existentes. A porcentagem de veículos que é distribuída ao longo dos melhores caminhos é, no entanto, consideravelmente maior.

Baseado nos tipos de veículos observados realizando entregas em campo, seis tipos de veículos de carga foram considerados no modelo 'Geração de Demandas' e, portanto, também modelados no VISSIM. As características associadas a cada um dos tipos de 
veículos, assim como o veículo de referência para determinação das mesmas são apresentados no Quadro 7.6.

Quadro 7.6 - Características dos tipos de veículos de carga adotados na modelagem

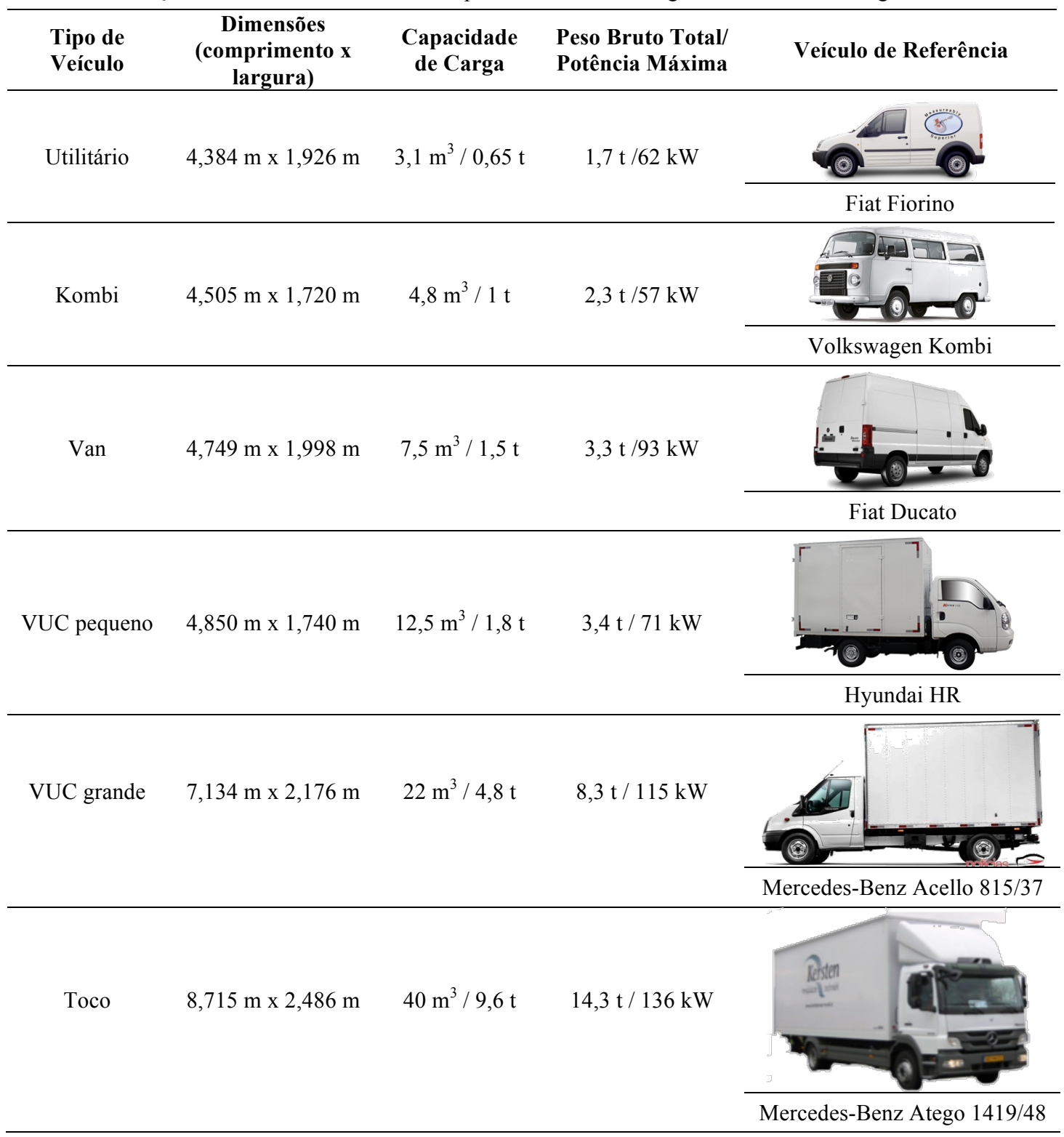

Para a modelagem dos veículos de carga no VISSIM, os seis tipos de veículos considerados foram agrupados em duas categorias: Car (para os tipos Utilitário, Kombi, Van e VUC pequenos) e $H G V$ (para os tipos VUC grande e Toco). Veículos da categoria $H G V$ (Heavy Goods Vehicle) têm associadas a eles distribuições de peso e potência, as quais influenciam na sua capacidade de aceleração e desaceleração, especialmente em vias inclinadas. 
Foram criadas ainda diversas classes de veículos, uma para cada veículo gerado pelo modelo 'Geração dos Veículos de Entrega'. Essa estratégia permitiu individualizar o comportamento desses veículos, uma vez que os objetos do VISSIM são atribuídos somente às classes e não aos veículos individualmente. Por exemplo, ao se definir uma área de velocidade reduzida (através de um objeto do tipo 'reduced speed areas') deve-se atribuir a essa área os veículos que por ela serão afetados, ou seja, que terão sua velocidade alterada. Essa atribuição, conforme mostra a Figura 7.26, é agregada por classe, ou seja, nesse exemplo, todos os veículos pertencentes à classe 10:Car seriam afetados pela área de velocidade reduzida.

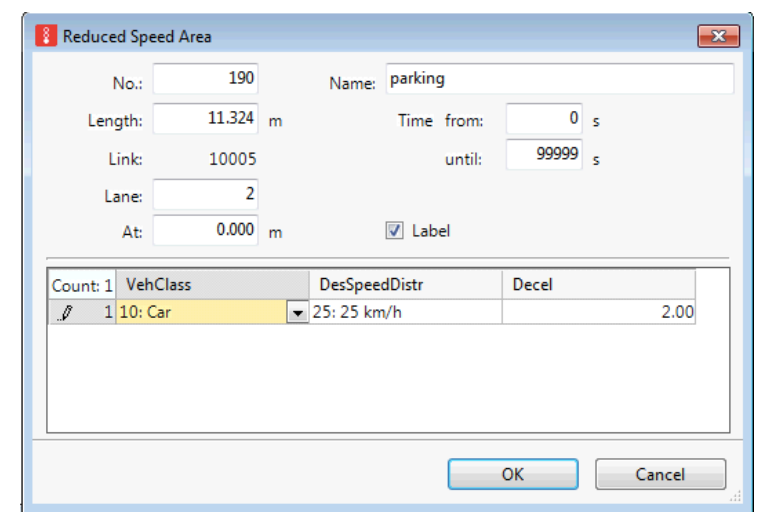

Figura 7.26 - Exemplo da atribuição de objetos do VISSIM à uma classe de veículos

A estratégia de criar uma classe para cada um dos veículos de carga permite, nesse exemplo, especificar veículo a veículo aqueles que serão afetados pela área de velocidade reduzida.

Para determinar as velocidades desejadas adotadas para os veículos de carga em rota de entrega, foi necessária uma nova coleta de dados. Durante quatro dias, 95 motoristas de veículos de carga foram abordados nas vias da área de simulação e perguntados sobre quais as velocidades médias praticadas por eles naquela via. Foram abordados tanto motoristas cujo veículo estava estacionado quanto aqueles parados no semáforo. Além da velocidade foi registrado também o tipo de veículo, de acordo com aqueles que foram considerados na modelagem, apresentados no Quadro 7.6. Os resultados obtidos são exibidos na Tabela E.1 do Anexo E.

A tabela 7.3, a seguir, exibe os valores para as velocidades desejadas adotadas no VISSIM, para cada tipo de veículo, em cada via. 
Para os tipos de veículos cujas velocidades, em determinadas vias, não puderam ser obtidas durante a coleta de dados, foram adotados os valores obtidos para esse mesmo tipo de veículo em outra via semelhante. Isso ocorreu principalmente para os veículos do tipo Toco, os quais não são frequentemente observados, uma vez que têm circulação restrita na área de simulação.

Tabela 7.3 - Velocidades desejadas adotadas para os veículos de carga

\begin{tabular}{lcccccc}
\hline \multicolumn{1}{c}{ Via } & \multicolumn{5}{c}{ Tipo de Veículo } & \\
\multicolumn{1}{c}{ Utilitário } & Kombi & Van & VUC pequeno & VUC grande & TOCO \\
\hline Adolfo Gordo & 30 & 35 & 30 & 25 & 30 & 20 \\
Apa & 25 & 30 & 30 & 30 & 25 & 20 \\
Barão de Campinas & 40 & 45 & 40 & 30 & 30 & 20 \\
Albuquerque Lins & 45 & 35 & 35 & 45 & 30 & 30 \\
Angélica & 40 & 35 & 40 & 25 & 35 & 30 \\
Barão de Limeira & 35 & 35 & 50 & 30 & 30 & 30 \\
Barra Funda & 45 & 35 & 35 & 30 & 30 & 30 \\
Brigadeiro Galvão & 45 & 40 & 40 & 25 & 30 & 30 \\
Dr Carvalho de Mendonca & 40 & 35 & 30 & 35 & 35 & 30 \\
Eduardo Prado & 40 & 35 & 35 & 35 & 35 & 40 \\
Gal Julio Marcondes Salgado & 40 & 40 & 45 & 35 & 40 & 30 \\
Nothmann & 35 & 35 & 30 & 40 & 35 & 30 \\
Pirineus & 25 & 20 & 30 & 35 & 20 & 20 \\
Ribeiro da Silva & 30 & 30 & 40 & 20 & 30 & 20 \\
São João (sentido L) & 50 & 45 & 45 & 30 & 45 & 40 \\
São João (sentido O) & 50 & 45 & 45 & 45 & 45 & 40 \\
Vitorino Carmilo & 35 & 25 & 25 & 25 & 30 & 20 \\
\hline
\end{tabular}

\subsubsection{Modelagem das Decisões de Estacionamento}

Os resultados do modelo 'Preferências de Estacionamento' serviram como base para a última etapa de modelagem no VISSIM, a qual engloba as decisões dos motoristas dos veículos de carga diante da indisponibilidade de uma vaga de estacionamento em frente ou dentro do estabelecimento no qual a entrega precisa ser realizada. Conforme explicado no Capítulo 6, cada decisão é representada por um conjunto de alternativas de estacionamento e pelas probabilidades de escolha de cada uma delas, as quais foram determinadas a partir dos dados obtidos nas entrevistas com os motoristas, durante a coleta de dados.

No VISSIM, os movimentos do veículos, derivados dessas decisões, foram modelados utilizando rotas do tipo dinâmica (através de objetos do tipo 'vehicle routing dynamic'). As rotas dinâmicas permitem que um veículo altere sua rota caso determinada condição seja verdadeira. Essas condições são verificadas nas seções de decisão da rota dinâmica, inseridas ao longo da rede. 
No caso da modelagem das decisões de estacionamento a condição verificada foi, invariavelmente, a disponibilidade da área de estacionamento que é o destino do veículo de carga. Estando essa área indisponível, diferentes estratégias foram adotadas de acordo com o fluxo de decisões de cada veículo, resultante do modelo 'Preferências de Estacionamento'. Como cada veículo tem sua própria rota de entrega e seu próprio fluxo de decisões, terá também seu próprio conjunto de decisões de rota dinâmica. Isso quer dizer que, ao longo da rede, diversas seções de decisão foram inseridas, mas um veículo só terá sua rota afetada por aquelas que a ele (através de sua classe) forem atribuídas. O exemplo ilustrado na Figura 7.27 ajuda a entender como funcionam as rotas dinâmicas. Supondo um veículo pertencente à classe 630 , e que tenha como destino o estabelecimento 121 , tome como ação seguir para o estabelecimento 42 caso a vaga de carga e descarga (em amarelo) não esteja disponível. Ao cruzar a seção de decisão de rota dinâmica (1) o veículo checa a condição ('destination parking lot full') e, se a mesma for satisfeita, segue para a vaga de estacionamento 42 , conforme a estratégia estabelecida ('specified parking lot - 42').

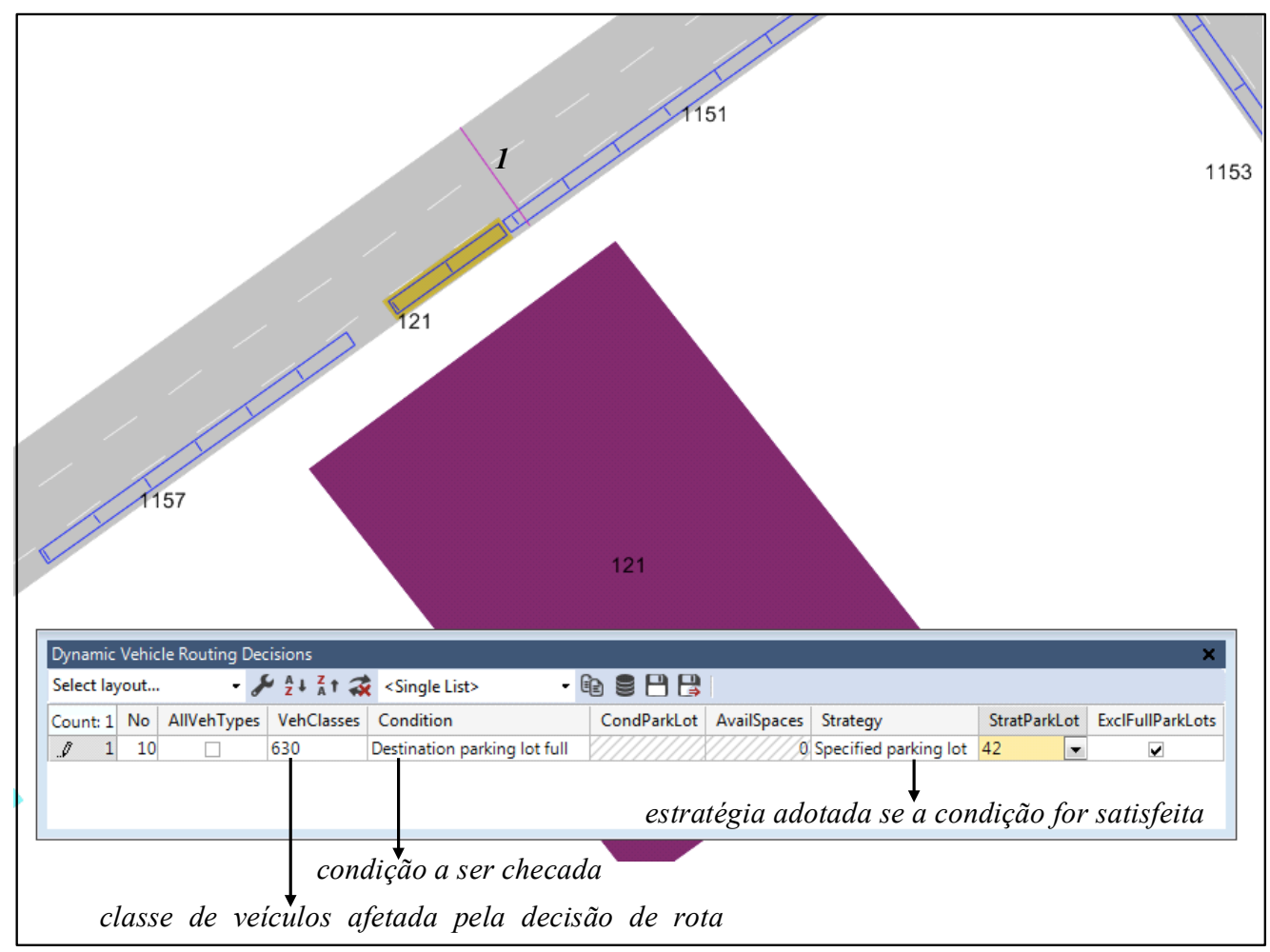

Figura 7.27 - Exemplo da modelagem de uma decisão de rota dinâmica ('vehicle routing dynamic') 
Nesse exemplo, nenhum outro veículo terá sua rota afetada pela seção de decisão 1 , uma vez que a mesma está atribuída somente à classe 630 e cada veículo de entrega tem sua própria classe.

Serão apresentados a seguir os diferentes possíveis fluxos de decisões, derivados do modelo 'Preferências de Estacionamento', e como foram modeladas, no VISSIM, as decisões de rotas dinâmicas e os objetos auxiliares que permitem a modelagem dos movimentos dos veículos de entrega diante dessas decisões.

É importante ressaltar que as decisões nos fluxogramas dependem do comportamento do motorista e não do veículo, i.e. o comportamento do motorista determina a escolhas das alternativas em cada decisão, o que resulta em um movimento do veículo. Na simulação, no entanto, é impossível dissociar a entidade motorista-veículo, uma vez que todos os movimentos desse segundo são derivados de fatores ligados ao primeiro, como a percepção e a agressividade do motorista. O próprio modelo Wiedmann 74, adotado no VISSIM e apresentado na Seção 7.1, estabelece claramente essa conexão.

Em cada um dos fluxogramas apresentados a seguir, o fluxo de decisões representado está destacado em vermelho, e representa a sequência de decisões e ações que a modelagem buscou representar no VISSIM. 
Fluxo de decisões 'A':

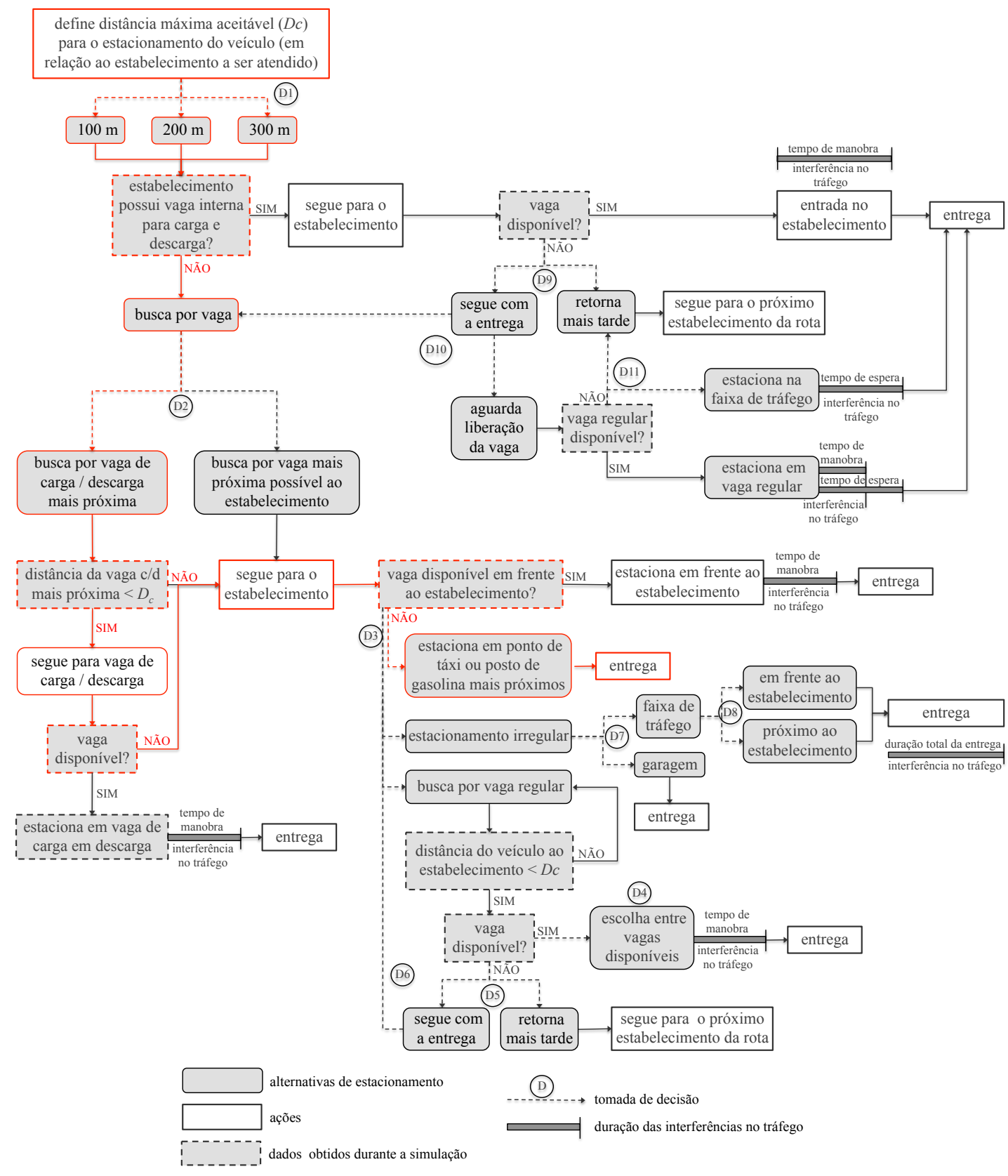

Figura 7.28 - Fluxo de decisões 'A'

Veículos de carga que obedecem ao fluxo 'A' de decisões (Figura 7.28) são aqueles cuja primeira opção de estacionamento são as áreas exclusivas para carga e descarga, desde que essas estejam próximas o suficiente do estabelecimento, ou seja, dentro da distância máxima $D_{c}$ estabelecida, e não haja uma vaga interna de carga e descarga no mesmo. Nesse caso, a zona de destino do veículo no arquivo 'trip chain' deixa de ser a área de estacionamento 
associada ao estabelecimento e passa a ser a zona onde está localizada a área de carga e descarga, como mostra o exemplo da Figura 7.29.

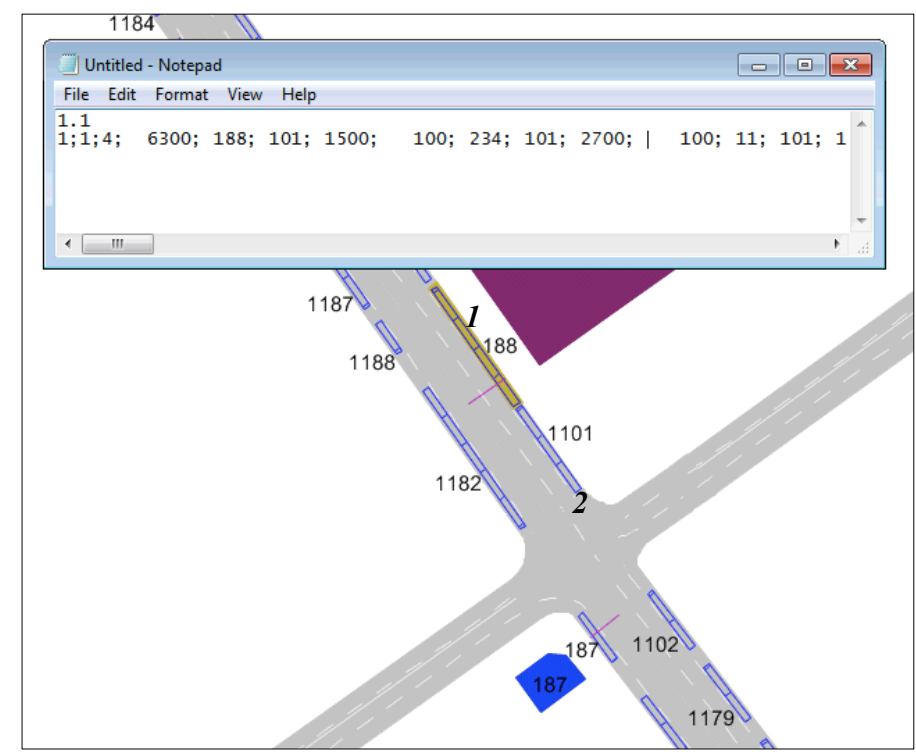

Figura 7.29 - Arquivo da 'trip chain' para rota com destino à área de carga e descarga

Nesse exemplo, o veículo tem como primeiro destino o estabelecimento 187. A opção do motorista, no entanto, é estacionar na área de carga e descarga (zona 188, em amarelo), razão pela qual esta é a zona de destino da primeira viagem no arquivo 'trip chain'.

Duas decisões de rota dinâmica são inseridas: a primeira (1), localizada próxima à zona de destino (nesse caso a área de carga e descarga), estabelece que, estando a vaga de carga e descarga indisponível (condição), o veículo deve seguir para o estabelecimento, ou seja, para a vaga da zona 187 (estratégia); a segunda decisão de rota dinâmica (2) é inserida próxima à essa mesma vaga (zona 187) e, caso a mesma não esteja disponível, determina que o veículo siga para a vaga localizada em um ponto de táxi ou posto de gasolina. As vagas localizadas nos postos de gasolina foram modeladas da mesma forma que uma vaga interna de carga e descarga (Figura 7.30). Elas podem ser consideradas fictícias, uma vez que não estão disponíveis para o estacionamento regular dos veículos de carga. 


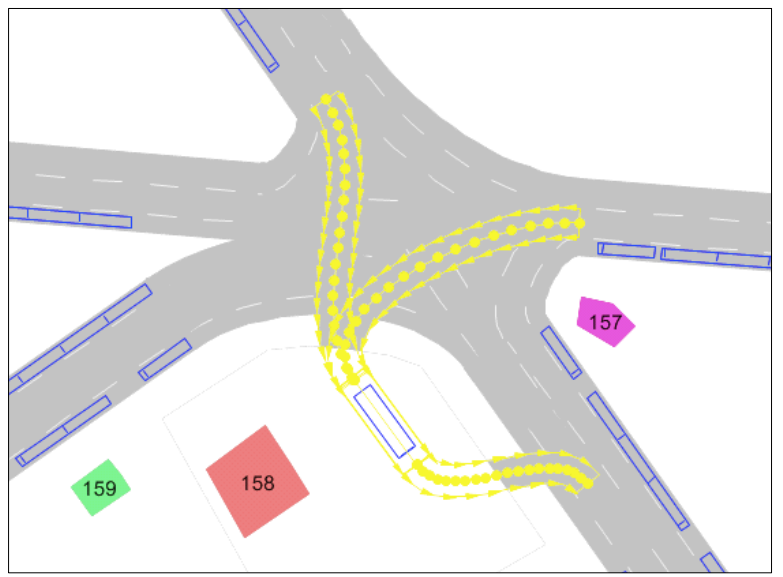

Figura 7.30 - Exemplo da modelagem de uma vaga de estacionamento em posto de gasolina 


\section{Fluxo de decisões 'B':}

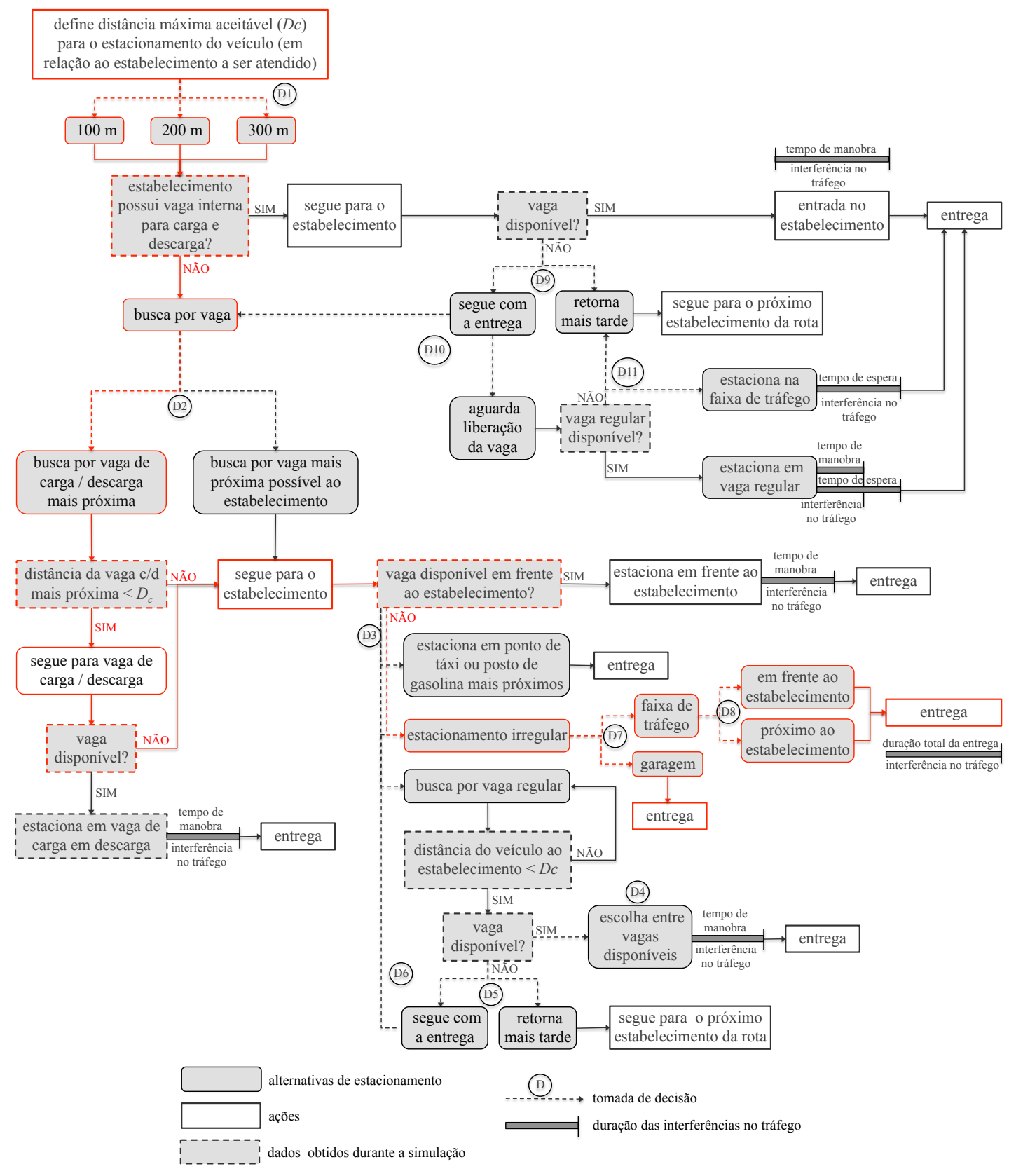

Figura 7.31 - Fluxo de decisões 'B'

No fluxo de decisões 'B' (Figura 7.31), a primeira opção de estacionamento também são as áreas exclusivas para carga e descarga, como no fluxo 'A'. Aqui, a segunda opção de estacionamento do veículo de carga, porém, é o estacionamento irregular, seja na faixa de tráfego ou em frente a alguma garagem. Nesse caso, as mesmas decisões de rota dinâmica 
do fluxo 'A' foram utilizadas, com a diferença que agora a vaga de estacionamento da estratégia da decisão (2) é uma vaga irregular.

Para o estacionamento irregular na faixa de tráfego, em fila dupla ou não, foi necessária a criação de uma nova vaga de estacionamento, a qual também pode ser considerada fictícia. No caso de estacionamento onde não ocorre fila dupla, bastou que uma nova vaga fosse inserida na posição de estacionamento (em frente ou próximo ao estabelecimento), conforme exemplifica a Figura 7.32.

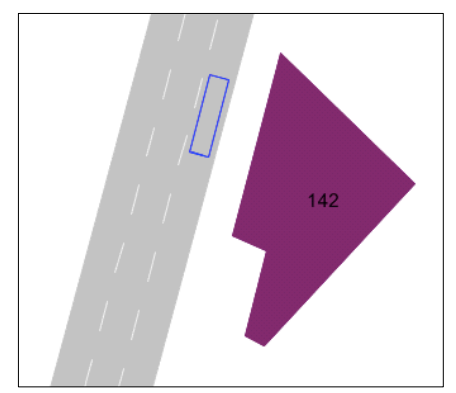

Figura 7.32 - Exemplo de vaga fictícia para estacionamento irregular na faixa de tráfego

Quando o motorista decide estacionar ao lado de uma faixa de estacionamento já existente, a modelagem do estacionamento irregular na faixa de tráfego consiste na criação de uma vaga em fila dupla. Nessa situação, duas limitações do VISSIM precisaram ser contornadas:

i. Dois veículos não podem estar estacionados em vagas adjacentes, localizadas no mesmo link. Quando isso acontece o veículo cujo destino é uma vaga de estacionamento em fila dupla (1) passa por essa vaga (em azul na Figura 7.33) mas não estaciona e, além disso, deixa a rede de simulação pela seção de saída mais próxima;

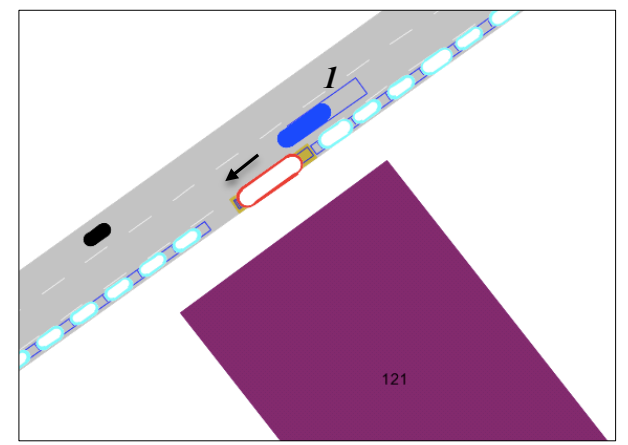

Figura 7.33 - Exemplo de vaga fictícia inserida no mesmo link que a vaga adjacente 
Esse problema foi resolvido inserindo a vaga em fila dupla em um conector criado sobre o link (Figura 7.34), o que levou a outra limitação do VISSIM.

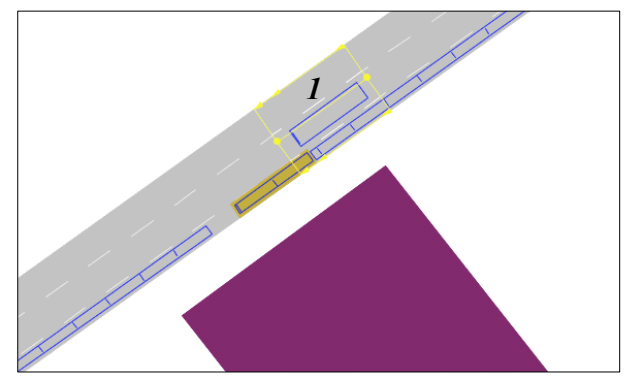

Figura 7.34 - Exemplo de vaga fictícia inserida em um conector auxiliar

ii. Estando a vaga de estacionamento em fila dupla em um conector diferente do link principal por onde passam os veículos, esses não percebem o veículo de carga estacionado e passam por cima dele durante a simulação (Figura 7.35).

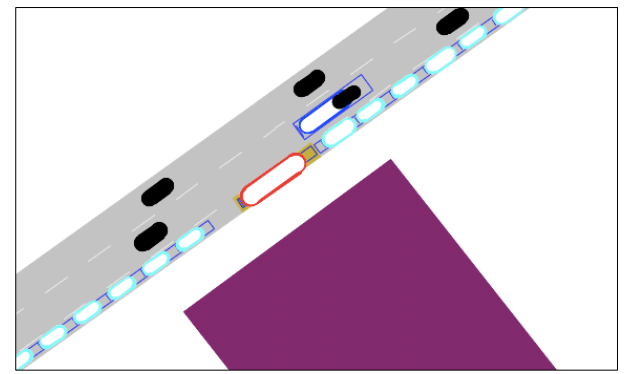

Figura 7.35 - Exemplo de veículo estacionado em fila dupla não sendo percebido pelos veículos que circulam na via

Esse novo problema foi solucionado trocando as posições das vagas. A vaga em fila dupla (1) foi posicionada no link principal e as vagas à ela adjacentes (2) e (3), posicionadas no conector, conforme a Figura 7.36.

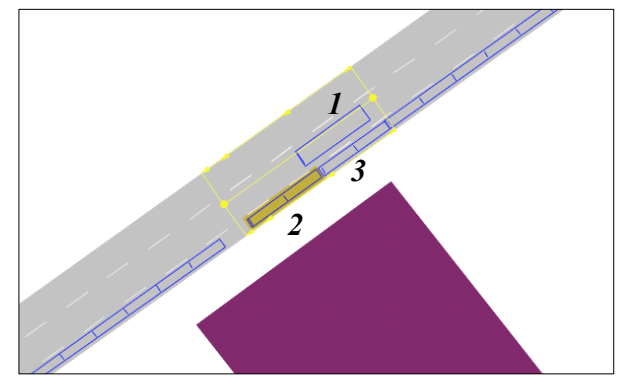

Figura 7.36 - Exemplo de vaga fictícia inserida no link principal e vagas regulares adjacentes inseridas em um conector auxiliar 
Com essa alteração, os veículos passaram a perceber o veículo de carga estacionado em fila dupla, uma vez que esse está no mesmo link por onde eles passam, e desviaram dele (Figura 7.37). Ao mesmo tempo as vagas adjacentes estão localizadas no conector, ou seja, não dividem o link com a vaga em fila dupla, não impedindo, então, que o veículo de carga estacione na mesma.

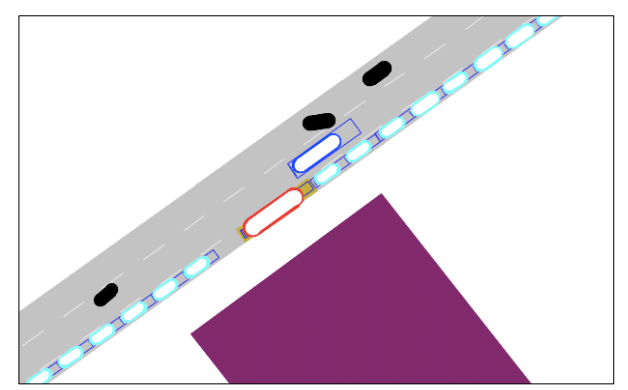

Figura 7.37 - Exemplo de veículo estacionado em fila dupla sendo percebido pelos veículos que circulam na via

A modelagem do estacionamento irregular na faixa de tráfego, em fila dupla ou não, encontrou ainda outra limitação do VISSIM: a impossibilidade dos veículos de realizarem ultrapassagens na contramão. Supondo uma situação onde haja uma veículo parado na faixa de tráfego em uma via estreita, de mão dupla, conforme ilustra o exemplo da Figura 7.38.

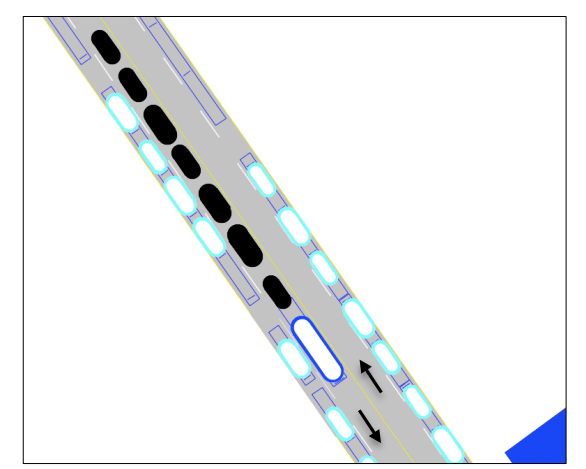

Figura 7.38 - Exemplo do fluxo bloqueado devido ao veículo estacionado em fila dupla e impossibilidade de ultrapassagem pela via de sentido oposto

Em uma situação real, e no caso da via de sentido oposto estar livre, haveriam veículos que optariam por ultrapassar o veículo de carga parado. No VISSIM, no entanto, essa possibilidade é inexistente, ficando todo o fluxo bloqueado atrás do veículo estacionado. Esse tipo de situação, portanto, não pode ser modelada no VISSIM. Foram modelados os estacionamentos irregulares apenas em vias com mais de uma faixa de tráfego ou cuja faixa de tráfego única fosse larga o bastante para permitir a ultrapassagem. 


\section{Fluxo de decisões ' $C$ ':}

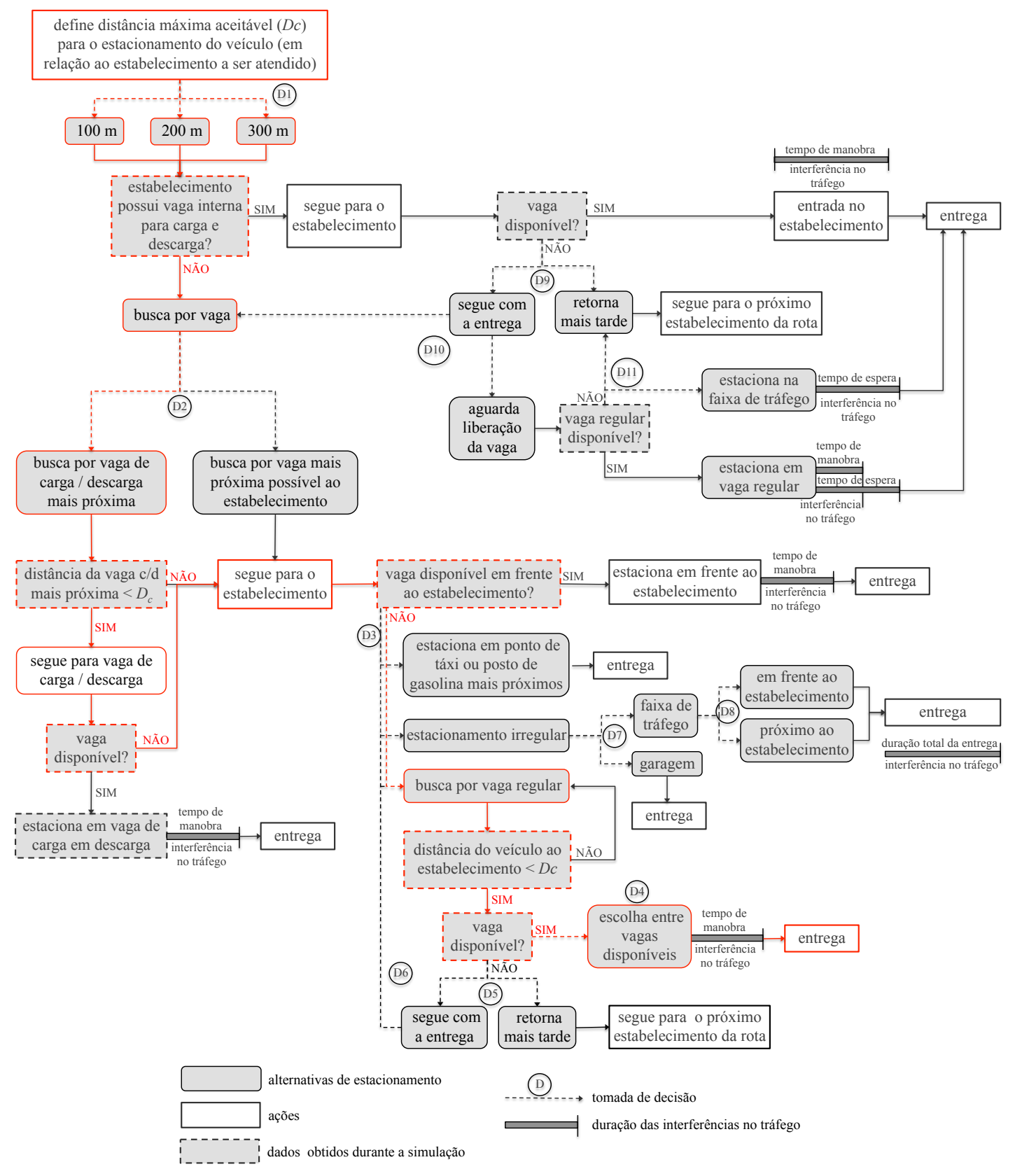

Figura 7.39 - Fluxo de decisões 'C'

O fluxo 'C' (Figura 7.39) representa os veículos que, diante da indisponibilidade da vaga de carga e descarga (sua primeira opção de estacionamento) e de uma vaga em frente ao estabelecimento, partem para a busca por uma vaga regular, dentro dos limites que respeitem a distância máxima $D_{c}$ estabelecida. 
A seção de decisão (1) dos fluxos 'A' e 'B' se mantém, localizada próxima à vaga de carga e descarga. Já a modelagem da busca por uma vaga regular utilizou diversas seções de decisão de rota dinâmica ao longo da via, a partir do momento em que o veículo passa pelo estabelecimento. As decisões de rota dinâmica tiveram suas estratégias baseadas na decisão D9, a qual opta por diferentes vagas disponíveis, considerando a proximidade ao estabelecimento versus a necessidade de atravessar a rua e/ou estacionar o veículo virando a esquina (conversão). Além disso, as vagas de destino consideradas na estratégia foram apenas aquelas cuja distância ao estabelecimento era menor do que Dc. Por exemplo, supondo um veículo que vai realizar uma entrega no estabelecimento 131 e cuja distância máxima de caminhada $\left(D_{c}\right)$ estabelecida pelo motorista seja de 100 metros. Supondo ainda que o veículo se aproxime do estabelecimento pelo caminho indicado pela seta na Figura 7.40 e que a preferência desse motorista é parar o mais próximo possível ao estabelecimento, mesmo que haja a necessidade de atravessar a rua. Sendo assim, as seções de decisão criadas ao longo da via e suas condições e estratégias são as mostradas nas Figuras 40 e 41 e no Quadro 7.7, respectivamente.

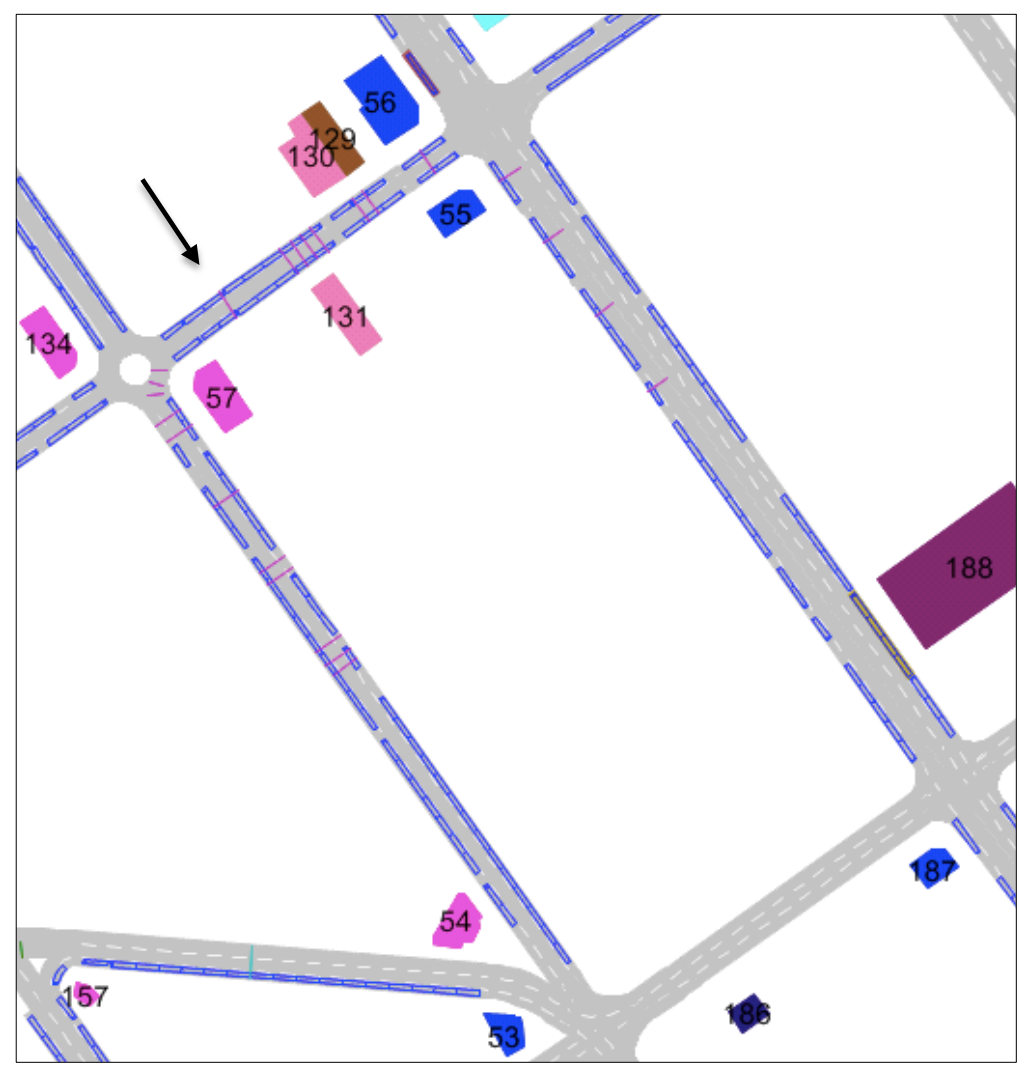

Figura 7.40 - Exemplo da modelagem de rota dinâmica para a busca por uma vaga de estacionamento 


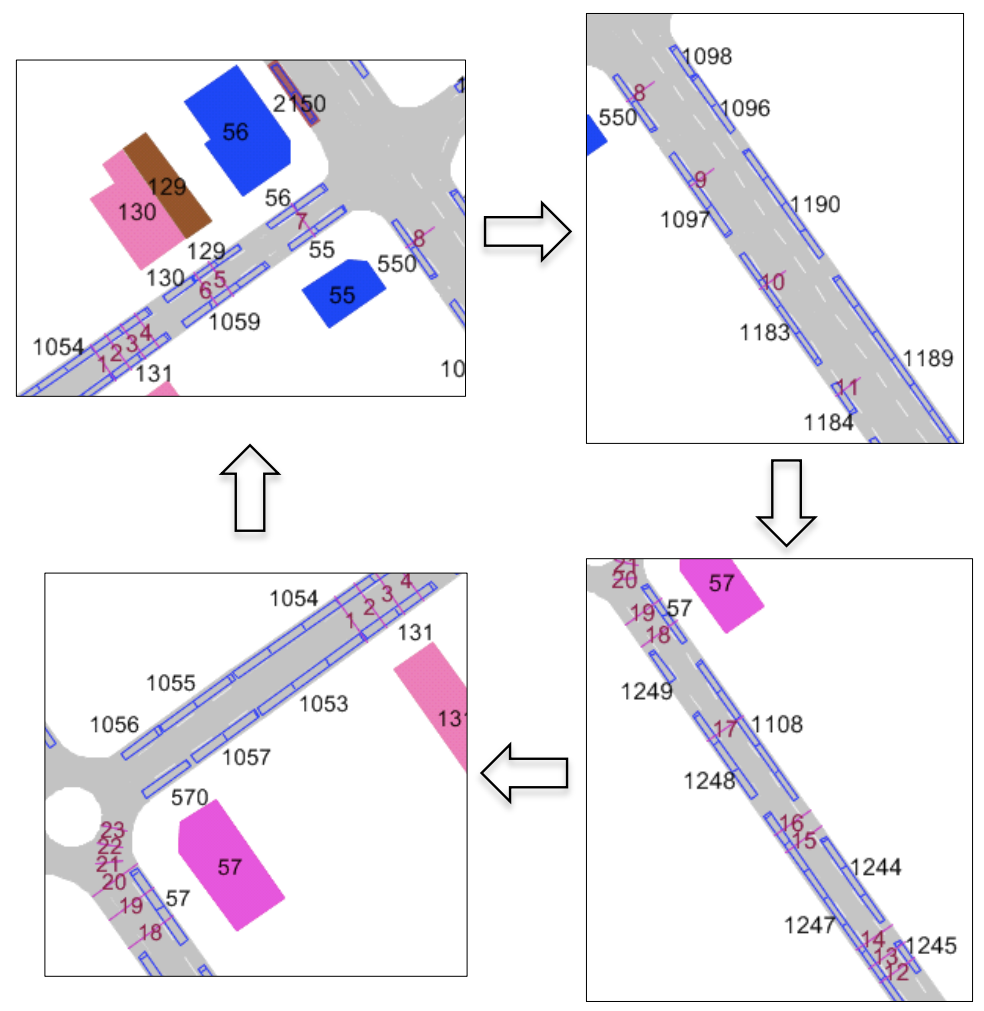

Figura 7.41 - Detalhe da modelagem de rota dinâmica para a busca por uma vaga de estacionamento

Quadro 7.7 - Estratégias das decisões de rota dinâmica para a busca por uma vaga de estacionamento

\begin{tabular}{ccc}
\hline Decisão & Condição & Estratégia \\
\hline 1 & estacionamento de destino (131) está lotado & seguir para 1059 \\
2 & estacionamento de destino (1059) está lotado & seguir para 130 \\
3 & estacionamento de destino (130) está lotado & seguir para 129 \\
4 & estacionamento de destino (129) está lotado & seguir para 2330 \\
5 & estacionamento de destino (2330) está lotado & seguir para 55 \\
6 & estacionamento de destino (55) está lotado & seguir para 56 \\
7 & estacionamento de destino (56) está lotado & seguir para 550 \\
8 & estacionamento de destino (550) está lotado & seguir para 1097 \\
9 & estacionamento de destino (1097) está lotado & seguir para 1183 \\
10 & estacionamento de destino (1183) está lotado & seguir para 1184 \\
11 & estacionamento de destino (1184) está lotado & seguir para 1248 \\
12 & estacionamento de destino (1248) está lotado & seguir para 1244 \\
13 & estacionamento de destino (1244) está lotado & seguir para 1247 \\
14 & estacionamento de destino (1247) está lotado & seguir para 57 \\
15 & estacionamento de destino (57) está lotado & seguir para 1249 \\
16 & estacionamento de destino (1249) está lotado & seguir para 1108 \\
17 & estacionamento de destino (1180) está lotado & seguir para 1053 \\
\hline
\end{tabular}




\begin{tabular}{ccc}
\hline \multicolumn{2}{c}{ Continuação } & \\
\hline Decisão & Estrção & seguir para 1054 \\
18 & estacionamento de destino (1053) está lotado \\
19 & estacionamento de destino (1054) está lotado & seguir para 1057 \\
20 & estacionamento de destino (1057) está lotado & seguir para 1055 \\
21 & estacionamento de destino (1055) está lotado & seguir para 570 \\
22 & estacionamento de destino (1570) está lotado & seguir para 1056 \\
23 & estacionamento de destino (1056) está lotado & seguir para nova busca (fluxo 'D') \\
\hline
\end{tabular}

Note -se que, após passar pela vaga 1184 e, estando ela indisponível, o veículo deve seguir para a vaga 1248, a mais de 200 metros de sua posição atual. Isso porque, a partir da vaga 1148 até a 1248, a distância até o estabelecimento é maior do que a aceitável pelo motorista, (que nesse exemplo é de 100 metros).

A decisão 23 diz respeito ao caso no qual, mesmo após a busca, nenhuma vaga disponível foi encontrada. Nesse caso o fluxo de ações passa a ser o fluxo 'D' (a seguir), no qual o motorista opta por continuar procurando por uma vaga, ou o fluxo 'E', quando o mesmo decide estacionar irregularmente ou em um posto de gasolina (ou ponto de táxi), se houver um próximo ao estabelecimento.

Todas as decisões de rota dinâmica precisam estar localizadas em links onde o veículo ainda não tenha passado, por isso é necessário saber previamente os caminhos percorridos por cada veículo na sua rota de entrega. Ao contrário, o veículo poderia ter seu destino alterado por uma decisão ligada a um estabelecimento que não é aquele no qual fará a entrega. Por exemplo: caso o veículo se aproximasse do estabelecimento 131 pelo caminho indicado na Figura 7.42 adiante, ele teria sua rota alterada pelas seções de decisão localizadas nessa via, sem nem mesmo ter passado em frente ao estabelecimento. Na prática, seria como se o motorista adivinhasse que as vagas em frente e mais próximas ao estabelecimento não estão disponíveis. 


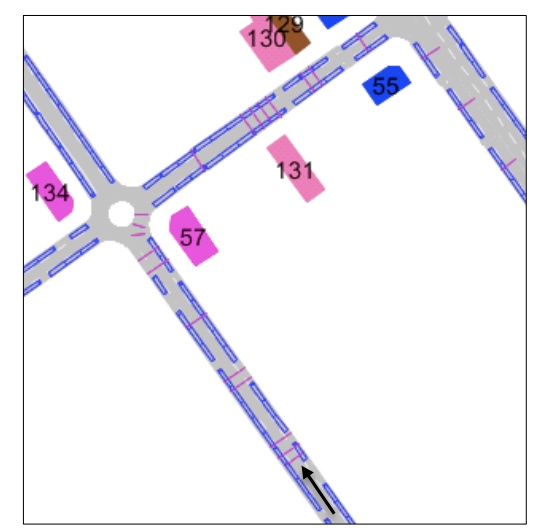

Figura 7.42- Exemplo da limitação do uso da decisão de rota dinâmica

Essa é uma limitação relevante do VISSIM, pois aumenta consideravelmente o esforço da modelagem e impede que mais opções de rotas de busca sejam utilizadas. Devido à essa limitação foi necessário rodar a simulação por diversas vezes para que as rotas dos veículos fossem acompanhadas e feitos os ajustes necessários; foi preciso, por exemplo, inserir uma nova seção de decisão imediatamente após cada uma das seções já criadas e que estão localizados após a vaga onde o veículo estacionou. A condição adotada foi do tipo 'sempre' (always) e o estacionamento da estratégia é a próxima zona de destino na rota de entrega. Essa novas seções de decisão têm a função de anular as possíveis alterações de rota devido às seções que regem a busca por vaga (já realizada) e garantir que o veículo siga para o próximo destino após realizar a entrega no estabelecimento atual. Esses ajustes, assim como a necessidade de conhecer os caminhos dos veículos previamente, não seriam necessários se fosse possível, durante a simulação, ativar ou desativar as seções de decisão.

Por fim, nos trechos de via onde estão localizadas as seções de decisão foram criadas também áreas de velocidade reduzida (em amarelo na Figura 7.43). Conforme explicado anteriormente, essas áreas foram atribuídas somente ao veículo afetado pelas seções de decisão, de forma que o mesmo tenha sua velocidade reduzida enquanto o motorista procura por uma vaga. 


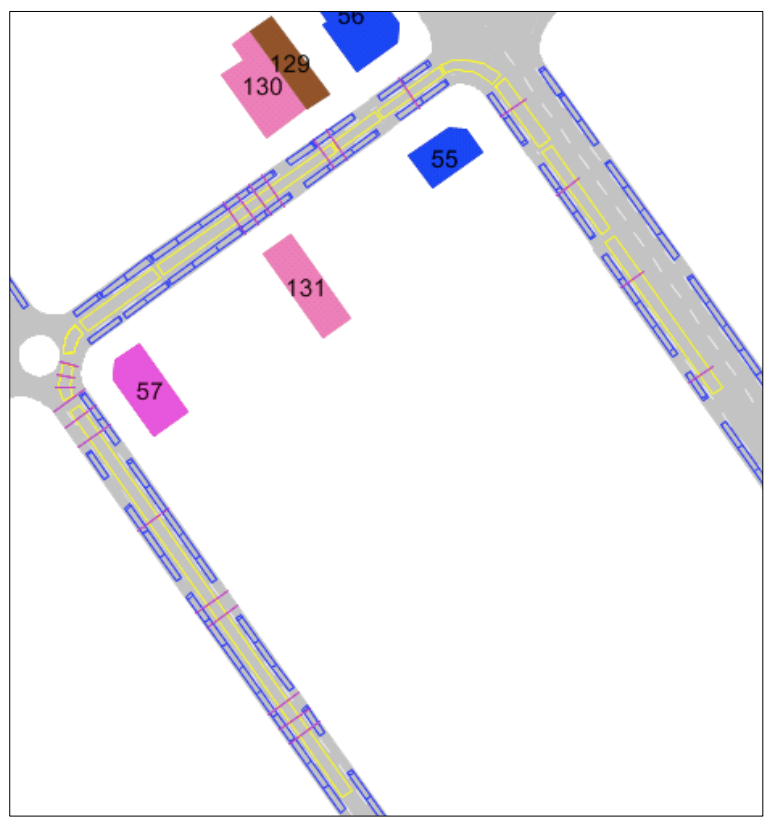

Figura 7.43 - Exemplo da inserção de áreas de velocidade reduzida (em amarelo) ao longo do percurso de busca por uma vaga de estacionamento 


\section{Fluxo de decisões ' $D$ ':}

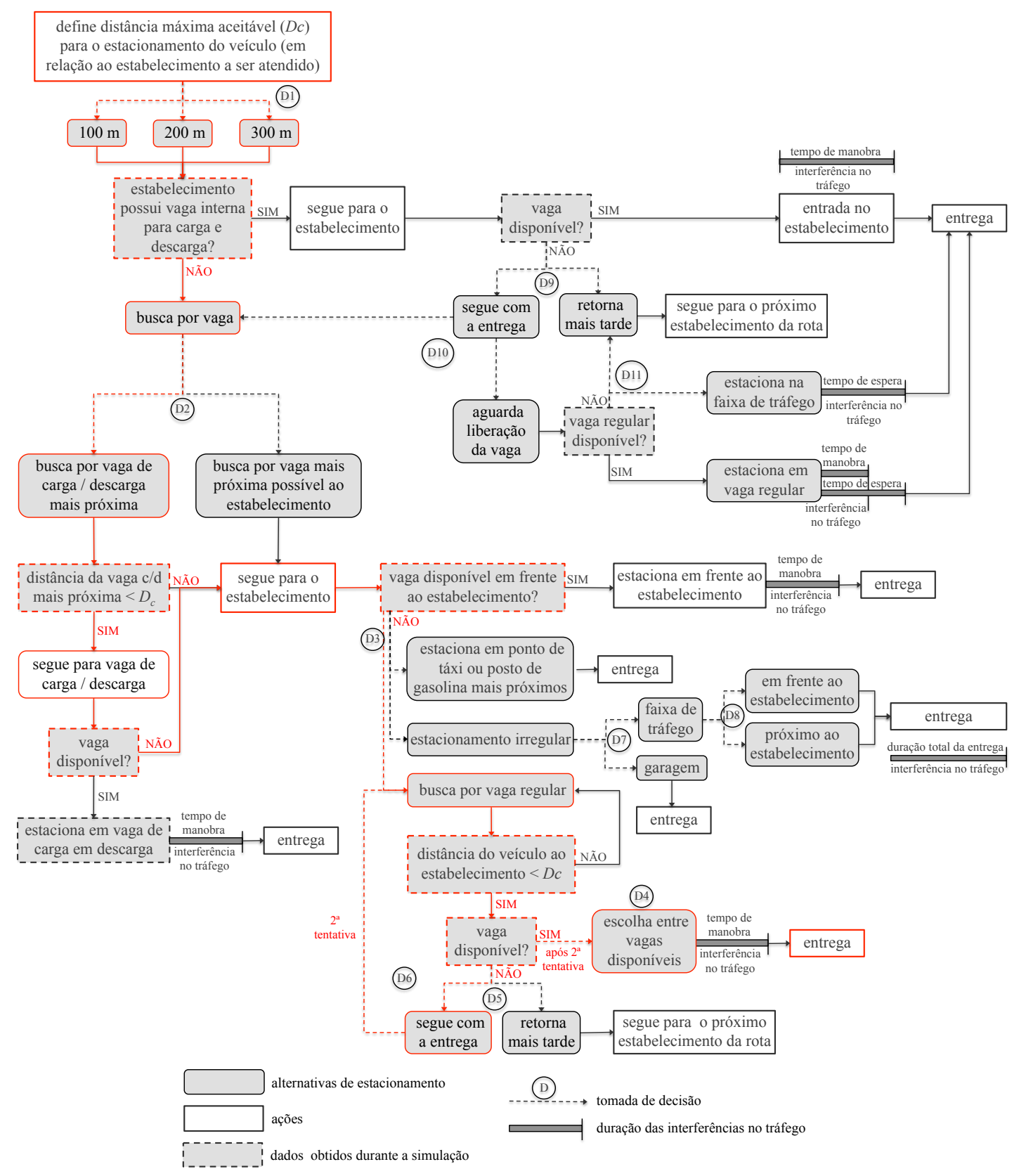

Figura 7.44 - Fluxo de decisões 'D'

O fluxo 'D' (Figura 7.44) representa a persistência do motorista em continuar procurando por uma vaga de estacionamento mesmo após uma primeira volta no quarteirão. Ou seja, o motorista detecta a vaga de carga e descarga indisponível e parte para uma vaga próxima ao estabelecimento; ao se deparar com essa vaga também indisponível decide buscar por uma outra vaga e dá uma volta no quarteirão; novamente não encontra uma vaga livre, mas, 
mesmo assim, escolhe continuar a busca até, finalmente, encontrar uma vaga livre. As decisões de rota dinâmica para busca, nesse caso, são as mesmas do fluxo 'C' e se estendem a outras vias (Figura 7.45), contanto que a distância $D_{c}$ não seja superada e as vias não façam parte do caminho utilizado pelo veículo para chegar ao estabelecimento (limitação do VISSIM explicada anteriormente).

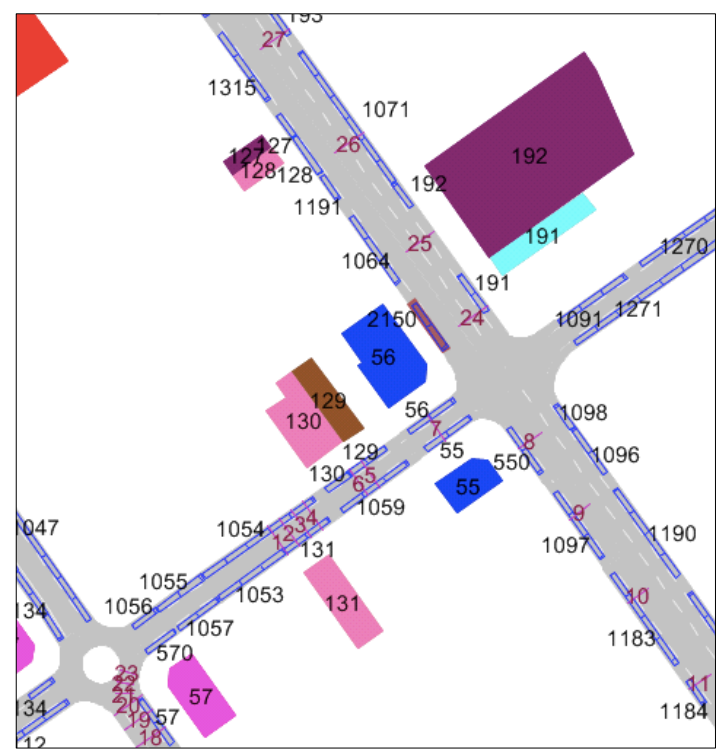

Figura 7.45 - Exemplo da modelagem de decisões de rota dinâmica para a segunda tentativa de busca por uma vaga de estacionamento

A decisão 23 é a responsável pelo início da nova busca e sua estratégia estabelece que o veículo siga para a próxima vaga a ser checada, nesse exemplo a vaga 191, e assim por diante, conforme mostrado no Quadro 7.8. Novas áreas de velocidade reduzidas também foram criadas nas vias por onde a busca se estende. As seções de decisão adicionais, que anulam as decisões por busca, são necessárias agora somente na via onde a nova busca é realizada.

Quadro 7.8- Estratégias para as decisões de rota dinâmica para a segunda tentativa de busca por uma vaga de estacionamento

\begin{tabular}{ccc}
\hline Decisão & Condição & Estratégia \\
\hline 1 a 22 & idem fluxo 'C' & idem fluxo 'C' \\
23 & estacionamento de destino (1056) está lotado & seguir para 191 \\
24 & estacionamento de destino (191) está lotado & seguir para 192 \\
25 & estacionamento de destino (192) está lotado & seguir para 1071 \\
26 & estacionamento de destino (1071) está lotado & seguir para 193 \\
27 & estacionamento de destino (193) está lotado & seguir para outra opção de \\
estacionamento (fluxo 'E')
\end{tabular}




\section{Fluxo de decisões 'E':}

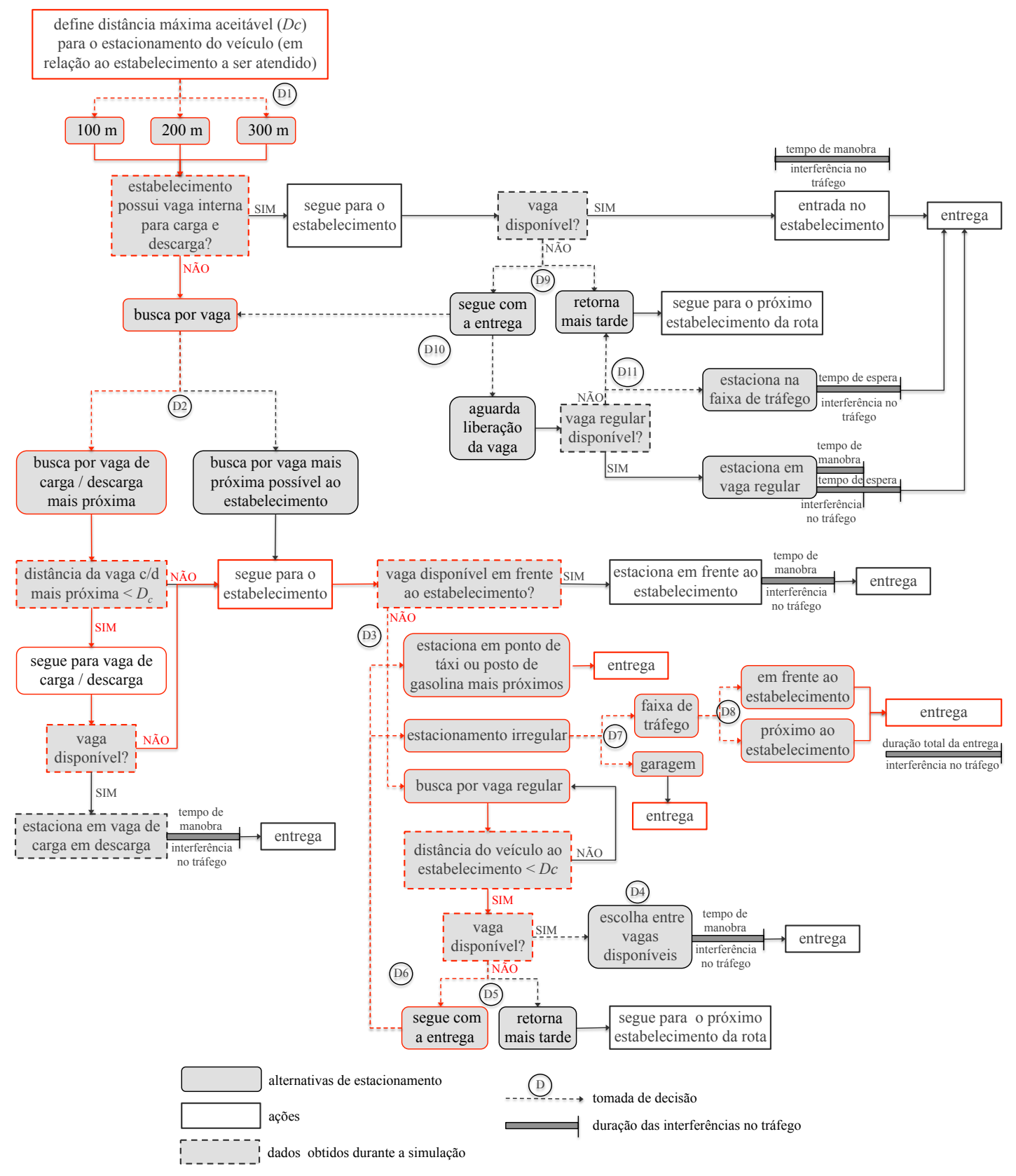

Figura 7.46 - Fluxo de decisões 'E'

No fluxo de decisões 'E' (Figura 7.46) são representadas as ações dos motoristas ao não obterem sucesso na busca por uma vaga regular, são elas: (i) seguir para um posto de gasolina ou ponto de táxi (caso haja algum próximo ao estabelecimento) ou (ii) estacionar irregularmente. Essas decisões podem ser tomadas tanto após a primeira tentativa de busca 
(fluxo 'C') quanto após a segunda tentativa de busca (fluxo 'D'). Sendo assim, o fluxo 'E' engloba quatro situações, entre as quais o motorista pode optar por:

i. Estacionamento irregular após a primeira tentativa de busca por uma vaga de estacionamento;

ii. Estacionamento em posto de gasolina ou ponto de táxi (caso existam) após primeira tentativa de busca por uma vaga de estacionamento;

iii. Estacionamento irregular após a segunda tentativa de busca por uma vaga de estacionamento;

iv. Estacionamento em posto de gasolina ou ponto de táxi (caso existam) após segunda tentativa de busca por uma vaga de estacionamento.

$\mathrm{Na}$ modelagem das duas primeiras situações, foram utilizadas as mesmas decisões de rota dinâmica do fluxo 'C', com a diferença que a estratégia da seção 23, agora, estabelece que o veículo siga ou para uma vaga de estacionamento irregular ou para o posto de gasolina/ponto de táxi mais próximo, conforme os fluxos 'A' e 'B', já apresentados.

$\mathrm{Na}$ modelagem das situações iii. e iv. foram utilizadas as mesmas decisões de rota dinâmica do fluxo 'D', sendo que, à seção de decisão 27 é atribuída a estratégia de que o veículo, após duas tentativas de busca, siga para uma vaga de estacionamento irregular ou para o posto de gasolina/ponto de táxi mais próximo.

Nas quatro situações as decisões adicionais que anulam as decisões de busca são necessárias apenas no trecho localizado após o local onde o veículo estacionou e somente se, nesse trecho, existirem seções de decisão que alterem a rota do veículo. Supondo que no exemplo da Figura 7.47, no qual o motorista opta por estacionar irregularmente em fila dupla, o caminho rumo ao próximo destino seja o indicado pelas setas. Nesse caso, as decisões adicionais deveriam ser criadas apenas após as seções 9, 10 e 11 . 


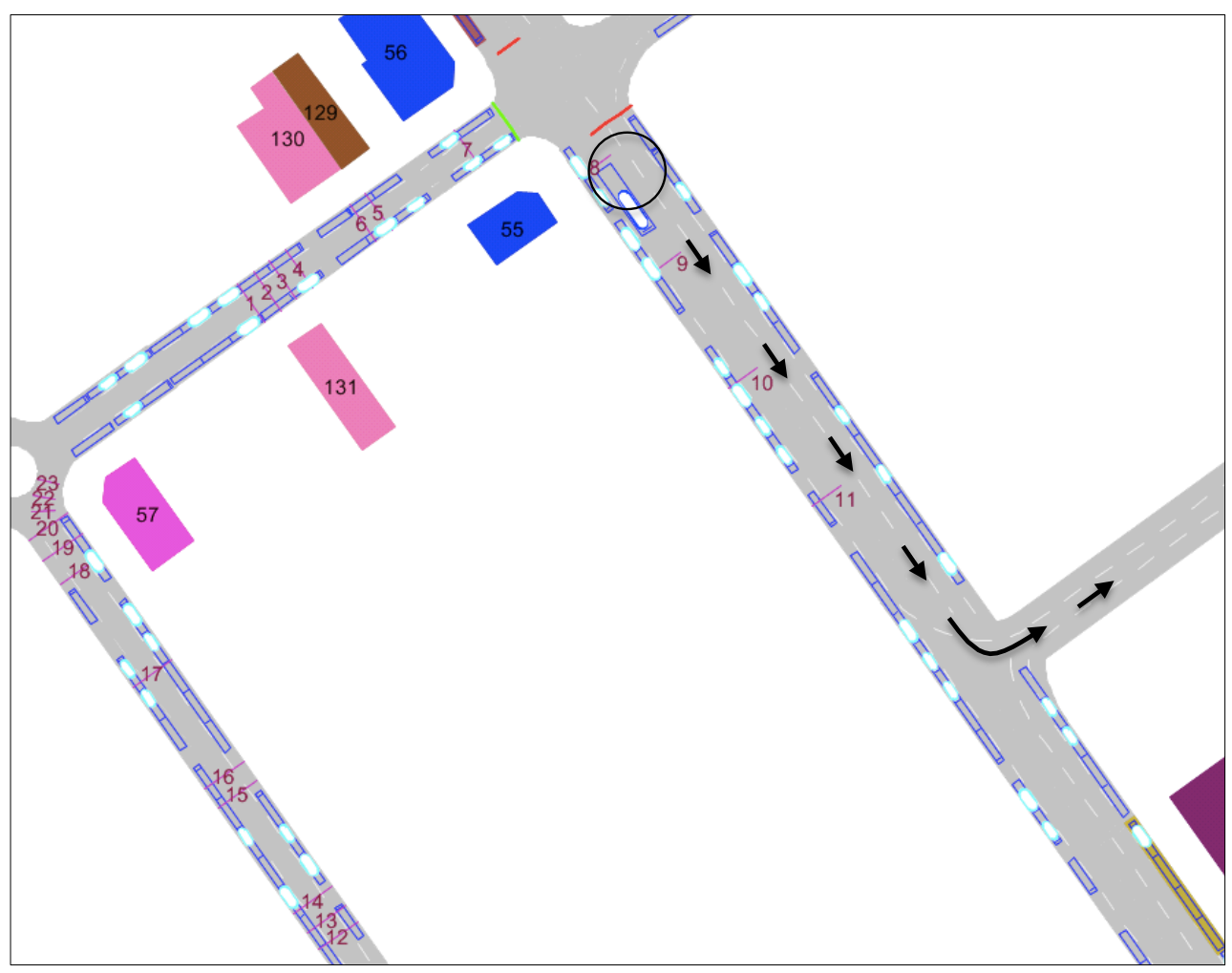

Figura 7.47 - Exemplo da modelagem das seções de decisão adicionais 
Fluxo de decisões ' $F$ ':

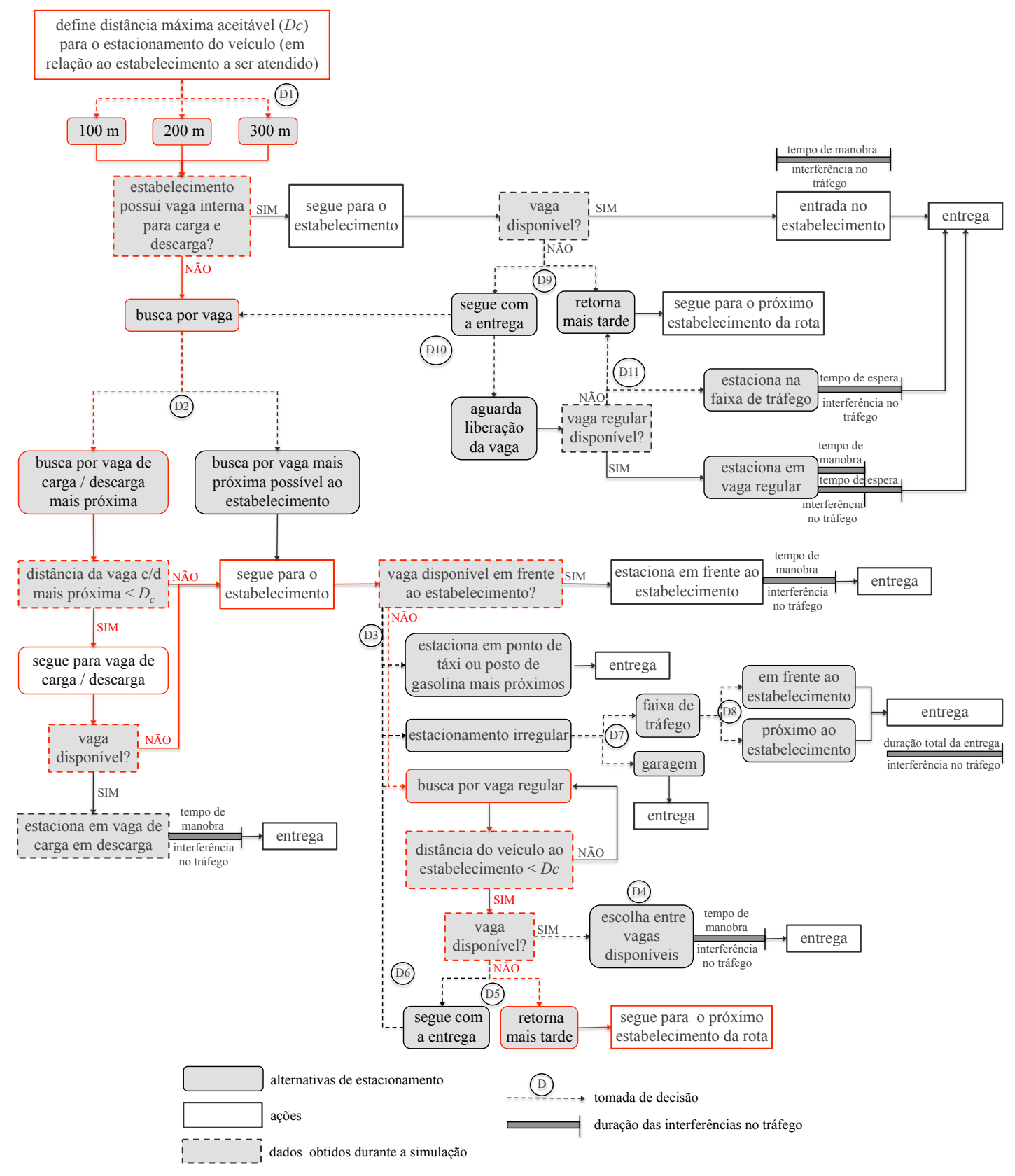

Figura 7.48 - Fluxo de decisões 'F'

A modelagem da opção por adiar a entrega e seguir para outro estabelecimento, representada pelo fluxo 'F' (Figura 7.48), esbarra em outra limitação do VISSIM a respeito das decisões de rotas dinâmicas. Até então, nos fluxos apresentados, a utilização das rotas dinâmicas permitiram que uma zona de destino fosse substituída por outra quando a área de estacionamento associada à primeira encontrava-se indisponível. Essa substituição não 
interferiu no restante da rota do veículo (modelada através de um arquivo do tipo 'trip chain') e este seguiu para o próximo estabelecimento a ser atendido. Quando há uma alteração na ordem de entregas, no entanto, a utilização de decisões de rotas dinâmicas torna-se inviável, conforme explica o exemplo a seguir.

Supondo um veículo cuja rota de entregas seja representada pelo arquivo 'trip chain' da Figura 7.49 e que, diante da indisponibilidade de vaga no estabelecimento 188, opção do motorista é seguir para o estabelecimento 234, realizar a entrega e retornar ao 188.

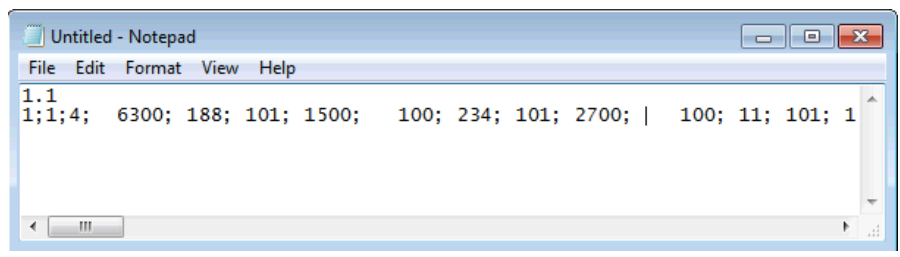

Figura 7.49 - Exemplo de rota a ser alterada pela decisão do motorista de adiar a entrega (retornar depois)

A utilização de uma decisão de rota dinâmica, nesse caso, apresentou os seguintes problemas:

- Se o veículo seguir para a zona 234, a duração do estacionamento nessa zona será aquela associada à zona 188, uma vez que a decisão de rota dinâmica substitui um destino pelo outro. Isso implica que, embora o veículo siga para o próximo estabelecimento, a duração total da entrega no mesmo não condiz com aquela que lhe foi atribuída;

- Além disso, uma vez que a zona 234 substituiu a zona 188 , essa última foi excluída da rota do veículo, impossibilitando o retorno do mesmo ao estabelecimento;

- Por fim, após o término do tempo de duração do estacionamento na zona 234 (em substituição à zona 188) o veículo foi excluído da rede de simulação, pois seu próximo destino era própria zona 234, o que não é permitido no VISSIM.

A solução, nesse caso, consistiu no acompanhamento das rotas dos veículos que obedecem ao fluxo de decisões ' $F$ ' para que fossem identificadas as situações nas quais não há disponibilidade de estacionamento e alteradas suas rotas de entrega originais no arquivo 'trip chain'. A cada alteração uma nova rodada da simulação e um novo acompanhamento da rota se fizeram necessários, o que tornou a modelagem ainda mais trabalhosa e demorada. 
Fluxo de decisões ' $G$ ':

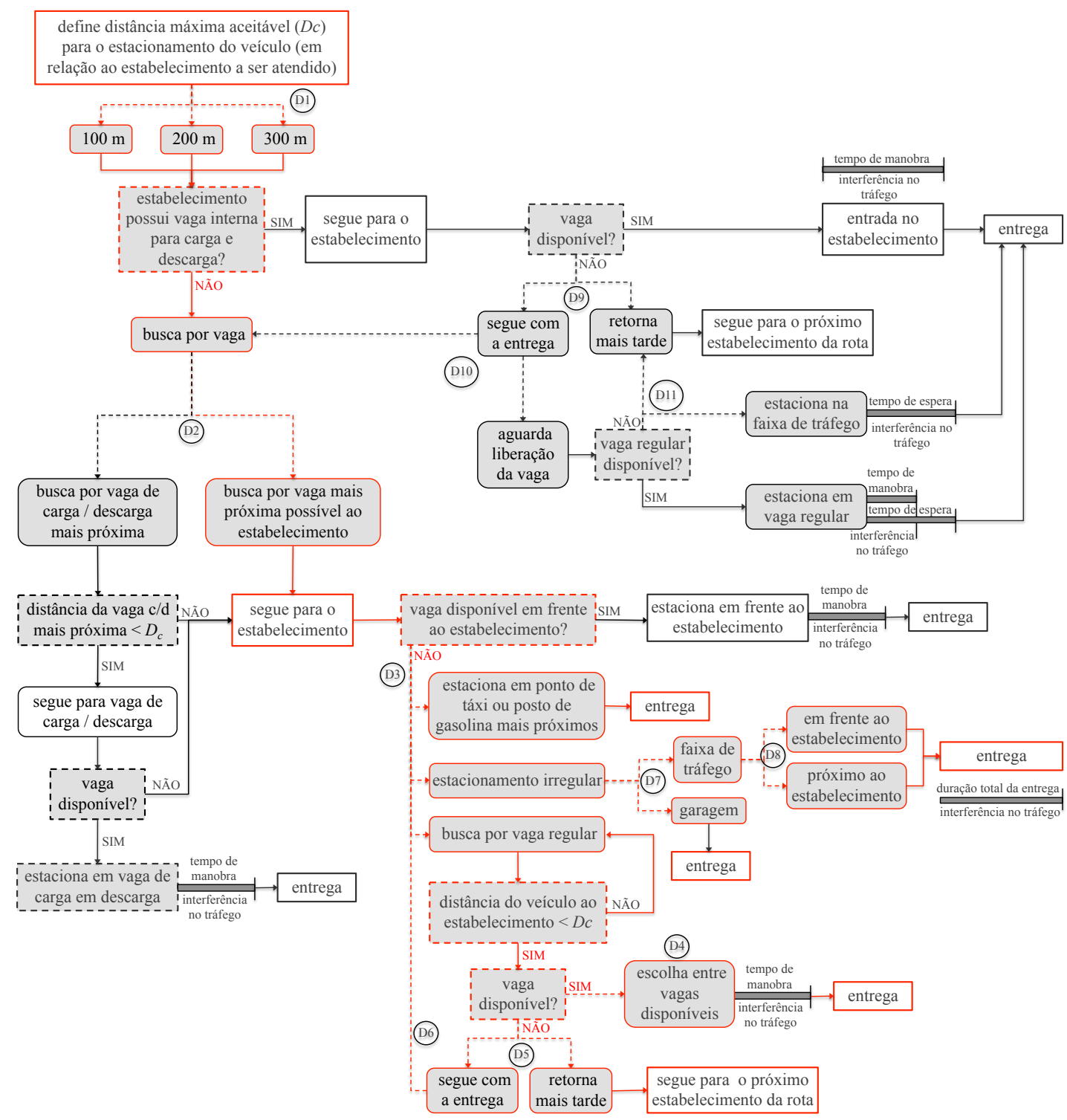

Figura 7.50 - Fluxo de decisões 'G'

No fluxo 'G' (Figura 7.50), ao contrário dos outros apresentados até então, a primeira opção de estacionamento do veículo é uma vaga regular, o mais próximo possível do estabelecimento. A partir daí são representados os seis possíveis fluxos de ações resultantes, os quais se equivalem aos apresentados até então ('A', 'B', 'C', 'D', 'E' e 'F'), com a única diferença que a primeira opção de estacionamento, que era uma vaga de carga e descarga nesses fluxos já apresentados, agora é uma vaga regular. A modelagem, portanto, diferiu apenas no destino inicial do veículo, que nesse caso é a zona associada à vaga de 
estacionamento do próprio estabelecimento, e prosseguiu exatamente a mesma do fluxo equivalente ('A', 'B', 'C', 'D', 'E' ou 'F').

\section{Fluxo de decisões ' $H$ ':}

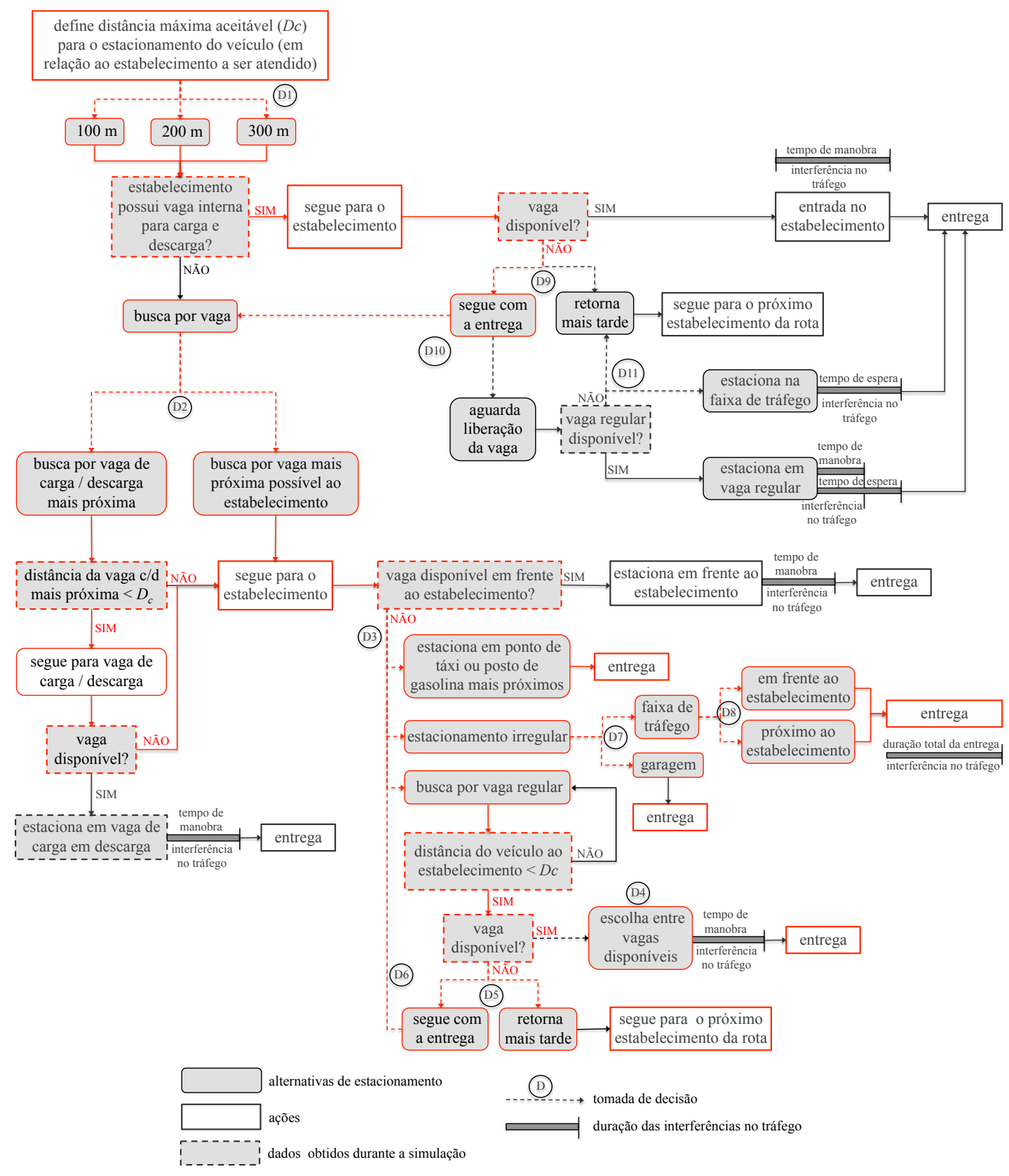

Figura 7.51 - Fluxo de decisões 'H'

O fluxo 'H' (Figura 7.51), assim como os próximos fluxos apresentados, considera a disponibilidade de uma vaga interna de carga e descarga no estabelecimento de destino. Para 
todos eles, a modelagem começou com a criação de uma vaga fictícia próxima à entrada do estabelecimento de entrega (vaga 2360 na Figura 7.52), na qual o veículo permanece estacionado durante poucos minutos, representando o tempo no qual o motorista verifica a disponibilidade da vaga interna e, estando essa vaga disponível, aguarda autorização para entrar no estabelecimento. A viagem até a zona equivalente a essa vaga fictícia foi então adicionada ao arquivo 'trip chain', como indica a Figura 7.53.

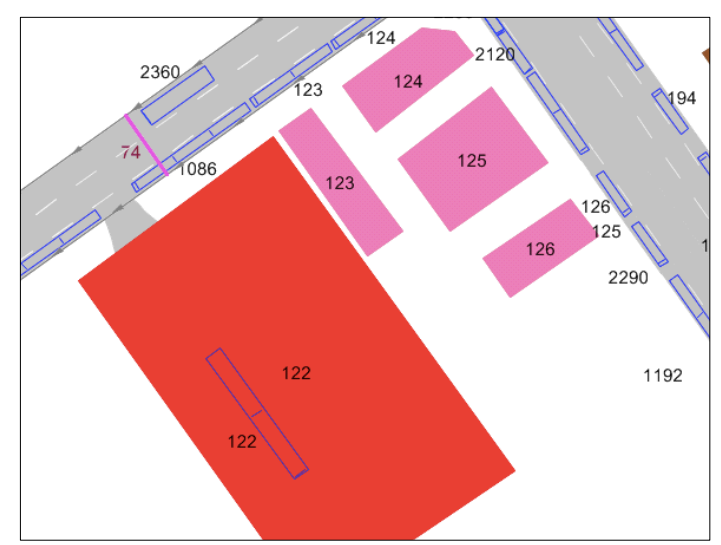

Figura 7.52 - Exemplo de vaga fictícia para espera por liberação de uma vaga interna ao estabelecimento

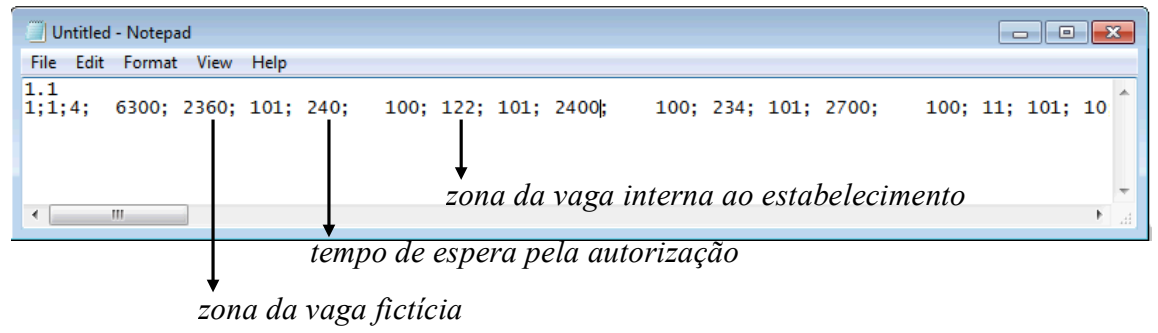

Figura 7.53 - Exemplo de inclusão da vaga fictícia de espera na rota original do veículo, no arquivo 'trip chain'

Diante da indisponibilidade da vaga interna de carga e descarga, o fluxo 'H' engloba todos os possíveis fluxos de ações derivados da decisão do motorista de seguir com a entrega, estacionando em uma outra vaga que não àquela interna ao estabelecimento (fluxos 'A' até 'G'). Para isso foi criada uma decisão de rota dinâmica logo após a vaga fictícia (74), para que uma nova vaga de estacionamento fosse atribuída ao veículo se a condição 'estacionamento de destino está lotado' for satisfeita. Essa nova vaga de estacionamento depende da decisão D5, podendo ser a vaga de carga descarga mais próxima ou a vaga regular mais próxima. A partir dessa decisão, e de acordo com o fluxo resultante, a modelagem obedece às mesmas decisões de rota dinâmica do fluxo equivalente já apresentado ('A', 'B', 'C', 'D', 'E', 'F' ou 'G'). 
Fluxo de decisões ' $I$ ':

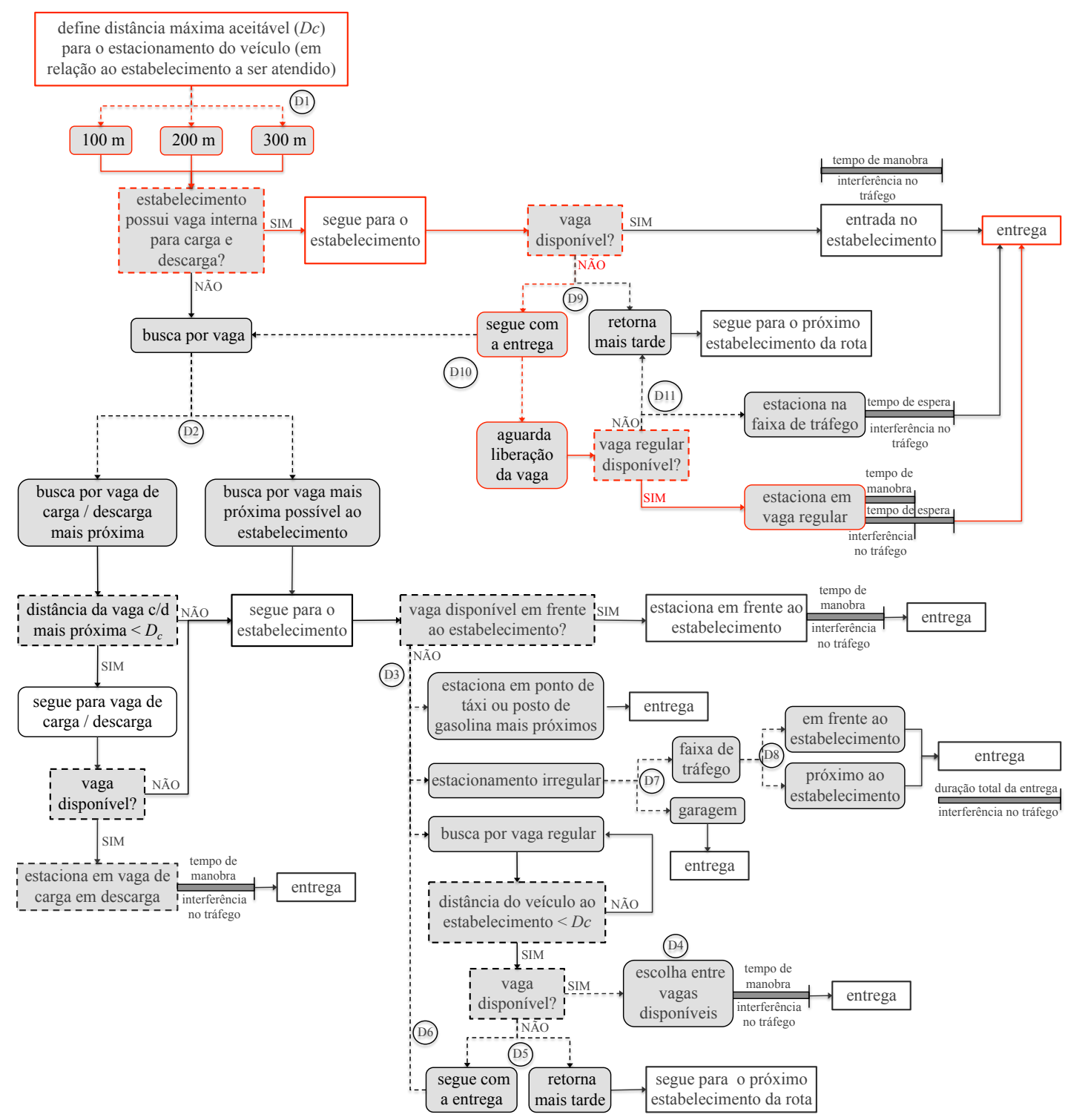

Figura 7.54 - Fluxo de decisões 'I'

O fluxo de decisões 'I', apresentado na Figura 7.54, representa a situação na qual o motorista decide esperar pela liberação da vaga interna de carga e descarga, considerando a existência de uma vaga regular disponível na qual o veículo possa estacionar a aguardar. Do ponto de vista da modelagem, essa situação se assemelha àquela na qual o motorista decide adiar a entrega e seguir para o próximo estabelecimento (fluxo ' $F$ '). Isso porque é preciso que o veículo siga para essa vaga de espera e depois retorne para a vaga interna ao estabelecimento. Pelas razões já citadas anteriormente, não foi possível utilizar as decisões 
de rota dinâmica nesse caso e, assim como para o a situação na qual ocorre o adiamento da entrega, foi preciso acompanhar as rotas de todos os veículos que obedecem ao fluxo ' $G$ ' e identificar a ocorrência de indisponibilidade das vagas internas de carga e descarga. Nesse caso, ainda, foi necessário determinar quanto tempo restava até que a vaga interna fosse liberada.

Identificada a necessidade de espera, uma nova viagem foi adicionada à rota original no arquivo 'trip chain', cuja zona de destino é a vaga de espera e o tempo mínimo de estacionamento a ela associada corresponde à duração da espera pela liberação da vaga interna de carga e descarga. 
Fluxo de decisões 'J':

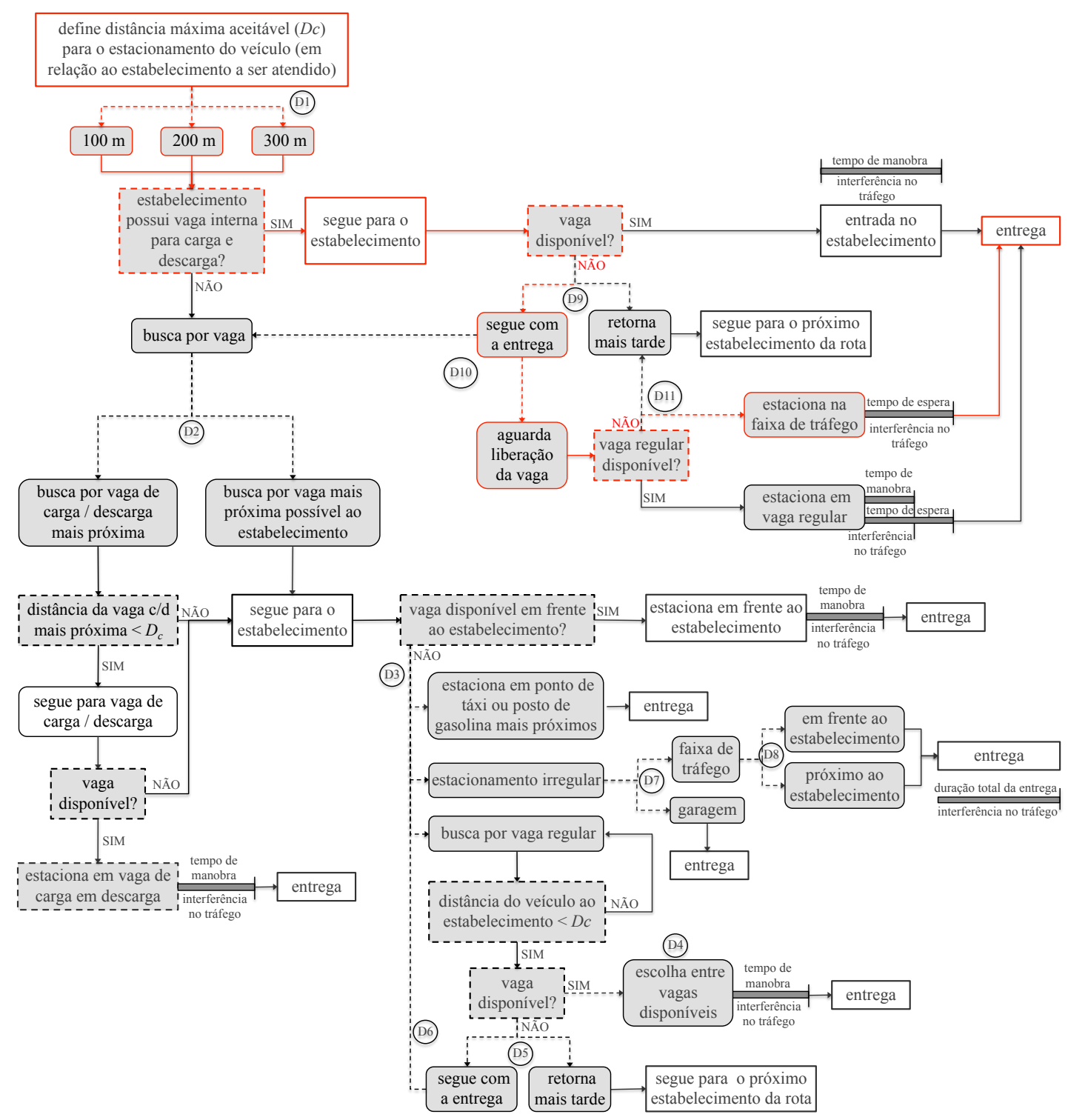

Figura 7.55 - Fluxo de decisões 'J'

Quando o motorista opta por esperar pela liberação da vaga interna ao estabelecimento e não há uma vaga regular disponível, sua ação é aguardar na faixa de tráfego. Essa situação é a representada pelo fluxo de decisões 'J', exibido na Figura 7.55. Nesse caso, diversas seções de decisão de rota dinâmica foram criadas ao longo do link, logo após a vaga fíctícia (2360) na qual o veículo estaciona para que seja verificada a disponibilidade da vaga interna. Cada seção de decisão corresponde à verificação de disponibilidade de uma das possíveis vagas nas quais o veículo estacionaria, respeitando a distância máxima $D_{c}$ estabelecida pelo 
motorista. Para todas as seções de decisão, à exceção da última, a estratégia consiste em fazer com que o veículo siga para a próxima vaga. Na última seção a estratégia adotada estabelece que o veículo siga para o seu destino original, ou seja, a vaga interna de carga e descarga. A Figura 7.56 e o Quadro 7.9 exemplificam essa parte da modelagem.

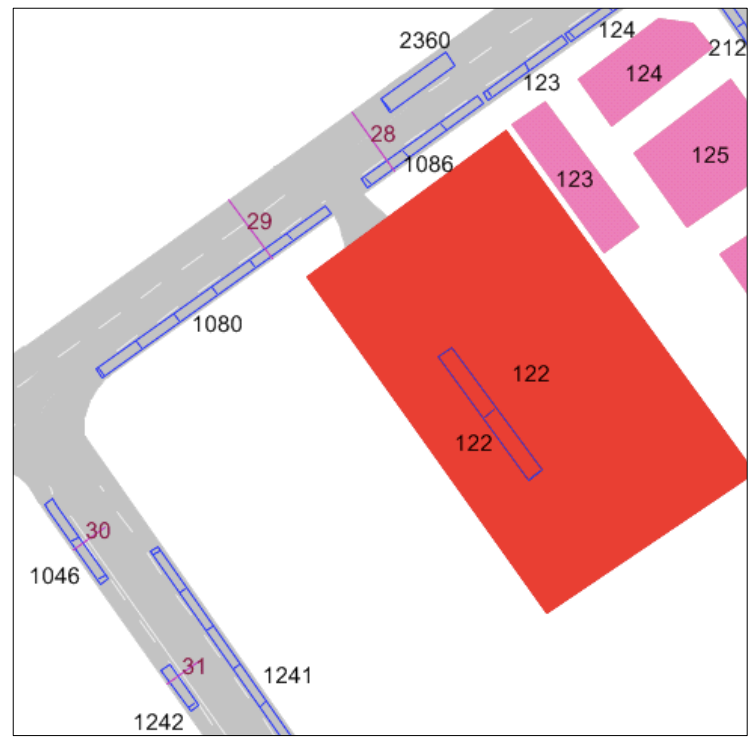

Figura 7.56 - Exemplo da modelagem de decisões de rota dinâmica para rotas que incluem vagas internas

Quadro 7.9 - Estratégias da modelagem de decisões de rota dinâmica para rotas que incluem vagas internas

\begin{tabular}{ccc}
\hline Decisão & Condição & Estratégia \\
\hline 28 & estacionamento de destino (122) está lotado & seguir para 1080 \\
29 & estacionamento de destino (1080) está lotado & seguir para 1046 \\
30 & estacionamento de destino (1046) está lotado & seguir para 1242 \\
31 & estacionamento de destino (1242) está lotado & seguir para 122 \\
\hline
\end{tabular}

Para simular a redução da velocidade do veículo durante a busca por uma vaga, áreas de velocidade reduzida também foram inseridas ao longo da via onde estão localizadas as seções de decisão.

Adicionalmente às decisões de rota dinâmica, uma regra de prioridade foi inserida para simular a espera do veículo pela liberação da vaga interna. A regra de prioridade é composta por uma linha de parada e uma ou mais linhas de conflito. Um veículo deve esperar na linha de parada caso haja outro veículo sobre uma das linhas de conflito. Sendo assim, uma linha de parada (em vermelho na Figura 7.57) foi inserida no início do conector que dá acesso ao estabelecimento e uma linha de conflito (em verde na Figura 7.57), no link onde está 
localizada a área de carga e descarga. Nos casos em que a capacidade da área de carga e descarga era de mais de um veículo, a linha de conflito foi posicionada junto à vaga que é liberada primeiro, razão pela qual também foi necessário acompanhar as rotas dos veículos durante a simulação.

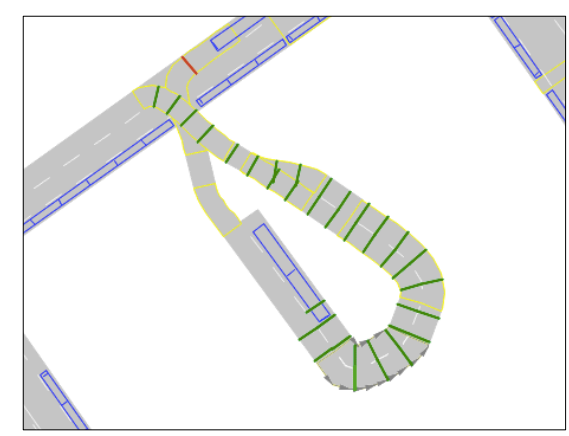

Figura 7.57 - Exemplo da modelagem das regras de prioridade para vagas internas

Ainda, para situações como a do exemplo, na qual os veículos entram e saem do estabelecimento pelo mesmo lugar, foi necessário inserir várias linhas de conflito ao longo do conector que liga a vaga interna ao link principal, garantindo que o veículo em espera (retido na linha de parada) só entrasse no estabelecimento quando o veículo que ocupava a vaga de estacionamento deixasse o mesmo [Figura 7.58 (a) e (b)].
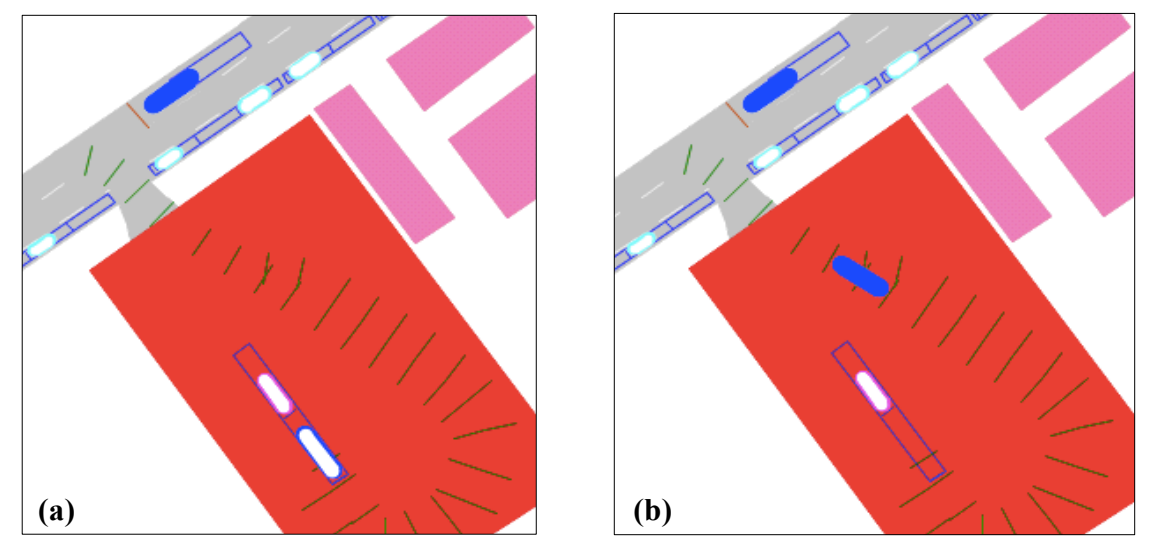

Figura 7.58 - Exemplo de veículo respeitando a regra de prioridade: (a) aguardando liberação da vaga interna e (b) entrando no estabelecimento após a saída do outro veículo 


\section{Fluxo de decisões ' $K$ ':}

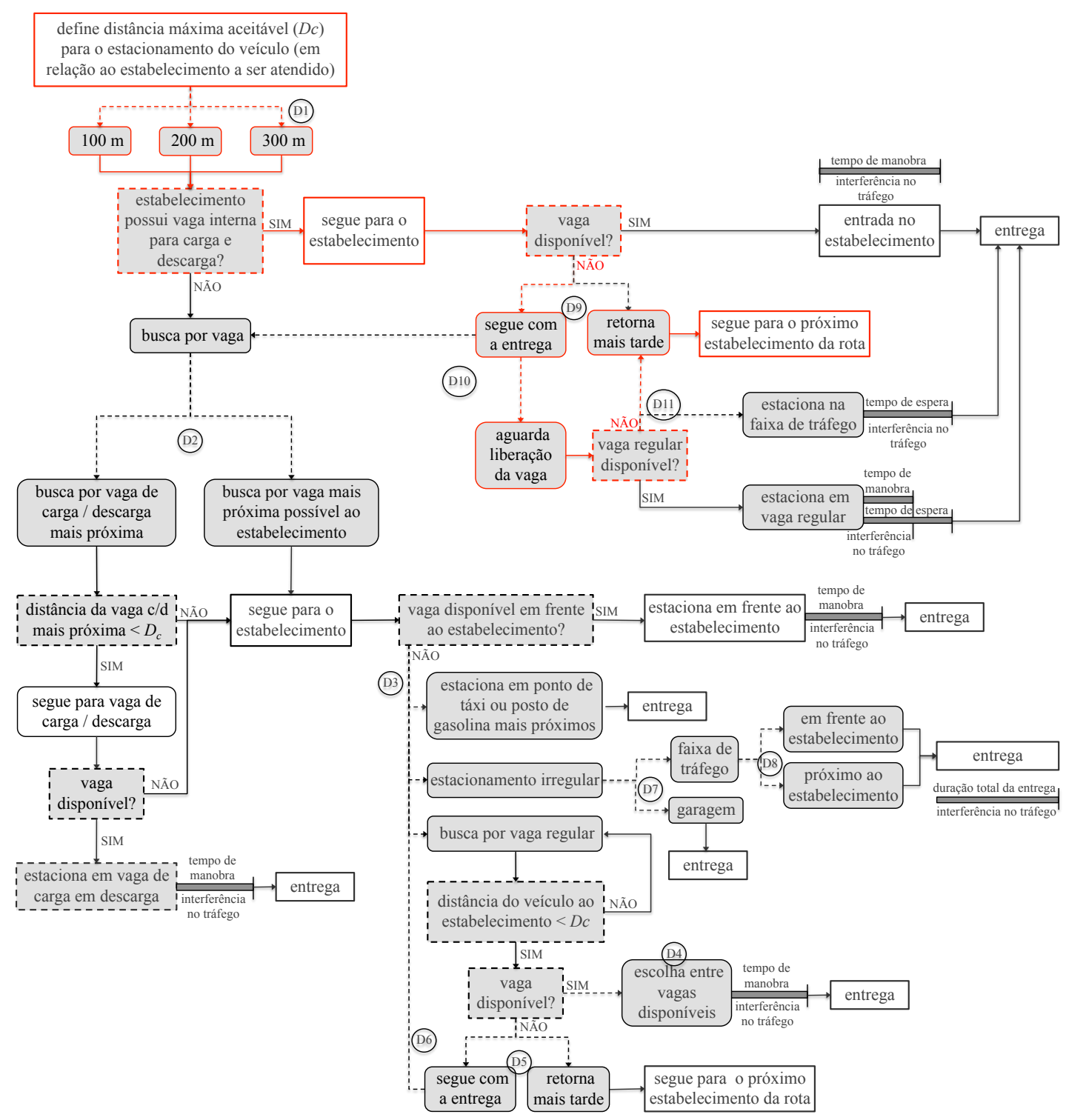

Figura 7.59 - Fluxo de decisões 'K'

Finalmente, o fluxo de decisões 'K' (Figura 7.59) representa a situação na qual o motorista decide adiar a entrega no estabelecimento cuja vaga interna de carga e descarga não está disponível. Como no fluxo 'F, onde a decisão é a mesma, a modelagem foi feita através do acompanhamento das rotas dos veículos e alteração de suas rotas originais. 


\section{EXPERIMENTOS DE SIMULAÇÃO}

Após a modelagem, no VISSIM, do ambiente de microssimulação capaz de representar os movimentos dos veículos de carga, procedeu-se aos experimentos computacionais, nos quais foram simulados três cenários representando a distribuição urbana de cargas em diferentes condições. O objetivo deste capítulo é mostrar que os resultados obtidos através da microssimulação permitem a avaliação de medidas voltadas à distribuição urbana de cargas sob uma perspectiva local, na qual é possível identificar e estimar os impactos causados pelos movimentos dos veículos de carga, de forma tão desagregada quanto for necessário.

\subsection{CENÁRIOS DE SIMULAÇÃO}

Para a área de simulação apresentada no Capítulo 7, três diferentes cenários foram simulados no VISSIM: um cenário base, considerando a situação atual, e dois outros cenários alternativos, refletindo alterações derivadas de medidas voltadas à distribuição urbana de cargas. Para cada um deles, a partir das demandas por entregas dos estabelecimentos localizados na área de simulação, foram geradas as rotas de entrega dos veículos de carga e as decisões de estacionamento para cada um desses veículos, sendo que ambas serviram de base para a modelagem do ambiente de simulação, conforme explicado no Capítulo 7.

\subsubsection{Cenário Base}

O cenário base representa a situação atual, considerando os dados obtidos nas coletas de dados, em especial nas etapas de observações das entregas e entrevistas com os motoristas, como dados de entrada para os modelos 'Geração das Demandas', 'Geração dos Veículos de Entrega' e 'Preferências de Estacionamento'. Os resultados fornecidos por esses modelos cujos são apresentados a seguir.

\section{Rotas de Entrega}

As rotas de entrega dos veículos de carga que atendem aos estabelecimentos da área de simulação foram geradas a partir dos resultados de 100 rodadas conjuntas dos modelos 'Geração das Demandas' e 'Geração dos Veículos de Entrega'. Os histogramas das Figuras 8.1 e 8.2, a seguir, mostram que o resultado mais frequente para o número total de entregas foi de 148, com sete ocorrências em 100 . 


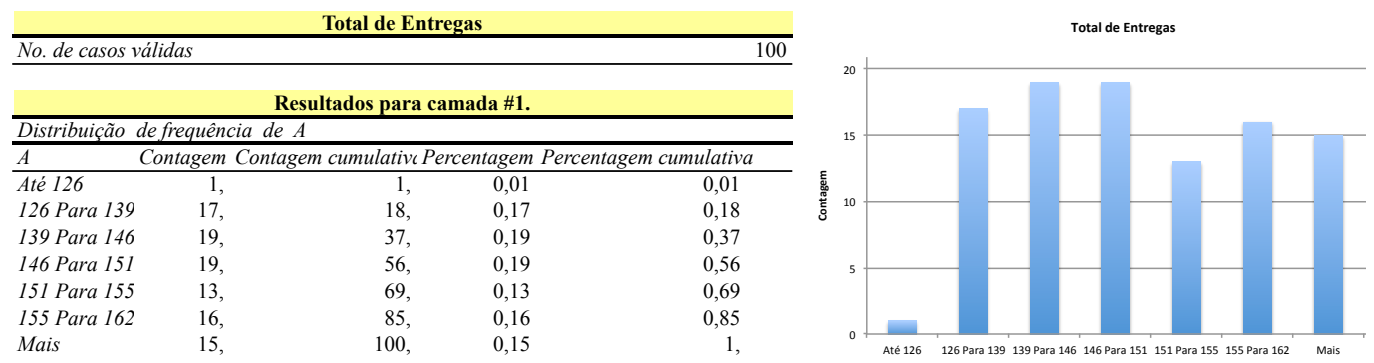

Figura 8.1- Histograma da frequência do número total de entregas na área de simulação

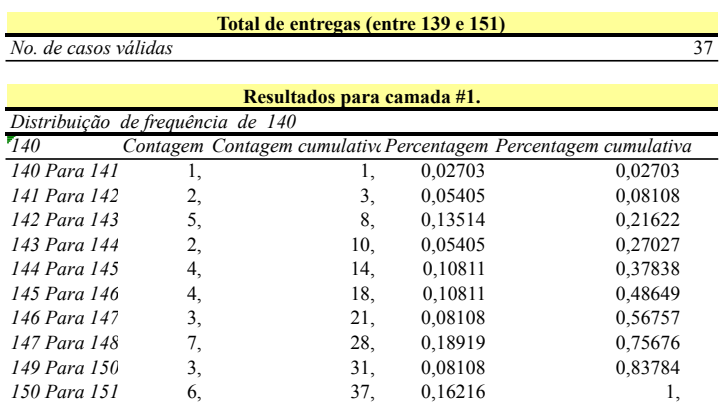

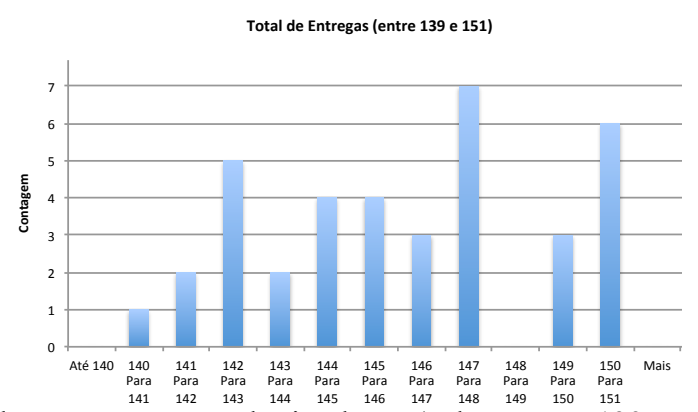

Figura 8.2 - Histograma da frequência do número total de entregas na área de simulação (valores entre 139 e 151)

Embora o resultado de 51 veículos tenha sido o mais frequente dentre as ocorrências de 148 entregas, conforme indica a Tabela 8.1, optou-se por utilizar um valor intermediário, de 46 veículos, correspondente à rodada de número 75.

\begin{tabular}{|c|c|c|}
\hline rodada & total de entregas & $\begin{array}{l}\text { número de } \\
\text { veículos }\end{array}$ \\
\hline 5 & 148 & 44 \\
\hline 13 & 148 & 42 \\
\hline 42 & 148 & 51 \\
\hline 48 & 148 & 42 \\
\hline 52 & 148 & 51 \\
\hline 75 & 148 & 46 \\
\hline 88 & 148 & 51 \\
\hline
\end{tabular}

Sendo assim, a Tabela 8.2 apresenta os resultados do modelo 'Geração dos Veículos de Entrega' para a rodada 75, com um total de 148 entregas a serem realizadas por 46 veículos.

\section{Decisões de Estacionamento}

O Quadro 8.1 traz os resultados do modelo 'Preferências de Estacionamento'. As células preenchidas na cor cinza representam, para cada veículo que realiza entregas na área de simulação, a alternativa escolhida para cada uma das decisões relacionadas à escolha do local de estacionamento. 
Tabela 8.2 - Rotas de entrega dos veículos do cenário base (situação atual)

\begin{tabular}{|c|c|c|c|c|c|c|c|c|c|c|c|c|c|c|c|c|c|c|c|c|c|c|c|c|c|c|}
\hline \multirow{2}{*}{ VEÍCULO } & \multirow{2}{*}{$\begin{array}{c}\text { TIPO DE } \\
\text { VEÍCULO }\end{array}$} & \multirow{2}{*}{$\begin{array}{l}\text { GRUPO DE PRODUTOS } \\
\text { TRANSPORTADO }\end{array}$} & \multirow{2}{*}{\begin{tabular}{|c|}
$\begin{array}{c}\text { HORÁRIO DE } \\
\text { ENTRADA NA } \\
\text { REDE }\end{array}$ \\
\end{tabular}} & \multirow{2}{*}{\begin{tabular}{l|l} 
SEÇÃO DE \\
ENTRADA \\
\cline { 3 - 3 }
\end{tabular}} & \multicolumn{21}{|c|}{ ROTA DE ENTREGA } & \multirow{2}{*}{\begin{tabular}{|c|} 
SEÇÃo \\
DE SAÍDA \\
DA REDE
\end{tabular}} \\
\hline & & & & & ID i I & DT & ID & DT & ID & DT & ID & DT & ID & DT & ID;DT & ID i & DT & ID & i DT & ID & i DT & ID & $;$ DT & ID & DT & \\
\hline 1 & \begin{tabular}{|l|} 
VUC PEQUENO \\
\end{tabular} & ALIMENTOS CONGELADOS & \begin{tabular}{|l|l|}
$9: 40: 07$ \\
\end{tabular} & \begin{tabular}{|c|c|}
8 \\
\end{tabular} & $120 ! 3$ & 300 & 150 & 300 & \begin{tabular}{|l|l}
$124 !$ \\
:
\end{tabular} & 240 & & & & & & & & & & & & & & & & 8 \\
\hline 2 & VUC GRANDE & ALIMENTOS CONGELADOS & 11:04:02 & 13 & $142 \mathrm{i} 6$ & 600 & 136 & 360 & & & & & & & i & & i & & & & & & & & | & 16 \\
\hline 3 & VAN & ALIMENTOS CONGELADOS & 11:07:15 & 19 & 204 & 900 & $141:$ & 900 & & & & & & & & & & & & & & & & & & 5 \\
\hline 4 & VUC GRANDE & BEBIDAS & $8: 34: 21$ & 7 & & 2400 & $147 !$ & 1500 & $202 !$ & 600 & 117 ! & 360 & $206 !$ & 900 & $151 ! 1500$ & & 1200 & & & & & & & & & 5 \\
\hline 5 & VUC GRANDE & BEBIDAS & 9:29:55 & 10 & 124 & 600 & 122 & 300 & $133 i$ & 1500 & 56 & 600 & 153 & 420 & \begin{tabular}{|l|l|}
143 & 600 \\
\end{tabular} & $205 \mathrm{i}$ & 600 & & & & & & & & & 16 \\
\hline 6 & VAN & BEBIDAS & $10: 13: 14$ & 13 & $\begin{array}{l:l}56 & 1 \\
1\end{array}$ & 1200 & 55 & 120 & 124 & 600 & 133 & $\begin{array}{l}900 \\
9\end{array}$ & 142 & 480 & \begin{tabular}{|l|l|}
203 & 600 \\
\end{tabular} & 114 & 600 & 184 & 120 & & & & & & & 16 \\
\hline 7 & VAN & BEBIDAS & 6:10:15 & 15 & $184 !$ & & & & & & & & & & 1 & & & & & & & & & & ! & 16 \\
\hline 8 & VUC PEQUENO & CARNES & 8:30:26 & 9 & $196 \div 6$ & 600 & 197 & 600 & 120 & 360 & 138 & 600 & 206 & 600 & \begin{tabular}{|l|l|}
150 & 360 \\
\end{tabular} & 191 & 900 & 126 & 1800 & 53 & 900 & 195 & $5: 180$ & & & 8 \\
\hline 9 & тосо & CARNES & 8:38:25 & 1 & 138 & 120 & 141 & 1800 & 120 & 1200 & 191 & 120 & 187 & 1200 & & & & & & & & & & & & 16 \\
\hline 10 & VAN & CARNES & 8:56:44 & 9 & $120 \mathrm{i}^{2} \mathrm{r}-2 \mathrm{k}$ & 240 & $191 j$ & 240 & & & & & & & i & & & & & & & & & & & 8 \\
\hline 11 & VAN & CARNES & 6:46:27 & 12 & 191 & 1200 & 141 & 900 & & & & & & & & & & & & & & & & & & 5 \\
\hline 12 & UTILITÁRIO & CARNES & 9:35:21 & 9 & & & & & & & & & & & ! & & ! & & & & & & & & & 8 \\
\hline 13 & VUC GRANDE & CIGARROS/BEBIDAS ALCOÓLICAS & 10:25:42 & 15 & $141 j^{1}$ & 1500 & & & & & & & & & & & i & & & & & & & & & 5 \\
\hline 14 & VAN & FLV & $8: 56: 12$ & 15 & $153: 2$ & 240 & $206:$ & 600 & $196:$ & 2400 & 117 & 2400 & & & & & & & & & & & & & & 6 \\
\hline 15 & VUC PEQUENO & FLV & 7:53:51 & 4 & $127 \mathrm{i}_{1}-{ }_{1}$ & 120 & 122 & 240 & & & & & & & 1 & & & & & & & & & & | & 6 \\
\hline 16 & UTILITÁRIO & FLV & $8: 06: 13$ & 4 & $140 \dot{a}^{2}-2$ & & 142 & 240 & 136 & 7200 & 55 & 300 & 128 & 1200 & $188: 1200$ & $187 \dot{j}$ & 600 & 53 & 800 & 121 & 180 & 195 & 5600 & & & 8 \\
\hline 17 & VAN & FLV & $8: 41: 43$ & 10 & $195 ! 1$ & 1800 & $55 !$ & 240 & $142 !$ & ! 1200 & & & & & & 1 & & & & & & & & & & 5 \\
\hline 18 & VUC GRANDE & FLV & 6:40:56 & 15 & 141 it & 1200 & 142 & |3600 & & & & & & & i & & i & & & & & & & & i & 5 \\
\hline 19 & VUC GRANDE & FLV & $8: 47: 00$ & 12 & 1411 & 1200 & 142 & 2400 & & & & & & & & & & & & & & & & & & 5 \\
\hline 20 & VUC PEQUENO & FLV & 9:06:25 & 13 & $141 !_{2}$ & 2400 & & & & & & & & & $!$ & & & & & & & & & & ! & 5 \\
\hline 21 & тосо & FLV & 7:31:20 & 4 & $141 \mathfrak{j}^{1}$ & 1200 & & & & & & & & & i & & 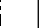 & & & & & & & & & 5 \\
\hline 22 & VUC PEQUENO & FRIOS/EMBUTIDOS & 9:14:26 & 1 & 188 & 420 & $122:$ & 1200 & & & & & & & 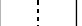 & & & & & & & & & & & 6 \\
\hline 23 & VUC GRANDE & FRIOS/EMBUTIDOS & $7: 20: 03$ & 4 & $56 ! 4$ & 480 & $53 !$ & 600 & & & & & & & ! & & & & & & & & & & ! & 16 \\
\hline 24 & VUC GRANDE & LATICíNIOS & $9: 06: 11$ & 13 & $188: 3$ & 360 & 126 & 900 & 122 & 420 & 121 & 1200 & $142 \vdots$ & 120 & \begin{tabular}{|l|l|}
144 & 240 \\
\end{tabular} & 140 & 1200 & 153 & 420 & 128 & 600 & 124 & $\begin{array}{ll}4240 \\
4\end{array}$ & & & 8 \\
\hline 25 & VUC PEQUENO & LATIĆ́NIOS & 9:23:32 & 9 & $121 ?$ & 240 & 140 & 420 & $188:$ & 360 & 122 & 360 & & & & & & & & & & & & & & 6 \\
\hline 26 & VAN & LATICíNIOS & $8: 25: 33$ & 9 & $141 \mathrm{i} 2$ & 240 & & & & & & & & & i & & & & & & & & & & & 5 \\
\hline 27 & VUC GRANDE & MERCEARIA SECA EM GERAL & $9: 38: 21$ & 7 & 1951 & 120 & 126 & 180 & 183 & 1800 & 140 & 1200 & 120 & 420 & 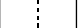 & & & & & & & & & & & 5 \\
\hline 28 & VUC GRANDE & MERCEARIA SECA EM GERAL & 9:24:33 & 12 & 193 & 1200 & & & & & & & & & 1 & & & & & & & & & & & 11 \\
\hline 29 & VUC GRANDE & MERCEARIA SECA EM GERAL & 10:52:51 & 13 & $53+3$ & & & & & & & & & & & & & & & & & & & & & 16 \\
\hline 30 & VAN & ovos & 9:55:50 & 4 & 138 & 900 & & & & & & & & & & & & & & & & & & & & 5 \\
\hline 31 & VUC GRANDE & ovos & 7:53:58 & 19 & $137 !$ & 120 & $142 !$ & 1200 & $146 !$ & 360 & $144 !$ & 3000 & 114 & 420 & $\mid 56 ! 1200$ & $55 !$ & 240 & 195 & 1200 & 122 & 2400 & $152 !$ & $2 \mid 600$ & 53 & 480 & 16 \\
\hline 32 & VUC GRANDE & ovos & 7:33:16 & 10 & 122 & 120 & 137 & 600 & & & & & & & & & & & & & & & & & & 5 \\
\hline 33 & VUC GRANDE & ovos & $10: 58: 15$ & 13 & $56: 3$ & & & & & & & & & & & & & & & & & & & & & 8 \\
\hline 34 & VUC GRANDE & PÃES & $7: 53: 13$ & 9 & $141 \mathrm{j} 1$ & 1200 & 140 & 420 & 113 & 360 & & & & & i & i & i & & & & & & & & & 6 \\
\hline 35 & VUC GRANDE & PÃES & 7:30:52 & 9 & $113 \vdots 4$ & 420 & & & & & & & & & & & & & & & & & & & & 6 \\
\hline 36 & VUC PEQUENO & PÃES & 10:17:02 & 10 & $113 !$ & 420 & & & & & & & & & $!$ & & I & & & & & & & & & 6 \\
\hline 37 & VAN & SNACKS & 8:35:07 & 4 & 142 & & & & & & & & & & i & i & i & & & & & & & & i & 5 \\
\hline 38 & КомBI & SNACKS & 8:41:17 & 13 & 142 & & & & & & & & & & & & & & & & & & & & & 5 \\
\hline 39 & VUC PEQUENO & SORVETES & $11: 24: 01$ & 1 & $188 !$ & 120 & $124 !$ & 180 & $122 !$ & 900 & & & & & ! & ! & i & & & & & & & & & 6 \\
\hline 40 & VUC PEQUENO & SORVETES & $10: 24: 19$ & 9 & $188: 3$ & 360 & 122 & 900 & & & & & & & & & & & & & & & & & & 6 \\
\hline 41 & VUC PEQUENO & SORVETES & $7: 38: 55$ & 10 & $\begin{array}{lll}53 & 1 \\
1\end{array}$ & 1200 & $203 !$ & 900 & & & & & & & & & & & & & & & & & & 6 \\
\hline 42 & VAN & OUTROS & 9:52:44 & 1 & $140 \mathrm{j}$ & 480 & 156 & $\begin{array}{l}300 \\
300\end{array}$ & 126 & | 480 & 185 & 240 & 124 & 480 & \begin{tabular}{|l|l|l|}
2400 \\
\end{tabular} & & i & & & & & & & & i & 8 \\
\hline 43 & VAN & OUTROS & $10: 12: 39$ & 10 & $126: 3$ & 360 & $140 !$ & 240 & & & & & & & & & & & & & & & & & & 6 \\
\hline 44 & UTILITÁRIO & OUTROS & $10: 29: 57$ & 9 & $141 !$ & 480 & $57 !$ & 300 & $193 !$ & 600 & $128 !$ & ! 900 & $126 !$ & 240 & $194 ! 420$ & 184 ! & 900 & & & & & & & & & 16 \\
\hline 45 & VAN & OUTROS & 10:55:21 & 1 & $141 j$ & & & & & & & & & & & & & & & & & & & & & 5 \\
\hline 46 & UTILITÁRIO & OUTROS & $11: 00: 52$ & 4 & $\begin{array}{l:ll}141 & 3 \\
3 & \end{array}$ & & & & & & & & & & & & & & & & & & & & & 5 \\
\hline
\end{tabular}




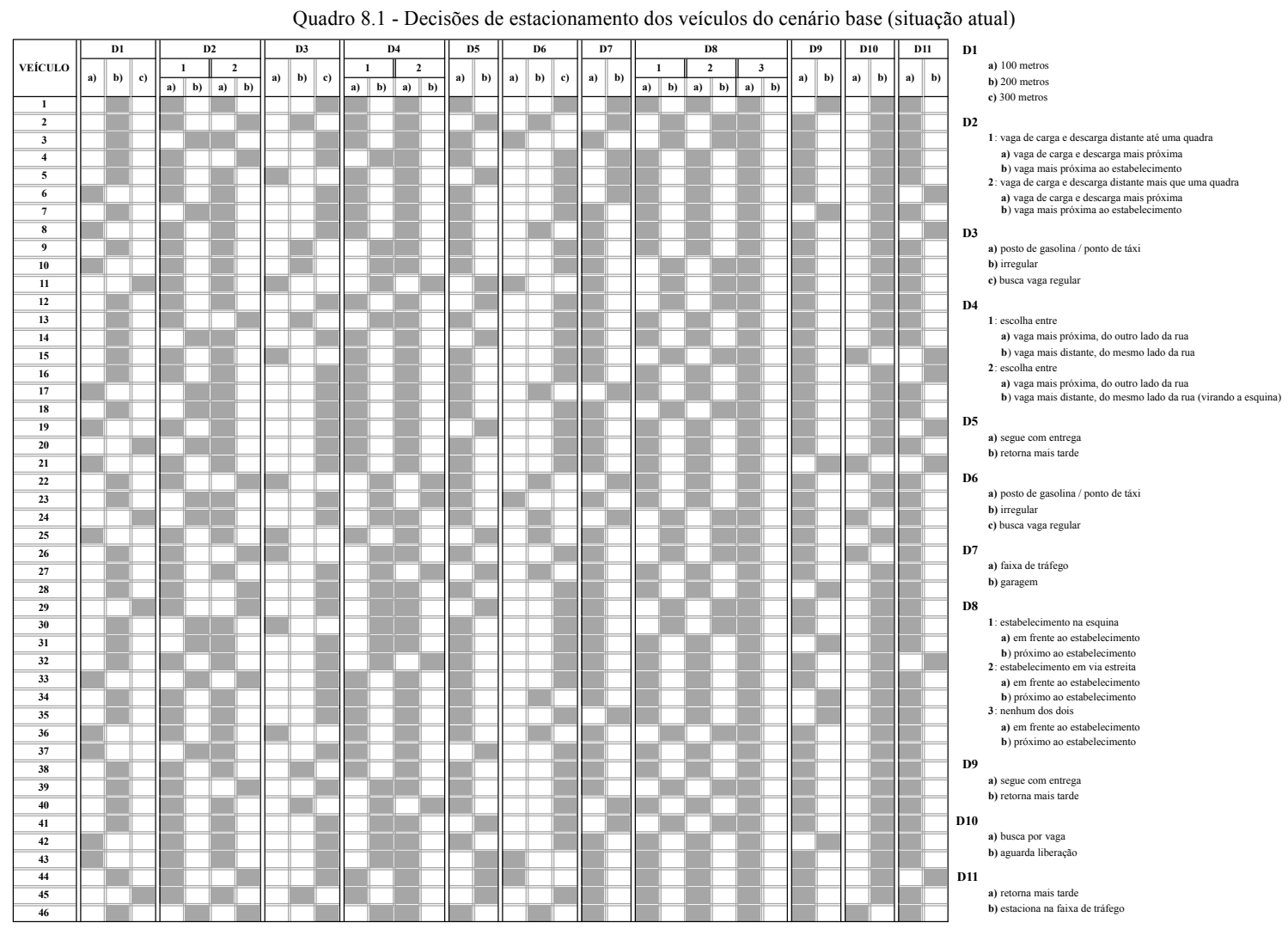




\subsubsection{Cenário Alternativo 1 - Consolidação de Cargas em Veículos Maiores}

O cenário alternativo 1 considera o transporte consolidado de produtos em veículos de carga maiores, do tipo Toco. Esse cenário busca representar a revogação da regulamentação atualmente em vigência no município de São Paulo, a qual restringe a circulação de veículos maiores do que 6,3 metros de comprimento apenas ao período entre $21 \mathrm{~h}$ e $5 \mathrm{~h}$. Nesse cenário, assume-se que todas as entregas (de diferentes fornecedores) demandadas por cada estabelecimento sejam realizadas por um único veículo. Ou seja, o cenário comporta-se como se houvesse um centro de consolidação próximo à área de simulação, no qual os produtos são recebidos dos fornecedores, separados e consolidados, de acordo com o seu destino, nos veículos que partem para a área de simulação. A escolha do veículo do tipo Toco tem como objetivo analisar os impactos da utilização de veículos de carga maiores, porém em menor quantidade, já que, devido à sua capacidade de carga de cerca de 40 toneladas, um único caminhão desse tipo substituiria cerca de dois VUCs grandes ou três VUCs pequenos.

\section{Rotas de Entrega}

Todas as entregas com destino a um mesmo estabelecimento, resultantes do modelo 'Geração de Demandas', foram agrupadas em uma única entrega. As entregas agrupadas serviram como dados de entrada para o modelo 'Geração dos Veículos de Entrega', o qual, dessa vez, considerou apenas os veículos do tipo Toco como opção para a realização dessas entregas. Considerando que esses veículos partem de um mesmo centro de consolidação, o modelo assumiu que todos eles iniciam suas rotas de entrega praticamente juntos, tendo sido adotada uma diferença de apenas cinco minutos entre o horário de entrada de cada um deles na rede de simulação. Além disso, como partem e retornam ao mesmo centro de consolidação, considerou-se que os veículos utilizam as mesmas seções de entrada e saída da rede.

As durações das entregas agrupadas foram calculadas considerando a expressão 3:

$T_{E(c)}=\sum_{p \in P} n_{p}\left(t_{p, c}-t^{\prime}\right)$

Onde,

$T_{E(c)}$ : tempo total de duração da entrega no estabelecimento $E$, pertencente à classe $c$; 
$P$ : conjunto dos grupos de produtos considerados;

$n_{p}$ : número de entregas de produtos do grupo $p$, recebidas pelo estabelecimento $E$;

$t_{p, c}$ : tempo total de duração de uma entrega de produtos do grupo $p$ em um estabelecimento da classe $c$;

$t^{\prime}$ : tempo médio total gasto entre a chegada do veículo e o início do descarregamento dos produtos.

O tempo médio total gasto entre a chegada do veículo e o início do descarregamento $\left(t^{\prime}\right)$ compreende a duração da manobra de estacionamento do veículo e o tempo entre o término do estacionamento e a abertura das portas de descarregamento. O tempo médio adotado foi de sete minutos e independe do grupo de produtos. Esse valor foi calculado a partir dos dados coletados durante as observações das entregas, apresentados na Tabela A.1 do Anexo A.

Considerando esses novos valores para a duração total das entregas nos estabelecimentos e a capacidade dos veículos do tipo Toco, o modelo 'Geração dos Veículos de Entrega' forneceu o resultado de sete veículos, cujas rotas de entrega estão apresentadas na Tabela 8.3 .

\section{Decisões de Estacionamento}

Para determinar as decisões dos motoristas, exibidas no Quadro 8.2, foram utilizadas as mesmas probabilidades adotadas no cenário base. Para a modelagem no VISSIM, no entanto, foi considerado que, para entregas em estabelecimentos próximos entre si, o veículo escolhe apenas um local de estacionamento, a partir do qual realiza as entregas. Assumiu-se também que a escolha desse local é regida sempre pelo próximo estabelecimento na sequência da rota. $\mathrm{O}$ critério adotado para avaliar a proximidade entre os estabelecimentos foi a distância máxima $D_{c}$ estabelecida para cada motorista. 
Tabela 8.3 - Rotas de entrega dos veículos do cenário alternativo 1 (consolidação de cargas em veículos maiores)

\begin{tabular}{|c|c|c|c|c|c|c|c|c|c|c|c|c|c|c|c|}
\hline \multirow{2}{*}{ VEÍCULO } & \multirow{2}{*}{$\begin{array}{c}\text { TIPO DE } \\
\text { VEÍCULO }\end{array}$} & \multirow{2}{*}{$\begin{array}{c}\text { GRUPO DE } \\
\text { PRODUTOS } \\
\text { TRANSPORTADO }\end{array}$} & \multirow{2}{*}{$\begin{array}{c}\text { HORARIO DE } \\
\text { ENTRADA NA } \\
\text { REDE }\end{array}$} & \multirow{2}{*}{$\begin{array}{l}\text { SEÇÁO DE } \\
\text { ENTRADA } \\
\text { NA REDE }\end{array}$} & \multicolumn{10}{|c|}{ ROTA DE ENTREGA } & \multirow{2}{*}{$\begin{array}{c}\text { SEÇÃO DE } \\
\text { SAÍDA DA } \\
\text { REDE }\end{array}$} \\
\hline & & & & & ID & DT & \begin{tabular}{l|l} 
ID & DT \\
\end{tabular} & \begin{tabular}{l|l} 
ID & DT
\end{tabular} & \begin{tabular}{l|l} 
ID & DT \\
\end{tabular} & \begin{tabular}{l|l|} 
ID & DT \\
\end{tabular} & \begin{tabular}{l|l} 
ID & DT
\end{tabular} & \begin{tabular}{l|l} 
ID & DT \\
\end{tabular} & \begin{tabular}{l|l} 
ID & DT \\
\end{tabular} & \begin{tabular}{l|l|} 
ID & DT \\
\end{tabular} & \\
\hline 1 & TOCO & VÁRIOS & $7: 00: 00$ & 10 & 121 & 1620 & $\begin{array}{l:l}120 & 2160 \\
\end{array}$ & \begin{tabular}{l|l}
142 & 10869
\end{tabular} & $\begin{array}{l:l}144 & 3240 \\
\end{array}$ & $\begin{array}{l:l}137 & 720 \\
\end{array}$ & $\begin{array}{l:l}138 & 1020 \\
\end{array}$ & & & & 11 \\
\hline 2 & TOCO & VÁRIOS & 7:05:00 & 10 & 202 & 600 & $\begin{array}{l:l}203 & 1500\end{array}$ & 204900 & $\begin{array}{lll}205 & 600\end{array}$ & $206: 2500$ & \begin{tabular}{l|l}
183 & 1800
\end{tabular} & 184 & 185 & 188 & 11 \\
\hline 3 & TOCO & VÁRIOS & $7: 10: 00$ & 10 & 195 & 6120 & $126 \mid 2160$ & $124 \mid 2340$ & 1232400 & $127 \mid 120$ & $128 \mid 2700$ & & & & 11 \\
\hline 4 & тосо & VÁRIOS & 7:15:00 & 10 & 113 & 1200 & $\begin{array}{l:l}114 & 1020\end{array}$ & $\begin{array}{l:l}117 & 2760\end{array}$ & $\begin{array}{l:l}150 & 300\end{array}$ & $\begin{array}{l:l}136 & 7560\end{array}$ & $\begin{array}{l:l}133 & 2400\end{array}$ & $\begin{array}{l:l}57 & 300\end{array}$ & $187: 1800$ & & 11 \\
\hline 5 & тосо & VÁRIOS & 7:20:00 & 10 & 122 & 6840 & \begin{tabular}{l|l}
55 & 900
\end{tabular} & $56 \mid 3840$ & $152: 600$ & $153 \mid 2280$ & $156 \mid 300$ & $151 \mid 1500$ & & & 11 \\
\hline 6 & TOCO & VÁRIOS & $7: 25: 00$ & 10 & 141 & 13080 & $53 \quad 4440$ & & & & & & & & 11 \\
\hline 7 & TOCO & VÁRIOS & $7: 30: 00$ & 10 & 191 & 1800 & $\begin{array}{l:l}193 & 1800\end{array}$ & 194 & 196,3000 & $197 \quad 600$ & $\begin{array}{l:l}143 & 600\end{array}$ & 140,4200 & 146 & $147 \quad 1500$ & 11 \\
\hline
\end{tabular}

ID: Identificação do Estabelecimento

DT: Duração Total da Entrega

Quadro 8.2 - Decisões de estacionamento dos veículos do cenário alternativo 1 (consolidação de cargas em veículos maiores)

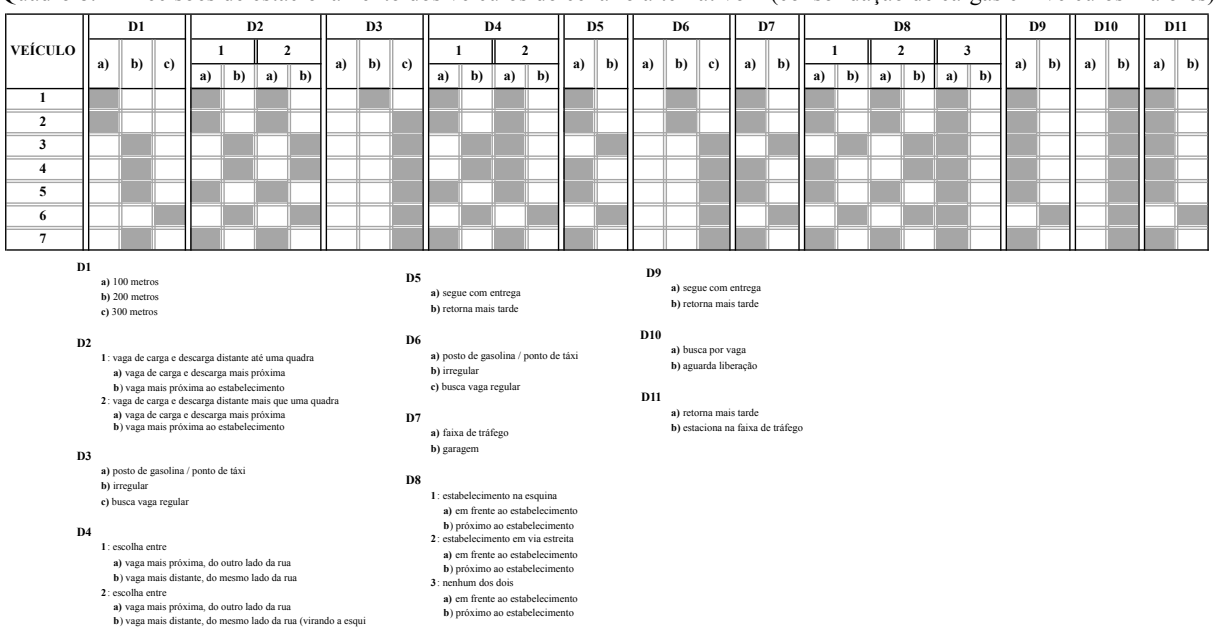




\subsubsection{Cenário Alternativo 2 - Vagas Exclusivas para Carga e Descarga}

O cenário alternativo 2 representa um aumento na disponibilidade das vagas exclusivas para os veículos de carga, o que foi obtido através da criação de novas áreas para carga e descarga, do reposicionamento de uma das áreas existentes e, principalmente, da proibição de utilização dessas áreas por veículos de passeio.

O cenário busca avaliar se o aumento na disponibilidade de vagas para carga e descarga teria um impacto positivo no tempo total e na distância extra percorrida pelos veículos de entrega devido à necessidade de procurar por uma vaga de estacionamento. Isso porque, das observações em campo foi possível detectar um elevado nível de ocupação irregular dessas vagas por veículos de passeio (até 88\%); ao mesmo tempo 71,5\% dos motoristas entrevistados durante a coleta de dados declararam que as vagas de carga e descarga são sua primeira opção de estacionamento.

As rotas de entrega dos veículos de carga e as decisões de estacionamento dos motoristas adotadas para a simulação desse cenário são as mesmas do cenário base.

\section{Reposicionamento e Criação de Vagas de Carga e Descarga}

Duas das quatro áreas de carga e descarga foram alteradas. A área de carga e descarga localizada na Rua Albuquerque Lins teve sua capacidade reduzida de treze para oito veículos, como mostra a Figura 8.3. Já a área localizada na Avenida Angélica foi movida para a Rua Brigadeiro Galvão (Figura 8.4) e teve sua capacidade aumentada de cinco para oito veículos e seu horário de utilização, antes das $10 \mathrm{~h}$ às $16 \mathrm{~h}$, ampliado para das $6 \mathrm{~h}$ às $16 \mathrm{~h}$.
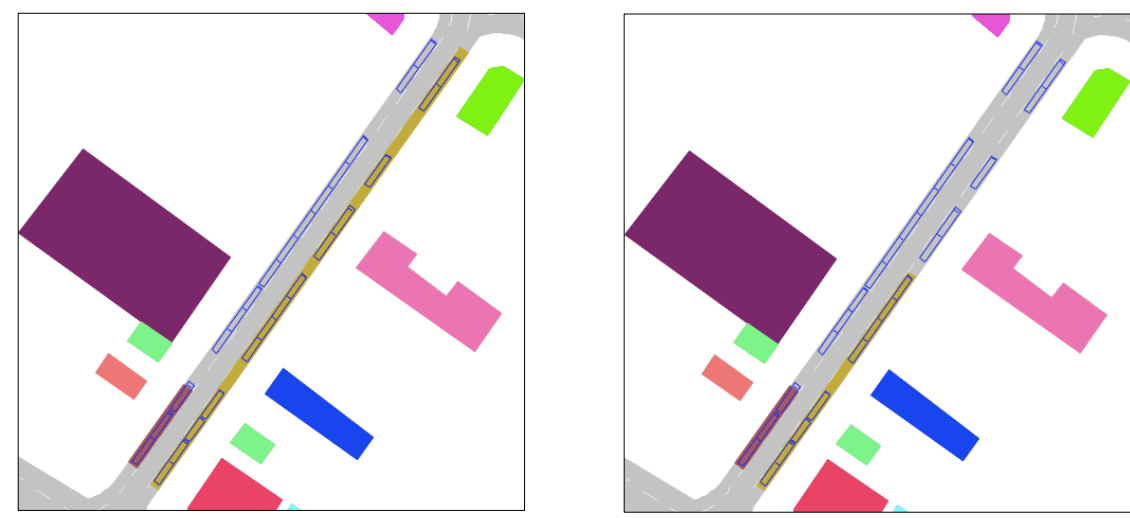

Figura 8.3 - Redução do número de vagas de carga e descarga na Rua Albuquerque Lins 

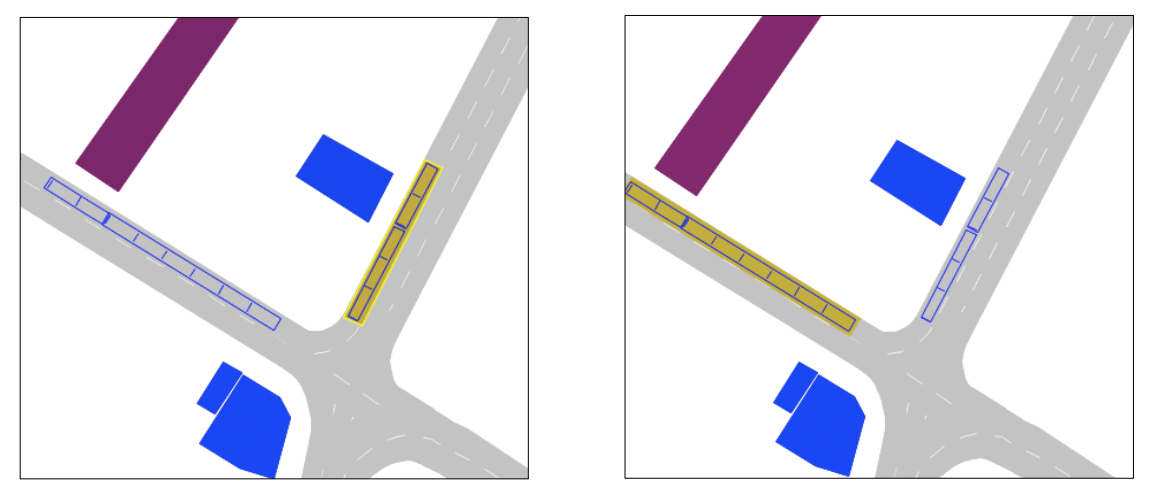

Figura 8.4 - Reposicionamento da área de carga e descarga da Avenida Angélica para a Rua Brigadeiro Galvão

A redução de capacidade da área de carga e descarga localizada na Rua Albuquerque Lins baseou-se na observação dos movimentos dos veículos de carga durante as rodadas preliminares da simulação, necessárias para a modelagem no VISSIM. Foi observado, para o cenário base, que não mais do que três veículos de carga solicitaram essa área de carga e descarga simultaneamente. Além disso, de acordo com os dados obtidos das observações em campo, a capacidade efetiva da área chegava a ser de apenas $30 \%$, cerca de 4 vagas, devido à sua ocupação por veículos de passeio. Ou seja, após a alteração houve, na realidade, um aumento de $50 \%$ na capacidade.

O reposicionamento da área de carga e descarga localizada na Avenida Angélica para a Rua Brigadeiro Galvão, assim como a ampliação do seu horário, também se apoiou nas rodadas preliminares da simulação para o cenário base. Em primeiro lugar, onze dos 46 veículos de entrega foram observados utilizando a área de estacionamento da Rua Brigadeiro Galvão totalizando duas horas e 48 minutos. Em segundo lugar, das 26 entregas que ocorreram nos estabelecimentos próximos à área da Avenida Angélica, 16 foram antes das 10h, ou seja, antes do horário no qual é permitido estacionar na área de carga e descarga. Por fim, o remanejamento para a Rua Brigadeiro Galvão liberou uma das faixas de tráfego da Avenida Angélica, o que espera-se resultar em uma melhoria da velocidade média nesse trecho da via e será verificado a partir dos resultados da simulação, apresentados na seção 8.2.

Além da alteração das áreas da Rua Albuquerque Lins e Avenida Angélica, uma nova área de carga e descarga, com capacidade para seis veículos, foi criada na Rua Barão de Limeira (Figura 8.5). O objetivo foi aumentar a disponibilidade de estacionamento nesse trecho da via, onde a menos de 100 metros de distância estão localizados 17 estabelecimentos, e cuja 
taxa de ocupação média das vagas de estacionamento é de $84 \%$. Além disso, buscou-se reduzir a ocorrência do estacionamento irregular em fila dupla, observado três vezes durante as rodadas preliminares da simulação para o cenário base.

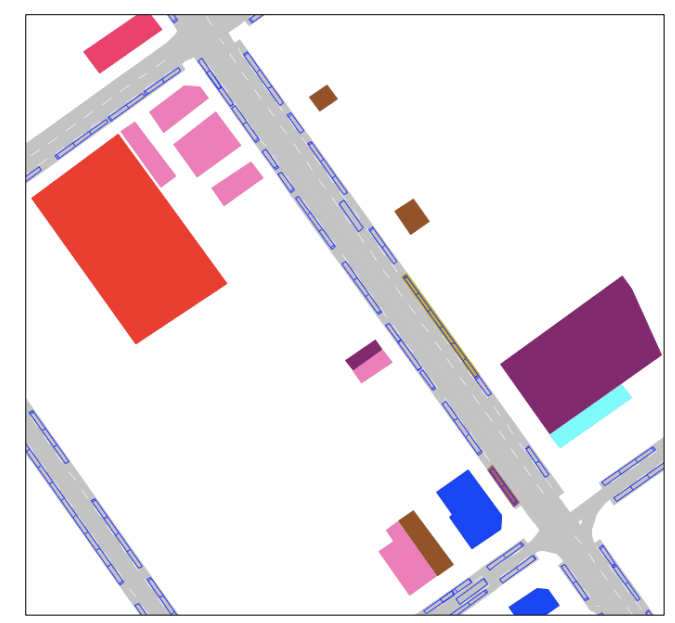

Figura 8.5 - Área de carga e descarga criada na Alameda Barão de Limeira

\section{Proibição do Uso das Vagas de Carga e Descarga}

Dos dados coletados em campo (apresentados na Tabela D.6 do Anexo D) pode-se constatar uma ocupação irregular média (considerando todo o período de simulação) das áreas de carga e descarga de até, aproximadamente, $70 \%$, como no caso da área localizada na Rua Barra Funda. Portanto, outra forma de aumentar a disponibilidade das vagas de carga e descarga nesse cenário foi através da proibição do uso irregular das mesmas, por veículos de passeio.

Sendo assim, para a modelagem desse cenário, no VISSIM, os veículos da classe 'parking cars' cujo destino era uma das áreas de carga e descarga foram realocados para as vagas regulares disponíveis mais próximas, o que aumentou ainda mais a taxa de ocupação dessas áreas e diminuiu sua disponibilidade aos veículos de carga cuja primeira opção de estacionamento não é uma vaga de carga e descarga.

\subsection{RESULTADOS DA SIMULAÇÃO}

As comparações entre os resultados obtidos através da microssimulação, para o cenário que representa a situação atual (cenário base) e para aqueles que representam a implementação 
de diferentes medidas voltadas à distribuição urbana de cargas (cenários alternativos), permitiram estimar os possíveis impactos decorrentes dessas medidas em termos dos seguintes aspectos:

- Impactos no tráfego veicular: velocidade média em cada segmento de link e formação de filas em cada segmento de link;

- Impactos nas operações dos veículos de carga: tempos de viagem, distância total percorrida, tempo para encontrar uma vaga de estacionamento, número de entregas realizadas e número de ocorrências de estacionamento irregular;

- Impactos nas emissões de $\mathrm{CO}_{2}:$ emissões provenientes dos veículos de carga que realizam entregas na área de simulação e emissões provenientes dos veículos que compõem o tráfego em geral.

\subsubsection{Impactos no Tráfego Veicular}

Os resultados da microssimulação no VISSIM permitiram obter informações sobre a formação de filas e as velocidades individuais dos veículos. Tais resultados podem estar desagregados por segmento de link e até mesmo por faixa, sendo possível, ainda, determinar o intervalo de tempo para o qual deseja-se que os mesmos sejam registrados. Com esse tipo de informação detalhada foi possível identificar se as alterações nas velocidades dos veículos ou na formação de filas poderia ser resultante da interação desses com os veículos de carga.

Velocidade Média nos Links da Rede

A Figura 8.6 exibe uma parte do arquivo que contém os dados de saída fornecidos pelo VISSIM para as velocidades dos veículos. Esses foram coletados por pontos de coleta de dados (objetos do tipo 'data collection points') inseridos ao longo da rede e que registram as informações de todos os veículos que passam por ele. 


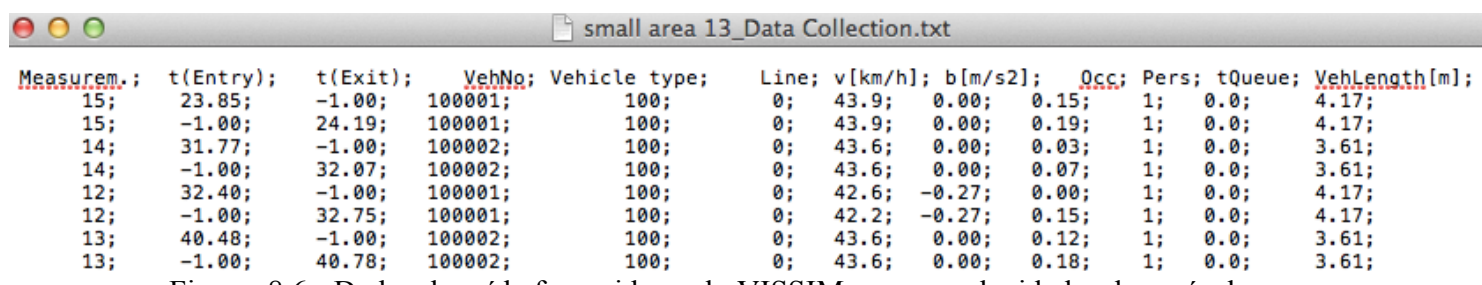

Figura 8.6 - Dados de saída fornecidos pelo VISSIM para as velocidades dos veículos

O arquivo contém as seguintes informações:

- Measurem.: identificação do ponto de coleta de dados;

- $t$ (Entry): tempo no qual a frente do veículo passa pelo ponto de coleta;

- $t$ (Exit): tempo no qual a traseira do veículo passa pelo ponto de coleta;

- VehNo: identificação do veículo;

- Vehicle type: tipo do veículo;

- Line: linha do transporte público (apenas para ônibus);

- $v[\mathrm{~km} / \mathrm{h}]$ : velocidade do veículo ao passar pelo ponto de coleta;

- $b\left[\mathrm{~m} / \mathrm{s}^{2}\right]$ : aceleração do veículo ao passar pelo ponto de coleta;

- Occ: tempo gasto pelo veículo na seção onde está localizado o ponto de coleta;

- Pers: número de pessoas no veículo;

- tQueue: tempo total no qual o veículo ficou parado em fila durante a simulação;

- VehLenght $[\mathrm{m}]$ : comprimento do veículo.

Durante a simulação as velocidades dos veículos foram registradas em todos os segmentos de link da rede, em cada uma de suas faixas de tráfego, por pontos de coleta localizados no ponto médio da extensão desses segmentos. As velocidades médias em cada faixa de segmento link foram então calculadas e agrupadas em intervalos de quinze minutos, para cada um dos cenários de simulação, conforme apresentado nas Tabelas 8.4, 8.5 e 8.6. Devido à desagregação dos dados foi possível identificar se nos segmentos de link e intervalos de tempo onde ocorreram alterações de velocidade havia a presença de um veículo de entrega que pudesse ser o causador dessa alteração. As situações nas quais as velocidades médias sofreram alterações devido à interferência dos veículos de carga também estão apresentadas, em destaque, nas Tabelas 8.4, 8.5 e 8.6, a seguir. 


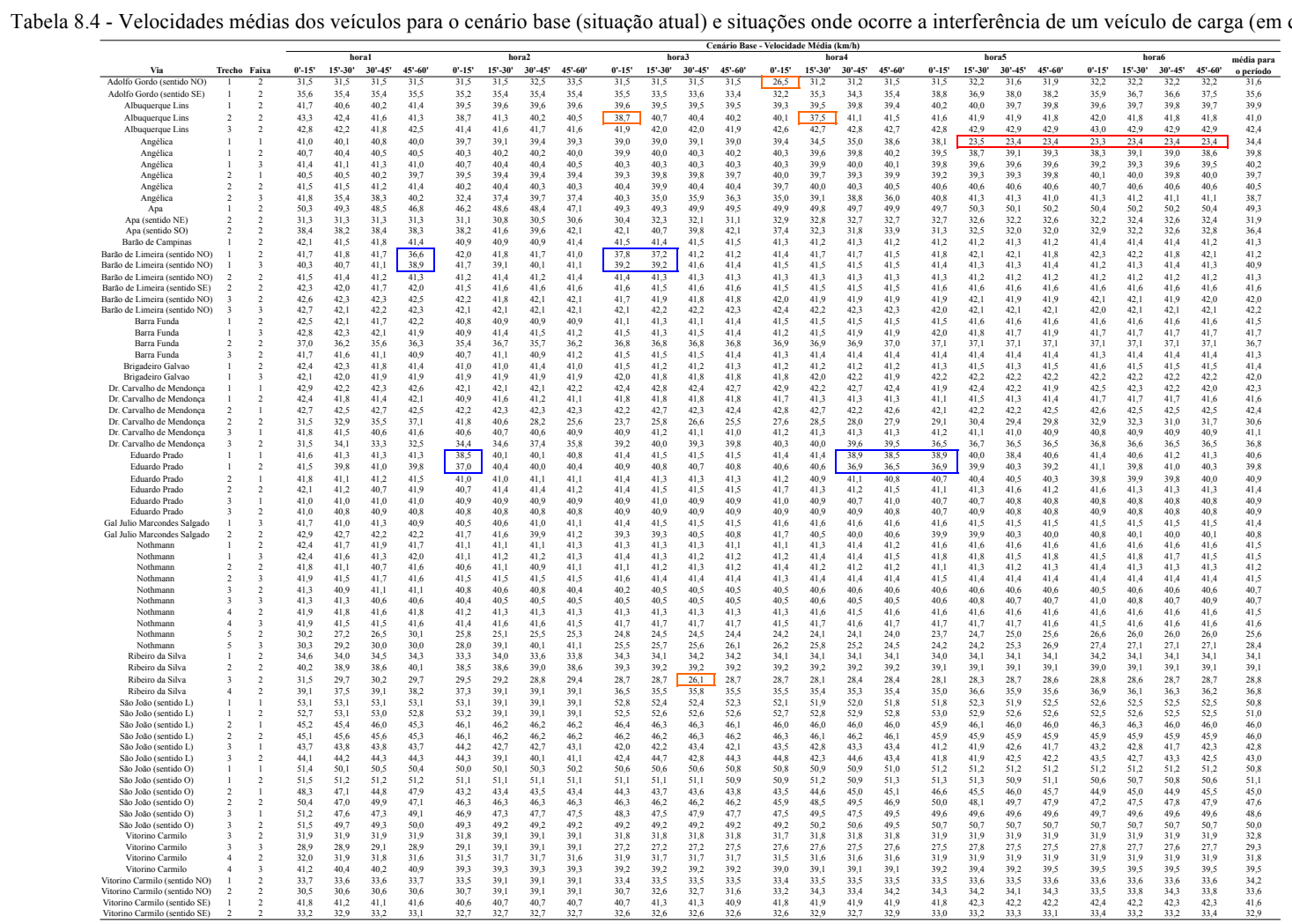


Tabela 8.5 - Velocidades médias dos veículos para o cenário alternativo 1 (consolidação de cargas em veículos maiores) e situações onde ocorre a interferência de um veículo

\begin{tabular}{|c|c|c|c|c|c|c|c|c|c|c|c|c|c|c|c|c|c|c|c|c|c|c|c|c|c|c|}
\hline & & & & & & & & & & & & ra3 & 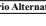 & Th- & hor & & & & & & & & & & & \\
\hline & Trecho Faika & $\theta^{\prime}-15^{\prime \prime}$ & $15^{5}-30^{\circ}$ & $30-45^{\prime}$ & $45-60^{\circ}$ & $\theta^{\prime \prime}-15^{\prime \prime}$ & $15^{\prime}-30^{\prime}$ & $300^{0}-45^{\prime}$ & $45-60^{\circ}$ & $\theta^{\prime}-15^{\prime}$ & $15 \cdot 30^{\circ}$ & $30^{\prime}-45^{\prime}$ & $45^{\prime}-60^{\circ}$ & $0^{\prime \prime-15^{\prime}}$ & $15 \cdot 300^{\prime}$ & $30^{\prime}-45^{\prime}$ & $45-60^{\circ}$ & $0^{\prime}-15^{\prime}$ & $15 \div 30^{\circ}$ & $30-45^{\prime}$ & $45-60^{\circ}$ & $\theta^{\theta-15^{\prime}}$ & $15 \div 30^{\circ}$ & $30-45^{\prime}$ & $45^{5}-60^{\prime}$ & $\begin{array}{l}\text { mediap } \\
\text { o perio }\end{array}$ \\
\hline dor & & $\begin{array}{l}31,5 \\
35.4\end{array}$ & $\begin{array}{l}31,5 \\
35,3\end{array}$ & $\begin{array}{l}31,5 \\
3,2,2\end{array}$ & $\begin{array}{l}3,1,5 \\
3,4.4\end{array}$ & $\begin{array}{l}31,5 \\
3,50\end{array}$ & $\begin{array}{l}3,1,3 \\
33,4\end{array}$ & $\begin{array}{l}31,2 \\
35,3\end{array}$ & $\begin{array}{l}31,3 \\
35,6\end{array}$ & $\begin{array}{l}3.1,2 \\
35,7\end{array}$ & $\begin{array}{l}31,3 \\
35,7\end{array}$ & $\begin{array}{l}\begin{array}{l}31,5 \\
35,7\end{array} \\
3\end{array}$ & $\begin{array}{l}31,2 \\
35,7\end{array}$ & $\begin{array}{l}31,6 \\
20.3\end{array}$ & $\begin{array}{l}31,5 \\
35,7\end{array}$ & $\begin{array}{l}3,1,5 \\
3,9 \\
3.9\end{array}$ & & 36.5 & $\begin{array}{l}3.1,9 \\
33.4\end{array}$ & $\begin{array}{l}3.1,8 \\
34,7\end{array}$ & & $33 ., 5$ & $\begin{array}{l}33,2 \\
33,9\end{array}$ & $\begin{array}{l}3,1 \\
3,9\end{array}$ & $\begin{array}{l}32,3 \\
339\end{array}$ & \\
\hline uquerqu & & & 41,7 & 40,5 & & 36,0 & 39,8 & 39,5 & & & & 39,5 & & 40,4 & 40,3 & 40,3 & & & & 99,7 & & & & 30,9 & & \\
\hline & & & 42,8 & 43,2 & & & & & & & & 41,9 & & 42,3 & 42.3 & 42,3 & & & & 42,2 & & & & 42,4 & & 41,8 \\
\hline 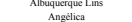 & & & $\begin{array}{l}4,7,7 \\
404\end{array}$ & $\begin{array}{l}42,7 \\
400 \\
040\end{array}$ & ${ }_{40}^{42}$ & $\begin{array}{l}4.1,6 \\
309 \\
309\end{array}$ & $\begin{array}{l}4.2,0 \\
405\end{array}$ & $\begin{array}{l}\begin{array}{l}41,9 \\
395\end{array} \\
395\end{array}$ & & 2 & & $\begin{array}{l}42,3 \\
39,1\end{array}$ & $\begin{array}{l}42,9 \\
39,\end{array}$ & 望, & $\begin{array}{l}42,9 \\
303\end{array}$ & $\begin{array}{l}4,7 \\
30,4 \\
304\end{array}$ & & & 22,99 & $\begin{array}{l}43,9 \\
364\end{array}$ & & & 1,1 & 3,5 & & $\begin{array}{l}42,6 \\
3.64\end{array}$ \\
\hline & & & 40,6 & 40,4 & & & 40,1 & 40,1 & & & & 40,1 & & 1. & 8 & 40,0 & & & & & & & & & & $\begin{array}{l}30,8,8 \\
33,2\end{array}$ \\
\hline $\begin{array}{l}\text { Angeticic } \\
\text { Angnatic }\end{array}$ & & $\begin{array}{l}41,4 \\
40.7\end{array}$ & $\begin{array}{l}40,5 \\
438 \\
3.8\end{array}$ & $\begin{array}{l}40,4 \\
403 \\
403\end{array}$ & $\begin{array}{l}41,1 \\
40.6\end{array}$ & $\begin{array}{l}40.4 \\
0.07 \\
307\end{array}$ & $\begin{array}{l}4.0,1 \\
40.93\end{array}$ & $\begin{array}{l}40,1 \\
397\end{array}$ & $\begin{array}{l}40,1 \\
309 \\
305\end{array}$ & $\begin{array}{l}40,1 \\
40,0 \\
300\end{array}$ & $\begin{array}{l}40,1 \\
48,5\end{array}$ & $\begin{array}{l}40,1 \\
389 \\
389\end{array}$ & $\begin{array}{l}40,1 \\
3.07 \\
387\end{array}$ & $\begin{array}{l}40,0 \\
385 \\
385\end{array}$ & $\begin{array}{l}3.99 \\
385\end{array}$ & 40,0 & & & 39,5 & 30,6 & & 15 & & & & $\begin{array}{l}40,1 \\
403 \\
393\end{array}$ \\
\hline & & & 4,2 & 40,8 & . & $\begin{array}{l}39,7 \\
40,6\end{array}$ & $\begin{array}{l}30,3 \\
40,5\end{array}$ & $\begin{array}{l}39,7 \\
40,6\end{array}$ & & & $\begin{array}{l}38,3 \\
40,1\end{array}$ & $\begin{array}{l}38,9 \\
40,1\end{array}$ & $\begin{array}{l}38,7 \\
40,1\end{array}$ & $\begin{array}{l}38,3 \\
40,1\end{array}$ & 40,0 & $\begin{array}{l}39,9 \\
39,9\end{array}$ & & & $\begin{array}{l}3.9,9 \\
40.1\end{array}$ & & & & & & & $\begin{array}{l}39,3 \\
40,4 \\
4\end{array}$ \\
\hline $\begin{array}{c}\text { Angelica } \\
\text { Aas }\end{array}$ & & $\begin{array}{l}41,9 \\
504\end{array}$ & $\begin{array}{l}40,5 \\
499\end{array}$ & $\begin{array}{l}41,9 \\
492\end{array}$ & 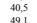 & $\begin{array}{l}40,4 \\
475 \\
475\end{array}$ & $\begin{array}{l}36,44 \\
475\end{array}$ & $\begin{array}{l}38,4 \\
478\end{array}$ & $\begin{array}{l}36,1 \\
476\end{array}$ & $\begin{array}{l}35,4 \\
485\end{array}$ & $\begin{array}{l}36,3 \\
498\end{array}$ & $\begin{array}{l}35,7 \\
491\end{array}$ & $\begin{array}{l}36,2 \\
496\end{array}$ & $\begin{array}{l}36,5 \\
502\end{array}$ & $\begin{array}{l}37,8 \\
499\end{array}$ & $\begin{array}{l}38,2 \\
500\end{array}$ & $\begin{array}{l}39,2 \\
500\end{array}$ & $\begin{array}{l}40,2 \\
499\end{array}$ & $\begin{array}{l}40,3 \\
4097\end{array}$ & $\begin{array}{l}41,2 \\
497 \\
497\end{array}$ & $\begin{array}{l}{ }^{40,3}, 3 \\
497\end{array}$ & $\begin{array}{l}4,2 \\
44,2 \\
4979\end{array}$ & $\begin{array}{l}4,7,7 \\
40.1\end{array}$ & $\begin{array}{l}41,3 \\
499\end{array}$ & $\begin{array}{l}41,6 \\
501\end{array}$ & 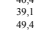 \\
\hline 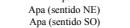 & & $\begin{array}{l}32,7 \\
38.4\end{array}$ & $\begin{array}{l}31,8 \\
38,4\end{array}$ & $\begin{array}{l}31,5 \\
38,4\end{array}$ & $\begin{array}{l}3,5 \\
3 ., 4 \\
38,4\end{array}$ & $\begin{array}{l}31 \\
38 \\
38\end{array}$ & $\begin{array}{l}30,7 \\
3.91\end{array}$ & $\begin{array}{l}30,2 \\
40.0\end{array}$ & $\begin{array}{l}30,7 \\
40,1\end{array}$ & $\begin{array}{l}30,2 \\
40.6\end{array}$ & & $\begin{array}{l}29,9 \\
36,8\end{array}$ & $\begin{array}{l}30,0 \\
37,3\end{array}$ & $\begin{array}{l}29.9 \\
36.2\end{array}$ & $\begin{array}{l}30,6 \\
31,7\end{array}$ & $\begin{array}{l}31,6 \\
31,4\end{array}$ & $\begin{array}{l}30,5 \\
34.3\end{array}$ & & $\begin{array}{l}32,7 \\
3.79\end{array}$ & $\begin{array}{l}32.6 \\
3 ., 7 \\
3.7\end{array}$ & & $\begin{array}{ll}32,2 \\
030,2\end{array}$ & $\begin{array}{l}32,6 \\
30.8\end{array}$ & $\begin{array}{l}32,6 \\
31.3\end{array}$ & $\begin{array}{l}32,8 \\
31,4\end{array}$ & (3), 35, \\
\hline & & & 42,0 & 41,3 & & & 4,2 & 40,9 & 41,2 & & & 32,6 & & & 34,9 & 35,7 & & & $\begin{array}{l}38,4 \\
8,4\end{array}$ & 40,0 & & & 41,6 & 41,8 & 4,4 & \\
\hline & & 42 & $\begin{array}{l}42,0 \\
42,0\end{array}$ & $\begin{array}{l}42,0 \\
42,3\end{array}$ & & 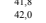 & $\begin{array}{l}4.9,9 \\
41,9\end{array}$ & $\begin{array}{l}41,8 \\
41,6\end{array}$ & & $\begin{array}{l}4.2,1 \\
41,3\end{array}$ & $\begin{array}{l}42,2 \\
42,0\end{array}$ & $\begin{array}{l}42,4 \\
42,0\end{array}$ & $\begin{array}{l}4.2,4 \\
41,6\end{array}$ & $\begin{array}{l}42,9 \\
42,0\end{array}$ & $\begin{array}{l}4.9,9 \\
41,1\end{array}$ & 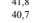 & & & , $1,1,3$ & & & $9_{7}^{9}$ & 2,.5. & & 年, & $\begin{array}{l}4.2,0 \\
41,6\end{array}$ \\
\hline & & & 41,3 & 41,4 & & 41,3 & 41,6 & 41,3 & & 41,6 & 39,8 & 40,9 & $4 ., 5$ & 39,8 & 39,8 & 39.9 & & & 41,3 & & & & & & 1, & $\begin{array}{l}4,6 \\
41,1 \\
4,1\end{array}$ \\
\hline 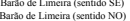 & & & $\begin{array}{l}4,7,7 \\
42,2\end{array}$ & $\begin{array}{l}4,1 \\
2,2.5 \\
42\end{array}$ & $\begin{array}{l}4,4,6 \\
42,1\end{array}$ & $\begin{array}{l}4.1,3 \\
42,0\end{array}$ & $\begin{array}{l}4.1,6 \\
42,0\end{array}$ & $\begin{array}{l}41,4 \\
41,9\end{array}$ & $\begin{array}{l}41,4 \\
41,9\end{array}$ & 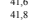 & $\begin{array}{l}4.1,4 \\
41,9\end{array}$ & $\begin{array}{l}4.1,2 \\
41,9\end{array}$ & $\begin{array}{l}41,3 \\
41,9\end{array}$ & $\begin{array}{l}41,2,2 \\
42,0\end{array}$ & $\begin{array}{l}3.9,7 \\
41,9\end{array}$ & $\begin{array}{l}3,9,6 \\
41.9\end{array}$ & $\begin{array}{l}40,6 \\
41,9\end{array}$ & $\begin{array}{l}9,6 \\
1,9\end{array}$ & $\begin{array}{l}4.1,2 \\
41,9\end{array}$ & $\begin{array}{l}40,3 \\
41,9\end{array}$ & & , & 1,6 & & $\begin{array}{ll}41,99 \\
12.5\end{array}$ & $\begin{array}{l}41,2,2 \\
442,0\end{array}$ \\
\hline . & & 42 & 42,3 & 42,5 & 42,6 & 42,1 & 42,1 & 42,1 & 42,1 & 42,0 & 42,5 & 42,3 & 42,3 & $\begin{array}{l}42,6 \\
42,6\end{array}$ & t2, & 42,3 & & & , 12,0 & & & & 3 & & & $\begin{array}{l}4,0,2 \\
42,2\end{array}$ \\
\hline & & & $\begin{array}{l}4,4,4 \\
4,1,8\end{array}$ & $\begin{array}{l}41,7 \\
42,5\end{array}$ & & & 4.,2 & (41,2, & & & 4.,4, & $\begin{array}{l}4,5,5 \\
4.12\end{array}$ & & $\begin{array}{l}41,5 \\
41,8\end{array}$ & $\begin{array}{l}4,1,6 \\
44,8\end{array}$ & 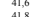 & & & 苚, & & & & & & & $\begin{array}{l}41,6 \\
41,7\end{array}$ \\
\hline $\begin{array}{l}\text { Barri } \\
\text { Bars }\end{array}$ & & $\begin{array}{l}4,7,0 \\
37,0\end{array}$ & $\begin{array}{l}4,8,8 \\
36,1\end{array}$ & 36,7 & $\begin{array}{l}4,2,0 \\
36,3\end{array}$ & $\begin{array}{l}40,8 \\
35,6\end{array}$ & $\begin{array}{l}4.1,0 \\
33,7\end{array}$ & $\begin{array}{l}4,1 \\
35,6\end{array}$ & 36,4 & $\begin{array}{l}4,7 \\
36,7 \\
367\end{array}$ & 齿, & $\begin{array}{l}4.7 \\
37,0\end{array}$ & 36.9 & $\begin{array}{l}4,8,8 \\
37,0\end{array}$ & $\begin{array}{ll}4 ., 8 \\
37,1\end{array}$ & $\begin{array}{l}4,1,8 \\
37,1\end{array}$ & $\begin{array}{l}+4,7,7 \\
37,7\end{array}$ & & 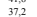 & & & : & , & & 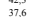 & $\begin{array}{l}41,7,8 \\
36,8\end{array}$ \\
\hline Bar & & 41,7 & 41,6 & 41,4 & $4 !$ & & $4,1,1$ & 41,1 & & 1 & & 41,0 & & 40,6 & 4,0 & 40,8 & & & 3 & & & & .6 & & & 41,2 \\
\hline $\begin{array}{l}\text { Brigacdiro } \\
\text { Brigatciro Gal }\end{array}$ & & $\begin{array}{l}42,6 \\
42,0 \\
4\end{array}$ & $\begin{array}{l}41,6 \\
42,5\end{array}$ & $\begin{array}{l}42,6 \\
42,0\end{array}$ & $\begin{array}{l}4,9,9 \\
42,4\end{array}$ & $\begin{array}{l}41,6,6 \\
42,5\end{array}$ & $\begin{array}{l}4 ., 6 \\
42,5\end{array}$ & $\begin{array}{l}4,6,6 \\
42,3\end{array}$ & $\begin{array}{l}4,6,6 \\
42,2\end{array}$ & $\begin{array}{l}4.1,6 \\
42,2\end{array}$ & $\begin{array}{l}4 \begin{array}{l}4,8 \\
2,3\end{array} \\
4.3\end{array}$ & $\begin{array}{l}42,0 \\
42,4\end{array}$ & $\begin{array}{l}4,2,0 \\
422,2\end{array}$ & $\begin{array}{l}42,2 \\
42,4\end{array}$ & $\begin{array}{l}4.2,3 \\
42,2\end{array}$ & $\begin{array}{l}4.2,3 \\
22,3\end{array}$ & $\begin{array}{l}42,3 \\
42,2\end{array}$ & 2,1 & $\begin{array}{ll}44.8 \\
42.2\end{array}$ & $\begin{array}{l}42,0 \\
42,2\end{array}$ & & , & $\frac{1,2}{2,2}$ & & $\begin{array}{l}4 ., 3 \\
4,21\end{array}$ & $\begin{array}{l}42,0 \\
42,3\end{array}$ \\
\hline anval & & $\begin{array}{l}43,0 \\
4,5\end{array}$ & $\begin{array}{l}42,6 \\
4,17\end{array}$ & 42,6 & 42,9 & $\begin{array}{l}42,5 \\
41.5\end{array}$ & $\begin{array}{l}42,6 \\
42,5\end{array}$ & 42,6 & 42,6 & $\begin{array}{l}42,5 \\
4.15 \\
4.5\end{array}$ & $\begin{array}{l}42,6 \\
4,5\end{array}$ & $\begin{array}{l}42,6 \\
41,5\end{array}$ & $\begin{array}{ll}42,6 \\
4,5\end{array}$ & $\begin{array}{l}42,7 \\
41.6\end{array}$ & $\begin{array}{l}42,4 \\
41,5\end{array}$ & $\begin{array}{l}42,3 \\
415\end{array}$ & $\begin{array}{l}42,4 \\
4,5\end{array}$ & 42,2 & 42,1 & $\begin{array}{l}42,2 \\
42,19 \\
419\end{array}$ & 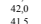 & & 42,3 & $\begin{array}{l}4,1 \\
42,5\end{array}$ & $\begin{array}{l}42,0 \\
425\end{array}$ & $\begin{array}{l}42,4 \\
41,8 \\
418\end{array}$ \\
\hline & & $\begin{array}{l}72,9 \\
42,9 \\
410\end{array}$ & $\begin{array}{l}32,8 \\
4,2,0 \\
4,0\end{array}$ & $\begin{array}{l}42,7 \\
42,7 \\
44,0\end{array}$ & $\begin{array}{l}2,5 \\
42,5 \\
4,15\end{array}$ & & $\begin{array}{l}72,4 \\
42,4 \\
3.19\end{array}$ & $\begin{array}{l}72,4 \\
42,4 \\
3.1\end{array}$ & $\begin{array}{l}\underbrace{42,4}_{2,4} \\
375\end{array}$ & $\begin{array}{l}723 \\
42,3 \\
205\end{array}$ & $\begin{array}{l}42,0 \\
42,0 \\
2\end{array}$ & $\begin{array}{l}72,1 \\
4,2,1 \\
3.06\end{array}$ & $\begin{array}{l}42,0 \\
42,0 \\
3286\end{array}$ & 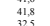 & $\begin{array}{l}42,0 \\
42,0 \\
3,0\end{array}$ & $\begin{array}{l}2,0 \\
42,0 \\
3,1\end{array}$ & 4, & t2,3, & t2.3.3 & 42,2 & $\begin{array}{l}7,3 \\
42,3 \\
2\end{array}$ & , & t2.,4 & $\begin{array}{l}72,2 \\
42,2 \\
3\end{array}$ & $\begin{array}{l}82,4 \\
42,4 \\
4\end{array}$ & $\begin{array}{l}41,8 \\
42,3 \\
4,3\end{array}$ \\
\hline Canalho de $\mathrm{M}$. & & 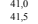 & $\begin{array}{l}41,0 \\
41,2\end{array}$ & $\begin{array}{l}41,0 \\
41,2\end{array}$ & $\begin{array}{l}4,1,0 \\
41,5\end{array}$ & $\begin{array}{l}\begin{array}{l}410,0 \\
40,6\end{array} \\
4\end{array}$ & $\begin{array}{l}31,9 \\
40.9 \\
40.9\end{array}$ & $\begin{array}{l}\begin{array}{l}36,1 \\
40,8\end{array} \\
4\end{array}$ & $\begin{array}{l}37,5 \\
40,9\end{array}$ & $\begin{array}{l}2.9,9 \\
40,9\end{array}$ & $\begin{array}{l}26,3 \\
40,9\end{array}$ & $\begin{array}{l}30,6 \\
40,8\end{array}$ & $\begin{array}{l}28,6 \\
40,9\end{array}$ & $\begin{array}{l}32,5 \\
40,7\end{array}$ & $\begin{array}{l}\begin{array}{l}31,0 \\
40,7\end{array} \\
4\end{array}$ & $\begin{array}{l}31,1,1 \\
40,7\end{array}$ & $\begin{array}{l}32,0 \\
40,7 \\
40,7\end{array}$ & $\begin{array}{l}30,7 \\
40,7\end{array}$ & $\begin{array}{l}31,3,3 \\
40,8\end{array}$ & 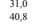 & $\begin{array}{l}30,9 \\
40,7 \\
40,7\end{array}$ & & $\begin{array}{l}31,7 \\
41,5\end{array}$ & $\begin{array}{l}31,9 \\
40.9 \\
40.9\end{array}$ & $\begin{array}{l}32,0 \\
41,0 \\
4,0\end{array}$ & $\begin{array}{l}33,3 \\
40,9 \\
40.9\end{array}$ \\
\hline Dr.Carvalho de M. & & 4,1 & $\begin{array}{l}7,2 \\
37,8\end{array}$ & $\begin{array}{l}4,2 \\
38,3\end{array}$ & 39,6 & $\begin{array}{l}4,6,3 \\
35,3\end{array}$ & 35,8 & 36,9 & 36,2 & $\begin{array}{l}+4,1,1 \\
37,1\end{array}$ & 39,4 & 39,4 & 37,6 & 39,5 & 39,8 & 39,8 & 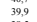 & 99,9 & 政, 0 & $\begin{array}{l}4.0,8 \\
40,2\end{array}$ & 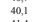 & & 40,7 & 年 & $\begin{array}{l}x_{40.9} \\
40.9\end{array}$ & $\begin{array}{l}40,9 \\
39,0 \\
-10\end{array}$ \\
\hline $\begin{array}{l}\text { EEva } \\
\text { Eddu }\end{array}$ & & $4,5^{3}$ & $\begin{array}{l}41,2 \\
40,6 \\
40.6\end{array}$ & $\begin{array}{l}41,3 \\
41,0\end{array}$ & $\begin{array}{l}41,2,2 \\
40.5\end{array}$ & $4,1,1$ & $\begin{array}{l}4.12,2 \\
40.7\end{array}$ & $\begin{array}{l}41,1 \\
40,6\end{array}$ & $\begin{array}{l}\begin{array}{l}41.3 \\
40.6\end{array} \\
4.06\end{array}$ & 14,4, & 38,5 & $\begin{array}{l}40,1 \\
40,7\end{array}$ & $\begin{array}{l}40,3 \\
39,7 \\
3.9\end{array}$ & $\begin{array}{l}38,5 \\
38.7 \\
\end{array}$ & $\begin{array}{l}4 ., 8 \\
40.5\end{array}$ & $\begin{array}{l}40,1 \\
0.4 \\
0.4\end{array}$ & 38,5 & $1,6.6$ & 4l, 4 & 41,5 & $41,4,4,0$ & & 42,0 & & & $\begin{array}{l}40,9 \\
40,6 \\
40,6\end{array}$ \\
\hline Edd & & & 41,5 & 41,2 & & & 4l, 6 & 41,2 & & & & 41,7 & & 41,8 & 41,6 & 41,6 & & & & & & & & & & . \\
\hline $\begin{array}{l}\text { Eduardo Prado } \\
\text { EEdauard Prato }\end{array}$ & & $\begin{array}{l}42,0 \\
4,1,0\end{array}$ & $\begin{array}{l}40,6 \\
4,2,2 \\
4.2\end{array}$ & $\begin{array}{l}4,1 \\
4,1,2 \\
4.2\end{array}$ & $\begin{array}{l}41,5 \\
4,2,2 \\
4.2\end{array}$ & $\begin{array}{l}40,6 \\
41,2\end{array}$ & $\begin{array}{l}4,6,6 \\
40,8 \\
40.8\end{array}$ & $\begin{array}{l}41,1 \\
4,0,9 \\
40.9\end{array}$ & $\begin{array}{l}4,1 \\
4,1,2 \\
4.2\end{array}$ & $\begin{array}{l}4,7 \\
40,8 \\
0 ., 8\end{array}$ & $\begin{array}{l}44,6, \\
39,8\end{array}$ & $\begin{array}{l}41,6,4 \\
40,4 \\
40.4\end{array}$ & $\begin{array}{l}{ }_{41,6}^{40,5} \\
4.0\end{array}$ & $\begin{array}{l}41,6 \\
39,6\end{array}$ & $\begin{array}{l}41,6,6 \\
40,1\end{array}$ & $\begin{array}{l}41,6 \\
3,6,6 \\
\end{array}$ & $\begin{array}{l}41,6,6 \\
40,5\end{array}$ & & $\begin{array}{l}4.1,6 \\
40,4\end{array}$ & $\begin{array}{l}41,6,5 \\
4,0,5\end{array}$ & $\begin{array}{l}4,6 \\
40,5\end{array}$ & & $\begin{array}{l}4,1,7 \\
40,2\end{array}$ & & 40,8 & $\begin{array}{l}41,5 \\
40,6 \\
40.6\end{array}$ \\
\hline & & $\begin{array}{l}41,2 \\
416\end{array}$ & $\begin{array}{l}41,0 \\
4.16 \\
4.10\end{array}$ & $\begin{array}{l}4,9 \\
4.14 \\
41\end{array}$ & & & & $\begin{array}{l}40,9 \\
410\end{array}$ & & & & 暨, & & $\begin{array}{l}40,2 \\
413 \\
413\end{array}$ & & $\begin{array}{l}40,5 \\
40,5 \\
44.4\end{array}$ & & & & & & & & & & $\begin{array}{l}40,7 \\
413 \\
413\end{array}$ \\
\hline 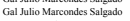 & & $\begin{array}{l}41,6 \\
42,9\end{array}$ & $\begin{array}{l}4,1,9 \\
41,9\end{array}$ & 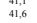 & $\begin{array}{l}4.1,6 \\
41,9\end{array}$ & $\begin{array}{l}40,4 \\
41,5 \\
4.5\end{array}$ & $\begin{array}{ll}4.1,7 \\
39,7\end{array}$ & $\begin{array}{l}41,0 \\
40,8\end{array}$ & $\begin{array}{l}40,6 \\
39,5 \\
3\end{array}$ & $\begin{array}{l}4,3,7 \\
38,7\end{array}$ & $\begin{array}{l}4,3,1 \\
35,1\end{array}$ & $\begin{array}{l}4,3,0 \\
33,0\end{array}$ & $\begin{array}{l}4,3 \\
36,4 \\
3.4\end{array}$ & $\begin{array}{l}4,3,3 \\
32,6\end{array}$ & $\begin{array}{l}4,4,4 \\
33,9\end{array}$ & $\begin{array}{l}4,4,4 \\
33,8\end{array}$ & & & & & & & (11,0.0 & & & $\begin{array}{l}4,3,3 \\
38,4 \\
3\end{array}$ \\
\hline $\begin{array}{l}\text { Nothmann } \\
\text { Nolthmann }\end{array}$ & & 42.3 & $\begin{array}{l}4,5 \\
4,2,2 \\
4.2\end{array}$ & $\begin{array}{l}42,4 \\
41,2 \\
4\end{array}$ & $\begin{array}{l}42.2 \\
42 .\end{array}$ & & 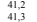 & $\begin{array}{l}41,0 \\
41,3 \\
41.3\end{array}$ & & & & $\begin{array}{l}38,5 \\
41,3 \\
41.3\end{array}$ & & & $\begin{array}{l}37,8 \\
3,1,1 \\
3\end{array}$ & & & & & & & & & & & 40,5 \\
\hline & & 41,8 & 41,7 & $4,7,7$ & & & 40,9 & 40,8 & & & & $\begin{array}{l}41,7 \\
401 \\
410\end{array}$ & & $\begin{array}{l}41,7 \\
399 \\
399\end{array}$ & 41,6 & & & & & & & & & & & 作 \\
\hline $\begin{array}{l}\text { Nolinamin } \\
\text { Nothman }\end{array}$ & & $\begin{array}{l}7,8 \\
41,6 \\
4.6\end{array}$ & $\begin{array}{l}41,4 \\
41,5 \\
4\end{array}$ & $\begin{array}{l}40,9 \\
40,1\end{array}$ & $\begin{array}{l}4,1,4 \\
41,4 \\
4\end{array}$ & 40 & $\begin{array}{l}4.4,7 \\
40.7\end{array}$ & $\begin{array}{l}4,4 \\
40,7 \\
4\end{array}$ & $\begin{array}{l}4,4 \\
40,6 \\
4\end{array}$ & $\begin{array}{l}7,4.6 \\
40.6\end{array}$ & & $\begin{array}{l}4,0 \\
40,2 \\
40,2\end{array}$ & $\begin{array}{l}4 ., 0 \\
40.0\end{array}$ & $\begin{array}{l}39,9 \\
40,1\end{array}$ & $\begin{array}{l}40,8 \\
40,0 \\
40,5\end{array}$ & $\begin{array}{l}401 \\
399, \\
39.9\end{array}$ & 40.8 & & & $\begin{array}{l}4,3 \\
40,4 \\
40,2\end{array}$ & & & $\begin{array}{l}4 ., 4 \\
4,1,8 \\
4.9\end{array}$ & & 41,9 & $\begin{array}{l}4,7 \\
40,7 \\
40,7\end{array}$ \\
\hline Nothmann & & $\begin{array}{l}41,4,4 \\
41,9\end{array}$ & $\begin{array}{l}4,1,8 \\
41,8 \\
4\end{array}$ & 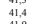 & 政, & 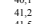 & ti, 4,2 & 列, & (41 & $\begin{array}{l}4 ., 6 \\
41,0\end{array}$ & & $\begin{array}{l}4,0,6 \\
4,0\end{array}$ & $\begin{array}{l}4,6,6 \\
41,0\end{array}$ & $\begin{array}{l}4,1 \\
41,0 \\
41,0\end{array}$ & $\begin{array}{l}4.0,5 \\
40,9\end{array}$ & $\begin{array}{l}4,0,6 \\
40,3 \\
4\end{array}$ & $\begin{array}{l}40,3 \\
40,3 \\
4\end{array}$ & $\begin{array}{l}4.0,0 \\
40,3 \\
40\end{array}$ & & $\begin{array}{l}4,2,2 \\
4,1\end{array}$ & $\begin{array}{l}40,3 \\
41,1\end{array}$ & & & & $\begin{array}{l}42,0 \\
4,1,8 \\
4\end{array}$ & $\begin{array}{l}40,8 \\
41,1 \\
4\end{array}$ \\
\hline 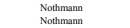 & & $\begin{array}{l}42,1 \\
2,9,2 \\
2,1\end{array}$ & 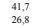 & $\begin{array}{l}419,9 \\
27,3\end{array}$ & $\begin{array}{l}4,1,6 \\
27,6 \\
\text { 2. }\end{array}$ & 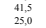 & $\begin{array}{l}4,1,5 \\
43,9\end{array}$ & $\begin{array}{l}\begin{array}{l}41,5 \\
24,7\end{array} \\
0\end{array}$ & $\begin{array}{l}4,5,5 \\
2,3,3\end{array}$ & $\begin{array}{l}4,1,4 \\
22,6\end{array}$ & $\begin{array}{l}44,3 \\
22,9\end{array}$ & $\begin{array}{l}\begin{array}{l}41,3 \\
24,5\end{array} \\
2.5\end{array}$ & $\begin{array}{l}41,3 \\
2,3,2\end{array}$ & $\begin{array}{l}41,2,2 \\
24,7\end{array}$ & $\begin{array}{l}40,6 \\
24,1\end{array}$ & $\begin{array}{l}40,9 \\
20,3,3\end{array}$ & $\begin{array}{l}40,6 \\
2,3,4\end{array}$ & $\begin{array}{l}{ }_{20,4}^{23,2} \\
2,\end{array}$ & $\begin{array}{lll}4,1,3 \\
\end{array}$ & $\begin{array}{l}40,5,5 \\
23,3\end{array}$ & $\begin{array}{l}{ }_{20,6}^{23,4} \\
2.0\end{array}$ & & 23,5 & $\begin{array}{l}{ }_{24,3}^{24,0} \\
24,\end{array}$ & $\begin{array}{l}{ }_{22,1} 2,8 \\
2,8\end{array}$ & $\begin{array}{l}\begin{array}{l}41,4 \\
24,4\end{array} \\
2\end{array}$ \\
\hline $\begin{array}{l}\text { mann } \\
\text { did Sili }\end{array}$ & & $\begin{array}{l}28,4 \\
34,6\end{array}$ & $\begin{array}{l}28,1 \\
3.4,1\end{array}$ & $\begin{array}{l}27,6 \\
33,2,\end{array}$ & $\begin{array}{l}28,3 \\
3.43\end{array}$ & $\begin{array}{l}27 \\
33\end{array}$ & $\begin{array}{l}2,6,4 \\
33.5\end{array}$ & $\begin{array}{l}26,5 \\
33,2\end{array}$ & & $\begin{array}{l}26,3 \\
33,9\end{array}$ & $\begin{array}{l}\begin{array}{l}29,2 \\
33,2\end{array} \\
3\end{array}$ & $\begin{array}{l}29,1 \\
33,4\end{array}$ & $\begin{array}{l}28,9 \\
33,0\end{array}$ & $\begin{array}{l}30,1 \\
32,0\end{array}$ & 31.8 & $\begin{array}{l}26,1 \\
31.8\end{array}$ & & & & & & & & & & $\begin{array}{l}27,3 \\
33,5\end{array}$ \\
\hline Ribit & & 40,1 & $\begin{array}{l}5,9,1 \\
39,4\end{array}$ & $\begin{array}{ll}3,2,2 \\
39,3\end{array}$ & 年 & $\frac{2}{2}$ & $\begin{array}{l}38,3 \\
38,6\end{array}$ & $\begin{array}{l}3,2,2 \\
38,5\end{array}$ & $\begin{array}{l}3,4,4 \\
38,2\end{array}$ & & $\begin{array}{l}3,2 \\
34,4\end{array}$ & $\begin{array}{l}3,4,4 \\
36,5\end{array}$ & $\begin{array}{l}33,0 \\
37,0\end{array}$ & & 31,8 & $\begin{array}{l}3,1,8 \\
36,6\end{array}$ & & & & & & & & & $\begin{array}{l}3,1 \\
39,5 \\
3\end{array}$ & $\begin{array}{l}33,5 \\
38,2\end{array}$ \\
\hline ta siva & & $\begin{array}{l}31,3 \\
37.8\end{array}$ & $\begin{array}{l}29,7 \\
3,7,7\end{array}$ & $\begin{array}{l}30,7 \\
3,7,7\end{array}$ & $\begin{array}{l}30,6 \\
3.77\end{array}$ & ${ }_{37}^{29}$ & $\begin{array}{l}28,7,7 \\
3.3,3\end{array}$ & $\begin{array}{r}28,7 \\
36,3\end{array}$ & $\begin{array}{l}28,7 \\
3.68\end{array}$ & & $\begin{array}{l}27,1 \\
3,5,\end{array}$ & $\begin{array}{l}26,2 \\
35,6\end{array}$ & $\begin{array}{l}26,4 \\
35,8\end{array}$ & $\begin{array}{l}24.3 \\
355\end{array}$ & $\begin{array}{l}2,7,2 \\
35,1\end{array}$ & $\begin{array}{l}27,1 \\
349\end{array}$ & & & & $\begin{array}{l}27 \\
{ }_{34}\end{array}$ & ${ }_{35}^{28}$ & & & & $\begin{array}{l}28 \\
36\end{array}$ & ${ }_{36,1}^{2.7}$ \\
\hline $\begin{array}{c}\mathrm{sat} \\
\text { sia }\end{array}$ & & $\begin{array}{c}53,2 \\
53,3\end{array}$ & $\begin{array}{l}53,1 \\
5,3\end{array}$ & $\begin{array}{c}53,1 \\
55,3\end{array}$ & $\begin{array}{c}53 \\
53\end{array}$ & & $\begin{array}{c}52,9 \\
52,8\end{array}$ & $\begin{array}{c}53,0 \\
526\end{array}$ & & & $\begin{array}{l}52,3 \\
526\end{array}$ & $\begin{array}{c}52,5 \\
526\end{array}$ & $\begin{array}{l}52,6 \\
526\end{array}$ & $\begin{array}{l}52,1 \\
52,\end{array}$ & $\begin{array}{l}51,8 \\
528\end{array}$ & $\begin{array}{l}51,8 \\
528\end{array}$ & & & & & & & & & & 52 \\
\hline s & & $\begin{array}{l}3,3,3 \\
45,6\end{array}$ & $\begin{array}{l}3,3 \\
45,7\end{array}$ & $\begin{array}{l}3,3,3 \\
45,8\end{array}$ & $\begin{array}{l}33 . \\
45.7\end{array}$ & & $\begin{array}{l}2,2,8 \\
46,6\end{array}$ & $\begin{array}{l}32,0 \\
46,2\end{array}$ & & 46,8 & 46 & $\begin{array}{l}2,2,6 \\
4,6,8\end{array}$ & . & $\begin{array}{l}32,7 \\
46,6\end{array}$ & $\begin{array}{l}3,8 \\
46,4\end{array}$ & $\begin{array}{l}32,8 \\
46,1\end{array}$ & & & & & & 0 & $\begin{array}{l}3.1,1 \\
46,4\end{array}$ & & . & 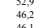 \\
\hline & & $\begin{array}{l}44,7 \\
44,3\end{array}$ & $\begin{array}{l}4,5,5 \\
43,7\end{array}$ & 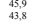 & $\begin{array}{l}45 \\
43 \\
43\end{array}$ & & 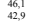 & 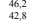 & & & & 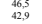 & $\begin{array}{l}46 \\
43 \\
4\end{array}$ & $\begin{array}{l}46,5 \\
43,6\end{array}$ & 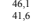 & $\begin{array}{l}46,0 \\
41,1\end{array}$ & $\begin{array}{l}4.5,9 \\
42,3\end{array}$ & & & $\begin{array}{l}46 \\
4{ }_{4}\end{array}$ & & & $\begin{array}{l}46,8,8 \\
43,2\end{array}$ & & $\begin{array}{l}4.6,4 \\
43,2\end{array}$ & $\begin{array}{l}4,6,1 \\
42,8\end{array}$ \\
\hline & & $\begin{array}{l}43,5 \\
51,6\end{array}$ & $\begin{array}{l}4,0 \\
40,5\end{array}$ & $\begin{array}{l}4.0 \\
40,7\end{array}$ & $\begin{array}{l}43,8 \\
50,9\end{array}$ & $\begin{array}{l}44,2 \\
50,2\end{array}$ & $\begin{array}{l}4,3,3 \\
0,4,\end{array}$ & $\begin{array}{l}\begin{array}{l}43,9 \\
5,0,3\end{array} \\
5,3\end{array}$ & 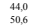 & $\begin{array}{l}43 . \\
50 .\end{array}$ & & $\begin{array}{l}\begin{array}{l}44,0 \\
5,0,8\end{array} \\
5\end{array}$ & $\begin{array}{l}43,3 \\
50,\end{array}$ & $\begin{array}{l}44,8 \\
50,8\end{array}$ & $\begin{array}{l}41,8 \\
0,9,9\end{array}$ & $\begin{array}{l}43,7 \\
50, \\
50,\end{array}$ & $\begin{array}{l}42,2 \\
51,1\end{array}$ & ${ }_{2}^{4}$ & $\begin{array}{l}4.1, \\
\text { sit, }\end{array}$ & $\begin{array}{l}{ }_{512}^{42}, \\
51,\end{array}$ & & 3 & & & $\begin{array}{l}\begin{array}{l}43,4 \\
51,6\end{array} \\
5,1,6\end{array}$ & $\begin{array}{l}43 . \\
40 .\end{array}$ \\
\hline & & $\begin{array}{l}51,4 \\
48,4\end{array}$ & $\begin{array}{l}51,4 \\
44,0\end{array}$ & $\begin{array}{l}51,1 \\
475\end{array}$ & $\begin{array}{l}51,2 \\
45,5\end{array}$ & $\begin{array}{l}51,0 \\
429\end{array}$ & $\begin{array}{l}51,3 \\
4010\end{array}$ & $\begin{array}{l}51,5 \\
431,5\end{array}$ & & & $\begin{array}{l}51,4 \\
446\end{array}$ & $\begin{array}{l}51,6 \\
44.5\end{array}$ & 51. & $\begin{array}{c}50,8 \\
44.4\end{array}$ & $\begin{array}{l}51,0 \\
453\end{array}$ & $\begin{array}{l}51,1 \\
447\end{array}$ & $\begin{array}{l}50,9 \\
44,6\end{array}$ & & $\begin{array}{l}51 \\
45\end{array}$ & & & 6 & & & $\begin{array}{l}51,0 \\
450\end{array}$ & $\begin{array}{l}51,1 . \\
452\end{array}$ \\
\hline $\begin{array}{l}\text { SSal } \\
\text { Sia }\end{array}$ & & $\begin{array}{l}48,2 \\
51,2\end{array}$ & $\begin{array}{l}4.4,0 \\
30,6\end{array}$ & $\begin{array}{l}47,5 \\
48,8\end{array}$ & 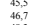 & $\begin{array}{l}42,9 \\
46,1\end{array}$ & $\begin{array}{l}4.4,0 \\
47,3\end{array}$ & $\begin{array}{l}\begin{array}{l}43,2 \\
47,2\end{array} \\
4\end{array}$ & $\begin{array}{l}4,4,4 \\
47,9\end{array}$ & $\begin{array}{l}4 ., 6 \\
48,2,\end{array}$ & 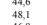 & $\begin{array}{l}44,5 \\
48,0\end{array}$ & $\begin{array}{l}4,5 \\
47,5\end{array}$ & 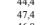 & $\begin{array}{l}\begin{array}{l}45,3 \\
49,0\end{array} \\
4\end{array}$ & $\begin{array}{l}44,7 \\
47,5\end{array}$ & 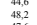 & 点 & $\begin{array}{l}45.4 \\
48.7\end{array}$ & $\begin{array}{l}\begin{array}{l}4,6,4 \\
49,3\end{array} \\
4\end{array}$ & $\begin{array}{l}45 \\
48 .\end{array}$ & 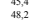 & $\begin{array}{l}4.5,7 \\
48,5\end{array}$ & & $\begin{array}{l}45,9 \\
48,5\end{array}$ & $\begin{array}{l}45,2 \\
48,3\end{array}$ \\
\hline & & $\begin{array}{l}50,8 \\
51,3\end{array}$ & $\begin{array}{l}50,6 \\
51,2\end{array}$ & $\begin{array}{l}4.8,7 \\
49,3\end{array}$ & $\begin{array}{l}4.8,3 \\
50,5\end{array}$ & $\begin{array}{l}\begin{array}{l}47,1 \\
48,6\end{array} \\
4\end{array}$ & 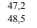 & $\begin{array}{l}\begin{array}{l}47,2 \\
48,2\end{array} \\
4\end{array}$ & $\begin{array}{l}47,2 \\
48,1\end{array}$ & $\begin{array}{l}47,2 \\
48,1\end{array}$ & $\begin{array}{l}\begin{array}{l}66,8 \\
48,4\end{array} \\
4\end{array}$ & 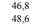 & $\begin{array}{l}46,9 \\
48,3\end{array}$ & $\begin{array}{l}46,8 \\
48,7\end{array}$ & $\begin{array}{l}46,9 \\
49,5\end{array}$ & $\begin{array}{l}\begin{array}{l}66,9 \\
49,2\end{array} \\
4\end{array}$ & $\begin{array}{l}47.4 \\
49\end{array}$ & $\begin{array}{l}48 \\
49 \\
49\end{array}$ & $\begin{array}{l}48.7 \\
49,\end{array}$ & 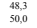 & & & & & $\begin{array}{l}490,0 \\
50,5\end{array}$ & $\begin{array}{r}4,1, \\
49,4\end{array}$ \\
\hline & & $\begin{array}{l}32,0 \\
28,1\end{array}$ & $\begin{array}{l}32,0 \\
27,8\end{array}$ & $\begin{array}{l}38,9 \\
28,1\end{array}$ & $\begin{array}{l}32,0 \\
27,7\end{array}$ & & $\begin{array}{l}3.1,7 \\
26,6\end{array}$ & $\begin{array}{l}31,7 \\
26,6\end{array}$ & & & $\begin{array}{l}31,7 \\
23,7\end{array}$ & $\begin{array}{l}31,7 \\
23,6\end{array}$ & & $\begin{array}{l}31,6 \\
24,7\end{array}$ & $\begin{array}{l}31,7 \\
24,3\end{array}$ & $\begin{array}{l}31, \\
24,\end{array}$ & & & $\begin{array}{l}31 \\
20 \\
20\end{array}$ & & & & & & & $\begin{array}{l}31,8 \\
23,9\end{array}$ \\
\hline & & $\begin{array}{l}32,1 \\
4,1,1\end{array}$ & $\begin{array}{l}\begin{array}{l}31,8 \\
40,9\end{array} \\
4\end{array}$ & 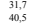 & $\begin{array}{l}31 \\
40\end{array}$ & & $\begin{array}{l}3.1,5 \\
38,3\end{array}$ & $\begin{array}{l}31,9 \\
37,6\end{array}$ & & & $\begin{array}{l}31,2 \\
36,1\end{array}$ & $\begin{array}{l}\begin{array}{l}31,1, \\
37,0\end{array} \\
3\end{array}$ & & $\begin{array}{l}30 . \\
35\end{array}$ & 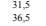 & $\begin{array}{l}\text { o, } \\
38,\end{array}$ & & & & & & $\begin{array}{l}8 \\
8 \\
8\end{array}$ & $\begin{array}{l}3.1,9 \\
40,0\end{array}$ & & $\begin{array}{l}32,4 \\
39,8\end{array}$ & $\begin{array}{l}31.6 \\
38,7\end{array}$ \\
\hline & & $\begin{array}{l}\frac{33,7}{30.9} \\
30.9\end{array}$ & $\begin{array}{c}33,3 \\
300\end{array}$ & $\begin{array}{l}33,2 \\
309\end{array}$ & $\begin{array}{l}33 \\
30\end{array}$ & & $\begin{array}{l}3,3,3 \\
3.3\end{array}$ & $\begin{array}{l}33,4 \\
310\end{array}$ & & & 31 & $\begin{array}{l}33 \\
31 \\
31\end{array}$ & & & $\begin{array}{l}33,6,6 \\
34,0\end{array}$ & $\begin{array}{l}33 \\
34\end{array}$ & & & & & & & ${ }_{2}^{.0}$ & & & 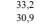 \\
\hline ino Carmilo (sentido SE) & & 33.2 & $\begin{array}{l}41,0,0 \\
33,0\end{array}$ & $\begin{array}{l}40,9 \\
328,\end{array}$ & $\begin{array}{l}41,4 \\
329\end{array}$ & & 328 & $\begin{array}{l}40,8 \\
32,7\end{array}$ & & & $\begin{array}{l}{ }_{4}^{11,4}, \\
32,\end{array}$ & & & & & & & & & 32,2 & & & . & & 33.5 & \\
\hline
\end{tabular}


Tabela 8.6 - Velocidades médias dos veículos para o cenário alternativo 2 (vagas exclusivas para carga e descarga) e situações onde ocorre a interferência de um veículo de

\begin{tabular}{|c|c|c|c|c|c|c|c|c|c|c|c|c|c|c|c|c|c|c|c|c|c|c|c|c|c|c|}
\hline & & & & & & & & & & & & & Sant & 2. & de & & & & & & & & & & & \\
\hline & & & & & $66^{\circ}$ & 15' & & & $-60^{\prime}$ & $\frac{0^{\prime}-15^{\prime}}{437}$ & ; $300^{\prime}$ & $30-45$ & 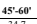 & $\frac{\theta^{\prime}-15^{\prime}}{34}$ & (5:30.30 & & & $\frac{\theta^{\prime \prime}-15^{\prime}}{3 y^{\prime 2}}$ & & $30^{\prime}-45$ & $45: 60^{\circ}$ & & $15^{\prime} \cdot 30^{\circ}$ & $30^{\prime}-45$ & $45^{\prime}-66^{\circ}$ & \\
\hline SE) & & & & 36.2 & $\begin{array}{l}31 \\
36 \\
36\end{array}$ & & $\begin{array}{l}3.2,8 \\
36,2\end{array}$ & $\begin{array}{l}34,1 \\
36,2\end{array}$ & $\begin{array}{l}31,7 \\
36,2\end{array}$ & & $\begin{array}{l}3.9,9 \\
34,8\end{array}$ & $\begin{array}{l}32,3 \\
35,3, \\
3.5\end{array}$ & $\begin{array}{l}34,3 \\
34,5\end{array}$ & $\begin{array}{l}32,4 \\
33,7 \\
3,7\end{array}$ & $\begin{array}{l}32,6 \\
34,7\end{array}$ & $\begin{array}{l}3.2,6 \\
38,6 \\
3\end{array}$ & 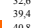 & $\begin{array}{l}32,8 \\
40,0\end{array}$ & $\begin{array}{l}3,1 \\
37,2\end{array}$ & $\begin{array}{l}3,2,9 \\
37,4\end{array}$ & $\begin{array}{l}3,13,1 \\
36,3\end{array}$ & $\begin{array}{l}3.3,2 \\
35,7\end{array}$ & $\begin{array}{l}3,6,6 \\
35,9\end{array}$ & 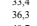 & 35,96 & \\
\hline . & & & $\begin{array}{l}40 . \\
38,\end{array}$ & $\begin{array}{l}{ }_{40,2}^{38,9} \\
38\end{array}$ & tis & & ${ }^{40}{ }^{40}$ & $\begin{array}{l}{ }^{40,2} \\
40,3\end{array}$ & & & & $\begin{array}{l}40,5 \\
41,3\end{array}$ & $\begin{array}{l}{ }_{40,6} \\
41,3\end{array}$ & $\begin{array}{l}{ }_{40,7}^{41,2} \\
41\end{array}$ & $\begin{array}{l}40,8[ \\
40.9 \\
40.9\end{array}$ & \begin{tabular}{|l|}
38,6 \\
$4 \cdot 2$
\end{tabular} & $\begin{array}{l}40,8 \\
4 ., 2\end{array}$ & $\begin{array}{l}\begin{array}{l}40,8 \\
40,9\end{array} \\
4\end{array}$ & $\begin{array}{l}40,6 \\
414,4\end{array}$ & 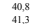 & & $\begin{array}{l}40,3 \\
4.1,9 \\
4\end{array}$ & $\begin{array}{l}4.3 \\
420 \\
420\end{array}$ & $\begin{array}{l}40,7 \\
442.2\end{array}$ & $\begin{array}{ll}40,4 \\
2,2\end{array}$ & \\
\hline jurtque & & $\begin{array}{l}43 \\
40 \\
40\end{array}$ & $\begin{array}{l}41,5 \\
39,8\end{array}$ & $\begin{array}{l}41,5 \\
39.8\end{array}$ & $\begin{array}{l}41 \\
39\end{array}$ & 4 & $\begin{array}{l}41,8 \\
39.4\end{array}$ & $\begin{array}{l}41,8 \\
3.5,5\end{array}$ & $\begin{array}{l}41,6,6 \\
39,1\end{array}$ & 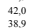 & it & $\begin{array}{l}42,0 \\
390\end{array}$ & $\begin{array}{l}42,1 \\
390\end{array}$ & $\begin{array}{l}42,5 \\
392\end{array}$ & $\begin{array}{l}42,6 \\
392\end{array}$ & $\begin{array}{l}42,7 \\
39,1\end{array}$ & $\begin{array}{l}42,5 \\
4.25 \\
3.92\end{array}$ & $\begin{array}{l}42,9 \\
300\end{array}$ & $\begin{array}{l}42,9 \\
39.1\end{array}$ & $\begin{array}{l}42,9 \\
390\end{array}$ & $\frac{42,9}{393}$ & 42,9 & $\begin{array}{l}43,2 \\
39,6\end{array}$ & $\begin{array}{l}43,1 \\
3999\end{array}$ & $\frac{43,2}{399}$ & 424 \\
\hline & & $\begin{array}{l}40,7 \\
40,5\end{array}$ & $\begin{array}{l}30,4 \\
40,4\end{array}$ & $\begin{array}{l}3,6 \\
40,4\end{array}$ & $\begin{array}{l}3,8,4 \\
40,4\end{array}$ & & 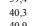 & $\begin{array}{l}40,3 \\
40,3\end{array}$ & $\begin{array}{l}4,1,3 \\
40,3\end{array}$ & $\begin{array}{l}3.3 \\
40,3\end{array}$ & 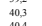 & $\begin{array}{l}3,0,0 \\
40,3 \\
40,8\end{array}$ & $\begin{array}{l}39,0 \\
40,3 \\
405\end{array}$ & $\begin{array}{l}39,2.2 \\
40.2\end{array}$ & $\begin{array}{l}3,2,2 \\
40,0,0 \\
40,0\end{array}$ & $\begin{array}{l}3,1 \\
40,1\end{array}$ & $\begin{array}{l}3,2 \\
40,2 \\
40.2\end{array}$ & 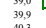 & & & $\frac{3.93}{40,1}$ & $\begin{array}{l}3,4 \\
40,2\end{array}$ & $\begin{array}{l}3,6 \\
40,3\end{array}$ & $\begin{array}{l}39,9 \\
40,4\end{array}$ & $\begin{array}{l}\frac{3,9,9}{40,4} \\
4\end{array}$ & \\
\hline $\begin{array}{l}\text { Angsedica } \\
\text { A }\end{array}$ & & $\begin{array}{l}41,5 \\
41,3\end{array}$ & $\begin{array}{l}40,9 \\
40.9 \\
40.9\end{array}$ & $\begin{array}{l}40,9 \\
40.9 \\
40.9\end{array}$ & $\begin{array}{l}40,9 \\
40.9 \\
40.9\end{array}$ & $\begin{array}{l}40,8 \\
40.9\end{array}$ & $\begin{array}{l}40,9 \\
40.8\end{array}$ & $\begin{array}{l}40,9 \\
40,3\end{array}$ & $\begin{array}{l}40,9 \\
40.3\end{array}$ & $\begin{array}{l}40,8 \\
40.0\end{array}$ & $\begin{array}{l}40,4 \\
39,7 \\
39.7\end{array}$ & $\begin{array}{l}40,8 \\
39,9\end{array}$ & $\begin{array}{l}40,5 \\
39.9\end{array}$ & $\begin{array}{l}40,4 \\
39,7 \\
39.7\end{array}$ & $\begin{array}{l}40,3 \\
39,6\end{array}$ & $\begin{array}{l}40,3 \\
30,6 \\
3.96\end{array}$ & $\begin{array}{l}40,3 \\
30,6 \\
3 ., 6\end{array}$ & $\begin{array}{l}40,3 \\
39,6\end{array}$ & $\begin{array}{l}4.5 \\
40,6 \\
40.6\end{array}$ & $\begin{array}{l}40,3 \\
30,6 \\
3,96\end{array}$ & $\begin{array}{l}40,3 \\
40.5\end{array}$ & $\begin{array}{l}40,6 \\
40,7\end{array}$ & $\begin{array}{l}4.9 \\
40.9 \\
40.9\end{array}$ & $\begin{array}{l}4,1,1 \\
44,7 \\
44.7\end{array}$ & $\begin{array}{l}40,8 \\
40.9\end{array}$ & \\
\hline 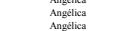 & & $\begin{array}{l}41,3 \\
41,5 \\
41,7\end{array}$ & $\begin{array}{l}4,9,1 \\
41,1 \\
41,6\end{array}$ & $\begin{array}{l}4,9,1 \\
41,1 \\
41,6\end{array}$ & $\begin{array}{l}4,9 \\
4,1,1 \\
41,6\end{array}$ & $\begin{array}{l}\text { al, } \\
41,1 \\
41,5\end{array}$ & $\begin{array}{l}40,8 \\
40,6 \\
41,3\end{array}$ & $\begin{array}{l}40,3 \\
40,5 \\
41,3\end{array}$ & $\begin{array}{l}40,6 \\
40,6 \\
41,5\end{array}$ & 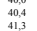 & $\begin{array}{l}39,1 \\
40,1 \\
34,6\end{array}$ & $\begin{array}{l}\begin{array}{r}39,9 \\
40,1 \\
38,8\end{array} \\
38.8\end{array}$ & 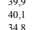 & $\begin{array}{l}39,7 \\
39,9 \\
3.4\end{array}$ & 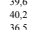 & $\begin{array}{l}3,6,6 \\
4.01 \\
3.94\end{array}$ & $\begin{array}{l}3.06 \\
4 ., 3 \\
3.63\end{array}$ & 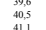 & $\begin{array}{l}4.69 \\
4.09 \\
4.13\end{array}$ & $\begin{array}{l}3,6 \\
4,9,9 \\
4,13\end{array}$ & 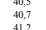 & 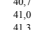 & 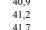 & 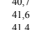 & 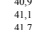 & 7 \\
\hline & & $\begin{array}{l}\text { sit, } \\
4,9,8 \\
3,3\end{array}$ & $\begin{array}{l}4,6 \\
4,6,6 \\
3,3\end{array}$ & 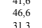 & $\begin{array}{l}4,6 \\
4,6,6 \\
3,13\end{array}$ & & 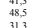 & $\begin{array}{l}4,3,4 \\
\text { s7, } \\
3,3\end{array}$ & & 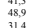 & $\begin{array}{l}3,5 \\
49,3 \\
\text { 3.,3 }\end{array}$ & $\begin{array}{l}3,8,8 \\
4,2,2 \\
\text { s.t. }\end{array}$ & 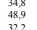 & 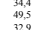 & $\begin{array}{l}36,5 \\
4,6,6 \\
\text { s., }\end{array}$ & $\begin{array}{l}3,9 \\
4,9,6 \\
3,26\end{array}$ & $\begin{array}{l}\begin{array}{l}56,3 \\
50,0,\end{array} \\
5,0\end{array}$ & $\begin{array}{l}\text { sil, } \\
50,1 \\
0,1\end{array}$ & $\begin{array}{l}4 ., 3 \\
50,2 \\
0.0\end{array}$ & $\begin{array}{l}14,3,3 \\
50,2\end{array}$ & $\begin{array}{l}\text { s1.2, } \\
50,2\end{array}$ & $\begin{array}{l}4.3 \\
50,2\end{array}$ & $\begin{array}{l}\text { sil, } \\
50,2\end{array}$ & $\begin{array}{l}\text { sit, } \\
50,4\end{array}$ & $\begin{array}{l}4,7 \\
50,7 \\
0.7\end{array}$ & \\
\hline & & $\begin{array}{l}\begin{array}{l}33,3 \\
39,5\end{array} \\
3\end{array}$ & $\begin{array}{l}\begin{array}{l}31,3 \\
39,0\end{array} \\
39\end{array}$ & 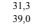 & $\begin{array}{l}\begin{array}{l}31,3 \\
39,0\end{array} \\
3.0\end{array}$ & $\begin{array}{l}33,2 \\
38,9\end{array}$ & $\begin{array}{l}31,3 \\
42,4 \\
42,\end{array}$ & $\begin{array}{l}\begin{array}{l}11,3 \\
40,3\end{array} \\
4\end{array}$ & $\begin{array}{l}\begin{array}{l}31,3 \\
41,7\end{array} \\
4\end{array}$ & $\begin{array}{l}\begin{array}{l}31,4 \\
42,5\end{array} \\
4\end{array}$ & 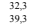 & $\begin{array}{l}\begin{array}{l}31,7 \\
37,3\end{array} \\
3,3\end{array}$ & $\begin{array}{l}32,2,2 \\
39,2\end{array}$ & $\begin{array}{l}\begin{array}{l}32,9 \\
36,7\end{array} \\
36\end{array}$ & $\begin{array}{l}32,4 \\
32,2\end{array}$ & $\begin{array}{l}32,6 \\
3,9\end{array}$ & $\begin{array}{l}33,4,4 \\
36,2\end{array}$ & $\begin{array}{l}32,2 \\
31,3\end{array}$ & $\begin{array}{l}31,0 \\
33,2\end{array}$ & $\begin{array}{l}31,1 \\
32,4\end{array}$ & $\begin{array}{l}\begin{array}{l}31,0 \\
31,6\end{array} \\
31,6\end{array}$ & $\begin{array}{l}30,6 \\
34,0 \\
34,0\end{array}$ & $\begin{array}{l}30,7 \\
34,3\end{array}$ & $\begin{array}{l}\begin{array}{l}30,7 \\
34,2\end{array} \\
3.0\end{array}$ & $\begin{array}{l}3,1,0 \\
34,1\end{array}$ & $1,6.6$ \\
\hline C Campinas & & & $\begin{array}{l}40,9 \\
417\end{array}$ & $\begin{array}{l}40,9 \\
47,7\end{array}$ & & & 44,1 & $\begin{array}{l}40,9 \\
417\end{array}$ & $\begin{array}{ll}41,0 \\
42,1\end{array}$ & & & 41,4 & $\begin{array}{l}41,4 \\
41,8\end{array}$ & $\begin{array}{l}41,4,4 \\
4,7\end{array}$ & & $\begin{array}{l}41,3 \\
4.18 \\
4.8\end{array}$ & 41,4 & $1,11,2$ & 41,4 & 41,4 & & 6 & 41,6 & 41,9 & 1,9 & \\
\hline neirat sent sent & & $\begin{array}{l}\begin{array}{l}2,3,3 \\
42,6\end{array} \\
4\end{array}$ & $\begin{array}{l}4,7,7 \\
41,5\end{array}$ & 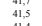 & $\begin{array}{l}4,7,7 \\
41,5\end{array}$ & $\begin{array}{l}44,3 \\
4,5\end{array}$ & $\begin{array}{l}42,0 \\
41,5\end{array}$ & $\begin{array}{l}4,7, ? \\
41,5\end{array}$ & $\begin{array}{l}42,1 \\
41,5 \\
4\end{array}$ & $\begin{array}{l}42,3 \\
41,4\end{array}$ & $\begin{array}{l}4,8,8 \\
41,5\end{array}$ & $\begin{array}{l}\begin{array}{l}42,1 \\
41,5\end{array} \\
4\end{array}$ & $\begin{array}{l}4,8,8 \\
4,1,5\end{array}$ & 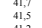 & $\begin{array}{l}41,8 \\
41,3 \\
4,3\end{array}$ & $\begin{array}{l}4,1,8 \\
41,4\end{array}$ & $\begin{array}{l}41,8 \\
4,3 \\
4,3\end{array}$ & $\begin{array}{l}4 ., 8 \\
4,2,2\end{array}$ & $\begin{array}{l}4.1,9 \\
41,3\end{array}$ & $\begin{array}{l}4,9 \\
41,4\end{array}$ & $\begin{array}{l}41,9 \\
41,3 \\
4\end{array}$ & $\begin{array}{l}4,2,0 \\
41,5\end{array}$ & $\begin{array}{l}4.2,4 \\
41,9\end{array}$ & $\begin{array}{l}4.2,5 \\
41,9\end{array}$ & $\begin{array}{l}4.2,1 \\
41,6\end{array}$ & 1,5 \\
\hline de Limeira asent & & $\begin{array}{l}{ }_{41,5}^{42,3} \\
4\end{array}$ & $\begin{array}{l}414,4 \\
41,7\end{array}$ & 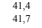 & $\begin{array}{l}41,4 \\
41,7\end{array}$ & $\begin{array}{l}44,3, \\
41,6\end{array}$ & 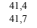 & $\begin{array}{l}{ }_{41,4,}^{41,7} \\
4\end{array}$ & 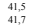 & $\begin{array}{l}41,6, \\
41,7\end{array}$ & 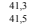 & $\begin{array}{l}\begin{array}{l}414,3 \\
41,6\end{array} \\
4\end{array}$ & $\begin{array}{l}41,5 \\
41,6 \\
4,6\end{array}$ & 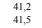 & 童11,4, & $\begin{array}{l}4,4,4 \\
41,1\end{array}$ & $\begin{array}{l}4,3 \\
4,3 \\
4,3\end{array}$ & $\begin{array}{l}4,1,4 \\
4 l, 1 \\
4\end{array}$ & $\begin{array}{l}4,1,3 \\
41,0 \\
4\end{array}$ & $\begin{array}{l}4,4,4 \\
41,0\end{array}$ & $\begin{array}{l}44,3,3 \\
41,0\end{array}$ & $\begin{array}{l}4,1 \\
40,9\end{array}$ & $\begin{array}{l}4,1,7 \\
41,3\end{array}$ & $\begin{array}{l}4,1,5 \\
41,1 \\
4\end{array}$ & $\begin{array}{l}{ }_{41,5}^{41,0} \\
4\end{array}$ & 1,4 \\
\hline 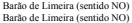 & & 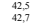 & $\begin{array}{l}42,2 \\
42,1\end{array}$ & $\begin{array}{l}{ }_{22,2}^{42,1} \\
42\end{array}$ & $\begin{array}{l}42,2 \\
42,2 \\
42.1\end{array}$ & $\begin{array}{l}42,1 \\
42,0\end{array}$ & $\begin{array}{l}42,1 \\
422.0\end{array}$ & $\begin{array}{l}{ }_{22,1}, 1,9 \\
41,9\end{array}$ & $\begin{array}{l}41,9 \\
41.9\end{array}$ & $\begin{array}{l}41,9 \\
41,9\end{array}$ & $\begin{array}{l}41,9 \\
42,0\end{array}$ & $\begin{array}{l}42,0 \\
41,9 \\
41,9\end{array}$ & $\begin{array}{l}42,0.0 \\
44_{22.2}\end{array}$ & $\begin{array}{l}42,0 \\
42,3 \\
42,\end{array}$ & $\begin{array}{l}41,8 \\
42,1\end{array}$ & $\begin{array}{l}42,0 \\
42,2 \\
4.22\end{array}$ & $\begin{array}{l}42,0 \\
42,1\end{array}$ & $\begin{array}{l}4,1,8 \\
42,1\end{array}$ & $\begin{array}{l}4,8 \\
42,1 \\
42,1\end{array}$ & $\begin{array}{l}4,8,8 \\
44,2.1\end{array}$ & $\begin{array}{l}4,8,8 \\
44.1\end{array}$ & $\begin{array}{l}4,9 \\
44_{4,22}\end{array}$ & $\begin{array}{l}4,2,2 \\
42,2\end{array}$ & $\begin{array}{l}42,2 \\
4424\end{array}$ & $\begin{array}{l}41,9 \\
427\end{array}$ & 2., \\
\hline Bar & & $\begin{array}{l}72,1 \\
42,6\end{array}$ & $\begin{array}{l}4,1,1 \\
41,0\end{array}$ & $\begin{array}{l}42,1 \\
41,0\end{array}$ & $\begin{array}{l}4,1,0 \\
41,0 \\
4\end{array}$ & $\begin{array}{l}2+, 0,0 \\
40,9\end{array}$ & $\begin{array}{l}4,0,9 \\
40,9\end{array}$ & 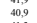 & $\begin{array}{l}40,9 \\
40,9\end{array}$ & 0,9 & $\begin{array}{l}42,0 \\
41,1 \\
4,1\end{array}$ & $\begin{array}{l}41,9 \\
41,0\end{array}$ & $\begin{array}{l}4,2,2 \\
41,4 \\
4\end{array}$ & $\begin{array}{l}42,3 \\
41,5\end{array}$ & $\begin{array}{l}42,1 \\
41,5 \\
4\end{array}$ & $\begin{array}{l}4,2,2 \\
41,5 \\
4.5\end{array}$ & $\begin{array}{l}42,1 \\
41,5 \\
4.9\end{array}$ & 先, & $\begin{array}{l}4.2,1 \\
41,6\end{array}$ & $\begin{array}{l}4,1,1 \\
41,6\end{array}$ & $\begin{array}{l}4,1 \\
41,5 \\
4.5\end{array}$ & $\begin{array}{l}4.2,2 \\
41,6\end{array}$ & 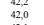 & $\begin{array}{l}24,4 \\
41,7\end{array}$ & $\begin{array}{l}4.2,9 \\
41,9\end{array}$ & , 1,4 \\
\hline & & 42,7 & 41,0 & $\begin{array}{l}41,0 \\
3,5\end{array}$ & $\begin{array}{l}4,0 \\
3,5,5 \\
3.5\end{array}$ & $\begin{array}{l}{ }_{4}^{4,0}, 0 \\
3,5\end{array}$ & $\begin{array}{l}41,0 \\
36,7\end{array}$ & $\begin{array}{l}4,1,3 \\
3,5,5 \\
\end{array}$ & & 1, & $\begin{array}{l}\begin{array}{l}41,6 \\
37,0\end{array} \\
3\end{array}$ & 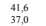 & $\begin{array}{l}41,6 \\
3,7,0\end{array}$ & $\begin{array}{l}41,6,6 \\
36,9\end{array}$ & $\begin{array}{l}41,7 \\
36,9 \\
36,\end{array}$ & $\begin{array}{l}4,7,7 \\
36,9\end{array}$ & 41,7 & 41,7 & $\begin{array}{l}41,6 \\
3.69 \\
3.6\end{array}$ & 41,7 & & & & $\begin{array}{l}41,7 \\
43,3\end{array}$ & $\begin{array}{l}41,6 \\
3.3,3\end{array}$ & 41,5 \\
\hline & & 41 & 40,8 & $\begin{array}{l}30,8 \\
40,3\end{array}$ & $\begin{array}{l}33 \\
40\end{array}$ & 4 & $\begin{array}{l}3 ., 1 \\
41,1\end{array}$ & (1),2 & $\begin{array}{l}36,8 \\
41,1\end{array}$ & & $\begin{array}{l}37,0 \\
41,3\end{array}$ & $\begin{array}{l}3,1,0 \\
41,3\end{array}$ & $\begin{array}{l}37,0 \\
41,3 \\
4\end{array}$ & 3 & $\begin{array}{l}3.9,9 \\
41,3\end{array}$ & $\begin{array}{l}3,6,9 \\
41,3\end{array}$ & & & & & & & & & & \\
\hline rit & & & $4,1,6$ & $\begin{array}{l}41,6 \\
42,6\end{array}$ & & & 41. & 41,6 & $\begin{array}{ll}41,8 \\
424\end{array}$ & & & 41,9 & $\begin{array}{ll}41,9 \\
422\end{array}$ & & 0 & & & & & & & & & & & 0 \\
\hline arvalho de & & 42,8 & $\begin{array}{l}4 ., 9 \\
41,9\end{array}$ & $\begin{array}{l}42,6 \\
41,9 \\
4\end{array}$ & $\begin{array}{l}4,6,6 \\
4,1,9\end{array}$ & $\begin{array}{l}42 \\
41 \\
41\end{array}$ & $\begin{array}{l}4,2,3 \\
42,3\end{array}$ & $\begin{array}{l}4.2,2 \\
42,5\end{array}$ & $\begin{array}{l}42,4 \\
42,2 \\
42\end{array}$ & & $\begin{array}{l}4.2,2 \\
42,4\end{array}$ & $\begin{array}{l}42,2 \\
42,5\end{array}$ & $\begin{array}{l}42,2 \\
42,4\end{array}$ & $\begin{array}{l}42,2 \\
42,4\end{array}$ & $\begin{array}{l}42,3 \\
42,4\end{array}$ & & & & & & & & & & & $\frac{5}{4.5}$ \\
\hline & & 42,2 & 41,5 & 4,5 & 41,5 & 41,4 & 41,4 & 4,4 & 41,4 & & 41,7 & 41,6 & 41,5 & 41,8 & 41,6 & 41,6 & 41, & & & & & & & & & \\
\hline & & $\begin{array}{l}42.9 \\
3.1 .5 \\
4\end{array}$ & $\begin{array}{l}42,0 \\
3,5 \\
3.5\end{array}$ & $\begin{array}{l}42,0 \\
3,5 \\
3,5\end{array}$ & $\begin{array}{l}42,0 \\
3,5 \\
3.5\end{array}$ & $\begin{array}{l}43,0 \\
35,4\end{array}$ & $\begin{array}{l}423 \\
303\end{array}$ & $\begin{array}{l}42,0 \\
32,0 \\
4\end{array}$ & $\begin{array}{l}42,2 \\
2,2 \\
29\end{array}$ & & ${ }_{42}^{42}$ & $\begin{array}{l}42,5 \\
32,6 \\
3\end{array}$ & $\begin{array}{l}42,4 \\
39,0 \\
39\end{array}$ & & 39,0 & & 39. $\quad \mathrm{C}$ & & & & & & & & & \\
\hline & & 41,7 & $\begin{array}{l}40,6 \\
40,6 \\
300\end{array}$ & 40,6 & $\begin{array}{l}40,6 \\
30,0 \\
3.0\end{array}$ & $\begin{array}{l}40,6 \\
30.6\end{array}$ & $\begin{array}{l}40,7 \\
40,7\end{array}$ & 40,6 & $\begin{array}{l}2,9 \\
40,9 \\
0.9\end{array}$ & & 41,2 & 41,1, & 4,1 & 413 & 40,9 & 4,2 & 40,9 & 9 & & & & & & & & 0 \\
\hline Ediando Prado & & $\begin{array}{l}36,3 \\
41,5 \\
4.5\end{array}$ & 染, & $\begin{array}{l}3,0,0 \\
38,4\end{array}$ & $\begin{array}{l}53,0 \\
38,4\end{array}$ & $\frac{3,3,0}{38,4}$ & $\begin{array}{l}5,0 \\
40,2 \\
40,2\end{array}$ & $\begin{array}{l}31,4 \\
41,4\end{array}$ & $\begin{array}{l}33,8 \\
40,8 \\
40,3\end{array}$ & s. & 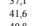 & $\begin{array}{l}31,4 \\
41,6\end{array}$ & 41,6 & $\begin{array}{l}36,7 \\
41,6\end{array}$ & 41,3 & $\begin{array}{l}3,4,5 \\
41,5 \\
4\end{array}$ & $\begin{array}{l}36,8 \\
41,5 \\
4\end{array}$ & 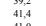 & $\begin{array}{l}3,2,2 \\
41,3\end{array}$ & $4,4,4$ & & & 41,6 & $\begin{array}{l}3,93 \\
41,6 \\
4\end{array}$ & & , \\
\hline & & & & $\begin{array}{l}36,4,4 \\
400 \\
400\end{array}$ & & & & & & & & & $\begin{array}{l}40,8 \\
411 .\end{array}$ & & 41,0 & & & & & & & & & & & \\
\hline 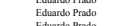 & & $\begin{array}{l}4,8 \\
42,0 \\
40\end{array}$ & $\begin{array}{l}+4,9,1 \\
41,1\end{array}$ & 年, 4,1 & $\begin{array}{l}4,9,1 \\
4,1,1\end{array}$ & 作, & 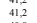 & 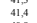 & 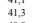 & $\begin{array}{l}4,4 \\
41,7\end{array}$ & $\begin{array}{l}41,3 \\
40,7\end{array}$ & 41,6 & $\begin{array}{l}4,1,0 \\
41,0\end{array}$ & $\begin{array}{l}40,8 \\
40,6\end{array}$ & 40,9 & (4,3, & $\begin{array}{ll}40,3 \\
41,3\end{array}$ & 41,4 & 41,2 & & & & $4,1,3$ & 41,2 & & 2 \\
\hline $\begin{array}{l}\text { Eddardo Prad } \\
\text { Eduardo Prad }\end{array}$ & & $\begin{array}{l}41,1 \\
41 .\end{array}$ & $\begin{array}{l}40,9 \\
40,8 \\
40.8\end{array}$ & $\begin{array}{l}40,9 \\
40,8\end{array}$ & $\begin{array}{l}40,9 \\
40,8 \\
4 ., 8\end{array}$ & $\begin{array}{l}40 \\
40\end{array}$ & $\begin{array}{l}40,8 \\
40,9\end{array}$ & 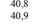 & $\begin{array}{l}40,8 \\
41,0 \\
4,0\end{array}$ & $\begin{array}{l}40,7 \\
41,1\end{array}$ & $\begin{array}{l}4,0,0 \\
4,1,1\end{array}$ & $\begin{array}{l}40,9 \\
41,1\end{array}$ & $\begin{array}{l}40,9 \\
41,1 \\
4,1\end{array}$ & $\begin{array}{l}41,0 \\
41,1\end{array}$ & $\begin{array}{l}41,1 \\
41,0\end{array}$ & 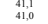 & $\begin{array}{l}41 . \\
41 . \\
4\end{array}$ & $4,1,1$ & $\begin{array}{l}4,0,6 \\
40,8\end{array}$ & & & & $\begin{array}{l}4.07 \\
4,2\end{array}$ & & & 9 \\
\hline 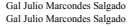 & & $\begin{array}{l}44,5 \\
43,0\end{array}$ & $\begin{array}{l}4,5,5 \\
42,0 \\
4\end{array}$ & $\begin{array}{l}\begin{array}{l}40,5 \\
42,0\end{array} \\
4,0\end{array}$ & $\begin{array}{l}40.5 \\
42,0 \\
4\end{array}$ & & $\begin{array}{l}41,2,5 \\
41,5\end{array}$ & $\begin{array}{l}\begin{array}{l}41,0 \\
39,7\end{array} \\
39\end{array}$ & $\begin{array}{l}40,5 \\
41,4 \\
4.4\end{array}$ & ${ }_{4}^{4}$ & & $\begin{array}{l}{ }_{41,6,6}^{40,0} \\
4\end{array}$ & $\begin{array}{l}44,7,2 \\
40,1\end{array}$ & $\begin{array}{l}{ }_{41,7}^{41,8} \\
4\end{array}$ & & 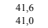 & 年, & & & & & & & & & \\
\hline Nothmann & & $\begin{array}{l}42,5 \\
42,4 \\
42\end{array}$ & $\begin{array}{l}4,1 \\
0,8,8 \\
40.0\end{array}$ & $\begin{array}{l}4,1,1 \\
0,0,8\end{array}$ & $\begin{array}{l}4,1 \\
40,8 \\
4.8\end{array}$ & & 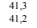 & 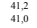 & $\begin{array}{l}41,2 \\
40,9 \\
40,9\end{array}$ & & $\begin{array}{l}{ }_{41,3}^{41,2} \\
4,2\end{array}$ & $\begin{array}{l}4,3 \\
40,9\end{array}$ & 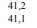 & $\begin{array}{l}\begin{array}{l}41,0,0 \\
40,9\end{array} \\
4\end{array}$ & 4,6 & $\begin{array}{l}41,0 \\
41,5 \\
4,5\end{array}$ & $\begin{array}{l}44,1,2, \\
41,2\end{array}$ & & $\begin{array}{l}4,7 \\
41,6 \\
4.6\end{array}$ & & & & & & & \\
\hline & & & & $\begin{array}{l}4,1 \\
4,3 \\
4,3\end{array}$ & & & & $\begin{array}{l}40,1 \\
41,3 \\
4,3\end{array}$ & & & & & $\begin{array}{l}40,1 \\
41,5 \\
4,5\end{array}$ & & & & & & & & & & & & & \\
\hline $\begin{array}{l}\text { Nothmann } \\
\text { Nofmmann }\end{array}$ & & $\begin{array}{l}{ }_{41,6}^{41,6} \\
41,\end{array}$ & 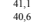 & 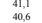 & $\begin{array}{l}\begin{array}{l}41,1 \\
40,6\end{array} \\
4.06\end{array}$ & $\begin{array}{l}{ }_{410,0}^{40,6} \\
40\end{array}$ & $\begin{array}{l}40,8 \\
40.5 \\
4.5\end{array}$ & $\begin{array}{l}{ }_{40,7}^{40,5} \\
40\end{array}$ & $\begin{array}{l}40,7 \\
40,5 \\
40.5\end{array}$ & $\begin{array}{l}40,6 \\
40,5\end{array}$ & $\begin{array}{l}{ }_{40,7}^{40,5} \\
40,5\end{array}$ & $\begin{array}{l}40,7 \\
40,5 \\
4\end{array}$ & $\begin{array}{l}40,7 \\
40.5 \\
40.0\end{array}$ & $\begin{array}{l}{ }^{40,6}, 6 \\
40,6\end{array}$ & $\begin{array}{l}41,0 \\
40,7\end{array}$ & 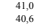 & $\begin{array}{l}41 . \\
40 .\end{array}$ & & $\begin{array}{l}4,2 \\
41,0 \\
4\end{array}$ & & & & & & & $1,0,0$ \\
\hline $\begin{array}{l}\text { Nothmam } \\
\text { Nothmana }\end{array}$ & & $\begin{array}{l}41,9 \\
41,8 \\
418\end{array}$ & $\begin{array}{l}41,5 \\
417\end{array}$ & $\begin{array}{l}4,5 \\
41,5 \\
417\end{array}$ & $\begin{array}{l}41,5 \\
417 \\
417\end{array}$ & ${ }_{41}^{41}$ & $\begin{array}{l}41,3 \\
416\end{array}$ & $\begin{array}{l}41,4 \\
44,6 \\
4.16\end{array}$ & 孚1,4, & & & & ${ }_{41,}^{41,}$ & & & & ${ }_{41}^{41,}$ & & & & & & & & & \\
\hline 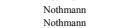 & & $\begin{array}{l}30,9 \\
31.0\end{array}$ & $\begin{array}{l}25,1 \\
26.9\end{array}$ & $\begin{array}{l}25,1 \\
2,69 \\
269\end{array}$ & $\begin{array}{l}25,1 \\
26.9 \\
26.9\end{array}$ & 23 & $\begin{array}{l}24,4 \\
26,7\end{array}$ & $\begin{array}{l}25,0 \\
22,5 \\
2.5\end{array}$ & $\begin{array}{l}24,5 \\
26.0 \\
26.0\end{array}$ & & $\begin{array}{l}24,2 \\
25,7\end{array}$ & & 24, 24,4 & & & & & & $\begin{array}{l}23,9 \\
22,3 \\
2.3\end{array}$ & & & & & & & \\
\hline 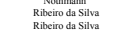 & & $\begin{array}{l}34,1 \\
402\end{array}$ & $\begin{array}{l}32,7 \\
389\end{array}$ & $\begin{array}{l}32,7 \\
389 \\
389\end{array}$ & $\begin{array}{l}32,7 \\
38.9 \\
389\end{array}$ & & $\begin{array}{l}32,8 \\
32,8 \\
200\end{array}$ & $\begin{array}{l}32,9 \\
3.29 \\
3.98\end{array}$ & & & $\begin{array}{l}33,2 \\
3,2\end{array}$ & $\begin{array}{l}33,4 \\
39.1 \\
30.1\end{array}$ & $\begin{array}{l}33,4 \\
39,1\end{array}$ & & $\begin{array}{l}33,2 \\
39,1\end{array}$ & $\begin{array}{l}33,3 \\
39,1 \\
39.1\end{array}$ & $\begin{array}{l}33 . \\
3.9 \\
32\end{array}$ & & $\begin{array}{l}33,5 \\
3.92\end{array}$ & & & & & & & \\
\hline $\begin{array}{l}\text { Riberion dalivala } \\
\text { Ribecio da Silva }\end{array}$ & & $\begin{array}{l}40,2 \\
31,4 \\
31,4\end{array}$ & $\begin{array}{l}32,9 \\
29,3 \\
2\end{array}$ & $\begin{array}{l}38,9 \\
29,3\end{array}$ & $\begin{array}{l}38,9,3 \\
29,3\end{array}$ & $\begin{array}{l}\frac{3}{38,8} \\
29,2\end{array}$ & $\begin{array}{l}3,3,0 \\
28,5\end{array}$ & $\begin{array}{l}39,9 \\
29,2 \\
29,2\end{array}$ & $\begin{array}{l}38,9 \\
28,7\end{array}$ & $\begin{array}{l}3,2,3 \\
28,3\end{array}$ & 年, & $\begin{array}{l}3,9,1 \\
26,7\end{array}$ & $\begin{array}{l}39,1 \\
28,5 \\
28\end{array}$ & $\begin{array}{l}39,0 \\
28,5\end{array}$ & $\begin{array}{l}39,1 \\
28,3\end{array}$ & $\begin{array}{l}389,1 \\
28,4\end{array}$ & $\begin{array}{l}38,7 \\
28,7 \\
28,7\end{array}$ & & $\begin{array}{l}3,2,2 \\
27,8\end{array}$ & & $\begin{array}{l}39 . \\
28 .\end{array}$ & $\begin{array}{l}39,2 \\
28,5\end{array}$ & $7_{9}^{7}$ & & &, 2 \\
\hline 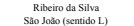 & & $\begin{array}{l}38,7 \\
532\end{array}$ & $\begin{array}{l}37,1 \\
53,1\end{array}$ & $\begin{array}{l}37,1 \\
3,3,1\end{array}$ & $\begin{array}{l}37,1 \\
5,1\end{array}$ & $\begin{array}{l}37,1 \\
53,1\end{array}$ & $\begin{array}{l}3,9 \\
52,9 \\
52,9\end{array}$ & $\begin{array}{l}36,9 \\
52,8\end{array}$ & $\begin{array}{l}36,8 \\
52,9\end{array}$ & $\frac{3}{5}$ & $\begin{array}{l}36,6 \\
52,1\end{array}$ & & $\begin{array}{l}36,1 \\
52,3\end{array}$ & $\begin{array}{l}35,7 \\
52,1\end{array}$ & $\begin{array}{l}35,5 \\
518\end{array}$ & $\begin{array}{l}35,6 \\
519\end{array}$ & $\begin{array}{l}35 . \\
52 .\end{array}$ & 35. & $\begin{array}{l}37,1 \\
51,9\end{array}$ & & $\begin{array}{l}35 \\
52\end{array}$ & & 7,4 & & & t. \\
\hline of sentido Ĺ & & $\begin{array}{l}53,3 \\
454\end{array}$ & 46.0 & $\begin{array}{l}53,3 \\
460\end{array}$ & & 46,0 & $\begin{array}{l}52,6 \\
4465\end{array}$ & $\begin{array}{l}52,9 \\
46,0\end{array}$ & $\begin{array}{l}52,7 \\
46,6\end{array}$ & & & $\begin{array}{l}52,6 \\
46,8\end{array}$ & $\begin{array}{l}52, \\
46.6\end{array}$ & 46,2 & 460 & $\begin{array}{l}52,7 \\
45,9\end{array}$ & $\begin{array}{l}52 . \\
45\end{array}$ & & & & & & & & & 46,1 \\
\hline & & $\begin{array}{l}45,0 \\
43,6\end{array}$ & $\begin{array}{l}45,7 \\
43.8 \\
43.8\end{array}$ & $\begin{array}{l}45,7 \\
438 \\
438\end{array}$ & $\begin{array}{l}45,7 \\
43,8\end{array}$ & $\begin{array}{l}45,7 \\
43,7\end{array}$ & $\begin{array}{l}45,9 \\
43,3\end{array}$ & $\begin{array}{l}45,9 \\
44,2 \\
4426\end{array}$ & $\begin{array}{l}45,9 \\
43,0\end{array}$ & & $\begin{array}{l}46,3 \\
43,2\end{array}$ & 年6. & $\begin{array}{l}46, \\
42.3\end{array}$ & $\begin{array}{l}46,3 \\
43.5\end{array}$ & $\begin{array}{l}46,3 \\
41.8\end{array}$ & $\begin{array}{l}46,3 \\
41.8 \\
41.8\end{array}$ & $\begin{array}{l}46 . \\
42 \\
42\end{array}$ & & & & & & $=\frac{2}{4}$ & & & t.t, \\
\hline & & $\begin{array}{l}4,3,3 \\
5,34\end{array}$ & $\begin{array}{l}43,6 \\
43,6 \\
5,00\end{array}$ & $\begin{array}{l}23,6 \\
43,6 \\
5,00\end{array}$ & $\begin{array}{l}7,6,6 \\
43,60 \\
5,00\end{array}$ & $\begin{array}{l}8,5,5 \\
43,5 \\
500\end{array}$ & 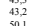 & 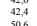 & $\begin{array}{l}8,3,3 \\
43,3 \\
503\end{array}$ & & $\begin{array}{l}2,2 \\
42,9 \\
\text { s., }\end{array}$ & 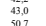 & $\begin{array}{ll}4.4 \\
40.7\end{array}$ & 44,3 & 年, & $\begin{array}{l}4,5 \\
42,5 \\
5,1,\end{array}$ & $\begin{array}{l}24 \\
4 \\
50.0\end{array}$ & & & & & & & & & $\begin{array}{l}4.3,3 \\
40,3 \\
508\end{array}$ \\
\hline & & $\begin{array}{ll}51,4 \\
51,4\end{array}$ & sil, & $\begin{array}{l}\text { sil. } \\
\text { sil. } \\
4222\end{array}$ & $\begin{array}{l}51,1 \\
42, \\
42\end{array}$ & 51 & 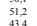 & 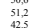 & $\begin{array}{l}51,2 \\
413 \\
437\end{array}$ & & 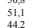 & $\begin{array}{l}51 \\
54 \\
44\end{array}$ & $\begin{array}{l}51, \\
51, \\
4.2\end{array}$ & $\begin{array}{c}50,8 \\
50,8 \\
40\end{array}$ & $\begin{array}{l}51,4 \\
44\end{array}$ & $\begin{array}{l}5,1,3 \\
5 \leq 6 \\
456\end{array}$ & $\begin{array}{l}51 . \\
55 \\
45\end{array}$ & $\begin{array}{l}5,5,5 \\
46,7\end{array}$ & $\begin{array}{l}5,9 \\
549 \\
449\end{array}$ & & & & & & & $\begin{array}{l}3,8 \\
5,1,1 \\
445\end{array}$ \\
\hline & & $\begin{array}{l}50,6 \\
510\end{array}$ & $\begin{array}{l}\text { tit, } \\
449 \\
470\end{array}$ & $\begin{array}{l}\text { 4.9. } \\
4470 \\
470\end{array}$ & $\begin{array}{l}44,9 \\
470\end{array}$ & $\begin{array}{l}4,99 \\
40 \\
40\end{array}$ & 47 & $\begin{array}{l}46,9 \\
4478 \\
447\end{array}$ & $\begin{array}{l}73,5 \\
44,5 \\
470\end{array}$ & $\begin{array}{l}47,7 \\
483\end{array}$ & $\begin{array}{l}46,9 \\
482 \\
482\end{array}$ & $\begin{array}{l}47,5 \\
478,5 \\
482\end{array}$ & $\begin{array}{l}77, \\
47,3\end{array}$ & $\begin{array}{l}416,6 \\
47^{4}, 6\end{array}$ & 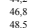 & $\begin{array}{l}\text { sit. } \\
48,9 \\
481\end{array}$ & 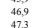 & $\begin{array}{l}4.9 \\
49,9 \\
4919\end{array}$ & $\begin{array}{l}48,4 \\
44,4 \\
409\end{array}$ & s. & $\begin{array}{l}\text { to } \\
49 \\
49\end{array}$ & & 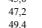 & 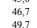 & $\begin{array}{l}46 \\
40 \\
40\end{array}$ & $\begin{array}{l}\begin{array}{l}44.5 \\
47,1 \\
48,3\end{array} \\
4\end{array}$ \\
\hline & & $\begin{array}{l}51,6 \\
32,2\end{array}$ & 319 & $\begin{array}{l}48,5 \\
319 \\
319\end{array}$ & $\begin{array}{l}48,5 \\
319 \\
319\end{array}$ & $\begin{array}{l}48,4 \\
31.9\end{array}$ & $\begin{array}{l}48,5 \\
4.8,5 \\
3.118\end{array}$ & 31.8 & $\begin{array}{l}48,7 \\
31.7\end{array}$ & & $\begin{array}{l}48,7 \\
4,7 \\
31.7\end{array}$ & $\begin{array}{l}49.9 \\
3.19\end{array}$ & $\begin{array}{l}48.7 \\
31.7\end{array}$ & $\begin{array}{l}48,6 \\
31.7\end{array}$ & $\begin{array}{l}49,6 \\
4,1,7\end{array}$ & $\begin{array}{l}49,3 \\
311,7 \\
3.7\end{array}$ & $\begin{array}{l}49,2 \\
31.7 \\
31.7\end{array}$ & 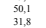 & $\begin{array}{l}5,2 \\
5,1,8 \\
3.1,8\end{array}$ & $\begin{array}{c}30,3 \\
31,8 \\
31,\end{array}$ & & & $\begin{array}{l}50,9 \\
3.24\end{array}$ & $\begin{array}{l}50,7 \\
3.22\end{array}$ & & $\begin{array}{l}4.9,5 \\
3.9 \\
3.19\end{array}$ \\
\hline & & $\begin{array}{l}27,3 \\
32.0\end{array}$ & $\begin{array}{l}26,7 \\
3.16\end{array}$ & $\begin{array}{l}26,7 \\
316\end{array}$ & $\begin{array}{l}26, \\
31.4\end{array}$ & $\begin{array}{l}26,7 \\
31.6\end{array}$ & $\begin{array}{l}26,6 \\
3.16\end{array}$ & $\begin{array}{l}26,3 \\
3.1,6 \\
3.1\end{array}$ & $\begin{array}{l}26 . \\
331 .\end{array}$ & & $\begin{array}{l}25,4 \\
31,7\end{array}$ & $\begin{array}{l}25,4 \\
31,7\end{array}$ & $\begin{array}{l}25, \\
31.3\end{array}$ & 31,7 & 256 & $\begin{array}{l}25,4 \\
31.8\end{array}$ & $\begin{array}{l}25 . \\
31 . \\
31\end{array}$ & & $\begin{array}{l}27,7 \\
3.1,8\end{array}$ & & & & $\begin{array}{l}28,7 \\
32,1\end{array}$ & $\begin{array}{l}28,8 \\
32,2\end{array}$ & & $\begin{array}{l}26,7 \\
26,7\end{array}$ \\
\hline 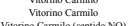 & & $\begin{array}{l}\text { sti, } \\
4,1,1\end{array}$ & $\begin{array}{l}3,6 \\
3,9,6 \\
3,2,\end{array}$ & $\begin{array}{l}31,6 \\
39,6 \\
3,2,\end{array}$ & 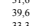 & $\begin{array}{l}3,9, \\
39, \\
3,2,\end{array}$ & $\begin{array}{l}3,6 \\
3,9,6 \\
3,2,\end{array}$ & $\begin{array}{l}3,6 \\
3,9,6 \\
3,2,\end{array}$ & $\begin{array}{l}31 \\
39 \\
33\end{array}$ & & $\begin{array}{l}\text { sis, } \\
38,7 \\
3,2\end{array}$ & $\begin{array}{l}31,7 \\
39,3 \\
3,5\end{array}$ & 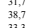 & & $\begin{array}{l}3.1 \\
38 .\end{array}$ & $\begin{array}{l}31,8 \\
38,5 \\
3,6\end{array}$ & & & & & & & & & & , 1,8 \\
\hline & & 3,3, & 等, & & . & & . & & & & & 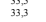 & 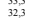 & & & $\begin{array}{l}3,3, \\
34,\end{array}$ & 3 & & & & & & 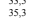 & $\begin{array}{l}33,28 \\
33,2\end{array}$ & & , 3,4 \\
\hline & & & & & & & & & & & & & & & & & & & & & & & & & & \\
\hline
\end{tabular}


Os valores destacados em azul, nas Tabelas 8.4 e 8.6, mostram a velocidade média nas Alamedas Barão de Limeira e Eduardo Prado em períodos nos quais ocorreram o estacionamento irregular dos veículos de entrega em uma das faixas de tráfego. É possível observar, ainda, que na faixa onde o veículo está estacionado (faixa 2) a redução da velocidade foi maior. Já os valores em destaque nas Tabelas 8.4 e 8.6, em vermelho na primeira e em verde na segunda, mostram, respectivamente, as velocidades médias na Avenida Angélica (segmento 1, faixa 1) para o cenário base e para o cenário alternativo 2. É possível observar que o reposicionamento da área de carga e descarga no cenário alternativo 2 resultou em um aumento na velocidade média da faixa onde a mesma estava localizada. A diferença ocorreu apenas a partir da hora 5 da simulação porque, no cenário base, somente a partir desse horário a área é liberada para uso.

Na Tabela 8.5 destaca-se, em amarelo, uma redução na velocidade média da Rua Adolfo Gordo na hora 4 da simulação em comparação com o cenário base no mesmo período. Isso porque, no cenário alternativo 1 , nesse mesmo período, dois veículos de carga do tipo Toco trafegam por essa via, na qual a velocidade adotada para esses caminhões é de $20 \mathrm{~km} / \mathrm{h}$. Para um deles ainda, a velocidade é de cerca de $12 \mathrm{~km} / \mathrm{h}$, uma vez que o mesmo busca por uma vaga de estacionamento.

Por fim, os valores destacados em laranja, nas Tabelas 8.4, 8.5 e 8.6, correspondem à redução de velocidade devido à formação de filas nos segmentos de via. Essas filas são decorrentes das manobras de estacionamento dos veículos de carga e serão discutas a seguir.

\section{Formação de Filas nos Links da Rede}

O mesmo tipo de análise realizado para as velocidades médias nos links pode ser feito considerando os resultados relativos às formações de filas. Informações relativas à formação de filas podem ser obtidas, no VISSIM, a partir dos dados registrados por pontos de contagem de filas (objeto do tipo 'queue counter'), inseridos ao longo da rede. Parte do arquivo gerado pelo VISSIM que contém esses registros é exibido na Figura 8.7. Nela, estão contidas as seguintes informações:

- TIMEINT: intervalo de tempo para o qual os dados serão registrados;

- QUEUECOUNTER: identificação do ponto de contagem de fila; 
- $Q L E N$ : fila média, calculada com base no comprimento de fila registrado em cada incremento de tempo; a fila é medida a montante do ponto de contagem;

- QLENMAX: comprimento máximo de fila registrado durante a simulação;

- QSTOPS: número de veículos que atingem a velocidade considerada limite para o início da fila.

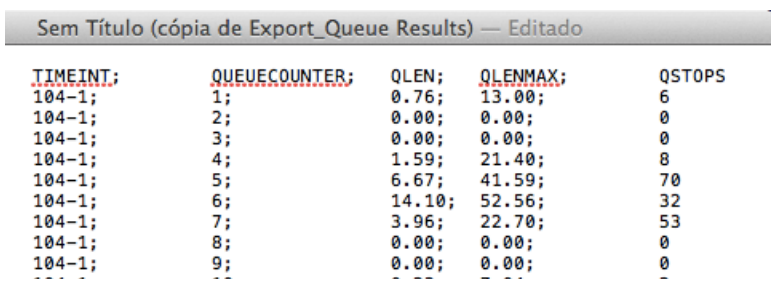

Figura 8.7 - Dados de saída fornecidos pelo VISSIM para as formações de filas

Nas tabelas 8.7, 8.8 e 8.9, a seguir, estão os resultados, para cada um dos cenários de simulação, para os comprimentos máximos de fila observados nos links onde ocorre estacionamento dos veículos de carga e naqueles por onde a fila possa se estender. Nas tabelas são destacadas as filas decorrentes da interferência dos veículos de carga em manobra de estacionamento ou estacionados na faixa de tráfego. 
Tabela 8.7 - Comprimentos máximos de fila para o cenário base (situação atual) e situações onde ocorre a interferência de um veículo de carga (em destaque)

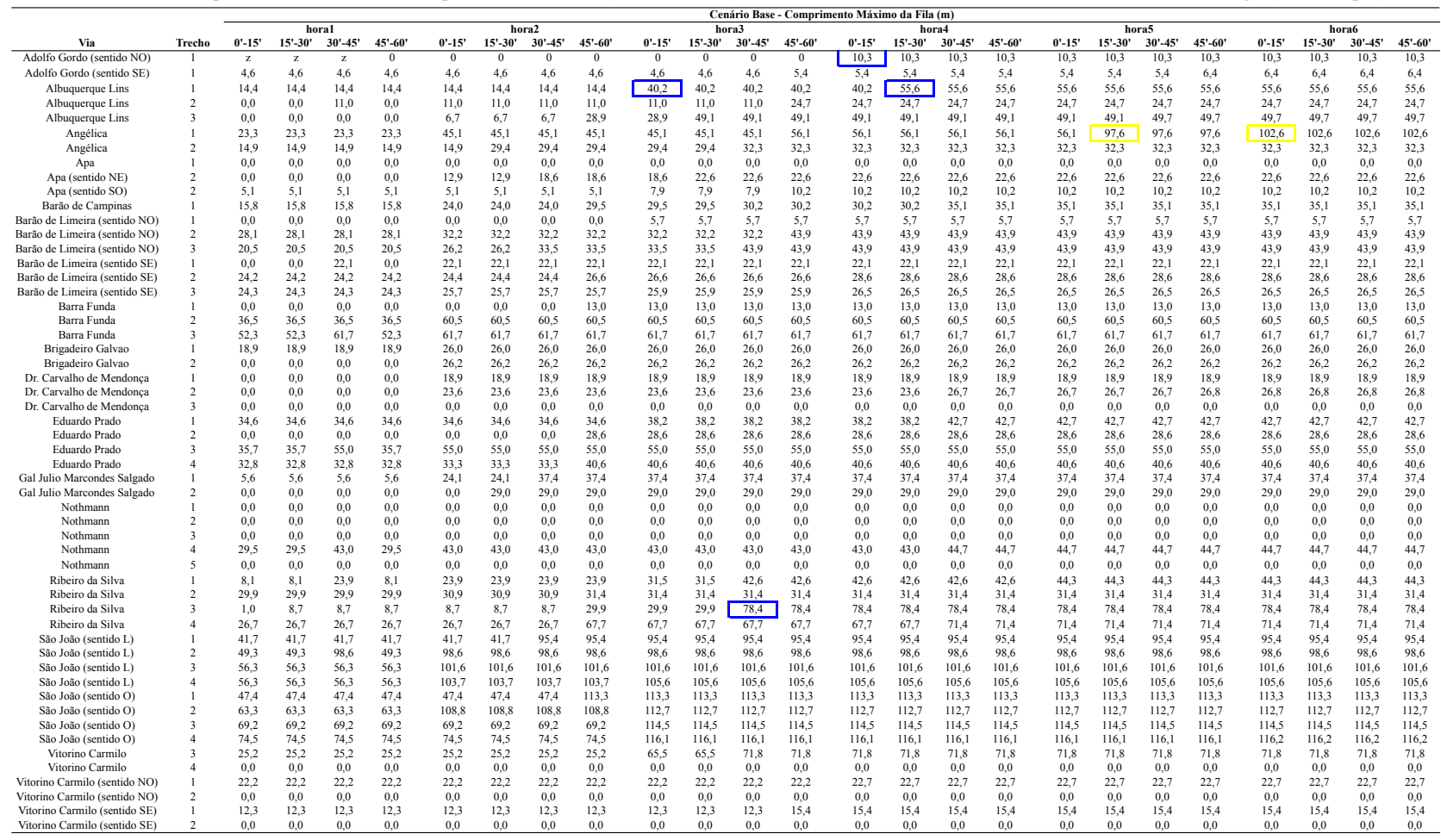


Tabela 8.8 - Comprimentos máximos de fila para o cenário alternativo 1 (consolidação de cargas em veículos maiores) e situações onde ocorre a interferência de um veículo de

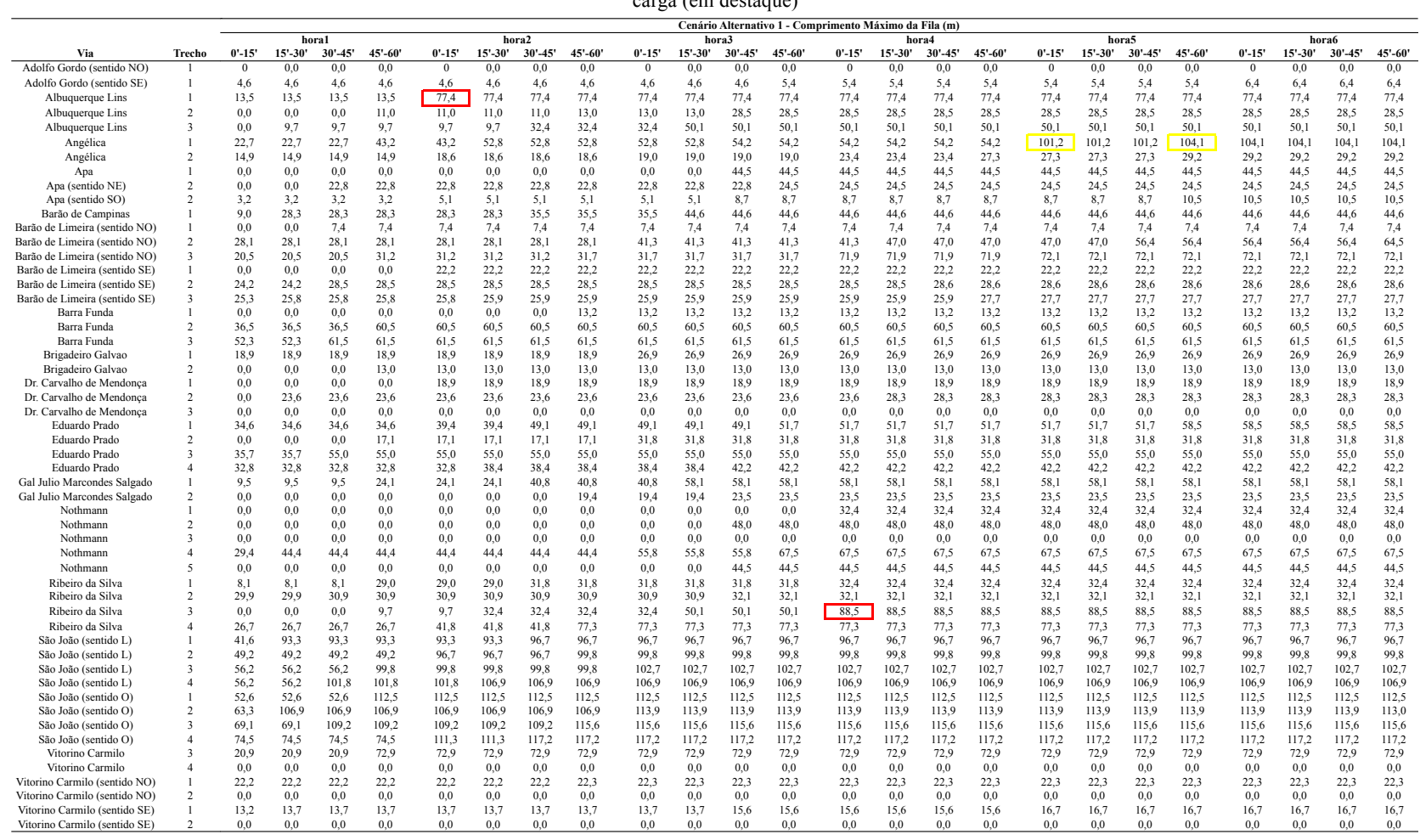


Tabela 8.9 - Comprimentos máximos de fila para o cenário alternativo 2 (vagas exclusivas para carga e descarga) e situações onde ocorre a interferência de um veículo de carga

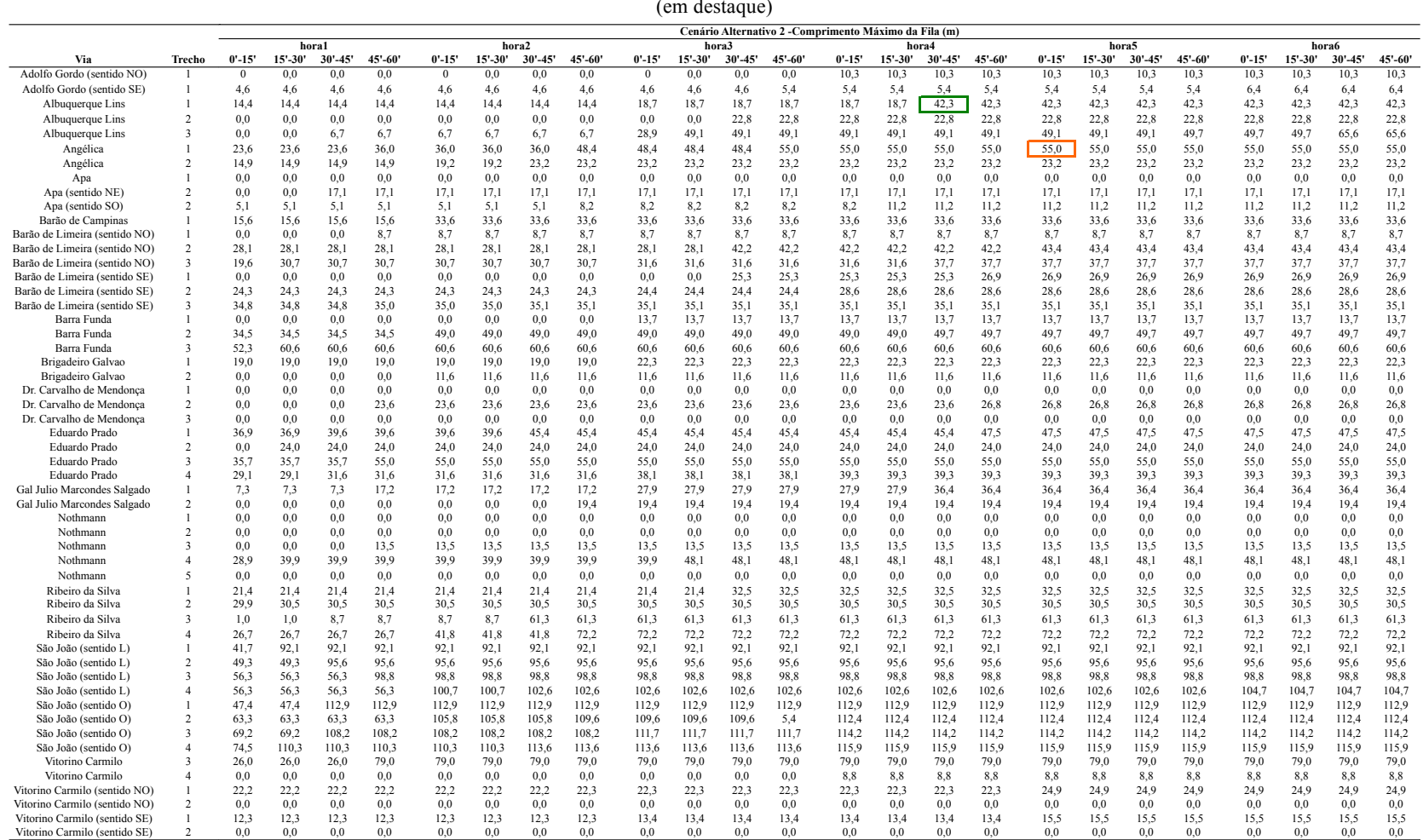


Os valores destacados em azul na Tabela 8.7 mostram, para o cenário base, as filas decorrentes da interferência causada pelos veículos em manobra de estacionamento. É possível observar que, na Rua Albuquerque Lins, o comprimento máximo da fila foi superado em dois momentos. $\mathrm{O}$ primeiro deles corresponde à manobra de estacionamento de um veículo de entrega do tipo Van na área de carga e descarga ali existente, a qual bloqueou o fluxo de veículos na via. O segundo também corresponde à manobra de estacionamento de um veículos de entrega nessa área, porém com duração maior, por se tratar de um do veículo tipo VUC grande. Nesse caso, a fila formada atingiu um comprimento maior do que a primeira, estendendo-se, inclusive até a Avenida São João, conforme ilustra a Figura 8.8.

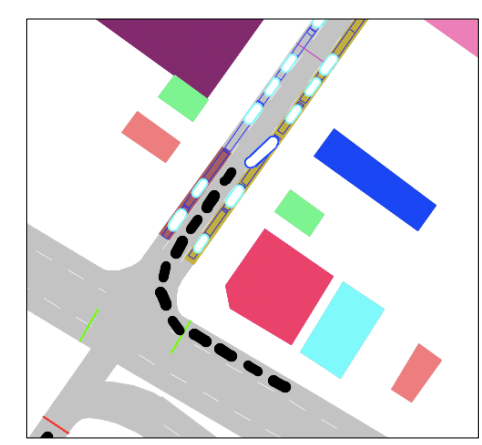

Figura 8.8 - Exemplo de formação de fila devido à manobra de estacionamento de um veículo de carga

Ao se observar o valore para este mesmo segmento de via na Tabela 8.9, destacado em verde, é possível perceber uma redução no comprimento máximo da fila. Isso se deu devido à menor necessidade de manobra dos veículos de entrega, uma vez que, no cenário alternativo 2, a utilização das áreas de carga e descarga está restrita somente aos veículos de carga e maiores espaços de estacionamento são disponibilizados.

A partir dos valores destacados em amarelo nas Tabelas 8.7 e 8.8 e em laranja na Tabela 8.9 é possível observar a redução no comprimento de fila que ocorre na Avenida Angélica (segmento 1) para o cenário alternativo 2, quando uma das faixas de tráfego é liberada devido ao reposicionamento da área de carga e descarga.

Finalmente, a Tabela 8.8 apresenta, em vermelho, os valores para os comprimentos máximos de fila da Rua Albuquerque Lins e Alameda Ribeiro da Silva. Ao comparar esses valores com os do cenário base é possível observar que: (i) os valores para o cenário alternativo 1 são maiores para ambas as vias e (ii) para a Rua Albuquerque Lins não há um crescimento da fila ao longo do tempo, como ocorre no cenário base. As justificativas para essas 
alterações estão no fato de que, em primeiro lugar, no cenário alternativo 1 as entregas são feitas com veículos maiores, do tipo Toco, os quais exigem um tempo maior de manobra de estacionamento, gerando uma fila maior. Esta fila, por sua vez, não é superada durante o restante de simulação, pois como as entregas em estabelecimentos próximos são todas realizadas por um único veículo, não ocorreu o estacionamento de outro veículo do tipo Toco na Rua Albuquerque Lins, e por isso não houve alteração no comprimento máximo da fila, como observado no cenário base.

É interessante observar que a ocorrência de filas se deu nas situações onde a manobra de estacionamento do veículo de carga ocorreu em vias de uma única faixa, ou seja, onde não é possível aos veículos realizarem ultrapassagem. Ainda, considerando o estacionamento dos veículos de carga na faixa de estacionamento, houve a formação de filas apenas na Avenida Angélica, onde, para os cenários base e alternativo 1, há uma área de carga e descarga. Nas outras situações de estacionamento na faixa de tráfego, houve apenas redução na velocidade, como mostrado anteriormente.

\subsubsection{Impactos na Operação dos Veículos de Carga}

Uma vez que os resultados da microssimulação permitem obter dados individuais dos veículos é possível analisar detalhadamente o desempenho dos veículos de carga em suas operações de entrega. Analisar os resultados da microssimulação sob essa perspectiva permite estimar reduções de custos nas operações da distribuição urbana e amplia o benefício do uso dessa ferramenta, uma vez que a torna de interesse também do setor privado.

Para isso foram considerados os seguintes parâmetros:

- Total de clientes atendidos versus total de clientes programados no período;

- Tempo total gasto pelo veículo, realizando entregas;

- Distância total percorrida (somatório da distância percorrida por todos os veículos);

- Tempo total procurando uma vaga pra estacionar (somatório do tempo gasto por todos os veículos);

- Número de ocorrências de estacionamento irregular. 
A distância total percorrida pelos veículos assim como os tempos totais na rede simulação foram obtidos através de arquivos que registram esse tipo de informação para cada um dos veículos da rede, conforme ilustra a Figura 8.9.

\begin{tabular}{|c|c|c|c|c|}
\hline VEHICLE: NO; & VENTYPE, & DESTZZONE; & DISTTRAVTOTAL; & TMINNETTOT. \\
\hline 30001; & 901; & 11; & 810.87 & 18000.00 \\
\hline $30002 ;$ & $902 ;$ & $-;$ & 4032.80 & 14992.00 \\
\hline 30003; & 903; & $-;$ & 1341.79; & 16118.00 \\
\hline $30004 ;$ & $904 ;$ & 11; & 2296.74 ; & 17700.00 \\
\hline 30005; & 905; & $-;$ & 3497.95 ; & 17033.00 \\
\hline 30006; & 906; & 11; & 2216.66 & 17500.00 \\
\hline 30007; & 907; & $-;$ & 4149.52; & 15371.00 \\
\hline
\end{tabular}

Figura 8.9 - Exemplo dos dados de saída fornecidos pelo VISSIM para os tempos de viagem e distâncias percorridas pelos veículos durante a simulação

Neles estão contidas as seguintes informações:

- VEHICLE:NO: identificação do veículo;

- VEHTYPE: tipo do veículo;

- DESTZONE: próxima zona de destino de veículo;

- DISTTRAVTOTAL: distância total percorrida pelo veículo;

- TMINNETTOT: tempo total gasto pelo veículo da rede.

Para obtenção do tempo gasto pelos veículos à procura de uma vaga de estacionamento foram utilizados pontos de coleta que registram o momento da simulação em que cada veículo passa por ele (objetos do tipo 'vehicle travel times'). Para cada um dos veículos de carga os pontos de coleta foram inseridos, ao longo da rede, em dois pontos: o primeiro na zona de destino do veículo, ou seja, na vaga de estacionamento para a este segue; o segundo na vaga de estacionamento onde, de fato, o veículo foi estacionado. Dessa forma, a diferença entre o momento que o veículo passa por sua zona de destino original até o momento no qual estaciona caracteriza o tempo gasto na busca por uma vaga. Para os caso nos quais o veículo opta por adiar a entrega após não obter sucesso na busca por uma vaga, foi necessário obter esse tempo através do acompanhamento da rota do veículo, durante a simulação.

A Tabela 8.10 apresenta os resultados consolidados de todos os veículos de entrega em cada um dos cenários considerados: 
Tabela 8.10 - Resultados para o desempenho dos veículos de carga durante as rotas de entrega

\begin{tabular}{lccc}
\hline & $\begin{array}{c}\text { Cenário } \\
\text { base }\end{array}$ & $\begin{array}{c}\text { Cenário } \\
\text { alternativo 1 }\end{array}$ & $\begin{array}{c}\text { Cenário } \\
\text { alternativo 2 }\end{array}$ \\
\hline Total de Veículos & 46 & 76 \\
\hline Total de Entregas Programadas & 148 & 148 \\
\hline Total de Entregas Realizadas & 135 & 145 & 143 \\
\hline $\begin{array}{l}\text { Distância Total Percorrida (km) } \\
\text { Tempo Total na Rede de Simulação } \\
\text { (hh:mm:ss) }\end{array}$ & 102,7 & 18,3 & 96,5 \\
\hline $\begin{array}{l}\text { Tempo Total Procurando Vaga } \\
\text { (hh:mm:ss) }\end{array}$ & $37: 13: 17$ & $32: 25: 14$ & $35: 26: 44$ \\
\hline \begin{tabular}{l} 
Ocorrências de Estacionamento Irregular \\
\hline
\end{tabular} & 11 & $01: 50: 40$ & $00: 42: 26$ \\
\hline
\end{tabular}

Os resultados obtidos para o cenários alternativo 1 indicam melhor desempenho das operações de entrega em todos os parâmetros considerados: total de veículos, tempo total na rede, tempo gasto procurando vaga de estacionamento e ocorrências de estacionamento irregular. Fica claro o impacto positivo no desempenho das entregas causado pela redução de tempo gasto na procura por estacionamento. A utilização de veículos maiores (cenário alternativo 1) gerou uma quantidade significativamente menor de veículos na área de entrega, o que reduziu o número de ocorrências de estacionamento irregular e, principalmente, a distância total percorridas por esses veículos, o que resulta em redução no consumo de combustível e tem impacto direto na emissão de poluentes. O número de entregas efetivadas também aumentou, devido, principalmente, à redução do tempo de procura por um local pra estacionar. O impacto na redução de custos também é evidente, consequência da diminuição da frota (o que gera, automaticamente, redução da mão de obra necessária) e do consumo de combustível, indicando que a consolidação de cargas em veículos maiores pode ser vantajosa também para as empresas que realizam as entregas na área urbana.

O aumento na disponibilidade das vagas de carga e descarga trazido pelo cenário 2 teve impacto, principalmente, ocorrência de estacionamento irregular, pois, mesmo com o número de veículos igual ao do cenário base, o número de ocorrências caiu significativamente, de onze para duas. À exceção do número de veículos, todos os outros 
parâmetros considerados também apresentaram melhores resultados, embora menos significativos do que para o cenário alternativo 1 .

\subsubsection{Impactos nas emissões de $\mathrm{CO}_{2}$}

As emissões de $\mathrm{CO}_{2}$ resultantes dos movimentos dos veículos durante a simulação foram calculadas através do modelo EnViver. O EnViver é um modelo agregado do VERSIT + micro, da empresa TNO Automotive, desenvolvido especialmente para o cálculo de emissões de poluentes baseado nos dados de microssimulação de tráfego resultantes do VISSIM.

O modelo utilizado, o EnViver Enterprise, é capaz de importar os dados dos fluxos de veículos simulados no VISSIM e calcular as emissões de $\mathrm{CO}_{2}$ baseado no perfil velocidadetempo desses veículos. O arquivo de saída do VISSIM que contém esses dados é chamado 'Vehicle Record', com extensão .fzp, e traz informações a respeito da posição dos veículos (em coordenadas) na rede de simulação ao longo do tempo.

O EnViver permite ainda que o usuário crie suas próprias classes de veículos para compor a frota utilizada no cálculo das emissões. Para isso é necessário fornecer ao modelo alguns parâmetros que englobam:

- Distribuição do tipo combustível utilizado;

- Taxa de emissão de $\mathrm{CO}_{2}$ dos veículos;

- Distribuição da idade da frota;

- Ano de implementação das normas Euro I a Euro V.

Além disso, cada classe de veículo criada deve estar associada ao tipo de via (urbana ou rodovia) e a uma das categorias adotadas pelo EnViver, sendo elas:

- Veículos leves ('light duty'): inclui automóveis e veículos de carga até $3.500 \mathrm{~kg}$;

- Veículos pesados médios ('heavy duty medium ): veículos com mais de $3.500 \mathrm{~kg}$;

- Veículos pesados ('heavy duty heavy'): veículos com mais de $20.000 \mathrm{~kg}$ e três ou mais eixos. 
Os valores adotados para os parâmetros 'tipo de combustível' e 'taxa de emissão de $\mathrm{CO}_{2}{ }^{\prime}$ estão apresentados na Tabela 8.11 e foram obtidos para cada um dos tipos de veículos utilizados como referência na modelagem dos fluxos de veículos no VISSIM. O tipo de combustível é aquele informado pelo fabricante, sendo que para veículos do tipo bicombustível foi considerado o uso apenas de gasolina, pois o EnViver não disponibiliza nenhum modelo que considere o etanol nos cálculos de emissão. As taxas de emissão de $\mathrm{CO}_{2}$ para os veículos de passeio e utilitários foram extraídos do PBE veicular 2014, realizado pelo Inmetro (PBE, 2014). Para os demais veículos a taxa de emissão foi calculada a partir dos fatores de emissão e dos dados de consumo de combustível, fornecidos pelo Programa Brasileiro GHG Protocol 2014 (GHG PROTOCOL, 2014).

\begin{tabular}{|c|c|c|c|c|c|}
\hline \multicolumn{2}{|c|}{ Tipo de Veículo } & Combustível & $\begin{array}{c}\text { Consumo de } \\
\text { Combustível }(C) \\
{[1 / \mathbf{k m}]}\end{array}$ & $\begin{array}{c}\text { Fator de } \\
\text { Emissão }(F) \\
{[g / l]}\end{array}$ & $\begin{array}{c}\text { Taxa de } \\
\text { emissão de } \\
\mathrm{CO}_{2}\left(F^{*} C\right) \\
{[\mathrm{g} / \mathbf{k m}]} \\
\end{array}$ \\
\hline \multirow{3}{*}{ 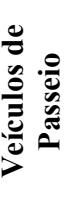 } & Compacto & gasolina & - & - & 96 \\
\hline & Sedan & gasolina & - & - & 129 \\
\hline & SUV & gasolina & - & - & 216 \\
\hline \multirow{6}{*}{ 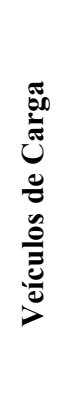 } & Utilitário & gasolina & - & - & 116 \\
\hline & Kombi & gasolina & 0,096 & 2.269 & 217 \\
\hline & Van & diesel & 0,1 & 2.670 & 267 \\
\hline & VUC pequeno & diesel & 0,125 & 2.671 & 333 \\
\hline & VUC grande & diesel & 0,131 & 2.671 & 349 \\
\hline & Toco & diesel & 0,180 & 2.671 & 480 \\
\hline
\end{tabular}

A idade média adotada para a frota dos veículos de passeio foi de 13,5 anos, calculada com base nos dados fornecidos pelo Denatran (Departamento Nacional de Trânsito), para os veículos registrados no município de São Paulo entre 1960 e 2014. Para os veículos de carga utilizou-se a idade média de 12,3 anos, divulgada pela ANTT (Agência Nacional de Transportes Terrestres) para o ano de 2014, a qual considerou dados fornecidos por transportadores autônomos, empresas e cooperativas.

Por fim, é necessário fornecer ao modelo o ano de implementação das normas Euro para regulamentação de emissão de poluentes, desde a Euro I até a Euro V. No Brasil, os anos de 
implementação dessas normas são: 1999 (Euro I), 2000 (Euro II), 2005 (Euro III), 2009 (Euro IV) e 2012 (Euro V).

As emissões de $\mathrm{CO}_{2}$ resultantes para o período de seis horas de simulação, para cada um dos cenários considerados, estão apresentadas na Tabela 8.12.

\begin{tabular}{|c|c|c|c|}
\hline \multirow[b]{2}{*}{ Origem da Emissão } & \multicolumn{3}{|c|}{ Emissão de $\mathrm{CO}_{2}(\mathrm{~g})$} \\
\hline & Cenário base & $\begin{array}{c}\text { Cenário } \\
\text { alternativo } 1 \\
\end{array}$ & $\begin{array}{c}\text { Cenário } \\
\text { alternativo } 2\end{array}$ \\
\hline Veículos do tráfego em geral & $3.064 .226,4$ & $3.035 .007,43$ & $3.057 .863,73$ \\
\hline $\begin{array}{l}\text { Veículos de carga que realizam } \\
\text { entregas na área de simulação }\end{array}$ & $29.532,4$ & $8.805,45$ & $27.631,76$ \\
\hline Total & $3.093 .758,80$ & $3.043 .812,88$ & $3.085 .495,49$ \\
\hline
\end{tabular}

É possível observar, a partir dos resultados, que o menor número de veículos necessários para realizar as entregas no cenário alternativo 1 tem um impacto expressivo nas emissões de $\mathrm{CO}_{2}$ provenientes dos veículos de carga. Mesmo os veículos do tipo Toco sendo mais poluente do que os demais, a redução chegou a 70\% em comparação ao cenário base. Isso porque, além do número menor de veículos, admitiu-se que os mesmo atendiam a mais de um estabelecimento a partir do mesmo local de estacionamento, o que reduziu ainda mais a distância total percorrida por eles e, consequentemente, a emissão do $\mathrm{CO}_{2}$. Considerando as emissões provenientes de todos os veículos a redução, para o cenário alternativo $1 \mathrm{em}$ comparação ao cenário base, foi de $2 \%$. A comparação entre os cenários alternativo 2 e base, também mostra um redução nas emissões, embora menos expressiva, de 7\%. Nesse caso, a redução considerando as emissões de todos os veículos foi de apenas $0,3 \%$. 


\section{CONCLUSÕES E RECOMENDAÇÕES}

A importância de considerar os impactos locais no processo de avaliação de medidas voltadas à distribuição urbana de cargas torna necessária a representação detalhada das atividades que compõem essa operação, assim como do ambiente urbano onde elas acontecem. A microssimulação torna-se então um técnica promissora, devido à sua capacidade de proporcionar um alto nível de detalhe à representação do sistema viário e à modelagem e observação do comportamento dos veículos. Outro diferencial é a possibilidade de representação dos fluxos de tráfego em ambientes virtuais bi ou tridimensionais permite a visualização do sistema e dos movimentos dos veículos, garantindo melhor compreensão dos resultados da microssimulação, inclusive por não especialistas.

Sendo assim, este trabalho propôs um procedimento para o uso da microssimulação de tráfego como ferramenta para a avaliação de medidas voltadas à distribuição urbana de cargas. O procedimento engloba um conjunto de coleta de dados e o desenvolvimento de três modelos que fornecem os parâmetros necessários à representação dos movimentos dos veículos de carga em um ambiente de microssimulação, de forma que possam ser estimados os possíveis impactos locais decorrentes da interação desses veículos com os outros veículos que compõem o tráfego em geral e com a infraestrutura disponível na área urbana onde acontece a distribuição.

A coleta de dados foi realizada em uma área de estudo de cerca de $1,0 \mathrm{~km}^{2}$, localizada na cidade de São Paulo. Foram realizadas observações de entregas, pesquisa em estabelecimentos comercias e entrevistas com motoristas. As informações obtidas para essa área serviram de base para o desenvolvimento de três modelos para a microssimulação e também serviram como dados de entrada para os mesmos. Os modelos desenvolvidos, 'Geração das Entregas', 'Geração dos Veículos de Entrega' e 'Preferências de Estacionamento' determinaram os dados necessários à representação dos movimentos dos veículos de carga no software de microssimulação VISSIM, para uma área de simulação de aproximadamente $0,3 \mathrm{~km}^{2}$, inserida dentro da área de estudo.

Foram realizados experimentos computacionais para três cenários, um cenário base, representando a situação atual da distribuição urbana e dois cenários alternativos: (i) cenário 
alternativo 1, no qual as entregas foram consolidadas em veículos maiores, e (ii) cenário alternativo 2, no qual se aumentou a oferta de vagas de carga e descarga. O principal objetivo dos experimentos foi analisar a capacidade da microssimulação como ferramenta para avaliar medidas à voltadas à distribuição urbana de cargas, considerando os resultados por ela fornecidos, em termos das estimativas dos impactos locais causados pelos veículos de carga.

Os resultados desagregados fornecidos pela microssimulação permitiram identificar quais das alterações nas velocidades e nas formações de filas que ocorreram durante a simulação foram, de fato, causadas pela interferência dos veículos de carga. Além disso, por permitir a análise individual dos veículos, foi possível avaliar o desempenho das operações dos veículos de carga para os três cenários, considerando fatores diretamente ligados à possibilidade de redução dos custos dessas operações, como o tempo gasto na procura por um vaga de estacionamento e a distância total percorrida pelos veículos, o que evidencia que o uso da microssimulação pode ser interessante também ao setor privado. Por fim, as emissões de $\mathrm{CO}_{2}$, tanto do tráfego em geral, quanto dos veículos de carga, também foram estimadas.

\subsection{SOBRE O PROCEDIMENTO PROPOSTO}

A desagregação na modelagem e na observação dos movimentos dos veículos, possibilitada pela microssimulação, torna necessária a coleta de quase todos os dados da rede simulada. Neste trabalho, a impossibilidade de acesso a séries de dados históricos dos fluxos de veículos ou a dados de projeto das vias tornou a obtenção desses dados mais demorada. Foram necessárias diversas horas dedicadas à contagem de veículos, ao levantamento da localização dos semáforos e áreas de estacionamento, e ao registro dos tempos semafóricos. No total, foram necessários cerca de dois meses para a coleta dos dados referentes à modelagem do sistema viário e do fluxo de veículos em geral.

No que diz respeito aos dados relativos à modelagem específica dos movimentos dos veículos de carga, o processo de obtenção de dados exigiu ainda mais tempo e esforço. Isso porque, neste caso, além de indisponíveis, a maioria das informações necessárias à caraterização da área de estudo sob uma perspectiva logística são inexistentes, como, por 
exemplo, o número de entregas recebidas em cada um dos estabelecimentos. Todas as coletas foram realizadas pessoalmente e, no total, a obtenção e organização dos dados coletados para a modelagem dos movimentos dos veículos de carga durou cerca de quatro meses para uma área de apenas $1,0 \mathrm{~km}^{2}$. Ainda, a limitação de recursos, principalmente de pessoal, levou à impossibilidade de registro de todos os dados durante as observações das entregas, o que resultou em algumas informações imprecisas e incompletas.

Embora tenha exigido um esforço significativo, o procedimento proposto é capaz de contornar o problema da falta de dados necessários à modelagem, uma vez que permitiu a obtenção desses, mesmo diante dessa limitação. Além disso, acredita-se que para tornar coleta de dados proposta ainda mais adequada à sua finalidade, é importante a disponibilização de mais recursos, principalmente de uma equipe estruturada dedicada à coleta de dados. Isso reduziria o tempo gasto nessa atividade e, principalmente, melhoraria a qualidade dos dados, tanto por diminuir a ocorrências de dados faltantes ou incorretos, como pela possibilidade de utilização de uma amostra maior.

Considerando os modelos propostos, 'Geração das Demandas', 'Geração dos Veículos de Entrega' e 'Preferências de Estacionamento', é importante ressaltar que diversas das dificuldades encontradas no desenvolvimento dos mesmos poderiam ser amenizadas uma vez que mais dados estivessem disponíveis para análise, o que esbarra novamente na necessidade de uma amostra maior para a coleta de dados e de uma equipe estruturada para realizar essa coleta. Dentre essas dificuldades pode-se citar as hipóteses consideradas nos modelos de 'Geração das Demandas' e 'Geração dos Veículos de Entrega' a respeito de todas as probabilidades adotadas (por exemplo a distribuição das entregas ao longo da semana, atribuição dos tipos de veículos aos grupos de produtos, etc.) e a utilização de valores médios para os tamanhos e tempos de duração das entregas. Esses valores foram todos calculados com base nas entregas observadas em campo e adotados mesmo quando o número de ocorrências se mostrou reduzido. Outra dificuldade do modelo 'Geração das Demandas' diz respeito à falta de correlação entre o número de entregas recebidas por um estabelecimento e sua classe e/ou número de funcionários, o que levou à necessidade de utilização dos dados reais de número de entregas para a aplicação desse modelo.

Além das limitações relativas ao volume de dados coletados, a necessidade de representar os movimentos dos veículos de carga impôs uma nova dimensão ao problema, ligada ao 
comportamento humano, o que é bastante complexo de ser tratado considerando apenas análises estatísticas, já que envolve um contexto multidisciplinar. Essa dimensão subjetiva está presente tanto no modelo 'Geração dos Veículos de Entrega', na definição das rotas dos veículos, como no modelo 'Preferências de Estacionamento', no qual são determinadas as escolhas dos motoristas em relação às alternativas para os locais de estacionamento dos veículos.

No modelo 'Geração dos Veículos de Entrega', as rotas de entrega dos veículos foram definidas buscando-se respeitar apenas condições objetivas que incluíram a capacidade do veículo, a janela de entrega disponível e a proximidade entre os estabelecimentos. Sabe-se, no entanto, que condições subjetivas envolvendo as preferências dos clientes e dos motoristas são também incorporadas à formação das rotas de entrega. Por exemplo, a preferência de um cliente por receber entregas apenas em determinado horário, ou uma alteração da rota, por parte do motorista, devido a conveniências pessoais, como seu horário e local de almoço.

O modelo 'Preferências de Estacionamento' buscou, através dos dados de entrevistas como os motoristas, estabelecer uma relação quantitativa que incorporasse a subjetividade presente nas preferências dos motoristas em relação à escolha dos locais onde estacionam seus veículos. Com a estrutura de entrevista formulada e o número de motoristas entrevistados, no entanto, não foi possível obter nenhuma relação significativa entre as respostas obtidas e os atributos considerados ('tipo de veículo', 'tipo de produto', 'posição da porta de descarregamento' e 'presença de ajudante'). O modelo adotou então valores de probabilidade baseados nas porcentagens das respostas dos motoristas para cada alternativa de escolha, considerando a amostra total. Acredita-se que, esse seja um campo onde a dimensão subjetiva seja muito expressiva e que, mesmo com uma amostra maior de entrevistados, os resultados ainda estariam sujeitos a fatores difíceis de mensurar. Ainda, as diversas observações realizadas em campo indicam uma certa discrepância em relação às informações fornecidas pelos motoristas durante a entrevista, principalmente em relação ao estacionamento irregular. Com base nas respostas dos motoristas, essa prática, com ocorreria com uma frequência muito menor do que aquela que se pode observar na realidade. Sendo assim, uma alternativa para aprimorar o modelo 'Preferências de Estacionamento' seria o cruzamento de dados obtidos em entrevistas (dados declarados) com dados provenientes de observações em campo (dados revelados). 
Por fim, o desenvolvimento dos modelos que compõem o procedimento proposto baseia-se nos dados de um área específica da cidade de São Paulo, o que não garante sua replicabilidade para outras áreas da cidade com diferentes características, como a densidade de estabelecimentos comerciais e infraestrutura viária disponível.

Recomenda-se então a validação do procedimento proposto em áreas com características diferentes daquelas que da área de estudo desse trabalho, de forma que a aplicação do mesmo possa ser ampliada para o resto da cidade, possibilitando, inclusive, o desenvolvimento de uma metodologia abrangente e sistemática para avaliação de medidas voltadas à distribuição urbana de cargas através do uso da microssimulação de tráfego.

É importante ressaltar que a aplicação do procedimento proposto a outras áreas da cidade estava prevista no plano de trabalho desta pesquisa. A mesma, porém, deixou de ser realizada devido ao prolongamento do tempo dedicado à modelagem no VISSIM, a qual exigiu um significativo esforço operacional, maior do que o previsto.

\subsection{SOBRE A MODELAGEM NO VISSIM}

Os resultados fornecidos pelo VISSIM para os experimentos realizados mostraram que a microssimulação é capaz de quantificar os impactos locais causados pelos veículos de carga em diferentes cenários de simulação.

Através do VISSIM foi possível obter dados desagregados de velocidade e formação de filas em cada um dos segmentos e faixas dos links da rede de simulação. Esses dados puderam ser agrupados em intervalos de 15 minutos, sendo que esse intervalo pode ser tão curto quanto se deseje, para incrementos de 0.2 segundos. Dessa forma, foi possível relacionar as alterações de velocidade e de formação de filas (que ocorreram durante a simulação) com os movimentos dos veículos de carga e, assim, identificar quais dessas alterações foram causadas devido a interferências dos veículos. A interface do software permite ainda que essas interferências sejam visualizadas durante a própria simulação em ambientes bi ou tridimensionais, facilitando a compreensão dos resultados. 
A possibilidade de obter os resultados individualizados dos veículos permitiu, ainda, que fosse analisado o desempenho dos veículos de carga em suas operações de entregas, levando em conta, por exemplo, o número de entregas efetivadas, a distância total percorrida e o tempo desperdiçado devido à necessidade de busca por vagas de estacionamento. Por fim, as emissões de $\mathrm{CO}_{2}$ também puderam ser estimadas, considerando tanto aquelas provenientes somente dos veículos de carga, como aquelas resultantes do tráfego geral.

Embora os resultados do VISSIM tenham se mostrado satisfatórios para a quantificação de impactos locais, a modelagem dos movimentos dos veículos de carga enfrentou diversas dificuldades devido a limitações do software.

A primeira, e maior limitação, e que não está relacionada apenas ao VISSIM, é que não existe um software de microssimulação específico para a distribuição urbana de cargas, ou seja, que seja capaz de representar as diversas atividades que compõem essa operação. Algumas dessas atividades, como o estacionamento de veículos sobre a calçada e a disposição da carga ao lado do veículo, ocupando um pedaço da faixa de tráfego, não puderam ser modeladas e foram desconsideradas no modelo. A ultrapassagem de veículos por vias de sentido oposto também não possível de ser representada. Outras limitações encontradas puderam ser contornadas, mas prejudicaram a fidelidade do modelo em relação à realidade além de aumentarem consideravelmente o esforço necessário para a modelagem. Para muitos casos foi necessário conhecer os percursos realizados pelos veículos, durante a simulação, para que alguns objetos do VISSIM pudessem ser modelados corretamente. Um exemplo é o caso no qual o motorista opta por realocar um determinado estabelecimento na rota de entrega devido à indisponibilidade de estacionamento. Muitas dessas limitações se devem ao fato de o programa não permitir que alguns parâmetros dos objetos possam ser alterados durante a execução da simulação, como consequência do que está ocorrendo. Por exemplo, desativar um uma decisão de rota dinâmica para determinado veículo (que altera a zona de destino do veículo) quando a rota do mesmo já tiver sido alterada por essa decisão. o mesmo já teve sua rota alterada por essa decisão.

A microssimulação de tráfego, portanto, permanece uma técnica promissora para a avaliação de medidas voltadas à distribuição urbana de cargas, mas depende do desenvolvimento de modelos mais flexíveis, capazes de representar as atividades dessa operação de forma mais realista e de reduzirem o esforço necessário à modelagem que existe atualmente. 


\section{REFERÊNCIAS}

ALLEN, J.; ANDERSON, S.; BROWNE, M.; JONES, P. A framework for considering policies to encourage sustainable urban freight traffic and goods/service flows. Report 1: Approach taken to the project. London. University of Westminster, 2000a, 51 p. Disponível em: $<$ http://home.wmin.ac.uk/transport/download /urbandistfinal1.pdf>. Acesso em: 13 dez. 2012.

ALLEN, J.; ANDERSON, S.; BROWNE, M.; JONES, P. A framework for considering policies to encourage sustainable urban freight traffic and goods/service flows. Report 2: Current goods and service operations in urban areas. London. University of Westminster, 2000b, 129 p. Disponível em: $<$ http://home.wmin. ac.uk/transport/download/urbandistfinal2.pdf $>$. Acesso em: 13 dez. 2012.

ALVARENGA, A. C.; NOVAES, A. G. N. Logística aplicada - Suprimento e Distribuição Física. 3. ed. São Paulo: Blücher, 2000, 210 p.

ANTT. Registro Nacional de Transporte Rodoviário de Cargas. RNTRC em números - Idade média dos veículos. Disponível em < http://appweb2.antt.gov.br/rntrc numeros/rntrc_emnumeros.asp $>$. Acesso em 24 mar. 2015.

ARIOTTI, P.; ARAÚJO. D. R. C.; MOSCARELli F. C. e CYBIS, H. B. B. Associação de modelos macroscópicos e microscópicos de tráfego para estudo de circulação. Anais do XVIII Congresso de Pesquisa e Ensino em Transportes, ANPET, Florianópolis, p. 478 - 489, 2004. Disponível em: <http://www.cbtu.gov.br/estudos/ pesquisa/anpet_xviiiCongrpesqens/ac/arq45.pdf>. Acesso em: 9 jan. 2013.

BALLOU, R.H; Gerenciamento da cadeia de suprimentos - logística empresarial. 5 ed. São Paulo: Bookman, 2006, 616 p.

BENJELLOUN, A.; CRAINIC. Trends, challenges and perspectives in city logistics. Buletinul AGIR, n. 4p. 45 - 51, 2009.

BENJELlOUN, A.; CRAINIC, T.G.; BIGRAS, Y. Towards a taxonomy of city logistics projects. Procedia Social and Behavioral Sciences (2), p. 6217 - 6228, 2010.

BOMFIM, C. Fila de caminhões vira área de risco em São Paulo. Jornal da Tarde, 02 mai. 2012. Disponível em: <http://www.estadao.com.br/noticias/cidades,fila-decaminhoes-vira-area-de-risco-em-sao-paulo,867779,0.htm>. Acesso em 07 jan. 2013.

BOMNEGOCIO. 2012. Disponível em: <http://www.bomnegocio.com/santa_catarina/ norte_de_santa_catarina/vw_volkswagen_kombi_11329990.htm > . Acesso em $11 \mathrm{dez}$. 2012.

BRITO F.; SOUZA, J. Expansão urbana nas grandes metrópoles - o significado das migrações intrametropolitanas e da mobilidade pendular na reprodução da pobreza. São Paulo em Perspectiva, v. 19, n. 4, p. 48 - 63,. 2005. 
CARDILLI, J. Roubo de carga cresce $39 \%$ após veto a caminhões na Marginal Tietê. Portal G1 SP, 27 abr. 2012. Disponível em: <http://habisp.inf.br/theke/ documentos/outros/sp2040-acidadequequeremos/>. Acesso em 07 jan. 2013.

CETESB. Qualidade do ar no estado de São Paulo 2011. Companhia Ambiental do Estado de São Paulo. Secretaria do Meio Ambiente, Governo do Estado de São Paulo, 2012, 120 p. Disponível em: <http://www.cetesb.sp.gov.br/ar/qualidade-do-ar/31publicacoes-e-relatorios>. Acesso em 19 jan. 2013.

CET-SP. Após restrição, lentidão cai $24 \%$ na Marginal Tietê e $13 \%$ na cidade no pico da manhã. Notícias, Companhia de Engenharia de Tráfego, 05 mar. 2012. Disponível em: <http://www.cetsp.com.br/noticias/2012/04/05/apos-restricao,-lentidaocai-24-na-marginal-tiete-e-13 na- cidade-no-pico-da-manha.aspx $>$. Acesso em: 23 de novembro de 2012.

CET-SP. Companhia de Engenharia de Tráfego. Disponível em: $<\mathrm{http}: / / \mathrm{www}$. cetsp. com.br>. Acesso em 07 jan. 2013.

CHRISTOPHER, M. O Marketing da Logística. 2002. 4a ed. São Paulo: Futura

COMPARECAR. 2012. Disponível em: <http://comparecar.uol.com.br/Modelo/FiatFiorino>. Acesso em 11 dez. 2012.

CUNHA, C. Avaliação de políticas públicas e programas governamentais: tendências recentes e experiências no Brasil. Trabalho elaborado durante o curso "The Theory and Operation of a Modern National Economy", ministrado na George Washington University, no âmbito do Programa Minerva, 2006, 41 p. Disponível em $<$ http://www.seplag.rs.gov.br/upload/Avaliacao_de_Politicas_Publicas_e_Programas_G overnamentais.pdf>. Acesso em 13 dez. 2012.

DABLANC L. Entre police et servic: l'action publique sur letransport de marchandises en ville - le cas des métropoles de Paris et New York. Champs-surMarne: Ecole nationale des ponts et chaussées, 1997, 450 p.

DABLANC, L. Goods transport in large european cities: difficult to organize, difficult to modernize. Transportation Research Part A, (41), p.280 - 285, 2007.

DABLANC, L.; RAKOTONARIVO, D. The impacts of logistics sprawl: how does the location of parcel transport terminals affect the energy efficiency of goods' movements in Paris and what can we do about it? Procedia Social and Behavioral Sciences (2), pp 6087 - 6096, 2010.

DENATRAN. Quantidade de Veículos por UF Município Ano de Fabricação Modelo (2015). Disponível em: < http://www.denatran.gov.br/frota2015.htm>. Acesso em 24 mar. 2015.

DUTRA, N.G.S. O enfoque de "city logistics" na distribuição urbana de encomendas. Santa Catarina: Universidade Federal de Santa Catarina, 2004, 212 p.

ESTRADA. 2012. Disponível em: <http://www.estrada.com.br/site.aspx/Frota $>$. Acesso em 11 dez. 2012. 
FACHINNI, D. Análise dos gaps de percepção dos atores envolvidos no transporte urbano de cargas em Porto Alegre. Porto Alegre: Universidade Federal do Rio Grande do Sul, 2006, 135 p.

FARIAS, C. R7 Notícias, 2009. Disponível em: <http://noticias.r7.com/saopaulo/fotos/imagens-do-cotidiano-da-favela-de-paraisopolis-4.html $>$. Acesso em 11 dez. 2012.

FIGLIOZZI, M.A. Analysis of the efficiency of urban commercial vehicle tours: data collection, methodology, and policy implications. Transportation Research Part B (41), p. 1014 - 1032, 2007.

FOTOSFACE. 2012. Disponível em: <http://fotosface.com.br/vw-kombi.html>. Acesso em 11 dez. 2012.

FOTOSFORD. 2012. Disponível em: <http:/www.fotosford.com.br/fotos\%20fenatran/ $815 \mathrm{vuc} /$ default.htm>. Acesso em $11 \mathrm{dez} .2012$.

GAZETA MERCANTIL. Restrições ao trânsito de caminhões em São Paulo mobiliza operadoras. 20 jun. 2008. Disponível em: <http://www.setcergs.com.br/site/ imprimir.asp? TroncoID $=612245 \&$ SecaoID $=729093 \&$ SubsecaoID $=0 \&$ Template $=. . /$ artig osnoticias/user_exibir.asp\&ID=919051>. Acesso em 07 jan. 2013.

GEBRESENBET, G.; NORDMARK, I.; TECHANE, B.; LJUNGBERG. Potential for optimised food deliveries in and around Uppsala city, Sweden. Journal of Transport Geography (19), p. 1456 - 1464, 2011.

GFK. Estudo GFK mercado de vizinhança, In: MEZA, Pequeno Varejo Cresce e Aparece Brasil Afora. Revista SuperHiper ABRAS (Associação Brasileira de Supermercados), 38, 4, p.42-71, 2012. Disponível em: <http://abrasnet.com.br/edicoesanteriores/Main.php?MagID=7\&MagNo=87>. Acesso em: 22 nov, 2012.

GHG PROTOCOL. Programa Brasileiro. Ferramenta de Cálculo. 2014. Disponível em: $\quad<$ http://186.202.166.152/ghg/htdocs/index.php?r=site/ferramenta $>$. Acesso em 25 jan. 2015.

GOLDMAN, T.; GORHAM, R. Sustainable urban transport: Four innovative directions. Tecnology in Society (28), p. 261-273, 2006.

HAN, L.D; CHIN, S.M; FRANZES, O.; HWANG H. Estimating the impact of pickup-and-delivery-related illegal parking activities on traffic. Transportation Research Record: Journal of the Transportation Research Board, v. 1906, p. 49-55, 2005 .

HENSHER, D., PUCKETT, S. Freight distribution in urban areas: the role of supply chain alliances in addressing the challenge of traffic congestion for city logistics. Working Paper ITS-WP-04-15. Institute of Transport Studies, University of Sydney, Australia, 2004.

HOLGUÍN-VERAS, J.; LIST, G. F.; MEYBURG, A. H.; OZBAY, K.; PASSWELL, R. E.; TENG H.; YAHALOM, S. An assessment of methodological alternatives for a 
regional freightmodel in the nymtc region. New York Metropolitan Transportation Council, 2001, 82 p.

HOLGUÍN-VERAS, J.; OZBAY, K.; KORNHAUSER, A. L.; UKKUSURI, S.; BROM, M.; IYER, S.; YUSHIMITO, W.; ALLEN, B.; SILAS, M. Overall impacts of off-hour delivery programs in the New York city metropolitan area. Transportation Research Record: Journal of the Transportation Research Board, 2011, p. 68 - 76.

HOLGUÍN-VERAS, J.; OZBAY, K.; KORNHAUSER, A. SHORRIS, A.; UKKUSURI, S. Integrative freight demand management in the New York city metropolitan area. United States Department of Transportation, 2010, $245 \mathrm{p}$. Disponível em <http://www.transp.rpi.edu/ usdotp/DRAFT_FINAL_REPORT.pdf $>$. Acesso em: 27 dez. 2012.

IOANNOU, P.; CHASSIAKOS, A. Modeling and route guidance of trucks in metropolitan areas. Los Angeles: Metrans Transportation Center, University of Southern California - Center for Advanced Transportation Technologies and California State University, 2001, 75 p.

JAYAKRISHNAN, R.; CORTÉS, C. E.; LAVANYA, R. e PAGÉS, L. Simulation of urban transportation networks with multiple vehicle classes and services: classifications, functional requirements and general-purpose modeling schemes, Institute of Transportation Studies, University of California, Irvine, 2002, 20 p. Disponível em: <http://www.ltrc.lsu.edu/TRB_82/TRB2003-001963.pdf $>$. Acesso em: 9 jan. 2013.

KANT, G.; QUAK, H.; PEETERS, R.; WOENSEL, T.v. Urban freight transportation: challenges, failures and successes. (Unpublished Manuscript). Tilburg University, Faculty of Economics and Business Administration and Delft University of Tecnology, Transport and Logistics, 2012, 18 p.

LAIZA, R. O.; SAVOY, D.; GREGÓRIO, L. C. M.; LOSADA, M. C. G.; SILVA, M. R. M. Restrições ao Trânsito de Caminhões em São Paulo. São Paulo: Companhia de Engenharia de Tráfego, 2009. Disponível em: <http://www.prefeitura.sp.gov.br/cidade/ secretarias/upload/chamadas/antp_zmrc_trabalho_final_11_08_11para_o_site_2012_13 38934691.pdf >. Acesso em 23 nov. 2012.

LOPES, F.F.; NEVES, M.F.; CONSOLI, M.A.; CASTRO, L.T. Estratégia de redes de empresas: o associativismo no pequeno varejo alimentar. In: SOBER - XLII Congresso Brasileiro de Economia e Sociologia Rural. Dinâmicas Setoriais e Desenvolvimento Regional. Brasil, 2004.

MA, L. Urban goods (off)loading chain. NECTAR Conference no 6 European Strategies In The Globalising Markets; Transport Innovations, Competitiveness and Sustainability in the Information Age, 16-18 May, Helsinki, Finland, 2001.

MACHADO, A. P. São Paulo quer ordenar distribuição metropolitana. Gazeta Mercantil, 17 set. 2007. Disponível em: <http://www.ilos.com.br/clipping/index.php? option $=$ com_content\&task=view\&id=2799\&Itemid=30>. Acesso em 03 jan. 2013. 
MARCUCCI, E.; GATTA, V.; STATHOPOULOS, A.; VALERI, E. Designing an efficient stated ranking experiment for ex-ante urban freight policy evaluation in a three agent type context: retailers, own-account and carriers. Working Papers of Italian society of Transport Economics. Disponível em: <http://www.sietitalia.org/ pubblicazioni.htm>. Acesso em 24 nov, 2012.

MAIA, F. V. B. Calibração e validação de modelos de meso e microssimulação do tráfego para a avaliação de intervenções tático-operacionais na malha viária urbana. Fortaleza: Universidade Federal do Ceará, 2007, 110 p. (Checar se ainda está no texto)

MAY, A. Traffic Flow Fundamentals. Prentice-Hall, Englewood Cliffs, New Jersey, 1990

MENEGHINI, A. São Paulo turns 450. The Associated Press Images, 2004. Disponível em: $<\mathrm{http}: / /$ www.apimages.com/OneUp.aspx?st=k\&kw=sao\%20paulo\%20sl um $\% 20$ meneghini\&showact $=$ results\&sort $=$ relevance $\&$ intv $=$ None $\&$ sh $=10 \&$ kwstyle $=$ and $\&$ adte $=1359509571$ \&pagez $=20 \&$ cfasstyle $=$ AND\&rids $=$ aadcea3ae1e6da1 1af9f0014c25 89dfb\&dbm=PY2004\&page=1\&xslt=1\&mediatype=Photo $>$. Acesso em $11 \mathrm{dez} .2012$.

MOORE, D.S. The Basic Practice of Statistics. Freeman, New York, 2007.

MOREIRA, D. Frame / Agência O Globo, 2013. Disponível em: <http://cbn.globoradi o.globo.com/sao-paulo/2013/01/24/NA-SAIDA-PARA-O-FERIADO-SP-TEM-145 QU ILOME TROS-DE-CONGESTIONAMENTO.htm>. Acesso em: 27 dez. 2012.

MUÑUZURI, J.; CORTÉS, P.; ONIEVA, L.; GUADIX, J. Modeling freight delivery flows: The missing link of urban transport analysis. Journal of Urban Planning and Development, 135(3), p. 91 - 99, 2009.

MUÑUZURI, J.; DUIN,J.R.H.; ESCUDERO, A. How efficient is city logistics? ecological footprint for urban freight deliveries. Procedia Social and Behavioral Sciences (2), pp 6165 - 6176, 2010.

O ESTADO DE SÃO PAULO. Novas restrições aos caminhões. Opinião, 15 nov. 2011. Disponível em: $<\mathrm{http}: / / \mathrm{www}$.estadao.com.br/noticias/impresso,novas-restricoesaos-caminhoes-, 798747,0.htm>. Acesso em 07 jan. 2013.

OGDEN, K.W. Urban goods movement: a guide to policy and planning. Aldershot: Ashgate, 1992, $417 \mathrm{p}$.

OLIVEIRA, L.K. Modelagem para avaliar a viabilidade da implantação de um sistema de distribuição de pequenas encomendas dentro dos conceitos de city logistics. Santa Catarina: Universidade Federal de Santa Catarina, 2007, 158 p.

PATIER D.; BROWNE, M. A methodology for the evaluation of urban logistics innovations. Procedia Social and Behavioral Sciences (2), p. 6229 - 6241, 2010.

PBE. Programa Brasileiro de Etiquetagem. Tabelas de Consumo/Eficiência Energética - Veículos Automotores Leves. Inmetro. Disponível em: < http://www.inm etro.gov. br/consumidor/pbe/veiculos_leves_2014.pdf>. Acesso em 25 mar. 2015. 
PEREIRA, F. M. A.; PEREIRA, L. A. ARBEX, F. F.; ARBEX, M.; CONCEIÇÃO, G. M.; SANTOS, U. P.; LOPES, A. C.; SALDIVA, P. H.; BRAGA, A. L.; CENDON, S. Effect of air pollution on diabetes and cardiovascular diseases in São Paulo. Brazilian Journal of Medical and Biological Research, 41(6), p. 526-32, 2008.

PIGATTO, G. Avaliação de relacionamento no canal de distribuição de produtos de mercearia básica. São Carlos: Universidade Federal de São Carlos, 2005, 239 p.

PORTAL. Inner urban freight transport and city logistics. Portal (Transport Teaching Material), 2003, 51 p. Disponível em <www.eu-portal.net>. Acesso em: 16/01/2013.

PORTAL NTC\&LOGÍSTICA. Restrição de circulação de caminhões em SP afetará transporte no País. 03 abr. 2008. Disponível em: <http://www.portalntc.org.br/index. php?option $=$ com_content\&view $=$ article $\&$ id $=17325 \% 3$ Arestricao-de-circulacao-decaminhoes-em-sp-afetara-transporte-no-pais-\&Itemid=270>. Acesso em 07 jan. 2013.

PORTAL TRANSPORTA BRASIL. Restrições na marginal Tietê completam um mês. 09 abr. 2012. Disponível em: <http://www.transportabrasil.com.br/2012/04/ restricoes-na-marginal-tiete-completam-um-mes/>. Acesso em 07 jan. 2013.

PORTUGAL, L. S. Simulação de tráfego: conceitos e técnicas de modelagem. Rio de Janeiro: Interciência Ltda, 2005, 198 p.

QUAK, H. J. Sustainability of urban freight transport: retail distribution and local regulations in cities. Rotterdam: Erasmus Universiteit Rotterdam, 2008, 242 p.

QUAK, H. KOSTER, R. The impacts of time access restrictions and vehicle weight restrictions on food retailers and the environment. European Journal of Transport and Infrastructure Research, 6, n. 2 p. 131-150, 2006.

RAKHA, H. A. Integration release $\mathbf{2 . 3 0}$ for Windows: user's guide. V. I. Transportation Systems Research Group, Queen's University. Kingston, 2010, 55 p. Disponível em: $<$ http://www.filebox.vt.edu/users/hrakha/Software/Integration\%20Manu al\%201\%20-\%20Ver2.30.pdf>. Acesso em 10 jan. 2013.

RAMOS, M.P.; SCHABBACH, L.M. O estado da arte da avaliação de políticas públicas: conceituação e exemplos de avaliação no Brasil. Revista Administração Pública, Rio de Janeiro 46(5), p. 1271-294, 2012.

RAMOS, Y. Portal ESP, 2012. Disponível em: <http://www.portalesp.com.br/2012/11/ correios-e-policia-militar-iniciam-distribuicao-das-provas-do-enem-no-piaui/181020121 7-32-25-prf-escolta-caminhoes-dos-correios-com-provas-do-enem-2/>. Acesso em 11 dez. 2012.

REIS, J. UOL, 2012. Disponível em: <http://economia.uol.com.br/album/2012/11/12/ favelas-pacificadas-atrai-gigantes-do-comercio.htm\#fotoNav=4>. Acesso em $11 \mathrm{dez}$. 2012. 
ROCHA, A. Agência O Globo, 2012. Disponível em: $<$ http://extra.globo.com/noticias/ rio/antes-de-ocupacao-pm-faz-operacoes-em-diversas-favelas-da-regiao-metropolitana6371853.html>. Acesso em 11 dez. 2012.

ROOIJEN, T.; QUAK, H. Local impacts of a new urban consolidation centre - the case of Binnenstadservice.nl. Procedia Social and Behavioural Sciences, 2, p. 5967 5979, 2010.

RUESCH, M.; GLÜCKER, C. City inquiry: european survey on transport and delivery of goods in urban areas. BESTUFS additional report. Zoetermeer: BESTUFS, 2001, 21p.

SECRETARIA DA FAZENDA DO ESTADO DE SÃO PAULO. Estabelecimentos cadastrados. Secretaria da Fazenda. Governo do Estado de São Paulo, 2012. Disponível em: <http://www.nfp.fazenda.sp.gov.br/lista_aprovacao.shtm>. Acesso em $15 \mathrm{dez}, 2012$.

SEMPLA; DIPRO. Histórico demográfico do município de São Paulo. Secretaria Municipal de Planejamento e Departamento de Estatística e Produção de Informação, 2003. Disponível em: <http://smdu.prefeitura.sp.gov.br/historico_demografico/1890. php>. Acesso em 04 dez. 2012.

SEMPLA; DIPRO. Território e desigualdades sociais. Olhar São Paulo: Contrastes Urbanos. Secretaria Municipal de Planejamento e Departamento de Estatística e Produção de Informação, 2004. Disponível em: <http://smdu.prefeitura.sp.gov.br/ contrastes_urbanos/>. Acesso em 09 dez. 2012.

SETCESP. A restrição ao caminhão e o abastecimento. Notícias, 08 mar. 2008. Disponível em: <http://www.setcesp.org.br/noticiacompleta.asp?codnoti=17081>. Acesso em 07 jan. 2013.

SILVA, M. R. M. Zona Máxima de Restrição de Circulação - ZMRC: restrição ao trânsito de caminhões em São Paulo. São Paulo: Companhia de Engenharia de Tráfego, 2011, 52 p.

SINAY, M.C.F.; NOVAES, A.G.; CAMPOS, V.B.G.; DEXHEIMER, L. Distribuição de carga urbana: componentes, restrições e tendências. In: Rio de Transportes, 2., v. 1, 2004, Rio de Janeiro. Anais eletrônicos do II Congresso Rio de Transportes. Rio de Janeiro, 2004.

SMDU; DIPRO. Domicílios segundo faixa de renda 2010. Infocidade. Secretaria Municipal de Desenvolvimento Urbano e Departamento de Estatística e Produção de Informação, 2010b. Disponível em: <http://infocidade.prefeitura.sp.gov.br/>. Acesso em 04 dez. 2012.

SMDU; DIPRO. Uso do solo urbano 2010. Infocidade. Secretaria Municipal de Desenvolvimento Urbano e Departamento de Estatística e Produção de Informação, 2010a. Disponível em: <http://infocidade.prefeitura.sp.gov.br/>. Acesso em $04 \mathrm{dez}$. 2012. 
SSP-SP; CAP. Risco de ocorrências criminais. Olhar São Paulo: Violência e Criminalidade. Secretaria de Segurança Pública do Estado de São Paulo e Coordenadoria de Análise e Planejamento, 2005. Disponível em: <http://smdu. prefeitura.sp.gov.br/criminalidade/ >. Acesso em 07 dez. 2012.

STATHOPOULOS, A.; VALERI, A.; MARCUCCI, E. Stakeholder reactions to urban freight policy innovation. Journal of Transport Geography, p. 35 - 45, 2012.

TERRA. Restrições de circulação impulsionam venda de caminhões leves em São Paulo. Transporte e Logística, nov. 2012. Disponível em: <http://transporteelogistica. terra.com.br/noticias/integra/272>. Acesso em 07 jan. 2013.

SÃO PAULO (Cidade). Decreto $n^{\circ} 48.338$, de 10 de maio de 2007. Estabelece normas para o trânsito de caminhões e para operações de carga e descarga em estabelecimentos situados no Município de São Paulo. Disponível em: <http://www3.prefeitura.sp.gov. $\mathrm{br} / \mathrm{cadlem} /$ secretarias/negocios_juridicos/cadlem/integra.asp?alt=11052007D $\% 2048338$ 0000>. Acesso em 13 jan. 2013.

SÃO PAULO (Cidade). Lei $\mathrm{n}^{\circ} 14.430$, de 13 de setembro de 2002. Plano Diretor Estratégico. Disponível em: <http://www.prefeitura.sp.gov.br/cidade/secretarias/sub prefeituras/upload/pinheiros/arquivos/lei_13430.pdf>. Acesso em: 29 nov. 2012.

SECRETARIA ESTADUAL DE TRANSPORTES. PDDT Vivo 2000/2020: 2a versão - Plano Diretor do Desenvolvimento dos Transportes. Governo do Estado de São Paulo, 2003.

SCHWEITZER, L.; TAYLOR, B. D. Just pricing: the distributional effects of congestion pricing and sales taxes. Transportation, Springer, 2008. doi: 10.1007/s11116-008-9165-9.

SMDU. SP 2040: a cidade que queremos. São Paulo: Secretaria Municipal de Desenvolvimento Urbano, 2012, 346 p. Disponível em: <http://habisp.inf.br/theke/do cumentos/outros/sp2040-acidadequequeremos/>. Acesso em 20 jan. 2013.

STM. PITU 2025 - Plano Integrado de Transporte Urbano. Secretaria de Transportes Metropolitanos do Governo do Estado de São Paulo, 2006, 199 p. Disponível em: $<$ http://www.stm.sp.gov.br/index.php/planoseprojetos/sumarioexecutivo /2114-pitu-2025-sumario-executivo $>$. Acesso em em 20 jan. 2013.

TAMAGAWA, D.; TANIGUCHI, E.; YAMADA, T. Evaluating city logistics measures using a multi-agent model. Procedia Social and Behavioral Sciences (2), p. $6002-6012,2010$.

TANIGUCHI, E.; KAKIMOTO,Y. Modelling effects of e-commerce on urban freight transport. In: Taniguchi, E.; Thompson, R.G., Logistics Systems for Sustainable Cities. Proceedings of the 3rd International Conference on City Logistics. Amsterdam: Elsevier, p. 135 - 146, 2004.

TANIGUCHI, E.; THOMPSON, R. G.; YAMADA, T.; DUIN, R. City logistics: network modelling and intelligent transport systems. Oxford: Pergamon, 2001, 252 p. 
TANIGUCHI, E.; THOMPSON, R.G., Logistics systems for sustainable cities. Proceedings of the 3rd International Conference on City Logistics. Amsterdam: Elsevier, 2004, 484 p.

TANIGUCHI, E.; THOMPSON, R.G. Modeling city logistics. Transportation Research Record: Journal of the Transportation Research Board, pp 45 - 51, 2002.

TANIGUCHI, E.; VAN DER HEIJDEN, R. An evaluation methodology for city logistics. Transport Reviews, 20, 1, p. 65-90, 2000.

THOMPSON, R. G. AusLink green paper submission. Melbourne: Freight and Logistics Group, Department of Civil and Environmental Engineering, The University of Melbourne, 2003, 14 p.

TOMTOM. Traffe Index 2015. Disponível em: $<$ http://www.tomtom.com/en_gb/traffic index/\#/>. Acesso em 13 nov. 2014.

TRB. Highway Capacity Manual - HCM 2000. Washington: Transportation Research Board of the National Academy of Sciences, 2000.

TRC. Diagnóstico do Roubo de Cargas. Disponível em: <http://www.guiadotrc.com.br/ grisco/rcargas.asp>. Acesso em 30 jan. 2013.

VASCONCELOS, A. P.; Modelos de atribuição/simulação de tráfego: o impacto na qualidade dos resultados de erros no processo de modelação. Coimbra: Faculdade de Ciências e Tecnologia da Universidade de Coimbra, 2004, 152 p.

VILARINHO, C. A. T. Calibração de modelos microscópicos de simulação de tráfego em redes urbanas. Porto: Faculdade de Engenharia da Universidade do Porto, 2008, 92 p. Disponível em: <http://repositorioaberto.up.pt/bitstream/10216/60070/1/000 129417.pdf >. Acesso em 11 jan. 2013.

WATKINS, C. J. C. H.; DAYAN, P. Q-learning. Machine Learning, 8, p. 279 - 292, 1992.

ZIONI, S.M. Espaços de carga na região metropolitana de São Paulo. São Paulo: Faculdade de Arquitetura e Urbanismo da Universidade de São Paulo, 2009, 293 p. 


\section{ANEXO A}

As tabelas a seguir contêm os dados coletados durante as observações das entregas, etapa da coleta de dados apresentada na seção 6.3.2. Em seguida são exibidos os valores adotados, calculados com base nos dados coletados, para os dados de entrada dos modelos 'Geração das Demandas' e 'Geração dos Veículos de Entrega', apresentados nas seções 6.4.1 e 6.4.2, respectivamente. 
Tabela A.1 - Dados coletados durante as observações das entregas

\begin{tabular}{|c|c|c|c|c|c|c|c|c|c|c|c|}
\hline Data & 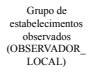 & 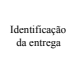 & $\begin{array}{l}\text { Nome do costablckimentu } \\
\text { atendido }\end{array}$ & Classed do stablectimento & Empresa que realiza a currega & Tipo de veciulo & 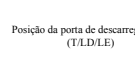 & 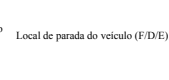 & 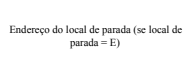 & 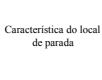 & Gripo de produlus sentrga \\
\hline 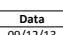 & Grupoobs & Identrega & $\begin{array}{ll}\text { Nomestrab } \\
\text { Bersect }\end{array}$ & 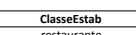 & Empresa & Tripoveic & 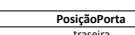 & $\begin{array}{l}\text { Localparada } \\
\end{array}$ & Enderesopparada & CaractParada & Grupoprod \\
\hline $\begin{array}{l}09912 / 13 \\
09 / 12 / 13 \\
0.13\end{array}$ & & $\begin{array}{l}1 \\
2 \\
2\end{array}$ & $\begin{array}{l}\text { Baranosesa } \\
\text { Baronesas }\end{array}$ & 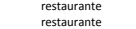 & $\begin{array}{c}\text { Minerva } \\
\text { n.id. }\end{array}$ & $\begin{array}{c}\text { van } \\
\text { van } \\
\text { van }\end{array}$ & $\begin{array}{c}\text { tratsestra } \\
\text { traseriata }\end{array}$ & 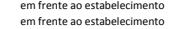 & & $\begin{array}{l}\text { zonn azul } \\
\text { zona azul }\end{array}$ & $\begin{array}{l}\text { Carnes } \\
\text { alimentos congelados }\end{array}$ \\
\hline o9/12/133 & 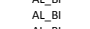 & & 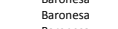 & $\begin{array}{l}\text { Sescaume } \\
\text { restarante }\end{array}$ & 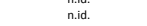 & van & 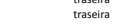 & 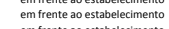 & & (20n azul & FLV \\
\hline $\begin{array}{l}090 / 12 / 13 \\
09 / 12 / 13 \\
0.13\end{array}$ & $\begin{array}{l}\text { ALLBI } \\
\text { AL BI }\end{array}$ & $\begin{array}{l}3 \\
3\end{array}$ & 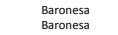 & $\begin{array}{l}\text { restararnte } \\
\text { restaranante }\end{array}$ & $\begin{array}{l}\text { n.id. } \\
\text { n.id. }\end{array}$ & $\begin{array}{l}\substack{\text { van } \\
\text { van }} \\
\text { nat }\end{array}$ & $\begin{array}{l}\text { traseira } \\
\text { traserara }\end{array}$ & 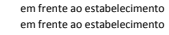 & & 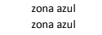 & 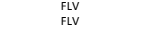 \\
\hline $\begin{array}{l}09912 / 13 \\
09 / 12 / 13\end{array}$ & 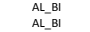 & $\begin{array}{l}3 \\
3\end{array}$ & 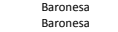 & $\begin{array}{l}\text { restararnte } \\
\text { restaranarte }\end{array}$ & $\begin{array}{c}\text { n.id. } \\
\text { n.id. }\end{array}$ & 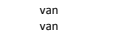 & 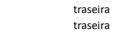 & 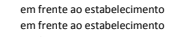 & & 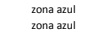 & 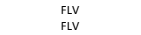 \\
\hline 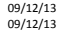 & & & $\begin{array}{l}\text { Baronesa } \\
\text { Baronesa }\end{array}$ & $\begin{array}{l}\text { restararnte } \\
\text { restaranarte }\end{array}$ & $\begin{array}{c}\text { n.id. } \\
\text { n.id. } \\
\text { (n) }\end{array}$ & 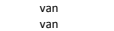 & $\begin{array}{l}\text { trasesira } \\
\text { trasera }\end{array}$ & 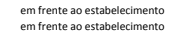 & & 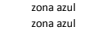 & 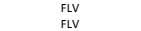 \\
\hline 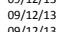 & $\begin{array}{ll}-1 & -1\end{array}$ & & $\begin{array}{c}\text { Sornose } \\
\text { Baronesa } \\
\text { Baronesa }\end{array}$ & $\begin{array}{l}\text { restarinte } \\
\text { restarante }\end{array}$ & Irmäos Avelino & van & 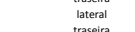 & 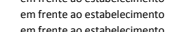 & & 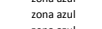 & niri seca en \\
\hline $\begin{array}{l}0991213 \\
09 / 12 / 13\end{array}$ & $\begin{array}{l}\text { ALBBI } \\
\text { ALLBI }\end{array}$ & $\begin{array}{l}5 \\
6 \\
\end{array}$ & $\begin{array}{l}\text { Baroness } \\
\text { Flor do Morpara }\end{array}$ & $\begin{array}{l}\text { resturante } \\
\text { lanchonete }\end{array}$ & $\begin{array}{l}\text { Kaulugna } \\
\text { Amber }\end{array}$ & $\begin{array}{l}\text { van } \\
\text { vuc grande }\end{array}$ & 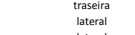 & 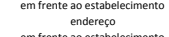 & Baroness de tru, 287 & 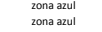 & $\begin{array}{l}\text { outros } \\
\text { bebidas }\end{array}$ \\
\hline $\begin{array}{l}09 / 12 / 13 \\
00 / 121 / 13 \\
0\end{array}$ & $\begin{array}{l}A L B L \\
A L B 1\end{array}$ & ${ }_{8}^{7}$ & $\begin{array}{c}\text { BBoronesa } \\
\text { Buffet franca }\end{array}$ & $\begin{array}{l}\text { restarante } \\
\text { buffet casa de efstas }\end{array}$ & $\begin{array}{l}\text { Gelo Neve } \\
\text { n.id. }\end{array}$ & $\begin{array}{l}\text { vucgrande } \\
\text { van }\end{array}$ & 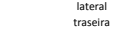 & $\begin{array}{l}\text { em frente a e estabele } \\
\text { dentro do estabelecili }\end{array}$ & & 2007 azul & $\begin{array}{c}\text { gelo } \\
\text { beeidas }\end{array}$ \\
\hline 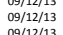 & 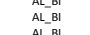 & 8 & 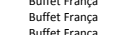 & 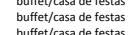 & $\begin{array}{l}\text { nace } \\
\text { vigor }\end{array}$ & $\begin{array}{l}\text { vuc grande } \\
\text { vund }\end{array}$ & 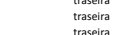 & 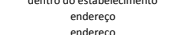 & 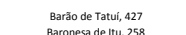 & $\begin{array}{l}\text { zona azul } \\
\text { and }\end{array}$ & 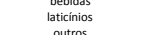 \\
\hline 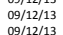 & 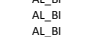 & $\begin{array}{l}11 \\
11 \\
11\end{array}$ & 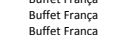 & 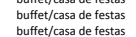 & $\begin{array}{c}\text { naid. } \\
\text { noid. } \\
\text { nat }\end{array}$ & $\begin{array}{c}\text { van } \\
\text { van } \\
\text { van }\end{array}$ & 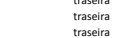 & 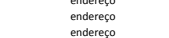 & 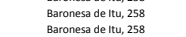 & 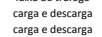 & 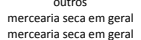 \\
\hline $\begin{array}{l}0912 / 13 \\
00 / 121 / 13\end{array}$ & 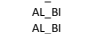 & ${ }_{11}^{11}$ & $\begin{array}{l}\text { Buffet franca } \\
\text { Buffet ranca }\end{array}$ & 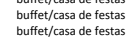 & 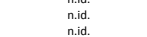 & $\begin{array}{c}\substack{\text { van } \\
\text { van }} \\
\text { and }\end{array}$ & 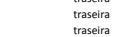 & $\begin{array}{l}\text { endereso } \\
\text { enderece }\end{array}$ & 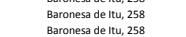 & 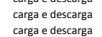 & 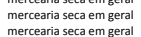 \\
\hline $\begin{array}{l}09 / 12 / 13 \\
00 / 121 / 13\end{array}$ & $\begin{array}{l}\text { ALEB } \\
\text { AL BI }\end{array}$ & ${ }_{12}^{11}$ & $\begin{array}{l}\text { Buffet franca } \\
\text { Buffet rannas }\end{array}$ & 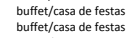 & $\begin{array}{l}\text { n.id } \\
\text { Fatto bene }\end{array}$ & 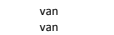 & $\begin{array}{l}\text { trasesiar } \\
\text { traserara }\end{array}$ & 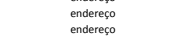 & 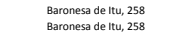 & $\begin{array}{l}\text { carge edescaraga } \\
\text { fatax de tratego }\end{array}$ & $\begin{array}{l}\text { mercerasisece e m geral } \\
\text { sovetes }\end{array}$ \\
\hline $\begin{array}{l}09 / 12 / 13 \\
00 / 121 / 13\end{array}$ & $\begin{array}{l}\text { ALLBI } \\
A L B I\end{array}$ & $\begin{array}{l}12 \\
13\end{array}$ & $\begin{array}{l}\text { Buffet frança } \\
\text { Busffet rannáa }\end{array}$ & $\begin{array}{l}\text { buffet//asa de festas } \\
\text { buftet//asade de estas }\end{array}$ & $\begin{array}{l}\begin{array}{c}\text { Fatto Bene } \\
\text { kentisa }\end{array} \\
\text {. }\end{array}$ & $\begin{array}{c}\text { van } \\
\text { van } \\
\text { and }\end{array}$ & $\begin{array}{l}\text { traserara } \\
\text { lateral }\end{array}$ & $\begin{array}{l}\text { enderece } \\
\text { dentroto dostabelimento }\end{array}$ & Baroness de ltu, 258 & faxix de tráfígo & $\underset{\substack{\text { sorvetes } \\
\mathrm{FIV}}}{\mathrm{F}}$ \\
\hline $\begin{array}{l}09 / 12 / 13 \\
00912 / 13\end{array}$ & 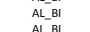 & ${ }_{13}^{13}$ & $\begin{array}{l}\text { Buffet franca } \\
\text { Buffet franca }\end{array}$ & 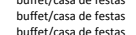 & 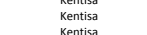 & van & 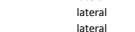 & 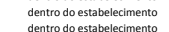 & & & FLV \\
\hline $\begin{array}{l}099121 / 13 \\
09 / 12 / 13\end{array}$ & AL_BI & $\begin{array}{l}13 \\
13\end{array}$ & $\begin{array}{l}\text { 酡etet rança } \\
\text { Buffet frança }\end{array}$ & 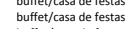 & $\begin{array}{l}\text { Rentisa } \\
\text { Kentisa }\end{array}$ & $\begin{array}{l}\text { van } \\
\text { van }\end{array}$ & 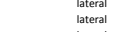 & 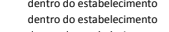 & & & $\begin{array}{l}\text { FlV } \\
\text { FIV }\end{array}$ \\
\hline $\begin{array}{l}09912 / 13 \\
09 / 12 / 13\end{array}$ & $\begin{array}{l}\text { AL_BI } \\
\text { AL } B 1\end{array}$ & $\begin{array}{l}13 \\
13\end{array}$ & $\begin{array}{l}\text { Buffet r Fança } \\
\text { Buffet rancáa }\end{array}$ & 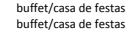 & $\begin{array}{l}\text { Rentisa } \\
\text { Kentisa }\end{array}$ & $\begin{array}{l}\substack{\text { van } \\
\text { van }} \\
\text { and }\end{array}$ & $\begin{array}{l}\text { lateral } \\
\text { aterat } \\
\text { ater }\end{array}$ & 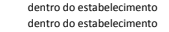 & & & 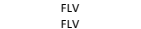 \\
\hline $\begin{array}{l}09 / 12 / 13 \\
0091213\end{array}$ & $\begin{array}{ll}A L-B I \\
A L B I\end{array}$ & ${ }_{13}^{13}$ & $\begin{array}{l}\text { Buffet França } \\
\text { Buffet renanga }\end{array}$ & $\begin{array}{l}\text { buffet/casa de festata } \\
\text { buffetc/casa de festas }\end{array}$ & $\begin{array}{l}\text { Kentisa } \\
\text { Kentisa }\end{array}$ & $\operatorname{van}_{\text {van }}$ & $\begin{array}{l}\text { atateral } \\
\text { laterar } \\
\text { lat }\end{array}$ & 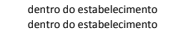 & & & Fiv \\
\hline 09/12/13 & AL-Bi & ${ }_{13}$ & $\begin{array}{l}\text { Surretr fança } \\
\text { Buffet franca }\end{array}$ & 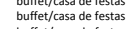 & $\begin{array}{l}\text { Kentisa } \\
\text { Kentisa }\end{array}$ & $\begin{array}{l}\text { van } \\
\text { van } \\
\text { and }\end{array}$ & $\begin{array}{l}\text { ateri } \\
\text { lateral }\end{array}$ & 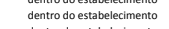 & & & FIV \\
\hline $\begin{array}{l}09 / 12 / 13 \\
00 / 1213\end{array}$ & $\begin{array}{ll}A L & \text { ALBI } \\
A L B I & \text { BI }\end{array}$ & ${ }_{13}^{13}$ & $\begin{array}{l}\text { Buffet França } \\
\text { Busffet Franca }\end{array}$ & $\begin{array}{l}\text { buffet/casa de festas } \\
\text { butfetecasade festata }\end{array}$ & $\begin{array}{l}\text { Kentisa } \\
\text { Kention }\end{array}$ & van & $\begin{array}{l}\text { lateral } \\
\text { gleterat } \\
\mid\end{array}$ & 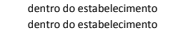 & & & Fiv \\
\hline 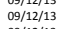 & 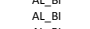 & $\begin{array}{l}13 \\
14\end{array}$ & $\begin{array}{l}\text { Dortet rança } \\
\text { Buffet França }\end{array}$ & 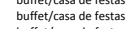 & $\begin{array}{l}\text { Kentus } \\
\text { Fatto Bene }\end{array}$ & $\underset{\substack{\text { van } \\
\text { van }}}{2}$ & 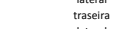 & enderesco & Baronesa de Itu, 258 & faixa de tráfego & $\begin{array}{l}\text { ffV } \\
\text { sovetes } \\
\text { s. }\end{array}$ \\
\hline $\begin{array}{l}09912 / 13 \\
09 / 12 / 13\end{array}$ & $\begin{array}{l}\text { ALBLI } \\
\text { ALLBI }\end{array}$ & $\begin{array}{l}15 \\
15\end{array}$ & $\begin{array}{l}\text { Buffet r rança } \\
\text { Buffet rranca }\end{array}$ & $\begin{array}{l}\text { buffet/casa de festatas } \\
\text { buffet/casa de festas }\end{array}$ & $\begin{array}{l}\text { Gelol Puro } \\
\text { Gelo puro }\end{array}$ & $\begin{array}{l}\text { vuc rande } \\
\text { vuc grande }\end{array}$ & $\begin{array}{l}\text { lateral } \\
\text { atereal }\end{array}$ & 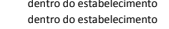 & & & $\begin{array}{c}\substack{\text { gelo } \\
\text { gelo }} \\
\text { fol }\end{array}$ \\
\hline & AL BI & 15 & $\begin{array}{l}\text { Buffet frança } \\
\text { Butft }\end{array}$ & 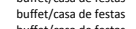 & $\begin{array}{l}\text { Gelo puro } \\
\text { Gello }\end{array}$ & $\begin{array}{l}\text { vogrande } \\
\text { vuc grande }\end{array}$ & lateral & dentro do estabelecicimento & & & $\begin{array}{l}\text { gelo } \\
\text { gelo }\end{array}$ \\
\hline $\begin{array}{l}09912 / 13 \\
09 / 12 / 13\end{array}$ & $\begin{array}{l}A L B I \\
A L L B I\end{array}$ & $\begin{array}{l}15 \\
16\end{array}$ & $\begin{array}{l}\text { Buffete França } \\
\text { Buffet França }\end{array}$ & 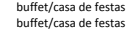 & $\begin{array}{l}\text { Gelo puro } \\
\text { nid. }\end{array}$ & $\begin{array}{l}\text { vUcrande } \\
\text { kombi }\end{array}$ & $\begin{array}{l}\text { lateral } \\
\text { aterat } \\
\text { later }\end{array}$ & 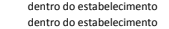 & & & 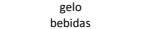 \\
\hline 10/12/13 & AL_B1 & 1 & Buffet França & buffet/casa de festas & n.id. & van & traseira & endereço & Baroness de tru, 258 & carga e descarasa & outros \\
\hline $\begin{array}{l}10 / 12 / 13 \\
101213 \\
1213\end{array}$ & $\begin{array}{l}\text { ALBBI } \\
A \perp-B I\end{array}$ & 2 & $\begin{array}{l}\text { Butfet franca } \\
\text { Buffet franas }\end{array}$ & 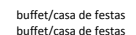 & $\begin{array}{c}\text { n.i.d. } \\
\text { nid } \\
\text { ind }\end{array}$ & $\begin{array}{l}\text { utiltatrio } \\
\text { vuccrade }\end{array}$ & 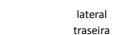 & $\begin{array}{l}\text { endereco } \\
\text { endereco }\end{array}$ & 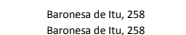 & 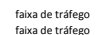 & $\begin{array}{l}\text { outros } \\
\text { outros }\end{array}$ \\
\hline $\begin{array}{l}10 / 12121 / 13 \\
10 / 13\end{array}$ & 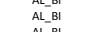 & & $\begin{array}{l}\text { Dortet rança } \\
\text { Buffet França }\end{array}$ & 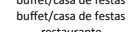 & nid. & vuc grande & traseita & dentrodo do estabebelecimento & & & outros \\
\hline $\begin{array}{l}10 / 12 / 133 \\
10 / 21 / 13\end{array}$ & $\begin{array}{l}\text { ALBBI } \\
\text { ALLBI }\end{array}$ & $\begin{array}{l}5 \\
6 \\
5\end{array}$ & $\begin{array}{l}\text { Baronesa } \\
\text { Buffet França }\end{array}$ & $\begin{array}{l}\text { restaruante } \\
\text { buffet/casa de festas }\end{array}$ & $\begin{array}{l}\text { n.id. } \\
\text { n.id. }\end{array}$ & $\begin{array}{c}\text { van } \\
\text { utilitrio }\end{array}$ & $\begin{array}{l}\text { trasaita } \\
\text { lateral } \\
\text { ater }\end{array}$ & 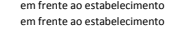 & & $\begin{array}{l}\text { zanna azul } \\
\text { faxa de trúfego }\end{array}$ & $\begin{array}{l}\text { laticicinos } \\
\text { outros }\end{array}$ \\
\hline $\begin{array}{l}10 / 12 / 13 \\
10 / 121 / 13 \\
\end{array}$ & 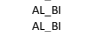 & ${ }_{8}^{7}$ & $\begin{array}{l}\text { Buffet franca } \\
\text { Buffet ranance }\end{array}$ & $\begin{array}{l}\text { buffet/casa de festass } \\
\text { buftet/casa de efestas }\end{array}$ & $\begin{array}{c}\text { n.id } \\
\text { Biodeli } \\
\text { B. }\end{array}$ & $\begin{array}{l}\text { utiltario } \\
\text { vuck crande }\end{array}$ & 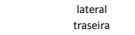 & 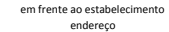 & Baronesa de to 259 & 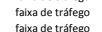 & $\begin{array}{l}\text { outros } \\
\text { outros }\end{array}$ \\
\hline $\begin{array}{l}10 / 12 / 13 \\
10 / 121 / 13 \\
\end{array}$ & $\begin{array}{l}\text { ALEB } \\
\text { ALLBI } \\
A L B I\end{array}$ & 9 & $\begin{array}{c}\text { Baronessa } \\
\text { Baronasa }\end{array}$ & $\begin{array}{l}\text { restaurante } \\
\text { restarate }\end{array}$ & 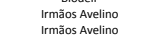 & $\begin{array}{c}\text { van } \\
\text { van } \\
\text { van }\end{array}$ & $\begin{array}{l}\text { lateral } \\
\text { laterat } \\
\text { letat }\end{array}$ & 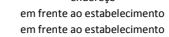 & & $\begin{array}{l}\text { zona arul } \\
\text { zona a aul }\end{array}$ & 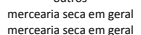 \\
\hline $\begin{array}{l}10 / 12 / 13 \\
10 / 121 / 13 \\
13\end{array}$ & $\begin{array}{c}\text { ALLBI } \\
\text { AL-BI }\end{array}$ & $\stackrel{9}{g}$ & $\begin{array}{c}\text { Baronesa } \\
\text { Branosesa }\end{array}$ & $\begin{array}{l}\text { restaurante } \\
\text { ressuarante }\end{array}$ & 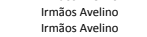 & $\begin{array}{c}\text { van } \\
\text { van } \\
\text { van }\end{array}$ & $\begin{array}{l}\text { lateral } \\
\text { latereal }\end{array}$ & 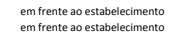 & & $\begin{array}{c}\text { zona azul } \\
\text { zona azul }\end{array}$ & 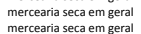 \\
\hline & & & & & & continua & & & & & \\
\hline
\end{tabular}




\begin{tabular}{|c|c|c|c|c|c|c|c|c|c|c|c|c|c|c|c|c|}
\hline \multicolumn{17}{|c|}{ continuação } \\
\hline 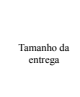 & & 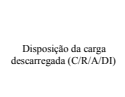 & 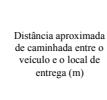 & 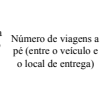 & Equipamento dca axxilio & 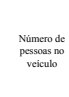 & 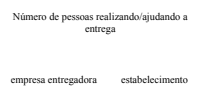 & 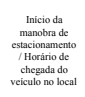 & 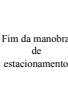 & 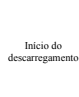 & 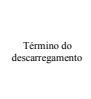 & 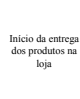 & 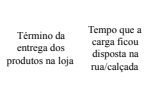 & 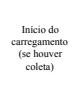 & 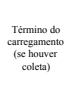 & 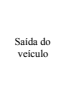 \\
\hline $\begin{array}{l}\text { Tamentrega } \\
4\end{array}$ & $\begin{array}{l}\text { Unidentrega } \\
\text { caixas }\end{array}$ & Disposiç̧̄oDescargaz & $\begin{array}{l}\text { Distancieantrega } \\
\text { 15 }\end{array}$ & Numviagensapé & Equppouxili: & $\frac{N u m p e s s o}{2}$ & $\begin{array}{l}\text { NumAjuddempresa } \\
1\end{array}$ & 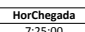 & 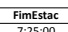 & 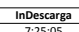 & FimDescarga & 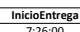 & $\begin{array}{l}\text { Fimentrega Temporua } \\
7.20 .13\end{array}$ & $\begin{array}{l}\text { Incarreg } \\
7.2013\end{array}$ & Fimacareg & 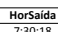 \\
\hline${ }_{2}^{4}$ & 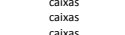 & rua & $\begin{array}{l}15 \\
10\end{array}$ & ${ }_{1}^{2}$ & & ${ }_{1}^{2}$ & 1 & $\begin{array}{l}727.550 \\
8.2500\end{array}$ & $\begin{array}{l}7.725: 00 \\
8: 25: 16\end{array}$ & 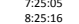 & & & $\begin{array}{l}7: 29913 \\
8: 27: 03\end{array}$ & $\begin{array}{l}77: 9913 \\
8: 27.03 \\
\end{array}$ & $\begin{array}{l}77: 99.38 \\
8: 27710\end{array}$ & $\begin{array}{l}7: 30.18 \\
8: 17 \\
\end{array}$ \\
\hline $\begin{array}{l}3 \\
2\end{array}$ & $\begin{array}{l}\text { caraxs } \\
\text { sacos }\end{array}$ & & $\begin{array}{l}15 \\
15\end{array}$ & $\begin{array}{l}1 \\
1\end{array}$ & & $2^{2}$ & 2 & 8:25:00 & $\begin{array}{l}8: 25: 00 \\
\end{array}$ & 8:25:05 & 8:25:15 & 8:25:15 & $\begin{array}{l}8.2858 \\
8.285\end{array}$ & & & 8:27:10 \\
\hline $2^{3}$ & 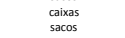 & & $\begin{array}{l}15 \\
15\end{array}$ & & & $\frac{2}{2}$ & 2 & & & $\begin{array}{l}8: 88: 58 \\
8: 3000\end{array}$ & $\begin{array}{l}8: 29: 00 \\
8: 30: 15 \\
\text { 8. }\end{array}$ & $\begin{array}{l}8: 29900 \\
8: 30: 27\end{array}$ & 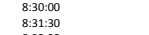 & & & \\
\hline $\begin{array}{c}\text { nid. } \\
1 \\
1\end{array}$ & 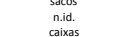 & & 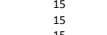 & ${ }_{1}^{1}$ & & $\frac{2}{2}$ & $\frac{2}{2}$ & & & 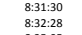 & $\begin{array}{l}8: 31: 199 \\
8 \text { 8:3:44 }\end{array}$ & 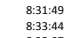 & 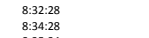 & & & \\
\hline 1 & $\begin{array}{l}\text { calaxis } \\
\text { caxas } \\
\text { caxaxas }\end{array}$ & & 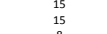 & ${ }_{1}^{1}$ & & $\begin{array}{l}2 \\
2\end{array}$ & $\frac{2}{2}$ & & & $\begin{array}{l}8: 855: 05 \\
8: 35: 34\end{array}$ & 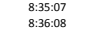 & 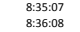 & & & & \\
\hline $\begin{array}{l}1 \\
17\end{array}$ & 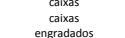 & & $\begin{array}{c}8 \\
5 \\
7\end{array}$ & $\frac{1}{1}$ & carrinho de mão & ${ }_{1}^{2}$ & $\frac{1}{1}$ & $\begin{array}{l}8: 89937 \\
9: 18: 00\end{array}$ & 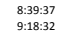 & $\begin{array}{l}8: 40: 16 \\
9: 19: 13\end{array}$ & 8:40:17 & 8:40:17 & 8:41:46 & & & 8:4:1:46 \\
\hline 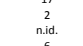 & 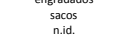 & calçada & $\begin{array}{c}15 \\
5 \\
\text { nid }\end{array}$ & 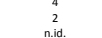 & carrinho de mão & $2^{3}$ & $2^{2}$ & 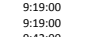 & 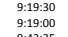 & $\begin{array}{l}9: 91930 \\
9: 25: 15 \\
9\end{array}$ & $\begin{array}{l}9: 23: 00 \\
9.2525 \\
9\end{array}$ & $\begin{array}{l}9: 23: 00 \\
9: 25: 25\end{array}$ & $\begin{array}{l}9: 96: 00 \\
9.3453 \\
9\end{array}$ & 9:36:00 & 9:36:15 & 9:35:09 \\
\hline $\begin{array}{l}6 \\
8 \\
\end{array}$ & $\begin{array}{l}\text { caices } \\
\text { caixas } \\
\text { caixas }\end{array}$ & & 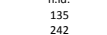 & 2 & 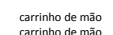 & $\frac{1}{2}$ & ${ }_{1}^{1}$ & $\begin{array}{l}9: 42: 00 \\
9: 40: 00 \\
9\end{array}$ & 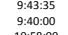 & 9:40:000 & 9:50:00 & 9:50:00 & 10:00:37 & & & $\begin{array}{l}10.57: 00 \\
10: 2025 \\
1\end{array}$ \\
\hline & $\begin{array}{l}\text { caxas, energadados } \\
\text { caxiss engradados }\end{array}$ & $\begin{array}{c}\text { rua } \\
\text { culasada }\end{array}$ & $\begin{array}{l}242 \\
35 \\
35\end{array}$ & 1 & 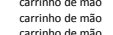 & $\begin{array}{l}1 \\
2 \\
2\end{array}$ & $\frac{1}{2}$ & $\begin{array}{l}10.58: 00 \\
11: 44: 00\end{array}$ & $\begin{array}{l}\begin{array}{l}10.58: 00 \\
11: 46: 47\end{array} \\
-10\end{array}$ & $\begin{array}{l}10.099: 01 \\
11: 49: 30\end{array}$ & 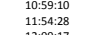 & $\begin{array}{l}10.95: 10 \\
11: 54: 28\end{array}$ & $\begin{array}{l}1010.45 \\
12: 04: 00\end{array}$ & 10:11:02 & & \\
\hline $\begin{array}{c}15,2,2 \\
4\end{array}$ & 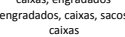 & 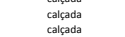 & $\begin{array}{l}{ }_{35}^{35} \\
35 \\
35\end{array}$ & $\begin{array}{l}1 \\
1\end{array}$ & $\begin{array}{l}\text { carrtrono demio } \\
\text { carrinho de majo }\end{array}$ & $\begin{array}{r}2 \\
2\end{array}$ & $\frac{2}{2}$ & & & $\begin{array}{l}120.500 \\
12: 16: 35 \\
1.235\end{array}$ & 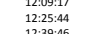 & 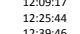 & 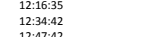 & & & \\
\hline 9 & $\begin{array}{l}\text { caxas } \\
\text { latas } \\
\text { atass }\end{array}$ & 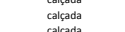 & $\begin{array}{l}35 \\
35 \\
355\end{array}$ & 1 & $\begin{array}{l}\text { carrtrono demio } \\
\text { carrinho de majo }\end{array}$ & $2_{2}^{2}$ & $\frac{2}{2}$ & & & $\begin{array}{l}1234442 \\
12: 47: 42\end{array}$ & $\begin{array}{l}12293.46 \\
12: 50: 11\end{array}$ & $\begin{array}{l}1229346 \\
125353\end{array}$ & $\begin{array}{l}12: 274: 42 \\
12: 59: 18\end{array}$ & 12:59:37 & 12:59:58 & 13:01:46 \\
\hline & 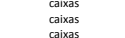 & $\begin{array}{l}\text { cafada } \\
\text { rua } \\
\text { and }\end{array}$ & $\begin{array}{l}35 \\
35\end{array}$ & ${ }_{1}^{1}$ & $\begin{array}{l}\text { carrirho de majo } \\
\text { carrinho de maio }\end{array}$ & $\begin{array}{l}2 \\
2\end{array}$ & $2_{2}^{2}$ & 11:48:11 & 11:48:11 & $\begin{array}{l}1115109 \\
11: 56: 20\end{array}$ & $\begin{array}{l}\text { 11:52:41 } \\
11: 57: 11\end{array}$ & $\begin{array}{l}\text { 11:5:4:41 } \\
11: 57: 11\end{array}$ & $\begin{array}{l}1: 156: 20 \\
12: 10: 00 \\
-1000\end{array}$ & 12:10:30 & 12:10:35 & 12:1:1:00 \\
\hline & 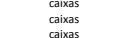 & & & 1 & $\begin{array}{l}\text { carrirhh de majo } \\
\text { carrinho de maio }\end{array}$ & $\frac{2}{2}$ & 2 & 15:08:00 & 15:19:55 & 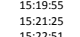 & $\begin{array}{l}1520.38 \\
\text { 15:212725 } \\
\text { s.52 }\end{array}$ & $\begin{array}{l}1520.38 \\
\text { 15:202725 } \\
\text { s.275 }\end{array}$ & 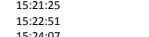 & & & \\
\hline & 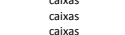 & & & $\begin{array}{l}1 \\
1 \\
1\end{array}$ & 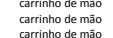 & & $\begin{array}{l}2 \\
2 \\
2\end{array}$ & & & 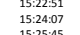 & $\begin{array}{l}152.252 \\
15224.45 \\
15245\end{array}$ & 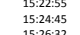 & 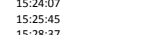 & & & \\
\hline 5 & $\begin{array}{l}\text { caxixs } \\
\text { caxixs } \\
\text { caixas }\end{array}$ & & & 1 & 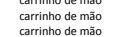 & $\begin{array}{l}2 \\
\frac{2}{2}\end{array}$ & $\begin{array}{l}2 \\
2 \\
2\end{array}$ & & & $\begin{array}{l}\text { is } 1525.45 \\
\text { 15:58.35 }\end{array}$ & 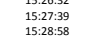 & 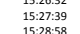 & 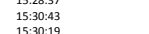 & & & \\
\hline $\begin{array}{l}5 \\
5\end{array}$ & $\begin{array}{c}\text { caxixs } \\
\text { caxaras }\end{array}$ & & & $\begin{array}{l}1 \\
1\end{array}$ & carrinho de mão & $2_{2}^{2}$ & 2 & & & $\begin{array}{l}15: 30: 18 \\
15: 30.19\end{array}$ & $\begin{array}{l}15: 30: 19 \\
15322.22\end{array}$ & 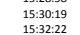 & $\begin{array}{l}153311.18 \\
15: 33320 \\
1\end{array}$ & & & \\
\hline${ }_{8}^{12}$ & $\begin{array}{l}\text { caixas } \\
\text { ciaxass }\end{array}$ & & & $\begin{array}{l}1 \\
1\end{array}$ & 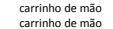 & ${ }_{2}^{2}$ & $\frac{2}{2}$ & & & 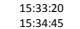 & 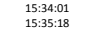 & $\begin{array}{l}15534: 01 \\
1535518\end{array}$ & $\begin{array}{l}15: 34: 45 \\
1.356311\end{array}$ & 15:36:11 & 15:43:07 & 15:4:23:3 \\
\hline${ }_{25}^{2}$ & $\begin{array}{l}\text { caixas } \\
\text { sacos }\end{array}$ & & 35 & 1 & 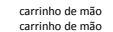 & ${ }_{2}^{2}$ & 2 & 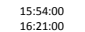 & $\begin{array}{l}155.54: 00 \\
1652424,43\end{array}$ & $\begin{array}{l}15: 54: 30 \\
16524.43\end{array}$ & 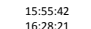 & $\begin{array}{l}15: 55.42 \\
15082.271\end{array}$ & 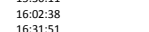 & 16:02:38 & 16:03:34 & $\begin{array}{l}16: 07: 42 \\
102\end{array}$ \\
\hline $\begin{array}{l}25 \\
25 \\
25\end{array}$ & $\begin{array}{l}\text { scoss } \\
\text { scoss }\end{array}$ & & & 1 & 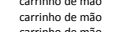 & 2 & 2 & & & 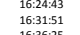 & $\begin{array}{l}16082.21 \\
16: 32.57 \\
1025\end{array}$ & $\begin{array}{l}16.82 .21 \\
16: 325757\end{array}$ & 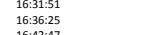 & & & \\
\hline $\begin{array}{l}25 \\
15\end{array}$ & $\begin{array}{l}\text { sacos } \\
\text { sacos }\end{array}$ & & & 1 & $\begin{array}{l}\text { cartrinh de me } \\
\text { carrino de me }\end{array}$ & 2 & 2 & & & $\begin{array}{l}16163: 25 \\
16: 43: 36\end{array}$ & $\begin{array}{l}16638.55 \\
16: 45: 41\end{array}$ & 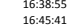 & $\begin{array}{l}106424.45 \\
16: 50: 45\end{array}$ & 16:50:45 & 16:5:1:00 & 16:51:05 \\
\hline $\begin{array}{l}135 \\
\text { nid. } \\
\text { nid. }\end{array}$ & $\begin{array}{c}\text { caixxs } \\
\text { n.id. }\end{array}$ & & 35 & $\begin{array}{l}10 \\
1\end{array}$ & $\begin{array}{l}\text { carrirho de me } \\
\text { carrinot de me, }\end{array}$ & ${ }_{3}^{2}$ & $\begin{array}{l}2 \\
2\end{array}$ & 16:53:00 & 16:53:00 & & & & & 17:06:29 & 17:06:51 & $\begin{array}{l}17: 1: 0: 06 \\
8890.00\end{array}$ \\
\hline ni.d. & nid. & & 35 & 1 & 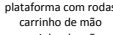 & 3 & 2 & 7.7000 & & 7:50:00 & & & & & & 8:20.000 \\
\hline $\begin{array}{l}\text { nind. } \\
\text { nid. }\end{array}$ & & & $\begin{array}{l}{ }_{35}^{35} \\
35\end{array}$ & $\begin{array}{l}1 \\
1\end{array}$ & 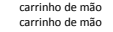 & $\begin{array}{l}2 \\
3\end{array}$ & 5 & 7:10:00 & & 8:10:00 & & & & & & 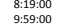 \\
\hline$\stackrel{2}{\text { n.id. }}$ & 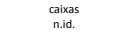 & & $\begin{array}{l}5 \\
5\end{array}$ & ${ }_{7}^{2}$ & 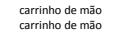 & & $\frac{2}{2}$ & 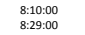 & 8:10:00 & & & & 8:12:00 & & 8:12:00 & $\begin{array}{l}8: 13: 300 \\
88: 5000\end{array}$ \\
\hline $\begin{array}{l}\text { nind. } \\
\text { nid. } \\
\text { nat. }\end{array}$ & 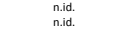 & Calsada & $\begin{array}{l}5 \\
35\end{array}$ & $\begin{array}{l}1 \\
1\end{array}$ & 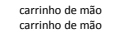 & $\begin{array}{l}2 \\
4\end{array}$ & ${ }_{4}^{2}$ & $\begin{array}{l}8: 522000 \\
90: 05: 00\end{array}$ & & & & & & & & 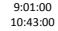 \\
\hline 2 & $\begin{array}{l}\text { calixs } \\
\text { caixas }\end{array}$ & $\begin{array}{l}\text { rua } \\
\text { rua } \\
\text { res }\end{array}$ & ${ }_{5}^{5}$ & $\begin{array}{l}1 \\
1\end{array}$ & 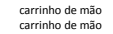 & 2 & 2 & & 9:13:23 & 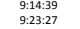 & $\begin{array}{l}9: 22: 09 \\
9: 27: 09\end{array}$ & $\begin{array}{l}9: 22: 09 \\
9: 27: 09\end{array}$ & $\begin{array}{l}9: 23: 27 \\
9: 22: 02 \\
9\end{array}$ & & & \\
\hline $\begin{array}{c}5 \\
10\end{array}$ & 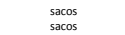 & $\substack{\text { rua } \\
\text { rua }}$ & $\begin{array}{l}5 \\
5\end{array}$ & 1 & 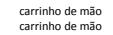 & $\frac{2}{2}$ & 2 & & & $\begin{array}{l}9: 293: 02 \\
9: 3200\end{array}$ & $\begin{array}{l}9: 31: 21 \\
9.34: 12\end{array}$ & $\begin{array}{l}9: 31: 21 \\
9934: 12\end{array}$ & $\begin{array}{l}9: 323: 00 \\
9: 36545\end{array}$ & & & 9:37:53 \\
\hline & & & & & & & & & & & & & & & & \\
\hline
\end{tabular}




\begin{tabular}{|c|c|c|c|c|c|c|c|c|c|c|c|}
\hline Data & $\begin{array}{c}\text { Grupo de } \\
\text { ctableckecinctons } \\
\text { observados } \\
\text { (OBERADOR } \\
\text { LOCAL) }\end{array}$ & $\begin{array}{c}\text { Idennificazaza } \\
\text { da entrega }\end{array}$ & $\begin{array}{l}\text { Nome do stablecceimento } \\
\text { atendido }\end{array}$ & Classe do cstablececimento & Empresa que realiza a entrega & Tipo de veiculo & $\begin{array}{l}\text { Posiçäio da porta ad descarcegamento } \\
\text { (TLLDLE) }\end{array}$ & Local dep paradad do veciculo (FDDF) & $\begin{array}{l}\text { Enderecco do local de parada (se local de } \\
\text { parada }=\mathrm{E} \text { ) }\end{array}$ & $\begin{array}{l}\text { Caracteristica do olocal } \\
\text { de parada }\end{array}$ & Grupo de produtuses entrega \\
\hline Data & Grupoobs & Identrega & Nomesstab & Classetstab & Empresa & TipoVeic & Posiç̧ăoporta & LocalParada & EndereçoParada & CaractParada & Grupoprod \\
\hline $10 / 12 / 13$ & AL_BI & 10 & Buffet França & buffet/casa de festas & Casineira & vuc grande & traseira & endereso & Baronesa de Itu, 259 & faixa de tráfego & outros \\
\hline 10/12/13 & AL_BI & 11 & Baronesa & restaurante & n.id. & van & traseira & em frente ao estabelecimento & & & outros \\
\hline $10 / 12 / 13$ & $\mathrm{AL}^{\mathrm{AL}-\mathrm{BB}}$ & 12 & $\begin{array}{l}\text { Baronesa } \\
\text { BRMani }\end{array}$ & $\begin{array}{l}\text { restaurante } \\
\text { plia de conveneîncia }\end{array}$ & $\begin{array}{l}\text { Verissimo } \\
\text { nid }\end{array}$ & nid: & $\begin{array}{c}\text { traseira } \\
\text { traseira }\end{array}$ & dentro do estabelecimento & & & $\begin{array}{l}\text { outros } \\
\text { celeta }\end{array}$ \\
\hline $\begin{array}{l}10 / 11 / 133 \\
10 / 12 / 13\end{array}$ & $\begin{array}{c}\text { AL__B } 1 \\
A L B 1\end{array}$ & ${ }_{14}^{13}$ & $\begin{array}{l}\text { BR Mania } \\
\text { Basoness }\end{array}$ & $\begin{array}{l}\text { loja de convenieiencia } \\
\text { restamante }\end{array}$ & n.id. & $\begin{array}{l}\text { n:id: } \\
\text { nor }\end{array}$ & $\begin{array}{l}\text { traseira } \\
\text { taterat }\end{array}$ & $\begin{array}{l}\text { dentro do estabelecimento } \\
\text { endereco }\end{array}$ & & & coleta \\
\hline $10 / 12 / 13$ & AL_BB & $\begin{array}{l}14 \\
15\end{array}$ & $\begin{array}{l}\text { Baronesa } \\
\text { Baronesa }\end{array}$ & $\begin{array}{l}\text { restaurante } \\
\text { restaurante }\end{array}$ & $\begin{array}{l}\text { Ambeve } \\
\text { n.id. }\end{array}$ & $\begin{array}{l}\text { vuc grande } \\
\text { vuc grande }\end{array}$ & lateral & 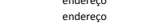 & $\begin{array}{l}\text { Baranosesa de itu, } 311 \\
\text { Baronesa de ttu, } 310\end{array}$ & & $\begin{array}{l}\text { bebidas } \\
\text { frios/embutidos }\end{array}$ \\
\hline $10 / 12 / 13$ & AL_BI & 16 & Baronesa & restaurante & AD'oro & vuc grande & traseira & endereso & Baronesa de Itu, 259 & faixa de tráfego & carnes \\
\hline 10/12/133 & AL_BI & 17 & 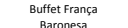 & buffet/casa de festas & Vigor & VuC grande & $\begin{array}{c}\text { traseira } \\
\text { tatasirat }\end{array}$ & $\begin{array}{l}\text { endereso } \\
\text { endereco }\end{array}$ & Baronesa de Itu, 258 & carga e descarga & $\begin{array}{l}\text { laticinios } \\
\text { lation }\end{array}$ \\
\hline & 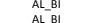 & $\begin{array}{l}18 \\
19\end{array}$ & $\begin{array}{l}\text { Baronesa } \\
\text { Buffet Eranca }\end{array}$ & $\begin{array}{l}\text { restaurante } \\
\text { buffettcasa de festas }\end{array}$ & $\begin{array}{l}\text { n.id. } \\
\text { nid. }\end{array}$ & $\begin{array}{l}\text { van } \\
\text { vuc prande }\end{array}$ & $\begin{array}{c}\text { traseira } \\
\text { trasira }\end{array}$ & $\begin{array}{l}\text { endereço } \\
\text { endereço }\end{array}$ & $\begin{array}{l}\text { Baronesa de litu, } 259 \\
\text { Bayronesa de the } 258\end{array}$ & $\begin{array}{l}\text { faixa de tráfego } \\
\text { cargaz edecargag }\end{array}$ & carnes \\
\hline $\begin{array}{l}10 / 11 / 13 \\
10 / 12 / 13 \\
\end{array}$ & $\begin{array}{l}\text { AL__B } \\
\text { AL BI }\end{array}$ & $\begin{array}{l}19 \\
20\end{array}$ & 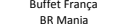 & $\begin{array}{l}\text { buffet/casade ad festas } \\
\text { loia de conveniência }\end{array}$ & $\begin{array}{l}\text { n.id. } \\
\text { Crystal, ttaipava }\end{array}$ & $\begin{array}{l}\text { vuc grande } \\
\text { vuc grande }\end{array}$ & $\begin{array}{c}\text { traseira } \\
\text { traseira }\end{array}$ & $\begin{array}{l}\text { endereso } \\
\text { dentro do estabelecimento }\end{array}$ & Baronesa de tut, 258 & carga e descarga & $\begin{array}{l}\text { outros } \\
\text { bebidas }\end{array}$ \\
\hline $10 / 12 / 13$ & AL_BI & 20 & BR Mania & loja de conveniência & Crystal, Itaipava & $\begin{array}{l}\text { vuc grande } \\
\text { vuche }\end{array}$ & lateral & dentro do estabelecimento & & & $\begin{array}{l}\text { beobidas } \\
\text { bebidas }\end{array}$ \\
\hline $10 / 12 / 13$ & AL_BI & 20 & BR Mania & loja de conveniênncia & Crystal, ttaipava & $\begin{array}{l}\text { vuc grande } \\
\text { valus }\end{array}$ & traseira & 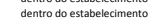 & & & $\begin{array}{l}\text { bebidas } \\
\text { bes }\end{array}$ \\
\hline 10/12/13 & AL_BI & 21 & Buffet França & buffet/casa de festas & Padaria Baronesa & vuc grande & traseira & & & & păes \\
\hline 10/12/13 & AL_BI & 22 & Buffet Franca & buffet/casa de festas & n.id. & Vuc grande & traseira & enderesoo & Baronesa de itu, 258 & faixa de tráfego & outros \\
\hline $\begin{array}{l}10 / 12 / 13 \\
10 / 12 / 13 \\
\end{array}$ & $\begin{array}{l}\text { AL__B } \\
A L B 1\end{array}$ & ${ }_{23}^{23}$ & $\begin{array}{l}\text { Buffet ranca } \\
\text { Buffet trancasa }\end{array}$ & $\begin{array}{l}\text { buffet/casa de festas } \\
\text { butfet casas de feftasas }\end{array}$ & $\begin{array}{l}\text { Polilacrne, Sadia } \\
\text { Policarne Sadiaa }\end{array}$ & $\begin{array}{l}\text { vuc grande } \\
\text { vuc prande }\end{array}$ & $\begin{array}{l}\text { traseira } \\
\text { traserara }\end{array}$ & 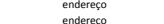 & $\begin{array}{l}\text { Baronosesa de tit, } 258 \\
\text { Baronesa de eltu, } 258\end{array}$ & $\begin{array}{l}\text { faixa de tráfégo } \\
\text { faixade tráfego }\end{array}$ & carnes \\
\hline $\begin{array}{l}10 / 12 / 13 \\
1 / 12 / 13\end{array}$ & $\begin{array}{l}A{ }_{A}^{A} \_B B \\
A L B 1\end{array}$ & $\begin{array}{l}23 \\
24\end{array}$ & $\begin{array}{l}\text { Butfettrança } \\
\text { Buffet Franca }\end{array}$ & 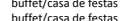 & $\begin{array}{l}\text { Policarne, Sadia } \\
\text { n.id. }\end{array}$ & $\begin{array}{l}\text { Vuc grande } \\
\text { vuc grande }\end{array}$ & $\begin{array}{l}\text { 估aseira } \\
\text { traseira }\end{array}$ & 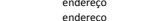 & $\begin{array}{l}\text { Baronesa a de tiu, } 258 \\
\text { Baronesa de titu, } 258\end{array}$ & $\begin{array}{l}\text { faixa de trátego } \\
\text { faixa de tráfego }\end{array}$ & $\begin{array}{l}\text { carnes } \\
\text { outros }\end{array}$ \\
\hline $10 / 12 / 13$ & $\begin{array}{ll}A L-B B \\
A L B I\end{array}$ & $\begin{array}{l}24 \\
26\end{array}$ & $\begin{array}{l}\text { Butfet rança } \\
\text { Baronesa }\end{array}$ & $\begin{array}{l}\text { butfettcasad de eftas } \\
\text { restaurante }\end{array}$ & $\begin{array}{l}\text { n.ta. } \\
\text { Morfrig Group }\end{array}$ & $\begin{array}{l}\text { vuc granoe } \\
\text { vuc grande }\end{array}$ & $\begin{array}{l}\text { 估aseira } \\
\text { traseira }\end{array}$ & $\begin{array}{l}\text { enderę̧⿻ } \\
\text { endero }\end{array}$ & Baronesa de itu, 259 & $\begin{array}{l}\text { zona azul } \\
\text { zong }\end{array}$ & $\begin{array}{l}\text { outros } \\
\text { carnes }\end{array}$ \\
\hline $11 / 12 / 13$ & AL_BI & 1 & $\begin{array}{l}\text { Baronessa } \\
\text { BR Mania }\end{array}$ & $\begin{array}{l}\text { loja de contarnveneiência } \\
\text { lo }\end{array}$ & $\begin{array}{l}\text { Nescrafé, Nescau } \\
\text { Nescou }\end{array}$ & $\begin{array}{l}\text { voc ganoe } \\
\text { van }\end{array}$ & 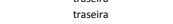 & dentro do estabelecimento & & & mercearia seca em geral \\
\hline $11 / 12 / 13$ & AL_BI & 2 & BR Mania & loja de conveniência & n.id. & van & traseira & dentro do estabelecimento & & & bebidas \\
\hline $11 / 12 / 13$ & AL_BI & 5 & Baronesa & restaurante & n.id. & van & traseira & enderę̧o & Baronesa de ltu, 258 & faixa de tráfego & FLV \\
\hline 11/12/13 & AL_BI & 6 & $\begin{array}{l}\text { Baronesa } \\
\text { Baroness }\end{array}$ & restaurante & n.id. & van & traseira & em frente ao estabelecimento & & zona azul & alimentos congelados \\
\hline 11/12/133 & $\begin{array}{l}\text { AL__B } \\
A L B 1\end{array}$ & $\begin{array}{l}7 \\
8\end{array}$ & $\begin{array}{l}\text { Baronesa } \\
\text { Buffet Eranca }\end{array}$ & $\begin{array}{l}\text { restaurante } \\
\text { butfetcasas de festas }\end{array}$ & $\begin{array}{l}\text { nid. } \\
\text { Ambey }\end{array}$ & van & $\begin{array}{c}\text { traseira } \\
\text { traseira }\end{array}$ & $\begin{array}{l}\text { em frente ao estabelecimento } \\
\text { endereco }\end{array}$ & Baronesa de titu, 259 & $\begin{array}{l}\text { zona azul } \\
\text { faixa de tráfego }\end{array}$ & $\begin{array}{c}\text { outros } \\
\text { bebidisas }\end{array}$ \\
\hline - & $\begin{array}{ll}A \text { AL_BB } \\
A L B 1\end{array}$ & 8 & $\begin{array}{l}\text { Sultet ranhya } \\
\text { Buffet Franca }\end{array}$ & 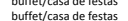 & $\begin{array}{l}\text { Amber } \\
\text { Amber }\end{array}$ & $\begin{array}{l}\text { van } \\
\text { vuc grande }\end{array}$ & 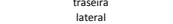 & $\begin{array}{l}\text { endereço } \\
\text { endereço }\end{array}$ & $\begin{array}{l}\text { Baronesa de ti tu, } 229 \\
\text { Baronesa de titu, } 258\end{array}$ & $\begin{array}{l}\text { faixa de tráfego } \\
\text { carga e descarga }\end{array}$ & $\begin{array}{l}\text { 祭bidas } \\
\text { bebidas }\end{array}$ \\
\hline $111 / 12 / 13$ & AL_BI & 8 & Buffet França & buffet/casa de festas & Ambev & vuc grande & lateral & endereso & Baronesa de itu, 258 & carga e descarga & $\begin{array}{l}\text { bebidas } \\
\text { bevas }\end{array}$ \\
\hline $11 / 12 / 13$ & AL_BI & $g$ & Baronesa & restaurante & n.id. & $\begin{array}{l}\text { vuc grande } \\
\text { vund }\end{array}$ & $\begin{array}{l}\text { lateral } \\
\text { lateral }\end{array}$ & endereço & Baronesa de ttu, 258 & carga e descarga & $\begin{array}{l}\text { carnes } \\
\text { cals }\end{array}$ \\
\hline $11 / 12 / 13$ & AL_BI & 10 & Buffet França & buffet/casa de festas & Kentisa & van & traseira & em frente ao estabelecimento & 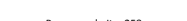 & zona azul & FLV \\
\hline 11/12/13 & AL_BI & 10 & $\begin{array}{l}\text { Buffet França } \\
\text { Buffetrfong }\end{array}$ & $\begin{array}{l}\text { buffet//casa de festas } \\
\text { buffet/cos def fastas }\end{array}$ & Kentisa & $\begin{array}{l}\text { vuc grande } \\
\text { vicusande }\end{array}$ & $\begin{array}{l}\text { lateral } \\
\text { atateal }\end{array}$ & endereşo & Baronesa de Ittu, 258 & faixa de tráfego & FLV \\
\hline $\begin{array}{l}11 / 11 / 13 \\
1112 / 13\end{array}$ & $\begin{array}{l}\text { AL__B } \\
\text { AL BI }\end{array}$ & ${ }_{12}^{11}$ & $\begin{array}{l}\text { Buffet rança } \\
\text { Buffet }\end{array}$ & $\begin{array}{l}\text { buffett/casa de festas } \\
\text { butffetcasa de efestas }\end{array}$ & $\begin{array}{l}\text { n.id. } \\
\text { sp3 }\end{array}$ & VUC grande & $\begin{array}{l}\text { lateral } \\
\text { traseira }\end{array}$ & $\begin{array}{l}\text { endereso } \\
\text { enderecos }\end{array}$ & $\begin{array}{l}\text { Baronesa de ltu, } 258 \\
\end{array}$ & faixa de tráfego & mercearia seca em geral \\
\hline $\begin{array}{l}111 / 1 / 2 / 13 \\
11 / 2133 \\
\end{array}$ & $\begin{array}{l}A{ }_{A}^{A} \_B \\
A L B 1\end{array}$ & ${ }_{13}^{12}$ & 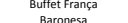 & $\begin{array}{l}\text { buffettcasad a e testas } \\
\text { restaurante }\end{array}$ & $\begin{array}{c}\text { SPB } \\
\text { nid }\end{array}$ & $\begin{array}{l}\text { van } \\
\text { TOCO }\end{array}$ & $\begin{array}{c}\text { traseira } \\
\text { traseira }\end{array}$ & $\begin{array}{l}\text { endereço } \\
\text { endereço }\end{array}$ & $\begin{array}{l}\text { Baronesa de ti tu, } 258 \\
\text { Baronesa de titu, 258 }\end{array}$ & $\begin{array}{l}\text { carga e descarga } \\
\text { carga e descarga }\end{array}$ & $\begin{array}{l}\text { outros } \\
\text { carnes }\end{array}$ \\
\hline 11/12/13 & AL BI & ${ }_{14}$ & $\begin{array}{l}\text { Baroness } \\
\text { Barosa }\end{array}$ & restaurante & 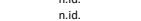 & van & $\begin{array}{l}\text { Trasera } \\
\text { traseita }\end{array}$ & $\begin{array}{l}\text { en frente ao e estabolecimento }\end{array}$ & & $\begin{array}{l}\text { Carge e descarga } \\
\text { zona azul }\end{array}$ & 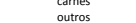 \\
\hline $11 / 12 / 13$ & AL_BI & 15 & Buffet França & buffet/casa de festas & n.id. & van & $\begin{array}{l}\text { tostena } \\
\text { traseira }\end{array}$ & & & & $\begin{array}{l}\text { outros } \\
\text { outs }\end{array}$ \\
\hline $11 / 12 / 13$ & AL_BI & 15 & Buffet França & buffet/casa de festas & n.id. & van & lateral & endereşo & Baronesa de Itu, 258 & carga e descarga & outros \\
\hline $11 / 12 / 13$ & AL_BI & 15 & Buffet França & buffet/casa de festas & n.id. & van & lateral & enderesco & Baronesa de itu, 258 & carga e descarga & outros \\
\hline 11/12/13 & AL_BB & ${ }_{15}^{15}$ & $\begin{array}{l}\text { Buffet França } \\
\text { Busffet }\end{array}$ & 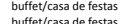 & $\begin{array}{c}\text { n.id. } \\
\text { nid }\end{array}$ & van & $\begin{array}{l}\text { lateral } \\
\text { lateral }\end{array}$ & $\begin{array}{l}\text { endereso } \\
\text { endereco }\end{array}$ & $\begin{array}{l}\text { Baronesa de Ittu, } 258 \\
\end{array}$ & carga e descarga & outros \\
\hline 11/12/133 & $\begin{array}{c}A \text { AL_BB } \\
A L B 1\end{array}$ & ${ }_{15}^{15}$ & $\begin{array}{l}\text { Buffet rençaa } \\
\text { Busfet trancaca }\end{array}$ & 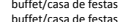 & n.id. & van & $\begin{array}{l}\text { lateral } \\
\text { lateral } \\
\text { nat }\end{array}$ & 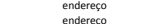 & 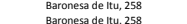 & $\begin{array}{l}\text { carga a edescarga } \\
\text { carrea e descarga }\end{array}$ & $\begin{array}{l}\text { outros } \\
\text { outros }\end{array}$ \\
\hline 11/12/13 & ${ }_{A L} A_{B 1}$ & ${ }_{15}^{15}$ & $\begin{array}{l}\text { Buffet renancaa } \\
\text { Buffet rancha }\end{array}$ & 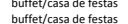 & 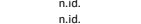 & $\begin{array}{l}\text { van } \\
\text { van }\end{array}$ & $\begin{array}{l}\text { lateral } \\
\text { lateral }\end{array}$ & 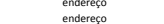 & 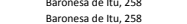 & $\begin{array}{l}\text { carge a edecaraga } \\
\text { carga e descarga }\end{array}$ & $\begin{array}{l}\text { outros } \\
\text { outros }\end{array}$ \\
\hline $11 / 12 / 13$ & AL_BI & 15 & Buffet França & buffet/casa de festas & n.id. & van & $\begin{array}{l}\text { laterat } \\
\text { lateral }\end{array}$ & $\begin{array}{l}\text { enderesc } \\
\text { endergao }\end{array}$ & Baronesa de itu, 258 & $\begin{array}{l}\text { carga e descargarga } \\
\text { carate }\end{array}$ & $\begin{array}{l}\text { ourtos } \\
\text { outros }\end{array}$ \\
\hline $11 / 12 / 13$ & AL_BI & 15 & Buffet França & buffet/casa de festas & n.id. & van & lateral & endereso & Baronesa de ltu, 258 & carga e descarga & $\begin{array}{l}\text { outros } \\
\text { outs }\end{array}$ \\
\hline $11 / 12 / 13$ & AL_BI & 15 & Buffet França & buffet/casa de festas & n.id. & van & lateral & endereşo & Baronesa de Ittu, 258 & carga e descarga & outros \\
\hline 11/12/13 & AL_BI & 15 & Buffet França & buffet/casa de festas & n.id. & van & lateral & enderesco & Baronesa de Itu, 258 & carga e descarga & outros \\
\hline 11/12/133 & $\begin{array}{l}\text { AL__B } \\
\text { AL BI }\end{array}$ & $\begin{array}{l}15 \\
15 \\
15\end{array}$ & $\begin{array}{l}\text { Buffet rancaa } \\
\text { Buffet }\end{array}$ & $\begin{array}{l}\text { buffet/casa de festas } \\
\text { buffetcosegde }\end{array}$ & n.id. & van & $\begin{array}{l}\text { lateral } \\
\text { lateral }\end{array}$ & $\begin{array}{l}\text { endereso } \\
\text { entereco }\end{array}$ & 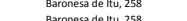 & $\begin{array}{l}\text { carga e descarga } \\
\text { carga e descarga }\end{array}$ & $\begin{array}{l}\text { outros } \\
\text { putros }\end{array}$ \\
\hline $\begin{array}{l}1171 / 1 / 13 \\
11 / 2 / 13\end{array}$ & $\begin{array}{ll}A A_{1}-B \\
A L\end{array}$ & ${ }_{16}^{15}$ & $\begin{array}{l}\text { Sulfet rença } \\
\text { Buffet Franca }\end{array}$ & 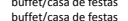 & $\begin{array}{l}\text { n.ta. } \\
\text { vigor }\end{array}$ & $\begin{array}{l}\text { van } \\
\text { van }\end{array}$ & $\begin{array}{l}\text { alteral } \\
\text { lateral }\end{array}$ & 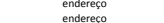 & 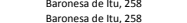 & $\begin{array}{l}\text { carga a descarga } \\
\text { carge e descarga }\end{array}$ & $\begin{array}{l}\text { outros } \\
\text { laticinios }\end{array}$ \\
\hline 11/12/13 & AL BI & ${ }_{17}^{10}$ & Buffet Franca & 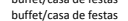 & $\begin{array}{l}\text { wickold } \\
\text { withold }\end{array}$ & $\begin{array}{l}\text { voc grande } \\
\text { vuc }\end{array}$ & raseira/lateral & enderefo & Baronesa de itu, 259 & faixa de tráfego & 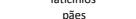 \\
\hline $11 / 12 / 13$ & AL_BI & 18 & Baronesa & restaurante & JBS & $\begin{array}{l}\text { vuc grande } \\
\text { vula }\end{array}$ & 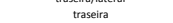 & endereço & Baronesa de lttu, 259 & faixa de tráf́ego & $\begin{array}{l}\text { pess } \\
\text { carnes }\end{array}$ \\
\hline $11 / 12 / 13$ & AL_BB & 18 & Baronesa & restaurante & JBS & VUC grande & traseira & em frente ao estabelecimento & & zona azul & carnes \\
\hline 11/12/13 & AL_BI & 19 & Buffet França & buffet/casa de festas & Fleischmann & VuC grande & & em frente ao estabelecimento & 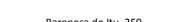 & zona azul & ovos \\
\hline 11/12/13 & AL_BI & 19 & 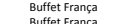 & buffet//casa de festas & Fleischmann & van & $\begin{array}{l}\text { traseira//ateral } \\
\text { thasera }\end{array}$ & enderę̧o & $\begin{array}{l}\text { Baronesa de Itu, } 259 \\
\end{array}$ & faixa de tráfego & ovos \\
\hline - $111 / 12 / 133$ & $\begin{array}{l}\text { AA__B B } \\
\text { AL B1 }\end{array}$ & ${ }_{21}^{20}$ & $\begin{array}{l}\text { Buffet rençä } \\
\text { Buffet Franca }\end{array}$ & $\begin{array}{l}\text { buffet casad a e festas } \\
\text { butfet/casas de efestas }\end{array}$ & $\begin{array}{c}\text { nid. } \\
\text { lindoia }\end{array}$ & $\begin{array}{c}\text { van } \\
\text { van }\end{array}$ & $\begin{array}{l}\text { trasesira } \\
\text { traseira }\end{array}$ & 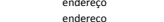 & 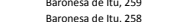 & $\begin{array}{l}\text { Taixa a e tráfego } \\
\text { faxixa de tráf́gego }\end{array}$ & $\begin{array}{l}\text { carnes } \\
\text { bebidas }\end{array}$ \\
\hline - & $\begin{array}{ll}A L-B C \\
A L B 1\end{array}$ & 21 & $\begin{array}{l}\text { Surtert fança } \\
\text { Buffet franca }\end{array}$ & 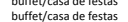 & $\begin{array}{l}\text { Lindoola } \\
\text { Lindoia }\end{array}$ & $\begin{array}{l}\text { voc grande } \\
\text { vuc }\end{array}$ & $\begin{array}{l}\text { araseff } \\
\text { traseira }\end{array}$ & $\begin{array}{l}\text { Enederes } \\
\text { endereco }\end{array}$ & Baronesa de itu, 258 & faixa de tráfego & $\begin{array}{l}\text { Deotcas } \\
\text { bebidas }\end{array}$ \\
\hline $11 / 12 / 13$ & AL_BI & 21 & Buffet França & buffet/casa de festas & Lindoia & vuc grande & traseira & endereso & Baronesa de ltu, 258 & faixa de tráfego & bebidas \\
\hline $11 / 12 / 13$ & AL_BI & 22 & BR Mania & buffet/casa de festas & Coca-cola & vuc grande & thaseira & enderę̧o & Baronesa de ltt, 258 & faixa de tráfego & $\begin{array}{l}\text { bebidas } \\
\text { bebs }\end{array}$ \\
\hline 11/12/13 & $\stackrel{\text { AL__BI }}{A L B 1}$ & $\begin{array}{l}22 \\
22\end{array}$ & $\begin{array}{l}\text { BR Mania } \\
\text { BR Mania }\end{array}$ & $\begin{array}{l}\text { buffet/casa de festas } \\
\text { buffet casa de efestas }\end{array}$ & $\begin{array}{l}\text { Coca-cola } \\
\text { Cocaccola }\end{array}$ & $\begin{array}{l}\text { vuc grande } \\
\text { vuc rande }\end{array}$ & $\begin{array}{l}\text { ateteral } \\
\text { lateral }\end{array}$ & $\begin{array}{l}\text { dentro do ostablatecimento } \\
\text { dentro do estabelecimento }\end{array}$ & & & $\begin{array}{l}\begin{array}{l}\text { bebidas } \\
\text { bebidas }\end{array} \\
\text {. }\end{array}$ \\
\hline $\begin{array}{l}111 / 1 / 13 \\
11 / 12 / 13\end{array}$ & $\begin{array}{l}{ }_{A}^{A} \text { A__B B } \\
\text { AL_I }\end{array}$ & ${ }_{22}^{22}$ & $\begin{array}{l}\text { BR Mania } \\
\text { BR Mania }\end{array}$ & $\begin{array}{l}\text { ubfftet/casad de estas } \\
\text { buffet/casa de festas }\end{array}$ & $\begin{array}{l}\text { Cocaccola } \\
\text { Coca-cola }\end{array}$ & $\begin{array}{l}\text { vuc grande } \\
\text { vuc grande }\end{array}$ & $\begin{array}{l}\text { lateral } \\
\text { lateral }\end{array}$ & $\begin{array}{l}\text { dentro do ostablelecimento } \\
\text { dentro do estabelecimento }\end{array}$ & & & $\begin{array}{l}\text { bebidas } \\
\text { bebidas }\end{array}$ \\
\hline
\end{tabular}




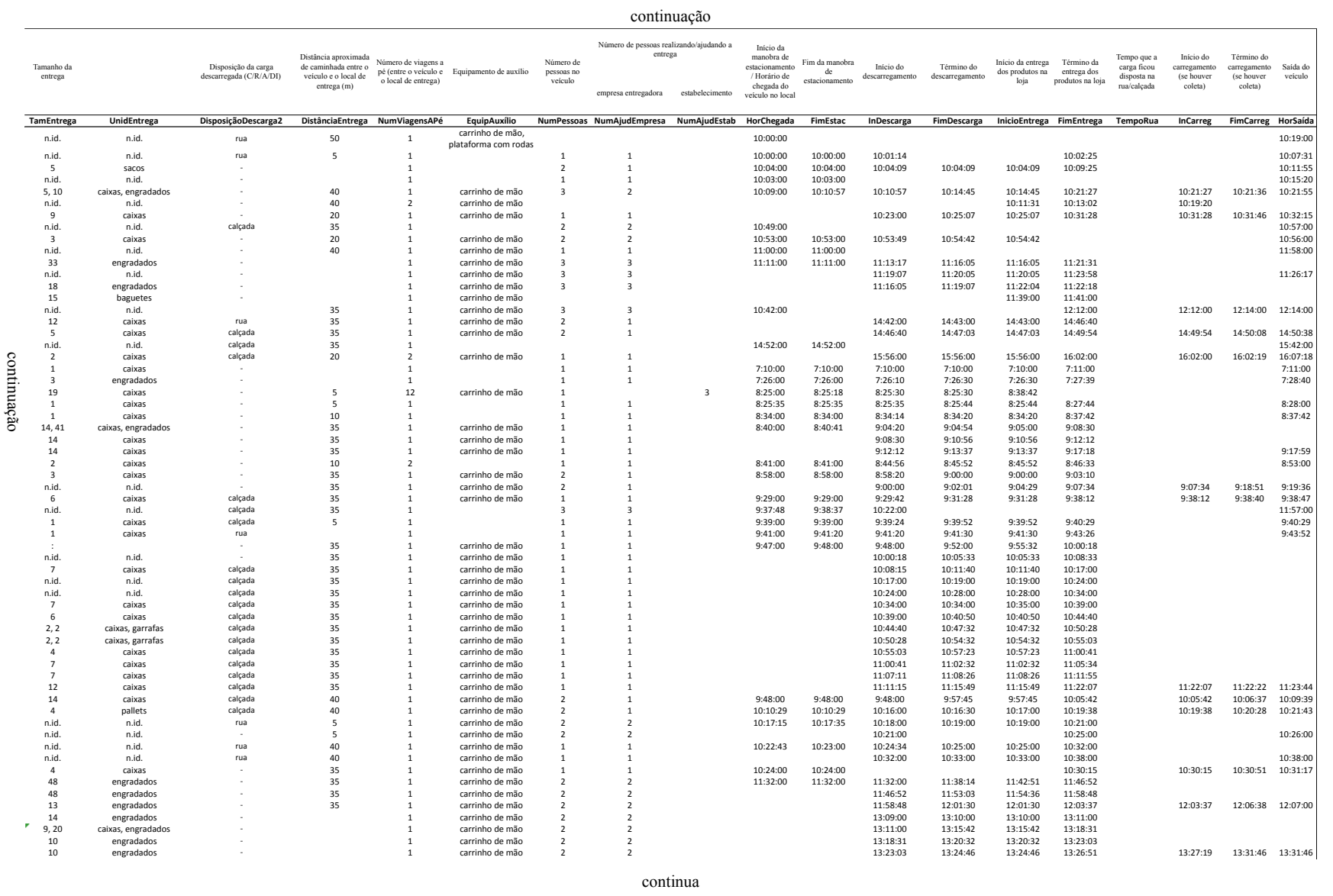




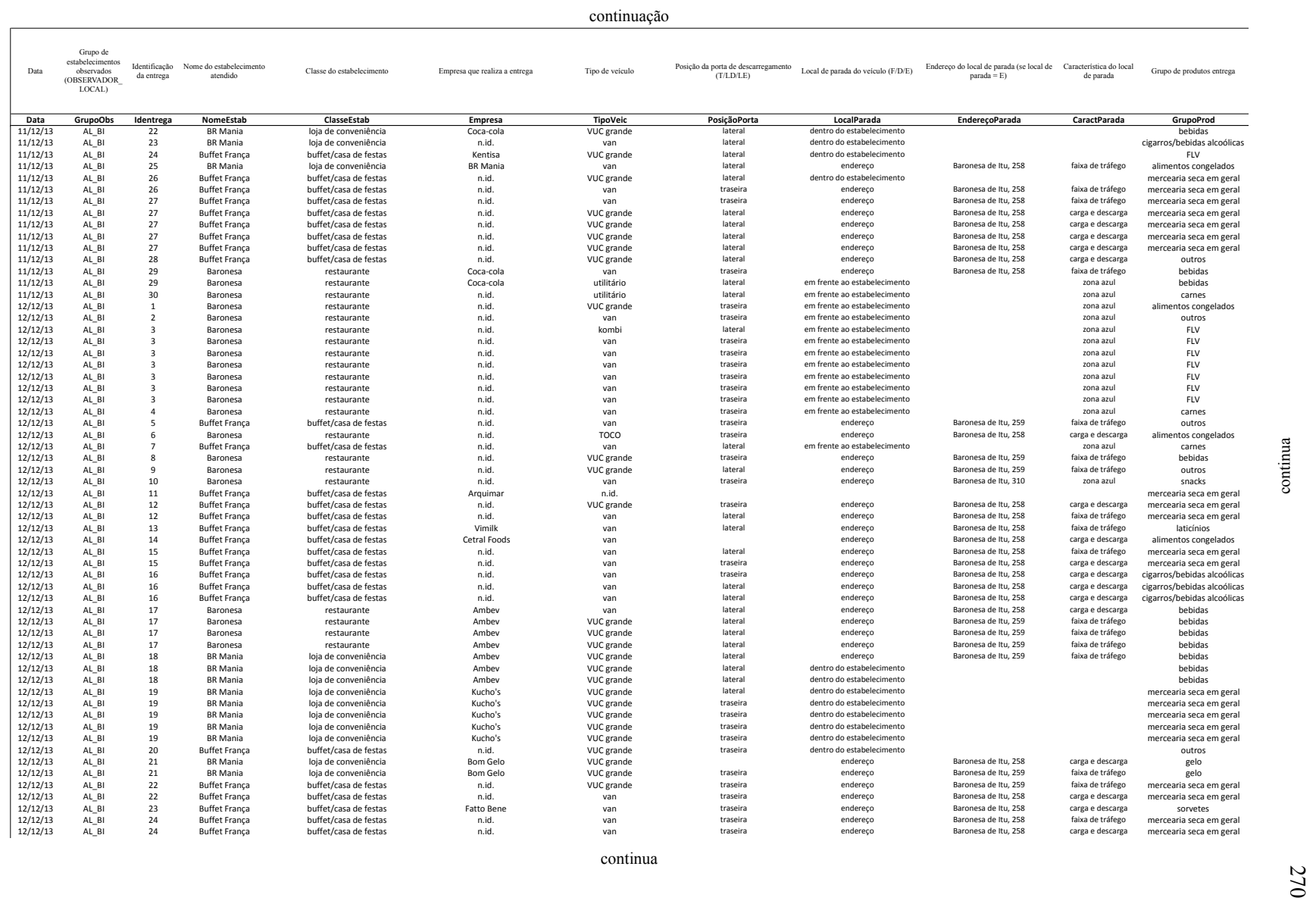




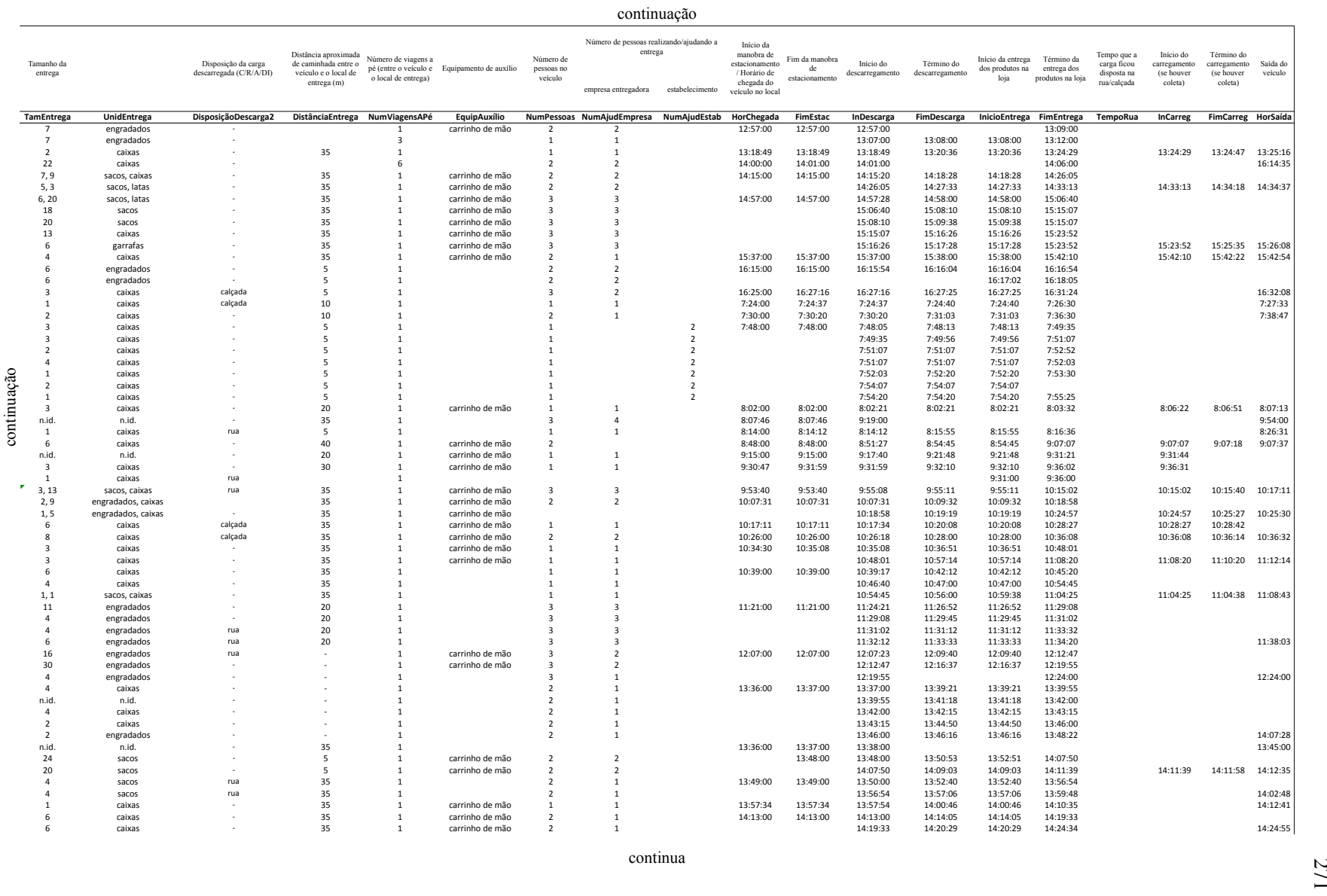


continuação

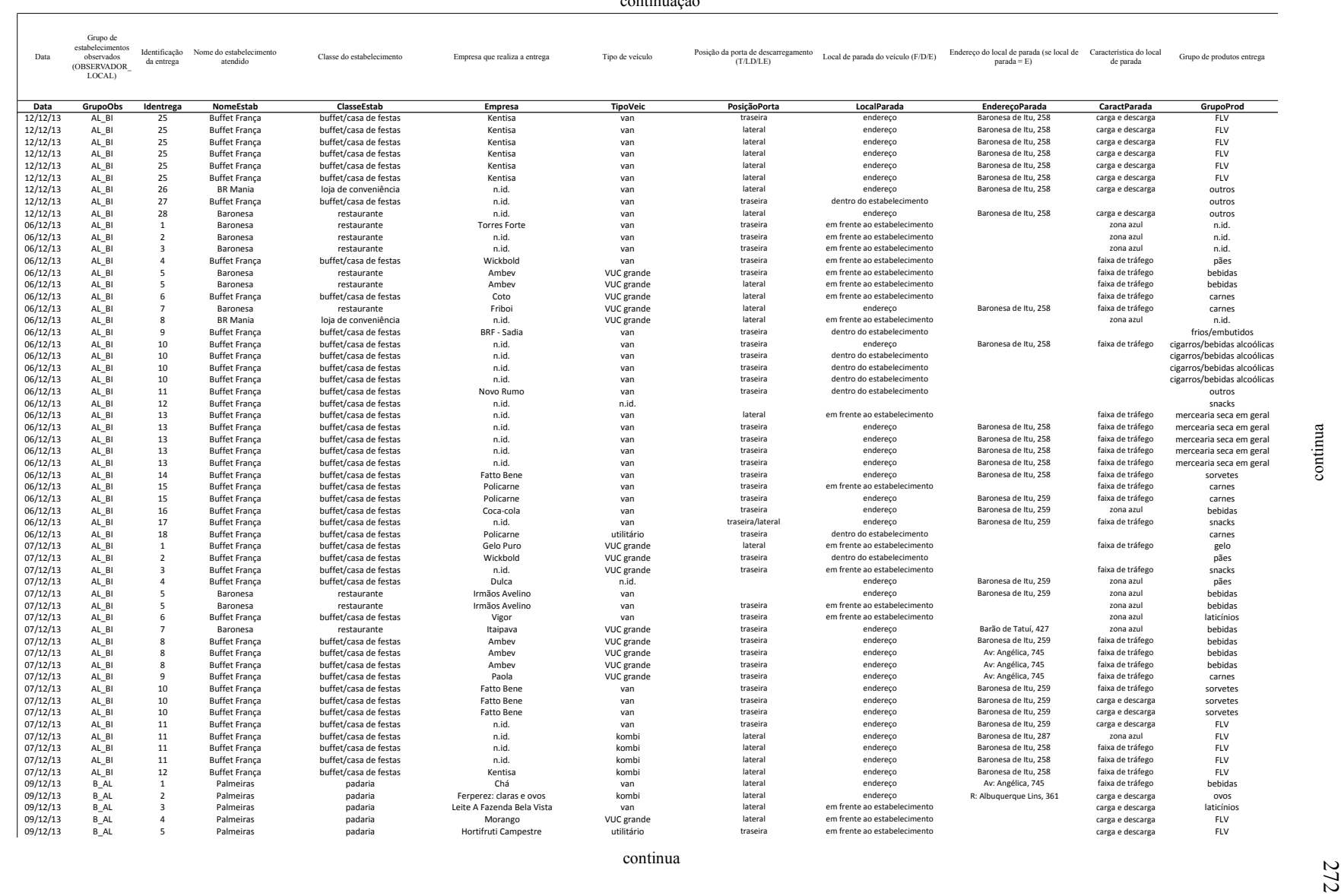




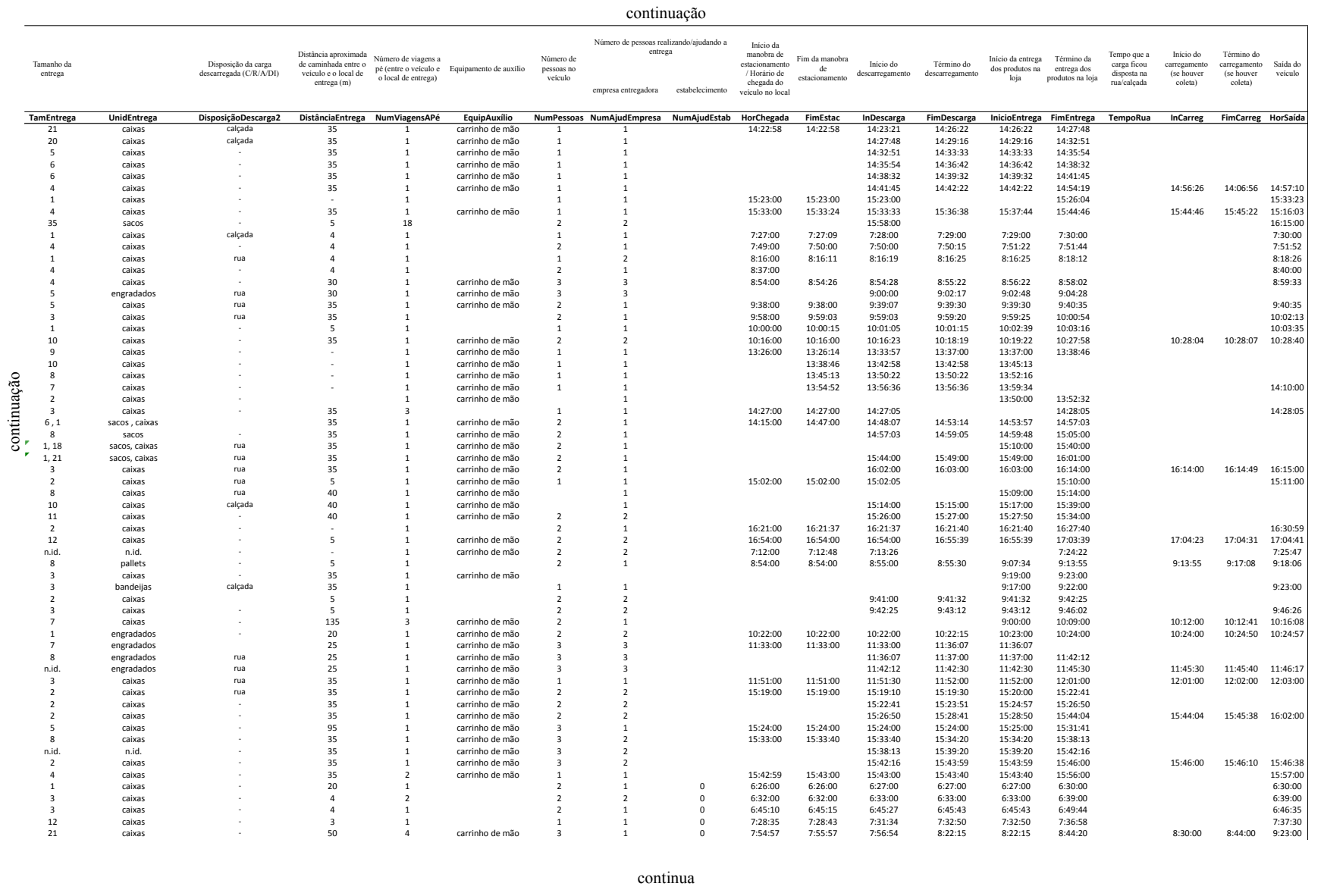


continuação

\begin{tabular}{|c|c|c|c|c|c|c|c|c|c|c|c|}
\hline Data & 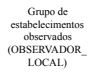 & $\begin{array}{l}\text { Idennificacaio } \\
\text { da entroga } \\
\text {. }\end{array}$ & $\begin{array}{l}\text { Nome do ctablaclecimento } \\
\text { atendido }\end{array}$ & Classe do stabelceimento & Empress que realiza a entrega & Tipo de veiculo & $\begin{array}{l}\text { Posiçăo dap porta de descarregamento } \\
\text { (T/LDDLLE) }\end{array}$ & Local de parada do veciculo (F,DEF) & $\begin{array}{l}\text { Endereceo do olocal de paradat (se local de } \\
\text { paradal }=\text { E) }\end{array}$ & $\begin{array}{l}\text { Caracterisitica do local } \\
\text { de parada }\end{array}$ & Ginpo de produtus entrega \\
\hline Data & Grupoobs & Identrega & NomeEstab & ClasseEstab & Empresa & Tipoveic & Posiçăoporta & LocalParada & EndereçoParada & CaractParada & GrupoProd \\
\hline $09 / 12 / 13$ & B_AL & 6 & Palmeiras & padaria & Pelissari queijos & VUC pequeno & Aberto & enderesc & R: Albuquerque Lins, 357 & carga e descarga & laticínios \\
\hline $09 / 12 / 13$ & B_AL & 7 & Eduana & restaurante & Horta Leve & van & traseira & enderesco & R: Albuquerque Lins, 324 & Outro & $\mathrm{FLV}$ \\
\hline $09 / 12 / 13$ & B-AL & 8 & Mercado Mally & supermercado pequeno & ER Distribuidora de ovos & utilitário & traseira & enderesco & R: Albuquerque Lins, 361 & carga e descarga & ovos \\
\hline $09 / / 12 / 13$ & ${ }_{B}^{B}$ AL & 9 & $\begin{array}{l}\text { Palmeiras } \\
\text { Palmeiras }\end{array}$ & padaria & $\begin{array}{l}\text { Mc Cain } \\
\text { Kikgo }\end{array}$ & vuc grande & traseira//ateral & $\begin{array}{l}\text { enderesco } \\
\text { endereco }\end{array}$ & R: Albuquerque Lins, 361 & carga e descarga & alimentos congelados \\
\hline $\begin{array}{l}09 / 12 / 13 \\
0912 / 13\end{array}$ & $\begin{array}{l}\text { B-AL } \\
B_{\text {B }}\end{array}$ & $\begin{array}{l}10 \\
11\end{array}$ & $\begin{array}{l}\text { Palmeiras } \\
\text { Eduana }\end{array}$ & $\begin{array}{c}\text { ppdarai } \\
\text { restaurante }\end{array}$ & $\begin{array}{c}\text { Kibon } \\
\text { BRE-Sadia }\end{array}$ & $\begin{array}{l}\text { van } \\
\text { vuc pequeno }\end{array}$ & $\begin{array}{c}\text { traseira } \\
\text { lateral }\end{array}$ & $\begin{array}{l}\text { enderesco } \\
\text { enderecos }\end{array}$ & $\begin{array}{l}\text { R: Albuquerque Lins, } 361 \\
\text { R:Albugueraue Lins } 3,31\end{array}$ & $\begin{array}{l}\text { Carga e descarga } \\
\text { carea edeccarag }\end{array}$ & $\begin{array}{l}\text { sorvetes } \\
\text { frios/embutidos }\end{array}$ \\
\hline $\begin{array}{l}09 / 1 / 1 / 13 \\
09 / 12 / 13\end{array}$ & $\begin{array}{l}\text { B_AL } \\
B_{\text {AL }}\end{array}$ & $\begin{array}{l}11 \\
12\end{array}$ & $\begin{array}{l}\text { Eduana } \\
\text { Mercado Mally }\end{array}$ & $\begin{array}{c}\text { restaurante } \\
\text { supermercado pequeno }\end{array}$ & $\begin{array}{l}\text { BRF-Sadia } \\
\text { Coca-cola }\end{array}$ & $\begin{array}{l}\text { vuc pequeno } \\
\text { vuc pequeno }\end{array}$ & $\begin{array}{l}\text { lateral } \\
\text { traseira }\end{array}$ & 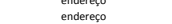 & $\begin{array}{l}\text { R: Albuquerque Lilss, } 361 \\
\text { R. Albuguergue Lins } 357\end{array}$ & $\begin{array}{l}\text { carga e edescarga } \\
\text { carea e descarga }\end{array}$ & $\begin{array}{l}\text { frios/embutidos } \\
\text { bebidas }\end{array}$ \\
\hline $\begin{array}{l}0991 / 1713 \\
09 / 12 / 13\end{array}$ & $\begin{array}{l}{ }_{B}^{B} \text { AL } \\
B_{B} A L\end{array}$ & $\begin{array}{l}12 \\
13\end{array}$ & $\begin{array}{l}\text { Mercado Mally } \\
\text { MJE }\end{array}$ & $\begin{array}{l}\text { supermercado pequeno } \\
\text { bombonière }\end{array}$ & $\begin{array}{l}\text { Coca-cola } \\
\text { Nestle }\end{array}$ & $\begin{array}{l}\text { Vuc pequeno } \\
\text { VUC pequeno }\end{array}$ & 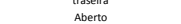 & $\begin{array}{l}\text { endereço } \\
\text { endereço }\end{array}$ & $\begin{array}{l}\text { R: Albuquequeue Lins, } 357 \\
\text { R: Albuquerque Lins, } 343\end{array}$ & $\begin{array}{l}\text { carge a eescarga } \\
\text { carga e descarga }\end{array}$ & $\begin{array}{l}\text { bebidas } \\
\text { mercearia seca em geral }\end{array}$ \\
\hline $\begin{array}{l}09 / 12 / 13 \\
0\end{array}$ & B_AL & 14 & Palmeiras & padaria & Mauri & van & $\begin{array}{l}\text { Muero } \\
\text { traseira }\end{array}$ & em frente ao estabelecimento & & carga e descarga & mercearia seca em geral \\
\hline $09 / 12 / 13$ & B_AL & 15 & $\mathrm{MJE}$ & bombonière & São Valentim & van & traseira & endereço & R: Albuquerque Lins, 361 & carga e descarga & păes \\
\hline $03 / 12 / 13$ & $\mathrm{~B}_{-} \mathrm{AL}$ & 1 & Palmeiras & padaria & Leite A Fazenda Bela Vista & vuc grande & lateral & em frente ao estabelecimento & & carga e descarga & laticinios \\
\hline $03 / 12 / 13$ & B_AL & 2 & Palmeiras & padaria & Ovos dois irmäos & $\begin{array}{l}\text { VuC grande } \\
\text { vic }\end{array}$ & lateral & em frente ao estabelecimento & & carga e descarga & ovos \\
\hline 03/12/13 & B_AL & 3 & Palmeiras & padaria & n.id. & VUC pequeno & traseira/lateral & endereço & R: Albuquerque Lins, 321 & carga e descarga & snacks \\
\hline $\begin{array}{l}03 / 12 / 13 \\
0312 / 133\end{array}$ & B_AL & $\begin{array}{l}4 \\
5\end{array}$ & $\begin{array}{l}\text { Palmeiras } \\
\text { Palmeiras }\end{array}$ & $\begin{array}{l}\text { padaria } \\
\text { padraia }\end{array}$ & Wickbold & $\begin{array}{l}\text { van } \\
\text { vucarande }\end{array}$ & traseira & em frente ao estabelecimento & & carga e descarga & păes \\
\hline 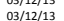 & $\begin{array}{l}{ }^{B} \text { BAL } \\
B_{\text {B }} \text { AL }\end{array}$ & $\begin{array}{l}5 \\
6\end{array}$ & $\begin{array}{l}\text { Palmeiras } \\
\text { Palmeiras }\end{array}$ & $\begin{array}{l}\text { padaria } \\
\text { padaria }\end{array}$ & $\begin{array}{l}\text { Pan } \\
\text { Pid } \\
\text { nid }\end{array}$ & $\begin{array}{l}\text { vuc granoe } \\
\text { vuc grande }\end{array}$ & $\begin{array}{l}\text { trasera } \\
\text { lateral }\end{array}$ & $\begin{array}{l}\text { em frente a o estabelecimento } \\
\text { em frente ao stabelecimento }\end{array}$ & & $\begin{array}{l}\text { fila dupla } \\
\text { carge descarga }\end{array}$ & $\begin{array}{c}\text { snacks } \\
\text { nid }\end{array}$ \\
\hline $03 / 12 / 13$ & BAL & 7 & $\begin{array}{l}\text { Palmintras } \\
\text { Palmeiras }\end{array}$ & $\begin{array}{l}\text { padarla } \\
\text { padaria }\end{array}$ & $\begin{array}{l}\text { hala. } \\
\text { vigor }\end{array}$ & $\begin{array}{l}\text { vulgranoe } \\
\text { van }\end{array}$ & $\begin{array}{l}\text { alater } \\
\text { traseira }\end{array}$ & 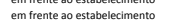 & & $\begin{array}{l}\text { carrace descarga } \\
\text { carga e descarga }\end{array}$ & $\begin{array}{l}\text { laticinios } \\
\text { lation }\end{array}$ \\
\hline $003 / 12 / 13$ & BAL & 8 & Palmeiras & padaria & Hortifruti Campestre & van & traseira & em frente ao estabelecimento & & carga e descarga & FLV \\
\hline $03 / 12 / 13$ & B_AL & 9 & Palmeiras & padaria & BRF-Sadia & kombi & traseira/lateral & enderesço & \#REF! & carga e descarga & frios/embutidos \\
\hline $03 / 12 / 13$ & B_AL & 10 & Palmeiras & padaria & Itaipava & vuc grande & traseira & em frente ao estabelecimento & & carga e descarga & bebidas \\
\hline $03 / 12 / 13$ & B_AL & 11 & Palmeiras & padaria & n.id. & VUC pequeno & traseira & em frente ao estabelecimento & & carga e descarga & n.id. \\
\hline $03 / 122 / 13$ & B_AL & 12 & Eduana & restaurante & FGA Food & kombi & lateral & & & carga e descarga & carnes \\
\hline $03 / 12 / 13$ & B_AL & 13 & Palmeiras & padaria & Aroumar Distribuidora & vuc grande & lateral & em frente ao estabelecimento & & carga e descarga & outros \\
\hline $03 / 12 / 13$ & B_AL & 14 & Palmeiras & padaria & n.id. & vuc grande & traseria//ateral & em frente ao estabelecimento & & carga e descarga & n.id. \\
\hline $03 / 122 / 13$ & B_AL & 15 & Palmeiras & padaria & Gelo-A & VUC pequeno & traseira & em frente ao estabelecimento & & carga e descarga & gelo \\
\hline $\begin{array}{l}03 / 1 / 1 / 13 \\
03 / 12 / 13\end{array}$ & $\begin{array}{l}{ }^{B} \text { B_AL } \\
\text { BAL }\end{array}$ & $\begin{array}{l}16 \\
17\end{array}$ & $\begin{array}{l}\text { Palmeiras } \\
\text { Palmeiras }\end{array}$ & $\begin{array}{l}\text { padaria } \\
\text { padaria }\end{array}$ & $\begin{array}{l}\text { Aurora } \\
\text { Panco }\end{array}$ & $\begin{array}{l}\text { vUc grande } \\
\text { van }\end{array}$ & $\begin{array}{l}\text { traseira//atareal } \\
\text { traresara/lateral }\end{array}$ & $\begin{array}{l}\text { endereço } \\
\text { em frente a a stabelecimento }\end{array}$ & \#REF! & $\begin{array}{l}\text { carga e descarga } \\
\text { carea edeccraga }\end{array}$ & $\begin{array}{l}\text { carnes } \\
\text { päes }\end{array}$ \\
\hline 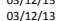 & B_AL & 18 & Palmeiras & padaria & Bimbo & vuc grande & 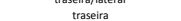 & $\begin{array}{l}\text { em frente a e estabelectimento } \\
\text { em frente a estabelecimento }\end{array}$ & & carga e descarga & $\begin{array}{l}\text { päes } \\
\text { păes }\end{array}$ \\
\hline 03/12/13 & BAL & 19 & Palmeiras & padaria & Empório de Minas & van & traseira & 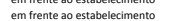 & & $\begin{array}{l}\text { carrace descarga } \\
\text { carga e descarga }\end{array}$ & $\begin{array}{l}\text { paes } \\
\text { păes }\end{array}$ \\
\hline $003 / 12 / 13$ & BAL & 20 & Palmeiras & padaria & Nestle & utilitário & traseira & em frente ao estabelecimento & & $\begin{array}{l}\text { carrace descarga } \\
\text { carga e descarga }\end{array}$ & mercearia seca em geral \\
\hline 03/12/13 & B_AL & 21 & Bar & bar tradicional & n.id. & van & traseira & em frente ao estabelecimento & & carga e descarga & $\begin{array}{l}\text { n.id. } \\
\text { netain }\end{array}$ \\
\hline $03 / 12 / 13$ & $\mathrm{~B}_{-} \mathrm{AL}$ & 22 & Bar & bar tradicional & n.id. & van & traseira & em frente ao estabelecimento & & carga e descarga & mercearia seca em geral \\
\hline $03 / 12 / 13$ & B_AL & 23 & Mercado Mally & supermercado pequeno & Yakult & kombi & lateral & em frente ao estabelecimento & & carga e descarga & bebidas \\
\hline 03/12/13 & $\begin{array}{l}\text { B_AL } \\
\text { BAL }\end{array}$ & ${ }_{25}^{24}$ & $\begin{array}{c}\text { Bar } \\
\text { Mercalo Maly }\end{array}$ & $\begin{array}{c}\text { bar tradicional } \\
\text { supermercado pequen }\end{array}$ & $\begin{array}{l}\text { RB Distribuidora } \\
\text { Carỹo }\end{array}$ & $\begin{array}{l}\text { VuC pequeno } \\
\text { vuc pequenon }\end{array}$ & traseira/lateral & em frente ao estabelecimento & & carga e descarga & bebidas \\
\hline $\begin{array}{l}03 / 1 / 12 / 13 \\
03 / 12 / 13\end{array}$ & $\begin{array}{l}\text { B_AL } \\
\text { BAL }\end{array}$ & $\begin{array}{l}25 \\
26\end{array}$ & $\begin{array}{l}\text { Mercado Mally } \\
\text { Bar }\end{array}$ & $\begin{array}{l}\text { supermercado oequeno } \\
\text { bar tradicional }\end{array}$ & $\begin{array}{l}\text { Carvão } \\
\text { n.id. }\end{array}$ & $\begin{array}{l}\text { vúp pequeno } \\
\text { vuc grande }\end{array}$ & lateral & em frente ao estabelecimento & 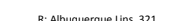 & 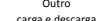 & $\begin{array}{l}\text { outros } \\
\text { thebidsas }\end{array}$ \\
\hline $\begin{array}{l}0 \\
03 / 12 / 133 \\
0313\end{array}$ & $\begin{array}{l}{ }_{B-A L}^{B-A L} \\
B_{A L}\end{array}$ & 27 & $\begin{array}{l}\text { Bar } \\
\text { Palmeiras }\end{array}$ & $\begin{array}{l}\text { bar tradiclonal } \\
\text { padaria }\end{array}$ & $\begin{array}{l}\text { n.lld. } \\
\text { n.id. }\end{array}$ & $\begin{array}{l}\text { vuU grande } \\
\text { vuc grande }\end{array}$ & $\begin{array}{l}\text { latetarl } \\
\text { lateral }\end{array}$ & $\begin{array}{l}\text { endereco } \\
\text { em frente ao estabelecimento }\end{array}$ & R:Albquuerque Lins, 321 & $\begin{array}{l}\text { carga e edescarga } \\
\text { Outro }\end{array}$ & $\begin{array}{l}\text { bebidas } \\
\text { n.id. }\end{array}$ \\
\hline - & BAL & 28 & Mercado Mally & $\begin{array}{l}\text { sudadi } \\
\text { supermeado pequeno }\end{array}$ & $\begin{array}{l}\text { Futap } \\
\text { Fruat }\end{array}$ & $\begin{array}{l}\text { vuc grande } \\
\text { vuc pequeno }\end{array}$ & $\begin{array}{l}\text { lateral } \\
\text { lateral }\end{array}$ & 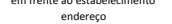 & R: Albuquerque Lins, 281 & $\begin{array}{l}\text { Outro } \\
\text { carga e descarga }\end{array}$ & $\begin{array}{l}\text { n.ld. } \\
\text { bebidas }\end{array}$ \\
\hline - & B_AL & 1 & MJE & bombonière & n.id. & vuc grande & 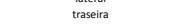 & em frente ao estabelecimento & & $\begin{array}{l}\text { cargad oescritga } \\
\text { carga e descarga }\end{array}$ & snacks \\
\hline $04 / 12 / 13$ & B_AL & 2 & Palmeiras & padaria & Souza Cruz & utilitário & traseira & em frente ao estabelecimento & & carga e descarga & cigarros/bebidas alcoólicas \\
\hline $04 / 12 / 13$ & B_AL & 3 & Palmeiras & padaria & n.id. & vuc grande & traseira & endereço & R: Albuquerque Lins, 327 & carga e descarga & outros \\
\hline $04 / 12 / 13$ & B_AL & 4 & Palmeiras & padaria & Coca-cola & vuc pequeno & traseira & enderesço & & carga e descarga & bebidas \\
\hline 04/12/13 & $\begin{array}{l}\text { B_AL } \\
\text { BAL }\end{array}$ & 5 & $\begin{array}{l}\text { Bar } \\
\text { Palmeizas }\end{array}$ & bar tradicional & $\begin{array}{l}\text { Multi Frango } \\
\text { Hotrifutit campestre }\end{array}$ & $\begin{array}{l}\text { vuC grande } \\
\text { vuY grande }\end{array}$ & $\begin{array}{c}\text { Aberto } \\
\text { trasesira }\end{array}$ & 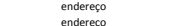 & $\begin{array}{l}\text { R: Albuquerque Lins, } 327 \\
\text { R. Albuguroue }\end{array}$ & carga e descarga & carnes \\
\hline 04/12/133 & B_AL & $\begin{array}{l}6 \\
7\end{array}$ & $\begin{array}{l}\text { Palmeiras } \\
\text { Palmeiras }\end{array}$ & padaria & $\begin{array}{l}\text { Hortifrutic campestre } \\
\text { nid }\end{array}$ & $\begin{array}{l}\text { VuC grande } \\
\text { vuc pequeno }\end{array}$ & trasera & $\begin{array}{l}\text { enderece } \\
\text { endereco }\end{array}$ & $\begin{array}{l}\text { R:Allabuquerque Lins, } 321 \\
\text { R. Albugereue }\end{array}$ & carga e descarga & $\begin{array}{ll}\mathrm{FlV} \\
\text { outros }\end{array}$ \\
\hline $\begin{array}{l}04 / 1 / 1213 \\
04 / 12 / 13\end{array}$ & $\begin{array}{l}{ }_{B}^{B} \text { - AL } \\
B_{\text {AL }}\end{array}$ & $\begin{array}{l}7 \\
8\end{array}$ & $\begin{array}{l}\text { Palmeiras } \\
\text { Eduana }\end{array}$ & $\begin{array}{c}\text { padara } \\
\text { restaurante }\end{array}$ & $\begin{array}{l}\text { n.id. } \\
\text { Horta Leve }\end{array}$ & $\begin{array}{l}\text { Vuc pequeno } \\
\text { van }\end{array}$ & $\begin{array}{c}\text { Aberto } \\
\text { traseiralateral }\end{array}$ & $\begin{array}{l}\text { endereço } \\
\text { endereco }\end{array}$ & $\begin{array}{l}\text { R: Albuquergue Lins, } 321 \\
\text { : Albuquerque Liss, } 350\end{array}$ & $\begin{array}{l}\text { carga e edeccarga } \\
\text { outro }\end{array}$ & $\begin{array}{c}\text { outros } \\
\text { FV }\end{array}$ \\
\hline 04/12/13 & BAL & 9 & $\begin{array}{l}\text { Palmeiras } \\
\text { Pals }\end{array}$ & padaria & Nestle & van & $\begin{array}{l}\text { lateral } \\
\text { lat }\end{array}$ & endereco & R: Albuquerque Lins, 371 & carga e descarga & mercearia seca em geral \\
\hline $04 / 12 / 13$ & B_AL & 10 & Palmeiras & padaria & Quejio & kombi & lateral & endereço & R: Albuquerque Lins, 327 & carga e descarga & frios/embutidos \\
\hline $04 / 12 / 13$ & B_AL & 11 & Palmeiras & padaria & Ambev & utilitário & traseira & em frente ao estabelecimento & & carga e descarga & bebidas \\
\hline $04 / 12 / 13$ & B-AL & 12 & MJE & bombonière & Bonafont & vuc grande & lateral & endereço & R: Albuquerque Lins,281 & carga e descarga & bebidas \\
\hline $04 / 12 / 13$ & B_AL & 13 & Palmeiras & padaria & Supermax & vuc grande & traseira & enderesco & R: Albuquerque Lins, 327 & carga e descarga & outros \\
\hline 04/12/133 & B_AL & 14 & $\begin{array}{l}\text { Palmeiras } \\
\text { Edyana }\end{array}$ & $\begin{array}{l}\text { padaria } \\
\text { pesturante }\end{array}$ & $\begin{array}{l}\text { Leite } \\
\text { Álkolat L }\end{array}$ & $\begin{array}{l}\text { van } \\
\text { vay }\end{array}$ & $\begin{array}{l}\text { lateral } \\
\text { lateral }\end{array}$ & $\begin{array}{l}\text { endereço } \\
\text { em frente a o stabelecimento }\end{array}$ & R: Albuquerque Lins, 353 & carga e descarga & $\begin{array}{l}\text { laticínios } \\
\text { entros }\end{array}$ \\
\hline 04/12/133 & B_AL & $\begin{array}{l}15 \\
16\end{array}$ & $\begin{array}{l}\text { Eduana } \\
\text { Palmeiras }\end{array}$ & restaurante & $\begin{array}{l}\text { Alcool } \\
\text { PO }\end{array}$ & vuc grande & lateral & em frente ao estabelecimento & B.Alturueraye Lins, 353 & carga e descarga & $\begin{array}{l}\text { outros } \\
\text { outros }\end{array}$ \\
\hline 04/12/13 & B-AL & 17 & MIE & $\begin{array}{l}\text { pauand } \\
\text { bomboniere }\end{array}$ & Doces e Sabor & vuc prande & 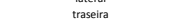 & em frente ao estabelecimento & & carga e descarga & $\begin{array}{l}\text { surtus } \\
\text { snacks }\end{array}$ \\
\hline $04 / 12 / 13$ & BAL & 18 & Bar & bar tradicional & n.id. & utilitário & traseira & endereço & R: Albuquerque Lins, 343 & carga e descarga & bebidas \\
\hline $05 / 12 / 13$ & B_AL & 1 & Palmeiras & padaria & n.id. & utilitário & & em frente ao estabelecimento & & outro & n.id. \\
\hline $05 / 12 / 13$ & $\mathrm{~B}_{-} \mathrm{AL}$ & 2 & Palmeiras & padaria & n.id. & van & lateral & em frente ao estabelecimento & & carga e descarga & mercearia seca em geral \\
\hline $05 / 12 / 13$ & B_AL & 3 & Palmeiras & padaria & Alliz & utilitário & traseira & em frente ao estabelecimento & S & carga e descarga & carnes \\
\hline $\begin{array}{l}05 / 1 / 1 / 13 \\
05 / 12 / 13\end{array}$ & $\begin{array}{l}\text { B_AL } \\
B_{\text {B }} \text { AL }\end{array}$ & $\begin{array}{l}4 \\
5\end{array}$ & $\begin{array}{l}\text { Palmeiras } \\
\text { Palmeiras }\end{array}$ & $\begin{array}{l}\text { padaria } \\
\text { padaria }\end{array}$ & $\begin{array}{l}\text { Acai frooty } \\
\text { Hortifituti Campestre }\end{array}$ & $\begin{array}{l}\text { vuc grande } \\
\text { vuc grande }\end{array}$ & $\begin{array}{l}\text { traseira///ateral } \\
\text { lateral }\end{array}$ & $\begin{array}{l}\text { enddereso } \\
\text { endereco }\end{array}$ & $\begin{array}{l}\text { R: Albuqueqruue Lins, } 361 \\
\text { R: das Palmeiras }\end{array}$ & & $\begin{array}{c}\text { outros } \\
\text { fEy }\end{array}$ \\
\hline & & & & & & & & & & & \\
\hline
\end{tabular}




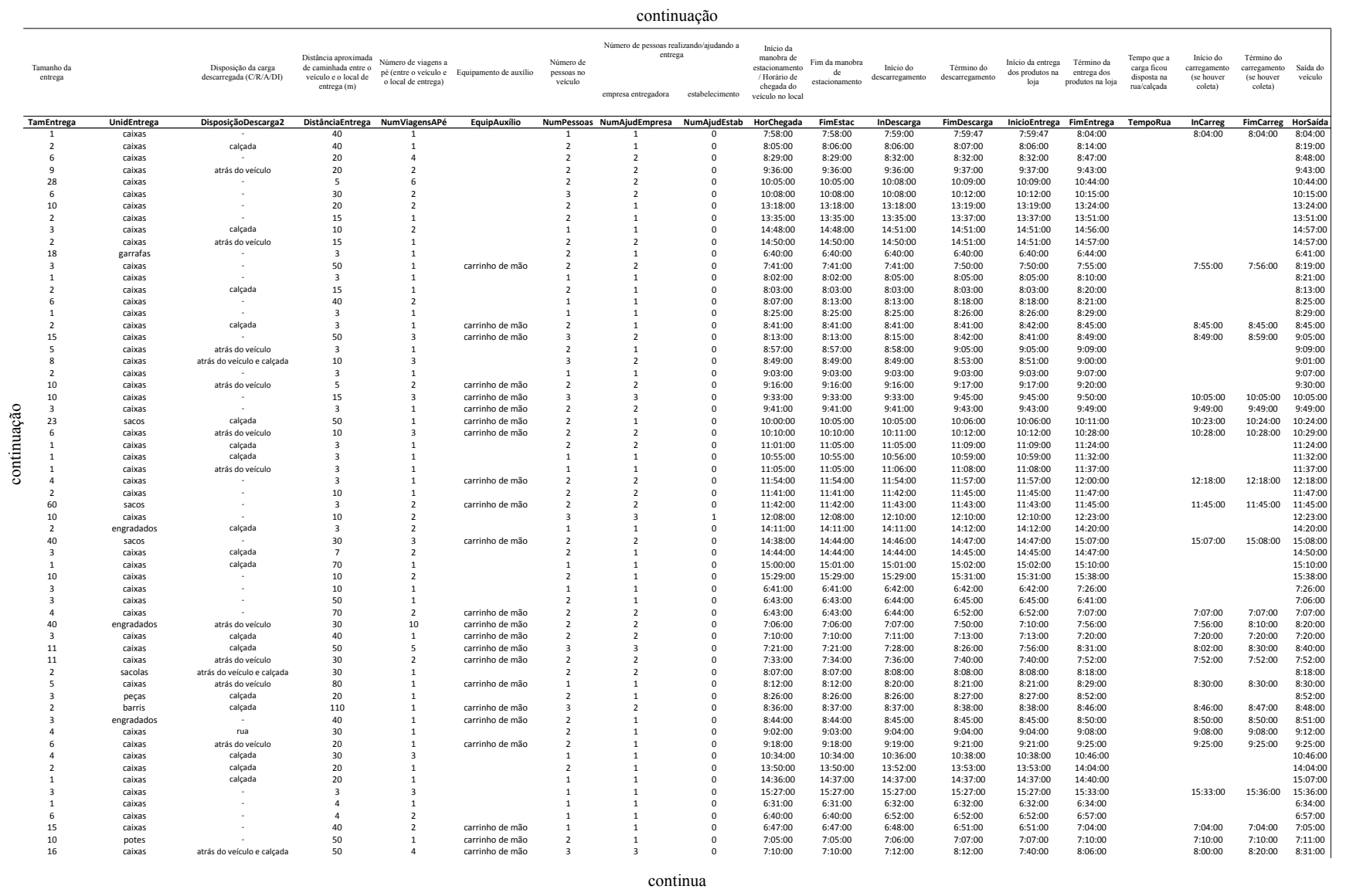




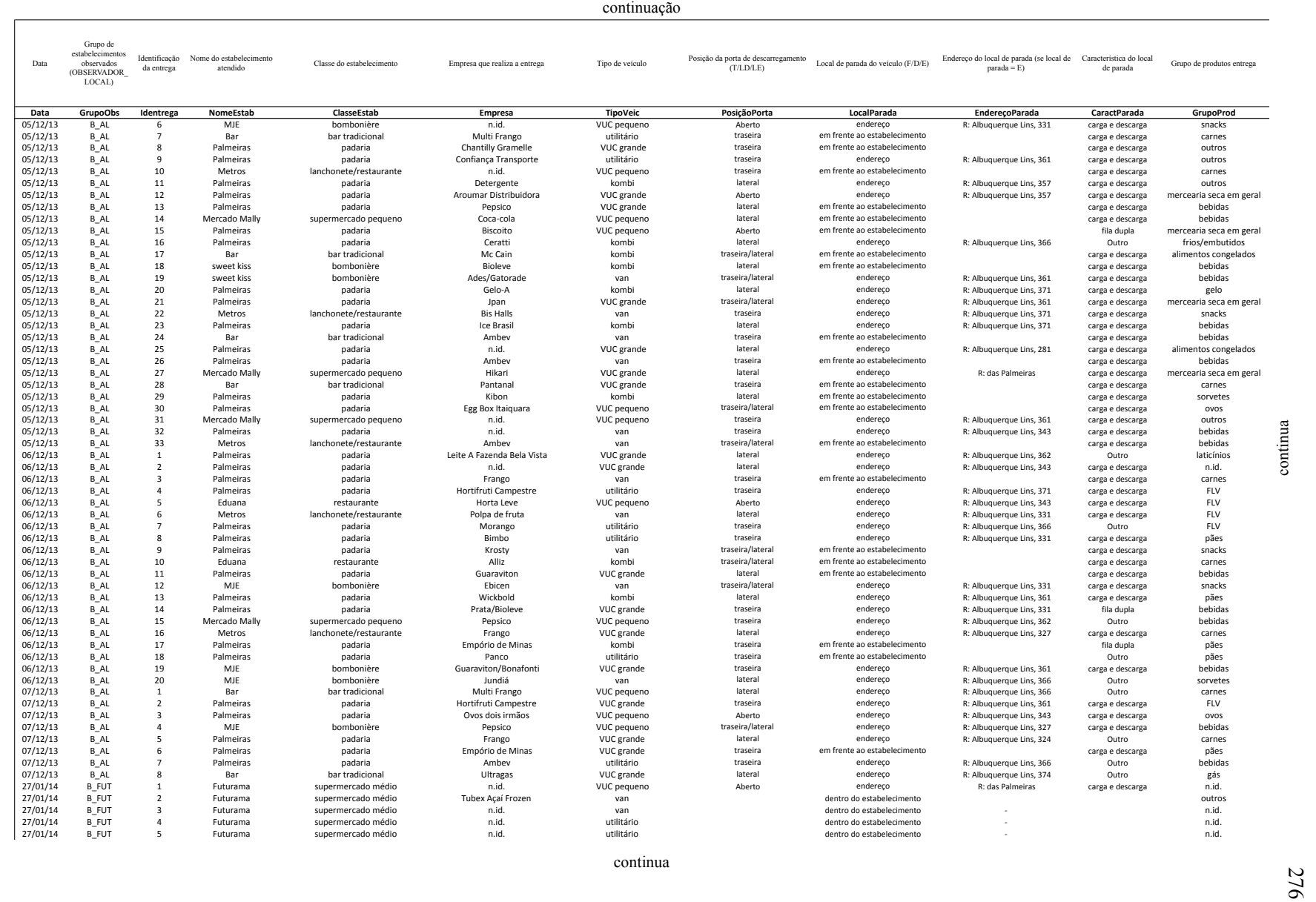




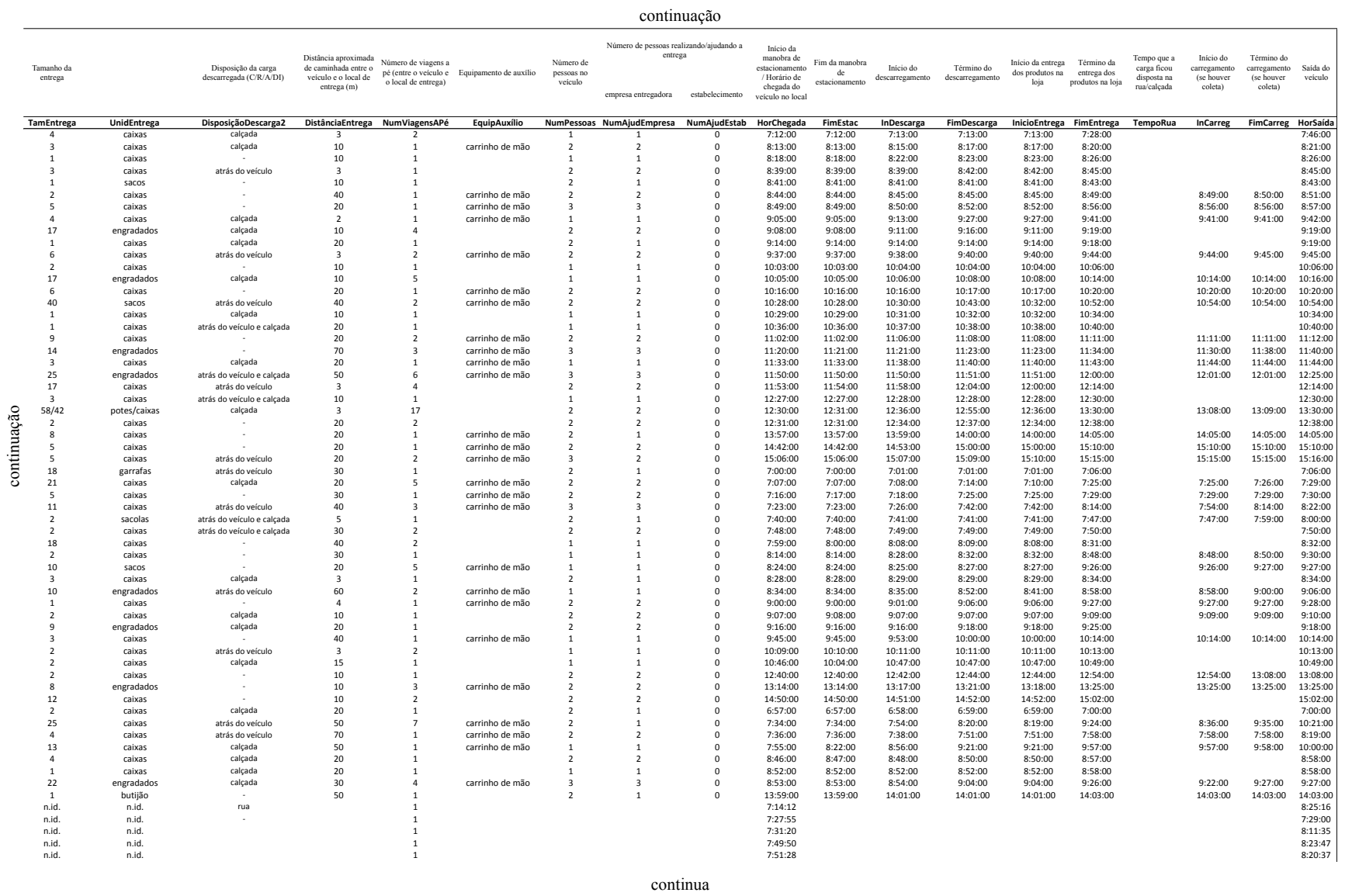


continuação

\begin{tabular}{|c|c|c|c|c|c|c|c|c|c|c|c|}
\hline Data & 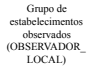 & $\begin{array}{l}\text { Identificasaio } \\
\text { da entroga }\end{array}$ & $\begin{array}{l}\text { Nome do sestableceimento } \\
\text { attendido }\end{array}$ & Classe do stabelceimento & Empresa que realiza a cnrrega & Tipo de veiculo & $\begin{array}{l}\text { Posiciáo da porta de descarregamento } \\
\text { (T/LD:LE) }\end{array}$ & Local de parada do v veciculo (FDDE) & 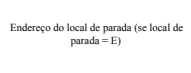 & $\begin{array}{l}\text { Caracteristica do local } \\
\text { de pernada }\end{array}$ & Girpo de produtus entrega \\
\hline Data & Grupoobs & Identrega & NomeEstab & Classeestab & Empresa & Tipoveic & PosiçăoPorta & $\begin{array}{l}\text { LocalParada } \\
\end{array}$ & Endereçoparada & CaractParada & GrupoProd \\
\hline $27 / 01 / 14$ & & & Futurama & supermercado médio & Frozen Logística & kombi & & & & & n.id. \\
\hline $27 / 01 / 14$ & B-FUT & 7 & Futurama & supermercado médio & n.id. & VUC pequeno & & $\begin{array}{l}\text { dentro do estabelecimento } \\
\text { ene }\end{array}$ & & & n.id. \\
\hline 27//01/14 & B.FUT & 8 & Futurama & supermercado médio & n.id. & van & & dentro do estabelecimento & & & n.id. \\
\hline 27/01/14 & B_FUT & 9 & Futurama & $\begin{array}{l}\text { supermercado médio } \\
\text { sunermercadomedio }\end{array}$ & n.id. & vuc pequeno & & dentro do estabelecimento & & & n.id. \\
\hline $\begin{array}{l}27 / 01 / 14 \\
2701 / 14\end{array}$ & $\begin{array}{l}\text { B_FUT } \\
B_{B \cup U T}\end{array}$ & $\begin{array}{l}10 \\
11\end{array}$ & $\begin{array}{l}\text { Futurama } \\
\text { Futurama }\end{array}$ & $\begin{array}{l}\text { supermercado médio } \\
\text { supermercado medio }\end{array}$ & $\begin{array}{l}\text { n.id. } \\
\text { Creme mel }\end{array}$ & $\begin{array}{l}\text { vuc grande } \\
\text { kombi }\end{array}$ & & $\begin{array}{l}\text { dentro do estabelecimento } \\
\text { dentro do estabelecimento }\end{array}$ & & & $\begin{array}{c}\text { n.id. } \\
\text { sorvetes }\end{array}$ \\
\hline $\begin{array}{l}27701 / 114 \\
27 / 01 / 14\end{array}$ & $\begin{array}{l}\text { BB.UT } \\
\text { BEUT }\end{array}$ & $\begin{array}{l}11 \\
12\end{array}$ & $\begin{array}{l}\text { Futurama } \\
\text { Futurama }\end{array}$ & $\begin{array}{l}\text { supermercadodo medio } \\
\text { supermercado médio }\end{array}$ & $\begin{array}{l}\text { Păo italiano Famiglia Franciulli } \\
\text { Pare }\end{array}$ & $\begin{array}{l}\text { kombi } \\
\text { vuc pequeno }\end{array}$ & & $\begin{array}{l}\text { dentrodo estabelecimento } \\
\text { dentro do stabelecimento }\end{array}$ & & & $\begin{array}{l}\text { sorvetes } \\
\text { pães }\end{array}$ \\
\hline $\begin{array}{l}27 / 00 / 14 \\
2714\end{array}$ & B. & 13 & $\begin{array}{l}\text { Futurama } \\
\text { Futurama }\end{array}$ & $\begin{array}{l}\text { supermercadodo medio } \\
\text { supermercado médio }\end{array}$ & 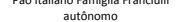 & $\begin{array}{l}\text { vucpequeno } \\
\text { utilitário }\end{array}$ & & dentro do estabelececimento & & & $\begin{array}{l}\text { paes } \\
\text { FLV }\end{array}$ \\
\hline $27 / 01 / 14$ & B FUT & 14 & Futurama & supermercado médio & Bimbo & van & & dentro do estabelecimento & & & päes \\
\hline $27 / 01 / 14$ & B.FUT & 15 & Futurama & supermercado médio & Dom Angelo & vuc grande & & dentro do estabelecimento & & & n.id. \\
\hline $27 / 01 / 14$ & B.FUT & 16 & Futurama & supermercado médio & n.id. & vuc grande & & dentro do estabelecimento & & & n.id. \\
\hline 27/001/14 & B.FUT & 17 & Futurama & supermercado médio & n.id. & vuc pequeno & & dentro do estabelecimento & & & n.id. \\
\hline $\begin{array}{l}27 / 01 / 14 \\
2701 / 144\end{array}$ & $\begin{array}{l}B \text { BEUT } \\
B \text { BUT }\end{array}$ & 18 & $\begin{array}{l}\text { Futurama } \\
\text { Fetrama }\end{array}$ & $\begin{array}{l}\text { supermercado médio } \\
\text { sumermercado medsio }\end{array}$ & $\begin{array}{l}\text { n.id. } \\
\text { nid. }\end{array}$ & $\begin{array}{l}\text { vuc grande } \\
\text { kombi }\end{array}$ & & $\begin{array}{l}\text { dentro do estabelecimento } \\
\text { dentrodo estableccimenta }\end{array}$ & & & n.id. \\
\hline $\begin{array}{l}27701 / 114 \\
27 / 01 / 14\end{array}$ & $\begin{array}{l}\text { B. EUT } \\
\text { BFUT }\end{array}$ & $\begin{array}{l}19 \\
20\end{array}$ & $\begin{array}{l}\text { Futurama } \\
\text { Futurama }\end{array}$ & $\begin{array}{l}\text { supermercadodo medio } \\
\text { supermercado médio }\end{array}$ & $\begin{array}{l}\text { nitd. } \\
\text { Minalba }\end{array}$ & $\begin{array}{l}\text { kombi } \\
\text { van }\end{array}$ & & $\begin{array}{l}\text { dentro do estabelecimento } \\
\text { dentro do stabelecimento }\end{array}$ & & & $\begin{array}{l}\text { carnes } \\
\text { bebidas }\end{array}$ \\
\hline $\begin{array}{l}27 / 01 / 14 \\
2714\end{array}$ & 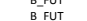 & 21 & $\begin{array}{l}\text { Futurama } \\
\text { Futurama }\end{array}$ & $\begin{array}{l}\text { Supermercado mededio } \\
\text { supermercado médio }\end{array}$ & $\begin{array}{l}\text { Minnaiod } \\
\text { Yakult }\end{array}$ & $\begin{array}{l}\text { van } \\
\text { vuc grande }\end{array}$ & & $\begin{array}{l}\text { dentro o e stabelecimento } \\
\text { dentro do estabelecimento }\end{array}$ & & & $\begin{array}{l}\text { Deloads } \\
\text { laticinios }\end{array}$ \\
\hline 27/01/14 & BFUT & 22 & Futurama & supermercado médio & n.id. & kombi & & $\begin{array}{l}\text { dentro do se estabelecimento } \\
\text { dentro do }\end{array}$ & & & $\begin{array}{l}\text { artemilios } \\
\text { nid. }\end{array}$ \\
\hline $27 / 01 / 14$ & B-FUT & 23 & Futurama & supermercado médio & Brico Bread & kombi & & dentro do estabelecimento & & & păes \\
\hline 27/01/14 & B & 24 & Futurama & supermercado médio & n.id. & Tосо & & dentro do estabelecimento & & & n.id. \\
\hline 27/001/14 & B.FUT & 25 & Futurama & supermercado médio & Banana Boat & vuc pequeno & & dentro do estabelecimento & & & outros \\
\hline 27/01/14 & B_FUT & 26 & Futurama & supermercado médio & n.id. & vuc grande & & dentro do estabelecimento & - & & n.id. \\
\hline 27/01/14 & B_FUT & 27 & Futurama & supermercado médio & n.id. & utilitário & & dentro do estabelecimento & & & n.id. \\
\hline 27/01/14 & B_FUT & & Futurama & & n.id. & van & & dentro do estabelecimento & & & n.id. \\
\hline 27/01/14 & B_FUT & 29 & Futurama & supermercado médio & n.id. & van & & dentro do estabelecimento & & & n.id. \\
\hline 27/01/14 & B_FUT & 30 & Futurama & supermercado médio & n.id. & VUC pequeno & & dentro do estabelecimento & & & n.id. \\
\hline 27/01/14 & $\begin{array}{l}\text { B_FFT } \\
\text { B FUT }\end{array}$ & ${ }_{32}^{31}$ & Futurama & supermercado médio & n.id. & kombi & & dentro do estabelecimento & & & n.id. \\
\hline $\begin{array}{l}27 / 01 / 144 \\
27 / 14\end{array}$ & $\begin{array}{l}\text { B_EOT } \\
\text { B FUT }\end{array}$ & $\begin{array}{l}32 \\
33\end{array}$ & $\begin{array}{l}\text { Futurama } \\
\text { Futurama }\end{array}$ & $\begin{array}{l}\text { supermercado mededio } \\
\text { supermercado médio }\end{array}$ & $\begin{array}{l}\text { n.id. } \\
\text { n.i.d. }\end{array}$ & $\begin{array}{l}\text { Vuc pequeno } \\
\text { van }\end{array}$ & & $\begin{array}{l}\text { dentro do estabelecimento } \\
\text { dentro do stabelecimento }\end{array}$ & & & nidi. \\
\hline $27 / 01 / 14$ & $\begin{array}{ll} & \\
B\end{array}$ & 34 & Futurama & $\begin{array}{l}\text { supermerccaco teato } \\
\text { supermercado médio }\end{array}$ & $\begin{array}{l}\text { n.t. } \\
\text { n.id. }\end{array}$ & $\begin{array}{l}\text { van } \\
\text { utilitário }\end{array}$ & & $\begin{array}{l}\text { dentro o e stabelecimento } \\
\text { dentro do estabelecimento }\end{array}$ & & & $\begin{array}{l}\text { n.tad. } \\
\text { n.id. }\end{array}$ \\
\hline $27 / 01 / 14$ & ( & 35 & Futurama & supermercado médio & n.id. & $\begin{array}{l}\text { vuc pequeno } \\
\text { vul }\end{array}$ & & dentro do estabelecimento & & & n.id. \\
\hline 28/01/14 & B_FUT & 1 & Futurama & supermercado médio & Wickbold & vuc pequeno & & dentro do estabelecimento & & & päes \\
\hline $28 / 01 / 14$ & B_FUT & 2 & Futurama & supermercado médio & n.id. & VUC pequeno & & dentro do estabelecimento & . & & n.id. \\
\hline 28/01/14 & B_FUT & 3 & Futurama & supermercado médio & Turma da Mônica & van & & dentro do estabelecimento & & & FLV \\
\hline 28/01/14 & B_FUT & 4 & Futurama & supermercado médio & n.id. & VUC pequeno & & dentro do estabelecimento & & & n.id. \\
\hline 28/01/14 & B_FUT & 5 & Futurama & supermercado médio & n.id. & van & & dentro do estabelecimento & & & n.id. \\
\hline $\begin{array}{l}28801 / 114 \\
28 / 01 / 14\end{array}$ & 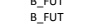 & $\begin{array}{l}6 \\
7\end{array}$ & $\begin{array}{l}\text { Futurama } \\
\text { Futurama }\end{array}$ & $\begin{array}{l}\text { supermercado mededio } \\
\text { supermercado médio }\end{array}$ & $\begin{array}{l}\text { n.id. } \\
\text { Netsle Sovertes }\end{array}$ & $\begin{array}{l}\text { vuC grande } \\
\text { vuc pequeno }\end{array}$ & & $\begin{array}{l}\text { dentro do estabelecimento } \\
\text { dentro do estabelecimento }\end{array}$ & : & & $\begin{array}{l}\text { n.id. } \\
\text { sorvetes }\end{array}$ \\
\hline $\begin{array}{l}28 / 01 / 14 \\
2814\end{array}$ & BFUT & 8 & Futurama & supermercado médio & Horta e Vida & vuc grande & & $\begin{array}{l}\text { dentro do sestabelecimento } \\
\text { dentro do estabelecimento }\end{array}$ & : & & $\begin{array}{l}\text { Sorvetes } \\
\text { FLV }\end{array}$ \\
\hline $28 / 01 / 14$ & B_FUT & 9 & Futurama & supermercado médio & n.id. & vuc grande & & dentro do estabelecimento & & & n.id. \\
\hline $28 / 01 / 14$ & B_FUT & 10 & Futurama & supermercado médio & Alhão & TOCO & & dentro do estabelecimento & & & n.id. \\
\hline $28 / 01 / 14$ & B_FUT & 11 & Futurama & supermercado médio & Panco & kombi & & dentro do estabelecimento & & & pāes \\
\hline 28/01/14 & B_FUT & 12 & Futurama & supermercado médio & n.id. & VuC grande & & dentro do estabelecimento & & & n.id. \\
\hline 28/01/14 & B_FUT & 13 & Futurama & supermercado médio & Floradi & kombi & & dentro do estabelecimento & & & n.id. \\
\hline $\begin{array}{l}28 / 01 / 144 \\
28 / 01 / 14\end{array}$ & $\begin{array}{l}\text { B. EUT } \\
\text { BFUT }\end{array}$ & $\begin{array}{l}14 \\
15\end{array}$ & & 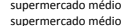 & 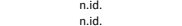 & $\begin{array}{l}\text { vuc grande } \\
\text { van }\end{array}$ & & $\begin{array}{l}\text { dentrod o estabelecimento } \\
\text { dentro do stabelecimento }\end{array}$ & & & n.id. \\
\hline $\begin{array}{l}28 / 01 / 144 \\
28 / 14\end{array}$ & 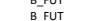 & 16 & $\begin{array}{l}\text { Futurama } \\
\text { Futurama }\end{array}$ & $\begin{array}{l}\text { Supermercado medélio } \\
\text { supermercado médio }\end{array}$ & $\begin{array}{c}\text { n.id. } \\
\text { n.id. }\end{array}$ & $\begin{array}{l}\text { van } \\
\text { Toco }\end{array}$ & & $\begin{array}{l}\text { dentro do estabelecimento } \\
\text { dentro do estabelecimento }\end{array}$ & & & $\begin{array}{l}\mathrm{FV} \\
\text { n.id. }\end{array}$ \\
\hline $28 / 01 / 14$ & BFUT & 17 & Futurama & supermercado médio & Yakult & vuc pequeno & & $\begin{array}{l}\text { dentro do se estabelecimento } \\
\text { dentro do stablecimento }\end{array}$ & : & & $\begin{array}{l}\text { nild. } \\
\text { laticinios }\end{array}$ \\
\hline $28 / 01 / 14$ & B_FUT & 18 & Futurama & supermercado médio & n.id. & kombi & & dentro do estabelecimento & & & n.id. \\
\hline $28 / 01 / 14$ & B_FUT & 19 & Futurama & supermercado médio & n.id. & van & & dentro do estabelecimento & . & & n.id. \\
\hline 28/01/14 & B_FUT & 20 & Futurama & supermercado médio & Xandố & VUC pequeno & & dentro do estabelecimento & & & laticinios \\
\hline 28/01/14 & B_FUT & 21 & Futurama & supermercado médio & n.id. & van & & dentro do estabelecimento & & & n.id. \\
\hline $28 / 01 / 14$ & B_FUT & ${ }_{23}^{22}$ & $\begin{array}{l}\text { Futurama } \\
\text { Feturam }\end{array}$ & $\begin{array}{l}\text { supermercado médio } \\
\text { sunermercastomedio }\end{array}$ & Panco & vuc pequeno & & 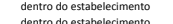 & & & päes \\
\hline $\begin{array}{l}28801 / 114 \\
28 / 01 / 14\end{array}$ & $\begin{array}{l}\text { B-FET } \\
\text { B.FUT }\end{array}$ & $\begin{array}{l}23 \\
24\end{array}$ & $\begin{array}{l}\text { Futurama } \\
\text { Futurama }\end{array}$ & $\begin{array}{l}\text { Supermercado mededio } \\
\text { supermercado médio }\end{array}$ & $\begin{array}{l}\text { n.id. } \\
\text { n.id. }\end{array}$ & $\begin{array}{l}\text { vuc grande } \\
\text { vuc prande }\end{array}$ & & $\begin{array}{l}\text { dentro do estabelecimento } \\
\text { dentro do stabelecimento }\end{array}$ & & & $\begin{array}{l}\text { paes } \\
\text { nid. }\end{array}$ \\
\hline $\begin{array}{l}28 / 01 / 144 \\
28 / 14\end{array}$ & B FUT & ${ }_{25}^{24}$ & $\begin{array}{l}\text { Futuramaa } \\
\text { Futurata }\end{array}$ & $\begin{array}{l}\text { Supermercado medélio } \\
\text { supermercado médio }\end{array}$ & $\begin{array}{l}\text { n.id. } \\
\text { n.i.d. }\end{array}$ & $\begin{array}{l}\text { vuc granoe } \\
\text { vuc rande }\end{array}$ & & $\begin{array}{l}\text { dentro do stabelecimento } \\
\text { dentro do estabelecimento }\end{array}$ & & & $\begin{array}{l}\text { nila. } \\
\text { n.id. }\end{array}$ \\
\hline $\begin{array}{l}28 / 01 / 14 \\
2814\end{array}$ & B_fUT & 26 & Futurama & supermercado médio & Kim & $\begin{array}{l}\text { VUC pequeno } \\
\text { vent }\end{array}$ & & dentro do estabelecimento & & & carnes \\
\hline $28 / 01 / 14$ & B_FUT & 27 & Futurama & supermercado médio & n.id. & vuc grande & & dentro do estabelecimento & & & n.id. \\
\hline $28 / 01 / 14$ & B_Fut & 28 & Futurama & supermercado médio & n.id. & Vuc pequeno & & dentro do estabelecimento & & & n.id. \\
\hline 28/01/14 & B_FUT & 29 & Futurama & supermercado médio & Leite A Fazenda Bela Vista & VUC pequeno & & dentro do estabelecimento & & & laticicios \\
\hline \multirow[t]{2}{*}{$28 / 01 / 14$} & $\begin{array}{l}\text { B. BUT } \\
\text { B, FUT }\end{array}$ & $\begin{array}{l}30 \\
31\end{array}$ & $\begin{array}{l}\text { Futurama } \\
\text { Futurama }\end{array}$ & $\begin{array}{l}\text { Supermercado ódio } \\
\text { supermercado médio }\end{array}$ & $\begin{array}{l}\text { Barontiniti. Frigorifico } \\
\text { B. }\end{array}$ & $\begin{array}{l}\text { vuc grande } \\
\text { kombi }\end{array}$ & & 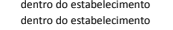 & & & $\begin{array}{l}\text { ni.id. } \\
\text { carnes }\end{array}$ \\
\hline & & & & & & contin & & & & & \\
\hline
\end{tabular}




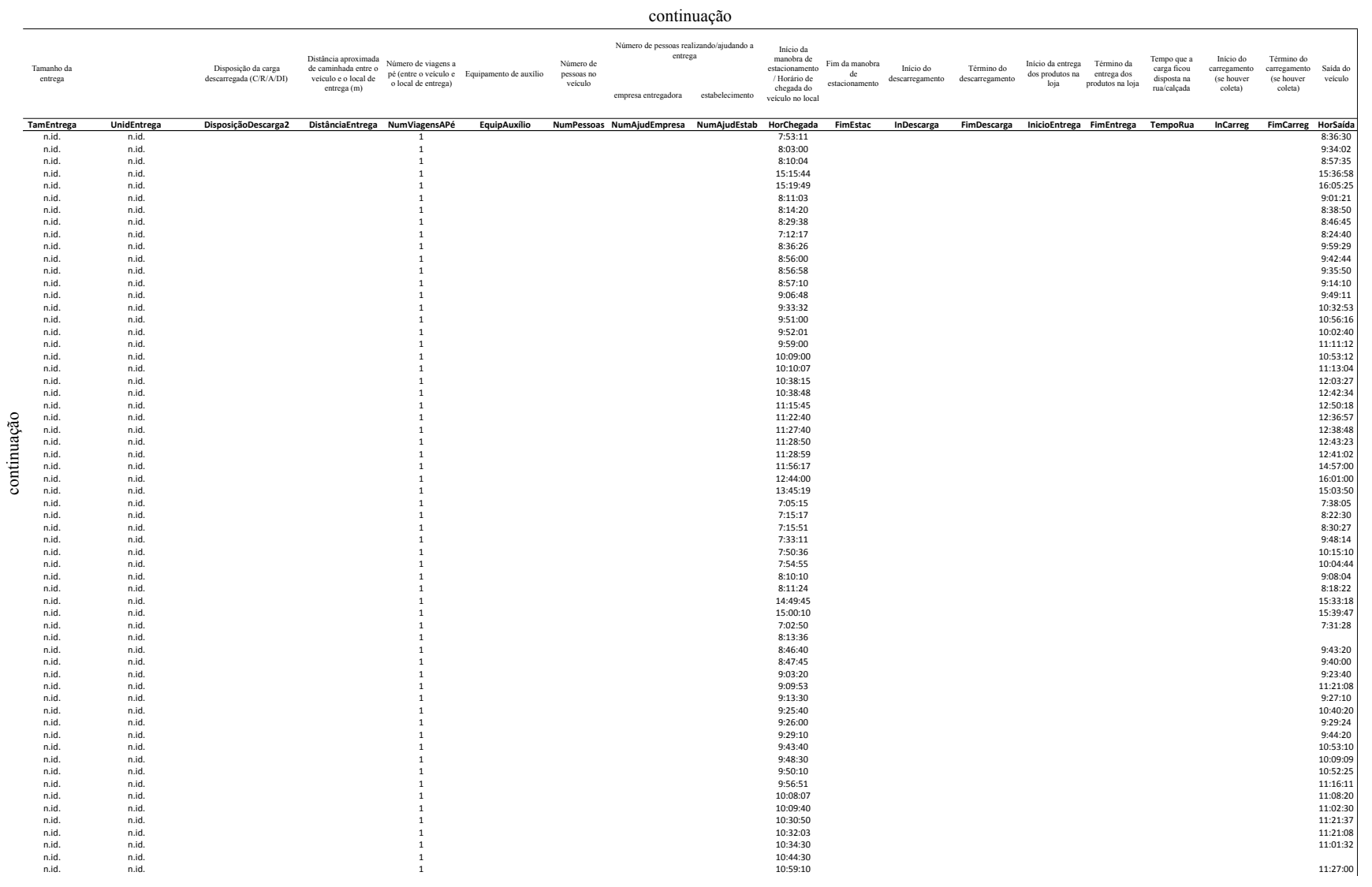

continua 
continuação

\begin{tabular}{|c|c|c|c|c|c|c|c|c|c|c|c|}
\hline Data & 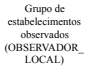 & $\begin{array}{l}\text { Identinicatago } \\
\text { da antrega }\end{array}$ & $\begin{array}{l}\text { Nome do cestablecicimento } \\
\text { atennido }\end{array}$ & Classe do stablecleinento & Empresa que realiza a entrega & Tipo de veiculo & $\begin{array}{l}\text { Posiçâa da porta de descarregamento } \\
\text { (TLLDLE) }\end{array}$ & Local de parada do veciculo (F,DE) & $\begin{array}{l}\text { Endercego do local de parada (se local de } \\
\text { parada }=\text { E) }\end{array}$ & $\begin{array}{l}\text { Caracterisicica do ocal } \\
\text { de parada }\end{array}$ & Ginpo de produtus entrega \\
\hline Data & Grupoobs & Identrega & NomeEstab & Classetstab & Empresa & Tipoveic & Posiçăoporta & $\begin{array}{l}\text { LocalParada } \\
\end{array}$ & EndereçoParada & CaractParada & GrupoProd \\
\hline $28 / 01 / 14$ & $B_{-F U T}$ & 32 & Futurama & supermercado médio & n.id. & Vuc pequeno & (2) & dentro do estabelectimento & (2) & . & n.id. \\
\hline 28/01/14 & B_FUT & 33 & Futurama & supermercado médio & n.id. & vuc grande & & dentro do estabelecimento & & & n.id. \\
\hline $\begin{array}{l}28 / 01 / 14 \\
28 / 0 / 1414\end{array}$ & 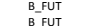 & $\begin{array}{l}34 \\
35\end{array}$ & $\begin{array}{l}\text { Futurama } \\
\text { Futurama }\end{array}$ & $\begin{array}{l}\text { supermercado médio } \\
\text { suuermercado medoio }\end{array}$ & $\begin{array}{l}\text { n.id. } \\
\text { nid. }\end{array}$ & $\begin{array}{l}\text { van } \\
\text { vuc cequeno }\end{array}$ & & $\begin{array}{l}\text { dentro do estabelecimento } \\
\text { Pats }\end{array}$ & & & n.id. \\
\hline $\begin{array}{l}28 / 01 / 14 \\
29 / 14\end{array}$ & $\begin{array}{l}B_{B}^{B} \text { B Fut } \\
B_{-} \text {FUT }\end{array}$ & $\begin{array}{c}35 \\
1\end{array}$ & $\begin{array}{l}\text { Futurama } \\
\text { Futurama }\end{array}$ & $\begin{array}{l}\text { Supermercadodo medólo } \\
\text { supermercado médio }\end{array}$ & Ovos Caipira Ana Maria Braga & $\begin{array}{l}\text { vuc pequeno } \\
\text { vombi }\end{array}$ & & $\begin{array}{l}\text { dentrodo e establelecimento } \\
\text { dentro do estabelecimento }\end{array}$ & & & $\begin{array}{l}\text { n.id. } \\
\text { ovos }\end{array}$ \\
\hline $29 / 01 / 14$ & B-FUT & 2 & Futurama & supermercado médio & 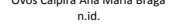 & $\begin{array}{l}\text { Kambl } \\
\text { van }\end{array}$ & & $\begin{array}{l}\text { dentro do estabelecimento } \\
\text { dentro do estabelecimento }\end{array}$ & & & $\begin{array}{l}\text { ovos } \\
\text { n.id. }\end{array}$ \\
\hline 29/01/14 & B_FUT & 3 & Futurama & supermercado médio & Batavo & vuc grande & & dentro do estabelecimento & & & $\begin{array}{l}\text { laticinios } \\
\text { lations }\end{array}$ \\
\hline $29 / 01 / 14$ & B_FUT & 4 & Futurama & supermercado médio & n.id. & vuc grande & & dentro do estabelecimento & & & n.id. \\
\hline 29/01/14 & B_Fut & 5 & Futurama & supermercado médio & n.id. & van & & dentro do estabelecimento & & & n.id. \\
\hline $29 / 01 / 14$ & B_FUT & 6 & Futurama & supermercado médio & n.id. & vuc pequeno & & dentro do estabelecimento & & & n.id. \\
\hline 29/01/14 & $\begin{array}{l}\text { B_FUT } \\
\text { B.FUT }\end{array}$ & 7 & Futurama & supermercado médio & Brico Bread & vuc grande & & dentro do estabelecimento & & & păes \\
\hline $\begin{array}{l}29 / 01 / 14 \\
29 / 01 / 14\end{array}$ & $\begin{array}{l}\text { B_FUT } \\
\text { B.FUT }\end{array}$ & ${ }_{9}^{8}$ & $\begin{array}{l}\text { Futurama } \\
\text { Futurama }\end{array}$ & $\begin{array}{l}\text { Supermercado médio } \\
\text { suuermercado medio }\end{array}$ & $\begin{array}{l}\text { n.id. } \\
\text { nid }\end{array}$ & $\begin{array}{l}\text { vuc grande } \\
\text { vuc grande }\end{array}$ & & $\begin{array}{l}\text { dentro do estabelecimento } \\
\text { dentro o establecemimento }\end{array}$ & & & n.id. \\
\hline $\begin{array}{l}29 / 01 / 144 \\
29 / 14\end{array}$ & 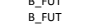 & $\begin{array}{c}9 \\
10\end{array}$ & $\begin{array}{l}\text { luturama } \\
\text { Futurama }\end{array}$ & $\begin{array}{l}\text { Supermerccado medolo } \\
\text { supermercado médio }\end{array}$ & $\begin{array}{l}\text { n.ld. } \\
\text { Minalba }\end{array}$ & $\begin{array}{l}\text { vuc grande } \\
\text { vuc grande }\end{array}$ & & $\begin{array}{l}\text { dentrodo e estabelecimento } \\
\text { dentro do estabelecimento }\end{array}$ & & & $\begin{array}{l}\text { n.t. } \\
\text { bebidas }\end{array}$ \\
\hline $29 / 01 / 14$ & & 11 & Futurama & supermercado médio & Akio & $\begin{array}{l}\text { vuc grande } \\
\text { vande }\end{array}$ & & dentro do estabelecimento & & & mercearia seca em geral \\
\hline $29 / 01 / 14$ & B.FUT & 12 & Futurama & supermercado médio & n.id. & utilitário & & dentro do estabelecimento & & & n.id. \\
\hline $29 / 01 / 14$ & B_FUT & 13 & Futurama & supermercado médio & Yakult & $\begin{array}{l}\text { vuc pequeno } \\
\text { vul }\end{array}$ & & dentro do estabelecimento & & & laticinios \\
\hline $29 / 01 / 14$ & B_FUT & 14 & Futurama & supermercado médio & n.id. & kombi & & dentro do estabelecimento & & & n.id. \\
\hline 29/01/14 & B_FUT & 15 & Futurama & 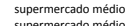 & n.id. & kombi & & dentro do estabelecimento & & & n.id. \\
\hline $\begin{array}{l}29 / / 1 / 14 \\
2901 / 14\end{array}$ & $\begin{array}{l}\text { B_FuT } \\
\text { B.FUT }\end{array}$ & $\begin{array}{l}16 \\
17 \\
17\end{array}$ & 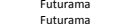 & $\begin{array}{l}\text { supermercado médio } \\
\text { supermercado medio }\end{array}$ & $\begin{array}{l}\text { n.id. } \\
\text { nid. }\end{array}$ & $\begin{array}{l}\text { Vuc pequeno } \\
\text { vuc pequeno }\end{array}$ & & 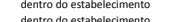 & & & n.id. \\
\hline $\begin{array}{l}29901 / 114 \\
29 / 114\end{array}$ & $\begin{array}{l}\text { B B FuT } \\
\text { B-FUT }\end{array}$ & $\begin{array}{l}17 \\
18\end{array}$ & $\begin{array}{l}\text { Futurama } \\
\text { futurama }\end{array}$ & $\begin{array}{l}\text { Supermercadodo medio } \\
\text { supermercado médio }\end{array}$ & $\begin{array}{l}\text { n.ild. } \\
\text { Ryco }\end{array}$ & $\begin{array}{l}\text { vuc pequeno } \\
\text { vuc pequeno }\end{array}$ & & $\begin{array}{l}\text { dentrodo e estabelecimento } \\
\text { dentro do estabelecimento }\end{array}$ & & & $\begin{array}{l}\text { n.id. } \\
\text { alimentos congelados }\end{array}$ \\
\hline $29 / 01 / 14$ & B_FUT & 19 & $\begin{array}{l}\text { Futuramaa } \\
\text { Futuana }\end{array}$ & $\begin{array}{l}\text { Supermetcraco meatio } \\
\text { supermercado médio }\end{array}$ & $\begin{array}{l}\text { Ryyco } \\
\text { BRF-Sadia }\end{array}$ & $\begin{array}{l}\text { vuc pequeno } \\
\text { van }\end{array}$ & & $\begin{array}{l}\text { aentro do estavelecimento } \\
\text { dentro do estabelecimento }\end{array}$ & & & $\begin{array}{l}\text { ailinentorcongealacos } \\
\text { frios/embutidos }\end{array}$ \\
\hline 29/01/14 & B_FUT & 20 & Futurama & supermercado médio & n.id. & vuc grande & & dentro do estabelecimento & & & n.id. \\
\hline 29/01/14 & B_FUT & 21 & Futurama & supermercado médio & Kibon & vuc grande & & dentro do estabelecimento & & & sorvetes \\
\hline 29/01/14 & B_FUT & 22 & Futurama & supermercado médio & Leite A Fazenda Bela Vista & vUC pequeno & & dentro do estabelecimento & & & laticinios \\
\hline 29/01/14 & B_FUT & 23 & Futurama & supermercado médio & n.id. & vuc grande & & dentro do estabelecimento & & & n.id. \\
\hline 29/01/14 & B_FUT & 24 & Futurama & supermercado médio & Floradi & vuC pequeno & & dentro do estabelecimento & & & n.id. \\
\hline $\begin{array}{l}29 / / 01 / 14 \\
2901 / 14\end{array}$ & $\begin{array}{l}\text { B_FUT } \\
\text { B.FUT }\end{array}$ & $\begin{array}{l}25 \\
26\end{array}$ & $\begin{array}{l}\text { Futurama } \\
\text { Futurama }\end{array}$ & supermercado médio & Xandó & vuc grande & & dentro do estabelecimento & & & laticinios \\
\hline $\begin{array}{l}29 / 01 / 14 \\
29 / 1 / 14\end{array}$ & $\begin{array}{l}\text { S } \\
B \text { FUT }\end{array}$ & 27 & $\begin{array}{l}\text { luturama } \\
\text { Futurama }\end{array}$ & $\begin{array}{l}\text { Supermercado medoro } \\
\text { supermercado médio }\end{array}$ & $\begin{array}{l}\text { n.lld. } \\
\text { n.id. }\end{array}$ & $\begin{array}{l}\text { van } \\
\text { vuc pequeno }\end{array}$ & & $\begin{array}{l}\text { dentro do e stabelecemento } \\
\text { dentro do estabelecimento }\end{array}$ & & & $\begin{array}{l}\text { n.lu. } \\
\text { nid. }\end{array}$ \\
\hline $\begin{array}{l}29 / 01 / 14 \\
29 / 14\end{array}$ & B FUT & 28 & Futurama & supermercado médio & n.id. & 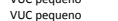 & & dentro do estabelecimento & & & n.id. \\
\hline $29 / 01 / 14$ & B_FUT & 29 & Futurama & supermercado médio & Tio João & 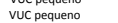 & & dentro do estabelecimento & & & mercearia seca em geral \\
\hline $29 / 01 / 14$ & B_FUT & 30 & Futurama & supermercado médio & n.id. & vuc grande & & dentro do estabelecimento & & & n.id. \\
\hline $29 / 01 / 14$ & B_FUT & 31 & Futurama & supermercado médio & Itaipava & van & & dentro do estabelecimento & & & bebidas \\
\hline 30/01/14 & B_FUT & 1 & Futurama & supermercado médio & Wickbold & van & & dentro do estabelecimento & & & păes \\
\hline 30/01/14 & B_FUT & 2 & Futurama & supermercado médio & Danone & VuC pequeno & & dentro do estabelecimento & & & laticínios \\
\hline $\begin{array}{l}30 / 01 / 14 \\
30 / 01 / 14\end{array}$ & $\begin{array}{l}\text { B_FuT } \\
\text { B.FUT }\end{array}$ & $\begin{array}{l}3 \\
4\end{array}$ & $\begin{array}{l}\text { Futurama } \\
\text { Futurama }\end{array}$ & $\begin{array}{l}\text { 年permercado médio } \\
\text { supermercado édio }\end{array}$ & $\begin{array}{c}\text { n.id. } \\
\text { n.id. }\end{array}$ & $\begin{array}{l}\text { vuc grande } \\
\text { vuc prande }\end{array}$ & & $\begin{array}{l}\text { dentro do estabelecimento } \\
\text { dentro do estabelecimento }\end{array}$ & & & $\begin{array}{c}\text { n.id. } \\
\text { nid }\end{array}$ \\
\hline $\begin{array}{l}30 / 01 / 14 \\
30 / 0 / 14\end{array}$ & $\begin{array}{l}\text { B_FUT } \\
\text { B,FUT }\end{array}$ & $\begin{array}{l}4 \\
5\end{array}$ & $\begin{array}{l}\text { Futurama } \\
\text { Futurama }\end{array}$ & $\begin{array}{l}\text { Supermercado medéio } \\
\text { supermercado médio }\end{array}$ & $\begin{array}{c}\text { n.id. } \\
\text { coca-cola }\end{array}$ & $\begin{array}{l}\text { vuC grande } \\
\text { vuC pequeno }\end{array}$ & & $\begin{array}{l}\text { dentror do e estabelecimento } \\
\text { dentro do estabelecimento }\end{array}$ & & & $\begin{array}{l}\text { n.id. } \\
\text { bebidas }\end{array}$ \\
\hline $30 / 01 / 14$ & B.FUT & 6 & Futurama & supermercado médio & n.id. & $\begin{array}{l}\text { vucequeno } \\
\text { vuc grande }\end{array}$ & & $\begin{array}{l}\text { dentro do estabelecimento } \\
\text { dentro do estabelecimento }\end{array}$ & ${ }^{\circ}$ & & $\begin{array}{l}\text { Deidas } \\
\text { n.id. }\end{array}$ \\
\hline $30 / 01 / 14$ & B_FUT & 32 & Futurama & supermercado médio & Banana Boat - Arcom & vuc grande & lateral & endereço & Av. Angêlica & faixa de tráfego & outros \\
\hline $30 / 01 / 14$ & B_FUT & 33 & Futurama & supermercado médio & n.d. & VuC grande & & dentro do estabelecimento & & & n.id. \\
\hline $30 / 01 / 14$ & B_FUT & 34 & Futurama & supermercado médio & n.id. & vUC grande & & dentro do estabelecimento & & & n.id. \\
\hline 30/01/14 & B_FUT & 34 & Futurama & supermercado médio & n.id. & utilitário & & & & & n.id. \\
\hline $\begin{array}{l}30 / 01 / 14 \\
30 / 01 / 14\end{array}$ & $\begin{array}{l}\text { B_FUT } \\
\text { B FUT }\end{array}$ & $\begin{array}{l}35 \\
36\end{array}$ & $\begin{array}{l}\text { Futurama } \\
\text { Futurama }\end{array}$ & $\begin{array}{l}\text { Supermercado médio } \\
\text { suuermercado medio }\end{array}$ & $\begin{array}{l}\text { n.id. } \\
\text { Panco }\end{array}$ & VUC pequeno & & 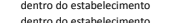 & & & n.id. \\
\hline $\begin{array}{l}30 / 01 / 14 \\
30 / 01 / 14\end{array}$ & $\begin{array}{l}\text { B_fUT } \\
\text { B_FuT }\end{array}$ & $\begin{array}{l}36 \\
37\end{array}$ & $\begin{array}{l}\text { Futurama } \\
\text { Futurama }\end{array}$ & $\begin{array}{l}\text { Supermercado medio } \\
\text { supermercado médio }\end{array}$ & $\begin{array}{l}\text { Panco } \\
\text { n.id. }\end{array}$ & $\begin{array}{l}\text { van } \\
\text { vuc grande }\end{array}$ & & $\begin{array}{l}\text { dentro do e estabelecimento } \\
\text { dentro do estabelecimento }\end{array}$ & & & $\begin{array}{l}\text { paes } \\
\text { n.id. }\end{array}$ \\
\hline 30/01/14 & B_FUT & 38 & $\begin{array}{l}\text { Futurama } \\
\text { feturama }\end{array}$ & supermercado médio & Famiglia Păo Italiano & van & & 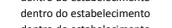 & & & päes \\
\hline 30/01/14 & B_FUT & 39 & Futurama & supermercado médio & Corus Logistica & utilitário & & dentro do estabelecimento & & & n.id. \\
\hline $30 / 01 / 14$ & B_FUT & 40 & Futurama & supermercado médio & n.id. & n:id: & & dentro do estabelecimento & & & n.id. \\
\hline $30 / 01 / 14$ & B_FUT & 41 & Futurama & supermercado médio & n.id. & VuC pequeno & lateral & endereço & Al: Barros (Angélica Grill) & faixa de tráfego & n.id. \\
\hline 30/01/14 & B_FUT & 42 & Futurama & supermercado médio & Yakult & VUC pequeno & & dentro do estabelecimento & & & laticicios \\
\hline $\begin{array}{l}30 / 01 / 14 \\
300 / 144\end{array}$ & $\begin{array}{l}\text { B_FUT } \\
\text { B FUT }\end{array}$ & ${ }_{44}^{43}$ & $\begin{array}{l}\text { Futurama } \\
\text { Futurama }\end{array}$ & $\begin{array}{l}\text { supermercado médio } \\
\text { sumenrmercado medoio }\end{array}$ & n.id. & kombi & & $\begin{array}{l}\text { dentro do estabelecimento } \\
\text { dentro do estabelecimento }\end{array}$ & & & $\begin{array}{c}\text { n.id. } \\
\text { nid }\end{array}$ \\
\hline $\begin{array}{l}30 / 00 / 144 \\
30 / 14\end{array}$ & $\begin{array}{ll} & \\
B\end{array}$ & $\begin{array}{l}44 \\
45\end{array}$ & $\begin{array}{l}\text { luturama } \\
\text { Futurama }\end{array}$ & $\begin{array}{l}\text { supermercado medéio } \\
\text { supermercado médio }\end{array}$ & $\begin{array}{l}\text { n.id. } \\
\text { Naor }\end{array}$ & $\begin{array}{l}\text { van } \\
\text { van }\end{array}$ & & $\begin{array}{l}\text { dentro do o estabelecemento } \\
\text { dentro do estabelecimento }\end{array}$ & & & $\begin{array}{l}\text { n.d. } \\
\text { mercearia seca em geral }\end{array}$ \\
\hline 30/01/14 & B.FUT & 46 & Futurama & supermercado médio & n.id. & van & & dentro do estabelecimento & & & n.id. \\
\hline $30 / 01 / 14$ & B_FUT & 47 & Futurama & supermercado médio & n.id. & kombi & & dentro do estabelecimento & & & n.id. \\
\hline 30/01/14 & B_FUT & 48 & Futurama & supermercado médio & n.id. & vuc pequeno & & dentro do estabelecimento & & & n.id. \\
\hline 30/01/14 & B_FUT & 49 & Futurama & supermercado médio & Horta e Vida & van & & dentro do estabelecimento & & & FLV \\
\hline 30/01/14 & B_FuT & 50 & Futurama & supermercado médio & Xandô & $\begin{array}{l}\text { vuc grande } \\
\text { continua }\end{array}$ & & dentro do estabelecimento & & & laticicinios \\
\hline
\end{tabular}




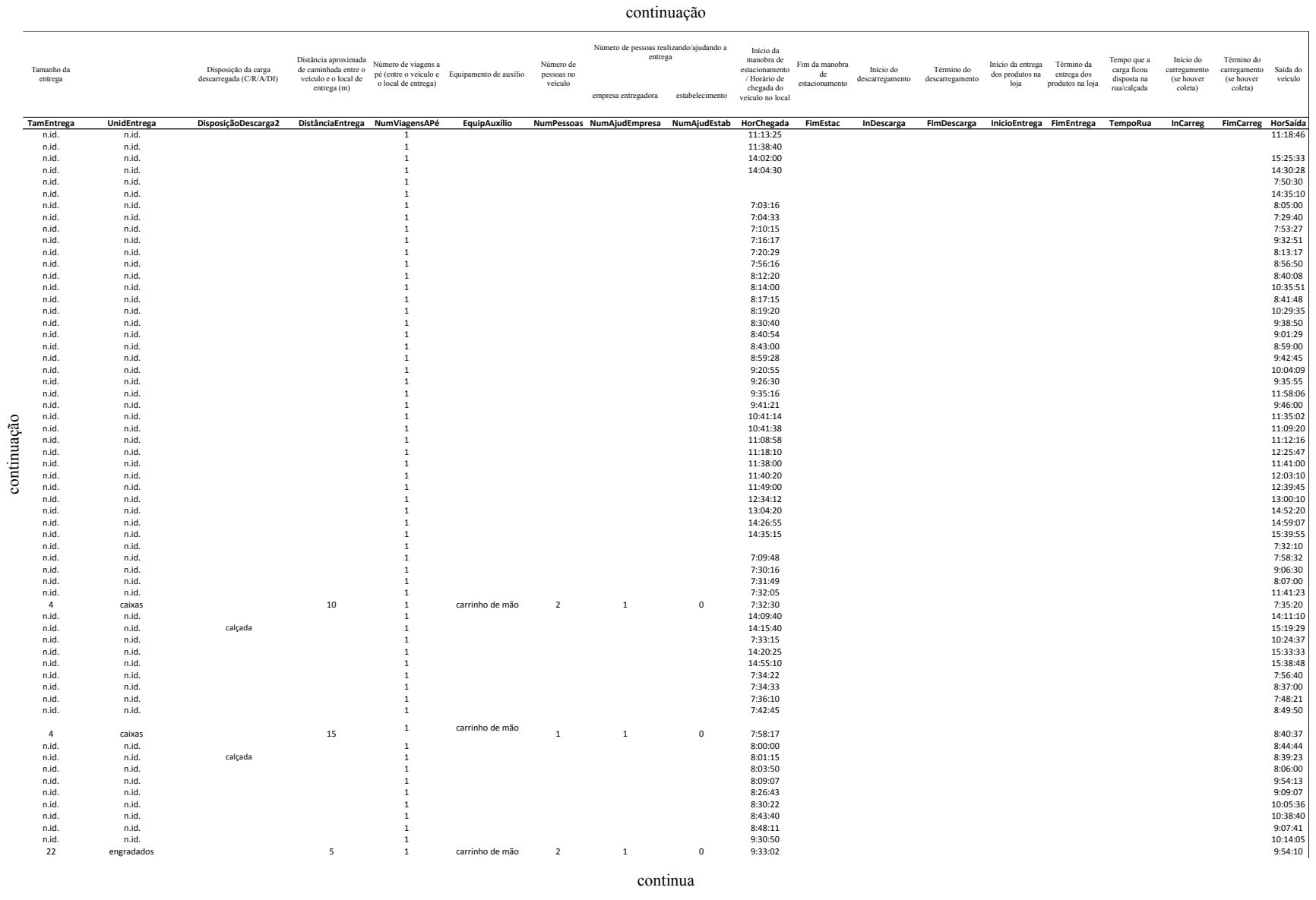


continuação

\begin{tabular}{|c|c|c|c|c|c|c|c|c|c|c|c|}
\hline Data & $\begin{array}{l}\text { Ginpos de } \\
\text { establacecimentos } \\
\text { obscrados } \\
\text { (OBSERVADDR } \\
\text { LOCAL) }\end{array}$ & $\begin{array}{l}\text { Identificacaio } \\
\text { die surtega }\end{array}$ & $\begin{array}{l}\text { Nome do estabclecincento } \\
\text { atchndido }\end{array}$ & Classe do cstableceinento & Empresa que realiza a entrcga & Tipo de veciulo & $\begin{array}{l}\text { Posiciaio da porta da decearcreganentio } \\
\text { (T/LDLL) }\end{array}$ & Local de parada do veciculo (F FDF) & 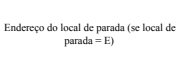 & $\begin{array}{c}\text { Caracteristica do local } \\
\text { de parada }\end{array}$ & Girpo od produtuos sentrga \\
\hline Data & Grupoobs & Identrega & NomeEstab & ClasseEstab & Empresa & Tipoveic & Posiçăoporta & $\begin{array}{l}\text { LocalParada } \\
\end{array}$ & Endereçoparada & CaractParada & GrupoProd \\
\hline & & & Futurama & & & & lateral & & Al: Barros & faixa de tráfego & \\
\hline 30/01/14 & B_FUT & 52 & Futurama & supermercado médio & n.id. & vuc grande & & dentro do estabelecimento & & & n.id. \\
\hline 30/01/14 & B_EUT & 53 & Futurama & supermercado médio & $\begin{array}{l}\text { n.id. } \\
\text {. }\end{array}$ & vuc pequeno & & dentro do estabelecimento & & & n.id. \\
\hline $\begin{array}{l}30 / 01 / 14 \\
30 / 14\end{array}$ & $\begin{array}{l}\text { B_FUT } \\
B \text { BET }\end{array}$ & 54 & $\begin{array}{l}\text { Futurama } \\
\text { Efturama }\end{array}$ & $\begin{array}{l}\text { supermercado médio } \\
\text { supermerccido édio }\end{array}$ & Leite A Fazenda Bela Vista & $\begin{array}{l}\text { utilitário } \\
\text { varegrod }\end{array}$ & & dentro do estabelecimento & & & laticinios \\
\hline $\begin{array}{l}30 / 01 / 14 \\
30 / 1414\end{array}$ & $\begin{array}{l}\text { B-FUT } \\
\text { B.FUT } \\
\text { FUt }\end{array}$ & $\begin{array}{l}55 \\
56\end{array}$ & $\begin{array}{l}\text { Futurama } \\
\text { Futurama }\end{array}$ & $\begin{array}{l}\text { supermercadodo médio } \\
\text { supermercado médio }\end{array}$ & $\begin{array}{l}\text { n.id. } \\
\text { nid }\end{array}$ & $\begin{array}{l}\text { vuc grande } \\
\text { vuc rande }\end{array}$ & & $\begin{array}{l}\text { dentro do estabelecimento to } \\
\text { dentrodo estabeleciment }\end{array}$ & & & $\begin{array}{l}\text { n.id. } \\
\text { nid }\end{array}$ \\
\hline $\begin{array}{l}30 / 01 / 14 \\
30 / 14\end{array}$ & S & $\begin{array}{c}56 \\
57\end{array}$ & $\begin{array}{l}\begin{array}{l}\text { futurama } \\
\text { Futurama }\end{array}\end{array}$ & $\begin{array}{l}\text { supermercado médio } \\
\text { supermercado médio }\end{array}$ & $\begin{array}{l}\text { n.id. } \\
\text { n.id. }\end{array}$ & $\begin{array}{l}\text { vuc grande } \\
\text { vuc pequeno }\end{array}$ & & $\begin{array}{l}\text { dentro do estabelecimento } \\
\text { dentro do estabelecimento }\end{array}$ & & & $\begin{array}{l}\text { n.id. } \\
\text { n.id. }\end{array}$ \\
\hline $30 / 01 / 14$ & BFUT & 57 & Futurama & supermercado médio & n.id. & vuc pequeno & & dentro do estabelecimento & & & 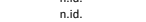 \\
\hline 30/01/14 & B_FUT & 58 & Futurama & supermercado médio & Ambev & utilitario & & dentro do estabelecimento & & & bebidas \\
\hline $31 / 01 / 14$ & B_FUT & 1 & Futurama & supermercado médio & n.id. & vuc grande & & dentro do estabelecimento & & & n.id. \\
\hline 31/01/14 & B_FUT & 2 & Futurama & supermercado médio & Bimbo & Vuc grande & & dentro do estabelecimento & & & pães \\
\hline $31 / 01 / 14$ & B_FUT & 3 & Futurama & supermercado médio & Floradi & Vuc grande & & dentro do estabelecimento & & & \\
\hline $\begin{array}{l}33 / 1 / 1 / 14 \\
31 / 1 / 14\end{array}$ & $\begin{array}{l}\text { B_FFT } \\
\text { B FUT }\end{array}$ & $\begin{array}{l}4 \\
5\end{array}$ & $\begin{array}{l}\begin{array}{l}\text { Futurama } \\
\text { Futurama }\end{array} \\
\text { a }\end{array}$ & $\begin{array}{l}\text { supermercadodo médio } \\
\text { supermercado médio }\end{array}$ & $\begin{array}{c}\text { n.id. } \\
\text { naid }\end{array}$ & vuc grande & & $\begin{array}{l}\text { dentro do estabelecimento } \\
\text { dentrode estabelecimento }\end{array}$ & & & $\begin{array}{l}\text { n.id. } \\
\text { Fly }\end{array}$ \\
\hline $\begin{array}{l}31 / 01 / 14 \\
31414\end{array}$ & 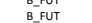 & $\begin{array}{l}5 \\
6\end{array}$ & Futurama & $\begin{array}{l}\text { supermercacom mealo } \\
\text { supermercado médio }\end{array}$ & $\begin{array}{l}\text { n.to. } \\
\text { n.id. }\end{array}$ & $\begin{array}{l}\text { Kumbl } \\
\text { vuc pequeno }\end{array}$ & & $\begin{array}{l}\text { dentro do sestabelecimento } \\
\text { dentro do stabelecimento }\end{array}$ & & & $\begin{array}{l}\text { outros } \\
\text { flves }\end{array}$ \\
\hline $31 / 01 / 14$ & B_FUT & 7 & Futurama & supermercado médio & Brico Bread & $\begin{array}{l}\text { vuc pequeno } \\
\text { valu }\end{array}$ & & dentro do estabelecimento & & & pâes \\
\hline $31 / 01 / 14$ & B_FUT & 8 & Futurama & supermercado médio & n.id. & vuc grande & & dentro do estabelecimento & & & n.id. \\
\hline $31 / 01 / 14$ & B_Fut & 9 & Futurama & supermercado médio & n.id. & kombi & & dentro do estabelecimento & & & n.id. \\
\hline $31 / 01 / 14$ & B_FUT & 10 & Futurama & supermercado médio & n.id. & van & & dentro do estabelecimento & & & n.id. \\
\hline 31/1/1/14 & $\begin{array}{l}\text { B_FUT } \\
\text { B FUT }\end{array}$ & ${ }_{11}^{11}$ & $\begin{array}{l}\text { Futurama } \\
\text { Futurama }\end{array}$ & $\begin{array}{l}\text { supermercado médio } \\
\text { sunermercado óddio }\end{array}$ & Famiglia Pão Italiano & Vuc pequeno & & dentro do estabelecimento & & & $\begin{array}{l}\text { pães } \\
\text { pebidss }\end{array}$ \\
\hline $\begin{array}{l}31 / 101 / 14 \\
31 / 01 / 14\end{array}$ & $\begin{array}{l}\text { B_EUT } \\
\text { B FUT }\end{array}$ & $\begin{array}{l}12 \\
13 \\
13\end{array} \mathrm{l} \mathrm{l}$ & $\begin{array}{l}\text { Futurama } \\
\text { Futurama }\end{array}$ & $\begin{array}{l}\text { supermercado médio } \\
\text { supermercadom médio }\end{array}$ & $\begin{array}{l}\text { Minalba } \\
\text { nid }\end{array}$ & $\begin{array}{l}\text { utilitário } \\
\text { vuc rande }\end{array}$ & & $\begin{array}{l}\text { dentro do estabelecimento } \\
\text { dentro destabeccimento }\end{array}$ & & & bebidas \\
\hline $\begin{array}{l}31 / 101 / 14 \\
31 / 14\end{array}$ & 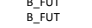 & $\begin{array}{l}13 \\
14\end{array}$ & $\begin{array}{l}\text { luturama } \\
\text { Futurama }\end{array}$ & $\begin{array}{l}\text { supermercadoomedocio } \\
\text { supermercado médio }\end{array}$ & $\begin{array}{l}\text { n.ld. } \\
\text { n.id. }\end{array}$ & $\begin{array}{l}\text { vuc grande } \\
\text { vuc grande }\end{array}$ & & $\begin{array}{l}\text { dentro do estabelecimento } \\
\text { dentro do estabelecimento }\end{array}$ & & & $\begin{array}{l}\text { n.t.l. } \\
\text { nid. }\end{array}$ \\
\hline 31/01/14 & B_FUT & 15 & Futurama & supermercado médio & Naor & kombi & & dentro do estabelecimento & & & mercearia seca em geral \\
\hline $31 / 01 / 14$ & B_FUT & 16 & Futurama & supermercado médio & n.id. & van & & dentro do estabelecimento & & & \\
\hline $31 / 01 / 14$ & B_Fut & 17 & Futurama & supermercado médio & n.id. & van & & dentro do estabelecimento & & & n.id. \\
\hline $31 / 01 / 14$ & B_FUT & 18 & Futurama & supermercado médio & n.id. & van & & dentro do estabelecimento & & & n.id. \\
\hline $31 / 01 / 14$ & B_FUT & 19 & Futurama & supermercado médio & Kisabor Farofa & vuc pequeno & & dentro do estabelecimento & & & mercearia seca em geral \\
\hline $\begin{array}{l}31 / 01 / 14 \\
331 / 14\end{array}$ & B_FUT & ${ }_{21}^{20}$ & Futurama & supermercado médio & Kim & $\begin{array}{c}\text { kombi } \\
\text { vycrand }\end{array}$ & & dentro do estabelecimento & & & pães \\
\hline $\begin{array}{l}31 / 01 / 14 \\
31 / 14\end{array}$ & $\begin{array}{ll}B \\
B \text { FUUT }\end{array}$ & 22 & $\begin{array}{l}\text { Futuramaa } \\
\text { Futurama }\end{array}$ & $\begin{array}{l}\text { supermercadoom medó } \\
\text { supermercado médio }\end{array}$ & $\begin{array}{l}\text { n.tad. } \\
\text { nid. }\end{array}$ & $\begin{array}{l}\text { voc grande } \\
\text { van }\end{array}$ & & $\begin{array}{l}\text { dentro do estabelecimento } \\
\text { dentro do stabelecimento }\end{array}$ & & & $\begin{array}{l}\text { n.tad. } \\
\text { nid. }\end{array}$ \\
\hline $31 / 01 / 14$ & BFUT & 23 & Futurama & supermercado médio & $\begin{array}{l}\text { n.id. } \\
\text { nod. }\end{array}$ & $\begin{array}{l}\text { van van } \\
\text { vuc pequeno }\end{array}$ & & $\begin{array}{l}\text { dentro do ostabelecimento } \\
\text { dentro do estabelecimento }\end{array}$ & & & $\begin{array}{l}\text { n.t.d. } \\
\text { nid. }\end{array}$ \\
\hline $31 / 01 / 14$ & B_FUT & 24 & Futurama & supermercado médio & n.id. & van & & dentro do estabelecimento & & & n.id. \\
\hline $31 / 01 / 14$ & B_FUT & 25 & Futurama & supermercado médio & Marilan & vuc pequeno & & dentro do estabelecimento & & & mercearia seca em geral \\
\hline $31 / 01 / 14$ & B_FUT & 26 & Futurama & supermercado médio & n.id. & utilitário & & dentro do estabelecimento & & & n.id. \\
\hline $01 / 02 / 14$ & B_FUT & 1 & Futurama & supermercado médio & n.id. & Vuc grande & & dentro do estabelecimento & & & n.id. \\
\hline $\begin{array}{l}01 / 1 / 20 / 144 \\
01 / 12 / 14\end{array}$ & $\begin{array}{l}\text { B_FUT } \\
\text { BFUT }\end{array}$ & $\frac{2}{3}$ & $\begin{array}{l}\text { Futurama } \\
\text { Futurama }\end{array}$ & $\begin{array}{l}\text { supermercado médio } \\
\text { sunermercado óddio }\end{array}$ & $\begin{array}{l}\text { Floradi } \\
\text { Batatata }\end{array}$ & $\begin{array}{l}\text { vuc grande } \\
\text { vuc gande }\end{array}$ & & $\begin{array}{l}\text { dentro do estabelecimento } \\
\text { dentrodoestabelecimento }\end{array}$ & & & 奋.id. \\
\hline $\begin{array}{l}01 / 02 / 14 \\
01 / 20214\end{array}$ & $\begin{array}{lll}B \\
B \text { BFUT }\end{array}$ & $\begin{array}{l}3 \\
4\end{array}$ & $\begin{array}{l}\text { Futurama } \\
\text { Futurama }\end{array}$ & $\begin{array}{l}\text { supermercadoomedecio } \\
\text { supermercado médio }\end{array}$ & $\begin{array}{l}\text { Batata } \\
\text { wickoold }\end{array}$ & $\begin{array}{l}\text { voc gande } \\
\text { vuc pequeno }\end{array}$ & & $\begin{array}{l}\text { dentro do se stabelecimento } \\
\text { dentro do estabelecimento }\end{array}$ & & & $\begin{array}{l}\text { plves } \\
\text { pầ }\end{array}$ \\
\hline $01 / 02 / 14$ & B.FUT & $\begin{array}{l}4 \\
5\end{array}$ & Futurama & supermercado médio & n.d. & $\begin{array}{l}\text { vuc pequeno } \\
\text { vequan }\end{array}$ & & dentro do estabelecimento & & & n.id. \\
\hline $01 / 02 / 14$ & B-FUT & 6 & Futurama & supermercado médio & Panco & van & & $\begin{array}{l}\text { dentro do estabelecimento } \\
\text { delate }\end{array}$ & & & pâes \\
\hline 01/02/14 & B_FUT & 7 & Futurama & supermercado médio & n.id. & vuc grande & & dentro do estabelecimento & . & & n.id. \\
\hline 01/02/14 & B_FUT & 8 & Futurama & supermercado médio & n.id. & van & & dentro do estabelecimento & & & n.id. \\
\hline $\begin{array}{l}0.1 / 20 / 14 \\
01 / 1 / 22 / 14\end{array}$ & $\begin{array}{l}\text { B.FUT } \\
\text { B.FUT }\end{array}$ & $\begin{array}{c}9 \\
10\end{array}$ & $\begin{array}{l}\text { Futurama } \\
\text { futurama }\end{array}$ & $\begin{array}{l}\text { supermercadodo médio } \\
\text { supermercado médio }\end{array}$ & $\begin{array}{l}\text { Famiglia nad. } \text { Pă Italiano } \\
\text { Fon }\end{array}$ & $\begin{array}{l}\text { vuc pequeno } \\
\text { vuc pequeno }\end{array}$ & & $\begin{array}{l}\text { dentroro o e estabelecimentt } \\
\text { dentrod o stabelecimento }\end{array}$ & & & $\begin{array}{l}\text { nid. } \\
\text { pâes }\end{array}$ \\
\hline $\begin{array}{l}01 / 02 / 14 \\
01 / 20214\end{array}$ & 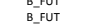 & 11 & $\begin{array}{l}\text { Futurama } \\
\text { Futurama }\end{array}$ & $\begin{array}{l}\text { supermercadodo médio } \\
\text { supermercado médio }\end{array}$ & $\begin{array}{l}\text { Famigliaia åoottaliano } \\
\text { Naor }\end{array}$ & $\begin{array}{c}\text { vup pequeno } \\
\text { utilitaicio }\end{array}$ & & $\begin{array}{l}\text { dentrodo o e stabelecimento } \\
\text { dentro do estabelecimento }\end{array}$ & & & $\begin{array}{l}\text { päes } \\
\text { mercaria seca em geral }\end{array}$ \\
\hline $01 / 02 / 14$ & B_FUT & 12 & Futurama & supermercado médio & $\begin{array}{l}\text { n.id. } \\
\text { n.t. }\end{array}$ & van & & $\begin{array}{l}\text { dentro do estabelecimento } \\
\text { delater }\end{array}$ & . & & 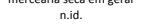 \\
\hline $01 / 02 / 14$ & B_FUT & 13 & Futurama & supermercado médio & n.id. & VuC grande & & dentro do estabelecimento & & & n.id. \\
\hline 01/02/14 & B_FUT & 14 & Futurama & supermercado médio & n.id. & utilitário & & dentro do estabelecimento & & & n.id. \\
\hline $01 / 02 / 14$ & B_FUT & 15 & Futurama & supermercado médio & & $\begin{array}{l}\text { utilitário } \\
\text { vuc }\end{array}$ & & dentro do estabelecimento & & & FLV \\
\hline $01 / 02 / 14$ & B_FUT & 16 & Futurama & supermercado médio & Leite A Fazenda Bela Vista & Vuc grande & & dentro do estabelecimento & & & laticinios \\
\hline $01 / 02 / 14$ & B_FUT & 17 & Futurama & supermercado médio & n.id. & Vuc grande & & dentro do estabelecimento & & & n.id. \\
\hline $01 / 02 / 14$ & B_FUT & 18 & Futurama & supermercado médio & n.id. & Vuc grande & & dentro do estabelecimento & & & n.id. \\
\hline $000002 / 1 / 144$ & $\begin{array}{l}\text { B_FUT } \\
\text { B FUT }\end{array}$ & ${ }_{20}^{19}$ & $\begin{array}{l}\text { Futurama } \\
\text { Futurama }\end{array}$ & $\begin{array}{l}\text { supermercadodo médio } \\
\text { supermercado médio }\end{array}$ & $\begin{array}{l}\text { Yakukt } \\
\text { Xando }\end{array}$ & $\begin{array}{l}\text { utilitário } \\
\text { kombi }\end{array}$ & & $\begin{array}{l}\text { dentro do estabelecimento } \\
\text { dentro do stabelecimento }\end{array}$ & & & $\begin{array}{l}\text { laticininos } \\
\text { laticinios }\end{array}$ \\
\hline $\begin{array}{l}01 / 1 / 22 / 14 \\
014\end{array}$ & $\begin{array}{l}B=U T \\
\text { B FUT }\end{array}$ & 21 & $\begin{array}{l}\text { Futurama } \\
\text { Futurama }\end{array}$ & $\begin{array}{l}\text { supermercadodomedio } \\
\text { supermercado médio }\end{array}$ & $\begin{array}{c}\text { Xandó } \\
\text { n.id. }\end{array}$ & $\begin{array}{l}\text { kombi } \\
\text { van }\end{array}$ & & $\begin{array}{l}\text { dentro do estabelecimento } \\
\text { detro }\end{array}$ & & & laticinios \\
\hline $\begin{array}{l}01 / 1 / 22 / 14 \\
01 / 14\end{array}$ & $\begin{array}{l}\text { B. } \\
\text { B_FUTT } \\
\text { B.FUT }\end{array}$ & 22 & $\begin{array}{l}\text { Futurama } \\
\text { Futurama }\end{array}$ & $\begin{array}{l}\text { supermercadoomededio } \\
\text { supermercado médio }\end{array}$ & $\begin{array}{l}\text { n.id. } \\
\text { n.id. }\end{array}$ & $\begin{array}{c}\text { van } \\
\text { kombi }\end{array}$ & & $\begin{array}{l}\text { dentro o o e stabelecimento } \\
\text { dentro do estabelecimento }\end{array}$ & & & $\begin{array}{l}\text { n.id. } \\
\text { n.id. }\end{array}$ \\
\hline $01 / 02 / 14$ & B_FUT & 23 & Futurama & supermercado médio & n.id. & Vuc grande & & dentro do estabelecimento & & & n.id. \\
\hline 01/02/14 & B_FUT & 24 & Futurama & supermercado médio & Ki Gelo & van & & dentro do estabelecimento & & & gelo \\
\hline $01 / 02 / 14$ & B_FUT & 25 & $\begin{array}{l}\text { Futurama } \\
\text {. }\end{array}$ & supermercado médio & n.id. & Vuc grande & & dentro do estabelecimento & & & n.id. \\
\hline 13/01/14 & B_HOR & 1 & Natural da Terra & hortifruti & Coleta de óleo & van & & & & & coleta \\
\hline
\end{tabular}




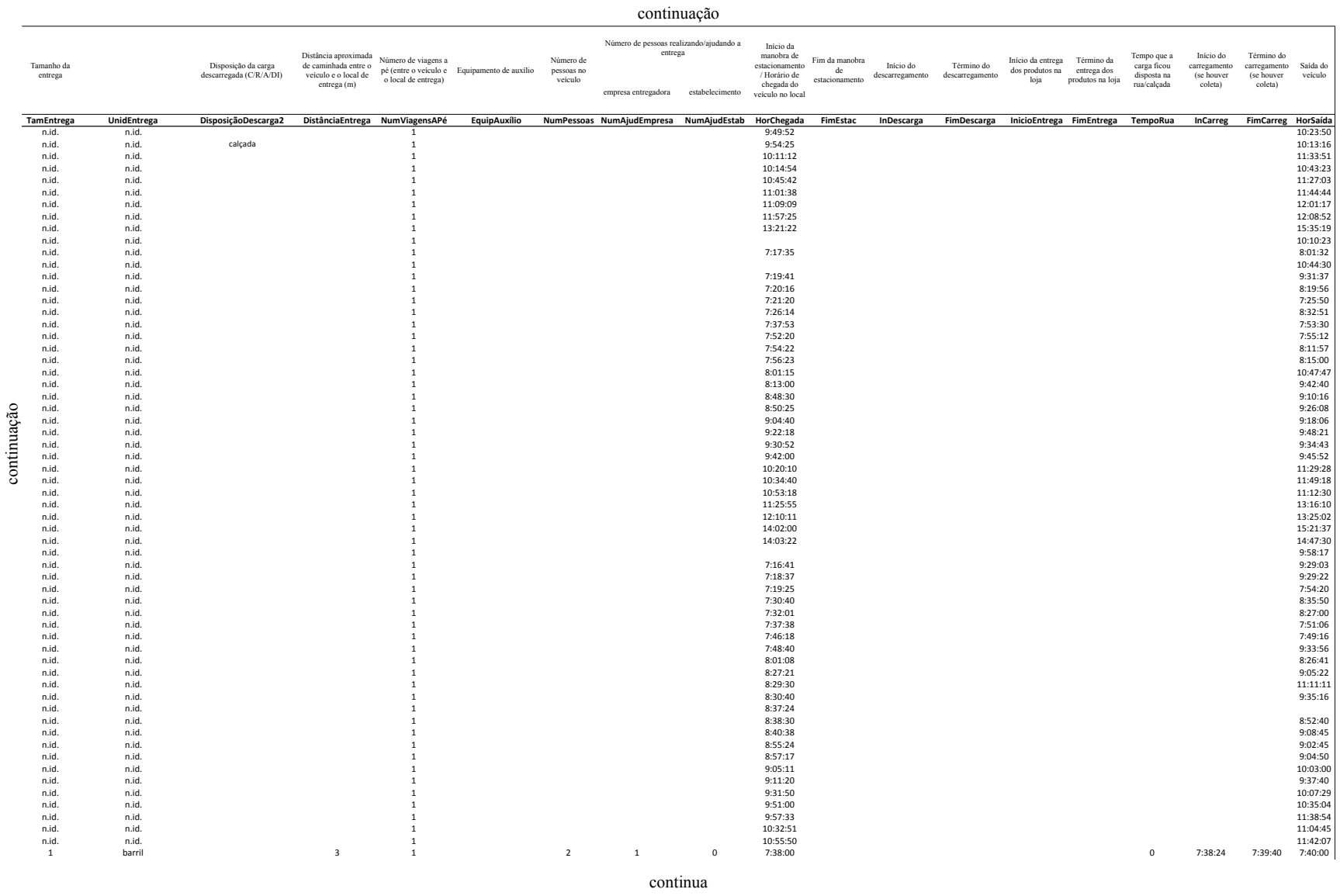




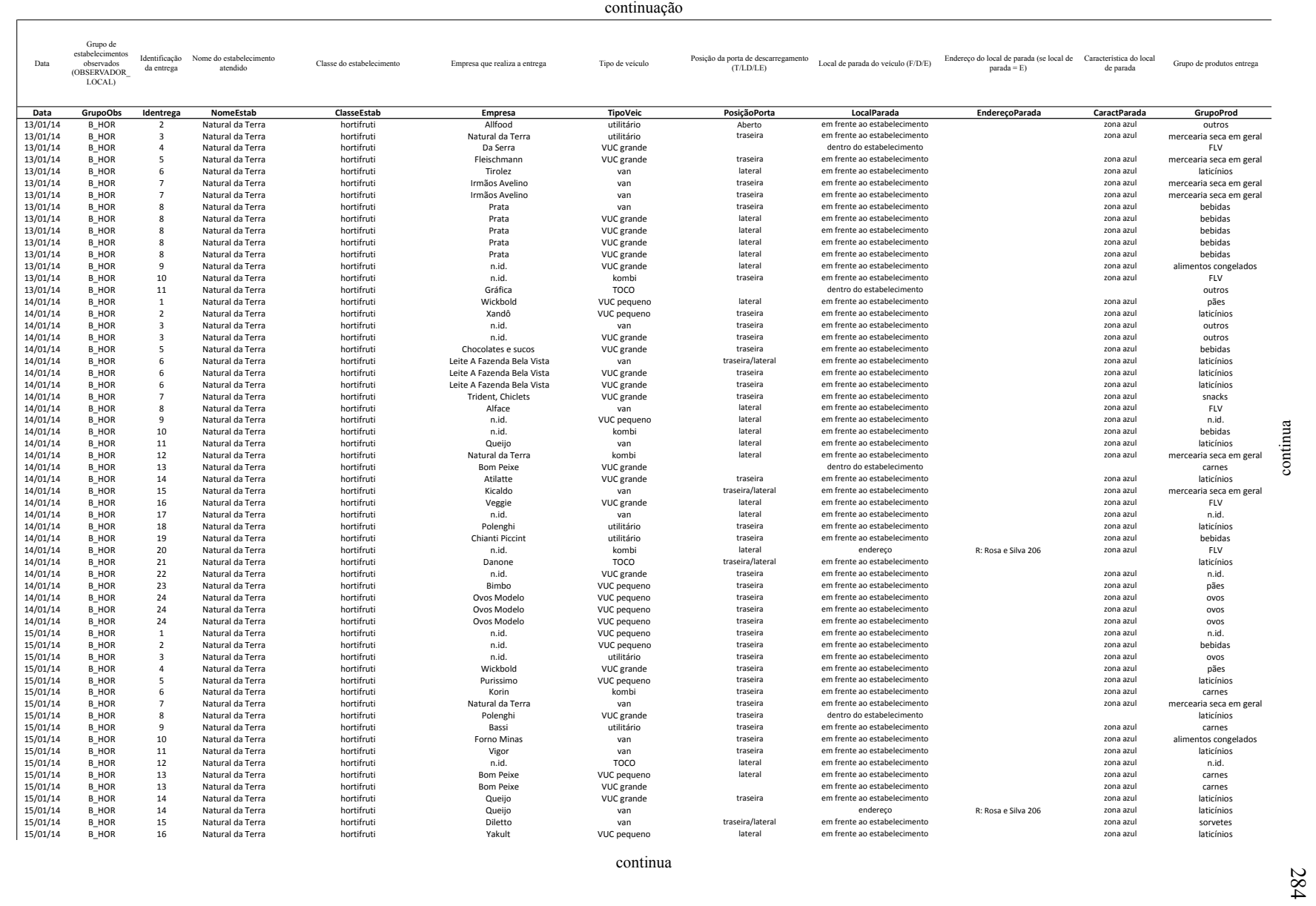




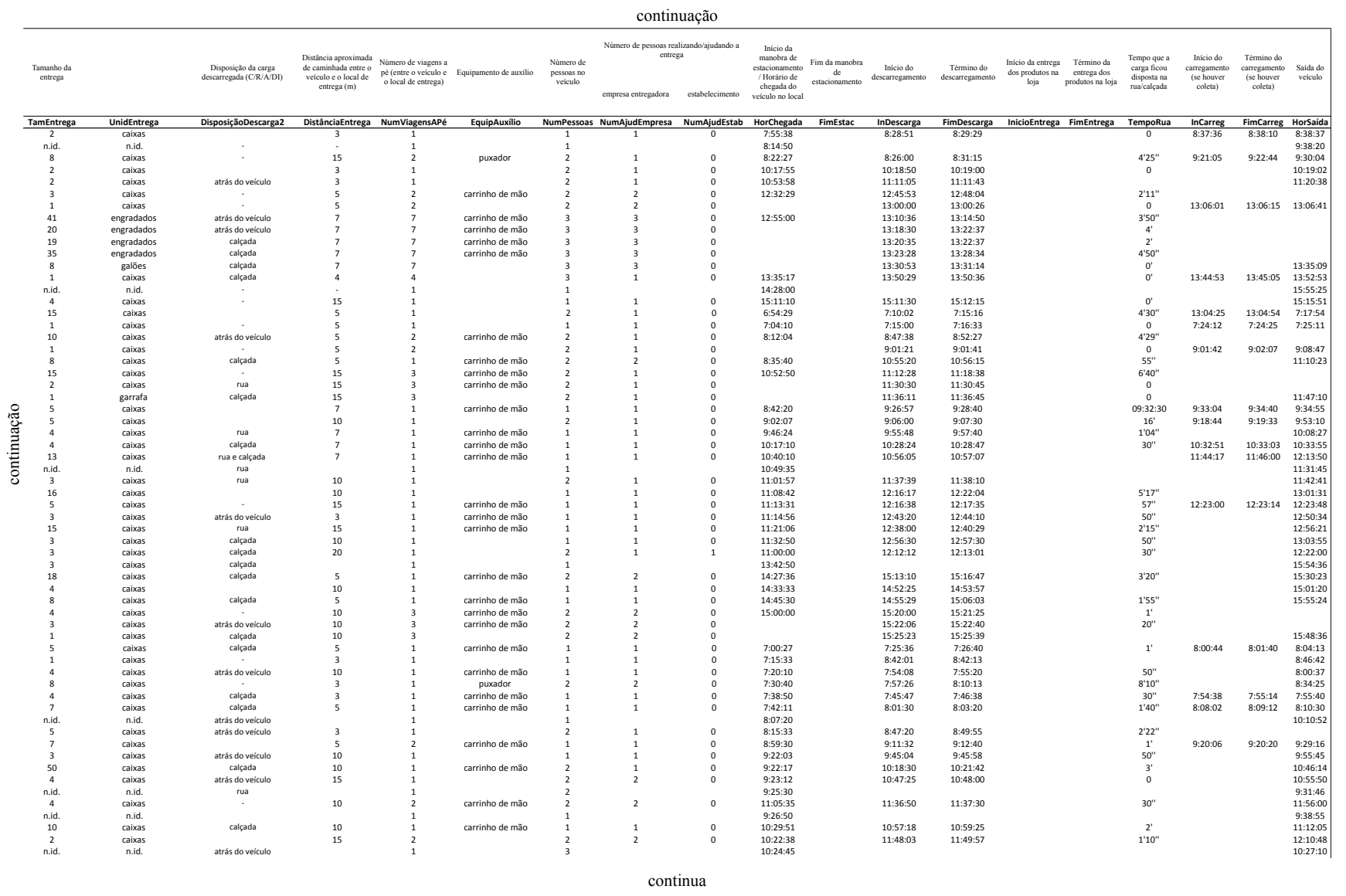




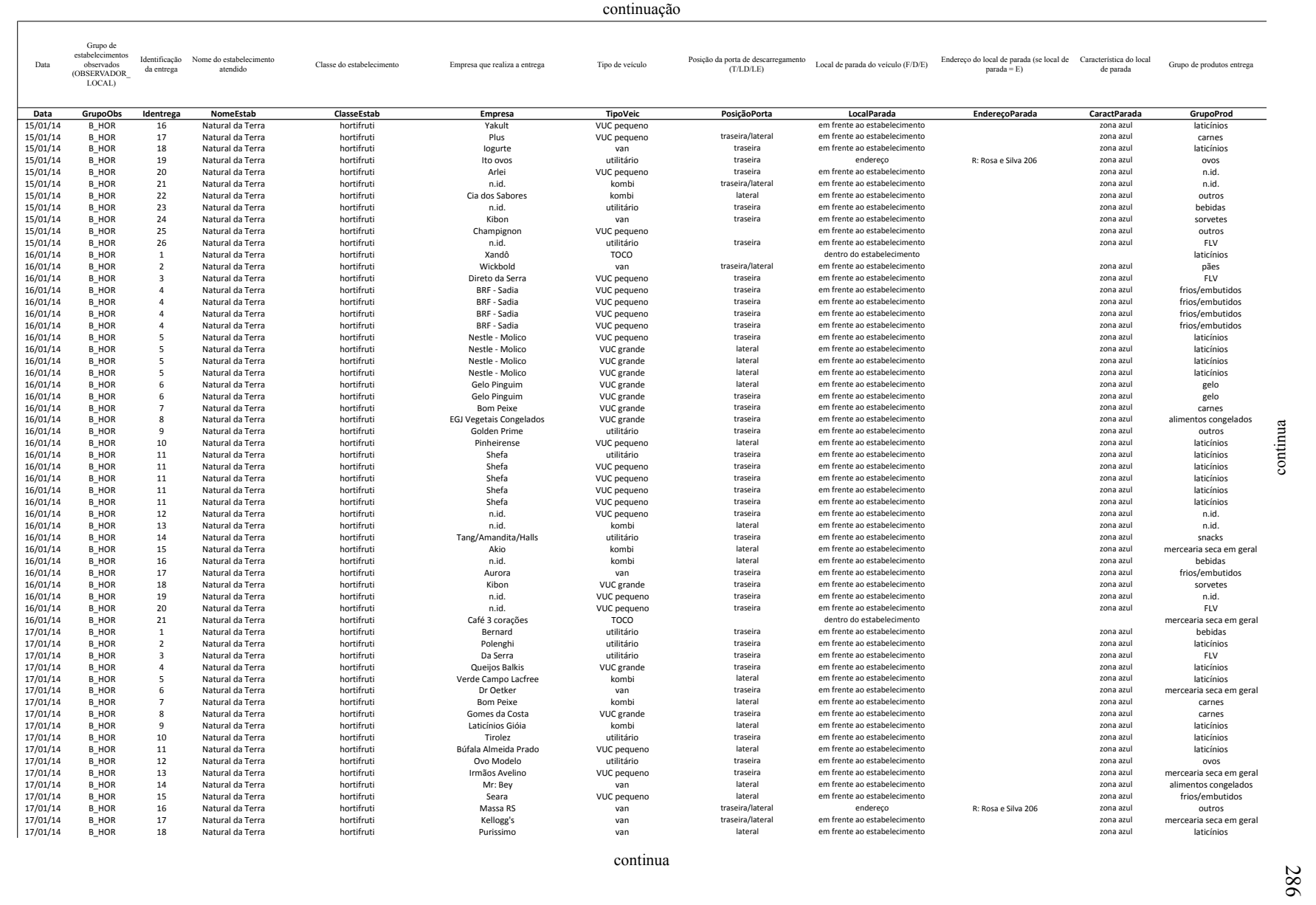




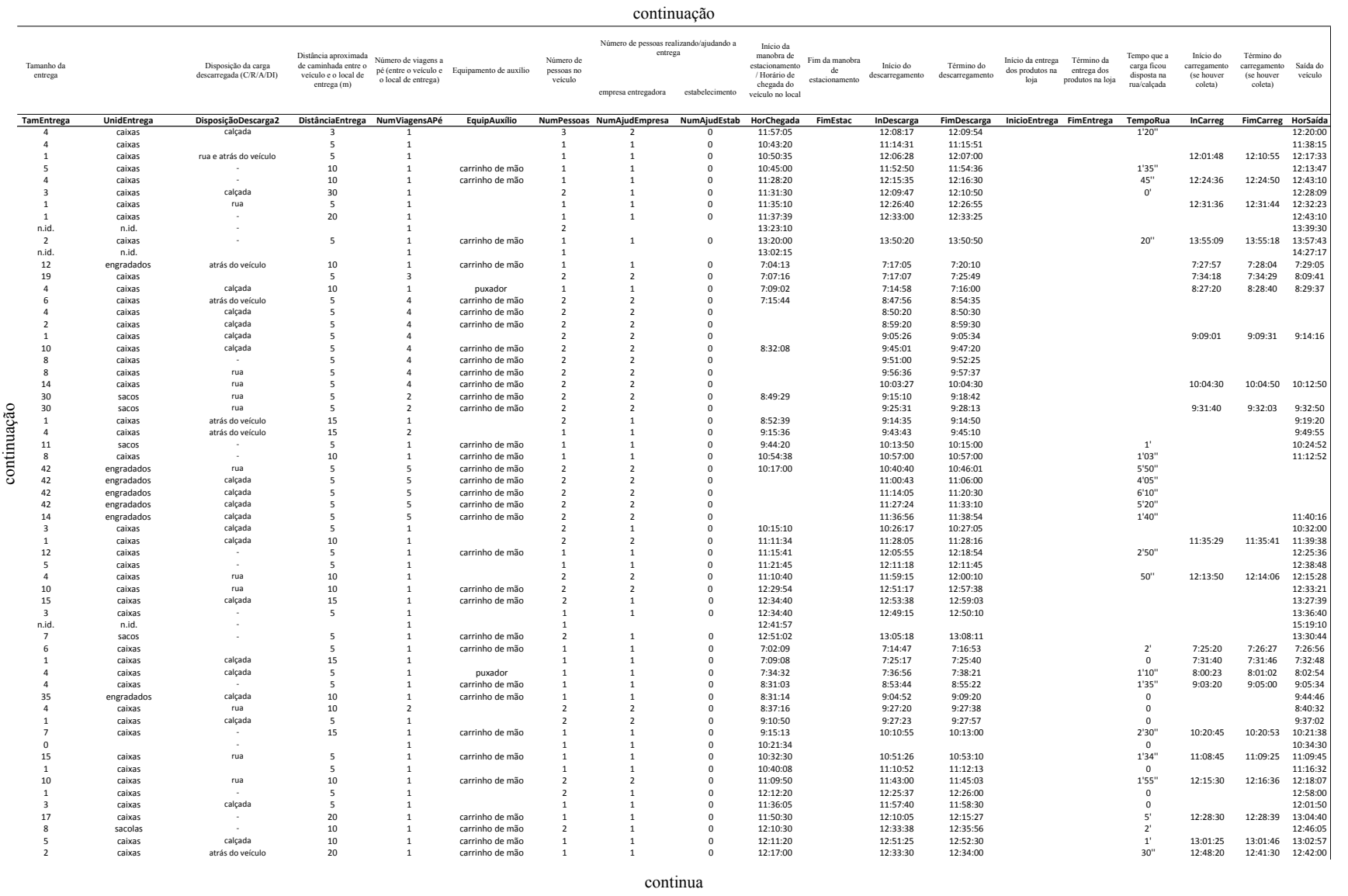




\begin{tabular}{|c|c|c|c|c|c|c|c|c|c|c|c|}
\hline Data & $\begin{array}{c}\text { Grupp de } \\
\text { establecimentos } \\
\text { obscrvados } \\
\text { (OBSERVADOR } \\
\text { LOCAL) }\end{array}$ & $\begin{array}{l}\text { Idennificacaio } \\
\text { dat entrega }\end{array}$ & $\begin{array}{l}\text { Nome do stabclecimento } \\
\text { atendido }\end{array}$ & Classe do stableclecimento & Empresa que realiza a cnrrega & Tipo de veciulo & 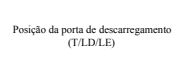 & Local d d parada do vociculo (FDE) & $\begin{array}{l}\text { Endereço do Iocal de paradad (sc local de } \\
\text { parada }\end{array}$ & $\begin{array}{c}\text { Caracterisitica do local } \\
\text { de parada }\end{array}$ & Ginpo de produtus entrega \\
\hline Data & Grupoobs & Identrega & NomeEstab & & Empresa & TipoVeic & Posiçăoporta & $\begin{array}{l}\text { LocalParada } \\
\end{array}$ & Endereçoparada & & Grupoprod \\
\hline $17 / 01 / 14$ & B_HOR & 19 & Natural da Terra & hortifruti & Ito ovos & kombi & $\begin{array}{l}\text { solyarould } \\
\text { lateral }\end{array}$ & em frente ao estabelecimento & & zona azul & ovos \\
\hline 17/01/14 & B_-HOR & 20 & Natural da Terra & hortifruti & Psicultura Cristalina & vuc pequeno & traseira & em frente ao estabelecimento & & zona azul & carnes \\
\hline $17 / 01 / 14$ & B-HOR & ${ }_{21}^{21}$ & Natural da Terra & $\begin{array}{l}\text { hortifruti } \\
\text { hontffuti }\end{array}$ & $\begin{array}{l}\text { n.id. } \\
\text {. }\end{array}$ & $\begin{array}{l}\text { vuc pequeno } \\
\text { Tace }\end{array}$ & traseira & 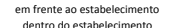 & & zona azul & $\begin{array}{c}F L V \\
\end{array}$ \\
\hline $17 / / 01 / 14$ & $\begin{array}{l}\text { B_HOR } \\
\text { B HOR }\end{array}$ & 22 & Natural da Terra & $\begin{array}{l}\text { hortiffuti } \\
\text { hetrffution }\end{array}$ & $\begin{array}{l}\text { Natural da Terra } \\
\text { Caté }\end{array}$ & $\begin{array}{l}\text { Toco } \\
\text { ycorande }\end{array}$ & & $\begin{array}{l}\text { dentro do estabelecimento } \\
\text { dentronte }\end{array}$ & & & mercearia seca em geral \\
\hline $\begin{array}{l}17 / / 11 / 14 \\
17 / 01 / 14\end{array}$ & $\begin{array}{l}\text { B_HOR } \\
\text { B HOR }\end{array}$ & ${ }_{24}^{23}$ & $\begin{array}{l}\text { Natural da Terra } \\
\text { Natural da Terra }\end{array}$ & $\begin{array}{l}\text { hortrifuti } \\
\text { hortifruti }\end{array}$ & $\begin{array}{l}\text { Café } \\
\text { Ninho }\end{array}$ & $\begin{array}{l}\text { vuc grande } \\
\text { utilitário }\end{array}$ & $\begin{array}{c}\text { trtaseira } \\
\text { traseira }\end{array}$ & $\begin{array}{l}\text { em fr frente a a e estabelecimimento } \\
\text { ef frente }\end{array}$ & & $\begin{array}{l}\text { zona azul } \\
\text { zona azul }\end{array}$ & $\begin{array}{l}\text { mercearia seca em geral } \\
\text { laticinios }\end{array}$ \\
\hline $\begin{array}{l}17 / 101 / 14 \\
17 / 14\end{array}$ & $\begin{array}{l}\text { B-HUK } \\
\text { B.HOR }\end{array}$ & ${ }_{25}^{24}$ & Natural da Terra & $\begin{array}{l}\text { hortrifuti } \\
\text { hortifuti }\end{array}$ & $\begin{array}{l}\text { Ninho } \\
\text { Danone }\end{array}$ & $\begin{array}{l}\text { uttilitario } \\
\text { vuc pequeno }\end{array}$ & $\begin{array}{l}\text { traserera } \\
\text { traseira }\end{array}$ & $\begin{array}{l}\text { em mirente a a estabelecimento } \\
\text { em frente ao estabelecimento }\end{array}$ & & $\begin{array}{l}\text { zona azul } \\
\text { zona azul }\end{array}$ & $\begin{array}{l}\text { laticinios } \\
\text { laticinios }\end{array}$ \\
\hline $17 / 01 / 14$ & B_HOR & 26 & Natural da Terra & hortifruti & Bimbo & vuc grande & lateral & em frente ao estabelecimento & & $\begin{array}{l}\text { zona azul } \\
\text { zonal }\end{array}$ & $\begin{array}{l}\text { partios } \\
\text { pâs }\end{array}$ \\
\hline $18 / 01 / 14$ & B_HOR & 1 & Natural da Terra & hortifruti & Da Serra & van & 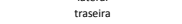 & em frente ao estabelecimento & & zona azul & $\mathrm{FLV}$ \\
\hline $18 / 01 / 14$ & B_HOR & 2 & Natural da Terra & hortifruti & Bom Peixe & VuC pequeno & traseira & em frente ao estabelecimento & & zona azul & carnes \\
\hline $18 / 01 / 14$ & B_HOR & 3 & Natural da Terra & hortifruti & Ovos Mantiqueira & vuc grande & traseira & em frente ao estabelecimento & & zona azul & ovos \\
\hline $18 / 01 / 14$ & B_HOR & 4 & Natural da Terra & hortiffuti & Beiruthe & vuc grande & lateral & em frente ao estabelecimento & & zona azul & pães \\
\hline $\begin{array}{l}18 / 11 / 14 \\
18 / 01 / 14\end{array}$ & $\begin{array}{l}\text { B_-HOR } \\
\text { B HOR }\end{array}$ & $\begin{array}{l}5 \\
5\end{array}$ & $\begin{array}{l}\text { Natural ad Terra } \\
\text { Natural da Tarra }\end{array}$ & $\begin{array}{l}\text { hortrifuti } \\
\text { hortiffuti }\end{array}$ & $\begin{array}{l}\text { BRF-SSadia } \\
\text { BRF-Sadia }\end{array}$ & $\begin{array}{c}\text { utilitário } \\
\text { vuc pequeno }\end{array}$ & $\begin{array}{l}\text { lateral } \\
\text { trasesara }\end{array}$ & $\begin{array}{l}\text { em frente a a estabelectimento } \\
\text { effrente }\end{array}$ & & $\begin{array}{l}\text { zona azul } \\
\text { zona azul }\end{array}$ & $\begin{array}{l}\text { frios/embutidos } \\
\text { frive }\end{array}$ \\
\hline & $\begin{array}{l}\text { B.HOR } \\
\text { B HOR }\end{array}$ & $\begin{array}{l}5 \\
5\end{array}$ & $\begin{array}{l}\text { Natural da Terra } \\
\text { Natural da Terra }\end{array}$ & $\begin{array}{l}\text { horttrifuti } \\
\text { hortifuti }\end{array}$ & $\begin{array}{l}\text { BRF-Sadia } \\
\text { BRF-Sadia }\end{array}$ & $\begin{array}{l}\text { Vuc pequeno } \\
\text { vuc pequeno }\end{array}$ & $\begin{array}{l}\text { traseira } \\
\text { traseira }\end{array}$ & $\begin{array}{l}\text { em retrente a e estabelectimento } \\
\text { em frente a e stabelecimento }\end{array}$ & & $\begin{array}{ll}20 \text {. } \\
\text { zona a azul }\end{array}$ & $\begin{array}{l}\text { Trlosembutitos } \\
\text { frios/embutidos }\end{array}$ \\
\hline $\begin{array}{l}18 / 71 / 14 \\
18 / 01 / 14\end{array}$ & 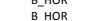 & $\begin{array}{l}5 \\
6\end{array}$ & Natural da Terra & hortiffutiti & 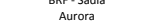 & $\begin{array}{l}\text { vac pequeno } \\
\text { vuc equeno }\end{array}$ & 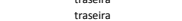 & em frente ao estabelecimento & & 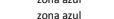 & $\begin{array}{l}\text { Trlosembutitos } \\
\text { frios/embutidos }\end{array}$ \\
\hline $18 / 01 / 14$ & B_HOR & 7 & Natural da Terra & hortiffuti & Massa & vuc grande & lateral & em frente ao estabelecimento & & zona azul & frios/embutidos \\
\hline $18 / 01 / 14$ & B_HOR & 8 & Natural da Terra & hortifruti & Xandó & utilitário & traseira & & & 2010 azul & $\begin{array}{l}\text { outros } \\
\text { Jaticinis }\end{array}$ \\
\hline $18 / 01 / 14$ & B_HOR & 9 & Natural da Terra & hortifruti & Leite A Fazenda Bela Vista & van & traseira//ateral & em frente ao estabelecimento & & 20na azul & laticinios \\
\hline 18/01/14 & B HOR & 10 & & hortiffuti & Mezzani & Yur arnod & traceizalateral & 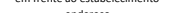 & & zona azul & laticíinios \\
\hline $03 / 02 / 14$ & B MA & 1 & 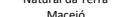 & supermercado pequeno & $\begin{array}{l}\text { Mezzzani } \\
\text { Wickpold }\end{array}$ & voc grande & 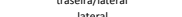 & endereço & R: Rosa e Silva, 206 & zona azul & outros \\
\hline $03 / 02 / 14$ & B_MA & 2 & Maceíó & supermercado pequeno & $\begin{array}{l}\text { Wirkbold } \\
\text { Transnova }\end{array}$ & $\begin{array}{l}\text { kombi } \\
\text { vuc pequeno } \\
\text { val }\end{array}$ & tatert & em rente ao estavelectimento & P. Racoselacs:o 2104 & $\begin{array}{ll}\text { 2oná azul } \\
\text { carge }\end{array}$ & paes \\
\hline $03 / 02 / 14$ & B-MA & 3 & Abelinha & 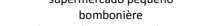 & $\begin{array}{l}\text { ndids. } \\
\text { n.id. }\end{array}$ & utilitario & 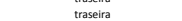 & endereço & $\begin{array}{l}\text { R: Da consalaçaco } 2104 \\
\text { Ren }\end{array}$ & carga e descarea & nid. \\
\hline $03 / 02 / 14$ & B_MA & 4 & Bom & caf́é/doceria/casa de sucos/sorveteria & n.id. & kombi & lateral & em frente ao estabelecimento & . & faixa de tráfego & n.id. \\
\hline 03/02/14 & B_MA & & Maceió & supermercado pequeno & Kero Coco - Guaraviton & kombi & traseira/lateral & endereço & R: Da Consalaç̧̃o 2104 & carga e descarga & bebidas \\
\hline $03 / 02 / 14$ & B-MA & 6 & Maceió & supermercado pequeno & n.id. & van & traseira/lateral & enderesco & R: Da Conssalą̧̧o 2104 & carga e descarga & n.id. \\
\hline $03 / 02 / 14$ & B_MA & 7 & Toledo & lanchonete & n.id. & vuc grande & traseira & enderesco & R: Da Consaląą̧o 2104 2104 & carga e descarga & n.id. \\
\hline $03 / 02 / 14$ & B_MA & 8 & Sujinhos & restaurante & Pano & van & traseira & endereço & R: Da Consalaç̧̄o 2104 & carga e descarga & n.id. \\
\hline 03/02/14 & B_MA & 9 & Maceió & supermercado pequeno & Rochina & kombi & lateral & enderesco & R: Da Conssalaç̧o 2104 & carga e descarga & sorvetes \\
\hline 03/02/14 & B_MA & ${ }_{11}^{11}$ & Maceió & restaurante & n.id. & vuc pequeno & lateral & $\begin{array}{c}\text { enderesc } \\
\text { enderece }\end{array}$ & 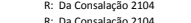 & carga e descarga & n.id. \\
\hline $\begin{array}{l}03 / 02 / 14 \\
03 / 02 / 14\end{array}$ & $\begin{array}{l}{ }_{B}^{B}-M A \\
B \text { MA }\end{array}$ & ${ }_{13}^{12}$ & $\begin{array}{l}\text { Maceció } \\
\text { Maceió }\end{array}$ & $\begin{array}{c}\text { restaurante } \\
\text { supermercado pequeno }\end{array}$ & n.id. & $\begin{array}{l}\text { kombi } \\
\text { vuc pequeno }\end{array}$ & $\begin{array}{c}\text { lateral } \\
\text { traseiralateral }\end{array}$ & $\begin{array}{l}\substack{\text { endiderço } \\
\text { endereç }} \\
\text {. }\end{array}$ & 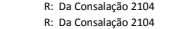 & $\begin{array}{l}\text { Carage e edccaraga } \\
\text { carra e escarga }\end{array}$ & $\begin{array}{c}\text { n.idd. } \\
\text { nid. }\end{array}$ \\
\hline 03/02/14 & 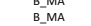 & ${ }_{14}^{13}$ & $\begin{array}{l}\text { Macelio } \\
\text { Bom }\end{array}$ & caf́é/doceria/casa de sucos/sorveteria & $\begin{array}{l}\text { n.d. } \\
\text { Leite }\end{array}$ & kombi & lateral & endereço & $\begin{array}{l}\text { R: Da consalaçaco } 2104 \\
\text { Re }\end{array}$ & $\begin{array}{l}\text { carga e descarga } \\
\text { cargats }\end{array}$ & $\begin{array}{l}\text { laticinios } \\
\text { late }\end{array}$ \\
\hline $03 / 02 / 14$ & B_MA & 16 & Maceió & 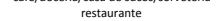 & n.id. & vuc pequeno & traseira & em frente ao estabelecimento & & faixa de tráfego & $\begin{array}{l}\text { laturios } \\
\text { laticinios }\end{array}$ \\
\hline $03 / 02 / 14$ & B-MA & 17 & Abelinha & bombonière & Pan & vuc pequeno & traseira & em frente ao estabelecimento & & faixa de tráfego & snacks \\
\hline $04 / 02 / 14$ & B_MA & 1 & Maceió & restaurante & n.id. & vuc pequeno & lateral & em frente ao estabelecimento & & falixa de tráfego & carnes \\
\hline $04 / 02 / 14$ & B_MA & 2 & Maceió & restaurante & Ambev & kombi & lateral & em frente ao estabelecimento & & vaga regular & bebidas \\
\hline 04/02/14 & B_MA & 3 & Maceió & restaurante & n.id. & vUC grande & lateral & em frente ao estabelecimento & & vaga regular & FLV \\
\hline 04/02/14 & B_MA & ${ }_{5}^{4}$ & Bom & café/doceria/casa de sucos/sorveteria & n.id. & kombi & lateral & em frente ao estabelecimento & & vaga regular & păes \\
\hline 04/02/14 & $\begin{array}{l}{ }^{B} \text { BMA } \\
\text { B MA }\end{array}$ & $\begin{array}{r}5 \\
6\end{array}$ & $\begin{array}{c}\text { Sujijhos } \\
\text { Bom }\end{array}$ & & $\begin{array}{l}\text { n.id. } \\
\text { Empório de Minas }\end{array}$ & $\begin{array}{c}\text { kombi } \\
\text { vuc pequeno }\end{array}$ & & & & & n.id. \\
\hline 04/02/14 & B_MA & $\begin{array}{r}6 \\
7\end{array}$ & Bom & café/doceria/casa de sucos/sorveteria & Empório de Minas & Vuc pequeno & & $\begin{array}{l}\text { dentro do estabelecimento } \\
\text { entente }\end{array}$ & & & alimentos congelados \\
\hline 04/02/14 & B_MA & $\begin{array}{l}7 \\
8\end{array}$ & Maceió & supermercado pequeno & 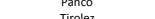 & $\begin{array}{l}\text { utilitário } \\
\text { vurcerande }\end{array}$ & 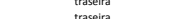 & em frente ao estabelecimento & 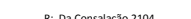 & vaga regular & $\begin{array}{l}\text { păes } \\
\text { pâs }\end{array}$ \\
\hline $\begin{array}{l}04 / 02 / 14 \\
04 / 02 / 14\end{array}$ & $\begin{array}{l}\text { B.MA } \\
\text { B_MA }\end{array}$ & $\begin{array}{l}8 \\
9\end{array}$ & $\begin{array}{l}\text { Maceio } \\
\text { Tradiçă }\end{array}$ & $\begin{array}{l}\text { supermercado pequeno } \\
\text { lanchonete }\end{array}$ & $\begin{array}{c}\text { tiroezez } \\
\text { n.id. }\end{array}$ & $\begin{array}{l}\text { vuc grande } \\
\text { utilitario }\end{array}$ & $\begin{array}{l}\text { trasera } \\
\text { traseira }\end{array}$ & $\begin{array}{l}\text { en fredereco } \\
\text { em fre ao estabelecimento }\end{array}$ & R: Da Consalą̧̧óo 2104 & $\begin{array}{l}\text { carbae eescarara } \\
\text { faxa de trátego }\end{array}$ & $\begin{array}{l}\text { laticinios } \\
\text { carnes }\end{array}$ \\
\hline $04 / 02 / 14$ & B-MA & 10 & Maceió & $\begin{array}{l}\text { restaurante } \\
\text { restates }\end{array}$ & $\begin{array}{l}\text { Irmăos Avelino } \\
\text { In }\end{array}$ & kombi & trasera & em frente ao estabelecimento & & 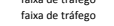 & $\begin{array}{l}\text { cartes } \\
\text { mercearia seca em geral }\end{array}$ \\
\hline $04 / 02 / 14$ & B_MA & 11 & Sujinhos & restaurante & BRF - Sadia & van & lateral & endereşo & R: Da Consalaç̧̃o 2104 & carga e descarga & frios/embutidos \\
\hline $04 / 02 / 14$ & B_MA & 12 & Maceió & supermercado pequeno & Danone & vuC pequeno & & dentro do estabelecimento & & & laticínios \\
\hline $04 / 02 / 14$ & B_MA & ${ }_{13}$ & Maceió & supermercado pequeno & n.id. & vuc grande & traseira//ateral & endereço & R: Da Consalaç̧̋̃o 2104 & carga e descarga & n.id. \\
\hline $04 / 02 / 14$ & B_MA & 14 & Maceió & supermercado pequeno & Yakult & kombi & lateral & em frente ao estabelecimento & & faixa de tráfego & laticínios \\
\hline $04 / 02 / 14$ & B_MA & 15 & Sujinhos & restaurante & Polenghi & VUC pequeno & traseira & endereço & R: Da Consalaçăo 2104 & carga e descarga & laticínios \\
\hline 04/02/14 & B_MA & 16 & $\begin{array}{l}\text { Maceió } \\
\text { Tradicoños }\end{array}$ & supermercado pequeno & $\begin{array}{l}\text { Kicaldo } \\
\text { S }\end{array}$ & $\begin{array}{l}\text { utilitário } \\
\text { vycratande }\end{array}$ & $\begin{array}{l}\text { lateral } \\
\text { traseirat }\end{array}$ & $\begin{array}{l}\text { endereço } \\
\text { endereco }\end{array}$ & 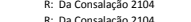 & carga e descarga & mercearia seca em geral \\
\hline $\begin{array}{l}04 / 02 / 14 \\
05 / 0 / 14\end{array}$ & $\begin{array}{l}\text { B-MA } \\
\text { B.MA }\end{array}$ & $\begin{array}{l}17 \\
11\end{array}$ & $\begin{array}{l}\text { Tradiçá } \\
\text { Maceió }\end{array}$ & $\begin{array}{l}\text { lanchonete } \\
\text { restaurante }\end{array}$ & $\begin{array}{l}\text { Ambev } \\
\text { n.id. }\end{array}$ & & $\begin{array}{c}\text { trasesira } \\
\text { traseralateral }\end{array}$ & $\begin{array}{l}\substack{\text { endiderce } \\
\text { endereco }} \\
\text {. }\end{array}$ & 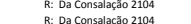 & $\begin{array}{l}\text { carra e edescarga } \\
\text { carra e edecarga }\end{array}$ & $\begin{array}{l}\text { bebidas } \\
\text { FV }\end{array}$ \\
\hline $\begin{array}{l}05 / 02 / 14 \\
05 / 02 / 14\end{array}$ & 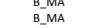 & $\frac{1}{2}$ & $\begin{array}{l}\text { Maceió } \\
\text { Maceió }\end{array}$ & $\begin{array}{l}\text { restuarante } \\
\text { supermercado pequeno }\end{array}$ & $\begin{array}{l}\text { nildi } \\
\text { wickbold }\end{array}$ & $\begin{array}{c}\text { Vec grande } \\
\text { kombi }\end{array}$ & $\begin{array}{l}\text { trasesara/ateral } \\
\text { lateral }\end{array}$ & $\begin{array}{l}\text { en fredereco } \\
\text { em fre ao estabelecimento }\end{array}$ & R: Ba Consalaç̧̧o 2104 & $\begin{array}{l}\text { carga e esescarga } \\
\text { vaga regular }\end{array}$ & $\begin{array}{l}\text { Fiv } \\
\text { păes }\end{array}$ \\
\hline $05 / 02 / 14$ & B_MA & 3 & Maceió & supermercado pequeno & Kibon & vuc pequeno & traseira & endereço & R: Da Consalaç̧̃o 2104 & carga e descarga & $\begin{array}{l}\text { porvestes } \\
\text { sors }\end{array}$ \\
\hline $05 / 02 / 14$ & B_MA & 4 & Sujinhos & restaurante & n.id. & vuc pequeno & lateral & endereço & R: Da Consalą̧̧̧o 2104 & carga e descarga & $\begin{array}{l}\text { carnes } \\
\text { cals }\end{array}$ \\
\hline $05 / 02 / 14$ & B_MA & 5 & Maceió & supermercado pequeno & n.id. & vuc grande & & dentro do estabelecimento & & & ovos \\
\hline $05 / 02 / 14$ & B_MA & 6 & Sujinhos & restaurante & Irmäos Avelino & vuc grande & traseira & 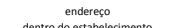 & R: Da Consalasẵo 2104 & carga e descarga & mercearia seca em geral \\
\hline $\begin{array}{l}05 / 02 / 14 \\
050 / 2 / 14\end{array}$ & B_MA & & $\begin{array}{c}\text { Bom } \\
\text { suinhos }\end{array}$ & $\begin{array}{l}\text { café/doceria/casa de sucos/sorveteria } \\
\text { restumarante }\end{array}$ & Café 3 coraçōoes & $\begin{array}{l}\text { van } \\
\text { uvt }\end{array}$ & traseira & dentro do estabelecimento & & faira de tréfeeg & mercearia seca em geral \\
\hline $\begin{array}{l}05 / 02 / 14 \\
05 / 02 / 14\end{array}$ & $\begin{array}{l}\text { B_MA } \\
\text { B_MA }\end{array}$ & $\begin{array}{l}8 \\
9\end{array}$ & $\begin{array}{l}\begin{array}{c}\text { Sulinhos } \\
\text { Maceió }\end{array} \\
\text {. }\end{array}$ & $\begin{array}{l}\text { restaurante } \\
\text { supermercado pequeno }\end{array}$ & $\begin{array}{l}\text { n.id. } \\
\text { n.i.d. }\end{array}$ & $\begin{array}{l}\text { uttilitario } \\
\text { vuc pequeno }\end{array}$ & traserara & $\begin{array}{l}\text { emm rente a a e estabelectmento } \\
\text { dentro do estabelecimento }\end{array}$ & & faixa de tráfego & $\begin{array}{l}\text { n.id. } \\
\text { outros }\end{array}$ \\
\hline
\end{tabular}




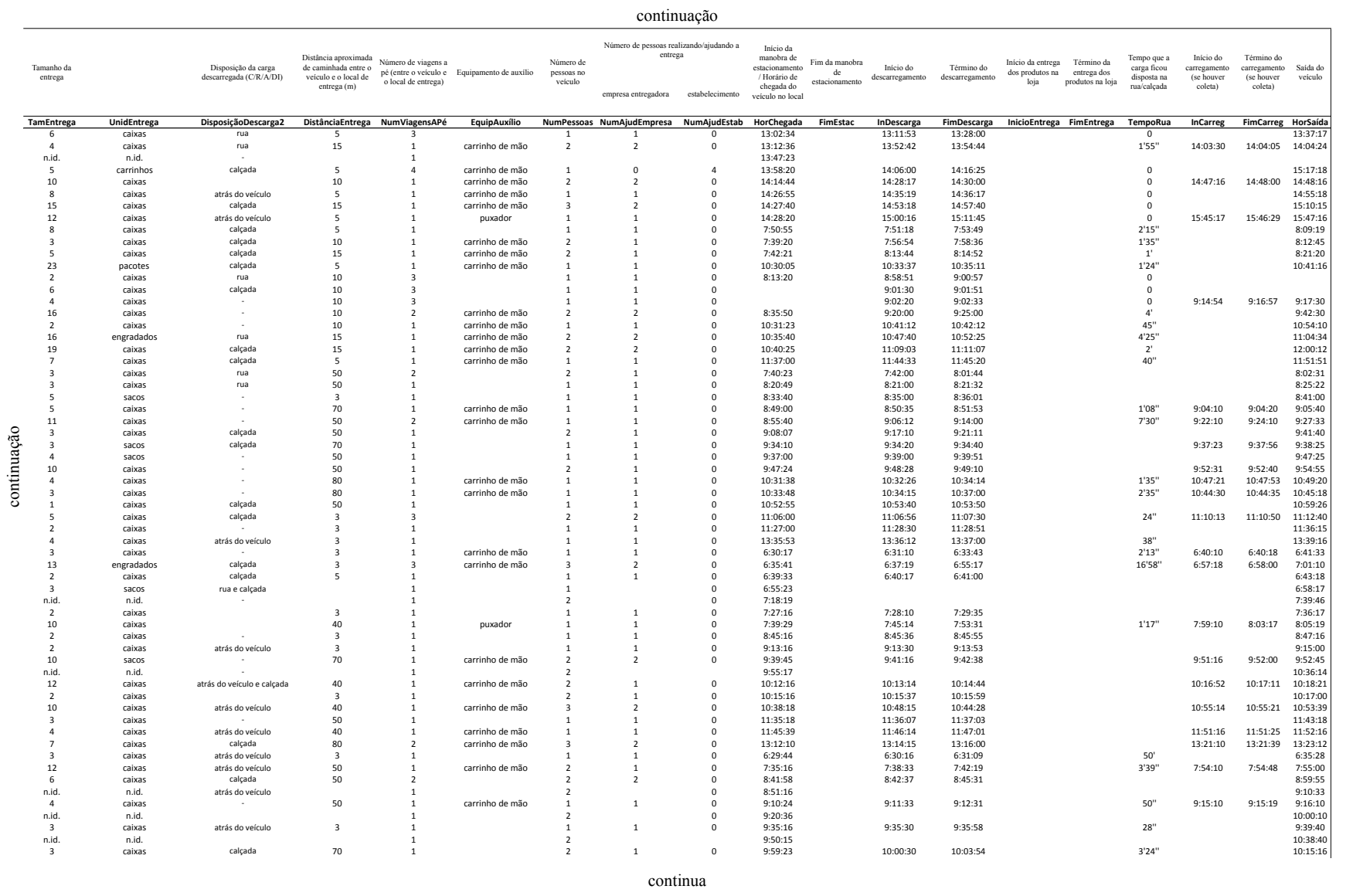




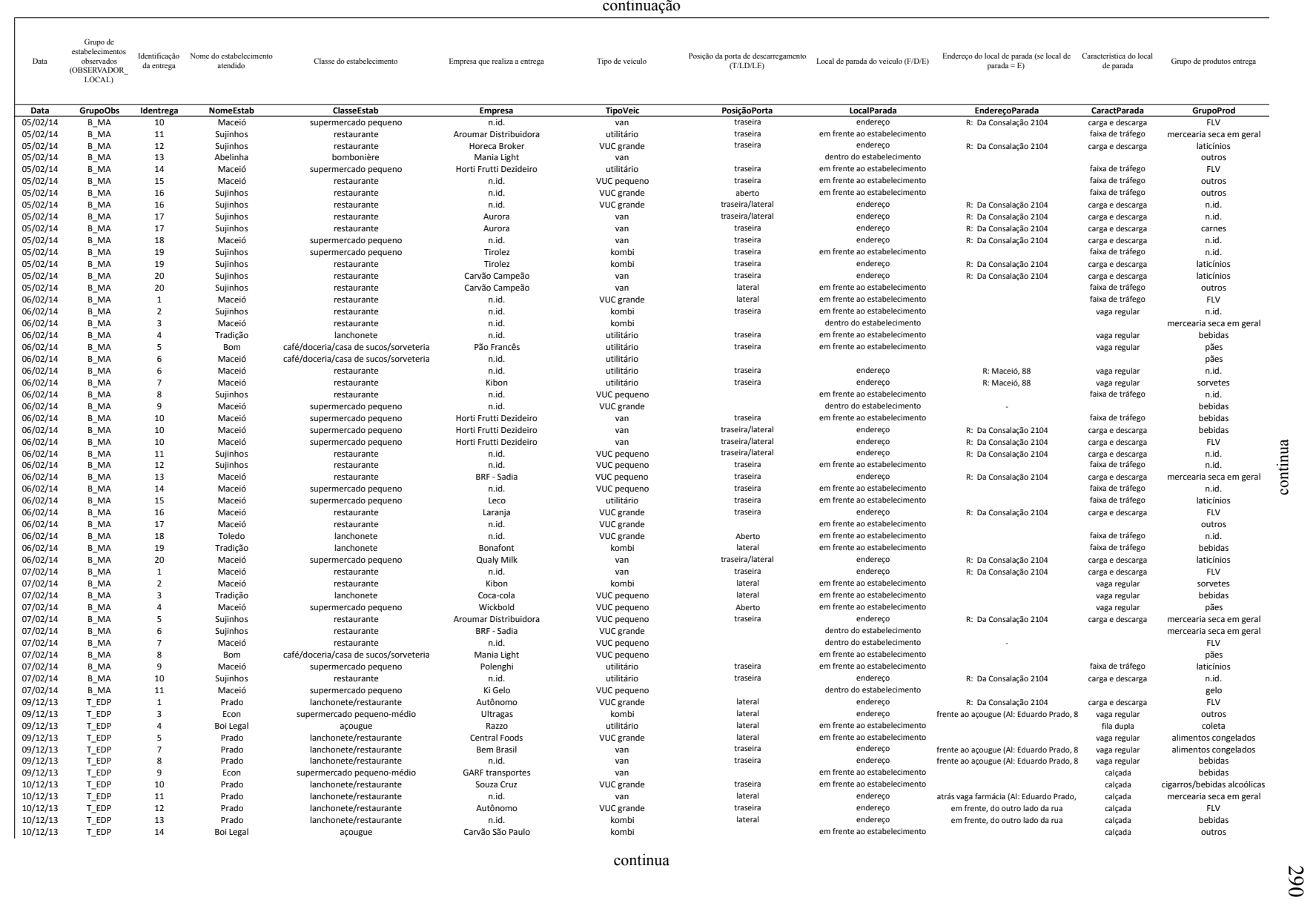




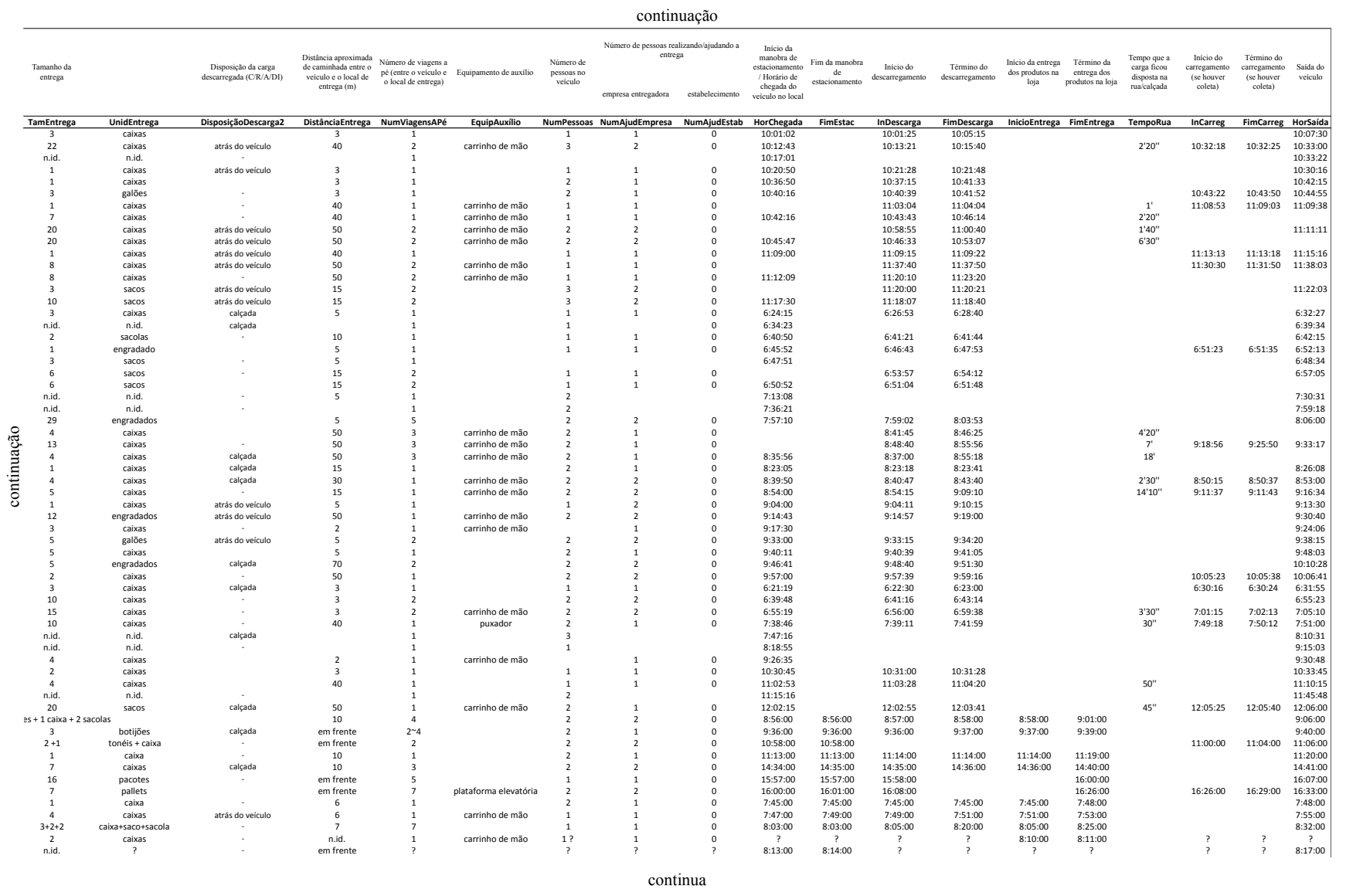


continuação

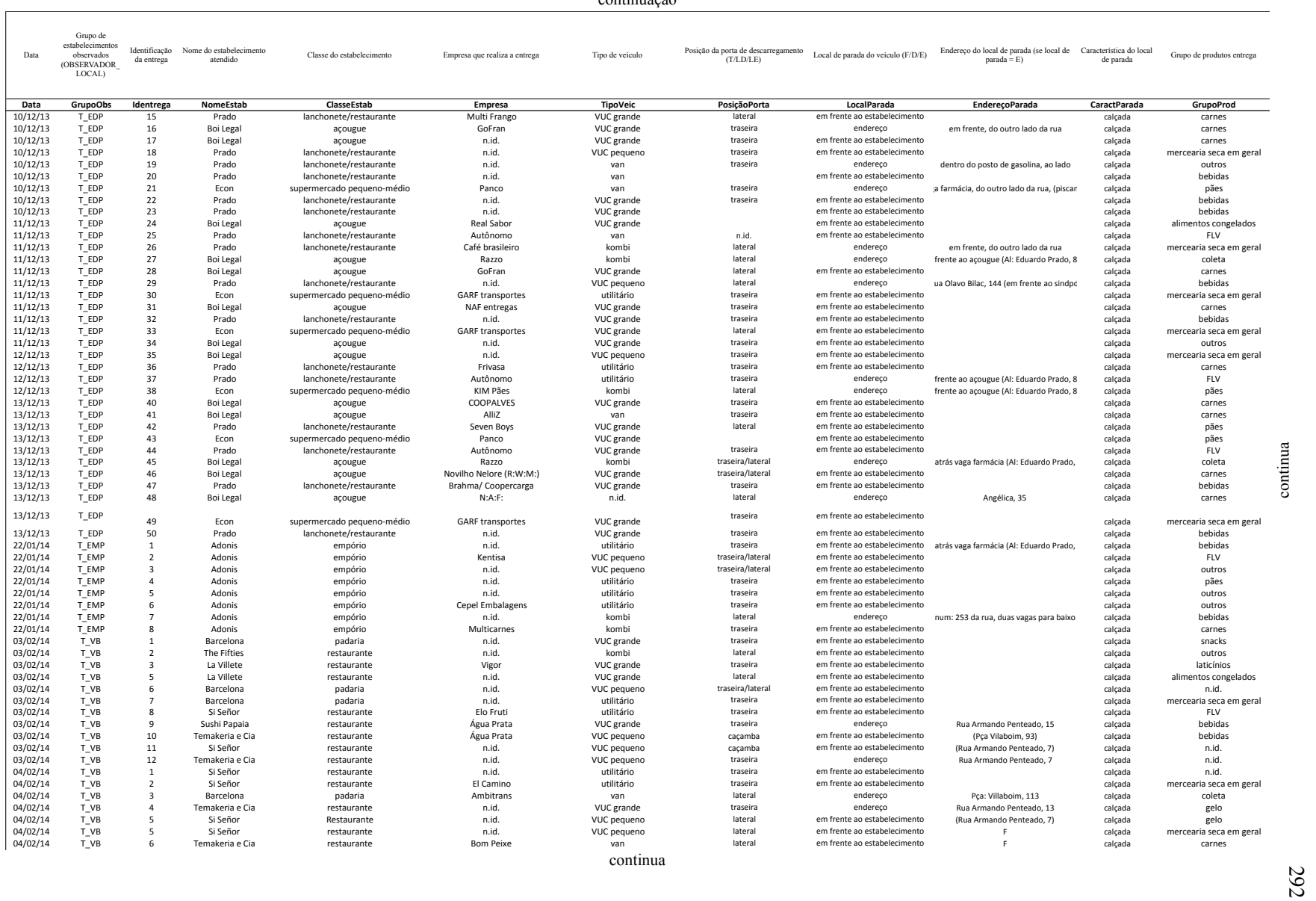




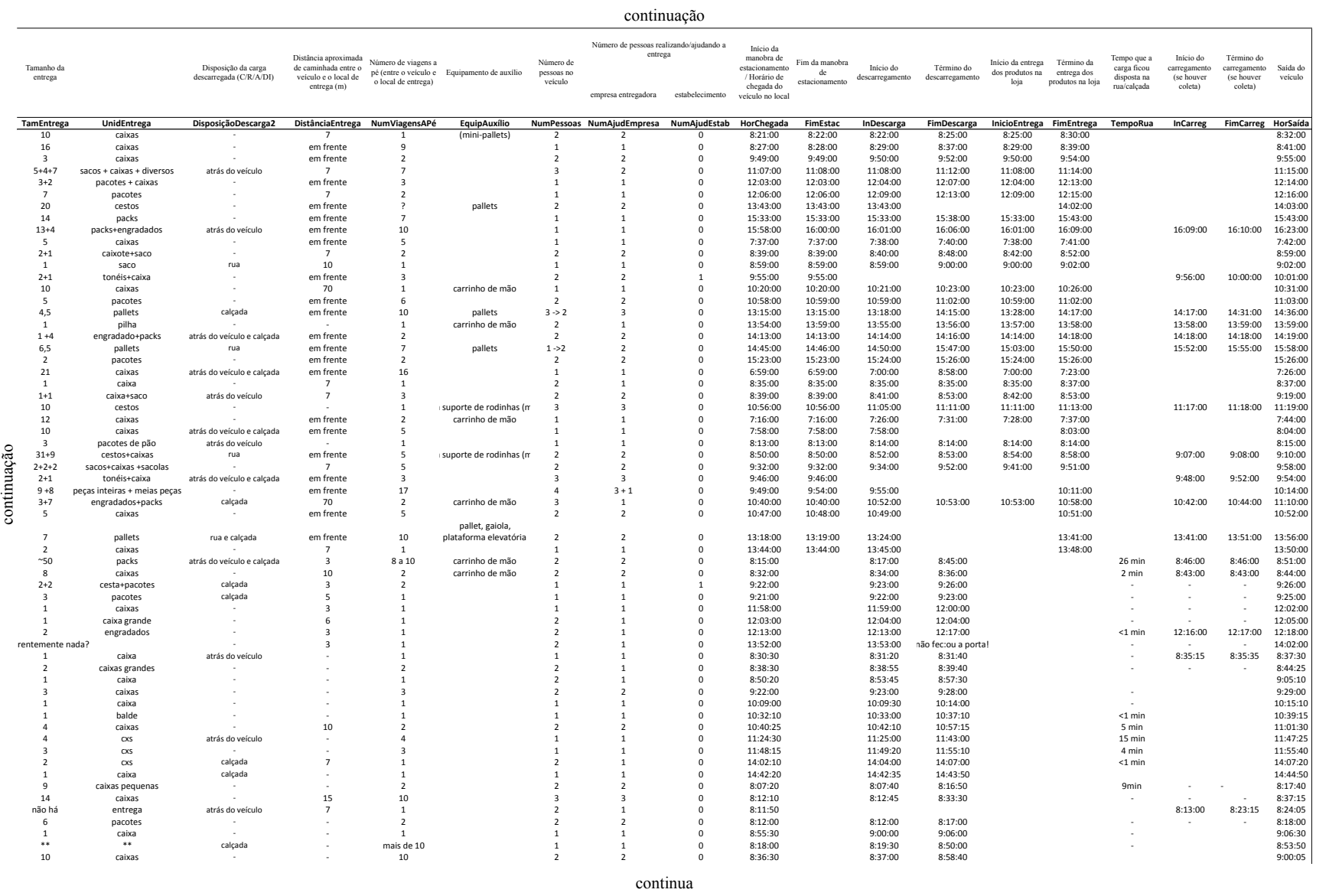


continuação

\begin{tabular}{|c|c|c|c|c|c|c|c|c|c|c|c|}
\hline Data & $\begin{array}{c}\text { Grippo de } \\
\text { estabelecinentos } \\
\text { obscrvads } \\
\text { (OBEREADOROR } \\
\text { LOCAL) }\end{array}$ & $\begin{array}{l}\text { Identificacáa } \\
\text { da entrega }\end{array}$ & $\begin{array}{c}\text { Nome do cestablececimento } \\
\text { atendido }\end{array}$ & Classs do stabercecimento & Empress que realiza a entrega & Tipo de veiculo & $\begin{array}{l}\text { Posiçä da porta de descarregamento } \\
\text { (TLDLLE) }\end{array}$ & Local de paradad do veciculo (FFD:E) & $\begin{array}{l}\text { Enderecó do Iocal de parada (sc local de } \\
\text { parada = E) }\end{array}$ & $\begin{array}{l}\text { Caracterisicia a do local } \\
\text { de parada }\end{array}$ & Ginpo de produtus entrega \\
\hline Data & Grupoobs & Identrega & NomeEstab & Classestab & Empresa & TipoVeic & Posiçăoporta & LocalParada & EndereçoParada & CaractParada & GrupoProd \\
\hline $04 / 02 / 14$ & T_VB & 7 & Si Señor & $\begin{array}{l}\text { Restaurante } \\
\end{array}$ & Pop Gelo & Vuc grande & traseira & em frente ao estabelecimento & (Rua Armando Penteado, 7) & calcada & carnes \\
\hline $04 / 02 / 14$ & T-VB & 7 & Si Señor & restaurante & Pop Gelo & vUC grande & lateral & endereşo & Pça: Villaboim, 113 & calçada & gelo \\
\hline $04 / 02 / 14$ & T_VB & 8 & $\begin{array}{l}\text { Barcelona } \\
\text { Barcolpon }\end{array}$ & padaria & $\begin{array}{l}\text { Rochinha Sorvetes } \\
\text { antive - produtos }\end{array}$ & $\begin{array}{l}\text { VuC grande } \\
\text { vac pouvpo }\end{array}$ & lateral & endereso & Pça: Villaboim, 113 & calcada & sorvetes \\
\hline 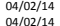 & 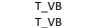 & ${ }_{10}^{9}$ & $\begin{array}{l}\text { Barcelona } \\
\text { siseñor }\end{array}$ & $\begin{array}{c}\text { padaria } \\
\text { restaurante }\end{array}$ & $\begin{array}{l}\text { Native - Produtos da natureza } \\
\text { EIIamino }\end{array}$ & $\begin{array}{l}\text { vuc pequeno } \\
\text { van }\end{array}$ & $\begin{array}{l}\text { lateral } \\
\text { lateral }\end{array}$ & $\begin{array}{l}\text { em frente ao estabelecimento } \\
\text { em mrente }\end{array}$ & & caląada & mercearia seca em geral \\
\hline $\begin{array}{l}04 / 02 / 14 \\
04 / 02 / 14\end{array}$ & T_VB & $\begin{array}{l}10 \\
11\end{array}$ & $\begin{array}{l}\text { Si Señor } \\
\text { Barcelona }\end{array}$ & $\begin{array}{l}\text { restaurante } \\
\text { padaria }\end{array}$ & $\begin{array}{l}\text { El camino } \\
\text { Cadburr-Adams }\end{array}$ & $\begin{array}{l}\text { van } \\
\text { van }\end{array}$ & $\begin{array}{l}\text { lateral } \\
\text { traseira/lateral }\end{array}$ & $\begin{array}{l}\text { em rrente a a estabelecimento } \\
\text { em frente ao estabelecimento }\end{array}$ & & $\begin{array}{l}\text { calçada } \\
\text { calsadada }\end{array}$ & $\begin{array}{l}\text { mercearia saca em geral } \\
\text { snacks }\end{array}$ \\
\hline $\begin{array}{l}04 / 02 / 14 \\
04 / 24\end{array}$ & & ${ }_{11}^{11}$ & $\begin{array}{l}\text { Barcelona } \\
\text { Si Señor }\end{array}$ & $\begin{array}{l}\text { padara } \\
\text { restaurante }\end{array}$ & $\begin{array}{l}\text { El Camino } \\
\text { Elystions }\end{array}$ & $\begin{array}{l}\text { van } \\
\text { utilitário }\end{array}$ & $\begin{array}{l}\text { nosterdatideral } \\
\text { n.id. }\end{array}$ & em frente ao estabelecimento & & $\begin{array}{l}\text { Caç̧ada } \\
\text { calcada }\end{array}$ & $\begin{array}{l}\text { Snacks } \\
\text { coleta }\end{array}$ \\
\hline $\begin{array}{l}04 / 02 / 14 \\
04 / 24\end{array}$ & T_VB & ${ }_{12}^{11}$ & Si Señor & $\begin{array}{l}\text { Sestudrante } \\
\text { restaurante }\end{array}$ & Elo Fruti & $\begin{array}{l}\text { utiutario } \\
\text { van }\end{array}$ & $\begin{array}{l}\text { traseira/atateral } \\
\text { the }\end{array}$ & em frente ao estabelecimento & & $\begin{array}{l}\text { Caç̧ada } \\
\text { calcada }\end{array}$ & FLV \\
\hline 04/02/14 & T_vB & 13 & Barcelona & padaria & BRF-Sadia & Vuc pequeno & $\begin{array}{l}\text { lateral } \\
\text { lats }\end{array}$ & em frente ao estabelecimento & & $\begin{array}{l}\text { lalsada } \\
\text { calcada }\end{array}$ & mercearia seca em geral \\
\hline $04 / 02 / 14$ & T_VB & 14 & Barcelona & padaria & BRF-Sadia & vuc grande & traseira & em frente ao estabelecimento & & calçada & frios/embutidos \\
\hline $04 / 02 / 14$ & T_vB & 15 & Barcelona & padaria & Emulzint & n.id. & traseira & enderesco & Igoas, a lado da padaria (entrada no 20 & calçada & outros \\
\hline 04/02/14 & T_VB & ${ }_{17}^{16}$ & $\begin{array}{l}\text { Bar da Praça } \\
\text { Lavilete }\end{array}$ & $\begin{array}{l}\text { bar premium } \\
\text { resturarate }\end{array}$ & n.id. & vuc grande & $\begin{array}{c}\text { traseira } \\
\text { ateral }\end{array}$ & $\begin{array}{l}\text { endereso } \\
\text { em frente a e estabelecimento }\end{array}$ & Atrás entr: Arm: Penteado, 14: “” & calcada & n.id. \\
\hline $\begin{array}{l}04 / 02 / 14 \\
04 / 02 / 14\end{array}$ & $\begin{array}{l}T=V B \\
T V B\end{array}$ & ${ }_{18}^{17}$ & $\begin{array}{l}\text { La Villete } \\
\text { Bar da Praca }\end{array}$ & $\begin{array}{l}\text { restatarante } \\
\text { bat premium }\end{array}$ & 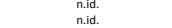 & $\begin{array}{c}\text { kombi } \\
\text { utilitário }\end{array}$ & $\begin{array}{l}\text { lateral } \\
\text { traseira }\end{array}$ & $\begin{array}{l}\text { em m frente aa estabelecimento } \\
\text { em frente a ostabelecimento }\end{array}$ & Rua Armando Penteado, 25 & $\begin{array}{l}\text { calcada } \\
\text { calcadad } \\
\text { and }\end{array}$ & $\begin{array}{c}\text { n.idd. } \\
\text { n.id. }\end{array}$ \\
\hline 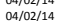 & T VB & ${ }_{19}^{18}$ & $\begin{array}{l}\text { Bardatillate } \\
\text { La vile }\end{array}$ & $\begin{array}{l}\text { bar remilum } \\
\text { restaurante }\end{array}$ & $\begin{array}{l}\text { h.l. } \\
\text { Sweety Ice }\end{array}$ & $\begin{array}{l}\text { utuliltário } \\
\text { kombi }\end{array}$ & nid. & $\begin{array}{l}\text { em irente ao estabelectritento } \\
\text { endereco }\end{array}$ & 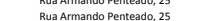 & $\begin{array}{l}\text { calçada } \\
\text { calcada }\end{array}$ & $\begin{array}{l}\text { n.la. } \\
\text { sorvetes }\end{array}$ \\
\hline 04/02/14 & T_VB & 20 & Si Señor & $\begin{array}{l}\text { Testaurante } \\
\text { restaurante }\end{array}$ & $\begin{array}{l}\text { nweetyce } \\
\text { n.id. }\end{array}$ & vuc pequeno & $\begin{array}{l}\text { n.ted } \\
\text { n.d. }\end{array}$ & $\begin{array}{l}\text { endereço } \\
\text { endereco }\end{array}$ & $\begin{array}{l}\text { Kua Armandoo Penteado, } 2 \mathrm{~S} \\
\text { Rua Armando Penteado, } 1\end{array}$ & $\begin{array}{l}\text { calçąa } \\
\text { calcada }\end{array}$ & $\begin{array}{l}\text { mercearia secte em geral } \\
\text { mect }\end{array}$ \\
\hline $04 / 02 / 14$ & T_VB & 22 & Barcelona & padaria & Casa do gás & vuc pequeno & $\begin{array}{c}\text { mimeita } \\
\text { trasera }\end{array}$ & endereço & Rua Armando Penteado, 7 & calcada & 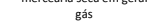 \\
\hline $04 / 02 / 14$ & T_VB & 23 & Barcelona & padaria & Byblos Rotisserie & vuc pequeno & traseira & em frente ao estabelecimento & & calcada & snacks \\
\hline $04 / 02 / 14$ & T_VB & 24 & Si Señor & Restaurante & n.id. & utilitário & traseira & em frente ao estabelecimento & & calçada & snacks \\
\hline $04 / 02 / 14$ & T_VB & 24 & Si Señor & restaurante & n.id. & utilitário & traseira & endereço & Rua Armando Penteado, 7 & calçada & n.id. \\
\hline $04 / 02 / 14$ & T_VB & 25 & $\begin{array}{l}\text { Si Señor } \\
\text { s señono }\end{array}$ & restaurante & El Jimador & vuC pequeno & traseira & endereço & Rua Armando Penteado, 7 & calçada & cigarros/bebidas alcoólicas \\
\hline 05/02/14 & T_VB & & Si Señor & restaurante & Nellore & van & & em frente ao estabelecimento & & calçada & \\
\hline $05 / 02 / 14$ & T_VB & 2 & Barcelona & padaria & n.id. & vuc pequeno & traseira & enderesco & Rua Armando Penteado, 25 & calçada & snacks \\
\hline $05 / 02 / 14$ & T_VB & 3 & $\begin{array}{l}\text { Temakeria e Cia } \\
\text { Sis Señor }\end{array}$ & $\begin{array}{l}\text { restaurante } \\
\text { restareante }\end{array}$ & n.id. & kombi & lateral & em frente ao estabelecimento & & calçada & sorvetes \\
\hline $\begin{array}{l}05 / 02 / 14 \\
05 / 0214\end{array}-24$ & T_VB & 5 & $\begin{array}{l}\text { Si Señor } \\
\text { La Villete }\end{array}$ & $\begin{array}{l}\text { restaurante } \\
\text { restareante }\end{array}$ & $\begin{array}{c}\text { Frigorifico BB } \\
\text { nid }\end{array}$ & 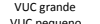 & $\begin{array}{l}\text { lateral } \\
\text { ans }\end{array}$ & em frente ao estabelecimento & & calçada & carnes \\
\hline $\begin{array}{l}05 / 02214 \\
05 / 02 / 14\end{array}$ & $\begin{array}{l}T=V B \\
T V B\end{array}$ & $\begin{array}{l}6 \\
7\end{array}$ & $\begin{array}{l}\text { La Villete } \\
\text { Temakeria e Cia }\end{array}$ & $\begin{array}{l}\text { restatarante } \\
\text { restaurante }\end{array}$ & $\begin{array}{l}\text { n.id. } \\
\text { ni.d. }\end{array}$ & $\begin{array}{l}\text { Vuc pequeno } \\
\text { vuc pequeno }\end{array}$ & $\begin{array}{l}\text { traseira///ateral } \\
\text { traseira//ateral }\end{array}$ & $\begin{array}{l}\text { endereco } \\
\text { em frente a estabelecimento }\end{array}$ & Rua Armando Penteado, 25 & $\begin{array}{c}\text { calçada } \\
\text { calegad }\end{array}$ & alimentos congelados \\
\hline $\begin{array}{l}05 / 02 / 14 \\
05 / 14\end{array}$ & T VB & $\begin{array}{l}7 \\
8\end{array}$ & Barcelona & $\begin{array}{l}\text { restaurante } \\
\text { Padaria }\end{array}$ & $\begin{array}{l}\text { h.la. } \\
\text { Sufresh }\end{array}$ & $\begin{array}{l}\text { vuc pqueno } \\
\text { vuc pequeno }\end{array}$ & $\begin{array}{l}\text { traseida/fateral } \\
\text { traseira }\end{array}$ & em frente ao estabelecimento & & 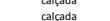 & $\begin{array}{l}\text { n.id. } \\
\text { nid. }\end{array}$ \\
\hline 05/02/14 & T_VB & 8 & Barcelona & padaria & Sufresh & $\begin{array}{l}\text { vuc pqqueno } \\
\text { vuc pequeno }\end{array}$ & $\begin{array}{l}\text { Trasserla } \\
\text { traseiralateral }\end{array}$ & 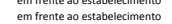 & & $\begin{array}{l}\text { calçada } \\
\text { calcada }\end{array}$ & $\begin{array}{l}\text { n.ld. } \\
\text { bebidas }\end{array}$ \\
\hline $05 / 02 / 14$ & T_VB & 9 & Barcelona & padaria & Buona Italia Alimentos & kombi & traserar/ateral & em frente ao estabelecimento & & $\begin{array}{ll} & \end{array}$ & alimentos congelados \\
\hline $05 / 02 / 14$ & T_VB & 10 & Bar da Praça & bar premium & Star Transportes & van & lateral & em frente ao estabelecimento & & calcada & alimentos congelados \\
\hline $05 / 02 / 14$ & T_VB & 11 & Si Señor & restaurante & n.id. & vuc pequeno & traseira & endereço & em frente à padaria & calçada & FLV \\
\hline $05 / 02 / 14$ & T_VB & 12 & Barcelona & padaria & n.id. & VuC pequeno & traseira & em frente ao estabelecimento & & calçada & alimentos congelados \\
\hline 05/02/14 & T_VB & 13 & 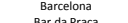 & padaria & n.id. & utilitário & traseira & $\begin{array}{l}\text { enderesço } \\
\text { endereco }\end{array}$ & , antes da esquina, entrada para 20 anda & calçada & n.id. \\
\hline $\begin{array}{l}05 / 02 / 14 \\
05 / 02 / 14\end{array}$ & $\begin{array}{l}T_{T}^{T} \text { VB } \\
T_{T} \mathrm{VB}\end{array}$ & ${ }_{14}^{14}$ & $\begin{array}{l}\text { Bar da Pracá } \\
\text { Bar da Praça }\end{array}$ & $\begin{array}{l}\begin{array}{l}\text { akr premium } \\
\text { bar premium }\end{array} \\
\text {. }\end{array}$ & $\begin{array}{c}\text { n.id. } \\
\text { nidd }\end{array}$ & $\begin{array}{c}\text { van } \\
\text { van }\end{array}$ & $\begin{array}{l}\text { lateral } \\
\text { cacamba }\end{array}$ & $\begin{array}{l}\text { endereco } \\
\text { em frente ao estabelecimento }\end{array}$ & , antes da esquina, entrada parta 20 anda & $\begin{array}{l}\text { calcada } \\
\text { calcadad }\end{array}$ & $\begin{array}{l}\text { n.id. } \\
\text { FLV }\end{array}$ \\
\hline $\begin{array}{ll}05 / 02 / 14 \\
05 / 142\end{array}$ & T_VB & ${ }_{15}^{14}$ & $\begin{array}{l}\text { Ear ad Praca, } \\
\text { Barcelona }\end{array}$ & $\begin{array}{l}\text { bap premum } \\
\text { padaria }\end{array}$ & $\begin{array}{l}\text { Antd. } \\
\text { Aroumar Distribuidora }\end{array}$ & $\begin{array}{c}\text { van } \\
\text { utilitário }\end{array}$ & $\begin{array}{l}\begin{array}{c}\text { caçmba } \\
\text { cacamba }\end{array} \\
\text {. }\end{array}$ & 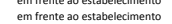 & & $\begin{array}{l}\text { calçada } \\
\text { calcada }\end{array}$ & bebidas \\
\hline $05 / 02 / 14$ & T_VB & 16 & Si Señor & $\begin{array}{l}\text { padardid } \\
\text { restaurante }\end{array}$ & Budweiser & vuc grande & lateral & endereço & , antes da esquina, entrada para 20 anda & 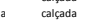 & bebidas \\
\hline $05 / 02 / 14$ & T_VB & 16 & Si Señor & restaurante & Budweiser & vuc grande & lateral & em frente ao estabelecimento & & lalcada & bebidas \\
\hline $05 / 02 / 14$ & T_VB & 16 & Si Señor & restaurante & Budweiser & vuc grande & lateral & em frente ao estabelecimento & & calçada & bebidas \\
\hline $05 / 02 / 14$ & T_vB & 17 & Barcelona & padaria & Lirium Ltda & vuc grande & lateral & em frente ao estabelecimento & & calçada & coleta \\
\hline $05 / 02 / 14$ & T_VB & 18 & Barcelona & $\begin{array}{c}\text { padaria } \\
\text { restarente }\end{array}$ & n.id. & van & cacamba & em frente ao estabelecimento & & calcada & nid. \\
\hline 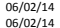 & $\begin{array}{l}\text { T_VB } \\
\text { T VB }\end{array}$ & $\frac{1}{2}$ & $\begin{array}{l}\text { La Villete } \\
\text { Si señor }\end{array}$ & $\begin{array}{l}\text { restaurante } \\
\text { restuarante }\end{array}$ & $\begin{array}{l}\text { Terra Brasil } \\
\text { Pop Gelo }\end{array}$ & $\begin{array}{l}\text { uttilitário } \\
\text { vuc pequeno }\end{array}$ & $\begin{array}{c}\text { traseira } \\
\text { traseira }\end{array}$ & $\begin{array}{l}\text { em rfente a e estabelececimento } \\
\text { em frente a o estabelecimento }\end{array}$ & & $\begin{array}{c}\text { calçada } \\
\text { calcada }\end{array}$ & $\begin{array}{c}\text { FLV } \\
\text { gelo }\end{array}$ \\
\hline $\begin{array}{l}06 / 02 / 14 \\
06 / 14\end{array}$ & T VB & 3 & Temakeria e Cia & $\begin{array}{l}\text { restaurante } \\
\text { restaurante }\end{array}$ & $\begin{array}{l}\text { Pop G Glo } \\
\text { n.id. }\end{array}$ & $\begin{array}{l}\text { vuc pequeno } \\
\text { vuc rande }\end{array}$ & $\begin{array}{l}\text { traseira } \\
\text { lateral }\end{array}$ & $\begin{array}{l}\text { em frente a o e estabelectimento } \\
\text { endereco }\end{array}$ & Rua Armando penteado, 21 & 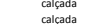 & $\begin{array}{l}\text { gelo } \\
\text { outros }\end{array}$ \\
\hline 06/02/14 & T_VB & 4 & Temakeria e Cia & $\begin{array}{l}\text { restaurante } \\
\text { restate }\end{array}$ & Maqgel & van & $\begin{array}{c}\text { alteral } \\
\text { traseira }\end{array}$ & 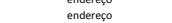 & $\begin{array}{l}\text { Ráa Armanaco penteaco, 12 } \\
\text { Rua Armando Penteado, } 1\end{array}$ & $\begin{array}{c}\text { caçcada } \\
\text { calcada }\end{array}$ & $\begin{array}{l}\text { Surtos } \\
\text { outros }\end{array}$ \\
\hline $06 / 02 / 14$ & T_VB & 4 & La Villete & $\begin{array}{l}\text { restaurante } \\
\text { restates }\end{array}$ & Maqgel & van & trasera & endereço & Rua Armando Penteado, 1 & $\begin{array}{l}\text { alsyoua } \\
\text { calcada }\end{array}$ & outros \\
\hline $06 / 02 / 14$ & T_VB & 4 & La Villete & restaurante & Maqgel & van & traseira & endereço & Rua Armando Penteado, 1 & calcada & outros \\
\hline $06 / 02 / 14$ & T_VB & 4 & Buddie's Burguer & restaurante & Maqgel & van & traseira & endereço & Rua Armando Penteado, 1 & calçada & gelo \\
\hline $06 / 02 / 14$ & T_vB & 4 & La Villete & restaurante & Maqgel & vuc grande & traseira & endereço & Rua Armando Penteado, 1 & calçada & gelo \\
\hline 06/02/14 & T_VB & 4 & Temakeria e Cia & restaurante & Maggel & Vuc grande & traseira & $\begin{array}{l}\text { endereço } \\
\text { enderecos }\end{array}$ & Rua Armando Penteado, 1 & calcada & gelo \\
\hline $\begin{array}{l}06 / / 22 / 14 \\
06 / 0 / 14\end{array}$ & T_vB & $\begin{array}{r}5 \\
6\end{array}$ & $\begin{array}{l}\text { Buddie's Burguer } \\
\text { Barda Praca }\end{array}$ & $\begin{array}{l}\text { restarante } \\
\text { Bar premium }\end{array}$ & $\begin{array}{l}\text { n.id. } \\
\text { Distribar }\end{array}$ & $\begin{array}{l}\text { vuC grande } \\
\text { kombi }\end{array}$ & $\begin{array}{l}\text { traseira } \\
\text { lateral }\end{array}$ & $\begin{array}{l}\begin{array}{l}\text { endereço } \\
\text { enderecco }\end{array} \\
\text {. }\end{array}$ & $\begin{array}{l}\text { Rua Arrmando Penteado, } 1 \\
\text { Rava Armando penteadoo }\end{array}$ & $\begin{array}{l}\text { calçada } \\
\text { calacada }\end{array}$ & $\begin{array}{l}\text { pães } \\
\text { pães }\end{array}$ \\
\hline $\begin{array}{l}06 / / 22 / 14 \\
06 / 2 / 14\end{array}$ & $\begin{array}{l}\text { TTVB } \\
\text { T.VB }\end{array}$ & $\begin{array}{l}6 \\
6\end{array}$ & $\begin{array}{l}\text { Bar da Praça } \\
\text { Bar da Praça }\end{array}$ & $\begin{array}{l}\text { 酐 remium } \\
\text { Bar premium }\end{array}$ & $\begin{array}{l}\text { Distribar } \\
\text { Distribar }\end{array}$ & $\begin{array}{l}\text { kombi } \\
\text { kombi }\end{array}$ & $\begin{array}{l}\text { lateral } \\
\text { lateral }\end{array}$ & $\begin{array}{l}\text { en frente ao estaço } \\
\text { embecimento }\end{array}$ & & $\begin{array}{l}\text { calçada } \\
\text { calcadata }\end{array}$ & $\begin{array}{l}\text { päes } \\
\text { pẽes }\end{array}$ \\
\hline $\begin{array}{l}06 / 02 / 14 \\
06 / 14\end{array}$ & T_VB & 6 & Bar da Praça & $\begin{array}{l}\text { Dapremium } \\
\text { Bar premium }\end{array}$ & $\begin{array}{l}\text { Siltrtibar } \\
\text { Distribar }\end{array}$ & kombi & $\begin{array}{l}\text { lateral } \\
\text { lateral }\end{array}$ & em frente a o estabelecimento & & $\begin{array}{l}\text { calçada } \\
\text { calcada }\end{array}$ & $\begin{array}{l}\text { paes } \\
\text { păes }\end{array}$ \\
\hline $06 / 02 / 14$ & T_VB & 6 & Bar da Praça & bar premium & Distribar & kombi & lateral & em frente ao estabelecimento & & calcada & bebidas \\
\hline $06 / 02 / 14$ & T_VB & 7 & Temakeria e Cia & restaurante & Stoq Alimentos & van & lateral & em frente ao estabelecimento & & calçada & mercearia seca em geral \\
\hline $06 / 02 / 14$ & T_VB & 8 & Barcelona & padaria & El Pozo & van & traseira & em frente ao estabelecimento & & calçada & mercearia seca em geral \\
\hline 06/02/14 & T_vB & 9 & Buddie's Burguer & restaurante & Maxis Alimentos & utilitário & $\begin{array}{c}\text { traseira } \\
\text { taterat }\end{array}$ & em frente ao estabelecimento & & calçada & FLV \\
\hline \multirow[t]{2}{*}{$\begin{array}{l}06 / / 22 / 14 \\
06 / 02 / 14\end{array}$} & $\begin{array}{l}T_{\text {T.VB }} \\
\text { T_VB }\end{array}$ & $\begin{array}{l}10 \\
10\end{array}$ & $\begin{array}{l}\text { Buddie's Burruer } \\
\text { Buddie's Burguer }\end{array}$ & $\begin{array}{l}\text { restuarante } \\
\text { restaurante }\end{array}$ & $\begin{array}{l}\text { Prata } \\
\text { Prata }\end{array}$ & $\begin{array}{l}\text { van } \\
\text { van }\end{array}$ & $\begin{array}{l}\text { acteral } \\
\text { traseira }\end{array}$ & $\begin{array}{l}\text { endereceso } \\
\text { endereço }\end{array}$ & $\begin{array}{l}\text { RuA Armando Penteado, } 48 \\
\text { em frente à adaria }\end{array}$ & $\begin{array}{l}\text { calcada } \\
\text { calçada }\end{array}$ & $\begin{array}{l}\mathrm{FV} \\
\mathrm{FLV}\end{array}$ \\
\hline & & & & & & continu & & & & & \\
\hline
\end{tabular}




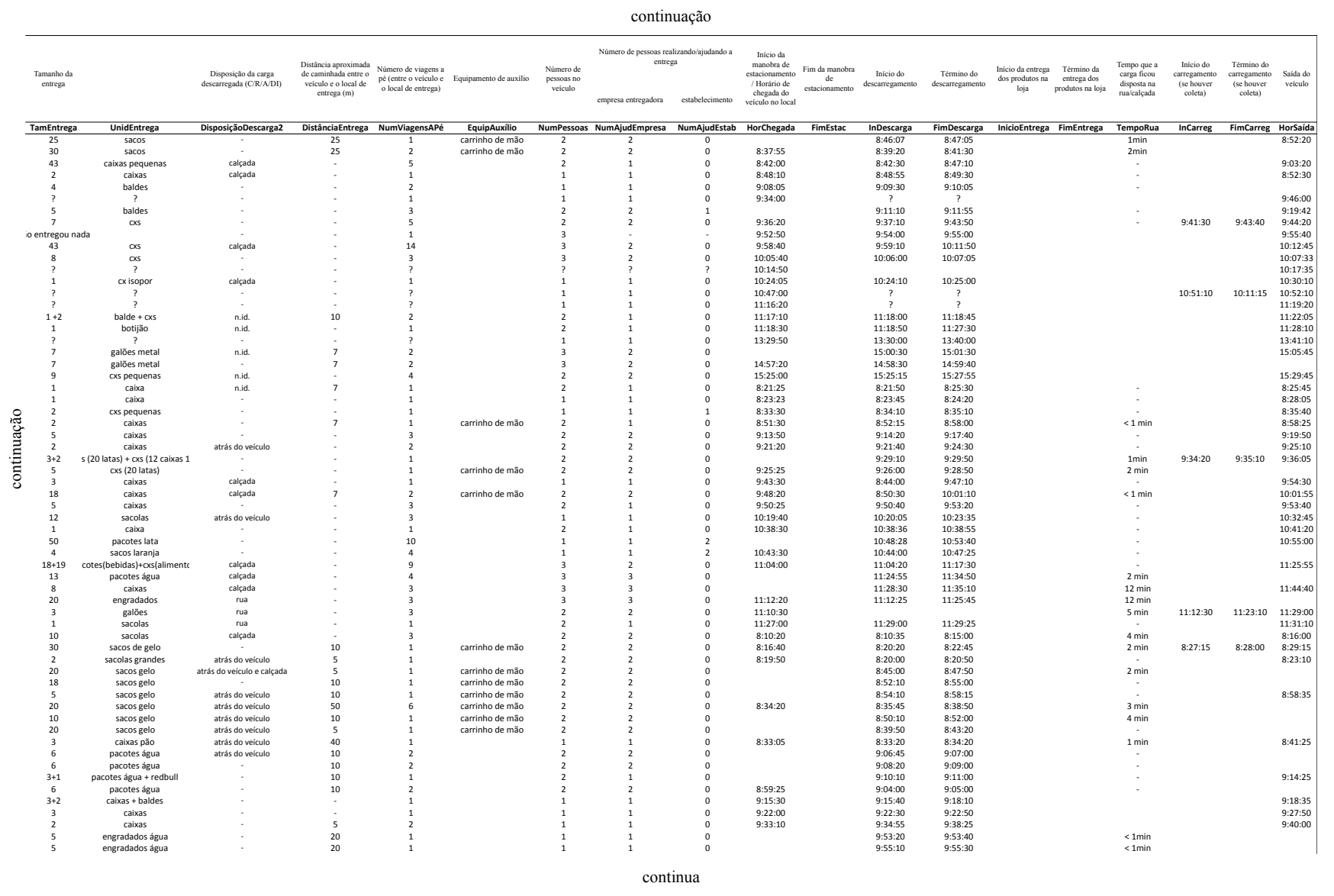




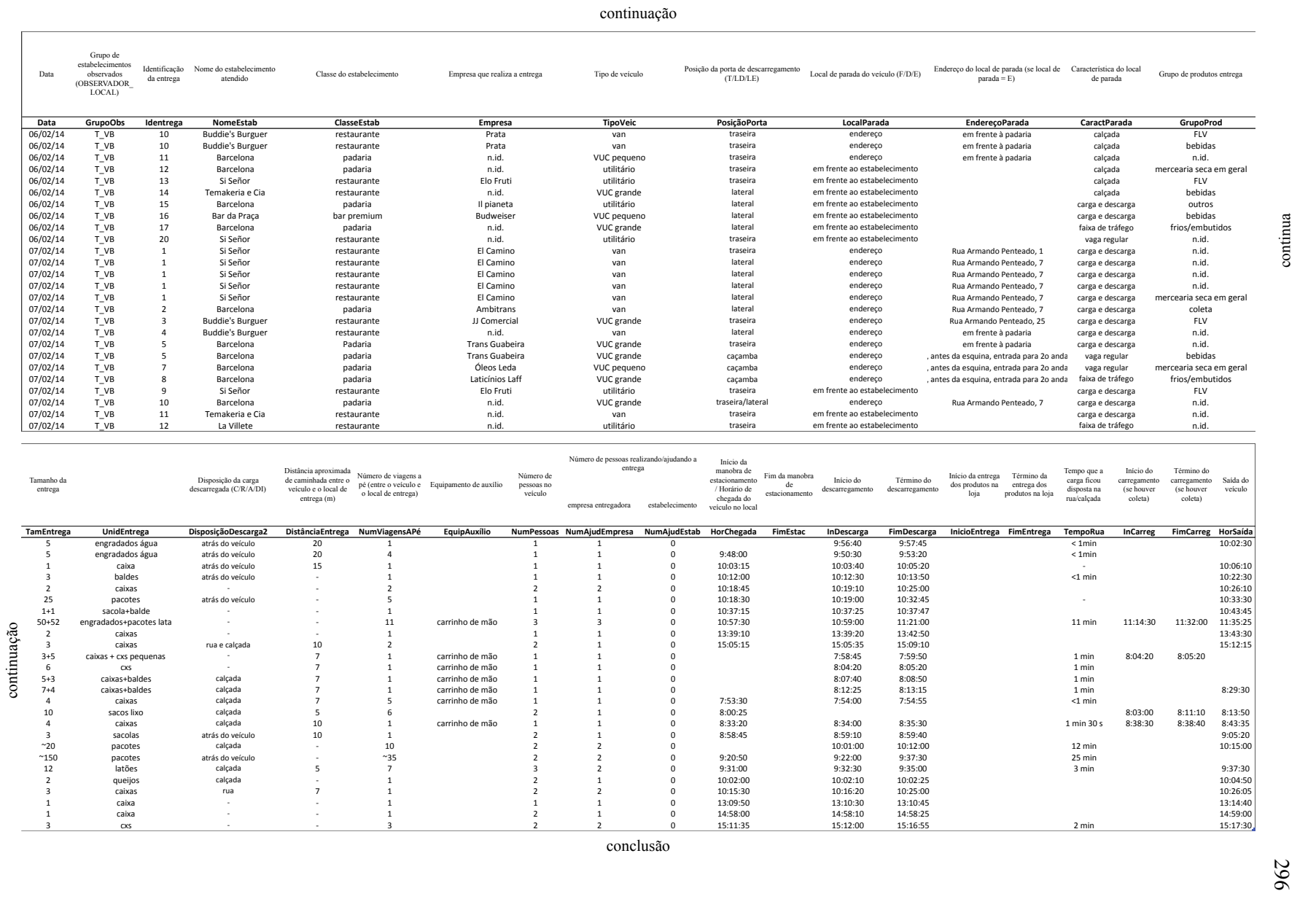


Tabela A.2 - Dados coletados durante as observações das entregas do shopping center

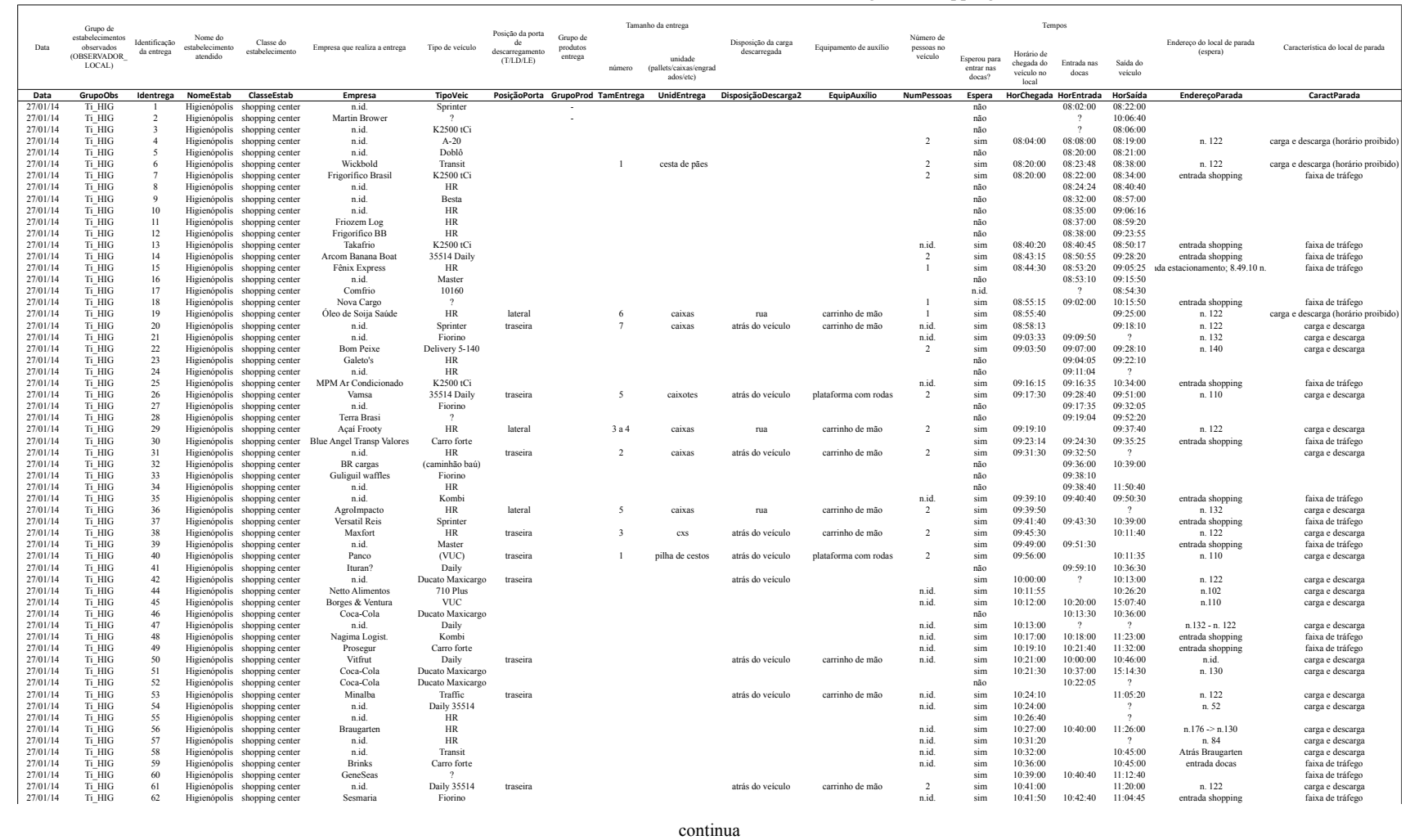




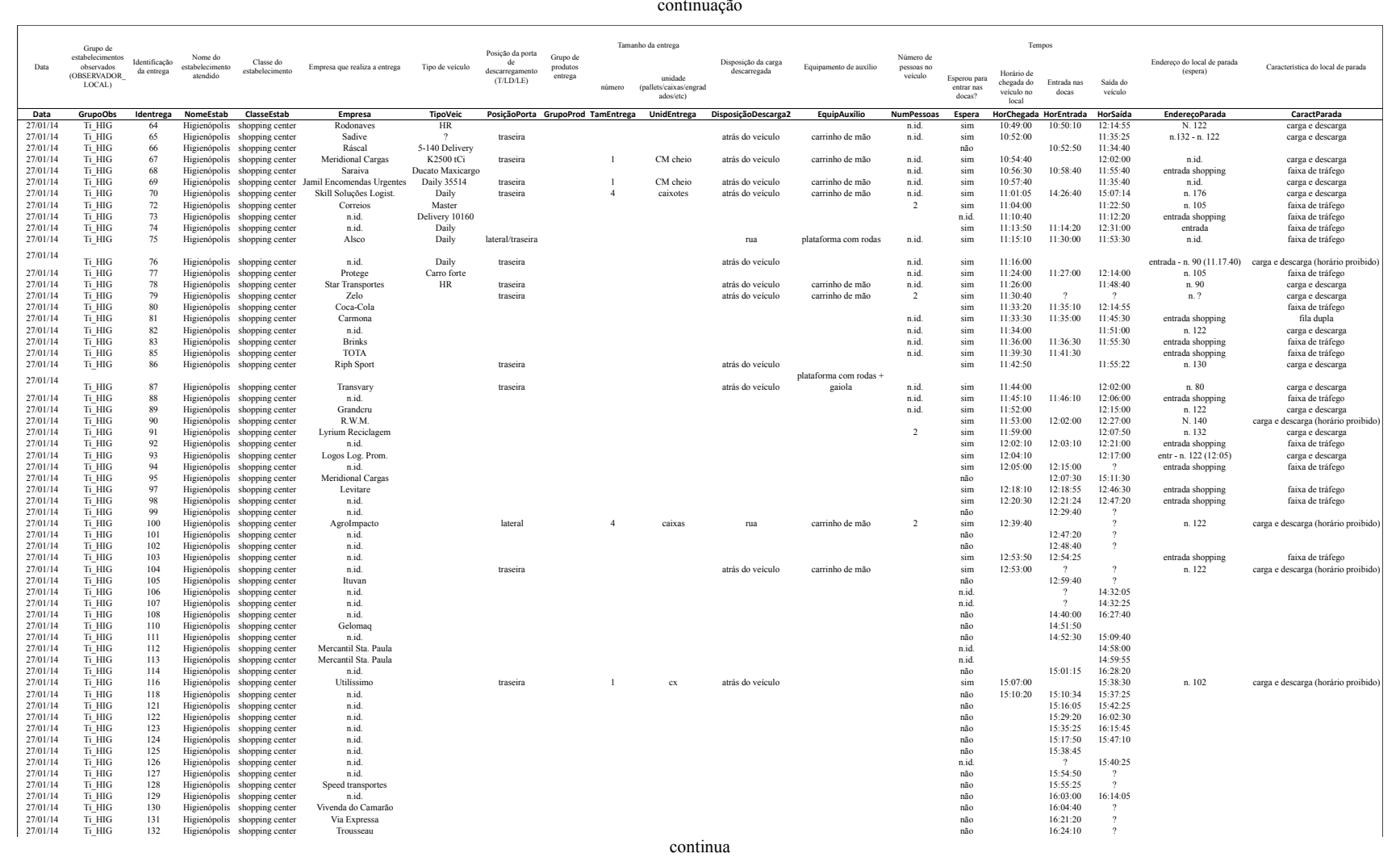




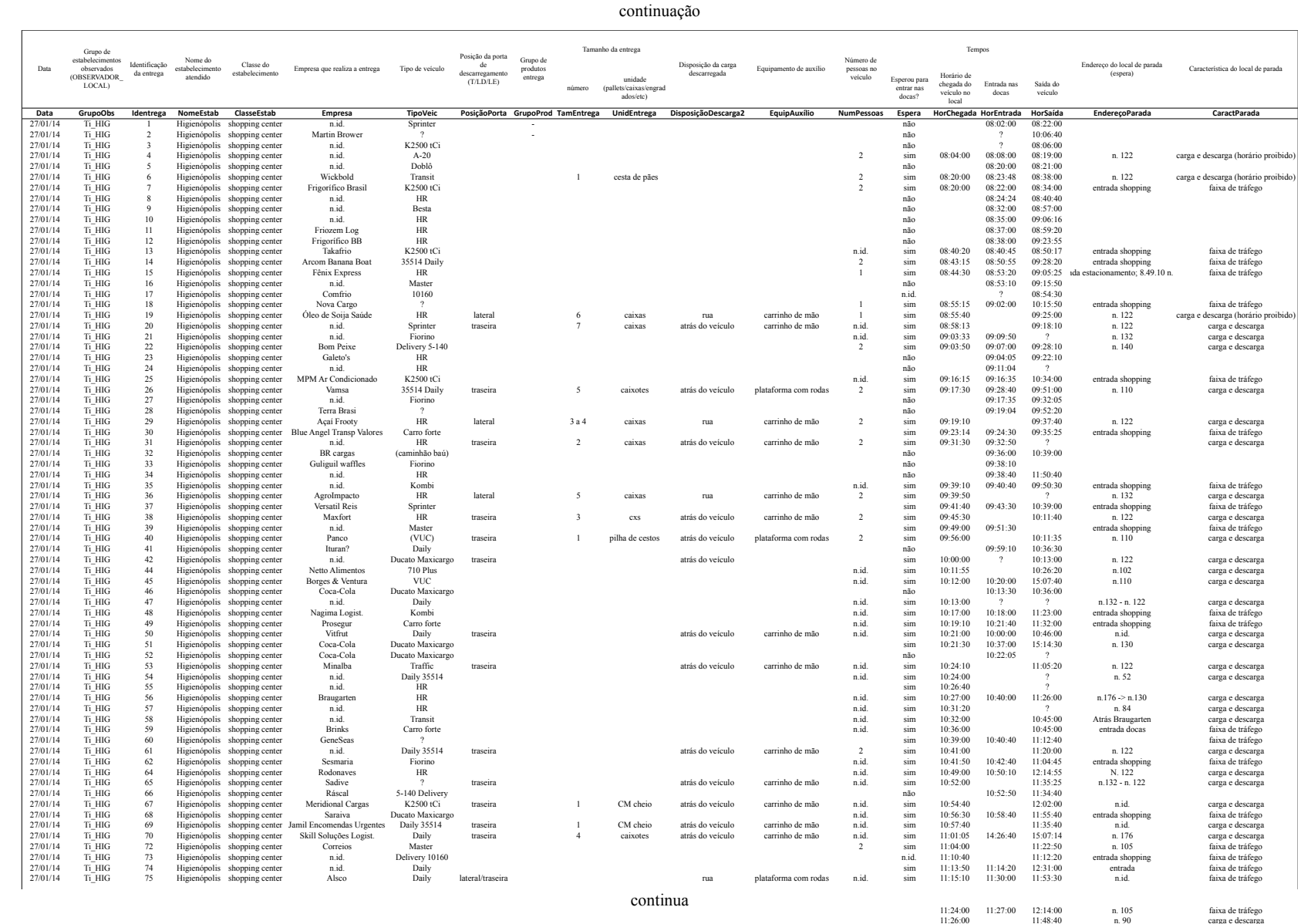




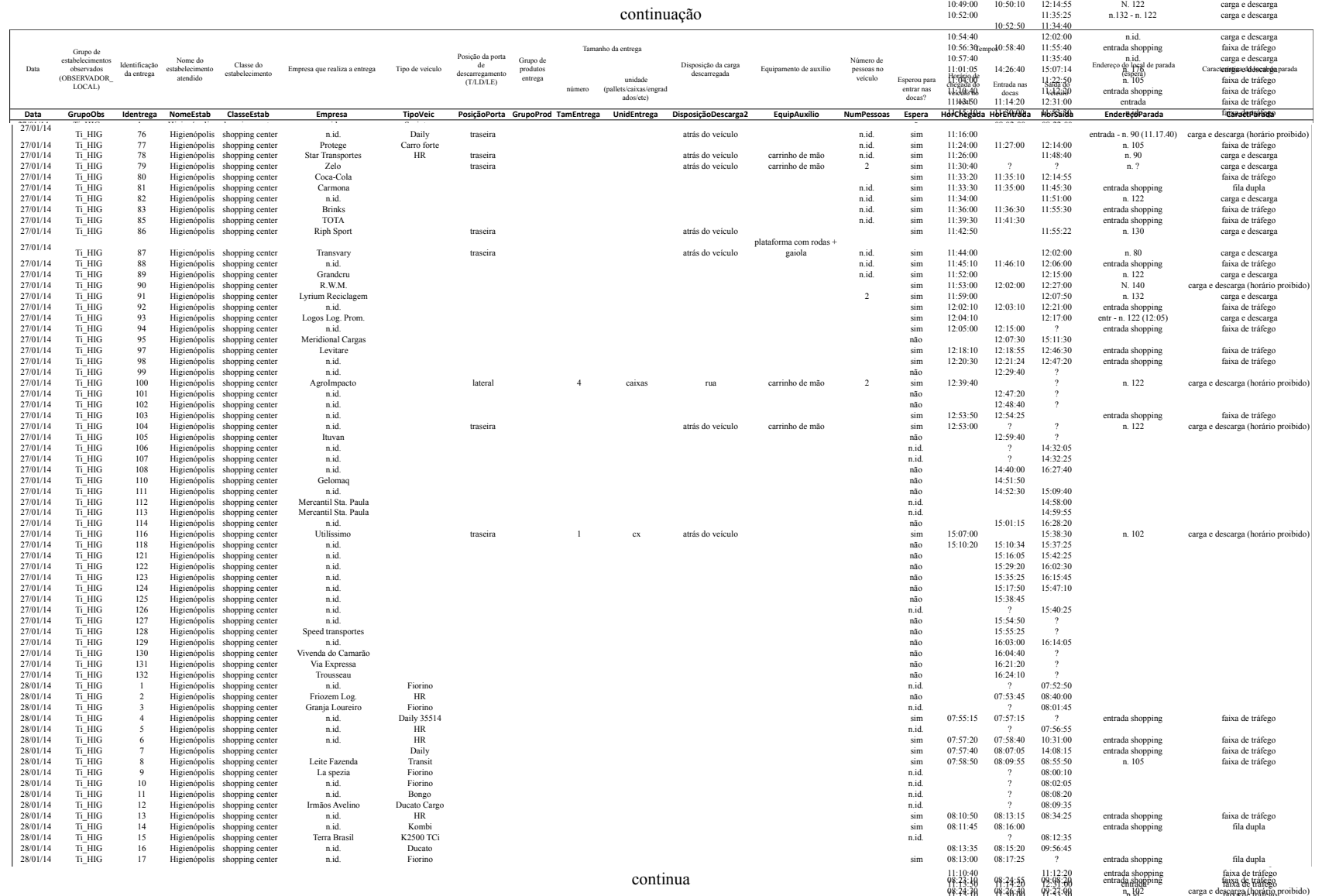




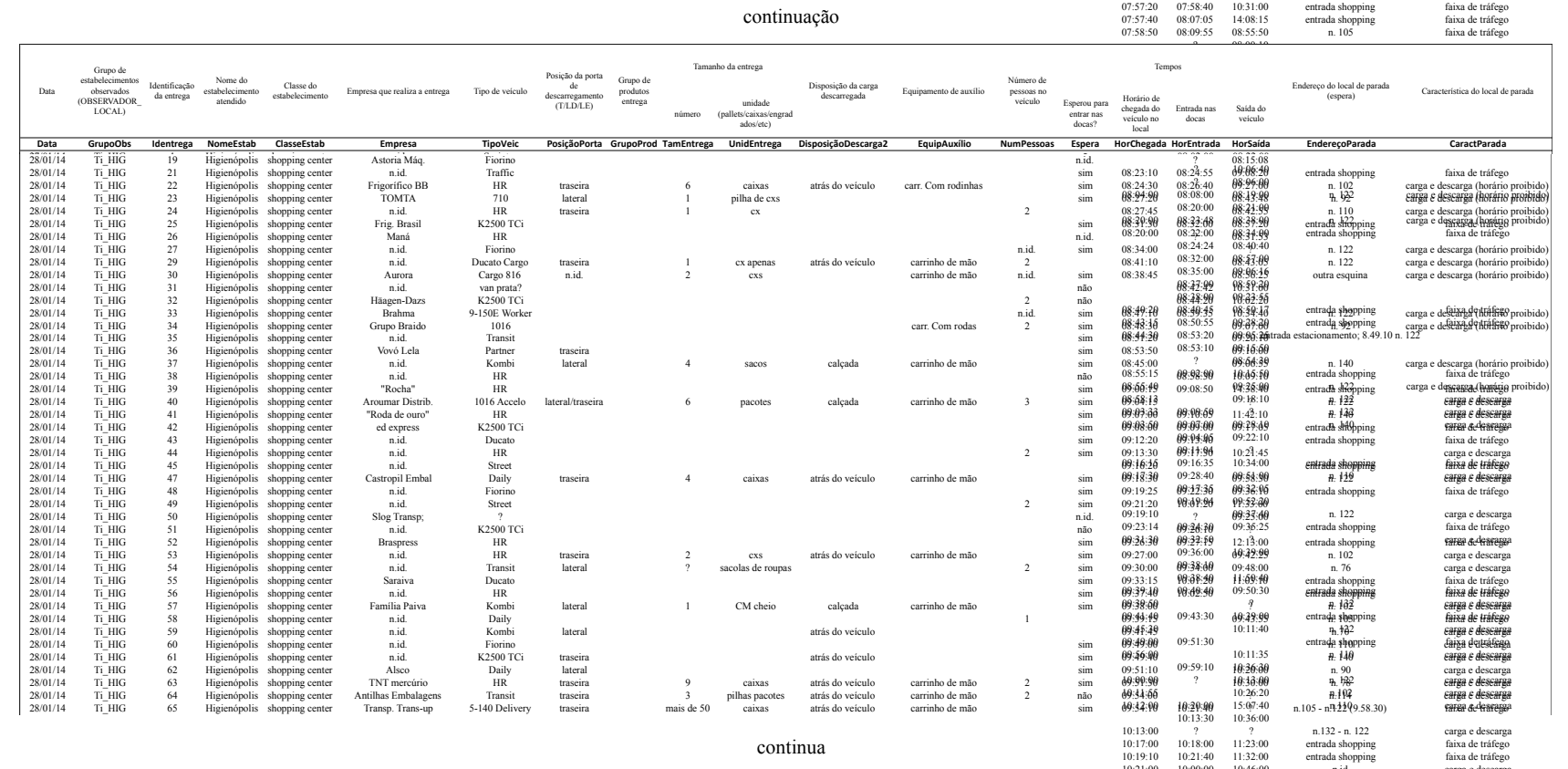




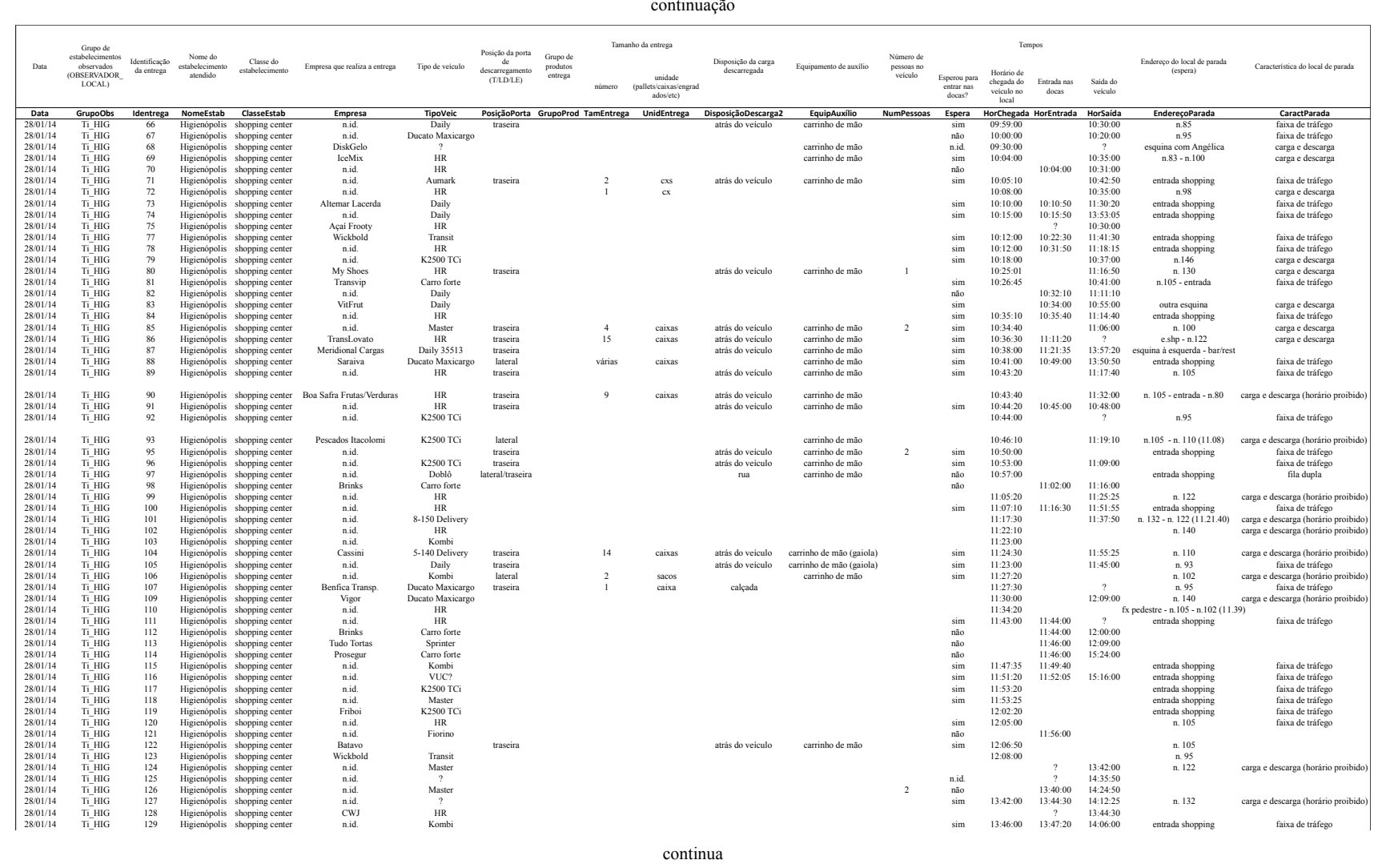




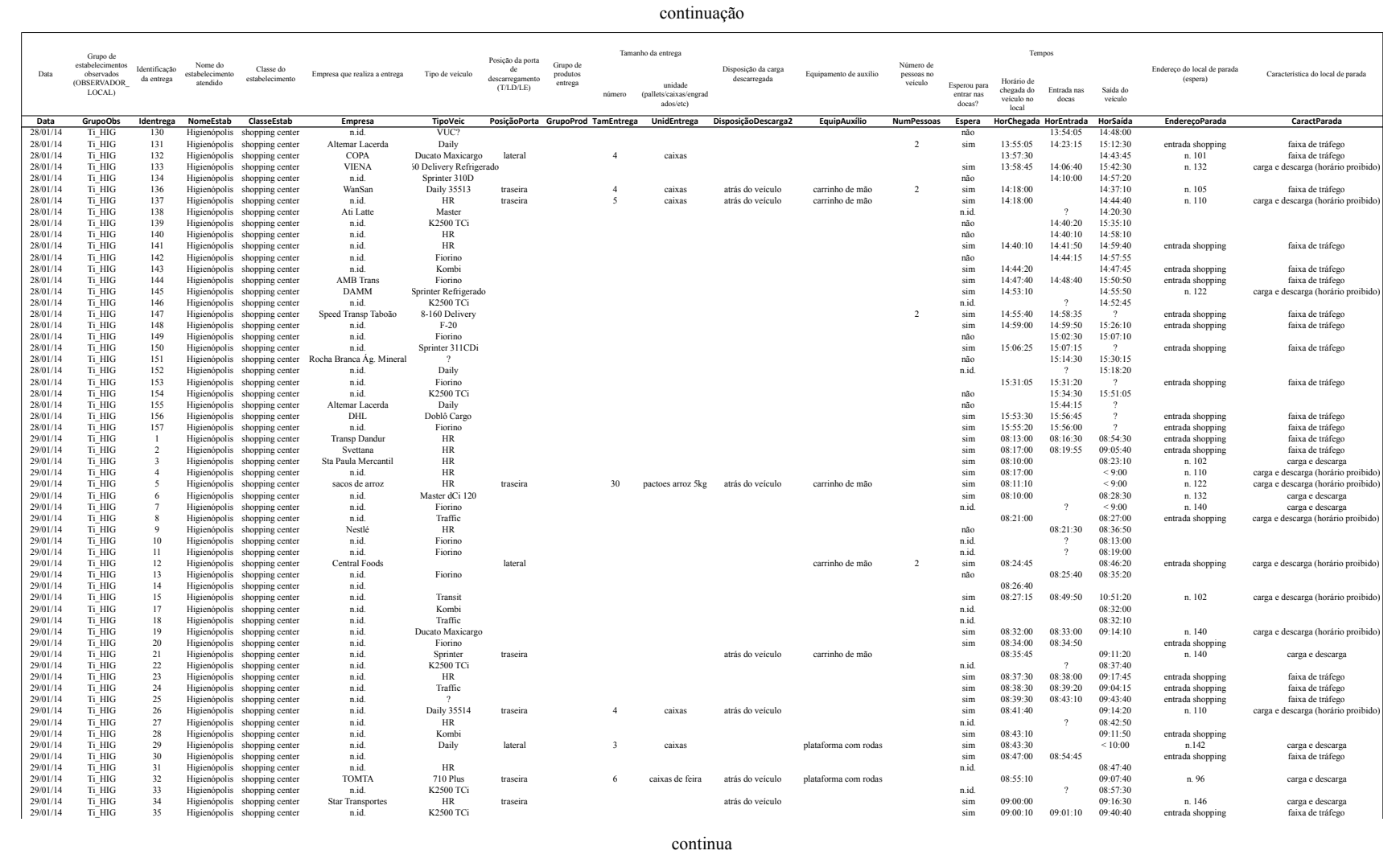




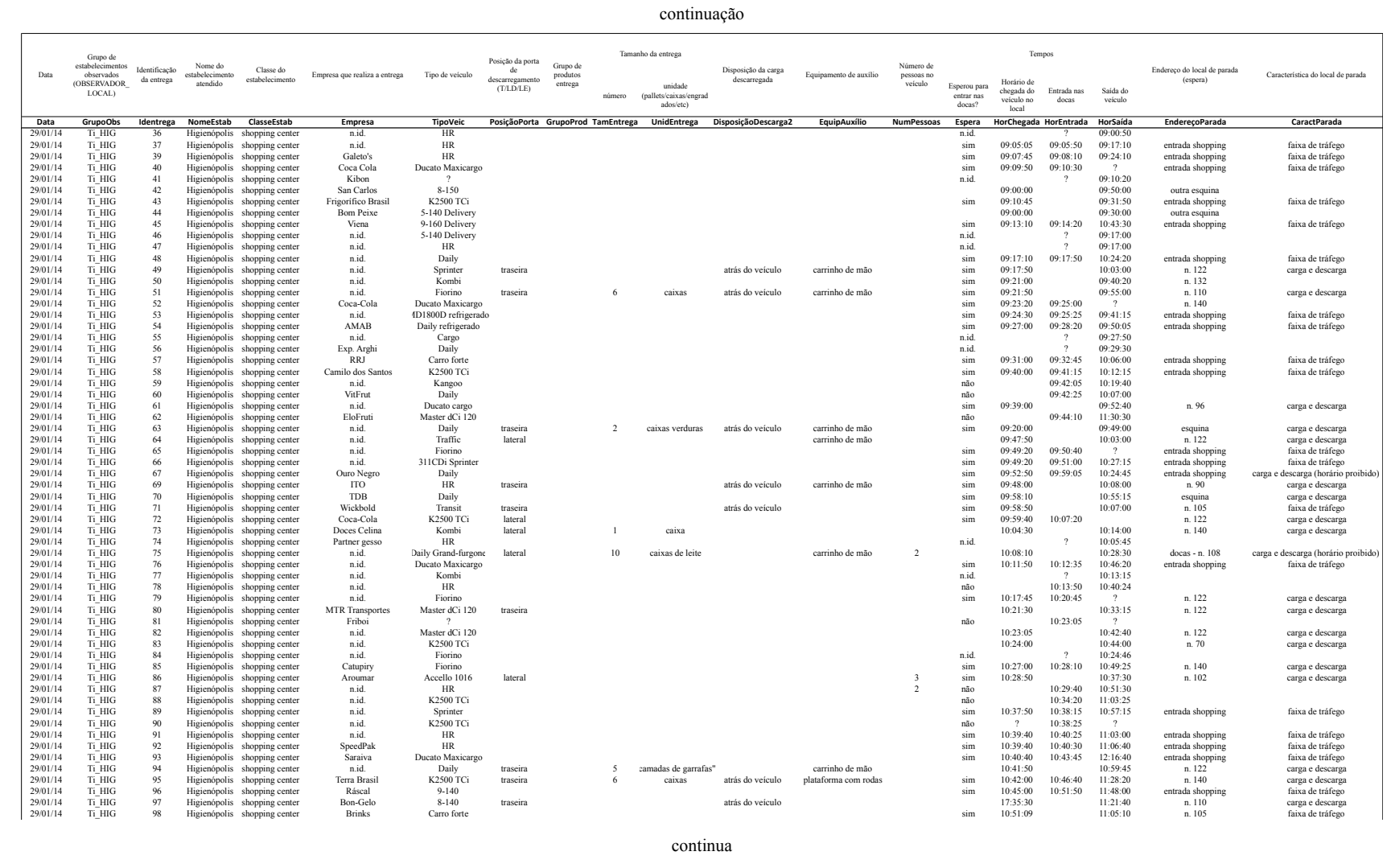




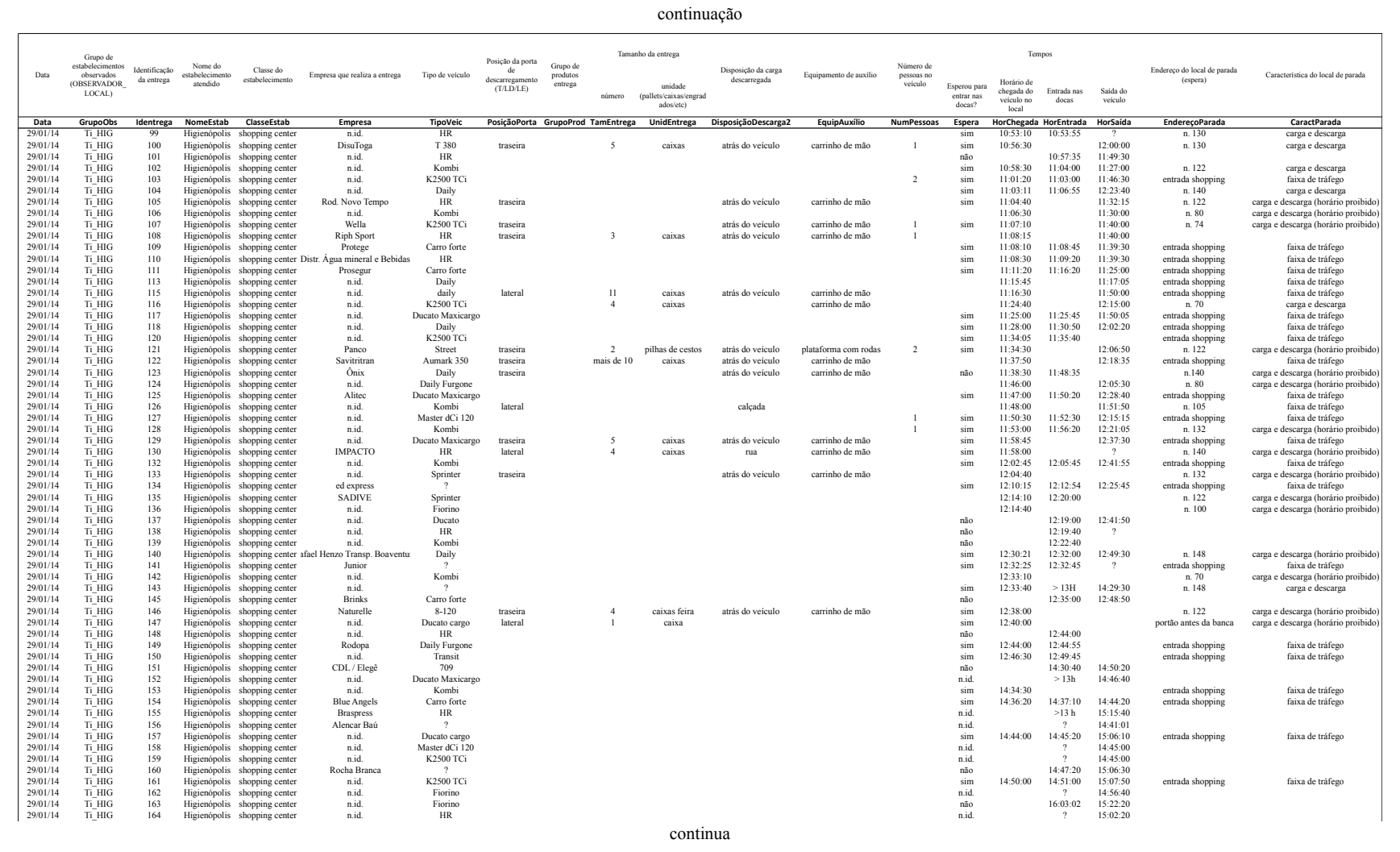




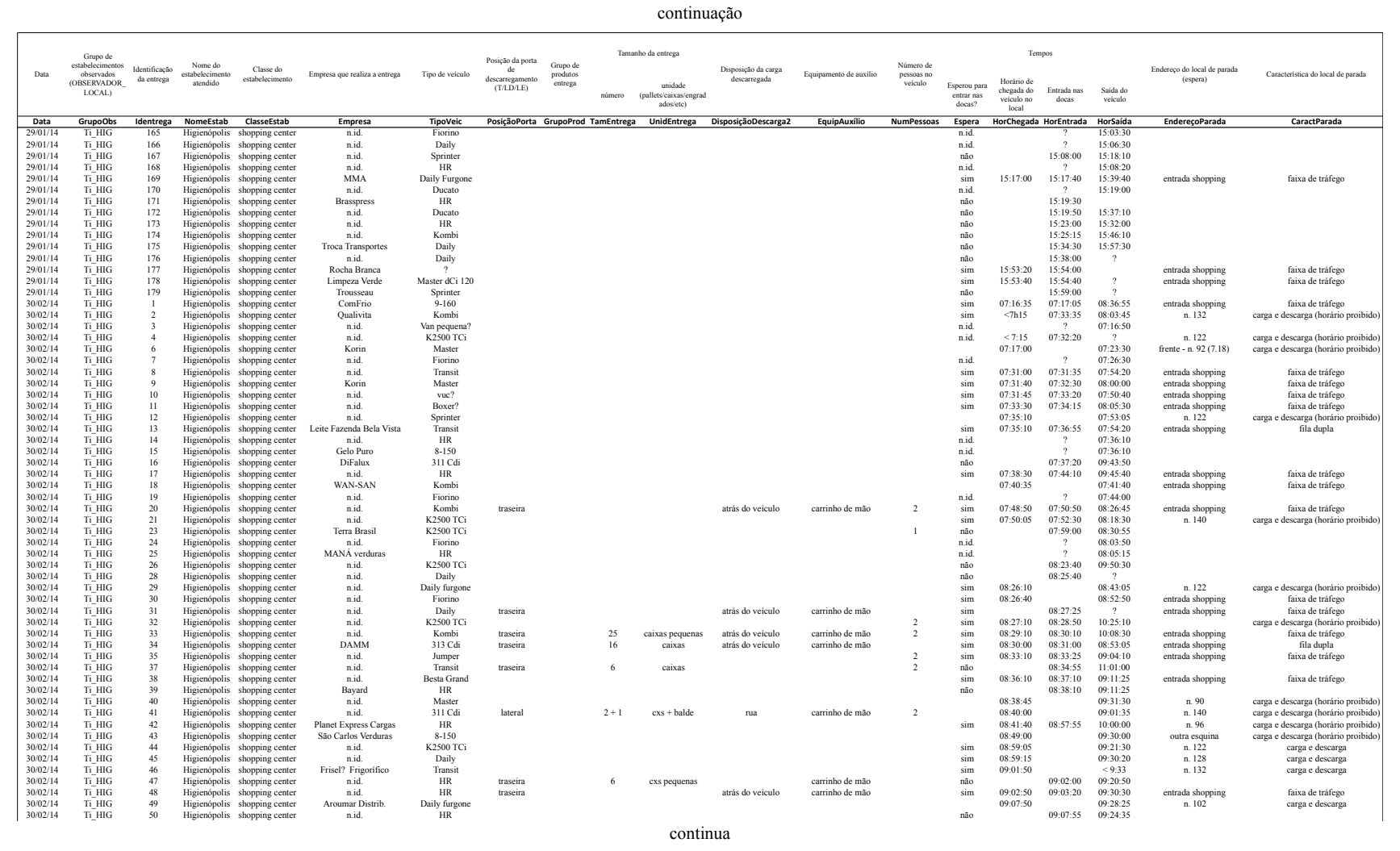




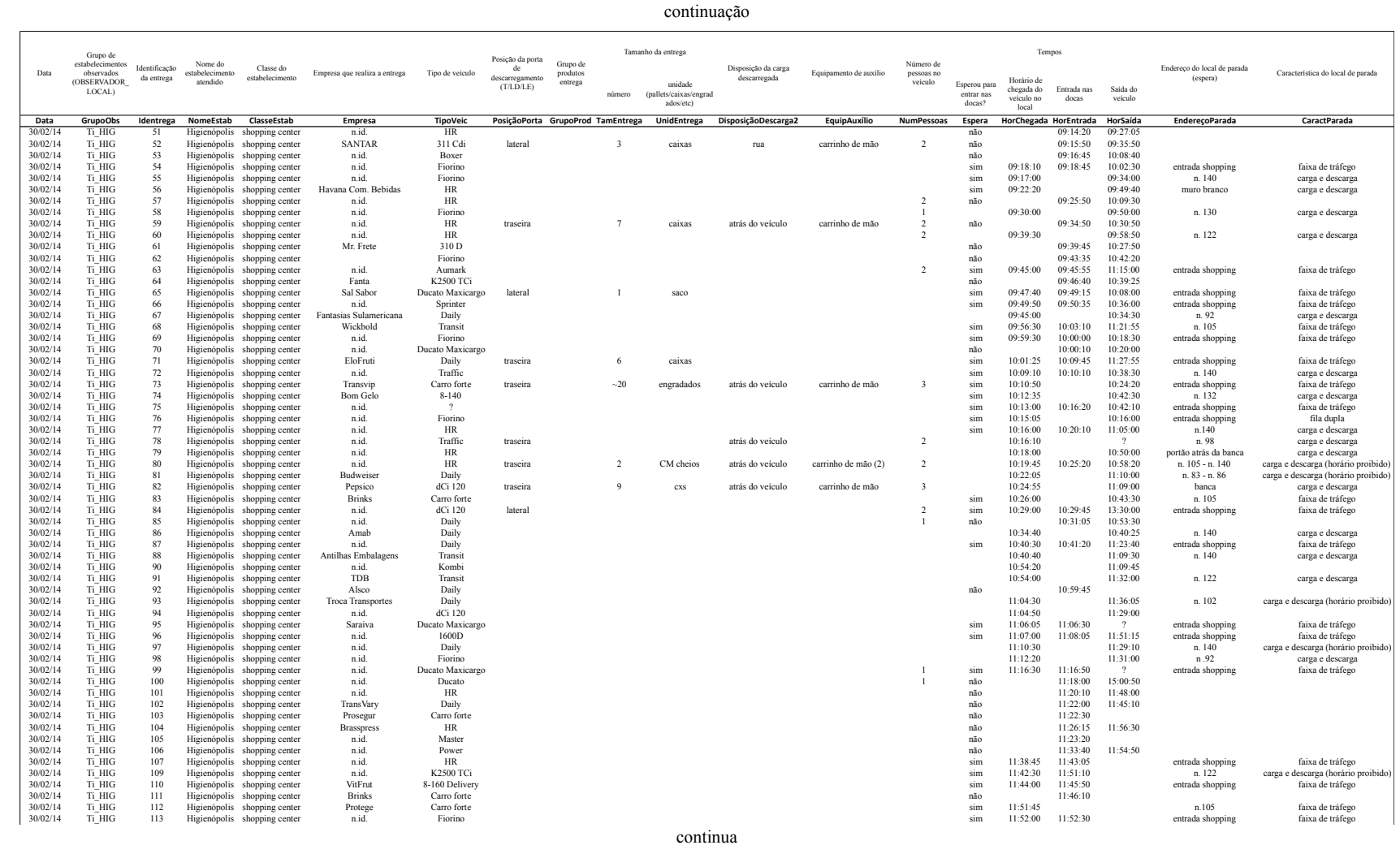




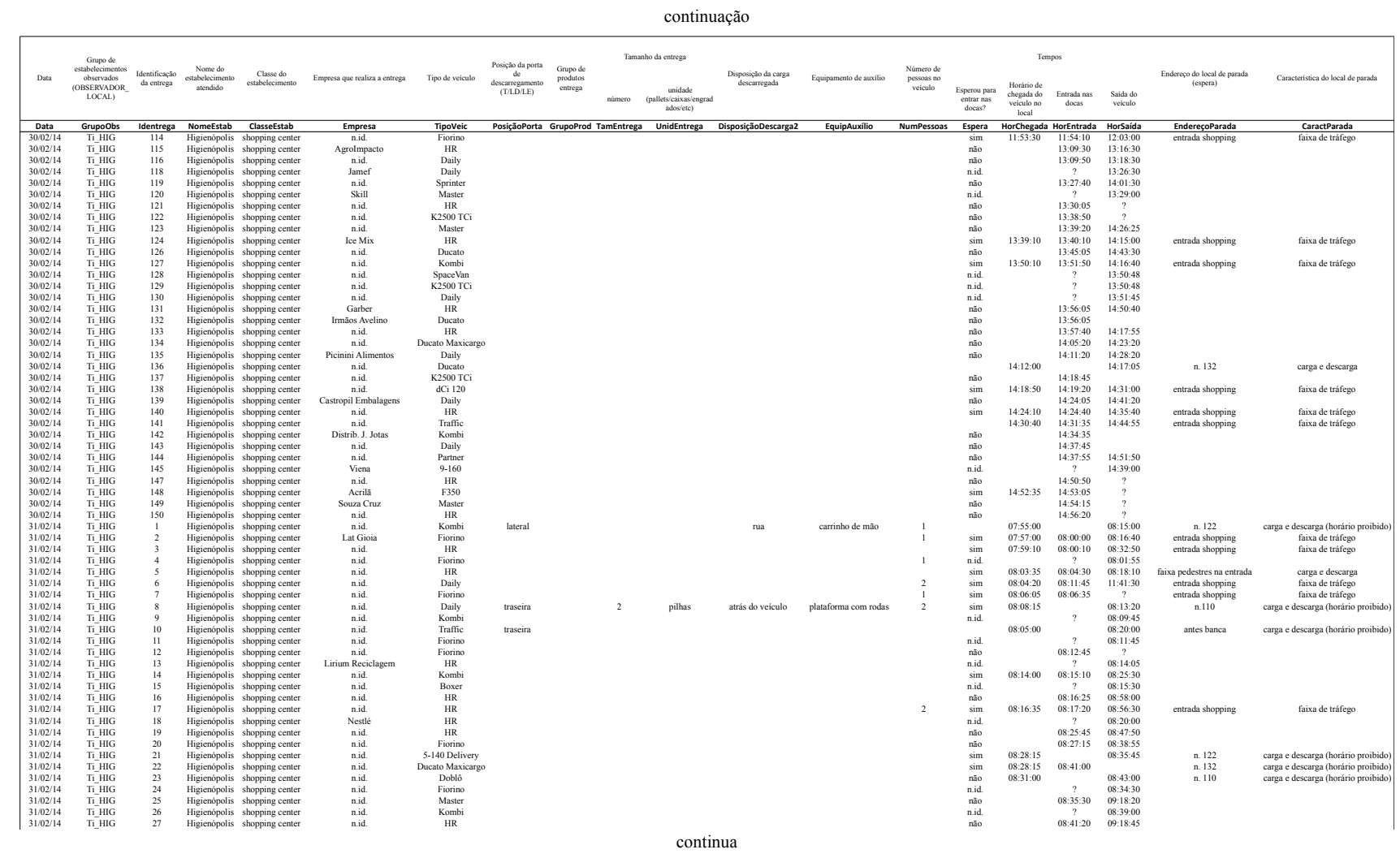




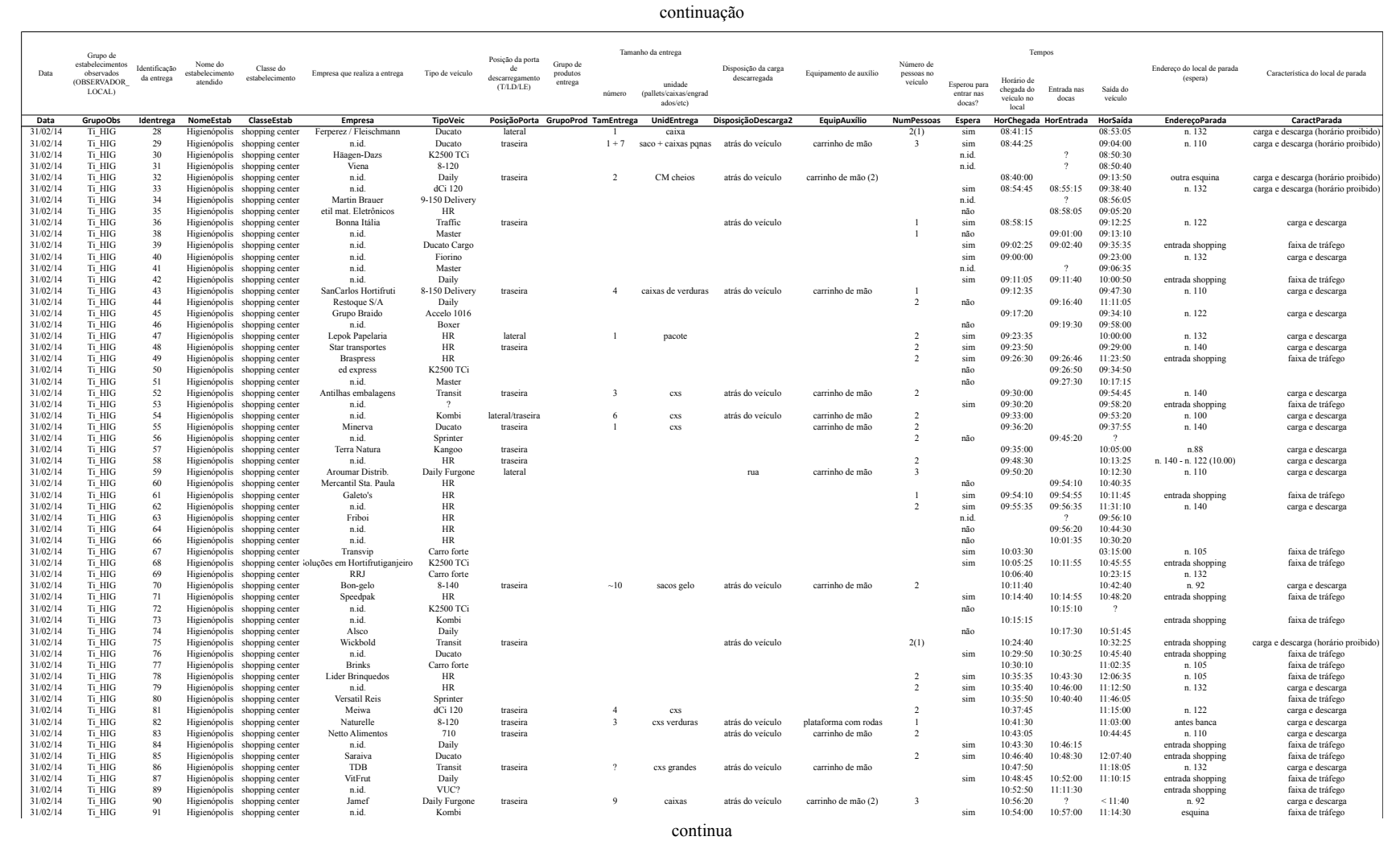




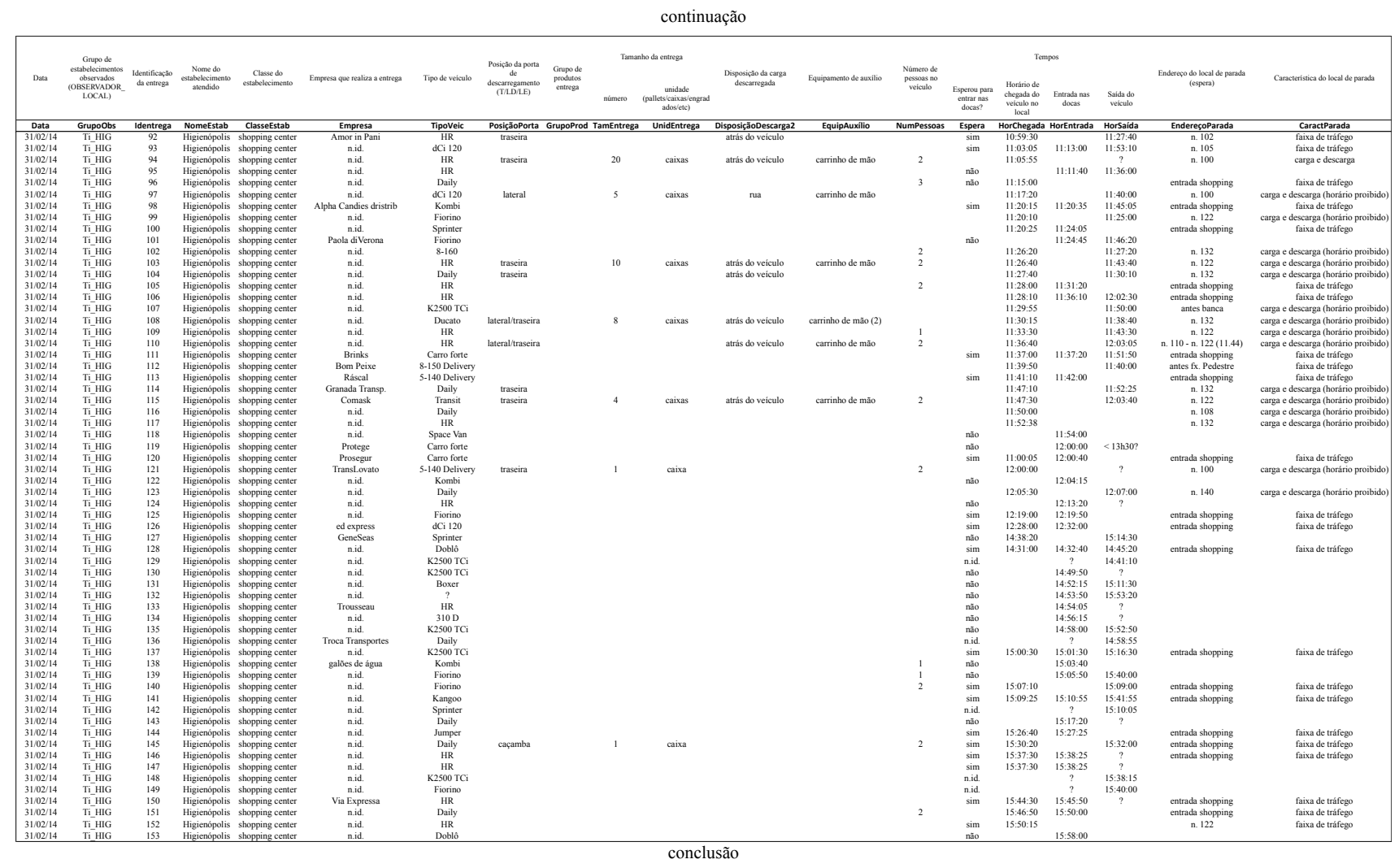


Tabela A.3 - Probabilidades de entrega na semana (por classe de estabelecimento e grupo de produtos) PROBABILIDADESDE ENTREGANA SEM ANA

\begin{tabular}{|c|c|c|c|c|c|c|c|c|c|c|c|c|c|}
\hline \multirow[b]{3}{*}{ Grupo de Produtos } & \multicolumn{13}{|c|}{ Classe de Estabelecimento } \\
\hline & Açougue & Adega & Bar Premium & $\begin{array}{c}\text { Bar } \\
\text { Tradicional }\end{array}$ & Bomboniere & $\begin{array}{l}\text { Café/sorveteri } \\
\text { a/doceria/casa } \\
\text { de sucos }\end{array}$ & Hortifruti & Lanchonete & $\begin{array}{l}\text { Lanchonete } \\
\text { / restaurante }\end{array}$ & $\begin{array}{c}\text { Loja de } \\
\text { conveniência }\end{array}$ & Padaria & Restaurante & $\begin{array}{l}\text { Supermercado } \\
\text { pequeno }\end{array}$ \\
\hline & & & & & & & & & & & & & \\
\hline alimentos congelados & 0,08 & - & 0,06 & 0,09 & - & 0,11 & 0,04 & 0,05 & 0,06 & 0,08 & 0,03 & 0,10 & 0,04 \\
\hline bebidas & - & 1,00 & 0,16 & 0,36 & 0,19 & 0,11 & 0,08 & 0,16 & 0,29 & 0,28 & 0,15 & 0,19 & 0,08 \\
\hline carnes & 0,67 & - & 0,06 & 0,16 & - & - & 0,09 & 0,08 & 0,12 & - & 0,06 & 0,05 & 0,04 \\
\hline $\begin{array}{l}\text { cigarros/bebidas } \\
\text { alcoólicas }\end{array}$ & - & - & 0,02 & - & - & - & - & - & 0,03 & 0,08 & 0,01 & - & 0,02 \\
\hline FLV & - & - & 0,15 & 0,09 & - & 0,08 & 0,10 & 0,11 & 0,15 & - & 0,11 & 0,14 & 0,12 \\
\hline frios/embutidos & 0,08 & - & 0,06 & 0,02 & - & - & 0,05 & 0,04 & 0,03 & - & 0,04 & 0,03 & 0,04 \\
\hline gás & - & - & - & 0,05 & - & - & - & - & - & - & - & 0,05 & - \\
\hline gelo & - & - & 0,05 & 0,04 & - & 0,12 & 0,01 & 0,02 & - & 0,08 & 0,03 & 0,19 & 0,04 \\
\hline laticínios & - & - & 0,06 & - & 0,06 & 0,06 & 0,26 & 0,08 & 0,06 & 0,03 & 0,08 & 0,05 & 0,21 \\
\hline mercearia seca em geral & - & - & 0,09 & 0,09 & 0,08 & 0,11 & 0,12 & 0,11 & 0,09 & 0,15 & 0,10 & 0,05 & 0,04 \\
\hline ovos & - & - & 0,07 & - & - & - & 0,06 & 0,06 & 0,06 & - & 0,06 & 0,05 & 0,04 \\
\hline pães & - & - & 0,10 & 0,08 & 0,08 & 0,12 & 0,06 & 0,12 & 0,03 & - & 0,13 & 0,05 & 0,15 \\
\hline snacks & - & - & - & - & 0,42 & 0,07 & 0,02 & 0,04 & 0,03 & 0,15 & 0,04 & 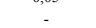 & 0,08 \\
\hline sorvetes & - & - & 0,06 & - & 0,08 & 0,11 & 0,03 & 0,04 & 0,03 & 0,08 & 0,03 & 0,02 & 0,08 \\
\hline outros & 0,17 & - & 0,07 & 0,01 & 0,08 & 0,11 & 0,08 & 0,08 & 0,03 & 0,08 & 0,13 & 0,04 & 0,04 \\
\hline
\end{tabular}


Tabela A.4 - Probabilidades de entrega no período de simulação PROBABILIDADESDE ENTREGA NA QUARTA-FEIRA (entre 6h e 12h)

\begin{tabular}{|c|c|c|c|c|c|c|c|}
\hline \multicolumn{8}{|c|}{ PROBABILIDADESDE ENTREGA NA QUARTA-FEIRA (entre $6 \mathrm{~h}$ e 12h) } \\
\hline Grupo de Produtos & Período & das $6 \mathrm{~h}$ às $7 \mathrm{~h}$ & das $7 \mathrm{~h}$ às $8 \mathrm{~h}$ & das $8 \mathrm{~h}$ às $9 \mathrm{~h}$ & das $9 \mathrm{~h}$ às $10 \mathrm{~h}$ & das $10 \mathrm{~h}$ às $11 \mathrm{~h}$ & das $11 \mathrm{~h}$ às $12 \mathrm{~h}$ \\
\hline alimentos congelados & 0,35 & 0,00 & 0,15 & 0,15 & 0,40 & 0,15 & 0,15 \\
\hline bebidas & 0,19 & 0,07 & 0,12 & 0,22 & 0,20 & 0,15 & 0,24 \\
\hline carnes & 0,25 & 0,06 & 0,14 & 0,32 & 0,22 & 0,22 & 0,04 \\
\hline $\begin{array}{l}\text { cigarros/bebidas } \\
\text { alcoólicas }\end{array}$ & 0,20 & 0,33 & 0,33 & 0,00 & 0,00 & 0,33 & 0,00 \\
\hline FLV & 0,17 & 0,07 & 0,30 & 0,33 & 0,17 & 0,11 & 0,02 \\
\hline frios/embutidos & 0,13 & 0,00 & 0,08 & 0,31 & 0,31 & 0,23 & 0,08 \\
\hline gás & 0,00 & 0,00 & 0,00 & 0,00 & 0,00 & 0,00 & 1,00 \\
\hline gelo & 0,00 & 0,00 & 0,10 & 0,50 & 0,10 & 0,30 & 0,00 \\
\hline laticínios & 0,22 & 0,03 & 0,13 & 0,18 & 0,21 & 0,33 & 0,11 \\
\hline mercearia seca em geral & 0,13 & 0,06 & 0,08 & 0,30 & 0,25 & 0,15 & 0,17 \\
\hline ovos & 0,31 & 0,10 & 0,40 & 0,10 & 0,10 & 0,20 & 0,10 \\
\hline pães & 0,10 & 0,07 & 0,39 & 0,23 & 0,11 & 0,16 & 0,05 \\
\hline snacks & 0,12 & 0,08 & 0,08 & 0,50 & 0,17 & 0,08 & 0,08 \\
\hline sorvetes & 0,19 & 0,08 & 0,08 & 0,38 & 0,08 & 0,23 & 0,15 \\
\hline outros & 0,25 & 0,02 & 0,14 & 0,22 & 0,28 & 0,24 & 0,10 \\
\hline
\end{tabular}

Tabela A.5 - Probabilidades de transporte (tipo de veículo - grupo de produtos) PROBABILIDADESDE TRANSPORTE (TIPO DE VEICULO - GRUPO DE PRODUTOS)

\begin{tabular}{|c|c|c|c|c|c|c|}
\hline \multicolumn{7}{|c|}{ Tipo de Veículo } \\
\hline \multicolumn{7}{|c|}{ Van $\quad$ VUC VUC grande } \\
\hline alimentos congelados & 0,12 & 0,09 & 0,24 & 0,16 & 0,39 & 0,00 \\
\hline bebidas & 0,00 & 0,00 & 0,67 & 0,00 & 0,33 & 0,00 \\
\hline carnes & 0,08 & 0,09 & 0,37 & 0,12 & 0,04 & 0,30 \\
\hline $\begin{array}{l}\text { cigarros/bebidas } \\
\text { alcoólicas }\end{array}$ & 0,03 & 0,10 & 0,26 & 0,10 & 0,50 & 0,00 \\
\hline FLV & 0,08 & 0,17 & 0,21 & 0,28 & 0,16 & 0,10 \\
\hline frios/embutidos & 0,20 & 0,07 & 0,13 & 0,27 & 0,33 & 0,00 \\
\hline gás & 0,00 & 0,00 & 0,00 & 1,00 & 0,00 & 0,00 \\
\hline gelo & 0,00 & 0,00 & 0,00 & 0,07 & 0,93 & 0,00 \\
\hline laticínios & 0,15 & 0,14 & 0,27 & 0,09 & 0,33 & 0,02 \\
\hline mercearia seca em geral & 0,16 & 0,10 & 0,44 & 0,04 & 0,26 & 0,00 \\
\hline ovos & 0,00 & 0,00 & 0,21 & 0,50 & 0,29 & 0,00 \\
\hline pães & 0,21 & 0,03 & 0,10 & 0,20 & 0,44 & 0,02 \\
\hline snacks & 0,35 & 0,35 & 0,18 & 0,06 & 0,06 & 0,00 \\
\hline sorvetes & 0,00 & 0,00 & 0,24 & 0,67 & 0,10 & 0,00 \\
\hline outros & 0,18 & 0,04 & 0,31 & 0,10 & 0,31 & 0,04 \\
\hline
\end{tabular}


Tabela A.6 - Tamanho médio da entrega (por classe de estabelecimento e grupo de produtos) DROP SIZE MEDIO $\left(\mathrm{m}^{3}\right)$

\begin{tabular}{|c|c|c|c|c|c|c|c|c|c|c|c|c|c|}
\hline \multicolumn{14}{|c|}{ DROP SIZE MEDIO $\left(\mathrm{m}^{3}\right)$} \\
\hline & & & & & & Class & de Estabelec & ento & & & & & \\
\hline & Açougue & Adega & Bar Premium & Bar Tradicional & Bomboniere & $\begin{array}{c}\text { Café/sorveteria/ } \\
\text { doceria/casa de } \\
\text { sucos }\end{array}$ & Hortifruti & Lanchonete & $\begin{array}{l}\text { Lanchonete } \\
\text { / restaurante }\end{array}$ & $\begin{array}{c}\text { Loja de } \\
\text { conveniência }\end{array}$ & Padaria & Restaurante & $\begin{array}{c}\text { Supermercado } \\
\text { pequeno }\end{array}$ \\
\hline \multicolumn{14}{|l|}{ Grupo de Produtos } \\
\hline alimentos congelados & 0,24 & & 0,86 & 0,07 & - & 0,07 & 0,53 & 0,04 & 0,29 & 0,05 & 0,41 & 0,19 & 0,35 \\
\hline bebidas & - & 0,20 & 0,33 & 0,33 & 0,21 & 0,05 & 0,20 & 0,30 & 0,25 & 0,08 & 0,63 & 0,22 & 0,32 \\
\hline carnes & 0,544 & - & 0,07 & 0,10 & - & - & 0,19 & 0,07 & 0,31 & - & 0,18 & 0,18 & 0,20 \\
\hline $\begin{array}{l}\text { cigarros/bebidas } \\
\text { alcoólicas }\end{array}$ & - & - & 0,01 & - & - & - & - & - & 0,01 & 0,01 & 0,11 & 0,45 & - \\
\hline FLV & - & - & 0,01 & 0,01 & - & 0,02 & 0,22 & 0,10 & 0,15 & - & 0,64 & 0,16 & 0,04 \\
\hline frios/embutidos & - & - & 0,03 & 0,01 & - & - & 0,52 & 0,12 & 0,12 & - & 0,35 & 0,04 & 0,08 \\
\hline gás & - & - & - & 0,05 & - & - & - & - & - & - & 0,06 & 0,03 & - \\
\hline gelo & - & - & 0,04 & 0,01 & - & 0,01 & 0,24 & 0,13 & 0,13 & 0,13 & 0,13 & 0,67 & 0,08 \\
\hline laticínios & - & - & 0,20 & - & 0,01 & 0,18 & 0,28 & 0,15 & 0,15 & 0,09 & 0,11 & 0,25 & 0,21 \\
\hline mercearia seca em ger & 0,84 & - & 0,35 & 0,43 & 0,07 & 0,11 & 0,43 & 0,30 & 0,17 & 0,15 & 0,19 & 0,05 & 0,61 \\
\hline ovos & - & - & 0,10 & - & - & - & 0,23 & 0,10 & 0,10 & - & 0,11 & 0,02 & 0,50 \\
\hline pães & - & - & 0,12 & 0,11 & 0,12 & 0,07 & 0,02 & 0,05 & 0,03 & - & 0,10 & 0,22 & 0,53 \\
\hline snacks & - & - & - & - & 0,13 & 0,03 & 0,31 & 0,06 & 0,07 & 0,25 & 0,20 & - & 0,04 \\
\hline sorvetes & - & - & 0,19 & - & 0,19 & 0,13 & 0,14 & 0,45 & 0,45 & 0,13 & 0,45 & 0,13 & 0,13 \\
\hline outros & 0,08 & - & 0,20 & 0,05 & 0,04 & 0,10 & 0,12 & 0,40 & 0,20 & 0,10 & 0,67 & 0,12 & 0,27 \\
\hline
\end{tabular}


Tabela A.7 - Tempo médio de duração da entrega (por classe de estabelecimento e grupo de produtos)

\begin{tabular}{|c|c|c|c|c|c|c|c|c|c|c|c|c|c|}
\hline \multicolumn{14}{|c|}{ TEMPO MÉDIO DE DURAÇĀO DA ENTREGA (min) } \\
\hline & & & & & & Clas & de Estabelec & & & & & & \\
\hline & Açougue & Adega & Bar Premium & Bar Tradicional & Bomboniere & $\begin{array}{c}\text { Café/sorveteria/ } \\
\text { doceria/casa de } \\
\text { sucos }\end{array}$ & Hortifruti & Lanchonete & $\begin{array}{l}\text { Lanchonete } \\
\text { / restaurante }\end{array}$ & $\begin{array}{c}\text { Loja de } \\
\text { conveniência }\end{array}$ & Padaria & Restaurante & $\begin{array}{l}\text { Supermercado } \\
\text { pequeno }\end{array}$ \\
\hline \multicolumn{14}{|l|}{ Grupo de Produtos } \\
\hline alimentos congelados & 5 & - & 13 & 3 & - & 9 & 27 & 10 & 7 & 25 & 10 & 5 & 37 \\
\hline bebidas & - & 37 & 37 & 11 & 8 & 43 & 61 & 12 & 12 & 28 & 25 & 13 & 15 \\
\hline carnes & 12 & - & 18 & 6 & - & - & 37 & 2 & 4 & - & 15 & 8 & 35 \\
\hline cigarros/bebidas alcoólicas & - & - & 32 & - & - & - & - & - & 13 & 25 & 23 & 16 & 36 \\
\hline FLV & - & - & 22 & 22 & - & 17 & 80 & 19 & 21 & - & 71 & 9 & 54 \\
\hline frios/embutidos & - & - & 33 & 44 & - & - & 59 & 48 & 39 & - & 11 & 23 & 44 \\
\hline gás & - & - & - & 4 & - & - & - & - & - & - & 12 & 23 & - \\
\hline gelo & - & - & 46 & 47 & - & 42 & 35 & 22 & 10 & 17 & 13 & 11 & 4 \\
\hline laticínios & - & - & 30 & - & 33 & 16 & 45 & 43 & 40 & 47 & 14 & 10 & 39 \\
\hline mercearia seca em geral & 27 & - & 32 & 3 & 16 & 16 & 34 & 31 & 6 & 47 & 9 & 22 & 13 \\
\hline ovos & - & - & 43 & - & - & - & 54 & 42 & 46 & - & 23 & 29 & 12 \\
\hline pães & - & - & 40 & 33 & 7 & 13 & 51 & 37 & 12 & - & 24 & 18 & 20 \\
\hline snacks & - & - & - & - & 28 & 35 & 61 & 26 & 4 & 37 & 19 & - & 32 \\
\hline sorvetes & - & - & 28 & - & 12 & 28 & 57 & 32 & 17 & 42 & 40 & 9 & 12 \\
\hline outros & 4 & - & 43 & 33 & 9 & 40 & 34 & 26 & 11 & 37 & 12 & 6 & 17 \\
\hline
\end{tabular}




\section{ANEXO B}

As tabelas a seguir contêm os resultados do modelo de regressão logística para os dados obtidos nas entrevistas com os motoristas. Os dados da regressão foram utilizados no desenvolvimento do modelo 'Preferências de Estacionamento', apresentado na seção 6.4 .

Tabela B.1 - Parâmetros da Regressão Logística

\begin{tabular}{|llll|}
\hline Factor Information & & & \\
Factor & Levels & & Values \\
Tipo de produto & 4 & bebidas; não perecíveis; perecíveis; outros \\
Tipo de veículo & 4 & kombi/van; utilitário; VUC grande; VUC pequeno \\
Presença de ajudante & 2 & não; sim \\
Posição da Porta & 3 & lateral; traseira; lateral/traseira \\
\hline
\end{tabular}

Tabela B.2 - Resultado da Regressão Logística para a pergunta 1

\begin{tabular}{|c|c|c|c|c|c|}
\hline $\begin{array}{l}\text { Variable } \\
\text { 1. Qual é a distância }\end{array}$ & a do ponto de & trega que voc & está disposto a & estacionar seu & jeiculo? \\
\hline & Value & Count & & & \\
\hline & 300 & 7 & (Reference ev & nt) & \\
\hline & 200 & 89 & & & \\
\hline & 100 & 41 & & & \\
\hline & Total & 137 & & & \\
\hline Logistic Regression T & & & & & \\
\hline $\begin{array}{l}\text { Predictor } \\
\text { Logit 1: }(200 / 300)\end{array}$ & Coef & SE Coef & $\mathrm{z}$ & $\mathrm{p}$-value & Odds Ratio \\
\hline Constant & 2,10701 & 1,31775 & 1,6 & 0,11 & \\
\hline Tipo de Produto & & & & & \\
\hline não perecíveis & 1,22856 & 1,3428 & 0,91 & 0,36 & 3,42 \\
\hline perecíveis & 1,13713 & 1,42567 & 0,8 & 0,425 & 3,12 \\
\hline outros & 1,54829 & 1,06517 & 1,45 & 0,146 & 4,7 \\
\hline Tipo de veículo & & & & & \\
\hline utilitário & 0,0056032 & 1,3234 & 0 & 0,997 & 1,01 \\
\hline VUC grande & 0,685929 & 1,25356 & 0,55 & 0,584 & 1,99 \\
\hline VUC pequeno & 0.365529 & 1,03746 & 0,35 & 0,725 & 1,44 \\
\hline $\begin{array}{l}\text { Presença de ajudante } \\
\text { sim }\end{array}$ & $-1,22013$ & 1,17749 & $-1,04$ & 0,3 & 0,3 \\
\hline Posição da Porta & & & & & \\
\hline traseira & $-0,248758$ & 0,57667 & $-0,87$ & 0,434 & 0,69 \\
\hline lateral/traseira & $-1,54433$ & 0,97044 & $-1,42$ & 0,345 & 0,26 \\
\hline Logit 2: $(100 / 300)$ & & & & & \\
\hline Constant & 1,35838 & 1,39828 & 0,97 & 0,331 & \\
\hline Tipo de Produto & & & & & \\
\hline não perecíveis & $-0,331706$ & 1,45335 & $-0,23$ & 0,819 & 0,72 \\
\hline perecíveis & $-1,16497$ & 1,57061 & $-0,74$ & 0,458 & 0,31 \\
\hline outros & 0,215328 & 1,08513 & 0,2 & 0,843 & 1,24 \\
\hline Tipo de veículo & & & & & \\
\hline utilitário & $-0,527877$ & 1,69881 & $-0,31$ & 0,756 & 0,59 \\
\hline VUC grande & 2,61149 & 1,31281 & 1,99 & 0,047 & 13,62 \\
\hline VUC pequeno & 2,03524 & 1,13053 & 1,8 & 0,072 & 7,65 \\
\hline $\begin{array}{l}\text { Presença de ajudante } \\
\text { sim }\end{array}$ & 1,21292 & 1,26952 & $-0,96$ & 0,339 & 0,3 \\
\hline Posição da Porta & & & & & \\
\hline traseira & $-0,86403$ & 0,73849 & $-0,47$ & 0,183 & 0,43 \\
\hline lateral/traseira & $-1,98463$ & 0,79308 & $-0,98$ & 0,567 & 0,32 \\
\hline
\end{tabular}


Tabela B.3 - Resultado da Regressão Logística para a pergunta 2

\begin{tabular}{|c|c|c|c|c|c|}
\hline $\begin{array}{l}\text { Variable } \\
\text { 2. Qual tipo de vaga }\end{array}$ & ocura para est & aro seu ve & & & \\
\hline & Value & & Count & & \\
\hline & carga e desca & & 98 & & \\
\hline & o mais próxin & ssível & 39 & (Reference event) & \\
\hline & Total & & 137 & & \\
\hline Deviance Table & & & & & \\
\hline Source & DF & Adj Dev & Adj Mean & Chi-Square & p-value \\
\hline Regression & 7 & 7,186 & 1,0266 & 7,19 & 0,41 \\
\hline Tipo de Produto & 3 & 5,992 & 1,9972 & 5,99 & 0,112 \\
\hline Tipo de veículo & 3 & 2,211 & 0,7369 & 2,21 & 0,53 \\
\hline Presença de ajudante & 1 & 0,454 & 0,4537 & 0,45 & 0,501 \\
\hline Posição da Porta & 1 & 3,4675 & 1,9983 & 1,43 & 0,28 \\
\hline Error & 129 & 156,477 & 1,213 & & \\
\hline Total & 136 & 163,663 & & & \\
\hline
\end{tabular}

Tabela B.4 - Resultado da Regressão Logística para a pergunta 3

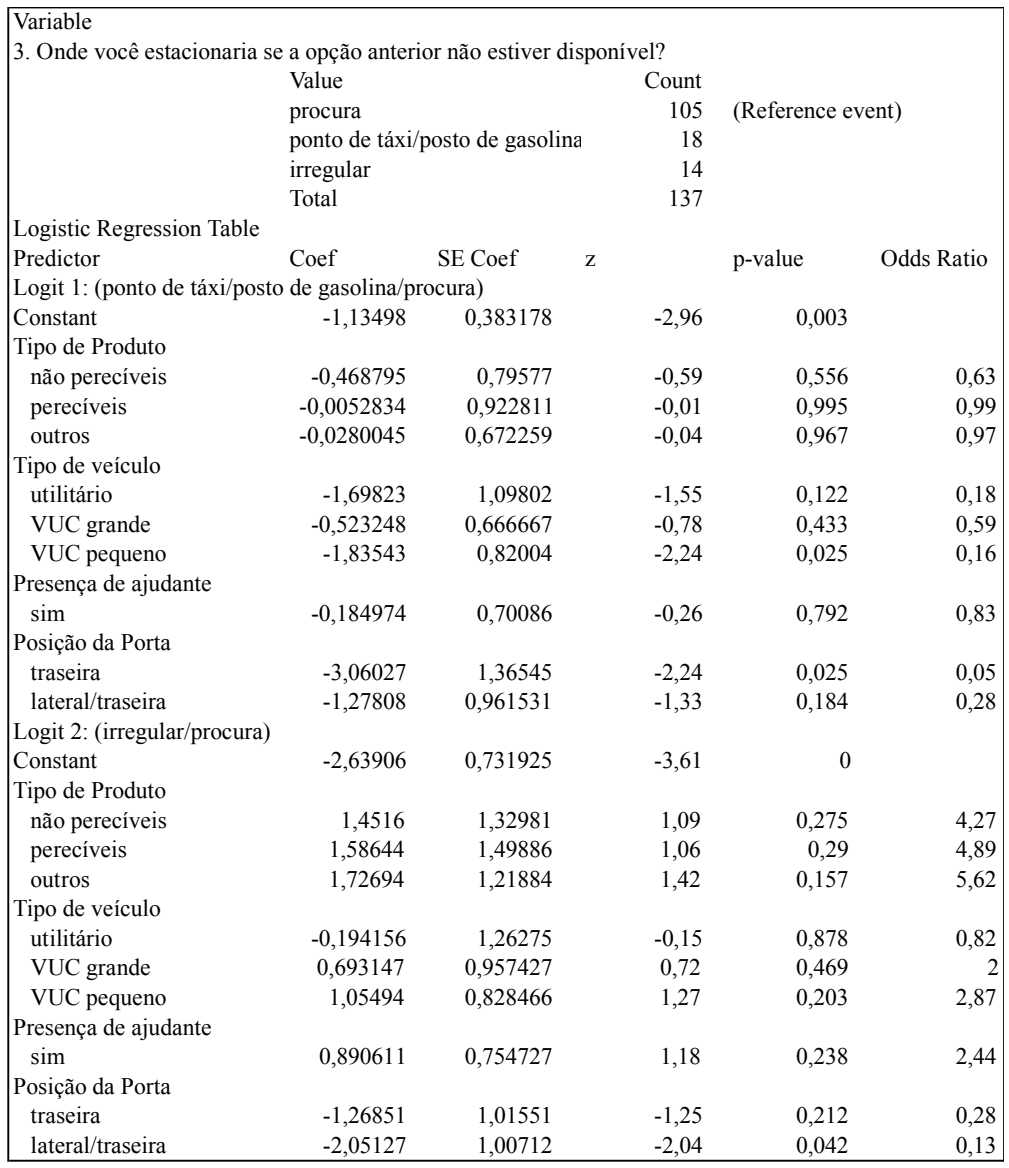


Tabela B.5 - Resultado da Regressão Logística para a pergunta 4

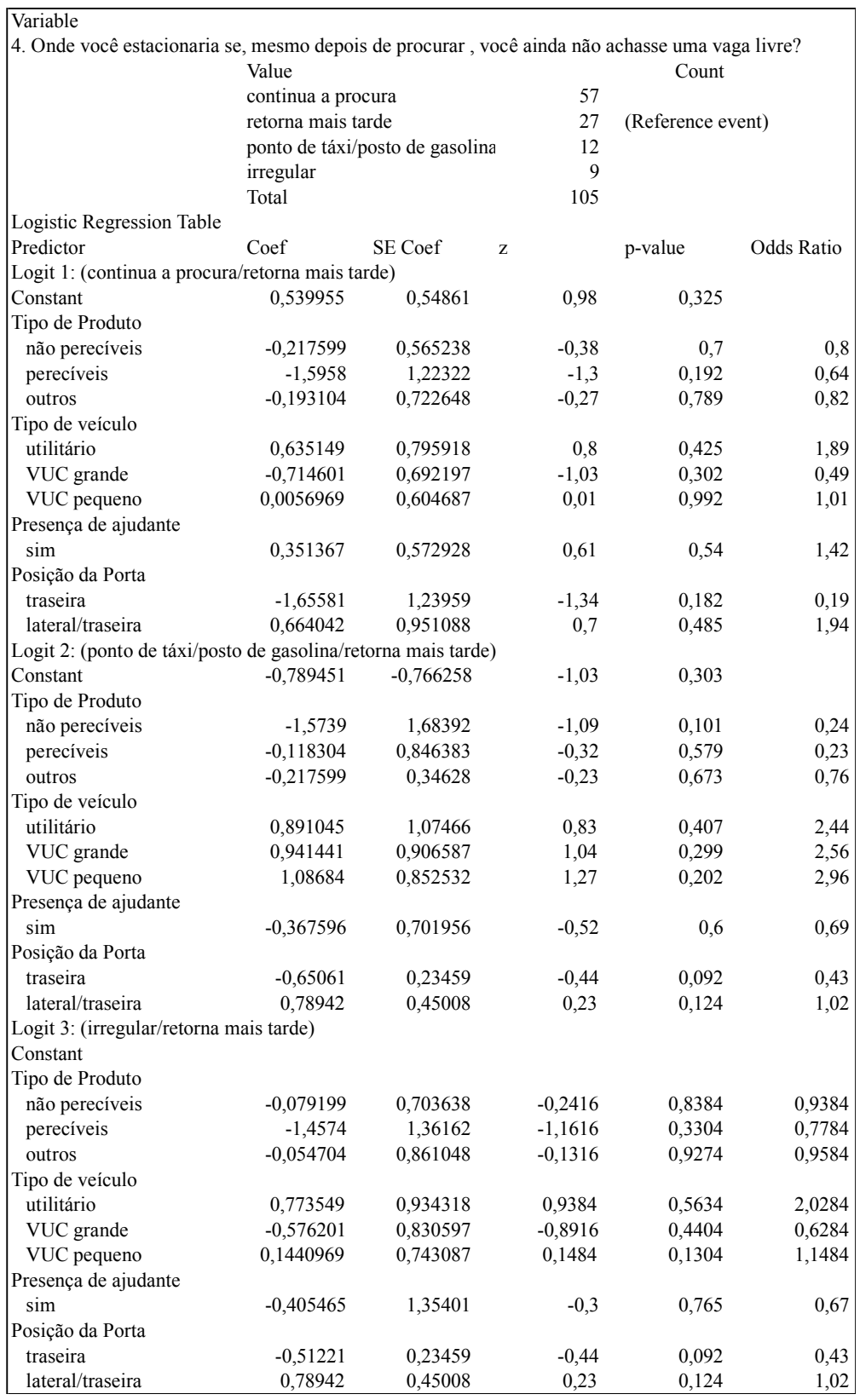

Tabela B.6 - Resultado da Regressão Logística para a pergunta 5

\begin{tabular}{|c|c|c|c|c|c|}
\hline \multicolumn{6}{|l|}{$\begin{array}{l}\text { Variable } \\
\text { 5. No caso em que }\end{array}$} \\
\hline \multicolumn{6}{|c|}{ Value } \\
\hline & faixa de tráfego & & 103 & \multirow{3}{*}{\multicolumn{2}{|c|}{ (Reference event) }} \\
\hline & garagem & & 34 & & \\
\hline & Total & & 137 & & \\
\hline \multicolumn{6}{|l|}{ Deviance Table } \\
\hline Source & $\mathrm{DF}$ & Adj Dev & Adj Mean & Chi-Square & p-value \\
\hline Regression & 9 & 8,392 & 0,9324 & 8,39 & 0,495 \\
\hline Tipo de Produto & 3 & 3,014 & 1,0046 & 3,01 & 0,389 \\
\hline Tipo de veículo & 3 & 2,936 & 0,9788 & 2,94 & 0,402 \\
\hline Presença de ajudante & 2 & 1,078 & 0,539 & 1,08 & 0,583 \\
\hline Posição da Porta & 1 & 0,578 & 0,578 & 0,058 & 0,447 \\
\hline Error & 106 & 152,108 & 1,435 & & \\
\hline Total & 115 & 160,5 & & & \\
\hline
\end{tabular}


Tabela B.7 - Resultado da Regressão Logística para a pergunta 6

\begin{tabular}{|c|c|c|c|c|c|}
\hline \multicolumn{6}{|l|}{ Variable } \\
\hline & Value & & Count & & \\
\hline & $\operatorname{sim}$ & & 60 & (Reference e & \\
\hline & depende & & 43 & & \\
\hline & Total & & 103 & & \\
\hline \multicolumn{6}{|l|}{ Deviance Table } \\
\hline Source & DF & Adj Dev & Adj Mean & Chi-Square & p-value \\
\hline Regression & 9 & 3,761 & 0,4178 & 3,76 & 0,926 \\
\hline Tipo de Produto & 3 & 0,84 & 0,2801 & 0,84 & 0,84 \\
\hline Tipo de veículo & 3 & 1,068 & 0,3561 & 1,07 & 0,785 \\
\hline Presença de ajudante & 2 & 1,91 & 0,9548 & 1,91 & 0,385 \\
\hline Posição da Porta & 1 & 0,46 & 0,4602 & 0,46 & 0,498 \\
\hline Error & 79 & 117,079 & 1,482 & & \\
\hline Total & 88 & 120,84 & & & \\
\hline
\end{tabular}

Tabela B.8 - Resultado da Regressão Logística para a pergunta 7

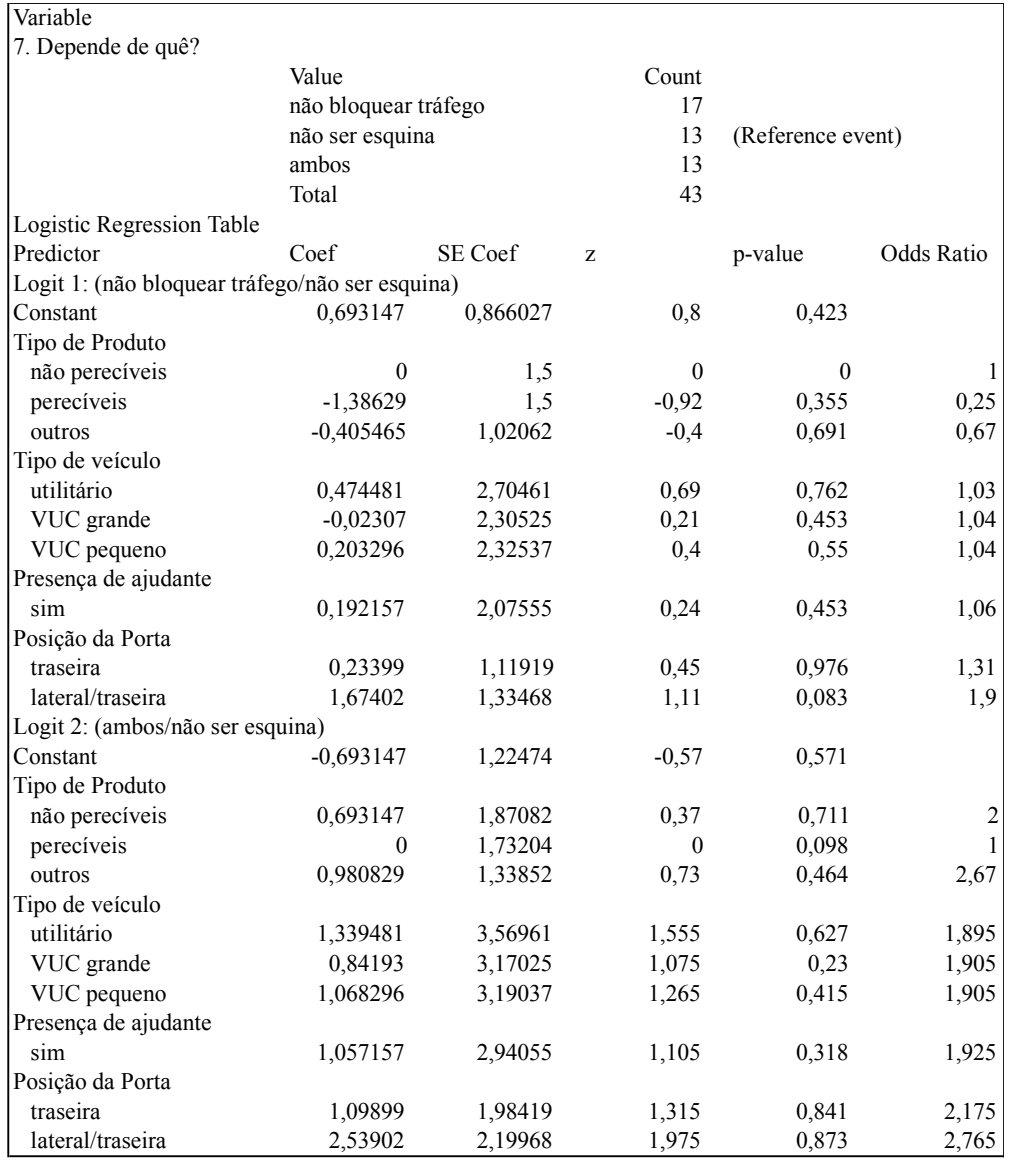


Tabela B.9 - Resultado da Regressão Logística para a pergunta 8

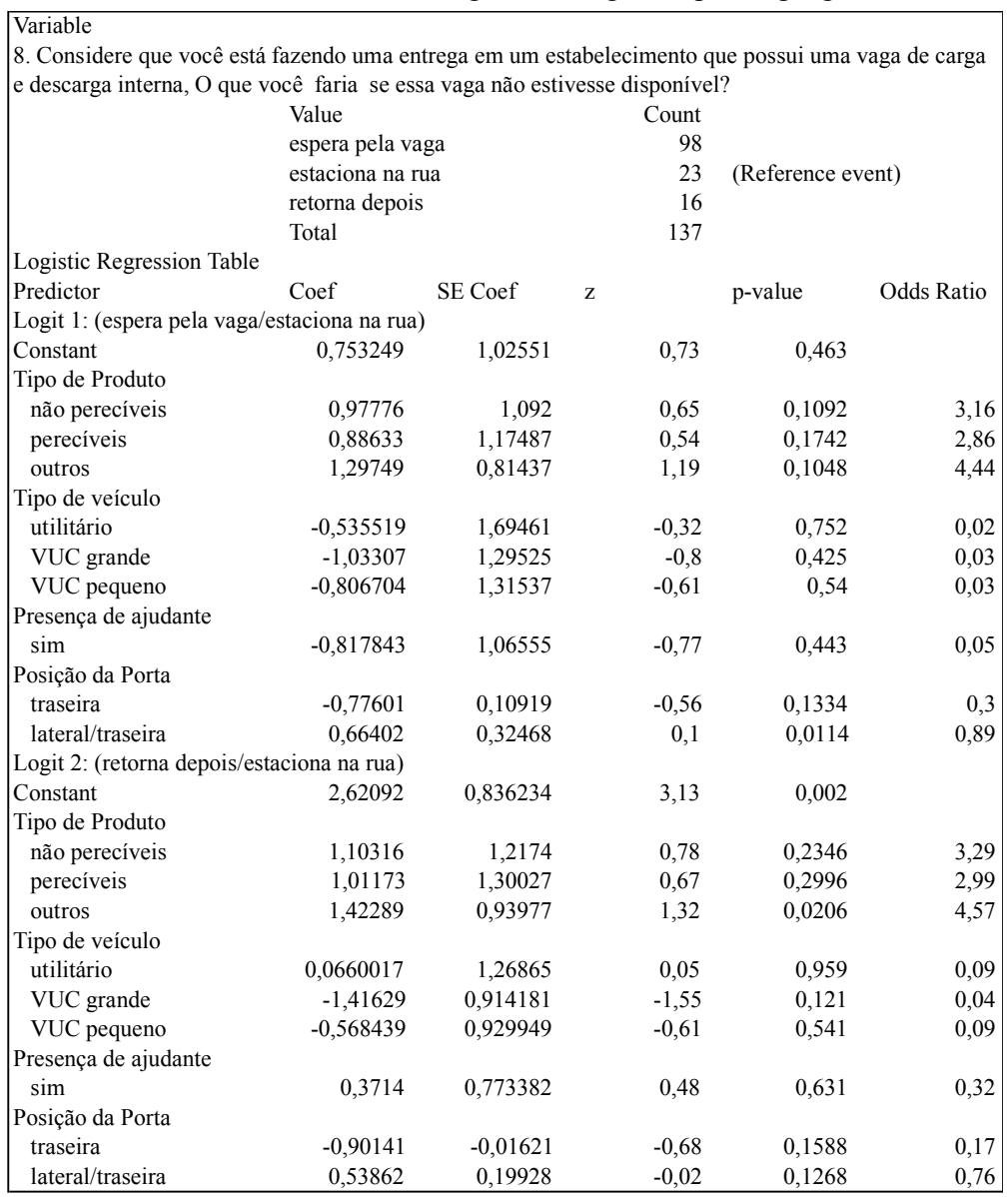

Tabela B.10 - Resultado da Regressão Logística para a pergunta 9

\begin{tabular}{|c|c|c|c|c|c|}
\hline \multicolumn{6}{|l|}{ Variable } \\
\hline & Value & & Count & \multirow{3}{*}{\multicolumn{2}{|c|}{ (Reference event) }} \\
\hline & \multicolumn{2}{|c|}{ estaciona irregularmente } & 14 & & \\
\hline & retorna depoi & & 84 & & \\
\hline & Total & & 98 & & \\
\hline \multicolumn{6}{|l|}{ Deviance Table } \\
\hline Source & DF & Adj Dev & Adj Mean & Chi-Square & p-value \\
\hline Regression & 7 & 2,921 & 0,41722 & 2,92 & 0,892 \\
\hline Tipo de Produto & 3 & 0,889 & 0,29641 & 0,89 & 0,828 \\
\hline Tipo de veículo & 3 & 1,545 & 0,51503 & 1,55 & 0,672 \\
\hline Presença de ajudante & 1 & 0,043 & 0,04267 & 0,04 & 0,836 \\
\hline Posição da Porta & 1 & 0,0564 & 0,23459 & 0,09 & 0,453 \\
\hline Error & 94 & 111,608 & 0,54327 & & \\
\hline Total & 97 & 118,528 & & & \\
\hline
\end{tabular}


Tabela B.11- Resultado da Regressão Logística para o cenário A do diagrama Variable

\begin{tabular}{|c|c|c|c|c|c|}
\hline \multicolumn{6}{|c|}{ Value } \\
\hline & opção 1 & & 79 & (Reference even & \\
\hline & opção 2 & & 58 & & \\
\hline & Total & & 137 & & \\
\hline \multicolumn{6}{|l|}{ Deviance Table } \\
\hline Source & DF & Adj Dev & Adj Mean & Chi-Square & p-value \\
\hline Regression & 9 & 15,508 & 1,7231 & 15,51 & 0,078 \\
\hline Tipo de Produto & 3 & 5,102 & 1,7007 & 5,1 & 0,164 \\
\hline Tipo de veículo & 3 & 5,211 & 1,7369 & 5,21 & 0,157 \\
\hline Presença de ajudante & 2 & 0,664 & 0,6636 & 2,13 & 0,345 \\
\hline Posição da Porta & 1 & 2,129 & 1,0646 & 0,66 & 0,415 \\
\hline Error & 127 & 171,183 & 1,3479 & & \\
\hline Total & 136 & 186,691 & & & \\
\hline
\end{tabular}

Tabela B.12- Resultado da Regressão Logística para o cenário B do diagrama

\begin{tabular}{|c|c|c|c|c|c|}
\hline \\
\hline \multicolumn{6}{|l|}{ Cenário B } \\
\hline & Value & & Count & & \\
\hline & opção 1 & & 111 & (Reference event) & \\
\hline & opção 2 & & 26 & & \\
\hline & Total & & 137 & & \\
\hline \multicolumn{6}{|l|}{ Deviance Table } \\
\hline Source & DF & Adj Dev & Adj Mean & Chi-Square & $\mathrm{p}$-value \\
\hline Regression & 9 & 12,286 & 1,3651 & 12,29 & 0,198 \\
\hline Tipo de Produto & 3 & 0,491 & 0,1638 & 0,49 & 0,921 \\
\hline Tipo de veículo & 3 & 4,897 & 1,6325 & 4,9 & 0,179 \\
\hline Presença de ajudante & 1 & 4,559 & 4,5586 & 4,56 & 0,033 \\
\hline Posição da Porta & 2 & 0,236 & 0,1181 & 0,24 & 0,889 \\
\hline Error & 127 & 120,852 & 0,9516 & & \\
\hline Total & 136 & 133,138 & & & \\
\hline
\end{tabular}

Tabela B.13- Resultado da Regressão Logística para o cenário C do diagrama

\begin{tabular}{|c|c|c|c|c|c|}
\hline \multirow{2}{*}{\multicolumn{6}{|c|}{$\begin{array}{l}\text { Variable } \\
\text { Cenário C }\end{array}$}} \\
\hline & & & & & \\
\hline & \multirow{2}{*}{\multicolumn{2}{|c|}{$\begin{array}{l}\text { Value } \\
\text { opcão } 1\end{array}$}} & \multicolumn{2}{|l|}{ Count } & \\
\hline & & & 39 & (Reference event) & \\
\hline & opção 2 & & 98 & & \\
\hline & Total & & 137 & & \\
\hline \multicolumn{6}{|l|}{ Deviance Table } \\
\hline Source & $\mathrm{DF}$ & Adj Dev & Adj Mean & Chi-Square & $\mathrm{p}$-value \\
\hline Regression & 9 & 6,661 & 0,74007 & 6,66 & 0,672 \\
\hline Tipo de Produto & 3 & 1,648 & 0,54921 & 1,65 & 0,649 \\
\hline Tipo de veículo & 3 & 4,894 & 1,63129 & 4,89 & 0,18 \\
\hline Presença de ajudante & 1 & 0,039 & 0,03926 & 0,04 & 0,843 \\
\hline Posição da Porta & 2 & 0,411 & 0,20568 & 0,41 & 0,814 \\
\hline Error & 127 & 157,003 & 1,23624 & & \\
\hline Total & 136 & 163,663 & & & \\
\hline
\end{tabular}

Tabela B.14- Resultado da Regressão Logística para o cenário D do diagrama

\begin{tabular}{|c|c|c|c|c|c|}
\hline \multicolumn{6}{|l|}{$\begin{array}{l}\text { Variable } \\
\text { Cenário D }\end{array}$} \\
\hline & Value & & Count & & \\
\hline & opção 1 & & 90 & (Reference event) & \\
\hline & opção 2 & & 47 & & \\
\hline & Total & & 137 & & \\
\hline \multicolumn{6}{|l|}{ Deviance Table } \\
\hline Source & DF & Adj Dev & Adj Mean & Chi-Square & p-value \\
\hline Regression & 9 & 8,56 & 0,9511 & 8,56 & 0,47 \\
\hline Tipo de Produto & 3 & 2,919 & 0,9729 & 2,92 & 0,404 \\
\hline Tipo de veículo & 3 & 6,483 & 2,1611 & 6,48 & 0,09 \\
\hline Presença de ajudante & 1 & 0,481 & 0,4809 & 0,48 & 0,335 \\
\hline Posição da Porta & 2 & 2,19 & 1,0949 & 2,19 & 0,488 \\
\hline Error & 127 & 167,636 & 1,32 & & \\
\hline Total & 136 & 176,195 & & & \\
\hline
\end{tabular}


Tabela B.15- Resultado da Regressão Logística para o cenário E do diagrama

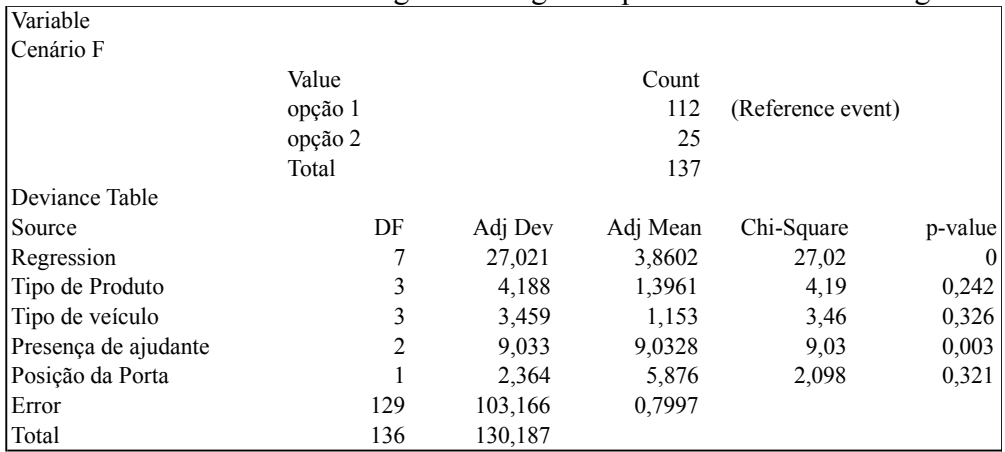

Tabela B.16- Resultado da Regressão Logística para o cenário F do diagrama

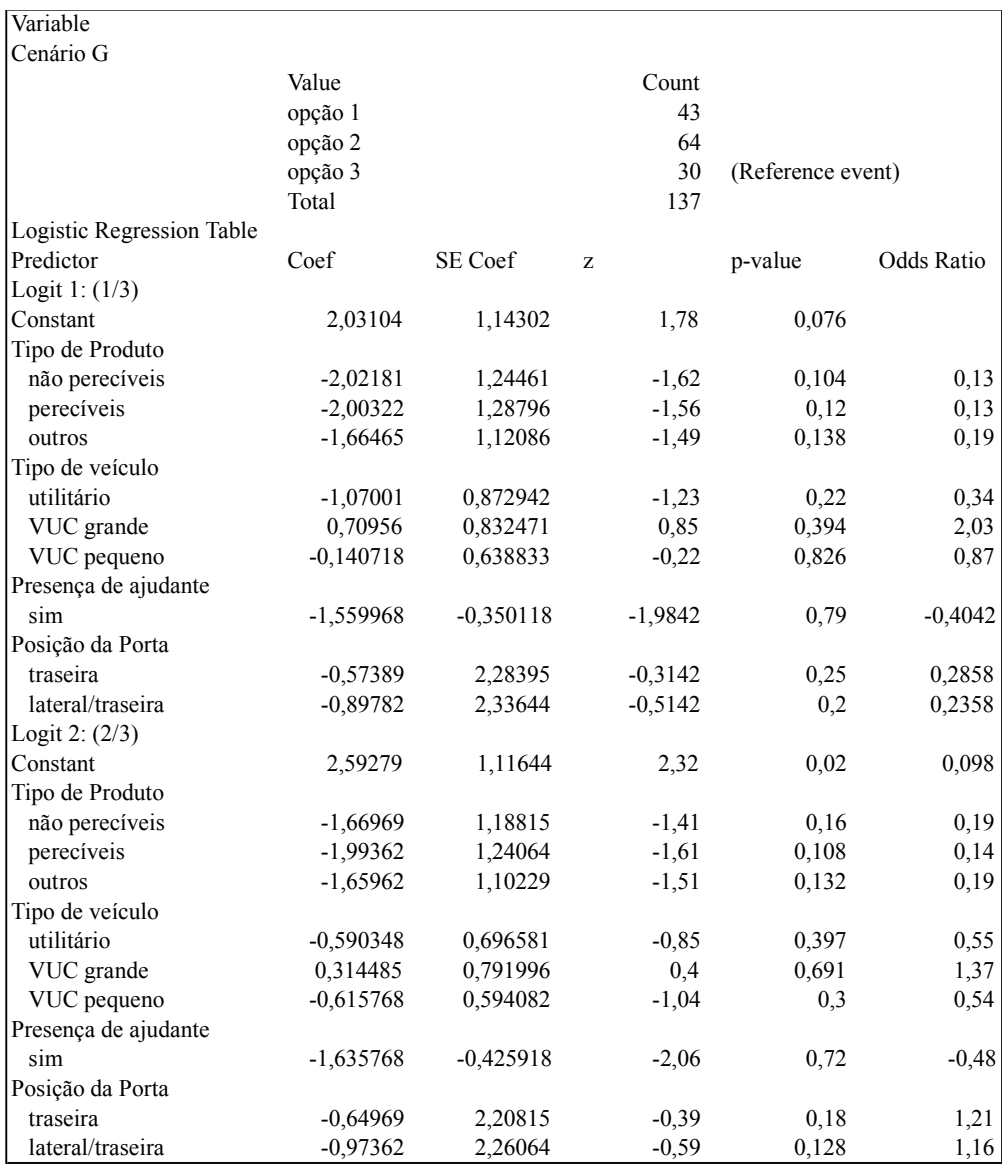

\section{B.1 Discussão sobre os resultados obtidos nas entrevistas com os motoristas}

Embora nenhuma relação estatística tenha sido encontrada entre as preferências de estacionamento reveladas pelos motoristas e os atributos considerados para as entregas ('tipo de veículo', 'tipo de produto', 'posição da porta de descarregamento' e 
'presença de ajudante'), as respostas obtidas nas entrevistas indicam algumas tendências em relação a essas preferências, as quais serão apresentadas a seguir:

- Motoristas de produtos do tipo "bebidas" estão mais dispostos a estacionar mais próximos ao local de entrega do que em áreas de carga e descarga, em relação a outros tipos de produtos.

- Motoristas de "não perecíveis" são os menos dispostos a estacionar em locais irregulares.

- Motoristas de "bebidas" são os menos dispostos a procurarem vagas de estacionamento mais do que outro tipo de produtos e consideram estacionar em locais irregulares mais do que outro tipo de produtos. Além disso, quando o estacionamento irregular é escolhido, esse grupo foi o que apresentou maior preferência por estacionar na faixa de tráfego

- A ausência de ajudantes excluiu o estacionamento irregular das respostas para a segunda opção de estacionamento.

- Motoristas de "bebidas" apresentaram maior preferência por estacionar em postos de gasolina quando uma vaga melhor localizada não está disponível.

Considerando as respostas obtidas para os diferentes cenários apresentados nos diagramas é possível observar algumas tendências de comportamento dos motoristas para seis diferentes situações. Para facilitar a compreensão da discussão, os diagramas (incluindo as porcentagens obtidas para as alternativas de cada um deles) são novamente apresentados ao final desta seção.

Qual é a distância que os motoristas estão dispostos a andar?

O cenário A mostra que 57,7\% dos motoristas preferem atravessar a rua para estarem mais próximos ao local de entrega, enquanto $42,3 \%$ preferem estacionar do mesmo lado, porém a meio quarteirão de distância. O grupo "bebidas" é uma exceção, uma vez que $75 \%$ dos entrevistados escolheram a opção 1 (estacionar mais próximo ao local de entrega, mesmo tendo que atravessar a rua). Para o cenário $B$, independentemente do tipo de produto ou outros atributos, a maioria dos motoristas $(81 \%)$ declarou preferir atravessar a rua ao estacionar virando a esquina.

O quão importante é, para os motoristas, observar seus veículos durante a entrega?

A comparação entre os cenários A e B mostra que, ao alterar a opção 2 para estacionar virando a esquina, a preferência dos motoristas diminui de 42,3\% para 19\%. Para os dois cenários a distância adicional da caminhada entre a opção 1 e 2 é a mesma (meio quarteirão distância), no cenário $\mathrm{B}$, no entanto, a vaga de estacionamento 2 está fora do campo de visão do motorista. Ainda, a presença de ajudante foi detectada em $74,5 \%$ das ocasiões nas quais os motoristas trocaram a opção 1 pela 2. 
Transformar uma vaga de estacionamento regular em uma vaga de carga e descarga torna-a mais propensa ao uso?

Comparando agora os cenários $\mathrm{B}$ e $\mathrm{C}$, a diferença entre as vagas de estacionamento 2 (que estão fora do campo de visão do motorista em ambos os casos) é que essas são regulares no cenário $\mathrm{B}$ e de carga e descarga no cenário $\mathrm{C}$. A preferência dos motoristas sobe de 19\% para 71,5\% quando essa área é de carga e descarga, ou seja, tornar a opção 2 uma vaga de carga e descarga reduziu o problema de falta de visibilidade do veículo e tornou a vaga uma opção mais atraente.

Como a distância de uma zona de carga e descarga afeta sua atratividade?

Considerando os cenários $\mathrm{C}, \mathrm{D}$ e $\mathrm{E}$ : de $\mathrm{C}$ para $\mathrm{D}$, a área de carga e descarga é movida do mesmo quarteirão que o local de entrega para o próximo quarteirão, o que faz com que a preferência dos motoristas cai de $71,5 \%$ para $34,3 \%$. Embora a distância de caminhada no diagrama seja a mesma, o fato da área de carga e descarga estar localizada em outro quarteirão, além da necessidade de atravessar a rua, afetou as escolhas dos motoristas.

A preferência dos motoristas cai a zero se a área de carga e descarga for posicionada a mais de dois quarteirões de distância (cenário E) e, mesmo se não houver nenhuma vaga disponível próxima ao estabelecimento (cenário F) a preferência pela carga e descarga anda é baixa $(18,2 \%)$.

Quando estacionamento irregular é considerado uma opção?

Ainda comparando os cenários E e F, o estacionamento irregular tornou-se uma opção para $81,8 \%$ dos motoristas quando nenhuma vaga estava disponível até dois quarteirões de distância do local de entrega. No cenário G, 46,7\% dos motoristas escolheram a opção de estacionamento 1, seguida das opções 1 (31,4\%) e 3(21,9\%). Nota-se que, mesmo as opções 2 e 3 não estando tão distantes do local de entrega, uma parte significativa dos motoristas preferiu o estacionamento irregular. Os resultados das entrevistas mostraram que apenas 10,2\% dos motoristas afirmaram que optariam pelo estacionamento irregular mas, num contexto específico mostrado no diagrama, este número sobe para $31,4 \%$. 


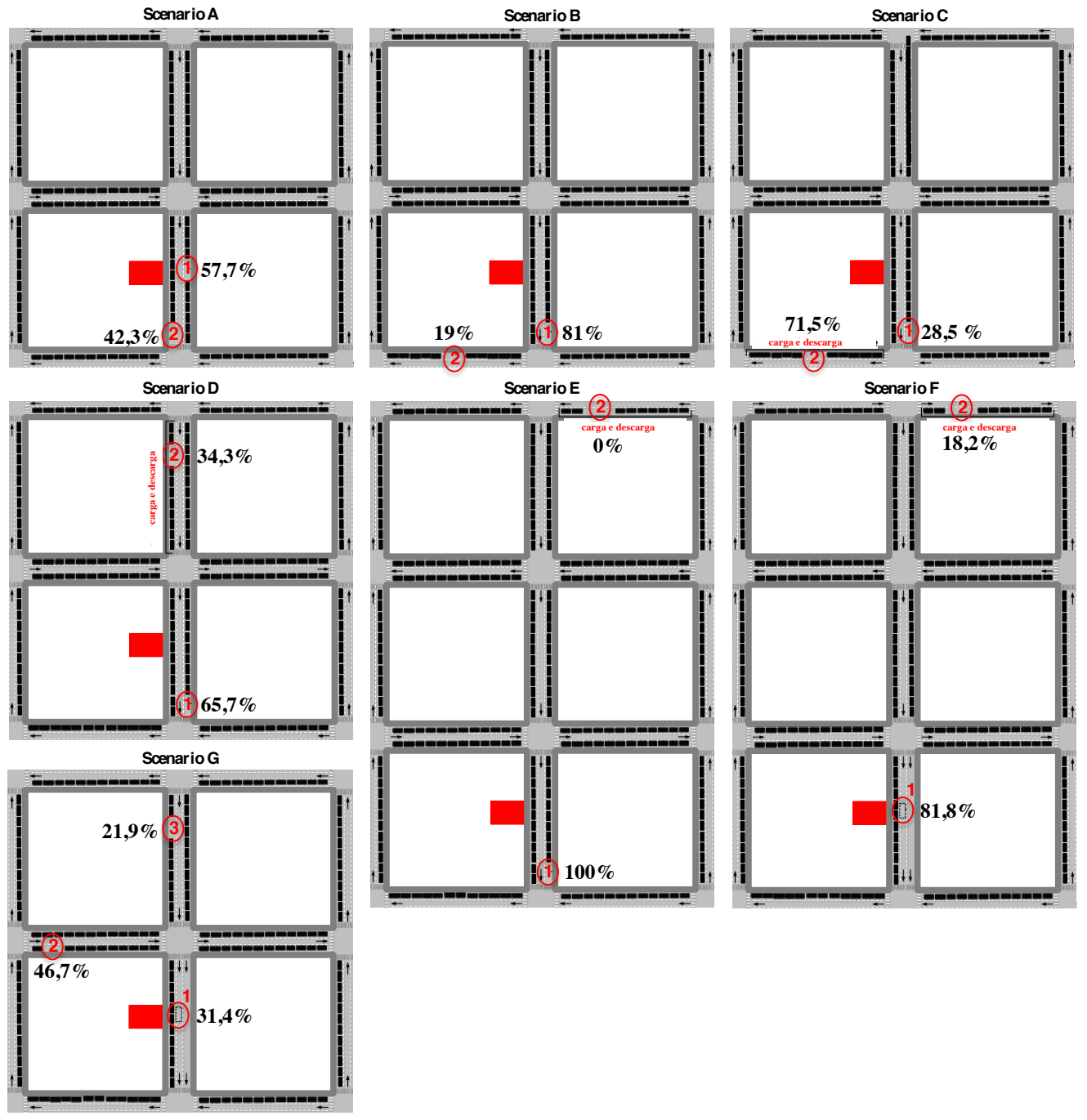

Figura B.1 - Diagramas utilizados nas entrevistas com os motoristas e porcentagens de resposta para cada alternativa 


\section{ANEXO C}

As informações apresentadas a seguir estão relacionadas aos procedimentos de coleta de dados para a representação do sistema viário, apresentados na seção 7.2.1.

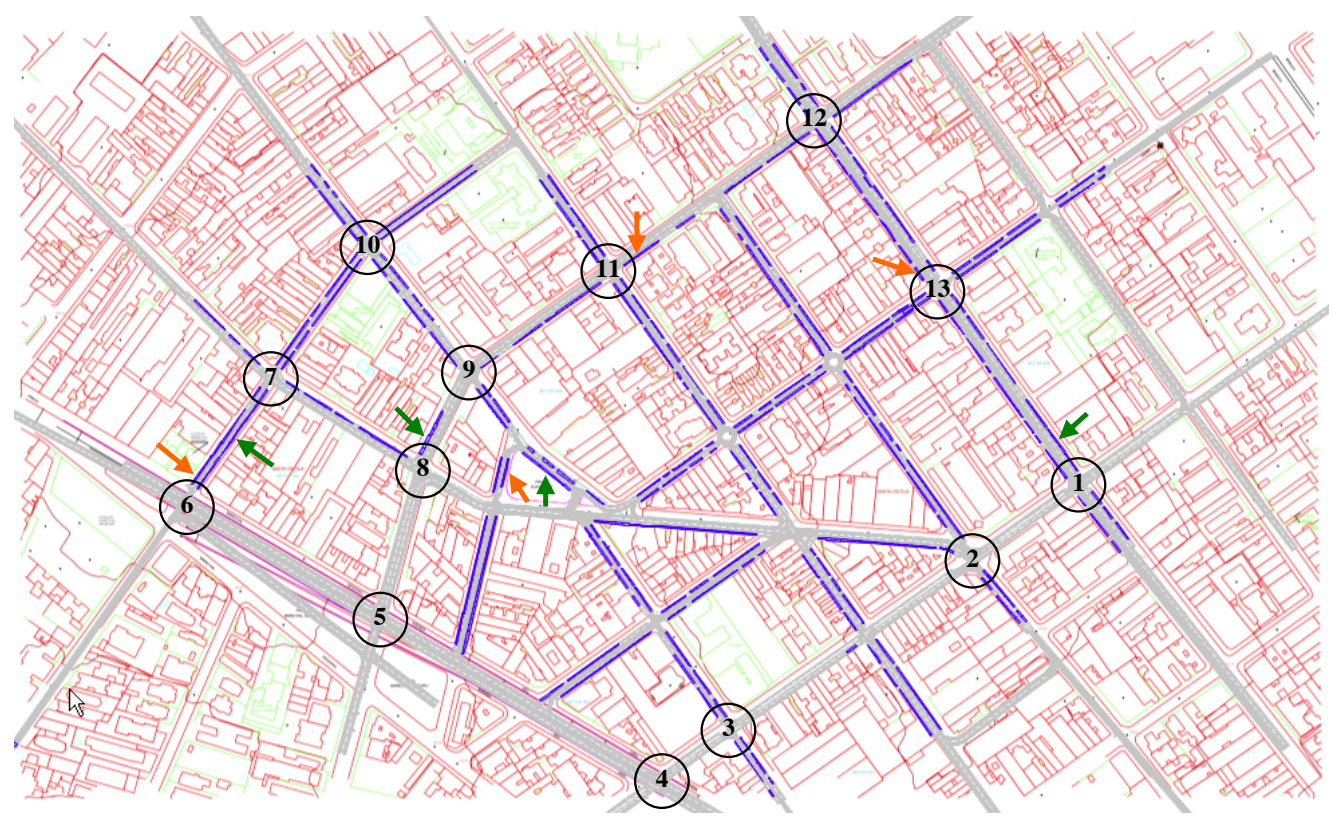

Figura C.1 - Mapeamento dos semáforos e das áreas de estacionamento da área de simulação

Na Figura C.1, as interseções semaforizadas então representadas pelos números circulados. As áreas de estacionamento estão representadas, sendo que aquelas que são de carga e descarga estão sinalizadas pela seta verde e aquelas que são vagas de táxi estão sinalizadas pela seta laranja. Ao todo foram mapeadas 807 vagas regulares, 4 áreas de carga e descarga (com capacidade para 30 veículos no total) e 4 áreas para estacionamento de táxi (com capacidade para 16 veículos no total) 


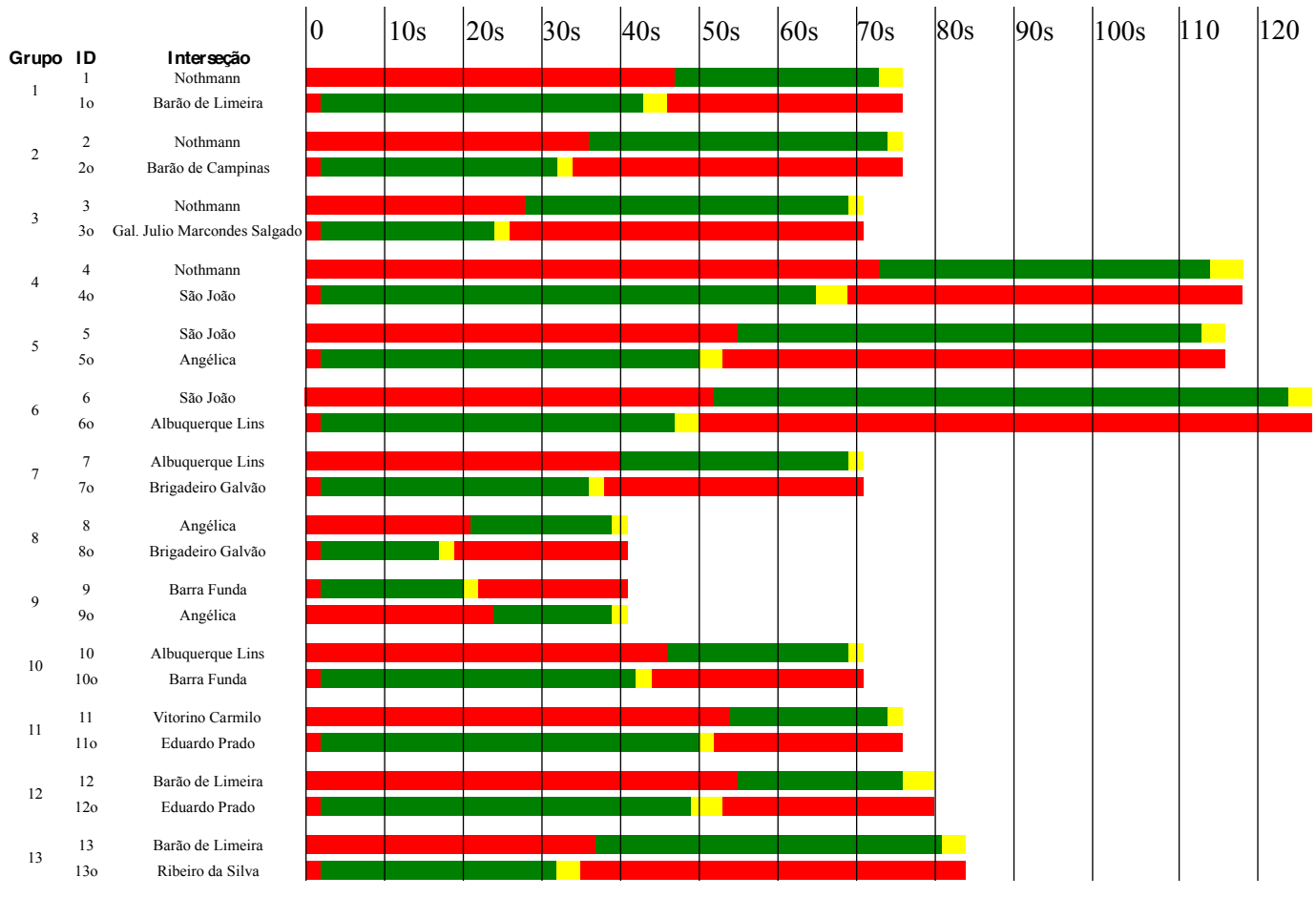

Figura C.2 - Tempos de verde, vermelho e amarelo para os semáforos identificados na área de simulação 


\section{ANEXO D}

As informações apresentadas a seguir estão relacionadas aos procedimentos de coleta de dados para a modelagem dos fluxos de veículos em geral, apresentados na seção 7.2.2.

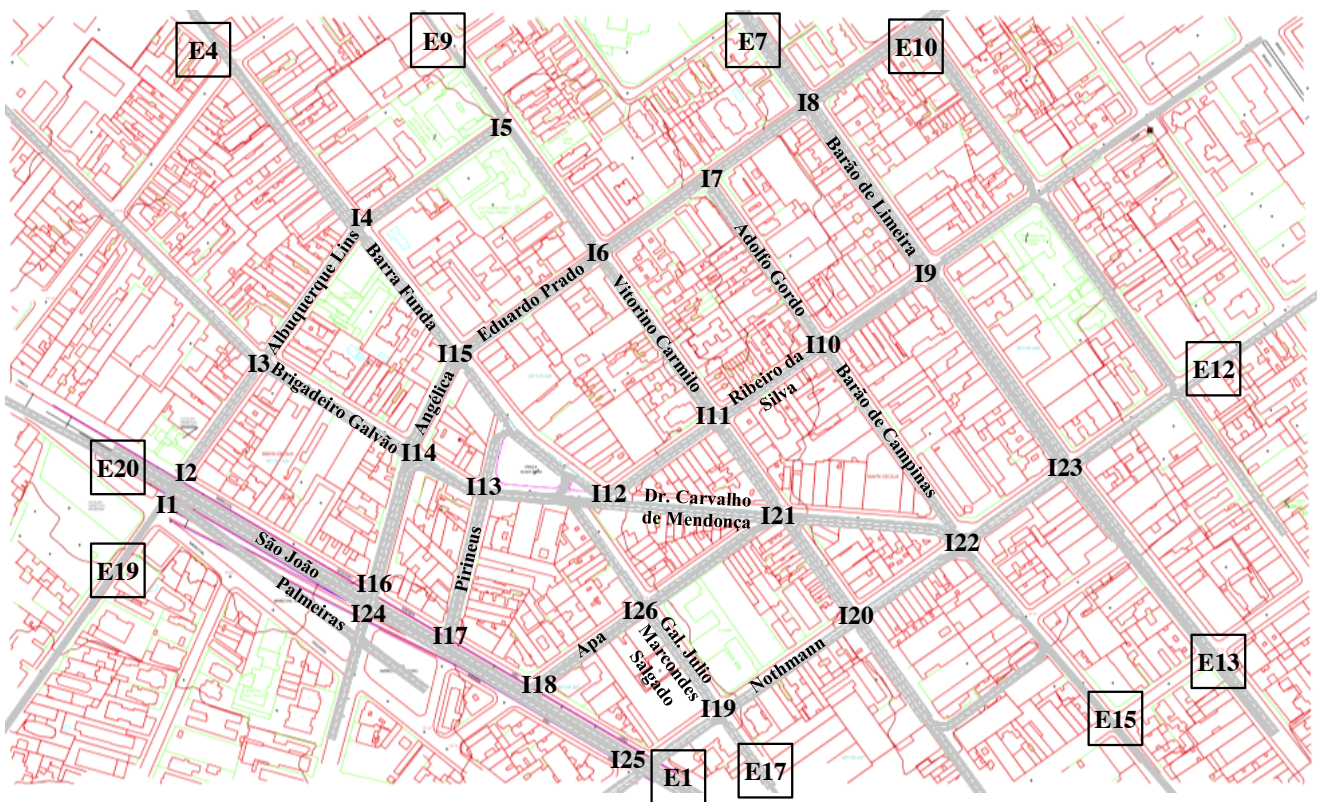

Figura D.1 - Seções de entrada e interseções da área de simulação

Tabela D.1 - Contagem de veículos nas seções de entrada da área de simulação (input de veículos)

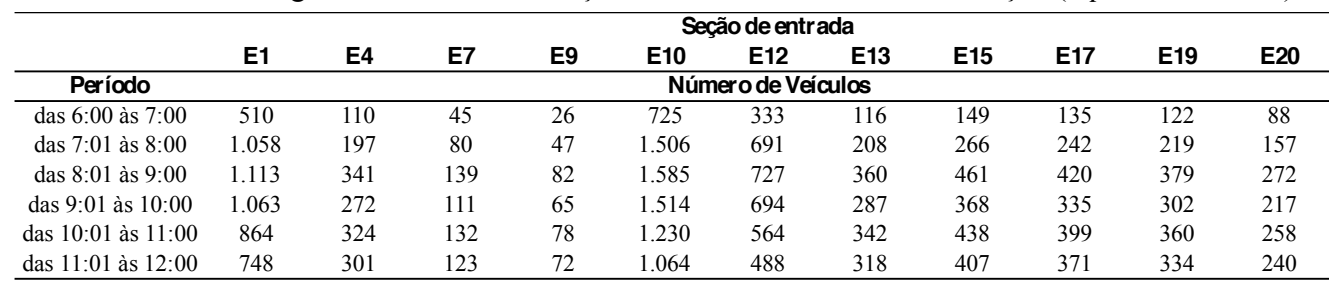


Tabela D.2 - Porcentagem dos movimentos de giro nas interseções da área de simulação

\begin{tabular}{|c|c|c|c|c|c|c|c|c|}
\hline \multirow[b]{2}{*}{ Inter seção } & \multirow{2}{*}{ Link de Origem } & \multirow{2}{*}{ Link de Destino } & \multicolumn{6}{|c|}{$\%$ dos M ovimentos } \\
\hline & & & $\begin{array}{l}\text { das 6:00 } \\
\text { às 7:00 }\end{array}$ & $\begin{array}{l}\text { das 7:01 } \\
\text { às } 8: 00\end{array}$ & $\begin{array}{c}\text { das } 8: 01 \\
\text { às } 9: 00\end{array}$ & $\begin{array}{l}\text { das } 9: 01 \\
\text { às 10:00 }\end{array}$ & $\begin{array}{l}\text { das 10:01 } \\
\text { às } 11: 00\end{array}$ & $\begin{array}{l}\text { das 11:01 } \\
\text { às 12:00 }\end{array}$ \\
\hline I1 & Albuquerque Lins & Palmeiras & $45 \%$ & $60 \%$ & $34 \%$ & $37 \%$ & $32 \%$ & $43 \%$ \\
\hline I1 & Albuquerque Lins & Albuquerque Lins & $37 \%$ & $50 \%$ & $49 \%$ & $29 \%$ & $35 \%$ & $49 \%$ \\
\hline I1 & Albuquerque Lins & São João & $18 \%$ & $32 \%$ & $5 \%$ & $17 \%$ & $16 \%$ & $27 \%$ \\
\hline $\mathrm{I} 2$ & São João & Albuquerque Lins & $10 \%$ & $6 \%$ & $5 \%$ & $9 \%$ & $3 \%$ & $4 \%$ \\
\hline $\mathrm{I} 2$ & São João & São João & $90 \%$ & $98 \%$ & $75 \%$ & $98 \%$ & $103 \%$ & $83 \%$ \\
\hline $\mathrm{I} 3$ & Brigadeiro Galvão & Albuquerque Lins & $16 \%$ & $25 \%$ & $30 \%$ & $1 \%$ & $21 \%$ & $8 \%$ \\
\hline $\mathrm{I} 3$ & Brigadeiro Galvão & Brigadeiro Galvão & $84 \%$ & $75 \%$ & $75 \%$ & $78 \%$ & $90 \%$ & $85 \%$ \\
\hline $\mathrm{I} 3$ & Albuquerque Lins & Brigadeiro Galvão & $47 \%$ & $44 \%$ & $46 \%$ & $47 \%$ & $32 \%$ & $47 \%$ \\
\hline $\mathrm{I} 3$ & Albuquerque Lins & Albuquerque Lins & $53 \%$ & $46 \%$ & $63 \%$ & $64 \%$ & $48 \%$ & $66 \%$ \\
\hline I4 & Barra Funda & Albuquerque Lins & $20 \%$ & $8 \%$ & $16 \%$ & $33 \%$ & $12 \%$ & $9 \%$ \\
\hline I4 & Barra Funda & Barra Funda & $80 \%$ & $77 \%$ & $83 \%$ & $91 \%$ & $90 \%$ & $74 \%$ \\
\hline I4 & Albuquerque Lins & Barra Funda & $37 \%$ & $35 \%$ & $32 \%$ & $48 \%$ & $23 \%$ & $47 \%$ \\
\hline I4 & Albuquerque Lins & Albuquerque Lins & $63 \%$ & $53 \%$ & $58 \%$ & $73 \%$ & $62 \%$ & $65 \%$ \\
\hline I5 & Albuquerque Lins & Vitorino Carmilo & $50 \%$ & $48 \%$ & $53 \%$ & $35 \%$ & $38 \%$ & $58 \%$ \\
\hline I5 & Albuquerque Lins & Vitorino Carmilo & $50 \%$ & $57 \%$ & $50 \%$ & $35 \%$ & $48 \%$ & $64 \%$ \\
\hline I6 & Eduardo Prado & Vitorino Carmilo (sentido NO) & $10 \%$ & $3 \%$ & $16 \%$ & $10 \%$ & $12 \%$ & $14 \%$ \\
\hline I6 & Eduardo Prado & Vitorino Carmilo (Sentido SE) & $4 \%$ & $10 \%$ & $0 \%$ & $7 \%$ & $3 \%$ & $0 \%$ \\
\hline I6 & Eduardo Prado & Eduardo Prado & $86 \%$ & $76 \%$ & $76 \%$ & $99 \%$ & $81 \%$ & $83 \%$ \\
\hline I6 & Vitorino Carmilo & Eduardo Prado & $55 \%$ & $54 \%$ & $42 \%$ & $62 \%$ & $69 \%$ & $43 \%$ \\
\hline I6 & Vitorino Carmilo & Vitorino Carmilo (sentido SE) & $45 \%$ & $53 \%$ & $41 \%$ & $45 \%$ & $46 \%$ & $49 \%$ \\
\hline I6 & Vitorino Carmilo & Eduardo Prado & $5 \%$ & $3 \%$ & $13 \%$ & $15 \%$ & $9 \%$ & $13 \%$ \\
\hline I6 & Vitorino Carmilo & Vitorino Carmilo (sentido NO) & $95 \%$ & $81 \%$ & $108 \%$ & $94 \%$ & $90 \%$ & $108 \%$ \\
\hline I7 & Eduardo Prado & Adolfo Gordo & $3 \%$ & $6 \%$ & $4 \%$ & $9 \%$ & $11 \%$ & $7 \%$ \\
\hline 17 & Eduardo Prado & Eduardo Prado & $97 \%$ & $91 \%$ & $97 \%$ & $92 \%$ & $92 \%$ & $98 \%$ \\
\hline I8 & Barão de Limeira & Eduardo Prado & $32 \%$ & $24 \%$ & $44 \%$ & $43 \%$ & $37 \%$ & $25 \%$ \\
\hline I8 & Barão de Limeira & Barão de Limeira (sentido SE) & $68 \%$ & $65 \%$ & $77 \%$ & $58 \%$ & $68 \%$ & $68 \%$ \\
\hline I8 & Eduardo Prado & Barão de Limeira (sentido NO) & $13 \%$ & $15 \%$ & $11 \%$ & $6 \%$ & $24 \%$ & $24 \%$ \\
\hline I8 & Eduardo Prado & Barão de Limeira (sentido SE) & $23 \%$ & $26 \%$ & $9 \%$ & $18 \%$ & $16 \%$ & $9 \%$ \\
\hline I8 & Eduardo Prado & Eduardo Prado & $64 \%$ & $56 \%$ & $70 \%$ & $72 \%$ & $49 \%$ & $62 \%$ \\
\hline I8 & Barão de Limeira & Eduardo Prado & $42 \%$ & $44 \%$ & $44 \%$ & $31 \%$ & $27 \%$ & $56 \%$ \\
\hline I8 & Barão de Limeira & Barão de Limeira (sentido NO) & $58 \%$ & $58 \%$ & $51 \%$ & $62 \%$ & $51 \%$ & $55 \%$ \\
\hline I9 & Ribeiro da Silva & Barão de Limeira (sentido NO) & $16 \%$ & $20 \%$ & $26 \%$ & $17 \%$ & $9 \%$ & $21 \%$ \\
\hline I9 & Ribeiro da Silva & Barão de Limeira (sentido SE) & $7 \%$ & $13 \%$ & $1 \%$ & $0 \%$ & $5 \%$ & $10 \%$ \\
\hline I9 & Ribeiro da Silva & Ribeiro da Silva & $77 \%$ & $70 \%$ & $80 \%$ & $77 \%$ & $87 \%$ & $77 \%$ \\
\hline I9 & Barão de Limeira & Barão de Limeira (sentido SE) & $100 \%$ & $89 \%$ & $90 \%$ & $98 \%$ & $86 \%$ & $107 \%$ \\
\hline I9 & Barão de Limeira & Barão de Limeira (sentido NO) & $88 \%$ & $101 \%$ & $80 \%$ & $100 \%$ & $93 \%$ & $78 \%$ \\
\hline I9 & Barão de Limeira (sentido NO) & Ribeiro da Silva & $12 \%$ & $12 \%$ & $7 \%$ & $12 \%$ & $4 \%$ & $3 \%$ \\
\hline $\mathrm{I} 10$ & Adolfo Gordo & Ribeiro da Silva & $99 \%$ & $107 \%$ & $88 \%$ & $87 \%$ & $86 \%$ & $111 \%$ \\
\hline $\mathrm{I} 10$ & Adolfo Gordo & Adolfo Gordo (sentido NO) & $1 \%$ & $8 \%$ & $7 \%$ & $6 \%$ & $3 \%$ & $5 \%$ \\
\hline $\mathrm{I} 10$ & Ribeiro da Silva & Adolfo Gordo & $12 \%$ & $17 \%$ & $7 \%$ & $8 \%$ & $19 \%$ & $11 \%$ \\
\hline $\mathrm{I} 10$ & Ribeiro da Silva & Ribeiro da Silva & $88 \%$ & $75 \%$ & $81 \%$ & $96 \%$ & $87 \%$ & $91 \%$ \\
\hline $\mathrm{I} 10$ & Barão de Campinas & Adolfo Gordo & $57 \%$ & $69 \%$ & $72 \%$ & $54 \%$ & $70 \%$ & $51 \%$ \\
\hline $\mathrm{I} 10$ & Barão de Campinas & Ribeiro da Silva & $43 \%$ & $50 \%$ & $56 \%$ & $29 \%$ & $32 \%$ & $39 \%$ \\
\hline I11 & Ribeiro da Silva & Vitorino Carmilo & $30 \%$ & $41 \%$ & $15 \%$ & $23 \%$ & $37 \%$ & $43 \%$ \\
\hline I11 & Ribeiro da Silva & Ribeiro da Silva & $70 \%$ & $72 \%$ & $59 \%$ & $66 \%$ & $66 \%$ & $65 \%$ \\
\hline I11 & Vitorino Carmilo & Ribeiro da Silva & $26 \%$ & $34 \%$ & $18 \%$ & $23 \%$ & $41 \%$ & $29 \%$ \\
\hline I11 & Vitorino Carmilo & Vitorino Carmilo & $74 \%$ & $68 \%$ & $89 \%$ & $69 \%$ & $80 \%$ & $68 \%$ \\
\hline $\mathrm{I} 12$ & Dr Carvalho de Mendonca & Ribeiro da Silva & $5 \%$ & $5 \%$ & $19 \%$ & $13 \%$ & $7 \%$ & $17 \%$ \\
\hline $\mathrm{I} 12$ & Dr Carvalho de Mendonca & Dr Carvalho de Mendonca & $95 \%$ & $83 \%$ & $80 \%$ & $105 \%$ & $81 \%$ & $83 \%$ \\
\hline $\mathrm{I} 13$ & Dr Carvalho de Mendonca & Pirineus (sentido N) & $13 \%$ & $11 \%$ & $20 \%$ & $2 \%$ & $26 \%$ & $27 \%$ \\
\hline $\mathrm{I} 13$ & Dr Carvalho de Mendonca & Pirineus (sentido S) & $1 \%$ & $1 \%$ & $2 \%$ & $5 \%$ & $9 \%$ & $10 \%$ \\
\hline $\mathrm{I} 13$ & Dr Carvalho de Mendonca & Brigadeiro Galvão & $84 \%$ & $71 \%$ & $92 \%$ & $79 \%$ & $79 \%$ & $99 \%$ \\
\hline $\mathrm{I} 13$ & Pirineus & Brigadeiro Galvão & $64 \%$ & $53 \%$ & $49 \%$ & $67 \%$ & $74 \%$ & $61 \%$ \\
\hline $\mathrm{I} 13$ & Pirineus & Pirineus & $36 \%$ & $40 \%$ & $22 \%$ & $32 \%$ & $36 \%$ & $44 \%$ \\
\hline $\mathrm{I} 14$ & Brigadeiro Galvão & Angélica & $54 \%$ & $39 \%$ & $55 \%$ & $55 \%$ & $42 \%$ & $39 \%$ \\
\hline $\mathrm{I} 14$ & Brigadeiro Galvão & Brigadeiro Galvão & $46 \%$ & $51 \%$ & $43 \%$ & $33 \%$ & $39 \%$ & $32 \%$ \\
\hline $\mathrm{I} 14$ & Angélica & Brigadeiro Galvão & $20 \%$ & $33 \%$ & $32 \%$ & $10 \%$ & $35 \%$ & $9 \%$ \\
\hline $\mathrm{I} 14$ & Angélica & Angélica & $80 \%$ & $65 \%$ & $76 \%$ & $69 \%$ & $83 \%$ & $92 \%$ \\
\hline $\mathrm{I} 15$ & Barra Funda & Angélica & $95 \%$ & $104 \%$ & $96 \%$ & $100 \%$ & $82 \%$ & $110 \%$ \\
\hline $\mathrm{I} 15$ & Barra Funda & Barra Funda & $5 \%$ & $0 \%$ & $14 \%$ & $10 \%$ & $5 \%$ & $3 \%$ \\
\hline $\mathrm{I} 15$ & Eduardo Prado & Angélica & $91 \%$ & $106 \%$ & $93 \%$ & $101 \%$ & $100 \%$ & $104 \%$ \\
\hline $\mathrm{I} 15$ & Eduardo Prado & Barra Funda & $9 \%$ & $7 \%$ & $6 \%$ & $2 \%$ & $14 \%$ & $0 \%$ \\
\hline I16 & Angélica & São João (sentido L) & $16 \%$ & $19 \%$ & $29 \%$ & $28 \%$ & $9 \%$ & $15 \%$ \\
\hline $\mathrm{I} 16$ & Angélica & São João (sentido O) & $10 \%$ & $4 \%$ & $20 \%$ & $23 \%$ & $-1 \%$ & $2 \%$ \\
\hline I16 & Angélica & Palmeiras & $38 \%$ & $34 \%$ & $25 \%$ & $43 \%$ & $33 \%$ & $39 \%$ \\
\hline I16 & Angélica & Angélica & $36 \%$ & $33 \%$ & $32 \%$ & $48 \%$ & $37 \%$ & $22 \%$ \\
\hline
\end{tabular}




\begin{tabular}{|c|c|c|c|c|c|c|c|c|}
\hline \multirow{2}{*}{ Interseção } & \multirow{2}{*}{ Link de Origem } & \multirow{2}{*}{ Link de Destino } & \multicolumn{6}{|c|}{$\%$ dos M ovimentos } \\
\hline & & & $\begin{array}{l}\text { das6:00 } \\
\text { às 7:00 }\end{array}$ & $\begin{array}{l}\text { das 7:01 } \\
\text { às 8:00 } \\
\end{array}$ & $\begin{array}{c}\text { das 8:01 } \\
\text { às } 9: 00\end{array}$ & $\begin{array}{l}\text { das 9:01 } \\
\text { às 10:00 } \\
\end{array}$ & $\begin{array}{l}\text { das 10:01 } \\
\text { às 11:00 }\end{array}$ & $\begin{array}{l}\text { das 11:01 } \\
\text { às 12:00 }\end{array}$ \\
\hline I 21 & Dr Carvalho de Mendonca & Vitorino Carmilo & $52 \%$ & $52 \%$ & $64 \%$ & $65 \%$ & $60 \%$ & $59 \%$ \\
\hline I 21 & Dr Carvalho de Mendonca & Apa & $45 \%$ & $53 \%$ & $58 \%$ & $38 \%$ & $30 \%$ & $49 \%$ \\
\hline $\mathrm{I} 21$ & Dr Carvalho de Mendonca & Dr Carvalho de Mendonca & $3 \%$ & $6 \%$ & $12 \%$ & $3 \%$ & $6 \%$ & $8 \%$ \\
\hline $\mathrm{I} 21$ & Vitorino Carmilo & Dr Carvalho de Mendonca & $26 \%$ & $15 \%$ & $20 \%$ & $15 \%$ & $29 \%$ & $28 \%$ \\
\hline I 21 & Vitorino Carmilo & Apa & $46 \%$ & $37 \%$ & $33 \%$ & $55 \%$ & $38 \%$ & $50 \%$ \\
\hline $\mathrm{I} 21$ & Vitorino Carmilo & Vitorino Carmilo & $28 \%$ & $43 \%$ & $28 \%$ & $27 \%$ & $35 \%$ & $35 \%$ \\
\hline $\mathrm{I} 22$ & Barão de Campinas & Nothmann & $47 \%$ & $33 \%$ & $36 \%$ & $41 \%$ & $50 \%$ & $49 \%$ \\
\hline $\mathrm{I} 22$ & Barão de Campinas & Dr Carvalho de Mendonca & $19 \%$ & $27 \%$ & $29 \%$ & $22 \%$ & $8 \%$ & $24 \%$ \\
\hline $\mathrm{I} 22$ & Barão de Campinas & Barão de Campinas & $34 \%$ & $47 \%$ & $31 \%$ & $20 \%$ & $42 \%$ & $24 \%$ \\
\hline $\mathrm{I} 22$ & Nothmann & Barão de Campinas & $6 \%$ & $0 \%$ & $5 \%$ & $16 \%$ & $10 \%$ & $2 \%$ \\
\hline $\mathrm{I} 22$ & Nothmann & Dr Carvalho de Mendonca & $27 \%$ & $14 \%$ & $33 \%$ & $33 \%$ & $42 \%$ & $16 \%$ \\
\hline $\mathrm{I} 22$ & Nothmann & Nothmann & $67 \%$ & $59 \%$ & $66 \%$ & $56 \%$ & $71 \%$ & $72 \%$ \\
\hline $\mathrm{I} 23$ & Nothmann & Barão de Limeira (sentido SE) & $14 \%$ & $27 \%$ & $11 \%$ & $26 \%$ & $4 \%$ & $24 \%$ \\
\hline I 23 & Nothmann & Nothmann & $80 \%$ & $69 \%$ & $68 \%$ & $83 \%$ & $82 \%$ & $88 \%$ \\
\hline $\mathrm{I} 23$ & Nothmann & Barão de Limeira (sentido NO) & $6 \%$ & $16 \%$ & $7 \%$ & $13 \%$ & $10 \%$ & $13 \%$ \\
\hline $\mathrm{I} 23$ & Barão de Limeira (sentido NO) & Nothmann & $30 \%$ & $16 \%$ & $28 \%$ & $21 \%$ & $44 \%$ & $22 \%$ \\
\hline $\mathrm{I} 23$ & Barão de Limeira & Barão de Limeira (sentido NO) & $70 \%$ & $80 \%$ & $67 \%$ & $55 \%$ & $74 \%$ & $80 \%$ \\
\hline $\mathrm{I} 23$ & Barão de Limeira (sentido SE) & Nothmann & $22 \%$ & $22 \%$ & $23 \%$ & $14 \%$ & $25 \%$ & $28 \%$ \\
\hline $\mathrm{I} 23$ & Barão de Limeira & Barão de Limeira (sentido SE) & $78 \%$ & $81 \%$ & $84 \%$ & $90 \%$ & $71 \%$ & $91 \%$ \\
\hline I 24 & São João & Angélica & $3 \%$ & $10 \%$ & $9 \%$ & $6 \%$ & $9 \%$ & $5 \%$ \\
\hline $\mathrm{I} 24$ & São João & São João & $97 \%$ & $85 \%$ & $91 \%$ & $93 \%$ & $85 \%$ & $111 \%$ \\
\hline $\mathrm{I} 25$ & São João & Nothmann & $10 \%$ & $9 \%$ & $2 \%$ & $0 \%$ & $5 \%$ & $19 \%$ \\
\hline $\mathrm{I} 25$ & São João & São João & $90 \%$ & $103 \%$ & $82 \%$ & $77 \%$ & $102 \%$ & $83 \%$ \\
\hline $\mathrm{I} 25$ & Nothmann & São João (sentido O) & $12 \%$ & $3 \%$ & $1 \%$ & $7 \%$ & $1 \%$ & $9 \%$ \\
\hline $\mathrm{I} 25$ & Nothmann & São João (sentido L) & $48 \%$ & $49 \%$ & $49 \%$ & $58 \%$ & $40 \%$ & $39 \%$ \\
\hline $\mathrm{I} 25$ & Nothmann & Nothmann & $40 \%$ & $50 \%$ & $43 \%$ & $50 \%$ & $47 \%$ & $37 \%$ \\
\hline I 26 & Gal Julio Marcondes Salgado & Apa & $1 \%$ & $4 \%$ & $1 \%$ & $6 \%$ & $0 \%$ & $10 \%$ \\
\hline I 26 & Gal Julio Marcondes Salgado & Gal Julio Marcondes Salgado & $99 \%$ & $109 \%$ & $97 \%$ & $109 \%$ & $89 \%$ & $91 \%$ \\
\hline $\mathrm{I} 26$ & Apa & Apa & $32 \%$ & $26 \%$ & $43 \%$ & $29 \%$ & $23 \%$ & $32 \%$ \\
\hline $\mathrm{I} 26$ & Apa & Gal Julio Marcondes Salgado & $68 \%$ & $68 \%$ & $61 \%$ & $75 \%$ & $62 \%$ & $69 \%$ \\
\hline
\end{tabular}

Tabela D.3 - Registro das velocidades praticadas e velocidades (desejadas) adotadas para as vias da área de simulação

\begin{tabular}{|c|c|c|c|c|c|c|c|c|}
\hline \multirow{2}{*}{ Segmento } & \multicolumn{6}{|c|}{ Velocidade registrada } & \multirow{2}{*}{$\begin{array}{l}\text { Velocidade } \\
\text { média }\end{array}$} & \multirow{2}{*}{$\begin{array}{c}\text { Velocidade } \\
\text { adotada }\end{array}$} \\
\hline & $\begin{array}{c}\text { das 6:00 } \\
\text { às 7:00 }\end{array}$ & $\begin{array}{c}\text { das 7:01 } \\
\text { às 8:00 }\end{array}$ & $\begin{array}{c}\text { das 8:01 } \\
\text { às 9:00 }\end{array}$ & $\begin{array}{l}\text { das9:01 } \\
\text { às 10:00 }\end{array}$ & $\begin{array}{c}\text { das } 10: 01 \\
\text { às } 11: 00\end{array}$ & $\begin{array}{l}\text { das 11:01 } \\
\text { às 12:00 }\end{array}$ & & \\
\hline Albuquerque Lins - 1 & 29 & 33 & 26 & 33 & 26 & 31 & 29,7 & 30 \\
\hline Albuquerque Lins - 2 & 41 & 42 & 39 & 43 & 40 & 38 & 40,5 & 41 \\
\hline Albuquerque Lins - 3 & 44 & 40 & 45 & 37 & 38 & 44 & 41,3 & 41 \\
\hline Albuquerque Lins - 4 & 41 & 39 & 42 & 43 & 44 & 38 & 41,2 & 41 \\
\hline São João (sentido L) - 1 & 56 & 50 & 53 & 55 & 50 & 52 & 52,7 & 53 \\
\hline São João (sentido L) - 2 & 50 & 55 & 55 & 51 & 55 & 50 & 52,7 & 53 \\
\hline São João (sentido L) - 3 & 54 & 48 & 54 & 55 & 48 & 49 & 51,3 & 51 \\
\hline São João (sentido L) - 4 & 54 & 50 & 55 & 50 & 49 & 53 & 51,8 & 52 \\
\hline São João (sentido L) - 5 & 54 & 48 & 54 & 55 & 53 & 55 & 53,2 & 53 \\
\hline São João (sentido O) - 1 & 54 & 50 & 56 & 56 & 55 & 55 & 54,3 & 54 \\
\hline São João (sentido O) - 2 & 56 & 50 & 56 & 48 & 50 & 54 & 52,3 & 52 \\
\hline São João (sentido O) - 3 & 56 & 55 & 49 & 56 & 56 & 51 & 53,8 & 54 \\
\hline São João (sentido O) - 4 & 54 & 55 & 56 & 56 & 52 & 55 & 54,7 & 55 \\
\hline São João (sentido O) - 5 & 54 & 49 & 54 & 52 & 52 & 51 & 52,0 & 52 \\
\hline Brigadeiro Galvão - 1 & 39 & 45 & 41 & 43 & 40 & 44 & 42,0 & 42 \\
\hline Brigadeiro Galvão - 2 & 38 & 43 & 41 & 45 & 44 & 45 & 42,7 & 43 \\
\hline Barra Funda -1 & 41 & 37 & 39 & 38 & 41 & 45 & 40,2 & 40 \\
\hline Barra Funda - 2 & 45 & 40 & 41 & 44 & 40 & 40 & 41,7 & 42 \\
\hline Barra Funda - 3 & 45 & 41 & 44 & 43 & 41 & 39 & 42,2 & 42 \\
\hline Eduardo Prado - 1 & 42 & 45 & 39 & 41 & 41 & 39 & 41,2 & 41 \\
\hline Eduardo Prado - 2 & 37 & 39 & 39 & 42 & 39 & 37 & 38,8 & 39 \\
\hline Eduardo Prado - 3 & 41 & 39 & 44 & 45 & 40 & 42 & 41,8 & 42 \\
\hline Eduardo Prado - 4 & 45 & 44 & 39 & 45 & 38 & 39 & 41,7 & 42 \\
\hline Vitorino Carmilo (sentido SE) - 1 & 29 & 33 & 31 & 26 & 28 & 35 & 30,3 & 30 \\
\hline Vitorino Carmilo (sentido SE) - 2 & 42 & 44 & 41 & 37 & 45 & 44 & 42,2 & 42 \\
\hline Vitorino Carmilo (sentido SE) - 3 & 28 & 34 & 29 & 34 & 26 & 27 & 29,7 & 30 \\
\hline Vitorino Carmilo (sentido SE) - 4 & 45 & 43 & 38 & 42 & 42 & 43 & 42,2 & 42 \\
\hline Vitorino Carmilo (sentido SE) - 5 & 45 & 44 & 43 & 44 & 40 & 44 & 43,3 & 43 \\
\hline
\end{tabular}




\begin{tabular}{|c|c|c|c|c|c|c|c|c|}
\hline \multirow{2}{*}{ Segmento } & \multicolumn{6}{|c|}{ Velocidade registrada } & \multirow{2}{*}{$\begin{array}{l}\text { Velocidade } \\
\text { média }\end{array}$} & \multirow{2}{*}{$\begin{array}{l}\text { Velocidade } \\
\text { adotada }\end{array}$} \\
\hline & $\begin{array}{c}\text { das6:00 } \\
\text { às 7:00 }\end{array}$ & $\begin{array}{c}\text { das7:01 } \\
\text { às } 8: 00\end{array}$ & $\begin{array}{c}\text { das 8:01 } \\
\text { às } 9: 00\end{array}$ & $\begin{array}{l}\text { das 9:01 } \\
\text { às 10:00 }\end{array}$ & $\begin{array}{c}\text { das 10:01 } \\
\text { às 11:00 }\end{array}$ & $\begin{array}{l}\text { das 11:01 } \\
\text { às 12:00 }\end{array}$ & & \\
\hline Vitorino Carmilo (sentido SE) - 6 & 37 & 40 & 43 & 44 & 41 & 38 & 40,5 & 41 \\
\hline Vitorino Carmilo (sentido SE) - 7 & 45 & 41 & 44 & 40 & 44 & 40 & 42,3 & 42 \\
\hline Vitorino Carmilo (sentido SO) - 1 & 38 & 45 & 37 & 45 & 43 & 43 & 41,8 & 42 \\
\hline Vitorino Carmilo (sentido SO) - 2 & 35 & 35 & 33 & 33 & 35 & 33 & 34,0 & 34 \\
\hline Vitorino Carmilo (sentido SO) - 3 & 38 & 40 & 41 & 42 & 45 & 42 & 41,3 & 41 \\
\hline Vitorino Carmilo (sentido SO) - 4 & 26 & 27 & 25 & 33 & 32 & 25 & 28,0 & 28 \\
\hline Vitorino Carmilo (sentido SO) - 5 & 45 & 38 & 43 & 37 & 41 & 44 & 41,3 & 41 \\
\hline Vitorino Carmilo (sentido SO) - 6 & 44 & 37 & 40 & 39 & 41 & 37 & 39,7 & 40 \\
\hline Vitorino Carmilo (sentido SO) - 7 & 41 & 45 & 44 & 41 & 38 & 37 & 41,0 & 41 \\
\hline Barão de Limeira (sentido SE) - 1 & 40 & 39 & 38 & 45 & 43 & 38 & 40,5 & 41 \\
\hline Barão de Limeira (sentido SE) - 2 & 42 & 42 & 44 & 43 & 40 & 44 & 42,5 & 43 \\
\hline Barão de Limeira (sentido SE) - 3 & 40 & 40 & 39 & 42 & 41 & 43 & 40,8 & 41 \\
\hline Barão de Limeira (sentido SE) - 4 & 39 & 37 & 45 & 41 & 37 & 39 & 39,7 & 40 \\
\hline Barão de Limeira (sentido SO) - 1 & 40 & 41 & 45 & 38 & 42 & 39 & 40,8 & 41 \\
\hline Barão de Limeira (sentido SO) - 2 & 39 & 43 & 43 & 37 & 41 & 38 & 40,2 & 40 \\
\hline Barão de Limeira (sentido SO) - 3 & 40 & 40 & 45 & 45 & 41 & 45 & 42,7 & 43 \\
\hline Barão de Limeira (sentido SO) - 4 & 37 & 44 & 45 & 44 & 40 & 38 & 41,3 & 41 \\
\hline Ribeiro da Silva - 1 & 43 & 45 & 42 & 38 & 43 & 40 & 41,8 & 42 \\
\hline Ribeiro da Silva - 2 & 38 & 39 & 39 & 43 & 42 & 40 & 40,2 & 40 \\
\hline Ribeiro da Silva - 3 & 25 & 31 & 27 & 31 & 32 & 31 & 29,5 & 30 \\
\hline Ribeiro da Silva - 4 & 40 & 37 & 45 & 43 & 37 & 44 & 41,0 & 41 \\
\hline Ribeiro da Silva - 5 & 43 & 42 & 41 & 41 & 42 & 43 & 42,0 & 42 \\
\hline Adolfo Gordo (sentido SE) & 26 & 29 & 33 & 25 & 30 & 33 & 29,3 & 29 \\
\hline Adolfo Gordo (sentido O) & 30 & 35 & 29 & 32 & 25 & 32 & 30,5 & 31 \\
\hline Barão de Campinas - 1 & 43 & 45 & 37 & 44 & 37 & 39 & 40,8 & 41 \\
\hline Barão de Campinas - 2 & 38 & 43 & 44 & 41 & 38 & 41 & 40,8 & 41 \\
\hline Barão de Campinas - 3 & 44 & 41 & 43 & 40 & 45 & 37 & 41,7 & 42 \\
\hline Dr Carvalho de Mendonca - 1 & 39 & 37 & 43 & 43 & 37 & 39 & 39,7 & 40 \\
\hline Dr Carvalho de Mendonca - 2 & 37 & 42 & 45 & 38 & 41 & 40 & 40,5 & 41 \\
\hline Dr Carvalho de Mendonca - 3 & 43 & 37 & 43 & 42 & 41 & 44 & 41,7 & 42 \\
\hline Pirineus (sentido N) - 1 & 34 & 33 & 29 & 31 & 34 & 28 & 31,5 & 32 \\
\hline Pirineus (sentido $\mathrm{S}$ ) - 1 & 33 & 32 & 32 & 35 & 32 & 25 & 31,5 & 32 \\
\hline Pirineus - 2 & 44 & 45 & 44 & 41 & 42 & 37 & 42,2 & 42 \\
\hline Angélica - 1 & 37 & 42 & 43 & 44 & 42 & 44 & 42,0 & 42 \\
\hline Angélica - 2 & 39 & 41 & 40 & 43 & 38 & 38 & 39,8 & 40 \\
\hline Angélica - 3 & 42 & 41 & 39 & 39 & 43 & 39 & 40,5 & 41 \\
\hline Gal Julio Marcondes Salgado - 1 & 37 & 41 & 43 & 37 & 39 & 42 & 39,8 & 40 \\
\hline Gal Julio Marcondes Salgado - 2 & 43 & 41 & 42 & 43 & 41 & 43 & 42,2 & 42 \\
\hline Nothmann - 1 & 41 & 41 & 45 & 43 & 41 & 43 & 42,3 & 42 \\
\hline Nothmann - 2 & 42 & 38 & 38 & 44 & 38 & 44 & 40,7 & 41 \\
\hline Nothmann - 3 & 42 & 39 & 45 & 39 & 37 & 39 & 40,2 & 40 \\
\hline Nothmann - 4 & 40 & 42 & 37 & 38 & 38 & 44 & 39,8 & 40 \\
\hline Nothmann - 5 & 32 & 27 & 28 & 27 & 29 & 30 & 28,8 & 29 \\
\hline Nothmann - 6 & 40 & 42 & 39 & 37 & 45 & 37 & 40,0 & 40 \\
\hline Apa - 1 & 38 & 45 & 45 & 45 & 44 & 43 & 43,3 & 43 \\
\hline Apa - 2 & 27 & 27 & 35 & 29 & 34 & 35 & 31,2 & 31 \\
\hline
\end{tabular}

Tabela D.4 - Registro da ocupação das vagas de estacionamento da área de simulação

\begin{tabular}{|c|c|c|c|c|c|c|c|c|c|c|c|c|c|}
\hline \multirow[b]{2}{*}{ Segmento } & \multirow{2}{*}{$\begin{array}{c}\text { Vagas } \\
\text { disponíveis }\end{array}$} & \multicolumn{12}{|c|}{ Vagas ocupadas/\% de ocupação } \\
\hline & & \multicolumn{2}{|c|}{$\begin{array}{c}\text { das 6:00 às } \\
7: 00\end{array}$} & \multicolumn{2}{|c|}{$\begin{array}{c}\text { das 7:01 às } \\
8: 00\end{array}$} & \multicolumn{2}{|c|}{$\begin{array}{c}\text { das 8:01 às } \\
9: 00\end{array}$} & \multicolumn{2}{|c|}{$\begin{array}{c}\text { das 9:01 às } \\
10: 00\end{array}$} & \multicolumn{2}{|c|}{$\begin{array}{c}\text { das 10:01 às } \\
11: 00\end{array}$} & \multicolumn{2}{|c|}{$\begin{array}{c}\text { das 11:01 às } \\
12: 00\end{array}$} \\
\hline Albuquerque Lins - 2 & 34 & 27 & $79 \%$ & 29 & $85 \%$ & 31 & $91 \%$ & 27 & $79 \%$ & 31 & $91 \%$ & 29 & $85 \%$ \\
\hline Brig & 1 & 16 & $89 \%$ & 15 & $82 \%$ & 17 & $92 \%$ & 4 & $78 \%$ & & $93 \%$ & 15 & $86 \%$ \\
\hline Barr & 25 & 22 & $88 \%$ & 23 & $90 \%$ & 19 & $77 \%$ & 20 & $79 \%$ & & $81 \%$ & 21 & $82 \%$ \\
\hline Edu & 15 & 11 & $73 \%$ & 12 & $80 \%$ & 13 & $89 \%$ & 14 & $91 \%$ & & $83 \%$ & 14 & $93 \%$ \\
\hline & 4 & 33 & $77 \%$ & 35 & $81 \%$ & 33 & $77 \%$ & 34 & $78 \%$ & & $85 \%$ & 39 & $91 \%$ \\
\hline Barã & 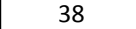 & 32 & $84 \%$ & 34 & $89 \%$ & 29 & $77 \%$ & 29 & $76 \%$ & & $92 \%$ & 33 & $88 \%$ \\
\hline Ribe & 26 & 17 & $65 \%$ & 2 & $91 \%$ & 25 & $95 \%$ & 24 & $92 \%$ & & $88 \%$ & 25 & $95 \%$ \\
\hline Adol & 41 & 29 & $71 \%$ & 39 & $94 \%$ & 34 & $83 \%$ & 34 & $84 \%$ & 32 & $78 \%$ & 34 & $82 \%$ \\
\hline & & 23 & $53 \%$ & 38 & $88 \%$ & 37 & $86 \%$ & 35 & $82 \%$ & 36 & $33 \%$ & 39 & $91 \%$ \\
\hline Apa - 1 & 29 & 18 & $62 \%$ & 22 & $75 \%$ & 27 & $92 \%$ & 25 & $87 \%$ & 27 & $92 \%$ & 27 & $93 \%$ \\
\hline
\end{tabular}


Tabela D.5 - Valores adotados para a ocupação das vagas de estacionamento da área de simulação

\begin{tabular}{|l|c|c|c|c|c|c}
\hline \multirow{2}{*}{ Via } & \multicolumn{6}{c}{$\%$ de ocupação (valores adotados) } \\
\cline { 2 - 7 } & $\begin{array}{c}\text { das6:00 } \\
\text { às7:00 }\end{array}$ & $\begin{array}{c}\text { das 7:01 } \\
\text { às 8:00 }\end{array}$ & $\begin{array}{c}\text { das8:01 } \\
\text { às9:00 }\end{array}$ & $\begin{array}{c}\text { das 9:01 } \\
\text { às 10:00 }\end{array}$ & $\begin{array}{c}\text { das 10:01 } \\
\text { às 11:00 }\end{array}$ & $\begin{array}{c}\text { das 11:01 } \\
\text { às 12:00 }\end{array}$ \\
\hline Albuquerque Lins & $79 \%$ & $85 \%$ & $91 \%$ & $79 \%$ & $91 \%$ & $85 \%$ \\
Brigadeiro Galvão & $89 \%$ & $82 \%$ & $92 \%$ & $78 \%$ & $93 \%$ & $86 \%$ \\
Barra Funda & $88 \%$ & $90 \%$ & $77 \%$ & $79 \%$ & $81 \%$ & $82 \%$ \\
Eduardo Prado & $73 \%$ & $80 \%$ & $89 \%$ & $91 \%$ & $83 \%$ & $93 \%$ \\
Vitorino Carmilo & $77 \%$ & $81 \%$ & $77 \%$ & $78 \%$ & $85 \%$ & $91 \%$ \\
Barão de Limeira & $84 \%$ & $89 \%$ & $77 \%$ & $76 \%$ & $92 \%$ & $88 \%$ \\
Ribeiro da Silva & $65 \%$ & $91 \%$ & $95 \%$ & $92 \%$ & $88 \%$ & $95 \%$ \\
Adolfo Gordo & $71 \%$ & $94 \%$ & $83 \%$ & $84 \%$ & $78 \%$ & $82 \%$ \\
Barão de Campinas & $71 \%$ & $94 \%$ & $83 \%$ & $84 \%$ & $78 \%$ & $82 \%$ \\
Dr Carvalho de Mendonça & $89 \%$ & $82 \%$ & $92 \%$ & $78 \%$ & $93 \%$ & $86 \%$ \\
Pirineus & $53 \%$ & $88 \%$ & $86 \%$ & $82 \%$ & $83 \%$ & $91 \%$ \\
Gal Julio Marcondes Salgado & $62 \%$ & $75 \%$ & $92 \%$ & $87 \%$ & $92 \%$ & $93 \%$ \\
Apa & $62 \%$ & $75 \%$ & $92 \%$ & $87 \%$ & $92 \%$ & $93 \%$ \\
\hline
\end{tabular}

Tabela D.6 - Registro da ocupação das vagas de estacionamento da área de simulação

\begin{tabular}{|c|c|c|c|c|c|c|c|c|c|c|c|c|c|}
\hline \multirow{2}{*}{$\begin{array}{c}\text { Segmento } \\
\text { (localização da área } \\
\text { de carga e descarga) }\end{array}$} & \multirow{2}{*}{$\begin{array}{c}\text { Vagas } \\
\text { disponíveis }\end{array}$} & \multicolumn{12}{|c|}{ Vagas de Carga e Descarga ocupadas por carros/ \% de ocupação } \\
\hline & & \multicolumn{2}{|c|}{$\begin{array}{c}\text { das 6:00 às } \\
7: 00\end{array}$} & \multicolumn{2}{|c|}{$\begin{array}{c}\text { das } 7: 01 \text { às } \\
8: 00\end{array}$} & \multicolumn{2}{|c|}{$\begin{array}{c}\text { das 8:01 às } \\
9: 00\end{array}$} & \multicolumn{2}{|c|}{$\begin{array}{c}\text { das } 9: 01 \text { às } \\
10: 00\end{array}$} & \multicolumn{2}{|c|}{$\begin{array}{c}\text { das 10:01 às } \\
11: 00\end{array}$} & \multicolumn{2}{|c|}{$\begin{array}{c}\text { das 11:01 às } \\
12: 00\end{array}$} \\
\hline Albuquerque Lins - 2 & 13 & 8 & $62 \%$ & 9 & $69 \%$ & 9 & $69 \%$ & 8 & $62 \%$ & 7 & $54 \%$ & 6 & $46 \%$ \\
\hline Angélica - 2 & 5 & 0 & $0 \%$ & 0 & $0 \%$ & 0 & $0 \%$ & 0 & $0 \%$ & 1 & $20 \%$ & 1 & $20 \%$ \\
\hline Barão de Limeira -3 & 4 & 0 & $0 \%$ & 1 & $25 \%$ & 1 & $25 \%$ & 1 & $25 \%$ & 0 & $0 \%$ & 0 & $0 \%$ \\
\hline Barra Funda - 3 & 8 & 7 & $88 \%$ & 6 & $75 \%$ & 6 & $75 \%$ & 4 & $50 \%$ & 4 & $50 \%$ & 5 & $63 \%$ \\
\hline
\end{tabular}

Tabela D.7 - Nova contagem de veículos nas seções de entrada da área de simulação durante a calibração do modelo (input de veículos)

\begin{tabular}{|c|c|c|c|c|c|c|c|c|c|c|c|}
\hline & \multicolumn{11}{|c|}{ Seção de entrada } \\
\hline & E1 & E4 & E7 & E9 & E10 & E12 & E13 & E15 & E17 & E19 & E20 \\
\hline Período & \multicolumn{11}{|c|}{ Número de Veículos } \\
\hline das 6:00 às 7:00 & 560 & 158 & 49 & 39 & 653 & 442 & 158 & 198 & 171 & 153 & 103 \\
\hline das 7:01 às 8:00 & 1.269 & 295 & 104 & 75 & 1.626 & 877 & 305 & 407 & 332 & 304 & 172 \\
\hline das 8:01 às 9:00 & 1.369 & 529 & 125 & 112 & 1.426 & 996 & 522 & 651 & 509 & 512 & 285 \\
\hline das 9:01 às $10: 00$ & 1.106 & 435 & 122 & 86 & 1.665 & 951 & 422 & 518 & 435 & 420 & 225 \\
\hline das $10: 01$ às $11: 00$ & 968 & 467 & 92 & 98 & 984 & 660 & 414 & 508 & 451 & 468 & 276 \\
\hline das $11: 01$ às $12: 00$ & 875 & 406 & 86 & 84 & 809 & 610 & 426 & 521 & 408 & 451 & 264 \\
\hline
\end{tabular}




\section{ANEXO E}

As informações apresentadas a seguir estão relacionadas aos procedimentos de coleta de dados para a modelagem dos fluxos de veículos em geral, apresentados na seção 7.2.3.

Tabela E.1 - Velocidades declaradas pelos motoristas dos veículos de carga

\begin{tabular}{|c|c|c|}
\hline Via & Tipo de Veículo & $\begin{array}{c}\text { Velocidade Praticada } \\
\text { Declarada }\end{array}$ \\
\hline Adolfo Gordo & kombi & 35 \\
\hline Adolfo Gordo & utilitário & 30 \\
\hline Adolfo Gordo & utilitário & 35 \\
\hline Adolfo Gordo & van & 30 \\
\hline Adolfo Gordo & VUC grande & 30 \\
\hline Adolfo Gordo & VUC pequeno & 25 \\
\hline Apa & kombi & 30 \\
\hline Apa & TOCO & 20 \\
\hline Apa & utilitário & 25 \\
\hline Apa & utilitário & 25 \\
\hline Apa & VUC grande & 25 \\
\hline Apa & VUC pequeno & 30 \\
\hline Barão de Campinas & kombi & 45 \\
\hline Barão de Campinas & utilitário & 40 \\
\hline Barão de Campinas & van & 40 \\
\hline Barão de Campinas & VUC grande & 30 \\
\hline Barão de Campinas & VUC pequeno & 30 \\
\hline Albuquerque Lins & kombi & 35 \\
\hline Albuquerque Lins & utilitário & 45 \\
\hline Albuquerque Lins & van & 35 \\
\hline Albuquerque Lins & VUC pequeno & 40 \\
\hline Albuquerque Lins & VUC pequeno & 40 \\
\hline Angélica & kombi & 35 \\
\hline Angélica & TOCO & 30 \\
\hline Angélica & utilitário & 45 \\
\hline Angélica & utilitário & 40 \\
\hline Angélica & van & 40 \\
\hline Angélica & VUC grande & 35 \\
\hline Angélica & VUC pequeno & 27 \\
\hline Barão de Limeira & kombi & 35 \\
\hline Barão de Limeira & utilitário & 35 \\
\hline Barão de Limeira & van & 45 \\
\hline Barão de Limeira & Van & 50 \\
\hline Barão de Limeira & VUC grande & 30 \\
\hline Barão de Limeira & VUC grande & 25 \\
\hline Barão de Limeira & VUC grande & 37 \\
\hline Barão de Limeira & VUC pequeno & 30 \\
\hline Barra Funda & kombi & 35 \\
\hline Barra Funda & utilitário & 45 \\
\hline Barra Funda & van & 35 \\
\hline Barra Funda & VUC grande & 25 \\
\hline Barra Funda & VUC grande & 30 \\
\hline Barra Funda & VUC pequeno & 25 \\
\hline Barra Funda & VUC pequeno & 30 \\
\hline Brigadeiro Galvão & kombi & 40 \\
\hline Brigadeiro Galvão & utilitário & 43 \\
\hline Brigadeiro Galvão & van & 42 \\
\hline Brigadeiro Galvão & VUC grande & 30 \\
\hline Brigadeiro Galvão & VUC pequeno & 25 \\
\hline Dr Carvalho de Mendonca & kombi & 35 \\
\hline Dr Carvalho de Mendonca & utilitário & 40 \\
\hline Dr Carvalho de Mendonca & Van & 30 \\
\hline Dr Carvalho de Mendonca & VUC grande & 35 \\
\hline Dr Carvalho de Mendonca & VUC grande & 35 \\
\hline
\end{tabular}


continuação

\begin{tabular}{|c|c|c|}
\hline Via & Tipo de Veículo & $\begin{array}{c}\text { Velocidade Praticada } \\
\text { Declarada }\end{array}$ \\
\hline Eduardo Prado & TOCO & 40 \\
\hline Eduardo Prado & utilitário & 40 \\
\hline Eduardo Prado & van & 35 \\
\hline Eduardo Prado & VUC grande & 35 \\
\hline Eduardo Prado & VUC grande & 33 \\
\hline Eduardo Prado & VUC pequeno & 35 \\
\hline Gal Julio Marcondes Salgado & kombi & 40 \\
\hline Gal Julio Marcondes Salgado & utilitário & 40 \\
\hline Gal Julio Marcondes Salgado & van & 45 \\
\hline Gal Julio Marcondes Salgado & VUC grande & 40 \\
\hline Gal Julio Marcondes Salgado & VUC pequeno & 35 \\
\hline Nothmann & kombi & 35 \\
\hline Nothmann & TOCO & 30 \\
\hline Nothmann & utilitário & 35 \\
\hline Nothmann & van & 30 \\
\hline Nothmann & VUC grande & 35 \\
\hline Nothmann & VUC pequeno & 40 \\
\hline Pirineus & kombi & 20 \\
\hline Pirineus & utilitário & 25 \\
\hline Pirineus & van & 29 \\
\hline Pirineus & VUC grande & 20 \\
\hline Pirineus & VUC pequeno & 35 \\
\hline Ribeiro da Silva & kombi & 30 \\
\hline Ribeiro da Silva & TOCO & 20 \\
\hline Ribeiro da Silva & utilitário & 30 \\
\hline Ribeiro da Silva & van & 40 \\
\hline Ribeiro da Silva & VUC grande & 30 \\
\hline Ribeiro da Silva & VUC pequeno & 20 \\
\hline Ribeiro da Silva & VUC pequeno & 20 \\
\hline São João (sentido L) & kombi & 45 \\
\hline São João (sentido L) & van & 45 \\
\hline São João (sentido L) & VUC pequeno & 30 \\
\hline São João (sentido O) & VUC grande & 45 \\
\hline São João (sentido O) & VUC pequeno & 45 \\
\hline Vitorino Carmilo & Kombi & 26 \\
\hline Vitorino Carmilo & utilitário & 35 \\
\hline Vitorino Carmilo & van & 20 \\
\hline Vitorino Carmilo & van & 25 \\
\hline Vitorino Carmilo & VUC grande & 30 \\
\hline Vitorino Carmilo & VUC pequeno & 20 \\
\hline Vitorino Carmilo & VUC pequeno & 30 \\
\hline
\end{tabular}

conclusão 